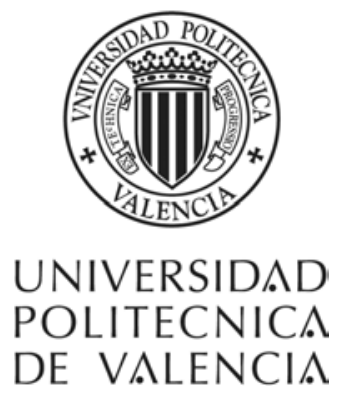

FACULTAD DE BELLAS ARTES DE SAN CARLOS

DEPARTAMENTO DE PINTURA

\title{
La imagen de la preadolescente y su representación en el arte
}

Tesis Doctoral presentada por María Silvestre Marco

Dirigida por el Dr. D. Joaquín Aldás Ruiz

Valencia, 2007 
Dedicado a mi madre, a mi abuela y a mi hermano.

\section{Agradecimientos:}

A Ximo Aldás por su consejo como maestro, compañero y director de tesis. A Luis Armand por sus siempre acertadas recomendaciones y sus sugerente libros. A Paula Santiago por escuchar mis ideas. A Javier Claramunt. A Carlos, por su paciencia y su alegría durante todos estos meses, por haberse marchado a El Salvador, a Jordania y a México cuando más lo necesitaba y por haber vuelto cuando lo necesitaba todavía más. A EQE. A mi madre, a mi hermano y a mi abuela, por ser mi fuerza y mi apoyo incondicional. $Y$ a todas aquellas personas, artistas o no, que directa o indirectamente me han aportado sus enseñanzas e inspirado en la ardua tarea de la investigación artística.

Portada: Naptime (1989) por Sally Mann. 
«¿De qué sirve un libro», pensó Alicia, «si no trae estampas ni diálogos?». Alicia en el País de las Maravillas, Lewis Carroll 



\section{ÍNDICE:}

Pág.

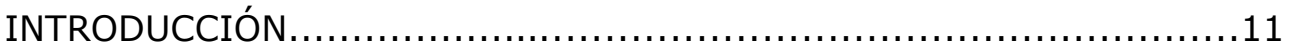

1. ANTECEDENTES LITERARIOS DEL ICONO DE LA PREADOLESCENTE

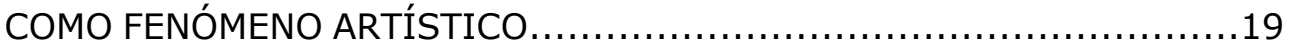

1.1. Tipos icónicos en la representación de infancia femenina.........20

1.1.1. El «niño romántico».........................................20

1.1.2. Las doncellas muertas y dormidas.........................22

1.1.3. Vírgenes, monjas, doncellas y niñas..........................32

1.1.4. Ángeles, seres extraordinarios y jóvenes perversas.........41

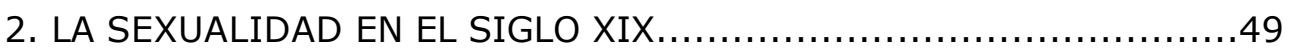

2.1. Sexualidad en la etapa victoriana.................................49

2.2. La prostitución infantil victoriana...............................53

2.2.1. «Cinco libras por una virgen». El Tributo de las jóvenes doncellas en la moderna Babilonia...................................56

2.3. Concepto victoriano de infancia..............................59

3. LA HERMANDAD PRERRAFAELISTA Y EL ARTE VICTORIANO...........65

3.1. La preadolescente en la pintura victoriana.......................67

3.2. La ilustración victoriana.......................................90

3.3. La ilustración pornográfica....................................102

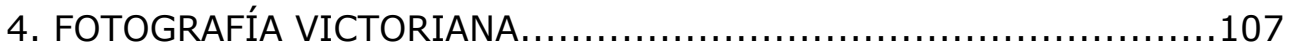

4.1. La fotografía victoriana........................................... 107

4.2. Fotografía postmortem ....................................... 115

4.3. Julia Margaret Cameron (1815-1879) .......................117

4.4. Fotografía del trabajo infantil...................................132

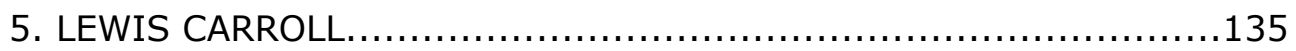

5.1. Lewis Carroll, pseudónimo de Charles Lutwidge Dodgson.......135

5.1.1. Charles Lutwidge Dodgson y el arte victoriano.............137

5.1.2. Las niñas, sus mejores amistades........................... 141

5.1.3. Alicia en el País de las Maravillas..............................146 
5.2. Las ilustraciones para su obra................................. 153

5.3. Fotografías de niñas............................................ 162

5.3.1. Las niñas como protagonistas..............................163

5.3.2. Alice, como primer icono de la preadolescente..............187

6. «LAS NIÑAS DEL CELULOIDE». LA PREADOLESCENTE EN EL CINE A

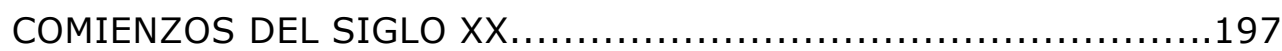

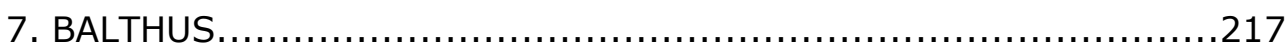

7.1. Sobre Baltasar Klossowski de Rola...........................217

7.2. La pintura de Balthus. Temas y símbolos.........................218

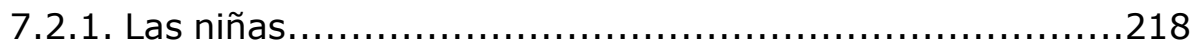

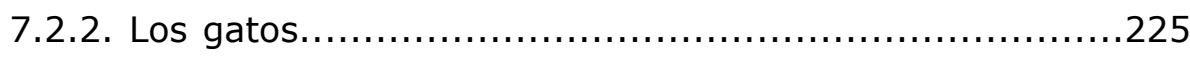

7.2.3. Los instrumentos de música...............................227

7.2.4. Erotismo y religiosidad....................................230

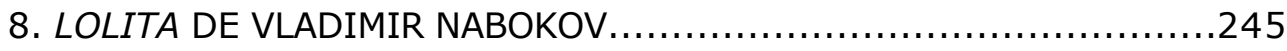

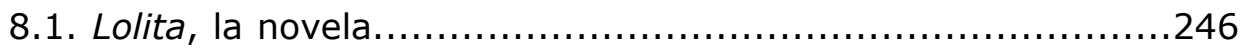

8.2. Lolita y las nínfulas............................................ 246

8.3. Humbert Humbert y Lolita.....................................253

8.4. Diferencias entre el pedófilo, el ninfulómano y el artista.......257

9. EL ICONO DE LOLITA. LA PREADOLESCENTE EN EL CINE.............261

9.1. El icono de la preadolescente en el cine. El cine tras la publicación de Lolita................................................263

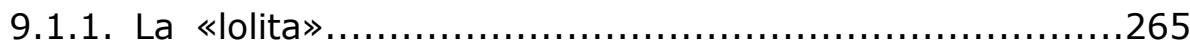

9.1.2. La preadolescente y el final de la inocencia................284

9.1.3. Alicia un siglo después..................................287

9.1.4. Las niñas siniestras....................................291

10. LA PREADOLESCENTE FOTOGRAFIADA............................301

10.1. Sally Mann ....................................................... 308

10.2. Graham Ovenden .............................................. 320

11. ALCANCE DEL ICONO DE LOLITA..................................... 329

11.1. Arte y pornografía.......................................330 
11.2. Concepto de infancia. Concepto de infancia. Desde mediados del siglo XX a principios del siglo XXI...........................333

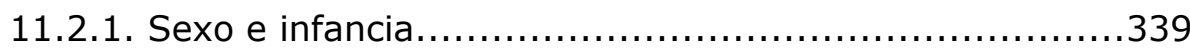

12.3. Pedofilia e Internet............................................ 341

12.3.1. Pornografía infantil...................................... 342

12.4. El «Complejo de Lolita» en la sociedad japonesa.................345

CONCLUSIONES............................................................ 359

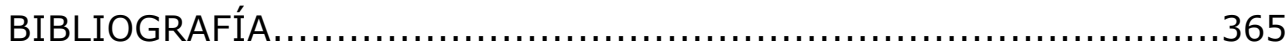

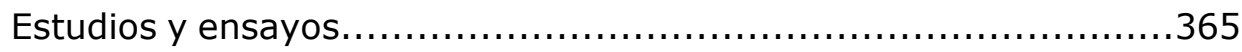

Ficción, cuentos y poesía............................................... 375

Diccionarios y enciclopedias............................................. 378

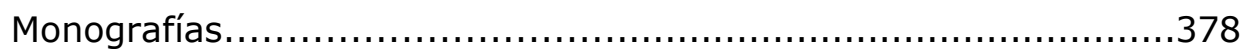

Textos y artículos en catálogos, periódicos y revistas especializadas...380

Documentos electrónicos...............................................383

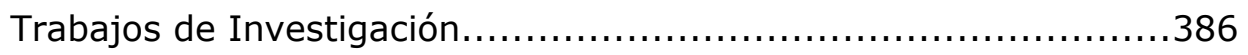

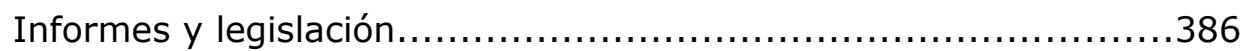

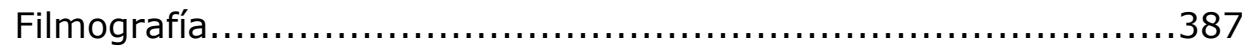

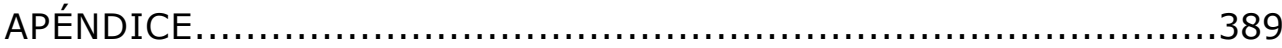

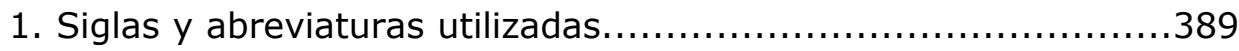

2. Criterios para referenciar bibliografías, documentos electrónicos, documentos audiovisuales y filmografías............................389

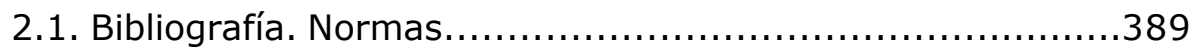

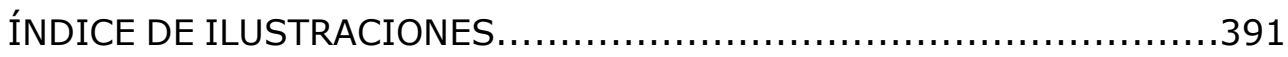

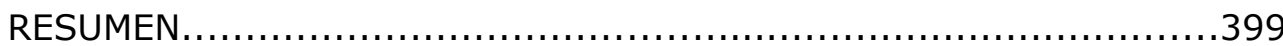

1. Resumen. Versión en castellano......................................400

2. Resum. Versió en valencià........................................401

3. Summary. English versión.............................................405 



\section{INTRODUCCIÓN:}

La presente tesis doctoral tiene sus inicios en el Trabajo de Investigación previo de la autora, que lleva por título La imagen de la preadolescente y su representación en el cine. El icono de Lolita (2003), así como en su propia experiencia y actividad artística como pintora, en la que el tema primordial de estudio es la imagen de la preadolescente y que lleva trabajando desde que realizara estudios de Bellas Artes en Southamton Institute of Higher Education, Southampton, Gran Bretaña, gracias a la concesión de una Beca Erasmus (1997-1998), de manera que durante la citada estancia, tomaría contacto directo con la pintura Prerrafaelista y la obra de otros artistas ingleses, que han desarrollado durante los dos últimos siglos una iconografía significativa de la feminidad infantil.

El propósito de la tesis es pues, el estudio de la representación de la preadolescencia femenina en las siguientes áreas: literatura, pintura, fotografía y cine desde el siglo XIX hasta la actualidad, analizando y desarrollando las características y particularidades que se dan en cada una de las áreas señaladas, tomando como eje de cada una de ellas, a los autores o artistas que han hecho de la representación de las niñas, un icono concreto de feminidad. Se señalarán puntos inéditos sobre la misma en las manifestaciones artísticas y literarias, indagando a través de diferentes épocas y artistas, las características que se le atribuyen como la sensualidad, el erotismo, la idealización, la pureza, la indefensión, etc, es decir, que se realizará un recorrido revelador y esclarecedor a través de cada una de las décadas de los siglos que abarca la investigación y se expondrá de qué manera se llega a configurar y determinar la existencia de este referente icónico, así como la de determinar la intervención de los autores y artistas en la creación 
del icono de «Lolita» durante el siglo XX, como concreción de la naturaleza de la preadolescente.

Para entender la complejidad y el alcance de su representación, es necesario ubicarse con exactitud en los lugares, costumbres, tradiciones, convenciones socio-culturales y conocimientos médicos respecto al concepto de infancia, concretando así los parámetros históricos y la relevancia de sus manifestaciones artísticas en cuanto a la cuestión que nos ocupa.

Se ha creído conveniente seguir un orden cronológico sin perder de vista el alcance que se tiene en la actualidad de la imagen infantil y por lo tanto realizar una construcción lógica que explique la evolución y desarrollo de su representación. Con tal propósito, la investigación toma como antecedentes y punto de partida, la cultura y sociedad occidental de mediados del siglo XVIII y principios del XIX, ubicando el objeto de estudio, dentro del contexto artístico, principalmente el de Inglaterra, en el que se desarrolló y propició una imagen e icono propio reconocible y significativo, ligado a las primeras consideraciones culturales del concepto de infancia. Para ello, se ha creído oportuno, comenzar la tesis estableciendo los parámetros de la imagen de la preadolescente a través de la identificación de su iconografía en la literatura precedente a éste periodo histórico, recogiendo las referencias del imaginario de los cuentos populares como Cenicienta o La bella durmiente; la poesía romántica inglesa que se recrea en la infancia como perfecto estado de inocencia; las heroínas de Shakespeare como Ofelia; La Dama de Shalott en la poesía de Tennyson, la funesta poesía de Edgar Allan Poe, etc, señalando las características de los mismos desde el punto de vista filosófico, histórico, socio-cultural, artístico o psicoanalítico desde los estudios referenciales de autores como Bram Dijkstra o Bruno Bettelheim para reconocer iconos o estereotipos femeninos como las 
«doncellas muertas y dormidas», las «vírgenes», los «ángeles» o las «jóvenes perversas».

Al definir el variable concepto de infancia según el ámbito histórico, social y cultural en el que se realiza el estudio en cada capítulo, se determinará la duración, los límites y naturaleza de la infancia femenina observando su representación artística. Así, se establece un segundo capítulo que nos ubica en el contexto social victoriano, referenciado mediante crónicas y artículos periodísticos que constatan la problemática del concepto de infancia en relación a la sexualidad, creándose el «Culto por las niñas».

En los siguientes capítulos se estudiará su representación en las manifestaciones artísticas de la Inglaterra victoriana. En el capítulo tercero, se analiza el cómo los iconos literarios de la preadolescente señalados anteriormente y la concepción social de la infancia se hacen patentes en la obra de los pintores principalmente prerrafaelistas, así como en la ilustración del momento, desarrollando y afianzando unas formas concretas del icono. El capítulo cuarto, parte de las premisas de estudio del capítulo anterior pero se centra en el desarrollo de la representación de las niñas en el ámbito de la recién inventada fotografía en el siglo XIX, observando sus lazos con la pintura prerrafaelista y con la creación de una nueva forma de representar la realidad. Se realiza un recorrido por los fotógrafos británicos más significativos respecto a la imagen infantil pero sobretodo en la fotógrafa amateur Julia Margaret Cameron, aportando una visión de la infancia no sólo desde la mirada femenina sino desde la maternidad. Con el quinto capítulo, se pretende llegar a uno de los grandes exponentes de la literatura y la fotografía del siglo XIX, Lewis Carroll, indagando en su personalidad así como en sus numerosas fotografías de niñas -como las 
de Alice Liddel-, en su libro Alicia en el País de las Maravillas y en las ilustraciones generada por él y otros dibujantes de la imagen de Alicia.

La «pasión por las niñas» que se manifiesta en las artes del siglo XIX, no pueden considerarse como un fenómeno o hecho aislado en la vida y obra de algunos individuos, sino que como se comprobará, la representación de la preadolescente será el fruto de un sinnúmero de características propias surgidas como consecuencia del pensamiento del conjunto de la sociedad de la Era victoriana, como también de la posterior cultura occidental, en la que la iconicidad de la preadolescente se hace evidente en multitud de manifestaciones artísticas, así como también en algunos comportamientos y fenómenos sociales como el «Complejo de Lolita».

Con Lewis Carroll se cierra el estudio en el contexto británico del siglo XIX, y se centra la investigación en desarrollo de los múltiples iconos de la púber en el cine, la pintura y la fotografía del siglo XX.

En el capítulo sexto y noveno, se profundizará en la imagen de las niñas en el cine. En el sexto, se observarán las primeras representaciones significativas en el cine en relación no sólo a los estereotipos heredados del siglo XIX sino a las nuevas concepciones de la feminidad y la sexualidad de comienzos del siglo XX. En el noveno se identificará con más detenimiento los diferentes iconos infantiles en el cine desde la segunda mitad del siglo $X X$, en el que claramente se desarrolla una iconografía de la misma, ligada a los géneros cinematográficos, pero que también se verá influenciada drásticamente por Lolita, la novela de Vladimir Nabokov -y que se estudiará con profundidad en el capítulo octavo-, definiéndose el más reconocible icono de la preadolescente con nombre propio. 
A nivel pictórico, se dedicará el capítulo séptimo en concreto al pintor Balthus, que aborda la representación femenina con una concreta iconografía de niñas desnudas que va más allá del ámbito de la sexualidad o del erotismo, ofreciendo una visión más particular y diferenciada de la del resto de sus contemporáneos.

En los capítulos décimo y undécimo, se aborda la imagen de la preadolescente durante las últimas décadas del siglo $X X$ y principios del XXI. Por un lado en el capítulo décimo, se analizan el enfoque que se hace a través de la fotografía actual, entablando un diálogo con la fotografía victoriana, en cuanto a temas y estereotipos de la infancia, en algunos casos tratadas bajo un imaginario tanto masculino como femenino, observando y analizando la obra de fotógrafos como Sally Mann o Graham Ovenden. El capítulo undécimo, recoge de manera conclusiva, el alcance del concepto e imagen de la infancia, y en concreto en el «icono de Lolita» y su relevancia en el campo de lo artístico, la pornografía e internet, así como las repercusiones del mismo en la sociedad del consumo, estudiando el caso del llamado «complejo de lolita» en la sociedad japonesa actual.

A modo de cierre, en las conclusiones, se recogen aquellos puntos imprescindibles para comprender las causas de la abundante y significativa cantidad de imágenes de adolescentes y preadolescentes mostradas e interpretadas ya sea en relación a un imaginario masculino, como a través de lecturas feministas, en términos eróticos o pervertidos en los medios de masas y el arte, y que ya se habían ido apuntando a lo largo de toda la tesis y más concretamente en el capítulo undécimo.

La tesis no responde a consideraciones antropológicas, es decir medico-científicas de la naturaleza de la preadolescente, sino que lo hace en base a su representación artística, confrontándola ante los 
problemas mismos que sugiere la imagen infantil como metáfora sexual. No debemos olvidar que independientemente de las consideraciones victorianas respecto a la naturaleza infantil que van desde la inocencia y la indefensión, al erotismo o la perversidad, existe una sexualidad infantil real, que sin duda nos ofrece la posibilidad de estudiar y analizar tanto como la sexualidad adulta dentro del contexto mismo de la representación humana.

Las fuentes primarias de estudio son aquellas obras, imágenes y soportes en las que se desarrolla la iconografía de la preadolescente: pintura, ilustración, fotografía o cine; por lo que se ha creído conveniente la aportación de una profusa documentación visual que clarifique las ideas y conclusiones aportadas. Sin embargo, es inevitable y necesario, asociar y confrontar los numerosos textos literarios, filosóficos, críticos o científicos que se han realizado en referencia o paralelamente a las formas visuales. Por un lado se han recopilado, seleccionado y estudiado las formas visuales propias de cada una de las etapas históricas que resultaran significativas respecto a la preadolescente, como por ejemplo la multitud de imágenes infantiles que se realizaran durante el periodo victoriano o los manga japoneses a finales del siglo $X X$, de manera que se observara objetivamente la relevancia visual del icono respecto a la representación misma de la infancia y de la feminidad.

A partir de los documentos visuales se ha procedido a la documentación, lectura e interpretación de las fuentes textuales. Son particularmente importantes aquellas que los propios artistas han generado como epístolas, declaraciones, diarios, etc, así como de los críticos o periodistas que has publicado sus trabajos en volúmenes o prensa. Por otro lado, se ha procedido de forma análoga con otras fuentes textuales, como novelas, cuentos populares, ensayos, teorías 
científicas, análisis sociológicos, etc, siendo algunos de estos textos fundamentales para la comprensión global de la imagen de la preadolescente en los diferentes contextos socioculturales como lo fue Lolita de Nabokov.

Ha sido igualmente necesario hacer uso de fuentes secundarias como estudios contemporáneos de autores e historiadores especializados, revistas, catálogos de exposiciones o documentos que nos sitúen e informen sobre documentación destruida o de difícil acceso en la actualidad como la ilustración pornográfica victoriana o la pedopornografía y ciberpederastia de la última década.

La mayoría de las fuentes textuales primarias con las que se ha trabajado, son documentos originales en lengua inglesa, lo que ha implicado la profundización en el conocimiento del idioma extranjero. A pesar de ello, se ha recurrido en numerosas ocasiones a fuentes secundarias escritas o traducidas al castellano para una mejor comprensión de los textos originales.

Sin duda, es completamente relevante la utilización de internet como herramienta de búsqueda y consulta por su inmediatez y eficacia, pero también por tratarse de uno elemento objeto de análisis dentro de los contenidos de la tesis. Sin embargo, sigue siendo discutible la calidad y veracidad de los contenidos e informaciones que se hallan en éste medio, por ello, todos los artículos, entrevistas, documentación visual, citas y demás bibliografía aportada desde el mismo, han sido tomadas de páginas web de instituciones de prestigio o que poseen publicación en papel, como revistas especializadas o prensa, o que puedan ser cotejadas con otros documentos para asegurarnos de su rigor. 
Esta tesis pretende dar a conocer en lengua castellana una temática de completa actualidad, que ha sido principal y particularmente desarrollada por el arte y la cultura anglófona.

La lectura de ésta tesis doctoral, se realiza a través del Departamento de Pintura de la Facultad de Bellas Artes de la Universidad Politécnica de Valencia puesto que la trayectoria artística de la autora se ha enfocado principalmente desde el trabajo pictórico, a pesar de haber tomado también contacto con otras disciplinas como el audiovisual o multimedia y que sin duda han influenciado en el enfoque interdisciplinar de la tesis doctoral, así como por su pertenencia como docente en éste mismo departamento.

La propia experiencia pictórica de la autora dentro de la temática de la preadolescente, supone un inevitable posicionamiento respecto al punto de vista que se hace del mismo, situándose por un lado como pintora que se enfrenta a las mismas problemáticas que los autores que en la tesis se analizan y que han intervenido en la formación de éste icono femenino y por otro como mujer e investigadora ante la construcción de un icono que va ligado al contexto socio-cultural de la historia de la civilización, en concreto la occidental, basada en preceptos y consideraciones esencialmente falocráticas sin dejar de lado a las consideraciones feministas en las concreción de los estereotipos e iconos de la feminidad. 


\section{ANTECEDENTES LITERARIOS DEL ICONO DE LA PREADOLESCENTE COMO FENÓMENO ARTÍSTICO.}

Para establecer los parámetros que definen la imagen de la preadolescente en el arte, no podemos dejar de lado a modo de precedente, la influencia de la literatura occidental de los pasados siglos.

Desde el siglo XIX, la representación de la preadolescente en la literatura y el arte ha sido determinada por las condiciones sociales y culturales de la mujer dentro de la sociedad occidental. Históricamente se ha asumido la sumisión y la pasividad como rasgos femeninos, de manera que las manifestaciones artísticas son un reflejo de tales concepciones sobre la naturaleza de la feminidad y consecuentemente la iconografía femenina ha estado marcada por un claro espíritu misógino que como señala Bram Dijkstra, derivó en una «guerra contra la mujer librada en el campo de batalla de las palabras y las imágenes» ${ }^{15}$.

La educación tradicional, mantenía a las niñas en la ignorancia sexual propiciando el desarrollo de la afectividad familiar cara al matrimonio y a la maternidad. La perfecta feminidad estaba ligada a la prolongación de la inocencia infantil al estado adulto, adjudicándosele atributos como la debilidad y la pasividad, y creando un vínculo de dependencia respecto al adulto masculino que debía ejercer moralmente su protección sobre la eterna infancia femenina.

Tal subordinación histórica de la mujer perpetuada por criterios masculinos, hacen de la «realidad» sociocultural, una realidad parcial y limitada, que proviene no tanto de la imaginación femenina como de la imaginación masculina respecto a la feminidad, respondiendo a las fantasías y necesidades eróticas masculinas. De hecho, las mujeres

${ }^{15}$ DIJKSTRA, Bram. Ídolos de perversidad. Madrid: Debate, 1994, prólogo vii. 
participaron también del pensamiento masculino, haciendo de ellas mismas el fetiche de la imaginación masculina, aceptando, defendiendo y transmitiendo, lo que la educación establecía, sin disponer de un lenguaje o imaginería propia con los que poder desarrollar su punto de vista desde y sobre la feminidad.

No será hasta finales de siglo XIX, cuando los incipientes movimientos feministas, contribuirán no sólo a nivel sociocultural sino también en el arte, a la desmitificación de iconos y estereotipos femeninos adultos e infantiles basados sobre todo en su capacidad intelectual, en la naturaleza de su sexualidad y en la ambigüedad entre la inocencia y la perversidad.

\subsection{Tipos icónicos en la representación de la infancia femenina.}

\subsubsection{El «niño romántico».}

Hasta finales del siglo XVIII, «la infancia» no constituía un tema de importancia en la literatura. Fue paralelamente a lo que conocemos como «renacimiento romántico» ${ }^{16}$ cuando la poesía de William Blake, con El deshollinador [The Chimney Sweeper], Cantos de inocencia [Songs of Innocence], Cantos de experiencia [Songs of Experience] o William Wordsworth, con su oda Atisbos de la Inmortalidad [Intimations of Immortality from recollections of Early Childhood], cuando se inició una visión idealizada de la infancia, enfatizando la inocencia y la virtud natural, creando el concepto de el «niño romántico» ${ }^{17}$. Blake advierte la

\footnotetext{
16 «Romantic revival».

17 «Romantic child». El término child, que en castellano significa niño, se utiliza en inglés indistintamente para el género masculino como el femenino, al igual que su plural children. En este caso, significa igual que en inglés, englobando niños/as. Peter Coveney, señala la categoría del «niño romático» en una época de «culto por lo sensible», entrando en conflicto la razón y lo sensible. En
} 
inocencia en la infancia misma y establece una antítesis entre ésta y la experiencia. Por su parte, Wordsworth, observar la infancia desde la experiencia vivida y autobiográfica; Coleridge reconoce en la infancia una «intuición» pura e intachable y una bondad natural que debe ser conservada, pero se opone a la idealización de Wordsworth o Blake.

Pero ya en el siglo XIX, se produjo un profundo vuelco sin precedentes hacia la figura infantil, convirtiéndolo en uno de los grandes tópicos literarios y artísticos. La sociedad había asumido la visión romántica y simbólica de la infancia, por lo que en la literatura que gira alrededor de personajes infantiles, se reafirma el sentido de inocencia pero también el de la fragilidad o el victimismo de la infancia bajo las condiciones sociales del momento. En este sentido, Charles Dickens, fue el escritor del siglo XIX que mejor supo adaptar el concepto romántico de infancia en la novela victoriana y como Wordsworth, tomaría su propia experiencia biográfica como punto de partida. El tratamiento que da a la infancia, enfatiza sobremanera en la sentimentalización que tiende a la autocompasión de su propia experiencia como niño. Otros autores manifestarían su profunda admiración por la niñez, en un «culto por la infancia» desbordado, como el poeta Ernest Dowson en un ensayo titulado "El culto al niño" [Cult of the Child] ${ }^{18}$.

Esta visión por la infancia, expresaba una profunda negación de sus responsabilidades como adultos ${ }^{19}$ y serviría de refugio nostálgico e imaginario para autores como Lewis Carroll ${ }^{20}$ con Alicia en el País de las Maravillas y J. M. Barrie con Peter Pan. «Todos los niños crecen, excepto uno» y ese niño es «Peter Pan», que personifica la concepción de

COVENEY, Peter. The Image of Childhood. The Individual and Society: a Study of the Theme in English Literature. London: Penguin Books, 1967, pág. 31.

${ }^{18}$ DOWSON, Ernest "The Cult of The Child". The Critic. August $17^{\text {th }}, 1889$.

${ }^{19}$ COVENEY, Peter. Op. cit., pág. 241.

${ }^{20}$ V. cap. 5. Lewis Carroll, pág. 135. 
inocencia del romanticismo. Peter no crece, no por que no pueda, sino por que no quiere. En el fondo, es consciente de lo que implica crecer, no sólo en responsabilidades, sino en la pérdida de la inocencia, la experiencia, la sexualidad, la vejez, la muerte...

En cambio, la infancia en la obra de Henry James ${ }^{21}$ resulta insólita respecto de la de Dickens. Aunque sus personajes infantiles tiene potencialmente una infancia de inocencia, viven con las frustraciones y el egoísmo del mundo adulto, que alteran sus destinos. A pesar de que James reafirma el victimismo, no sentimentaliza la pérdida de la inocencia, sino que aprovecha esa inferioridad, para hacer de ellos un instrumento con el que mostrar la maldad y la depravación del mundo adulto, visión que algunos científicos victorianos reafirmarían respecto a la perversidad natural infantil. Personajes como «Miles» y «Flora» en Otra vuelta de tuerca, son el reflejo de la perversión sexual de los adultos que deben cuidar de ellos. En los niños se manifiesta la dualidad bondad-maldad, como las cualidades de todo ser humano.

\subsubsection{Las doncellas muertas y dormidas.}

Sin duda la relación entre mujer-muerte-erotismo ha sido uno de los grandes tópicos de la literatura y el arte durante los siglos XVIII y XIX. Son numeroso autores de sensibilidad romántica como Shelley, Keats, Flaubert, Poe o Baudelaire en Himno a la belleza [Hymne à la Beauté $f^{2}$ o El monstruo o El paraninfo de una ninfa macabra [Le

\footnotetext{
${ }^{21}$ Aunque Henry James nació en Nueva York en 1843, muy pronto viajaría junto a su familia por toda Europa, sobre todo a Inglaterra. Se le considera un autor tanto británico como americano. Sintió gran admiración por autores como Balzac, Flaubert, Turguenev y desdeñaba a Zola, Dickens, Oscar Wilde o Joseph Conrad.

22 BAUDELAIRE, Charles. Las flores del mal. Madrid: Cátedra, 1997, pág. 141.
} 
monstre ou le paranymphe d'une nymphe macabre $]^{23}$, que darían testimonio en sus obras una relación íntima entre la Belleza y la Muerte ${ }^{24}$. Tanto en la literatura como en la pintura o el cine, la muerte de una preadolescente o adolescente, ha sido un recurso de gran dramatismo en el conjunto de la narración. Los ejemplos son numerosos: «Beth» en Mujercitas de Louisa Mary Alcott, la pequeña «Eva» en La Cabaña del tío Tom de Harriet Stowe, etc...

Los artistas prerrafaelistas encontraron en el tópico de la doncella muerta, un tema recurrente en La dama de Shalott [The Lady of Shalott], poema escrito en 1832 por Alfred Lord Tennyson. Entre 1850 y 1915, se realizaron al menos unos 54 trabajos artísticos basados en el poema, sin incluir ilustraciones de libros. Artistas prerrafaelistas como Rossetti, Hunt, Millais y más tarde Burne-Jones o Waterhouse, realizaron algunos de los trabajos más conocidos sobre el mismo.

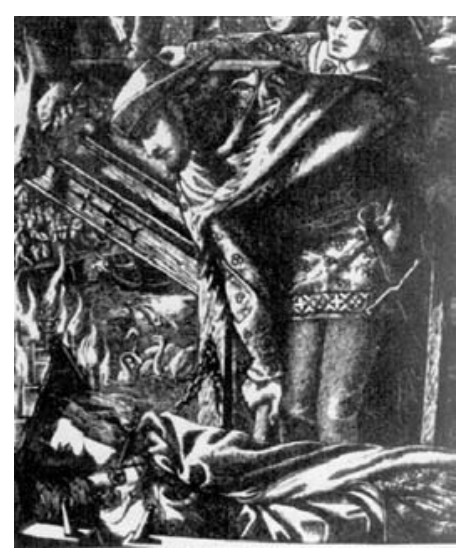

Fig. 1. La dama de Shalott (1857), ilustración de Dante Gabriel Rossetti.

El poema escrito a partir del mito artúrico, narra la leyenda de la «Dama de Shalott», una doncella enamorada del caballero «Lanzarote del Lago», la cual por causa de una maldición se encuentra encerrada en una torre ${ }^{25}$, desde la que sólo puede ver el exterior a través del reflejo en un espejo ${ }^{26}$. Allí teje sin cesar un hermoso tapiz ${ }^{27}$. A pesar de que

\footnotetext{
${ }^{23}$ Id., pág. 591.

24 PRAZ, Mario. La carne, la muerte y el diablo en la literatura romántica. Barcelona: El Acantilado, 1999, págs. 72-80.

${ }^{25}$ Algunos investigadores hayan las raíces de la doncella prisionera en una torre de la historia de Santa Bárbara.

${ }^{26}$ Recuérdese el paralelismo con el «Mito de la caverna» en La República de Platón.

${ }^{27}$ Se la describe como una artista, pues ella canta, teje, etc. Algunos autores han señalado que La dama de Shalott representa metafóricamente al artista que rechaza la sociedad preservando su
} 
una vidente presagiara su desgraciado futuro, decide mirar directamente a través de la ventana del torreón para ver a su amado caballero. Pero su atrevimiento lo paga con su vida. Su cuerpo muerto es colocado en una barca que la conduce río abajo hacia «Camelot». Allí, Lanzarote junto a otros caballeros reciben la barca con la misteriosa y desconocida dama.

El desenlace de la leyenda, nos conduce hacia la muerte de la «dama», pues decide mirar a través de la ventana. Su castigo por caer en las vanidades del mundo, es la muerte, la cual, se puede interpretar como el fin de la inocencia, la pérdida de la virginidad, la sexualidad, el pecado carnal o la lujuria.

En 1859, Tennyson volvió a retomar la leyenda de la «Dama de Shalott», esta vez en el personaje de «Elaine» en Lanzarote y Elaine $^{28}$, incluido dentro de uno de sus poemas líricos más memorables, Los idilios del rey.

Como en La dama de Shalott, Elaine, también llamada la «doncella del lirio de Astolat», es una joven hermosa que se encuentra en lo alto de una torre, bordando una cobertura para el escudo de Lanzarote, el caballero del que está enamorada, el cual le dobla o triplica en edad. Conocedora de su propia muerte, Elaine escribe una carta para Lanzarote y la reina Ginebra. El padre y hermanos de Elaine, la colocan tras su muerte en una barca, tapada por el cobertor que ella misma

integridad artística. Por otro lado, sus acciones son la propias de las Nereidas, las divinidades marinas, nietas de Océano, bellísimas, que todo el tiempo, tejen, hilan y cantan. GRIMAL, Pierre. Diccionario de mitología griega y romana. Barcelona: Paidos, 1981, pág. 377.

${ }^{28}$ Libro 60, «Lancelot and Elaine», en el poema Idylls of the King Poetical Works of Alfred Tennyson. London: Macmillan, 1911, pág. 416. 
había tejido y la carta. La acompaña un servidor mudo ${ }^{29}$. Así que al llegar a Camelot, Lanzarote y la Corte reciben el bote con la doncella. Tras leer la carta, Lanzarote se da cuenta del amor que la dama le profesaba. Irónicamente Lanzarote no sabe de su existencia hasta que ella muere y es sólo entonces, ante el cuerpo ya cadáver de la doncella, cuando se percata de su belleza y de que él también la ama.

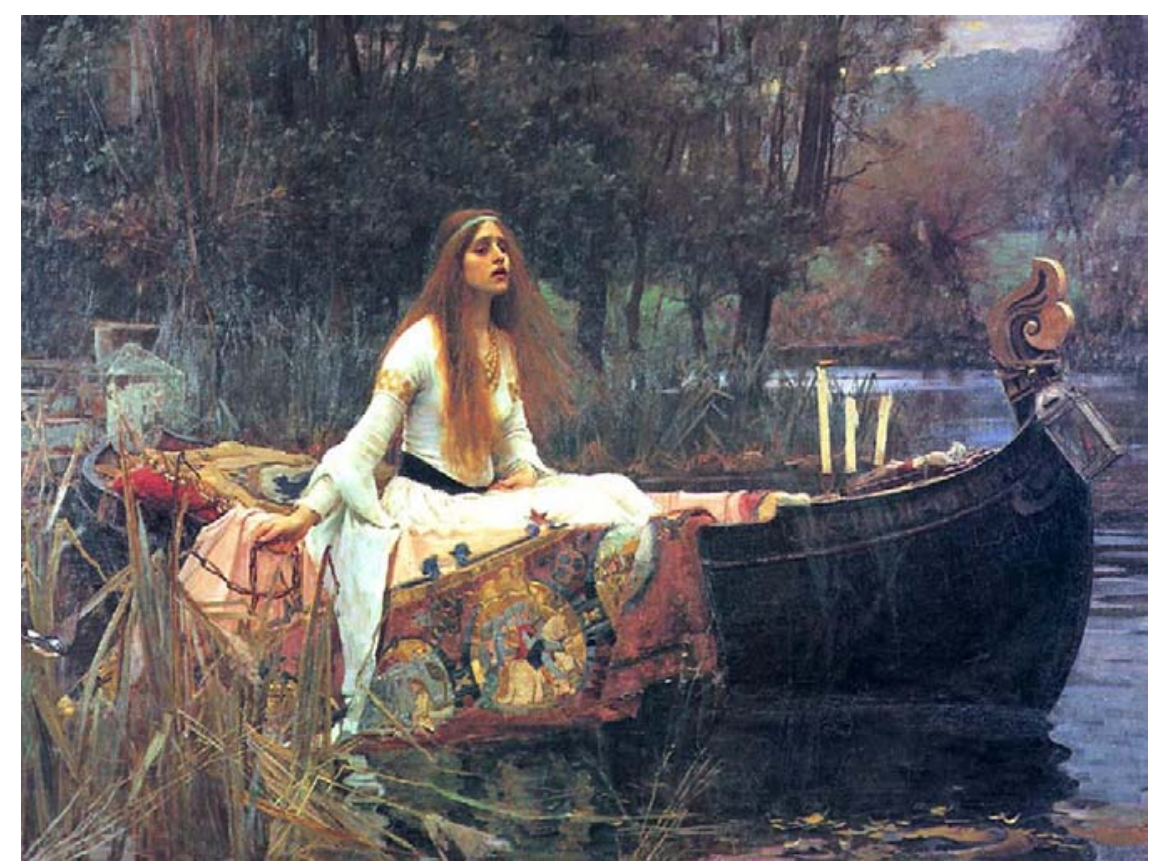

Fig. 2. La Dama de Shalott (c. 1888) por John William Waterhouse.

A pesar de que Elaine es siempre representada como una joven adolescente, en su esbeltez se insinúa un cuerpo casi infantil. De hecho, Tennyson introduce constantemente términos que enfatizan su semblante aniñado y la candidez infantil de la «doncella del lirio» ${ }^{30}$.

\footnotetext{
${ }^{29}$ Algunos autores identifican al servidor mudo como un reflejo de la pureza del silencio femenino de Elaine, en MONTGOMERY, Lucy Maud. The Annotaded Anne of Green Gables. New York/Oxford: Oxford University Press, 1997, pág. 460.

30 Lanzarote la llama su «niña».
} 
El trágico destino de las heroínas de Tennyson, contribuyó tanto en hombres como en mujeres a alimentar el idealismo del medievo inglés de tradición y mitología celta y paraíso arcaico. El crítico francés, Hippolyte Taine ${ }^{31}$, observa, que las niñas Iloraban cuando escuchaban el relato de Elaine ${ }^{32}$.

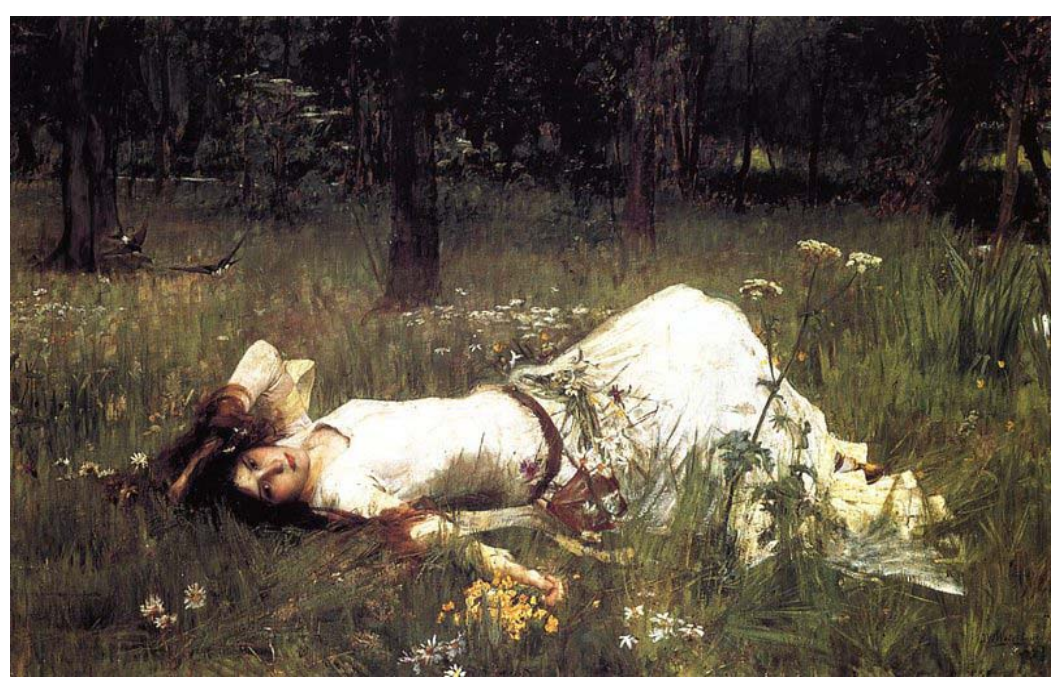

Fig. 3. Ofelia (1889) por John William Waterhouse.

«Ofelia» en Hamlet de Shakespeare, ofreció a la imaginación victoriana una inagotable fuente de interpretaciones que se ajustaban al canon de belleza agonizante y sufriente. Ofelia como Elaine, sufren las consecuencia de un amor no correspondido; el siempre desenlace fatal del suicidio indolente, ahogándose en el río ${ }^{33}$. John Ruskin la calificaría ésta forma de morir de «muerte débil», pues la virtud femenina en Ofelia

\footnotetext{
${ }^{31}$ TAINE, H. Histoire de la Littérature Anglaise, 1863-64 [Trad. History of English Literature].

32 Cf. con la representación de la «doncella del lirio» en Ana de las Tejas Verdes de Lucy Maud Montgomery, pág. 40 del presente trabajo.

${ }^{33}$ La muerte en el agua puede considerarse como una especie de rito funerario, como el de cubrir al cadáver con tierra. PROPP, Vladimir. Las raíces históricas del cuento. Madrid: Editorial Fundamentos, 1987, pág. 289.
} 
debiera hallarse en ayudar a Hamlet en los momentos críticos ${ }^{34}$, en lugar de dejarse arrastrar por el deleite del ser moribundo tan del gusto de la mujer victoriana.

Edgar Allan Poe escribiría: «...la muerte de una bella mujer es, indudablemente, el más poético tópico del mundo...» ${ }^{35}$. Algunos autores, como L. A. Fiedler, han llegado a señalar con ironía la «peligrosidad» de tales afirmaciones: «...la única mujer que está a salvo es la que está muerta; pero incluso si ella, es joven y bella, sólo está a salvo a medias, como algunos americanos saben, recordando la necrofilia de Edgar Allan Poe. La única "a salvo", es la fémina preadolescente agonizante o muerta...» ${ }^{36}$.

La obra de Poe es un compendio de la exaltación erótica de la muerte. El fetichismo necrófilo se evidencia en numerosos escritos y poemas. En 1836, Poe contrajo matrimonio con Virginia Clemm, la cual era todavía una niña. Su actitud infantil la acompañó hasta su muerte en 1847. Poe idolatraba a su joven esposa, que más que esposa, resultó ser para él la esencia del alma pura y eterna. En 1849, escribió el poema Annabel Lee, en el que recuerda a un amor de juventud, «Annabel Lee», muerta prematuramente y a la que todavía ama. Sin duda, Annabel es Virginia:

$$
\begin{aligned}
& \text { «(...) Allí vivía una doncella conocida } \\
& \text { por el nombre de Annabel Lee; } \\
& \text { (...) un viento llegó desde una nube, helando } \\
& \text { a mi hermosa Annabel Lee; }
\end{aligned}
$$

\footnotetext{
${ }^{34}$ RUSKIN, John. Sésamo y lirios. Ensayos Sociales. Buenos Aires: Espasa-Calpe, 1950, pág. 92.

35 Traducción de la autora, POE, Edgar A. "The Philosophy of Composition". Edgar Allan Poe: Essays and Reviews. New York: Ed. G.R. Thompson, The Library of America, 1984, págs. 13-25. Cit. en HARDING, Ellen. Re-framing the Pre-Raphaelites: Historical and Theoretical essays. Aldershot: Scolar Press, 1996, pág. 173.

${ }^{36}$ Trad. de la autora. FIEDLER, L. A. Love and Death in American Novel. New York: Criterion Books, 1960, pág. 264.
} 
(...) y la apartó de mi lado, para enterrarla en un sepulcro en aquel reino junto al mar.

(...) y así, durante la noche, permanezco tendido al lado de mi querida, mi querida, mi vida y mi novia, allá en el sepulcro junto al mar en su tumba junto al mar sonoro».

O como en Ulalume (1846), el amor perdido se manifiesta en el eco fantasmal, de un nombre escrito sobre una tumba:

\author{
«(...) y fuimos hasta donde la puerta de una tumba, \\ la puerta de una legendaria tumba; \\ y dije: «¿Qué hay escrito, dulce hermana, \\ en la puerta de esta legendaria tumba?» \\ Ella contestó: «Ulalume, Ulalume
} iEs el sepulcro de tu perdida Ulalume! $(\ldots)^{37} \gg$.

En la poesía de Poe, el amante se recrea con la muerte de la amada. Son muchachas muertas hace años, en la juventud, cuando el primer amor y a la que todavía ama incluso por encima de los posteriores amores.

Julia Kristeva, indica que para superar el desapego por la pérdida de la difunta, el «objeto perdido», debe ser reconvertido en objeto erótico, o sublimándolo. Pero si esta conversión no se realiza adecuadamente, por ejemplo, convirtiéndolo en creación artística, la difunta permanece en el sujeto. Esta es la actitud de Edgar Allan Poe, vagando en la oscuridad buscando amores espectrales ${ }^{38}$.

\footnotetext{
37 Poe utiliza las palabras no tanto por su significado como por capacidad sonora de evocar. Así, con «Ulalume, Ulalume» consigue crear una atmósfera ultraterrena, de ensoñación, de eco lejano.

38 PEDRAZA, Pilar. Espectra. Descenso a las criptas de la literatura y el cine. Madrid: Valdemar, 2004, pág. 14.
} 
Pero la muerte, a veces es sólo en apariencia. Un recurso paralelo, es el de la doncella dormida. Dormir, conlleva un abandono físico y psíquico y ello se asocia a la vulnerabilidad sexual. Bram Dijkstra señala que el sueño actúa como metáfora de la virginidad. La muerte y el sueño, son una metáfora de la pasividad femenina, vista como virtud dentro de los valores victorianos.

A menudo, los cuentos infantiles o de hadas han incorporado este tipo de figuras para expresar un ideal de virtud femenina o unos valores morales concretos, como en Blancanieves y los siete enanitos o La bella durmiente. Con los descubrimientos del psicoanálisis a finales del siglo XIX, se revelaron los contenidos violentos o sexuales en los cuentos de hadas. Este ocultamiento, se debió en gran medida a autores como Perrault, los hermanos Grimm o Hans Christian Andersen, que realizaron recopilaciones de cuentos populares, modificándolos y reescribiéndolos a menudo de tal manera, que las formas originales procedentes de la tradición oral quedaron enmascaradas bajo una narración dulcificada.

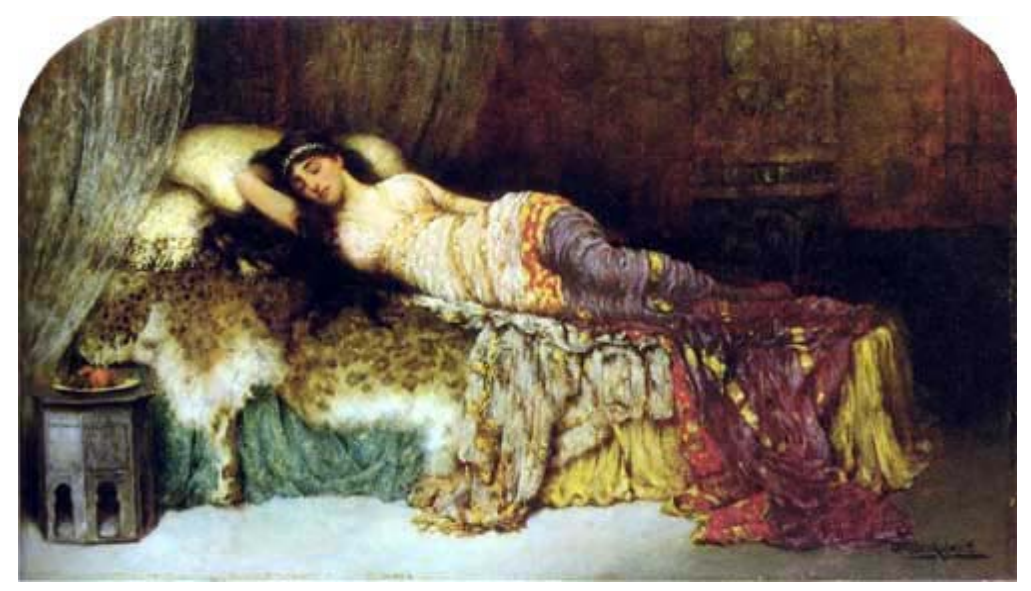

Fig. 4. La bella durmiente (s.a) por William A. Breakspeare. 
En 1765, se expuso la primera escultura del Museo de cera de Madame Tussaud, en Londres. Se trataba de la figura más antigua modelada por Philippe Curtis -mentor de Madame Tussaud-, La bella durmiente. El público acudía expectante para observar aquella figura que además de mostrar una apariencia humana, contaba con un mecanismo interno que subía y bajaba el pecho simulando la respiración.

Aurora $^{39}$, la «Bella Durmiente», es un personaje extraordinario, pues es su inactividad, su «falta de acción», es la que define verdaderamente su «acción» en el contexto del cuento. Bruno Bettelheim, señalaría que se trata de la encarnación de la perfecta feminidad ${ }^{40}$. El cuento comienza con el nacimiento de Aurora, la hija de un rey y una reina. Durante la fiesta del bautizo, siete hadas madrinas le concederían un regalo, destinado a que cuando creciese se convirtiese en la princesa más perfecta del mundo. Las hadas, una tras otra, le regalaron belleza, elegancia, inteligencia, ser espléndida bailarina, una cantante maravillosa y una música excepcional. La hadas ofrecen a la niña todas aquellas consideradas virtudes femeninas, destinadas a hacerla una buena esposa y princesa. Pero un hada malvada, que no había sido invitada se presentó enfadada y le echó una maldición: «Que la princesa se pincharía el dedo con una rueca y moriría». Pero todavía faltaba una de las hadas madrinas por concederle su regalo y esta añadió a la maldición, que no moriría sino que permanecería en un profundo sueño durante 100 años hasta que un príncipe la despertara. A pesar de las precauciones del rey y la reina, que mandaron quemar

\footnotetext{
${ }^{39}$ Aurora es el nombre en la versión original francesa de Perrault, también utilizado en la película de animación de Walt Disney.

${ }^{40}$ BETTELHEIM, Bruno. Psicoanálisis de los cuentos de hadas. Barcelona: Biblioteca de bolsillo, Crítica, 2003, pág. 244.
} 
todas las ruecas del reino, la maldición se cumpliría ${ }^{41}$. El estado de sueño paraliza el proceso de crecimiento y de madurez sexual esperando a que pasen los 100 años. Estos 100 se asocian con un estado de pasividad previa a su primera menstruación así como la maldición representa simbólicamente la menstruación ${ }^{42}$.

De la misma manera, otras doncellas también preservan su virginidad en el estado de sueño o semejanza de muerte ${ }^{43}$. Como en $\mathrm{La}$ bella durmiente, Blancanieves es una hermosa niña que permanece en un estado de muerte aparente. Blancanieves, como el resto de doncellas dormidas, llega a ese estado al sucumbir ante la tentación, esta vez en forma de manzana, elemento de la iconografía judeo-cristiana, que nos remite al pecado original y a la pérdida de la inocencia. La relación edípica de la niña con su padre y la belleza de ésta, hace surgir los celos constantes de la madrastra, que decide matarla. La belleza excepcional de la niña, como la de otras heroínas literarias, no sólo representa la hermosura física, sino que también la bondad y la nobleza de la doncella ${ }^{44}$.

Blancanieves, ya había escapado de la muerte a manos de un cazador al que la madrastra había ordenado matarla, pero éste

\footnotetext{
${ }^{41}$ El intento por evitar la maldición, hace referencia al Mito de Edipo.

42 Bettelheim encuentra un profuso simbolismo freudiano en los distintos acontecimientos del cuento. La sexualidad frenada por el sueño, la llegada de esa mima sexualidad mediante la simbólica menstruación al pincharse el dedo con una rueca y sangrar, etc... La maldición, que en el cuento en lengua inglesa es "curse", significa también "menstruación".

${ }^{43}$ Lo que Vladimir Propp llama muerte «ficticia» O «mágica», a la que se le atribuye la presencia de un objeto extraño en el cuerpo, como en el caso de la manzana envenenada en la garganta de Blancanieves. PROPP, Vladimir. Op. cit., pág. 184.

${ }^{44}$ El cuento señala que Blancanieves al cumplir los siete años, era tan hermosa como la luz del día y mucho más que la Reina. En los pasados siglos, se consideraba a menudo que la edad de transición de la infancia a la edad adulta comenzaba a los 7 años de edad.
} 
compadecido ante la belleza de la niña no la mató ${ }^{45}$. Tras varios intentos fallidos, la madrastra logra engañar a Blancanieves, que cae muerta tras morder una manzana envenenada que ésta le ofrece, disfrazada de anciana buhonera. Los enanos, deciden fabricar una caja de cristal donde meterla en lugar de enterrarla, pues el cuerpo de Blancanieves no se corrompe y conserva las mejillas sonrosadas. Un príncipe que la ve, pide a los enanos que se la regalen pues ya no puede vivir sin verla. Los enanos y el príncipe, son personajes que manifiestan el impulso necrófilo, ya que la niña sigue siendo objeto de deseo, veneración y atracción tras su muerte ${ }^{46}$. Así pues, el príncipe ordena a sus criados que transporten el féretro, pero durante el camino, tropiezan y eso provoca que la niña expulse el trozo de manzana que había quedado atragantado, volviendo a la vida. El príncipe tras contarle lo ocurrido le pide como esposa y ésta acepta. Es decir, que Blancanieves, ha dejado de ser niña para poder asumir su condición de madurez sexual.

\subsubsection{Vírgenes, monjas, doncellas y niñas.}

En la sociedad victoriana, la virginidad, constituía una de las virtudes femeninas, la cual debía conservarse hasta el matrimonio. Por otro lado, la virginidad no sólo se trataba de un estado de pureza y castidad en términos de sexualidad, sino también mentales. Fácilmente, la «virginidad» podía prolongarse más allá de lo físico, en el estado de inocencia mental.

\footnotetext{
45 El cazador para dar prueba de la muerte de Blancanieves, le entrega a la madrastra el hígado y pulmones de un jabato, los cuales ordena cocinar y convencida de que se tratan de los de la niña se los come. La madrastra descubre el engaño al preguntar a su espejo mágico si ella es la más hermosa, a lo que contesta que Blancanieves es la más bella y que sigue viva, oculta en el bosque en casa de unos enanos. Comentario en base a la versión de los Hnos. Grimm.

${ }^{46} \mathrm{Su}$ belleza permanece intacta pues así como deben permanecer las difuntas. Como señala Mario Praz, «lo horrendo se transformó en uno de los elementos propios de la belleza». PRAZ, Mario. Op. cit., pág. 69.
} 
Los cuentos infantiles como ya se ha visto, abordaban en sus versiones originales temas morales que ilustraban los beneficios de un tipo de conductas sobre otras. Por ello y como moraleja moral, algunas vírgenes, las «doncellas» de los cuentos, caen en la fatalidad tras sucumbir en las tentaciones, Blancanieves, la Bella durmiente, o la Dama de Shalott, entre otras.

Son varios los aspectos que sin duda, hicieron de La dama de Shalott uno de los temas preferidos de los artistas prerrafaelistas. Por un lado su muerte y por otro, el confinamiento en la torre, que sugiere una obsesión de la Inglaterra victoriana respecto a la virtud femenina: el resguardo de la virginidad. La prisión es su virginidad y su virtud es puesta a prueba mostrándole indirectamente el mundo exterior en el reflejo del espejo. Pero el deseo le supera. El aprisionamiento, es decir, la maldición, alude a un estado de clausura como el de una monja. El hecho mismo de ser prisionera en una torre, encierra múltiples significados. La «Dama», no sólo está prisionera en una torre en sentido literal, sino que es una doncella reprimida a la pasión, a la sensualidad y al amor que su juventud experimenta. La Dama de Shalott se resguarda de las tentaciones y de los placeres mundanos, para dedicarse a una vida espiritual, cercana a Dios, en su caso a través del $\operatorname{arte}^{47}$ y la resignación, como pretendían los artistas prerrafaelistas. Su rechazo por lo mundano y lo carnal, es puesto a prueba, pues ella puede ver el mundo en el reflejo del espejo.

Algunos comportamientos pecaminosos de las doncellas son más evidentes y nos enuncian el posible destino. Pero en otros relatos, las metáforas utilizadas sólo parecen ser reveladas por el psicoanálisis. Bettelheim, por ejemplo nos descubre, el carácter inmaduro de la

\footnotetext{
${ }^{47}$ N. B. el cap. 3. La Hermandad Prerrafaelista y el arte victoriano, pág. 65.
} 
heroína del cuento La cuidadora de gansos de los Hnos. Grimm ${ }^{48}$. La pérdida del pañuelo con las gotas de sangre aunque es perdido involuntariamente parece indicar que inconscientemente, la princesa no desea casarse y perder la virginidad y con ello se desencadena un retraso o cambio de los acontecimientos. La princesa todavía no está preparada para los retos de una vida adulta, lo que desvela su juventud sexual. Existe otra versión francesa que utiliza como elemento mágico una manzana de oro en lugar del pañuelo con las gotas de sangre. La manzana en éste caso hace referencia a Eva y los frutos del árbol del Paraíso, pero de nuevo, se hace referencia a la madurez sexual que la princesa no puede todavía asumir.

La incapacidad de las «princesas de los cuentos de hadas» para enfrentarse a las dificultades que les sobrevienen, es la representación de la inmadurez sexual de las niñas. No es casual, que las «princesas» sean prisioneras o sufran desgracias justo en el cambio de la niñez a la adolescencia, cuando el cuerpo siente el despertar sexual.

\footnotetext{
${ }^{48}$ GRIMM, Hermanos. Cuentos de los hermanos Grimm. Barcelona: Ediciones B, 2000, pág. 223. El cuento comienza cuando una bella princesa montada sobre su caballo parlante, Farala, se dirige al reino donde un príncipe la aguarda para contraer matrimonio. Le acompaña una doncella de cámara que monta sobre otro caballo. Antes de marchar, la reina, su madre, le regala un pañuelo manchado de tres gotas de su sangre, recomendándole su guarda, pues le hará falta. Pero por el camino, la princesa pierde sin darse cuenta el pañuelo en un riachuelo y la doncella decide hacerse pasa por la princesa, amenazando a la princesa de muerte si dijese algo. La princesa promete silencio. La falsa princesa, es recibida con honores por el rey y el príncipe, mientras a la verdadera princesa, la ponen a cuidar gansos junto a un joven. Temiendo que Farala hable, la falsa princesa manda a un desollador, que sacrifique al caballo, pero la cuidadora de gansos, logra que la cabeza de Farala sea colgada en una puerta por dónde ella pasa con los gansos. El cuidador de gansos advierte el extraño comportamiento de su nueva acompañante, que habla con la cabeza del caballo y se lo dice al rey, que busca la manera de descubrir el misterio escondiéndose en una gran caldera. La cuidadora de gansos, grita su secreto en el interior de una caldera, por la que el rey escucha lo sucedido. Sin desvelar la verdad, el rey le pregunta a la falsa princesa, cual sería el castigo para alguien que hiciera, lo que ella había hecho. Ésta le describe una atroz martirio hasta la muerte. Entonces el rey descubre la trama y la condena al castigo que ella misma había imaginado. Finalmente la princesa se casa con el príncipe y viven dichosamente.
} 
Rapunzel, en la versión de los Hnos. Grimm, trata de una bella niña que vivía feliz y sin preocupaciones con una hechicera. La niña fue arrebatada de los brazos de su madre al nacer, como castigo por comer lechugas de su huerto durante el embarazo. Pero al cumplir la niña los doce años ${ }^{49}$, la bruja que la cuida, temerosa de que otros puedan observar su belleza, la oculta en una torre ${ }^{50}$. La niña debe lanzar su larga y dorada trenza ${ }^{51}$ para que la bruja trepe por ella y pueda visitarla, lo que también hará el príncipe hasta que sea descubierto por la hechicera ${ }^{52}$.

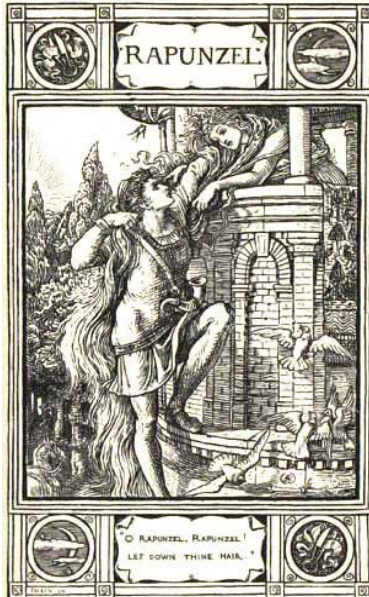

Fig. 5. Rapunzel (1882). Walter Crane para Household Stories from the Collection of the Brothers Grimm.

Como la Dama de Shalott, la niña es preservada de la sexualidad y de la realidad circundante, recurriendo al confinamiento en una torre. Por otra parte, Rapunzel acepta casarse con el príncipe, no tanto por el enamoramiento, sino por que piensa que el matrimonio con un joven bien

\footnotetext{
49 Es generalmente a la edad de doce años cuando las niñas entran el la pubertad, les llega la menstruación y sienten los primeros impulsos sexuales.

50 Como La dama de Shalott, de Tennyson.

${ }^{51}$ La cabellera dorada servirá también de instrumento de liberación o mediador como en el poema de Christina Georgina Rossetti, Goblin Market (1865), en el que una bondadosa niña es expulsada de su casa por su hermanastra, pero la niña es cuidada y alimentada por numerosos animalitos del campo a cambio de uno de sus rizos dorados. ROSSETTI, Christina Georgina. El mercado de los duendes. Valencia: Pre-Textos, 2004. La cabellera femenina constituye uno de los fetiches sexuales más comunes de la imaginación masculina. Numerosos autores sugieren que el vello púbico es sustituido por el subconsciente por la cabellera femenina, connotándola impúdica y obscena. Véase The Unconscious Significante of Hair, Londres: 1951, pág. 67. Tesis previa de R. Von Krafft-Ebing. Psychopathia Sexualis. New York: 1965, pág. 49 (1ª ed. 1886). Citados en BORNEY, Erika. La cabellera femenina. Un dialogo entre poesía y pintura. Madrid: Cátedra, 1994, pág. 15.

52 La reclusión de las jóvenes es comparada a la «segregación» realizada durante la purificación menstrual, de manera que se eviten los peligros relativos al contacto con la mujer durante la menstruación, según la creencia popular. PROPP, Vladimir. Op. cit., págs. 55 y 59.
} 
parecido, será mucho mejor que el vivir aislada con la compañía de la bruja que la visita: «...y cuando él le preguntó si lo quería por esposo, viendo la muchacha que era joven y apuesto», pensó, «Me querrá más que la vieja»53.

El simbolismo de Caperucita Roja, responde a un contenido verdaderamente singular respecto a la inocencia y la virginidad infantil. Si bien existen múltiples versiones del cuento, en todas se enfatizan de manera más o menos evidente la inocencia frente a la sexualidad de la ambigua niña ${ }^{54}$. La inocencia está representada claramente por la pequeña Caperucita. El propio título ${ }^{55}$ del cuento se enuncia por la pequeña prenda roja que lleva la niña, y es pequeña la niña por que la caperuza es pequeña. Durante el cuento, Caperucita se muestra no sólo como una niña inocente y sencilla sino que su ingenuidad es casi estupidez, como podemos ver en la escena cuando confiada, le cuenta al lobo donde vive su abuelita o cuando le pregunta al lobo metido dentro de la cama, disfrazado de la abuelita. Caperucita parece nadar contracorriente, pues su actitud es completamente irresponsable. Al comienzo del cuento cuando su madre le pide que visite a la abuelita, le aconseja no salirse del camino y le advierte de los peligros de hablar con los desconocidos ${ }^{56}$. Obviamente los peligros son sexuales, sin embargo, lo primero que hace es internarse en el bosque y hablar confiada con el Lobo.

${ }^{53}$ AAVV. Érase una Vez... Una colección de los mejores cuentos de hadas. Montreal: Tormont Publications, 2004.

${ }^{54}$ Charles Perrault adaptó numerosos cuentos de la tradición oral como Cenicienta o La bella durmiente para divertimento de la corte de Luis XIV. Pero Caperucita roja, era más bien lo que los alemanes llaman «Schrechmärchen», es decir, una historia de miedo para prevenir a las niñas del trato con desconocidos.

55 El título en inglés es Little Red Riding Hood, pero el título original que le dieron los Hnos. Grimm es el de Little Red Cap, el cual resulta más obvio y apropiado. Hood, capa o capilla en castellano se cambia por el término Cap, caperuza.

${ }^{56}$ Esto es más evidente en la versión de Perrault. 
Así pues Caperucita, no es todo ingenuidad. Bettelheim, identifica en el rojo de la caperuza, una representación simbólica de las pasiones sexuales y violentas y la transmisión de una prematura sexualidad por parte de la abuelita a su nieta, regalándole la caperuza. Otros investigadores como Erich Fromm, consideran la «caperuza» un símbolo de la menstruación y con ella la llegada de la pubertad.

La extravagante escena de Caperucita y el Lobo en la cama, no deja sino de evidenciar por una parte, el carácter ingenuo de la niña que intrigada pregunta al Lobo disfrazado de abuelita, por el tamaño de sus orejas, su boca, etc... Por otro lado, responde más a una escena de seducción de Caperucita hacia el Lobo. El Lobo, representa al seductor masculino. Bettelheim, señala el deseo Edípico, en este caso de Elektra, en la figura de Caperucita. Muerta la madre -la abuela es la representación maternal-, la hija -Caperucita- desea inconscientemente seducir o ser seducida por el padre -el Lobo-. La crítica feminista, ha identificado la idea de devorar a Caperucita, y previamente también a la abuelita, como una metáfora de la violación.

La segunda figura masculina, es la de el Cazador ${ }^{57}$. Cuando éste entra en la casa de la abuelita y ve al Lobo sobre la cama, le dice: «¿Aquí estás, viejo verde? Con el tiempo que llevaba buscándote» ${ }^{58}$. Con «viejo verde» se resalta de nuevo la seducción, en este caso del Lobo hacia Caperucita, pues es lo que se diría de un hombre adulto que seduce a una jovencita.

Así pues, los cuentos de hadas ahondan en la virtud femenina, y ponen de manifiesto los peligros de una vida femenina poco «recta» o

\footnotetext{
${ }^{57}$ En la versión de Perrault, «Caperucita», muere tras ser engullida por el lobo, terminando así la historia. Los Hnos. Grimm aportaron un final en el que ella y la abuelita son salvadas por un cazador.

58 La sexualidad y la seducción, es más evidente y metafórica en la versión de Perrault.
} 
alejada de las convenciones sociales que dictan el concepto de feminidad y las conductas virtuosas, mediante un simbolismo avenido por las diferentes tradiciones culturales en las que se desarrollan los relatos orales y escritos. Por otro lado, ilustran cuáles son pues las actitudes a seguir para un crecimiento virtuoso, entendido en términos de virginidad, castidad, bondad, sencillez.

Cenicienta ${ }^{59}$ es sin duda el más conocido de los cuentos de hadas, si bien es un cuento sobre las rivalidades fraternales y de la humillación de una joven que es obligada a hacer de sirvienta de sus hermanastras, también lo es por el triunfo de la heroína gracias a su belleza y sus dotes naturales, por encima de las penurias.

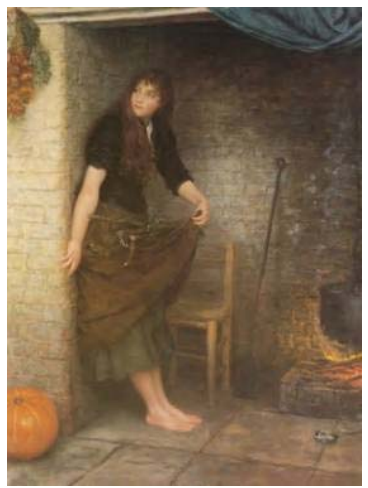

Fig. 6. Cenicienta (1899) por Valentine Cameron Prinsep.
Profundizando en el significado psicoanalítico dado por Bettelheim, el pie se introduce y desliza en el interior de la zapatilla de manera que quede bien ajustado, de la misma manera que el pene en el interior de la vagina ${ }^{60}$, así como la pérdida de la zapatilla de cristal $^{61}$, hace referencia a la pérdida de la virginidad, tras el intento por conservarla, escapando rápidamente del baile antes de la medianoche.

\footnotetext{
${ }^{59}$ Cenicienta procede de un antiguo relato chino escrito en el siglo IX d. C, que ya contaba con una larga tradición. En él se ensalzaba la belleza de la muchacha a través de sus pequeños pies, considerados en la cultura china como signos de virtud y belleza.

60 Numerosas tradiciones orientales como occidentales asocian las zapatillas como símbolo sexual y representación simbólica de la vagina. BETTELHEIM, Bruno. Op. cit., pág. 277 y n. 99 y 100.

${ }^{61} \mathrm{El}$ hecho de que se trate de unas zapatillas de cristal se ha debatido por numerosos autores, justificando esta particularidad, como un equívoco de Perrault al escuchar el cuento, confundiendo la palabra vair (piel jaspeada), por verre (cristal), fonéticamente similares en francés. Otros autores apuntan al cambio intencionado. BETTELHEIM, Bruno. Op. cit., pág. 259.
} 
No es casual que en numerosos cuentos populares, las niñas o jóvenes sean representadas como huérfanas de padre -probablemente Caperucita-, o de madre como Blancanieves o Cenicienta, y que son adoptados por brujas como Rapunzel o personas que los esclavizan y explotan como los personajes de Charles Dickens. Aunque lo niños huérfanos y desvalidos de sus novelas como Oliver Twist o David Cooperfield, se han convertido en el paradigma de la orfandad en la Inglaterra victoriana, Dickens jamás dio un protagonismo rotundo a ninguna huérfana.

Charlotte Brontë sin embargo, se aproximó a la orfandad femenina mediante su famosa novela Jane Eyre. En ella, se narra la vida de la «pobre, vulgar y huérfana» Jane, que como los protagonistas de Dickens, se verán obligados a vivir su infancia y juventud enfrentándose a las dificultades de la vida de la «dudosa» caridad de las instituciones benéficas de la época y con parientes tiránicos. No obstante, la escritora canadiense Lucy Maud Montgomery, utilizó el ideal melancólico y el atractivo del romanticismo de los poemas de Tennyson y los ideales prerrafaelistas para definir el carácter enamoradizo de la «huérfana» y de influencia post-romántica en Ana de las Tejas Verdes, sin abordar la orfandad en términos de dramatismo. Su novela publicada en junio de 1908 obtuvo un gran éxito juvenil. En ella se narra la historia de una extravagante e imaginativa pelirroja que es adoptada por dos hermanos. Ana, como los protagonistas de las historias de Dickens, había sufrido siempre privaciones y vivido en diferentes hogares incluso cuidando niños cuando ella misma era una niña. Pero la novela comienza cuando Anna está a punto de ser adoptada «por error» por los hermanos, Marilla y Matthew Cuthbert, que lo que en realidad deseaban era un chico para ayudar en la granja. La propia Ana Shirley, a menudo se identifica con las obras de Tennyson y con el infortunio de Elaine de Los 
idilios del rey. En el capítulo $28^{62}$, Ana quiere representar junto a otras niñas, Jane y Ruby, la escena de Elaine muerta en la barca. Ruby -una de las niñas-, tiene miedo a interpretarla pues está muerta, a lo que Jane agrega: «Desde luego que sería romántico». Así que es Ana la que la interpreta. Por desgracia, el bote tiene el fondo agujereado y no tiene remos, y a medida que avanza río abajo se va llenando de agua hasta hundirse. Ana logra sujetarse a un puente de madera, pero sus amigas, que la esperan en otro punto del margen del río, no se percatan y sólo logran ver el bote medio hundido, pensando que Ana se ha ahogado y que ha muerto como «la doncella del lirio». En esta escena se refleja la añoranza de una época inexistente, que incluso décadas después de la etapa victoriana seguiría vigente.

Mientras algunas jóvenes vírgenes, luchan por salir adelante en la vida o conservar su virginidad sin demasiado éxito, otros personajes, permanecen firmes en su castidad. Así la representación de personajes cristianos, resultan no sólo moralizadores, sino también edificantes y admirables, sobre todo en su representación infantil, como la Virgen María niña en La juventud de la Virgen María [Girlhood of Mary Virgin] (1849) de Rossetti o Santa Isabel de Hungría en Santa Isabel de Hungría (1882) por Sándor Liezen-Mayer. ${ }^{63}$. Santa Isabel de Hungría era una noble medieval que tras quedar viuda, abandona las vanidades del mundo para unirse a Dios en la consagración religiosa de la vida contemplativa. Fue canonizada en 1235. Su amor sí es correspondido por Cristo y es por ello que se la representa dedicada a los pobres, en oración y en la mortificación.

\footnotetext{
62 "Una desgraciada doncella de los lirios". MONTGOMERY, Lucy Maud. Ana la de Tejas Verdes. Barcelona: Emecé Editores, 1996, pág. 250.

63 Millais, Rossetti, Collinson o Marianne Stokes entre otros trabajaron esta temática.
} 


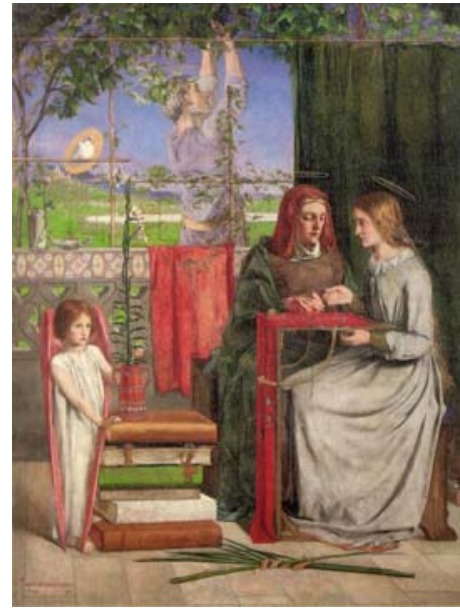

Fig. 7. La juventud de la Virgen María (1848-9) por Dante Gabriel Rossetti.

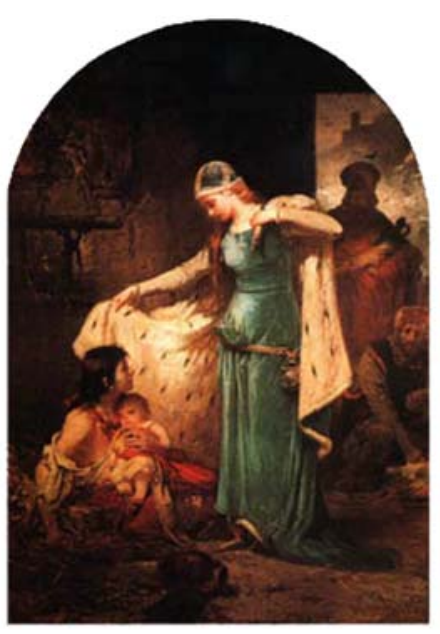

Fig. 8. Santa Isabel de Hungría (1882) por Sándor Liezen-Mayer.

La santidad es la cualidad que deben ambicionar las jóvenes, según la moral victoriana. Y esa ambición pasa por la observancia de la castidad, la abnegación, el «ser persistente e incorruptiblemente buena, instintiva e infaliblemente sabia» como aleccionaría John Ruskin en Sésamo y lirios, en ser la «monja hogareña» que identifica Dijkstra64, perfecta representación de santa y niña en una misma persona.

\subsection{4. Ángeles, seres extraordinarios y jóvenes perversas.}

En la imaginación colectiva imperante de finales de los siglos XVIII y XIX, la mujer tenía sentido como tal dentro de extremos espirituales ${ }^{65}$, es decir, que se definía en términos de santidad o de condenación, pues la mujer, es sólo humana en la medida que se relaciona con el mundo masculino. Es en la intimidad de la vida

\footnotetext{
${ }^{64}$ DIJKSTRA, Bram. Óp cit., págs. 14, 22.

${ }^{65}$ AUERBACH. Woman and the Demon: The Life of a Victorian Myth. Cambridge: Harvard University Press, 1982, pág. 64.
} 
femenina, donde la mujer desarrolla su verdadera naturaleza, la cual sólo es percibida por el hombre en forma de enigmático misterio.

La Biblia habla de siete arcángeles (Tb. 12,15; Ap. 1,4). De ellos no se explicita su sexo, sin embargo a algunos se les conoce por su nombre propio masculino e incluso por apariencia masculina como Gabriel (Dan. 8, 15-16; 9,21; Lc. 1, 19, 26) o Miguel Arcángel (Dan. 10, 13. 20; Ap. 12, 7; Jdt. 9) y en contadas ocasiones, aparecen en el Antiguo Testamento en formas femeninas y el Zohar, Libro de la cábala judía, los ángeles son masculinos y femeninos. También se les conoce por nombres colectivos según su nivel jerárquico como Principados, Arcángeles, Dominios, Virtudes, Querubines (Ex. 1,4; Heb. 9,5), Serafines (Is. 6, 17), etc ${ }^{66}$. Los ángeles ${ }^{67}$ son espíritus creados por Dios (Sal. 148:2,5; Col 1:16) y su Naturaleza es pura (Mat. 8:16; 12:45; Lu. 7:21; 11:26; Hechos. 19:12; Ef.6:12; Heb. $1: 14)$. Son «Criaturas Morales» (Gen. 1:27; Jn. 8:44; 2 Ped. 2:4; Judas 6) y Su labor es esencialmente la de servir a Dios según Su obra (Dan. 10:13,20).

San Agustín diría al respecto: «El nombre de ángel indica su oficio, no su naturaleza. Si preguntas por su naturaleza, te diré que es un espíritu; si preguntas por lo que hace, te diré que es un ánge/» ${ }^{68}$. La angeología cristiana inicialmente representaba a los ángeles en género masculino, procedentes de la representación del

\footnotetext{
${ }^{66}$ Cada tres coros de ángeles constituyen una jerarquía y todos ellos forman la corte celestial: Jerarquía Suprema -serafines, querubines y tronos-, Jerarquía Media -dominaciones, virtudes, potestades- y Jerarquía Inferior -principados, ángeles, arcángeles-. Sobre la existencia de los ángeles, AQUINO, Tomás de. Madrid: Suma teología. BAC, 1994.

${ }^{67}$ Del latín «angelu» y del griego «angelos», significa mensajero.

68 «Angelus officii nomen est, non naturae. Quaeris nomen huius naturae, spiritus est; Quaeris officium, ángelus est: ex eo quod est, spiritus est, ex eo quod agit, angelus». Psal. 103, 1, 5. Lo recoge San Agustín, en el Concilio Ecuménico Lateranense , S. IV.
} 
dios griego Eros, pero sobre todo de Cupido, su equivalente romano. No es hasta el siglo $\mathrm{XV}$, cuando encontramos ángeles del género femenino.

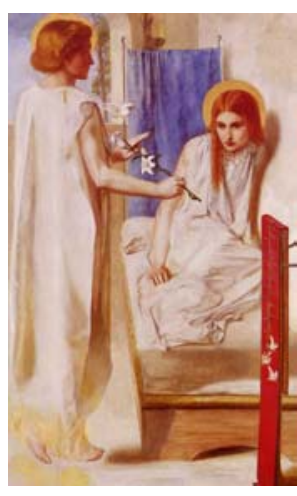

Fig. 9. Ecce Ancilla Domini (1850), Dante Gabriel Rossetti.

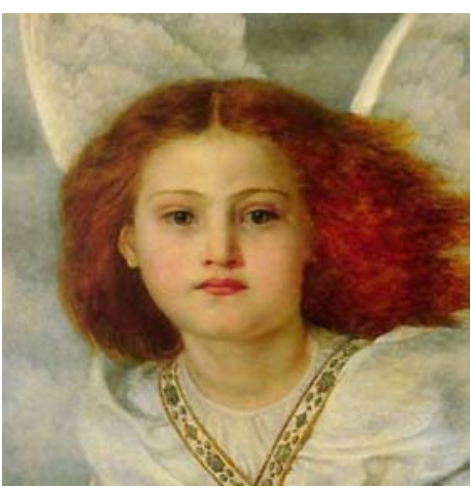

Fig. 10. Pájaro de Dios [Bird of God] (1861) por Joanna Boyce.

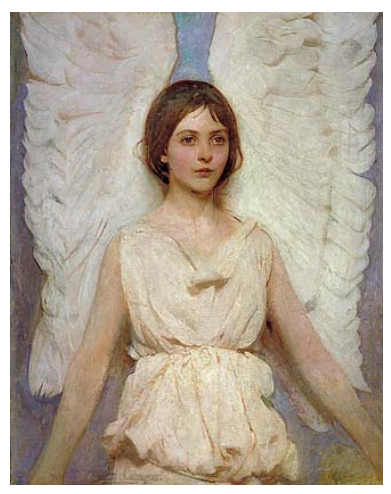

Fig. 11. Ángel (1887), Abbott Handerson Thayer.

La maldad femenina toma fuerza con la femme fatale desarrollada por el simbolismo europeo, que retoma personajes mitológicos femeninos característicamente malvados, ya fuera por su carácter seductor, sensual, pervertido e inquietante, o incluso asesino, que provocaba la desgracia de los hombres que osaban a cercarse a ellas. Son mujeres como Venus, Proserpina o Circe, pero también bíblicos o históricos como Lilith, Eva, Salomé, Judith o Cleopatra.

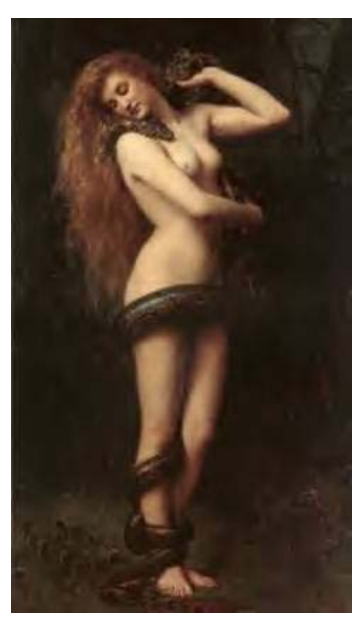

Fig. 12. Lilith (1887) por John Collier.

En la literatura encontramos personajes como Andrómeda, que Jules Laforgue define como «una pequeña arpía absolutamente 
depravada» ${ }^{69}$ o como Salomé, que se caracteriza por su seductora juventud y por el compendio de maldad, perversión y pecado. El rey Herodes Antipas el Tetrarca, su padrastro, durante su fiesta de cumpleaños le ruega y suplica que baile para él ofreciéndole a cambio cualquier cosa que ella desee. Salomé sabedora de su poder baila concupiscentemente y le pide ${ }^{70}$ a cambio la cabeza de Juan el «Bautista». Sin embargo y según el Evangelio de Mateo, la cabeza de Juan el «Bautista», no es tanto el deseo de Salomé como el de su ofendida madre Herodías, pues el «Bautista» había proclamado públicamente su adulterio con Herodes, hermano de su aún esposo Felipe. De hecho ni siquiera el nombre de ella aparece como tal sino como la «hija de Herodías». No fue casi hasta el siglo XIX, que la figura de Salomé cobró una renovada importancia iconográfica, en textos como Herodiade del simbolista Stéphane Mallarmé, Al revés [A Rebours] (1884), de Joris Karl Huysmans, Salomé de Oscar Wilde o Herodías de Gustave Flaubert, que nos presenta a una jovencísima Salomé, que es utilizada por su madre para sus propios fines, e ignorante incluso de quién es el hombre del cual pide su cabeza. Salomé es una virgen, pero que sin embargo, baila como una concubina, retorciéndose como si se tratase de «un amor que pide ser satisfecho», entre la corte de Herodes e invitados. Así, los artistas simbolistas encontraría en Salomé las cualidades y características esenciales de la «femme fatale», convirtiéndola en uno de los iconos de maldad femenina más representativos. Sin embargo son pocas las representaciones que respetan la edad natural de Salomé que la transforman en una voluptuosa bailarina exótica.

\footnotetext{
69 LAFORGUE, Jules. "Moralités légendaires", Oeuvres Completes. Vol. III. Paris: Mercure de France, [s.d.]. Citado por DIJKSTRA, Bram. Op cit., pág. 196.

${ }^{70}$ Nuevo Testamento. Mt, 14. 3-8, Mr. 6. 17-25. 
Éstas bases de tradición judeo-cristiana entraron en contacto con la mitología greco-romana y asumieron sus formas y representaciones femeninas, a las cuales que a menudo se les asociaban características animales, como serpientes o rapaces, tal y como se puede observar en la iconografía románica o gótica. En los seres mitológicos emanan el misterio de la existencia en un plano imaginario, sobrenatural, y que comparten cualidades a menudo humanas y divinas. Se trata de seres pre-cristianos que fueron muy del gusto de los artistas victorianos.

Las formas monstruosas, a menudo no se rigen por la condenación infernal sino por la continuidad divina de la mitología greco-romana, celta, escandinava 0 en diversas tradiciones precristianas. Dentro de tal iconografía, la metamorfosis humana-animal constituye la apoteosis del misterio de lo femenino y de sus cualidades sobrehumanas. Se trata de sirenas, esfinges, harpías, etc... de rostros de doncella y cuerpo deforme o de animal, o seductoras doncellas de cuerpo esbelto e infantil como las hadas y las ninfas, que conocidas por su fogosidad sexual derivaron en algunos casos hacia las peligrosas ninfomaníacas ${ }^{71}$ Ondinas.

Homero nos describiría por primera vez a las «sirenas» en la Odisea, como mujeres mitad ave de plumaje rojizo, mitad rostro de virgen. También Ovidio ${ }^{72}$ las describe con cara de doncella y voz humana. Las sirenas destacan no tanto por su belleza -sus cuerpos tienen forma animal-, sino por su canto, que hechiza a los navegantes ${ }^{73}$. El simbolismo greco-romano de pájaros de mal agüero y

\footnotetext{
${ }^{71}$ Precisamente la patología sexual de la ninfomanía proviene de la palabra ninfa ( $\left.v u \mu \varphi \eta\right)$, doncellas mitológicas, que viven en los bosques y las aguas, característicamente eróticas.

72 OVIDIO NASÓN, Publio. Metamorfosis. V. Madrid: Ediciones Cátedra, 1995.

73 GRIMAL, Pierre. Diccionario de mitología griega y romana. Barcelona: Piados, 1981, pág. 483; V. también HOMERO. Odisea. Madrid: Ediciones Cátedra, 2005.
} 
perdición de almas fue derivándose durante el medievo, barroco y finales del siglo XIX hacia el simbolismo sexual de las mismas, asociándolas a la perdición, a la lujuria y a la prostitución.

Fue con Hans Christian Andersen, que cambió la concepción greco-romana de las sirenas, descartando la visión terrible o sexual y acercándola al ideal de inocencia infantil y destino funesto de las heroínas victorianas en su cuento La sirenita.

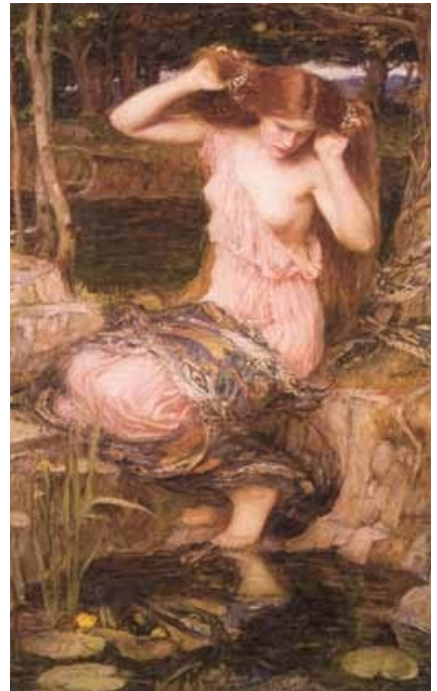

Fig. 13. Lamia (1909) por John William Waterhouse.

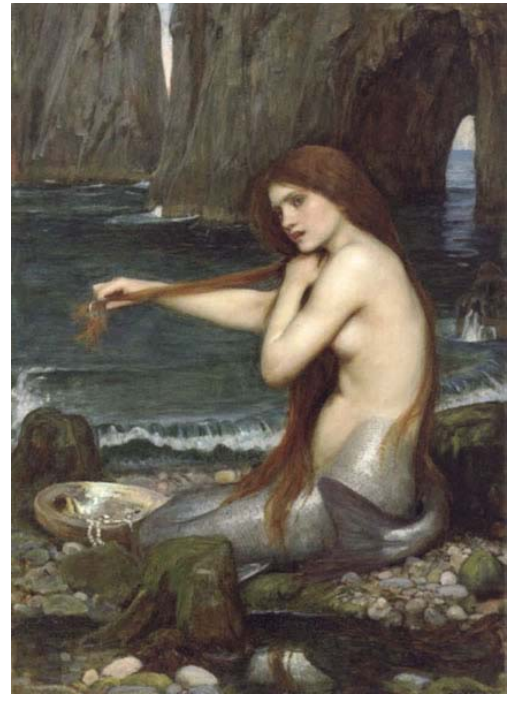

Fig. 14. Sirena (1901) por John William Waterhouse.

Durante el siglo XIX, las leyendas y cuentos tradicionales para niños, adquirieron también el nombre de «cuentos de hadas» ${ }^{74}$, en los cuales no se contaban necesariamente historias en los que apareciesen las Hadas, sino que englobaba en conjunto a seres y personajes de muy distintas tradiciones $y$ folklores. En general el término «Hadas», comprenden un gran número de seres como los duendes, gnomos, elfos ...,

\footnotetext{
${ }^{74}$ En inglés «Fairy Tales».
} 
también conocidos genéricamente como «seres feéricos», «gentecilla» 0 «habitantes del País de las Hadas». En su mayoría son seres del género femenino, aunque también los hay masculinos, de una belleza extraordinaria generalmente y que tienen la capacidad de transformarse en cabras, perros, o zorras ${ }^{75}$.

Las «hadas» tiene distintos orígenes y se hallan leyendas de ellas tanto en la mitología irlandesa como en la de las islas británicas o en los países escandinavos. Su nombre procede del latín fatum, que significa hado, destino. Su origen parece confluir en tradiciones paralelas al Antiguo Testamento. Algunas versiones los definen como ángeles caídos, como las almas del «Purgatorio» o los niños sin bautizar y otras como los hijos «ocultos» de Eva, pues hallándose ella lavando a sus hijos en el río, Dios le habló y Eva temerosa, ocultó a los que faltaban por lavar y Dios le advirtió que esos hijos quedarían invisibles a los hombres. William Shakespeare, nombraba a las Hadas en muchas de sus obras, como la Reina Mab en Romeo y Julieta o a Oberón y Titania, rey y reina de las hadas con sus respectivos séquitos en el contexto de Atenas en la Grecia Clásica en la comedia teatral El sueño de una noche de verano.

Durante la Inglaterra victoriana, la búsqueda de las Hadas y la demostración científica de las misma, se convirtió en una de las obsesiones de numerosos intelectuales y científicos bajo la influencia de la parasicología y el espiritismo que estudiaban las nuevas corrientes ocultistas como la Teosofía. Entre éstos aficionados se hallaba el escritor Sir Arthur Conan Doyle, conocido por su serie de novelas de Sherlock Holmes, que convencido de la existencia de las Hadas, llegó a escribir un estudio demostrativo respecto a las $\operatorname{mismas}^{76}$, usando como base las

${ }^{75}$ FROUD, Brian; LEE, Alan; LACKIN, David (ed.). Hadas. Madrid: Modadori, 1983.

${ }^{76}$ DOYLE, Arthur Conan. El misterio de las hadas. El baquero. Barcelona: José J. de Olaneta, Editor, 2003. 
fotografías tomadas por unas niñas en 1917 -las hadas de Cottingleyindagando la posibilidad de que fuesen auténticas y no un trucaje ${ }^{77}$. En ellas las hadas tenían una aspecto juvenil, vestían a la moda y según las niñas sus vestidos eran de color rosa, verde, azul lavanda y malva pálido y sus alas de colores más intensos hasta transformarse en blanco.

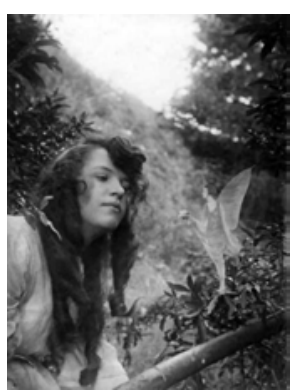

Fig. 15. Un hada ofrece a Elsie un ramillete de jacintos silvestres (1917). Foto tomada por Frances.

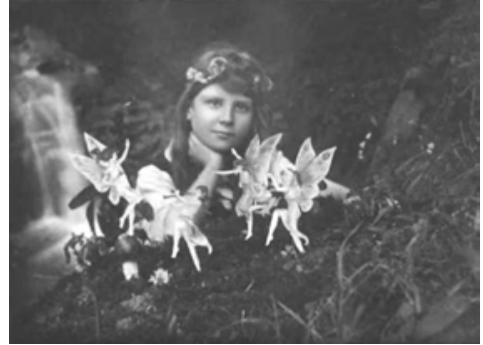

Fig. 16. Frances y las hadas (1917). Fotografía tomada por Elsie.

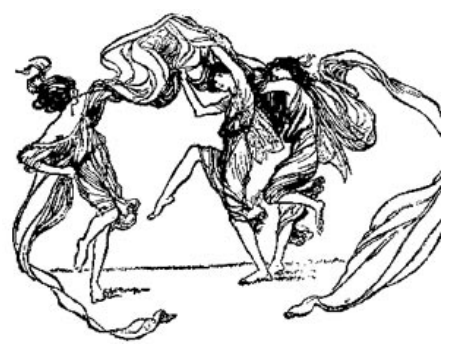

Fig. 17. Ilustración del libro El Libro de Regalo de la Princesa María.

77 En 1971, Elsie, una de aquellas niñas ya anciana, declaró en entrevista para la BBC-TV, que las fotografías eran auténticas. Sin embargo, a principios de los años ochenta, se publicó un artículo en The British Journal of Photography, en el que Elsie habían confesado finalmente al periodista Joe Cooper, que las fotografías habían sido trucadas, sin embargo Frances -la otra niña- también octogenaria, negaba el trucaje y aseguraba que Elsie mentía deseosa de verse libre de los periodistas. En 1978 el escritor Fred Getting, encontró unos dibujos muy parecidos a las hadas fotografiadas junto a Frances en un libro titulado El Libro de regalo de la Princesa María [The Princess Mary's Gift Book], publicado en 1915. 


\section{LA SEXUALIDAD EN EL SIGLO XIX.}

Para abordar el concepto de infancia en la sociedad occidental, es necesario ubicarse en el siglo XIX y más en concreto en la cultura y sociedad británica durante la etapa victoriana y en el tipo de relaciones que se establecieron entre las estructuras sociales, la sexualidad y la prostitución victoriana y cómo se identificaba el concepto victoriano de infancia, en una combinación de sexualidad e idealización de la inocencia, en las representaciones artísticas.

En 1837, Victoria, sube al trono de Inglaterra, con tan sólo dieciocho años de edad, convirtiéndose en reina del mayor imperio colonial del momento. La magnitud y relevancia de su reinado no sólo será a nivel económico-político, sino que sentará las bases de la moralidad inglesa del siglo XIX y que tendrá su reflejo tanto en sus colonias como en el resto de Europa y el nuevo país que está naciendo, Estados Unidos de América. La Era Victoriana, será conocida por ser una etapa marcadamente moralista y puritana. Tras un reinado de sesenta y tres años, Victoria moriría el 22 de enero de 1901. En las postrimerías del siglo XIX, la muerte de la monarca fue como la señal misma del final de la moralidad establecida, resurgiendo la sexualidad reprimida en las nuevas formas y usos sociales que el nuevo siglo ofrecía.

\subsection{Sexualidad en la etapa victoriana.}

La palabra sexualidad comenzó a utilizarse a principios del siglo XIX únicamente en términos biológicos y no fue hasta 1889, que J. Matthews Duncan utilizó el término como «posesión de poderes sexuales 
o capacidad de tener sentimientos sexuales» ${ }^{1}$, diferenciando así entre reproducción y sexualidad como haría también Freud.

El código sexual que se exigía a la sociedad media y alta victoriana era claramente arbitrario y represor. A menudo muchos médicos ejercían su influencia sobre sus pacientes tanto masculinos como femeninos, en el cumplimiento de tal código no escrito, generando estados de represión, culpabilidad y ansiedad frente al tabú social, el sexo. Sin duda, las mujeres se llevaron la peor parte, que se vieron relegadas exclusivamente a la vida doméstica, permaneciendo ignorantes e inmaduras sexualmente, mientras que los hombres, debían asumir sus responsabilidades matrimoniales con sentimientos de culpabilidad e intranquilidad haciendo uso de los servicios de las prostitutas. Hombres de toda condición social hacían uso de la prostitución tanto en las calles como en los prostíbulos. Las prostitutas de alto standing ofrecían servicios de moda en los prostíbulos, como los «trucos franceses», satisfaciendo las perversiones que la aburrida vida conyugal no les daba, pues como ya se ha señalado, las mujeres de buena educación carecían de conocimientos sexuales y tenían una restringida vida pública condicionada por la estricta etiqueta de comportamiento social. La sexualidad en el ámbito doméstico estaba únicamente destinada a la formación de la familia y no a la de proporcionar placer a los cónyuges.

Donald Pearsall, señala que la regla dorada de los victorianos era «mejor estar preocupados, que ocupados en el sexo $^{2} »$, sin embargo no siempre se cumplía esta regla. La pretendida respetabilidad de la

\footnotetext{
${ }^{1}$ DUNCAN, J. Matthews. Clinical Lectures on the Diseases of Women. London: J. and A. Churchill, 1889. Citado por MAVOR, Carol. Op. cit., pág. 10.

2 Introducción de PEARSALL, Ronald. The Worm in the Bud. The World of Victorian Sexuality. London: Penguin Books, 1983, pág. 15.
} 
moralidad victoriana era la fachada de lo que un escritor francés llamaría, «los obscenos traseros de la vida inglesa» ${ }^{3}$.

La sexualidad era una región oscura a desterrar de la mente junto con las perversiones y anomalías. El sexo se convirtió en un terreno confuso y prohibido, generando un clima de ansiedad y obsesión generalizada. La represión ejerció un efecto social de introspección imaginaria, en el que todo podía entenderse en términos sexuales, haciendo por ejemplo de la inocente conversación entre un hombre y una mujer, una relación pecaminosa o de las voluptuosas formas de un piano de cola, un referente del atractivo de las formas femeninas. De hecho, la sexualidad sumergida dio la bienvenida a la proliferación de grabados y fotografías pornográficas. La policía a menudo confiscaba éste material y lo destruía como ocurrió durante las décadas de 1840 y 60 , de las que no se encuentra pornografía.

No obstante, dentro de las contradicciones propias de la sociedad victoriana encontramos que las luchas de los movimientos feministas hacen patente que la mujer no se verá durante mucho más tiempo relegada a la vida privada y que formará parte de la política y la vida social durante la segunda mitad del siglo XIX. La presencia pública de las mujeres, asombraría y crearía confusión en la mentalidad social colectiva reforzando todavía más, las sensaciones de antagonismo sexual ya existentes y fomentando sin embargo, reacciones de temor sexual entre numerosas mujeres.

Las evidencias físicas y visibles del «vicio» sexual, no eran tan claramente detectables, pues como señala Lynda Nead, las categorías entre prostitutas y damas respetables se entremezclaban dando lugar a innumerables confusiones por parte de la sociedad y de la policía. La

${ }^{3}$ [«The fouled hindquarters of English life»]. Introducción de PEARSALL, Ronald. Op. cit., pág. 16. 
vida pública femenina y los renovados valores de mercado abrían un nuevo marco en el plano del vestuario que introducía vestimentas que únicamente usaban las prostitutas y que ahora añadían a la moda de las damas de clase media-alta. La frecuente confusión con respecto a la identidad de las damas que experimentaban un nuevo tipo de libertad pública, se convirtió en tema de broma social. Mientras las prostitutas podían pasar por damas virtuosas «contemplando escaparates» por el elegante entorno de Regent Street, éstas últimas podían ser tomadas e incluso abordadas como prostitutas. En una ocasión, los todavía jóvenes pintores Rossetti, su hermano William y Woolner quedaron con Millais, Hunt y otro amigo en encontrarse en Tottenham Court Road, una confluida calle londinense, para buscar modelos. Se percataron de varias jóvenes, pero no hallaron el coraje necesario para dirigirse a ellas. Las muchachas avisaron a la policía al sentirse perseguidas, insultadas y acosadas como vulgares prostitutas ${ }^{4}$.

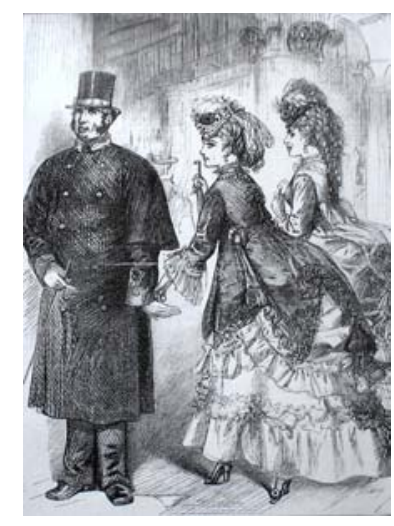

Fig. 1. Prostituta comprando el silencio a un policía

(s. XIX), grabado anónimo.

\footnotetext{
${ }^{4}$ MARSH, Jan. The Pre-Raphaelites. Their Lives in Letters and Diaries. London: Collins \& Brown Limited, 1996, pág. 21. También NEAD, Lynda. Myths of Sexuality Representations of Women in Victorian Britain. Oxford: Basil Blackwell, 1988, págs. 102, 180-181. Cit. en WALKOWITZ, Judit. La ciudad de las pasiones terribles. Narraciones sobre el peligro sexual en el Londres Victoriano. Col. Feminismos. Madrid: Ediciones Cátedra, 1995, pág. 110, n. 29.
} 


\subsection{La prostitución infantil victoriana.}

La etapa victoriana constituyó una época con un gran aumento de la prostitución infantil, en su mayoría niñas, apenas adolescentes, que maquilladas con «cosméticos baratos» ${ }^{5}$, rondaban el centro urbano de Londres. Sin duda la principal causa era el hecho de que hasta 1885, la edad núbil estaba marcada hasta los doce años de edad, lo cual hacía que muchas niñas se encontraran en el circuito de la prostitución sin una «cierta protección»

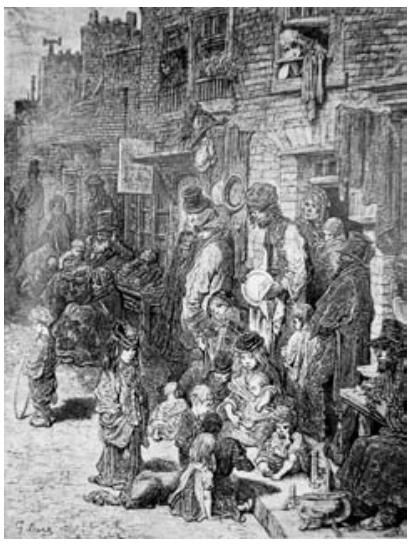

Fig. 2. Wentworth Street. (s. XIX), grabado anónimo. que la Ley les podía proporcionar dada su condición infantil.

En tres diferentes hospitales londinenses se registrarían 2.700 casos de enfermedades venéreas en niñas de entre 11 y 16 años, en el plazo de tan sólo ocho años ${ }^{6}$. Sin embargo, la Rescue Society of London, que rescataba a mujeres y niñas del ámbito de la prostitución, negaba en sus informes la existencia de prostitución infantil y señalaban que muchas de las jóvenes que se habían iniciado voluntariamente en la prostitución lo hacían a la edad de 16 años ${ }^{7}$. Además, dentro de las jóvenes de clase trabajadora, muchas

\footnotetext{
${ }^{5}$ PEARSON, Michael. The Age of Concent: Victorian Prostitution and it's Enemies. New York: Randon House, 1962, pág. 28.

${ }^{6}$ PEARSALL, Ronald. Op cit., pág. 368.

${ }^{7}$ El reverendo Merrick señala que hasta 1885, la edad núbil era a los 13 años. A partir de esta fecha se cambió la edad núbil a los 16, pero dentro de la prostitución, la edad de inicio seguía siendo hacia los 13. MERRICK, Rev. G. Work Among the Fallen, as Seen in the Prison Cells. A paper read before the Ruri-Decanal Chapter of St. Margaret's and St. John's, Westminster, in the Jerusalem Chamber, on Thursday, July 17, 1890. London: Ward, Lock, 1890, págs. 33 y 40.
} 
declaraban haber tenido su primera relación sexual dentro de la franja de edad de entre los 12 a los 16 años, seducidas por sus señores, si trabajaban como sirvientas o por hombres de su mismo status social. A menudo, los contactos no se producían voluntariamente, sino por violación o incesto. «La violación -señala Michelle Perrot- se consideraba como una variante de los comportamientos ordinarios en la relación hombres-mujeres ${ }^{8}$. De hecho, estas experiencias marcaban a las jóvenes de tal forma que se veían empujadas a la prostitución como medio de vida. Según un estudio de Kinsey en 1950, el 6\% de 8.000 mujeres de raza blanca de clase media tuvieron su primer contacto sexual con un adulto durante su infancia ${ }^{9}$. Inglaterra tenía un grave problema con la prostitución infantil, pero el centro de prostitución infantil de Europa era Bruselas. Allí se encontraban niñas de todas partes de Europa, entre ellas numerosas inglesas que eran raptadas y llevadas hasta allí. Otra de las causa que fomentó la búsqueda de vírgenes fueron las numerosas epidemias de enfermedades venéreas como la sífilis o la gonorrea. El miedo al contagio, contribuyó en gran medida al aumento de la prostitución infantil. Tras las epidemias de cólera, entre 1831 y 1849, las prostitutas se pusieron en el punto de mira de los reformadores sanitarios que las identificaron como las principales transmisoras de infecciones, lo que hizo que se corriera la creencia generalizada de que con la violación de vírgenes se evitaban y curaban tales enfermedades. Los precios de las vírgenes eran altos y se buscaban estratagemas, sobre todo entre médicos y comadronas, para simular posteriores

\footnotetext{
8 AA.VV. Historia de la vida privada. De la Revolución francesa a la Primera Guerra Mundial. vol. IV. Barcelona: Círculo de Lectores, 1993, pág. 145.

${ }^{9}$ [«May God have mercy on the destroyers of these children-sometimes their own»] «Que Dios tenga misericordia de los destructores de los niños, a veces de sus propios hijos». Thirthy-first Annual Report of the Rescue Society. [London]: 1883.
} 
pérdidas de virginidad $y$ ofrecer a las menores de nuevo como vírgenes.

La prostituta representaba públicamente el vicio femenino que contrastaba con los estereotipos de virtud femenina adquiridos de la mujer doméstica, que se identificaban con la identidad burguesa ${ }^{10}$. Así se contraponían las ideas de pasión y deseo sexual frente al llamado «ángel de la casa», la virtud femenina, la dulzura, la bondad y la inocencia e ignorancia sexual. Las prostitutas mostraban una sexualidad y una actitud lujuriosa que no correspondía a la «naturaleza femenina», es decir, carente de apetito sexual y que por tanto se asemejaba al deseo sexual propio e imperativo de la naturaleza masculina. Para muchos, la prostitución no sólo era una lacra social sino que puesto que las mujeres eran «asexuadas» en los términos ya establecidos, el deseo sexual por parte de las prostitutas no desempeñaba ningún papel, siendo deleznable e inútil ${ }^{11}$. Las prostitutas eran la basura humana, mucho peor que los hombres que las frecuentaban.

Las hojas de sociedad se hacían eco de los numerosos casos de acoso sexual infantil, utilizando términos eufemísticos como «ofensa al pudor» o «violación de la inocencia» ${ }^{12}$. Pero por otro lado, la

\footnotetext{
${ }^{10}$ WALKOWITZ, Judit. Op. cit., pág. 56. Sobre la identidad masculina burguesa frente a la femenina, escribe la deconstructivista feminista Mary Poovey, Uneven Developments: The Ideological Work of Gender in Mid-Victorian England. Chicago: University of Chicago Press, 1988.

11 Un informe de la Comisión Real en 1871 afirma que no había «comparación entre las prostitutas y los hombres que se relacionan con ellas. En un sexo, la trasgresión es cuestión de ganancia; en el otro es la satisfacción irregular de un impulso natural» en "Report of the Royal Commission on the Administration and Operation of the Contagious Diseases Acts 1868-69". Parlamentary Papers, 29. London: C. 408, 1871, según n. 28, cap. 1 de WALKOWITZ, Judit. Op. cit., pág. 59.

12 Traducción de los términos al castellano de la autora. Ronald Pearsall recoge algunos de los eufemismos con que los periódicos de sociedad hacían referencia a los sucesos de acoso sexual infantil, como «indecent assault», «interference with young children», «the violation of innocence» 0 «the despoliation of purity», en PEARSALL, Ronald. Op. cit., pág. 438.
} 
prostitución infantil se trataba a menudo en clave de humor. La «afición» de muchos hombres de buscar relaciones sexuales con vírgenes, no era tratada siempre como una perversión o una atrocidad sexual, sino como un «gusto» o una excentricidad. Así escribió Oscar Wilde sobre Leonard Smithers, editor de la revista erótica Audrey Beardsley: «...a él le encantan las primeras ediciones, especialmente las de mujeres: las niñas eran su pasión...». Si bien no era laudable, tampoco era un asunto de interés público, expresando así el sentimiento generalizado ${ }^{13}$.

En este sentido son significativos los diarios íntimos, publicados con el título de Mi vida secreta [My Secret Life] del autor anónimo, con el sobrenombre de «Walter», en el que relata sus experiencias sexuales, y toda clase de perversiones imaginables. Sin duda, los numerosos encuentros con niñas, «juvenil punks»-como él las denomina-, son una evidencia de la amplia variedad de servicios sexuales y tipos de prostitución.

\subsection{1. «Cinco libras por una virgen». El tributo de las jóvenes doncellas en la moderna Babilonia.}

Sin duda uno de los capítulos más polémicos de la etapa victoriana fue la publicación en 1885 de una serie de artículos en la Palm Mall Gazette, PMG, que ponían en evidencia la existencia del tráfico de niñas en los prostíbulos londinenses.

Fue durante los días 6, 7, 8 y 9 de julio de 1885, cuando bajo el título El tributo de las jóvenes doncellas en la moderna Babilonia [The Maiden Tribute of Modern Babylon], aparecieron tales artículos

\footnotetext{
${ }^{13}$ PEARSALL, Ronald. Op. cit., pág. 359.
} 
firmados por William Thomas Stead ${ }^{14}$, director de la Palm Mall Gazette. Días antes, su autor advertía a los lectores con la siguiente nota escrita en la gaceta: «...aquellos que sean remilgados, y todos aquellos que sean mojigatos, $y$ todos aquellos que prefieran vivir en un falso paraíso de inocencia y pureza imaginaria, egocéntricos y ajenos a las horribles realidades que atormentan a quienes pasan sus vidas en el infierno londinense, harán bien en no leer la "Palm Mall Gazette" del lunes y los días sucesivos...».

El artículo describía el cómo las jóvenes eran engañadas, raptadas y violadas, bajo los efectos de drogas o tras la puerta cerrada de una habitación. Stead presentaba estos hechos de manera análoga al mito griego del Laberinto del Minotauro. De la misma manera, las jóvenes eran raptadas del laberinto londinense y entregadas al devorador «hombre rico».

Tras el sensacionalismo, llegó la nube del escándalo para Stead, que fue acusado de la compra de una joven, por cinco chelines, el mismo delito que había denunciado en su periódico. Durante el juicio, la prensa atacó ferozmente, criminalizándole de antemano de los hechos acusatorios. Stead alegó en su defensa, que tal comportamiento formaba parte de la investigación que llevaba entre manos para así demostrar realmente, la facilidad para comprar vírgenes en el mercado de la trata de blancas londinense. Tras pocos meses en prisión y sin esclarecer realmente los hechos, Stead fue puesto en libertad, convirtiéndose en abanderado de la lucha contra la prostitución infantil.

El artículo de Stead tuvo imprevistas repercusiones de orden político y social. Aunque El tributo fue tachado de periodismo sensacionalista -las ventas de la PMG se elevaron considerablemente-

\footnotetext{
${ }^{14}$ William Thomas Stead casualmente murió en el desgraciado viaje inaugural y último del Titanic.
} 
e incluso por el resto de la prensa como «la más vil parcela de obscenidad», despertando la conciencia social de los lectores frente al peligro sexual que corrían las niñas y jóvenes de clase media y baja.

Pero sin duda, la repercusión más importante fue la revisión legal de la noción de infancia. En "Hora de cierre para las niñas"15, Stead, comparaba la legislación sobre la edad núbil con las leyes de caza y pesca, diciendo: «Los peces que no están en temporada, no son adecuados para comer. Las niñas que no han alcanzado la pubertad no son adecuadas ni siquiera para que las seduzcan».

Tras la suspensión, de las Leyes de enfermedades contagiosas en 1883, los reformadores puritanos intentaron hacer público los efectos de la prostitución infantil sin demasiado éxito, para que el Parlamento tomara en consideración el asunto de las niñas y retrasara la edad núbil. En gran medida, «El tributo» forzó la opinión de los legisladores que en 1885, aprobaron la Ley de enmienda al Derecho Penal ${ }^{16}$, que elevó la edad núbil de las niñas de los trece a los dieciséis años. Pero las consecuencias afectaron a otros grupos sociales, pues se intensificó la persecución de las prostitutas y sus proxenetas por parte de la policía. Además la ley ilegalizó los «actos indecentes» en los que participaran hombres, esto es, no sólo a los que hacían uso de las prostitutas sino también a los homosexuales. Se crearon comités de vigilancia para supervisar la aplicación de dicha ley, como también el llamado Movimiento de pureza social que luchaba para erradicar el vicio y la lujuria «masculina». Entre esos vicios, se encontraba la

\footnotetext{
15 "Close Time for Girls" en "The Maiden Tribute of Modern Babylon". Palm Mall Gazette, 8 de julio de 1885, pág. 5.

${ }^{16}$ La Ley de enmienda al Derecho Penal [Criminal Law Amendment Act] de 1885, por un lado protegía a las niñas pero por otro las consideraba ciudadanos incompletos o de $2^{\mathrm{a}}$ clase.
} 
pornografía. Se publicaron además ilustraciones que describían las violaciones y perversiones relatadas en «El tributo».

\subsection{Concepto victoriano de infancia.}

Teniendo en cuenta los numerosos cambios, sociales y culturales que se provocaron alrededor de la infancia, la educación obligatoria, las leyes de edad núbil, así como la propia categorización de infancia, podríamos afirmar que el siglo XIX fue verdaderamente el «siglo del niño» ${ }^{17}$.

Los victorianos, se conmovían ante la belleza y las formas del desnudo femenino. Si en la abundante literatura pornográfica de la época victoriana se hacía énfasis en los genitales, vello púbico, pechos, nalgas y piernas, en ese orden, en el arte victoriano, el vello púbico será sutilmente suprimido, pues era éste un elemento prerrogativo únicamente de los artistas especializados en la pornografía y no de los artistas que acostumbraba a mostrar sus obras en la Royal Academy. A ello se uniría la admiración por las niñas que se irá delineando como una obsesión sexual en la vida de numerosos hombres victorianos como Dickens, Kilbert, Lewis Carroll el conocido matemático y creador de Alicia en el País de las Maravillas o John Ruskin, pintor y teórico de la Hermandad Prerrafaelista. En este «romance» por la infancia, cultivaban sus amistades infantiles con los detalles más gentiles y amorosos que el decoro victoriano les permitía. Por ejemplo, Edward Burne-Jones, ilustraba sus cartas con

\footnotetext{
17 CUNNINGHAM, Hugh. Children and Childhood in Western Society Since 1500. London: Longham Group Limited, 1995, pág. 163.
} 
humor a la pequeña Katie Lewis ${ }^{18}$ o al igual que Lewis Carroll, dedicaba poemas acrósticos a su pequeñas amistades ${ }^{19}$.

Los autores románticos -también los victorianos más tarde-, aislaban el mundo infantil del adulto por medio de la inocencia y la pureza, creando una fantasía secreta que alimentaba el sentimiento de nostalgia por la edad perdida.

Ruskin es conocido por ser uno de los más eminentes hombres victorianos a los que se le conocieron amistades infantiles. Se ha especulado cómicamente sobre su noche de bodas con la joven Effie Gray. Se decía que a causa de su visión de crítico de arte, idealizó de tal manera el desnudo femenino que jamás llegó a consumar el matrimonio debido al shock recibido la noche de bodas al observar el vello púbico de su esposa ${ }^{20}$.

El cuerpo infantil de una niña era con diferencia más admirado que el cuerpo femenino adulto. La carencia de voluptuosidades y de vello púbico, ejercían un mayor poder de seducción más por sus capacidades sexuales en potencia que por la evidencia de las mismas, como sí que sucede con el cuerpo adulto, resultando opresivo y exigente a los ojos del reprimido hombre victoriano. En este sentido, los victorianos llegaron a minimizar el género femenino o masculino en

\footnotetext{
${ }^{18}$ ROSE, Andrea. Op. cit., págs. 31-33.

19 WULLSCHLAGER, Jackie. Inventing Wonderland: The Lives ans Fantasies of Lewis Carroll, Edward Leard, J.M. Barrie, Kenneth Grahame and A.A. Milne. London: Methurn, 1995, pág. 12.

${ }^{20}$ Así lo atestigua la propia Effie Gray en una carta dirigida a sus padres hacia 1852. Effie había sido acusada por sus padres de desatender sus deberes conyugales. Ella respondió a esta cuestión, explicando que la negativa a mantener relaciones sexuales era de John Ruskin, pues deseaba preservar su belleza, por motivos religiosos y excusas diversas. Años más tarde le confesó que él la había imaginado bastante más diferente a cómo era ella. Tras conseguir la anulación de matrimonio, confirmando médicamente su virginidad, se casó con Millais en 1855 y John Ruskin se enamoró de Rose La Touche, una niña de 10 años. MARSH, Jan. Op. cit., pág. 53.
} 
la infancia, en un único género «neutro» ${ }^{21}$, que se identifica con el cuerpo de las niñas.

La diferencia entre infancia y adolescencia estaba delimitada arbitrariamente. La infancia, durante gran parte de la etapa victoriana se estableció hasta la edad de doce años ${ }^{22}$. A partir de esa edad, a las niñas se las consideraba preparadas para el sexo y por lo tanto podían contraer matrimonio. Como ya se ha señalado, se podían establecer relaciones sexuales con niñas debido a la gran cantidad de burdeles que contaban con niñas que ejercían la prostitución. Es precisamente durante el siglo XIX cuando comenzaron a escribirse los estudios más extensos sobre la pederastia. Este hecho tal vez se explica en el intento por definir la categoría de «infancia» y por lo tanto su diferencia respecto a la categoría de «adulto».

Sin embargo no todas las miradas hacia la infancia se manifestaron en términos sexuales, al menos no superficialmente. Se produjo un vuelco hacia la idealización de la infancia personificada en las «niñas», propiciada por la exaltación romántica de la infancia y por el fundamentalismo cristiano. Es el Ilamado «Culto por las niñas», las cuales eran tratadas con veneración y admiración.

Esa creciente admiración y búsqueda de compañía de niñas de un gran número de hombres de edad madura, podría tener su origen

\footnotetext{
${ }^{21}$ GORHAM, Deborah. The Victorian Girl and The femenine Ideal. Bloomington: Indiana University Press, 1982, págs. 68 y 83. Roland Barthes y Louis Marin, definen el juego y la ambigüedad del género «neutro» (neutre), como aquello que no es femenino ni masculino, ni sujeto ni objeto. BARTHES, Roland. Roland Barthes por Roland Barthes. Barcelona: Ediciones Paidós Ibérica, 2004 y MARIN, Louis. Utopiques: Jeux d'espace Paris: Les Éditions de Minuit, 1973. Krafftel- Ebing, señala que los niños y niñas, antes de la pubertad tienen una sexualidad «neutra». KRAFFTL-EBING. Psychopathia Sexualis. Brooklyn (N.Y.): Physicians and Surgeons Book Co., 1931, pág. 186. Cit. en KINCAID, James R. Child Loving. The Erotic Child and Victorian Culture. New York: Routledge, 1992, págs. 15 y 64.

${ }^{22}$ Con la Ley de enmienda al Derecho Penal de 1885.
} 
en la incapacidad para mantener relaciones de amistad y sexuales adultas motivadas por el estado de represión sexual característica de la etapa victoriana. Y puesto que las virtudes como la bondad, la pureza y la inocencia en las mujeres eran consideradas supremas sobre las virtudes intelectuales, las niñas encarnaban todas ellas a través de su sencillez e ignorancia.

Michelet afirmaba ${ }^{23}$ que todo lo que una niña necesitaba saber en la vida podía enseñársele estudiando una flor, por su silencio, su dulzura, su pasividad y su manejabilidad. La fragilidad física y la incapacidad para las cuestiones prácticas para la vida, para la acción, hacían de la mujer una flor, que debía ser tratada por el hombre como el jardinero con sus rosas ${ }^{24}$, con el máximo cuidado y dedicación. La niñas sin duda representan esas rosas en capullo, en su máxima simplicidad a la cual las mujeres debían aspirar a convertirse. Por lo tanto, debían seguir siendo como niñas, no crecer.

Sin embargo, los crecientes cambios en el papel público de la mujer dieron como resultado una incertidumbre respecto a las virtudes que debían poseer las mujeres -en concreto las niñas y muchachas-, para formarse íntegramente dentro de los patrones de moralidad, religiosidad y educación victoriana. Así, John Ruskin, haciéndose partícipe y estandarte de la función social masculina de aleccionar a las féminas, expresaba su particular preocupación: «...han surgido cuestiones respecto a la educación y aspiraciones de las mujeres, que han turbado a las mentes simples $y$ han excitado a las inquietas ${ }^{25}$. Estas mentes «simples» e «inquietas» son las de las jóvenes. En sus escritos, insiste en la inocencia por naturaleza de las muchachas pero

\footnotetext{
${ }^{23}$ Citado en DIJKSTRA, Bram. Op. cit., pág. 15.

${ }^{24}$ Ibíd.

${ }^{25}$ RUSKIN, John. Sésamo y lirios. Ensayos Sociales. Buenos Aires: Espasa-Calpe. 1950, pág. 7.
} 
también en sus limitaciones intelectuales, sobre los peligros de la vanidad, la falta de piedad, la ociosidad y la crueldad, estos últimos como los más detestables en una joven a los ojos de Dios. El «deber» y la «misión» de las mujeres deben ir ligados íntimamente a la de los hombres, no como seres diferentes e independientes sino como complementarios y de mutua necesidad. Esta reivindicación se aleja de las diferencias sexuales irreconciliables de la lucha de sexos. Deplora las erróneas ideas en los hombres, pero sobre todo en las mujeres respecto a la sumisión femenina en base a su debilidad. Halla que la virtud femenina se hace ejemplar en las heroínas de Shakespeare como Cordelia, Desdémona, Isabel, Rosalinda o la Reina Catalina, como también las hay en la mitología griega en la «sabia Casandra», la «divina Andrómaca», la «hogareña y paciente Penélope» o la «piadosa e intrépida Antígona». Todas ellas, mujeres decididas, de carácter firme, «esperanza seria» y «propósito infalible» ${ }^{26}$, pues la verdadera función femenina está en ser «guiadora» no en ser «resolutiva». La belleza femenina, según Ruskin, se halla en «la paz majestuosa fundada en la memoria de los años felices y útiles». Pero esa belleza se crea gracias a la infancia que es «todavía más majestuosa (...) Ilena de cambio y de promesa» ${ }^{27}$.

No obstante, en su insistente voluntad por instruir, Ruskin se ve amilanado por la desilusión al comprobar que no todas las jóvenes hacen buen uso de su natural pureza. Ruskin explicaría que había escrito Sésamo y lirios, por amor: «... para complacer a una muchacha, y si no fuera por lo que recuerdo de ella y de unas cuantas más, quizá refundiría ahora algunas de las frases de "Lirios" con un tono muy distinto...» y continúa explicando, que con el pasar de los

\footnotetext{
${ }^{26}$ Íd., pág. 92.

27 Íd., págs. 105 -106.
} 
años «... el ver la extrema maldad que hay en las mujeres, cuando yo no había creído sino en la extrema bondad $\gg^{28}$.

Nos hallamos pues, ante una de las más representativas actitudes victorianas respecto a la feminidad, una relación amor-odio, admiración-repulsión que desembocaría en una búsqueda de la pureza exacerbada en las formas infantiles pero también en la más acentuada misoginia, que remarcaba una tendencia natural a la prostitución, a la maldad y al libertinaje femenino, características propias de la mentalidad infantil. A este respecto, los científicos victorianos Lomboso y Ferrero afirmaban que los niños y las niñas eran unos salvajes por evolucionar, que no destrozaban el mundo «gracias» a su fragilidad física y en ese sentido eran semejantes a las mujeres, y que precisamente las mujeres, no eran sino niñas grandes de tendencias malvadas, más numerosas y variadas que las de los hombres, aunque generalmente latentes ${ }^{29}$.

\footnotetext{
28 Íd., pág. 30.

${ }^{29}$ Caesar LOMBOSO, y William FERRERO, The Female Ofender. New York: Appleton, 1899. V. sobre la maldad infantil de Paul ADAM. Op. cit., en nota 39, capítulo 8. Lewis Carroll, pág. 145,
} 


\section{LA HERMANDAD PRERRAFAELISTA Y EL ARTE VICTORIANO.}

El Prerrafaelismo constituye una de las formas artísticas neorrománticas más importantes del siglo XIX y uno de los primeros movimientos modernos del arte británico. Oscar Wilde lo denominaría como el «renacimiento inglés del arte».

La Hermandad Prerrafaelista -P.R.B ${ }^{1}-$, se fundó el verano de 1848 en Londres, inicialmente por William Holman Hunt, Dante Gabriel Rossetti y John Everett Millais, un reducido grupo de jóvenes artistas ${ }^{2}$ unidos por el rechazo común hacia la Royal Academy of Arts, es decir, el arte burgués imperante y por otro, la búsqueda de un «arte total», por el que mediante el análisis pictórico, casi científico de la naturaleza representada, se alcanzase simbólicamente la esencia humana y divina, produciéndose una dialéctica entre la poética plástica y la concepción moral y religiosa de la existencia. Influenciados en parte por los Nazarenos alemanes, comenzarían con el trabajo en comunidad -perdiéndose así las autoría de las obras-, y con la recuperación de las formas artesanales, rechazando precisamente, las formas de producción en serie de la nueva sociedad industrial. Realizarían obsesionados por un pasado idealizado y utópico-, una revisión de las formas artísticas y literarias prerrománticas y románticas sajonas, haciendo una relectura del arte medieval, convergiendo en el neogoticismo, medievalismo, la escuela romántica inglesa, Shakespeare y la Biblia. A pesar del rechazo por la manufactura industrial, se dejarían cautivar por las nuevas técnicas de reproducción de la realidad, es decir, la fotografía.

\footnotetext{
${ }^{1}$ P.R.B, Pre-Raphaelite Brotherhood.

2 Un círculo formado por «los chicos de la hermandad» (Boys of the Brotherhood) y sus «hermanas prerrafaelistas» (Pre-raphaelite Sisters). MARSH, Jan. The Pre-Raphaelites. Their Lives in Letters and Diaries. London: Collins \& Brown Limited, 1996, pág. 8.
} 
A pesar de que a los pocos años de su creación, la Hermandad Prerrafaelista se disolvió como tal, renació de nuevo su filosofía estética en diversos núcleos intelectuales de la sociedad victoriana, que ya habían mantenido contacto con la hermandad desde sus comienzos, como el llamado Movimiento de Oxford ${ }^{3}$ con Edward BurneJones o la Arts \& Crafts con William Morris.

Sería un error estudiar únicamente las manifestaciones pictóricas de la preadolescente realizadas por los hombres, sin comprobar de qué manera las mujeres se hicieron partícipes de las tendencias contemporáneas y su visión particular de género. Tenemos un extenso legado de obras, diarios y documentos varios que nos sitúan en la sensibilidad y el arte victoriano. Trabajaban codo con codo junto a sus compañeros masculinos. Eran esposas, madres e ilustradas como la fotógrafa Julia Margaret Cameron ${ }^{4}$, Joanna Boyce, Kate Bunce o Marianne Preindesberger Stokes. Algunas eran amantes y esposas como Elizabeth Siddal. Sus resultados tardíos las relegaron a meras seguidoras, pero su idealismo, su admiración por las formas medievales, el brillante uso del color, el detalle, la función moralizante y su búsqueda de la belleza entre lo humano y la naturaleza fueron las mismas que aquellos primeros resultados de mediados del siglo XIX.

Se trata pues de un movimiento neorromántico no sólo social y religioso sino también estético, liderado a nivel filosófico por John Ruskin. En un ensayo a favor de los pintores prerrafaelistas, escribiría: «Mientras toda finalidad del arte ha sido la enseñanza moral, naturalmente tomo la realidad como su primer objetivo y la belleza como el segundo. Mas cuando perdió todo propósito en la

\footnotetext{
${ }^{3}$ Oxford Movement

${ }^{4}$ Su estudio se realizará con más detenimiento en el capítulo 4. Fotografía victoriana, pág. 117.
} 
enseñanza moral, tomó, naturalmente, la belleza como primero y la realidad como segundo» 5 .

Lothar Hönninghausen señala: «Como consecuencia de esta nueva forma de ver, cada detalle aparece de forma relevante y como extraído de su contexto por un teleobjetivo. Al suceder ello con todos los pormenores, éstos adquieren una sugestión simbólica, heterogénea y sin finalidad concreta, pero aportan de esta forma al cuadro prerrafaelista aquella impresión característica de una desnaturalizada opulencia e intensidad ${ }^{6}$. Pero se trata de una realidad limitada. El choque entre tradición romántica e industrialización, se hizo palpable socialmente en una falsa moralidad, una grave represión sexual y un aumento de la prostitución, sobre todo infantil. El profundo puritanismo de la sociedad victoriana se manifestaría mediante un filtro embellecedor, eliminando lo vulgar, lo terrible o lo pernicioso de la pretendida realidad representada.

\subsection{La preadolescente en la pintura victoriana.}

El misticismo religioso y la recuperación de las viejas leyendas medievales de la literatura revitalizaron la poesía lírica y las historias del Rey Arturo y los mitos bíblicos. Con ello, la imagen de la «virgen», encarnada en la Virgen María o las doncellas hechizadas o enamoradizas como La dama de Shalott u Ofelia, se convertirían en los personajes predilectos del imaginario prerrafaelista ${ }^{7}$, contraponiéndose así, al tópico

\footnotetext{
5 "Prerrafaelismo" en RUSKIN, J. Las piedras de Venecia. Barcelona: Iberia, 1961, pág. 274.

6 HÖNNINGHAUSEN, Lothar. Präraphaeliten und Fin de Siècle. Symbolistische Tendenzen in der englischen Spätromantik [Los prerrafaelistas y el fin de siglo. Las tendencias simbólicas en el romanticismo tardío inglés]. Munich: Wilhelm Fink, 1971, pág. 57. Traducción tomada de MELTKEN, Günter. Los prerrafaelistas. El realismo ético y una torre de marfil en el siglo XIX. Barcelona: Blume, 1974 , pág. 25.

${ }^{7}$ Los artistas prerrafaelistas concebirían mejor a la preadolescente dentro de la iconografía femenina que los simbolistas que dejarían de lado la figura infantil.
} 
masculino de la «femme fatale» que desarrollarían los artistas simbolistas. A esto se uniría como desencadenante de la búsqueda de un ideal femenino en la figura de la preadolescente, un sentimiento de incertidumbre y un profundo desencanto del ideal femenino romántico motivado en gran medida por el movimiento sufragista y el reciente papel social de la mujer ${ }^{8}$. El «culto a la infancia», que nació de la visión romántica de finales del siglo XVIII con Wordsworth y William Blake, se explicitó con el «culto a las niñas».

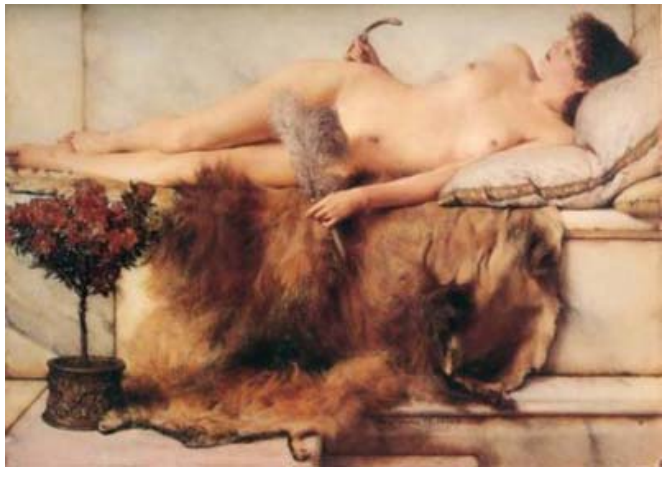

Fig. 1. En el Tepidarium (1881) por Sir Lawrence Alma-Tadema.

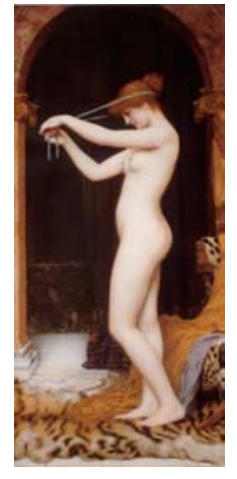

Fig. 2. Venus anudándose el cabello (1897) por John William Godward.

Las bellezas de rostro pálido, mirada perdida y enigmática, con el cabello largo cayendo sobre los hombros, casi espectral e inmaterial es el estereotipo de erotismo femenino más repetido una y otra vez por los artistas prerrafaelistas y victorianos. El desnudo femenino, era representado con formas infantiles, rostros angelicales, cuerpos poco desarrollados, pecho incipiente y con la zona genital oculta por un velo o tejido, o sin vello púbico, como se observa en las modelos de Laurence Alma-Tadema, Frederick Leighton o John William Godward.

\footnotetext{
${ }^{8}$ DIJKISTRA, Bram. Op. cit., pág. 185.
} 
A pesar de que las mujeres de Frederick Leighton (1799-1892) son el paradigma del erotismo de la escuela academicista, logra en los conjuntos Madre e hija (1865) y La lección de música (1877) unos resultados de ternura que fueron el elogio de la crítica. La niñita con los pies descalzos, ofrece a su madre unas cerezas, como una pequeña ninfa sirviente, o un ángel que acompaña el reposo de una Venus.

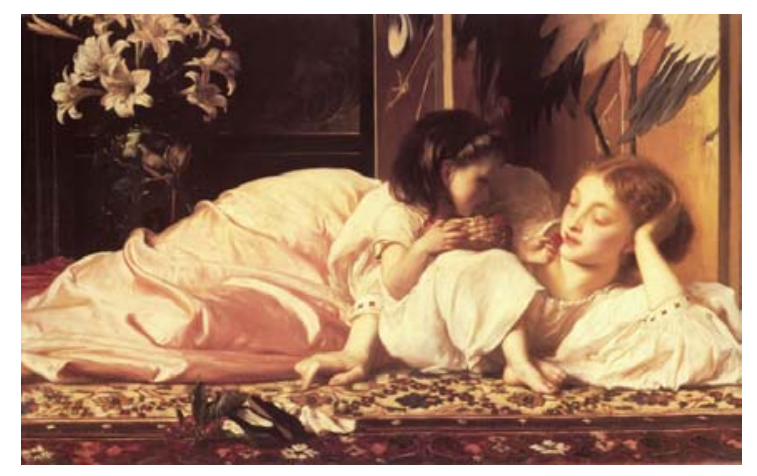

Fig. 3. Madre e hija (1865) por Frederick Leighton.

Con La lección de música, el pintor nos muestra la necesidad de la enseñanza de las artes en las niñas y jóvenes. Así, se produce la transmisión de la virtud de la madre-institutriz en la niña mediante la música, sirviéndose de un tópico que ya hubieran trabajado otros pintores como Vermeer. Cosmo Monkhouse afirma respecto a $\mathrm{La}$ lección de música (1877) que se trata quizás de «la más perfecta de las pinturas, un sueño de pureza y una de las más tiernas emociones», y sigue: «no podía apartar la mirada de la adorable niñas (...) sentada sobre las faldas de su madre» ${ }^{9}$. La observación de Monkhouse, incurre en un error pues aunque en apariencia parezca que la niña se encuentra sobre las piernas de su madre, no es así. Se encuentra sentada junto a ella, pues los pies de la madre están entrecruzados dejando ver parcialmente un pie bajo el otro. Es muy probable que

\footnotetext{
${ }^{9}$ MONKHOUSE, Cosmo. British Contemporary Artist. London: Heinemann, 1899, págs. 107-8.
} 
Leighton, conocedor de la pintura Renacentista, utilizara la enigmática composición de las piernas de La Virgen y el Niño con Santa Ana de Leonardo da Vinci como referente.

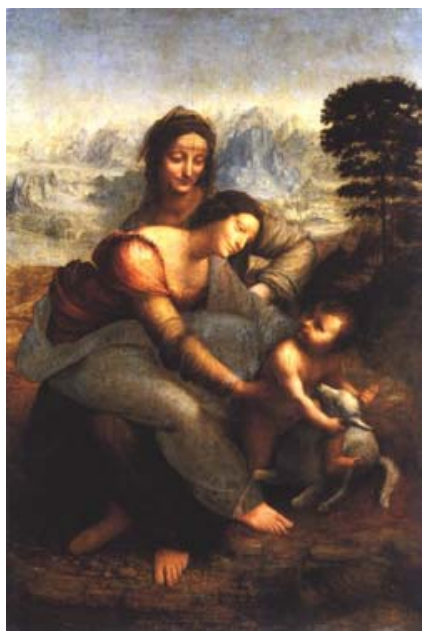

Fig. 4. La Virgen y Niño con Santa Ana (1510) por Leonardo Da Vinci.

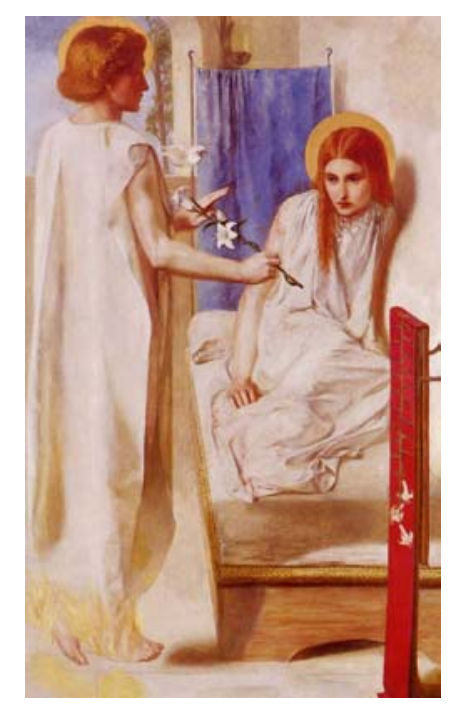

Fig. 6. Ecce Ancilla Domini (1850) por Dante Gabriel Rossetti.

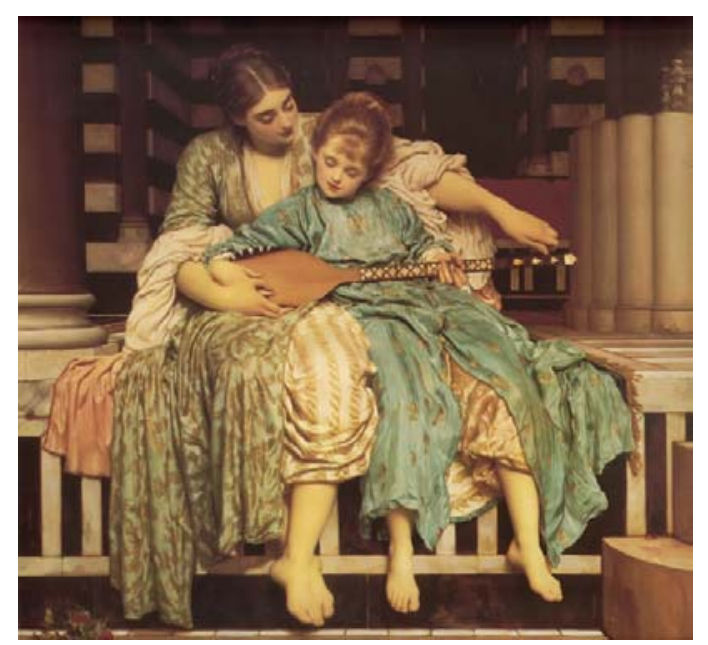

Fig. 5. La lección de música (1877) por Frederick Leighton.

Del mismo modo que la pureza arquitectónica se encontraba en las formas góticas, el culto a la Virgen María, era la expresión del alma infantil, la inocencia y la pureza original. Ruskin ${ }^{10}$, enfatizaría sobre la santidad original del sexo femenino, encontrando su ideal en la Virgen María y relegando el papel femenino al del ámbito doméstico donde desarrollar su natural pasividad, docilidad, emotividad y carácter infantil.

\footnotetext{
${ }^{10}$ RUSKIN, John. Sésamo y lirios. Ensayos Sociales. Buenos Aires: Espasa-Calpe, 1950.
} 
Tales formas femeninas adquirieron características de seducción en la obra de Dante Gabriel Rossetti (1828-82). La vírgenes o heroínas, manifiestan una sensibilidad idealizada y una belleza que trasciende a posibles interpretaciones entre sensualidad, fe religiosa y mística. Además, Rossetti, que era un gran admirador de la obra de Edgar Alan Poe, comparte con él la evocación necrófila. Encontramos en su Beata Beatix (c. 1864-70), el paradigma de virgen que se debate entre el éxtasis místico y la lascivia pecaminosa, encarnada en su modelo por excelencia Jane Morris.

Esa atracción por la belleza de las muertas se ve más enfatizada si puede por el episodio de su vida, cuando siete años después de la muerte de su esposa, Elizabeth Siddal, le escribió unos poemas dedicados, los cuales hizo colocar bajo la cabeza de la difunta por lo que hizo extraer el ataúd de su tumba.

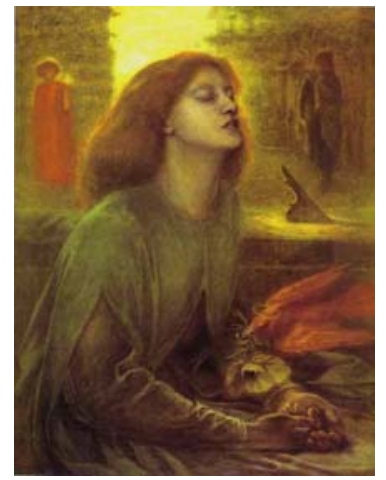

Fig. 7. Beata Beatrix (c. 186470) por Dante Gabriel Rossetti.

Para John Everett Millais (1829-96), la carnalidad de las doncellas de Rossetti, se transforma en tristeza y melancolía en su ideal femenino. Sus vírgenes con la mirada perdida, se abandonan a un destino funesto, como La dama de Shalott-Elaine de Tennyson u Ofelia de Shakespeare. Millais, enfatiza el dramatismo del suicidio en su Ofelia ${ }^{11}$ (1851-52), utilizando el simbolismo de la flores. Nos podemos percatar de las flores, entre otras, las «rosas» que simbolizan el amor, la belleza y la juventud y las «margaritas», que son la inocencia. Contrapuestas sin embargo,

\footnotetext{
${ }^{11}$ La modelo fue Elizabeth Siddal (1829-62). Posó dentro de una bañera con agua que era calentada por unas lámparas, pero se apagaron y Millais no se percató. Elizabeth, cogió un grave catarro y su padre le reclamó 50 libras por los perjuicios causados. Millais resolvió el asunto pagando las facturas médicas. MARSH, Jan. Op. cit., pág. 22.
} 
están los «pensamientos», que representan al pensamiento y al amor vanidoso, así como los «no me olvides», que su propio nombre lo dice. Junto al «sauce llorón», abandono y renuncia amorosa, hay unas «ortigas», que simbolizan el dolor, así como las «amapolas» y el «ojo de faisán» que ambas significan el sueño y la muerte.

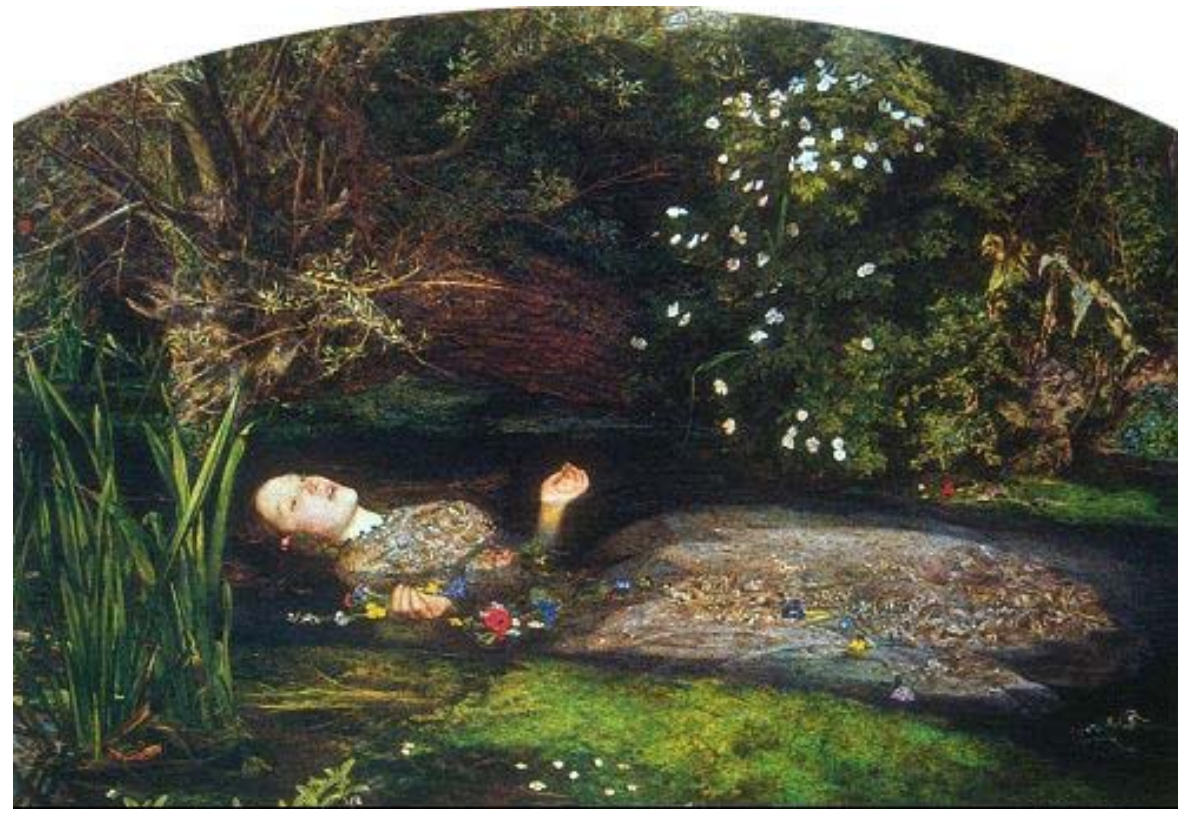

Fig. 8. Ofelia (1851-52) por Sir John Everett Millais.

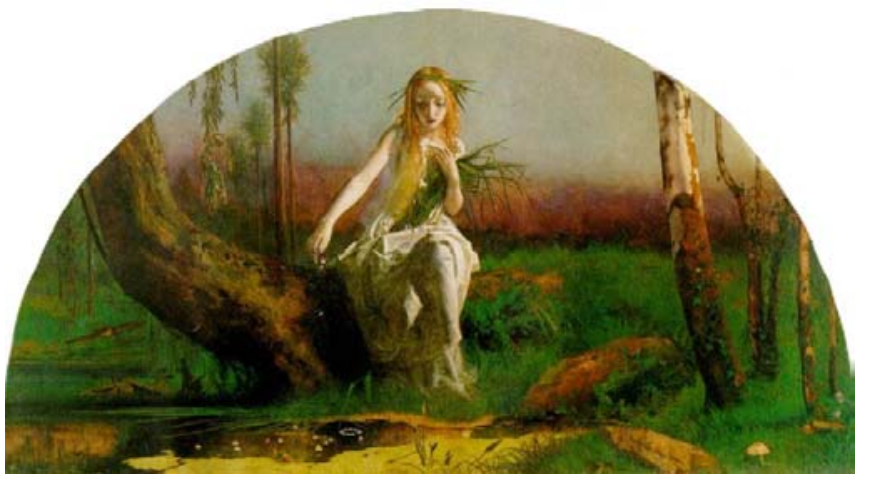

Fig. 9. Ofelia (1853) por Arthur Hughes.

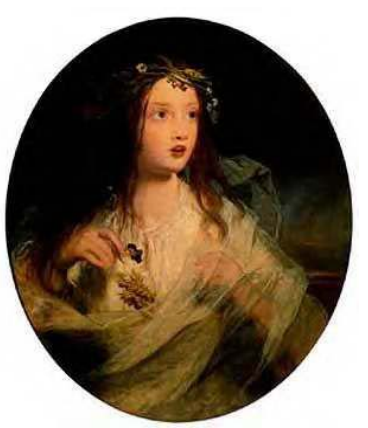

Fig. 10. Ofelia (XIX) por James Sant. 
A pesar de la juventud de Ofelia, los artistas victorianos, la mostraron en contadas ocasiones como una preadolescente, constituyendo tales casos una percepción excepcional de la edad del personaje. Ofelia (1853) de Arthur Hughes (1832-1915), constituye una de estas excepciones en la que se nos muestra a una jovencísima Ofelia momentos antes de lanzarse al agua, cubriendo su cabello con una corona de espigas, ornamento con el que se solía representar tradicionalmente a los locos. La escena misma del «suicidio» parece tener un sentido más completo si la protagonista es representada como adolescente o como mujer, como en Ofelia (1851-52) de Millais, entendiéndose que su locura se desencadena a través de los estímulos sexuales o amorosos frustrados más propios de una mujer desarrollada que de una niña.

Para los artistas prerrafaelistas el poema alegórico de La dama de Shalott de Tennyson constituyó uno de los tópicos femeninos predilectos. William Holmat Hunt realizaría varias versiones de La dama de Shalott, perfilándola como un personaje apasionado. En uno de sus primeros bocetos de La dama de Shalott (1850), indaga en los elementos alegóricos del poema como el espejo donde se refleja el exterior de la torre, la vida de los lugareños y a Lanzarote del Lago, su amado caballero. Alrededor del espejo, dentro de unas esferas aparecen escenas de lo que sabe, será su destino: el cómo mirará a través del espejo, tomará una barca y morirá río a bajo hacia Camelot al encuentro con Lanzarote. Es una escena sobria, sin la decoración del interior de la torre. En el grabado que realizaría en 1857, y en versiones posteriores, abandona los elementos narrativos de la maldición mostrados en el dibujo de 1850, y desarrolla la conducta pecaminosa y pasional de la Dama. Su aspecto es voluptuoso pues su cabellera está suelta, volando ondulante sobre ella -en contraste con el cabello recogido «comedidamente» de la anterior-, y su figura es más sensual, con gesto arrebatado, de manera 
que parece que en un arranque de locura se haya enroscado alrededor del vestido con el hilo con el que tejía. En realidad se trata de dos escenas diferentes. La primera representa a la Dama de Shalott en un estado infantil mental y físico de la misma, ignorante a la maldición, sin pasiones, obediente, recluida y virginal tejiendo sin cesar en su torre. En la segunda, la inocencia infantil se desvanece con el desarrollo físico y el nacimiento del impulso sexual, con el deseo, que es precisamente lo que a los ojos de la moral victoriana, representa un problema para la virtud femenina.

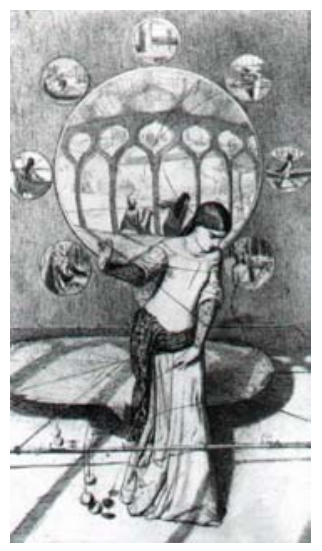

Fig. 11. La dama de Shalott (1850), dibujo de William Holmat Hunt.

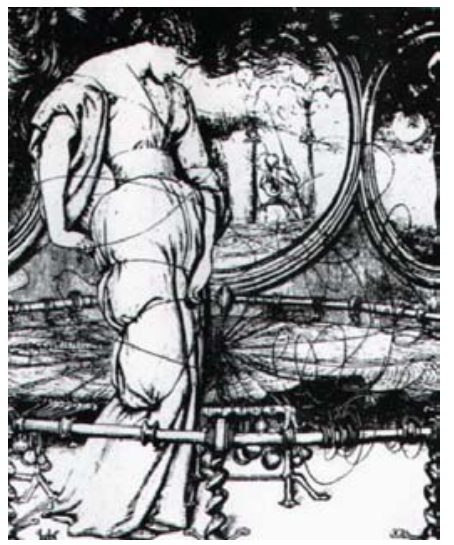

Fig. 12. La dama de Shalott (1857), grabado de William Holmat Hunt.

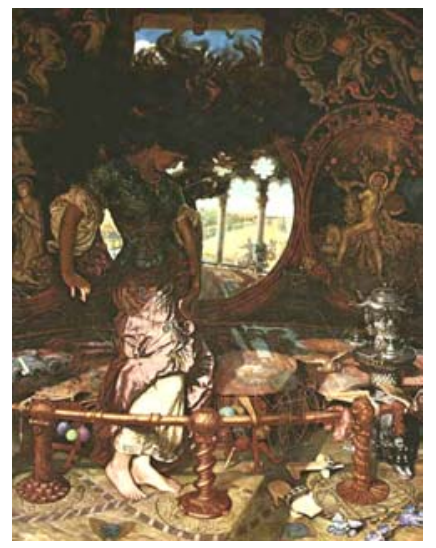

Fig. 13. La dama de Shalott (1889) por William Holmat Hunt.

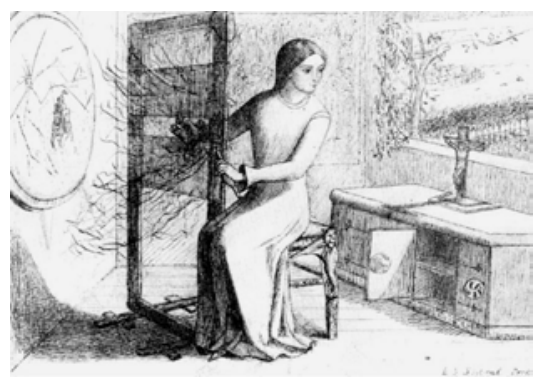

Fig. 14. La dama de Shalott (1853) dibujo de Elisabeth Siddall.
Elizabeth Siddall (1829-1862) por su parte nos ofrece una imagen mucho más cándida de La dama de Shalott. Su aspecto es semejante al de La dama de Shalott (1850) de Hunt. Con curiosidad, mira a través de la ventana, sin que haya nada en su persona, su rostro aniñado, su trabajo 
laborioso, como el de Santa Isabel de Hungría, sobre la peligrosidad que supone tal acto. Este tipo de interpretación del poema de Tennyson, guarda mayor similitud con la visión que nos ofrece Hunt en su versión de 1850, tan sólo tres años antes que el de Siddall.

John William Waterhouse (1849-1917), realizaría también varias versiones de la Dama de Shalott. Su interpretación la hace con un grado de sensualidad inusitado. No se trata de una delirante mujer como la de Hunt en sus versiones tardías, sino que nos la muestra en un momento intermedio, en el que siendo todavía doncella se produce el despertar sexual de forma pavorosa enfatizándolo mediante su aspecto de animalito excitado y atrapado en la trampa de un cazador ${ }^{12}$.

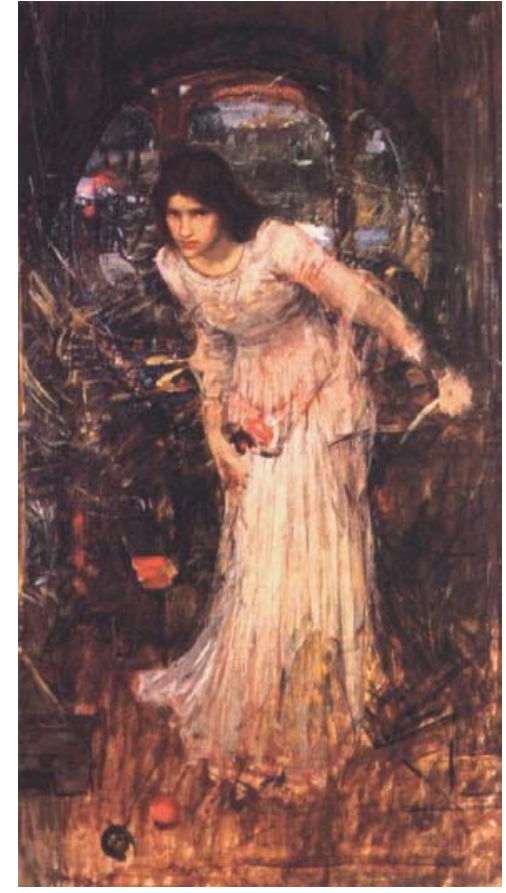

Fig. 15. Estudio para La dama de Shalott (1894) por John William Waterhouse.

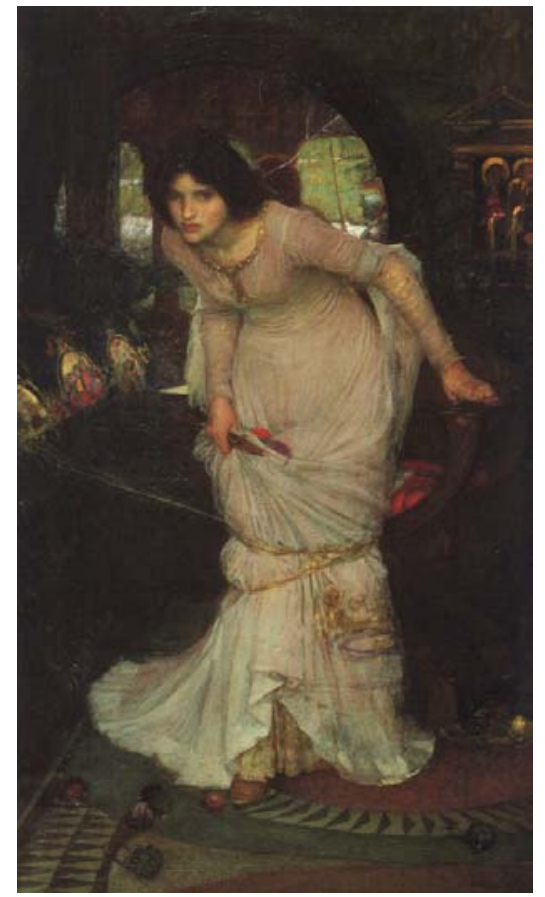

Fig. 16. La dama de Shalott (1894) por John William Waterhouse.

\footnotetext{
12 «Death and the Maiden: The Lady of Shalott and the Pre-rafaelites», en HARDING, Ellen. Re-framing the Pre-Raphaelites: Historical and Theoretical essays. Aldershot: Scolar Press, 1996, pág. 180.
} 
En gran medida, fueron los artistas prerrafaelistas los que incentivaron la relación entre mujer, sueño, muerte y apariencia de muerte, convirtiéndose en uno de los grandes temas de la representación, sobre todo para la fotografía. Los artistas, escritores y en general la sociedad occidental entera, experimentaron una morbosa atracción necrófila en la figura femenina difunta y en la de los niños, que se expresa en numerosas obras como en el estudio del cadáver de una joven, El anatomista [Der Anatom] (1869) de Gabriel Von Max (1840-1915), en el que el forense con gesto pensativo aparta la mortaja que la cubre dejando al descubierto unos senos perfectamente inmaculados, haciéndonos partícipes de la extraña experiencia de la sublimación de la muerte femenina. John Collier en La muerte de Albine (1895), sigue las pautas de la representación propias de la convención funeraria de la época, en la que los difuntos y en especial las mujeres y los bebés, eran colocados para la ceremonia del velatorio familiar, envueltos entre flores y gasas.

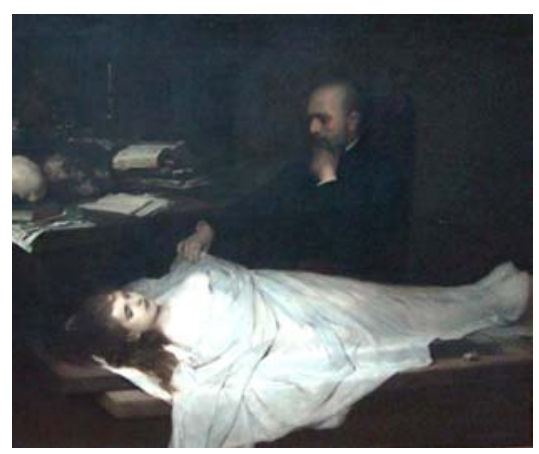

Fig. 17. El anatomista (1869) por Gabriel Von Max.

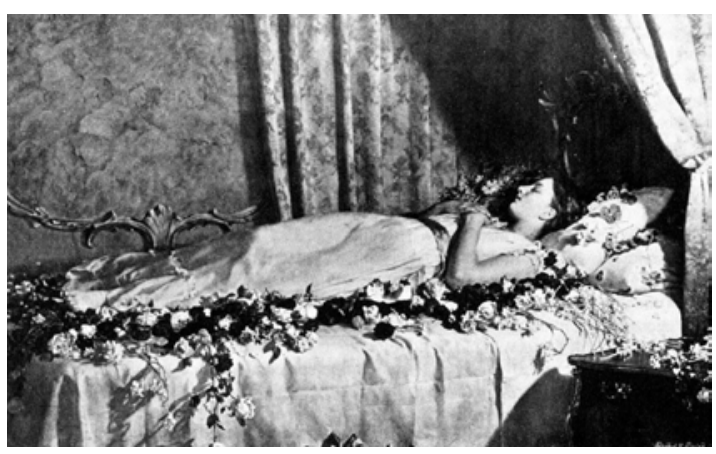

Fig. 18. La muerte de Albine (1895) por John Collier.

Respecto al sueño, las escenas que se recrearon ofrecían un aspecto bucólico o placentero enfatizando la debilidad física y el carácter soñador pero poco creativo del género femenino. 
En La hija del leñador (1860), de Arthur Hughes se introducen elementos de carácter metafórico como una pequeña ardilla y un petirrojo que parecen velar inocentemente por el sueño de la niñita, mientras en el fondo se observa a sus padres trabajando. Los elementos naturales, animales, plantas, indican su origen ancestral, su pertenencia a la naturaleza ${ }^{13}$ como ser

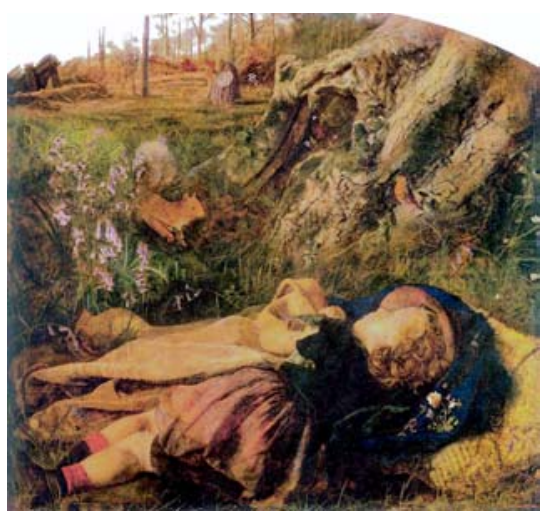

Fig. 19. La hija del leñador (1860) por Arthur Hughes. todavía puro y primigenio, anterior al pecado original.

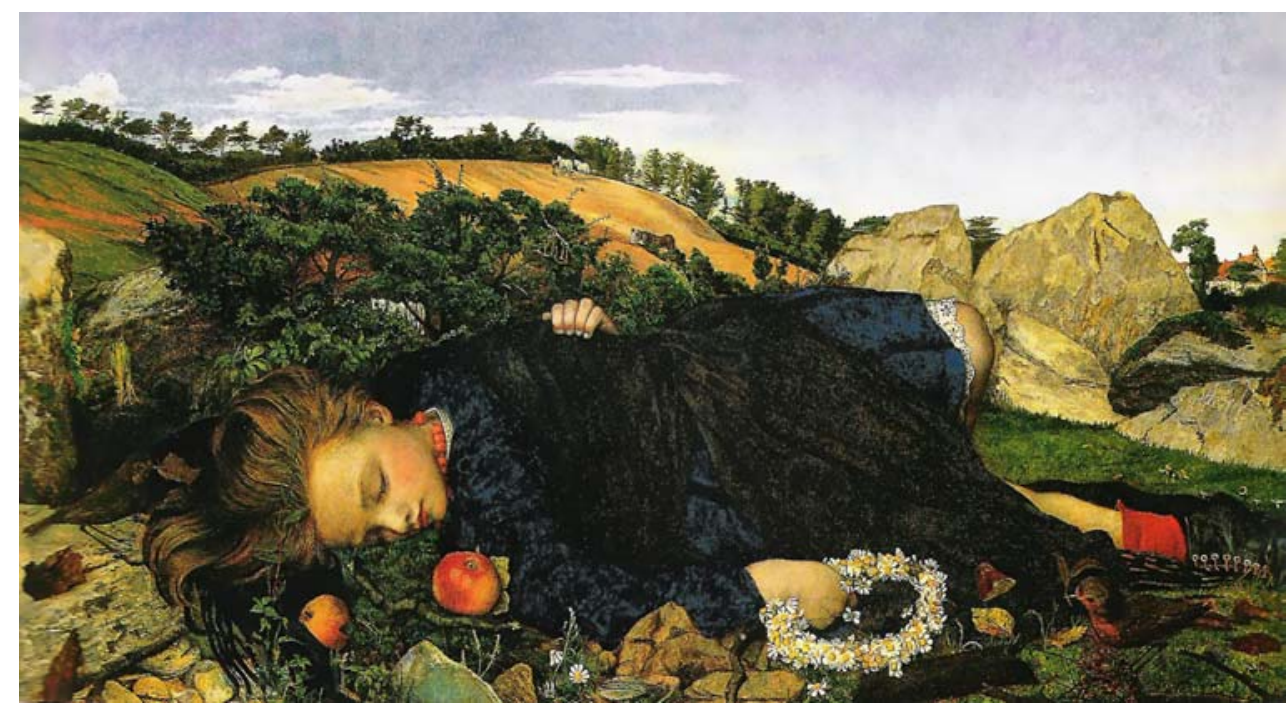

Fig. 20. Petirrojos en los tiempos modernos (circa 1860) por John Roddam Spencer Stanhope.

Con mayores connotaciones sexuales son los petirrojos macho y hembra de Petirrojos de los tiempos modernos de John Roddan Spencer Stanhope (1829-1908). La niña yace de espaldas en una actitud algo

${ }^{13}$ BARTRAM, Michael. The Pre-Raphaelite Camera: Aspects of Victorian Photography. Boston: Little Brown, 1985, pág. 152. 
más seductora que la inocente niñita de Hughes. Su cabello está alborotado, el vestido revuelto y junto a ella hay unas manzanas. ¿No estaremos ante una jovencísima «Eva» en el Paraiso ${ }^{14}$.

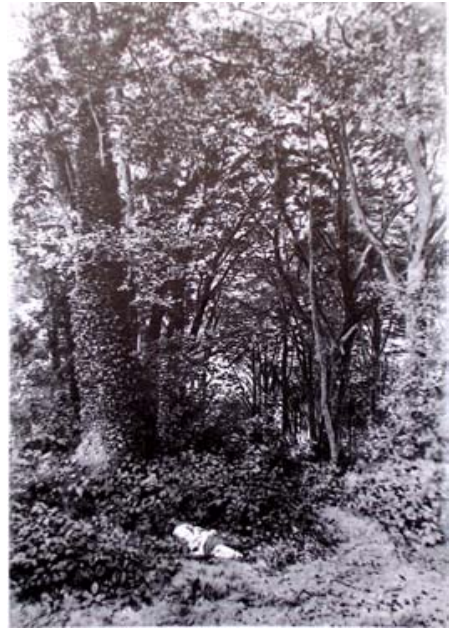

Fig. 21. Perdida en el bosque (1860) guache de Edmund George Warren.
Mucho más inquietante resulta la escena de la niñita, aparentemente dormida, que nos presenta Edmund George Warren (1834-1909) en Perdida en el bosque de 1860. El estado de sueño o muerte de una pequeña en lo frondoso del bosque sugiere disponibilidad sexual, sexo ilícito, oculto y prohibido. Estas pequeñas «Caperucitas» parecen no ser conscientes de los peligros del bosque.

El pintor francés Adolphe-William Bouguereau (1825-1905), que trabajaría profusamente la imagen de la preadolescente con el estilo de gran influencia clásica y del Renacimiento, enfatiza la belleza del cuerpo humano sobre todo en las niñas y las jóvenes en actitud meditativa o de contemplación, con escenas idealizadas de la vida rural o de la mendicidad infantil como en Bohemia de 1890 , en la que una muchacha descalza se encuentra sentada al margen del río Sena con Notre Damme al fondo. Descanso en la cosecha (1865) es una obra singular dentro del conjunto de retratos de niñas y jóvenes. En él utiliza el descanso y la hora de la siesta como excusa para mostrar tímidamente un erotismo si acaso al descubierto por los pies descalzos y una mirada de ensoñación, como si soñara despierta.

14 STALEY, Allen; NEWALL, Christopher. Prerrafaelistas. La visión de la naturaleza. Barcelona: Fundación La Caixa, 2004, pág. 193. 


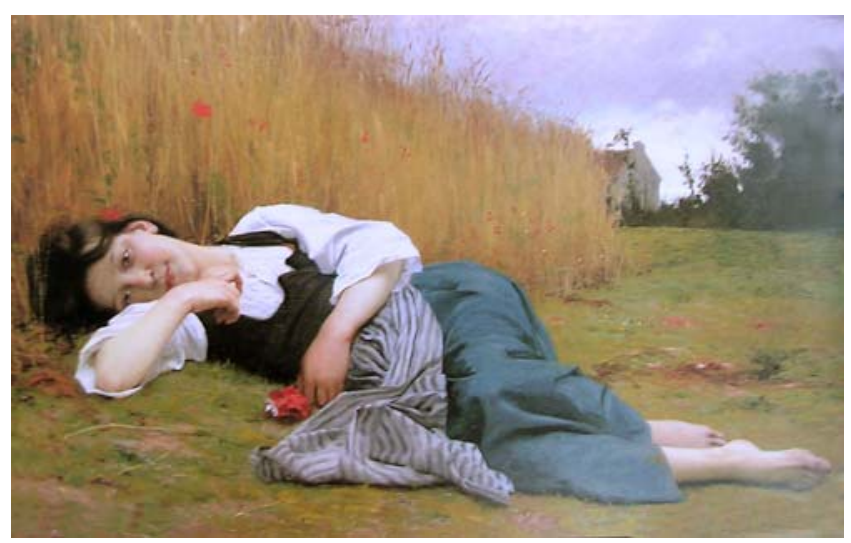

Fig. 22. Descanso en la cosecha (1865) por Adolphe-William Bouquereau.

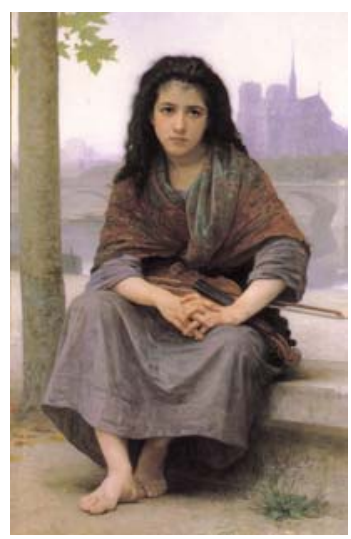

Fig. 23. Bohemia (1890) por Adolphe-William Bouguereau.

La temática pastoril era muy popular en la pintura francesa del siglo XIX. Las gentes del ámbito rural, y más las niñas, poseían simbólicamente las virtudes humanas de pureza y sencillez, así como la ignorancia, la inocencia y el arraigo a la tierra, a la naturaleza, que con tanto énfasis buscaban también los pintores ingleses victorianos. Bouguereau sin embargo, no desaprovecharía en otras ocasiones la imaginería que sugiere aspectos sexuales como en El botijo roto (1891), en el que se presenta a una muchacha sentada junto a una fuente, $y$ a sus pies aparece un botijo roto, que la tradición francesa relaciona con la pérdida de la virginidad ${ }^{15}$.

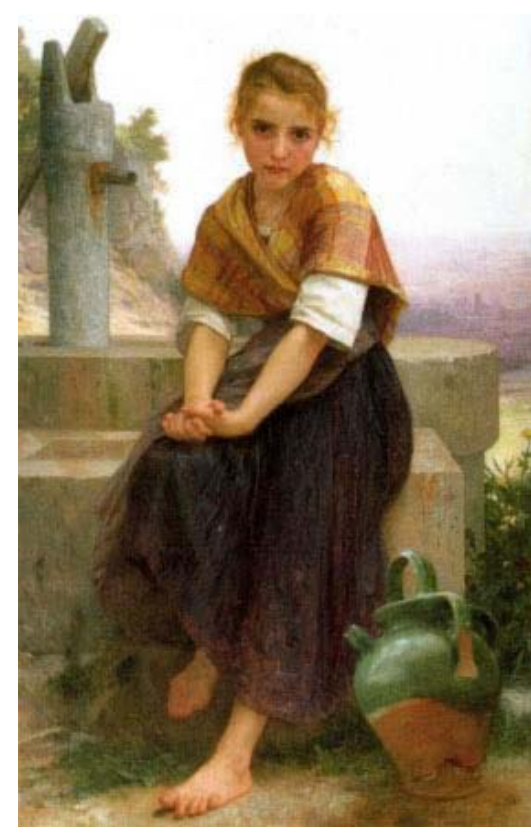

Fig. 24. El botijo roto (1891) por Adolphe-William Bouguereau.

${ }^{15}$ WISSMAN, Fronia E. Bouguereau. San Francisco: Pomegranate Art Books, 1996. 


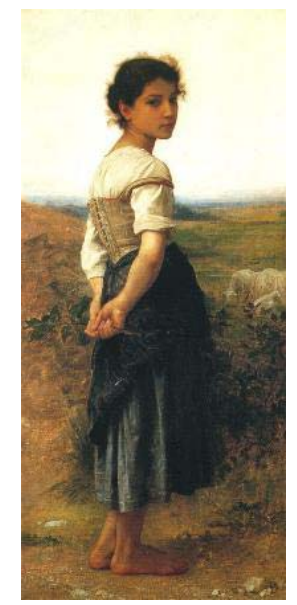

Fig. 25. Joven Pastora (1885) por AdolpheWilliam Bouguereau.

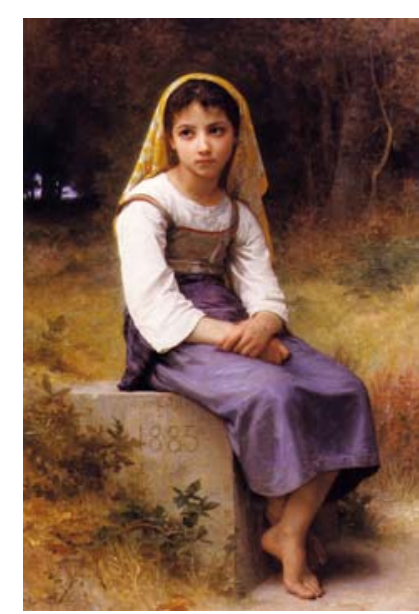

Fig. 26. Meditación (1885) por Adolphe-William Bouguereau.

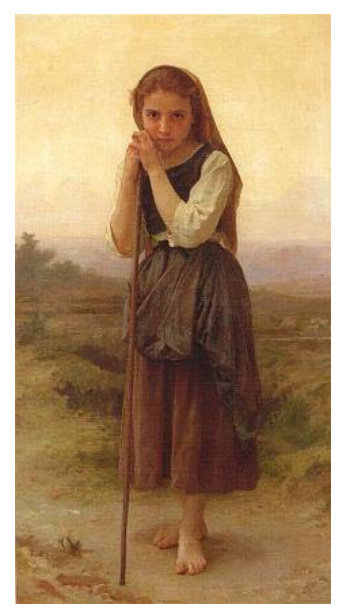

Fig. 27. Pastorcita (1891) por Adolphe-William Bouguereau.

John Everet Millais, que fue llamado el «Reynolds victoriano», ha sido considerado el maestro británico del retrato infantil de la segunda mitad del siglo XIX. Su interés por el retrato infantil no sólo radicaba en los beneficios económicos que obtenía gracias a tales trabajos sino por el compartir junto a gran parte de los artistas de sus época, un profundo sentimiento de admiración y «adoración» por la figura infantil. Así, Millais escribiría en una carta a su amigo Charles Collins: «... el único rostro que puedes pintar y ser considerado hermoso por cualquiera sería el rostro de una niña de unos ocho años» ${ }^{16}$. Al igual que Bouguereau, Millais también fijó su mirada en las niñas del ámbito rural pero su visión es algo distinta. En Hojas de otoño de 1856, enfatiza la sensación de melancolía no sólo en el rostro de las niñas, sino por el evidente simbolismo de las hojas muertas, que marcan el comienzo del otoño y el final del verano comparable al final de la infancia, como cambio traumático hacia la

${ }^{16}$ Cit. WARNER, Malcome, "John Everett Millais's 'Autumn Leaves': a Pictured Full of Beauty and withow Subject" en PARRIS, Leslie (ed.) Pre-Raphaelite Papers. London: The Tate Galley, 1984, págs. 137-8. 
adolescencia. Todas se involucran en la recogida de hojas a excepción de la más pequeña de cabello rubio, que a diferencia de sus compañeras, observa el trabajo mientras come una manzana. Se trata de una niña todavía, que aún no ha llegado a la pubertad y por tanto permanece ignorante al cambio de estación como metáfora de la adolescencia. En esa misma línea hallamos La muchacha ciega (1854-56). Millais vuelve a utilizar a las mismas niñas que en Hojas de otoño. Las niñas bien pudieran ser vagabundas o mendigas -probablemente hermanas-, que viven de las limosnas que obtienen de tocar su acordeón. La pequeña lazarillo son los ojos de la mayor, sin embargo, la dependencia es mutua. Sentadas junto al camino, su vida tal vez cambie algún día, auspiciado por los grajos sobre los cultivos y el arco iris tras la lluvia ${ }^{17}$. Tanto en $L a$ muchacha ciega (1854-56) de Millais, como en Bohemia (1890) de Bouguereau, la idealización de las condiciones económicas de la infancia se alejan de la realidad circundante, de la trata de blancas, del trabajo infantil o de los malos tratos.

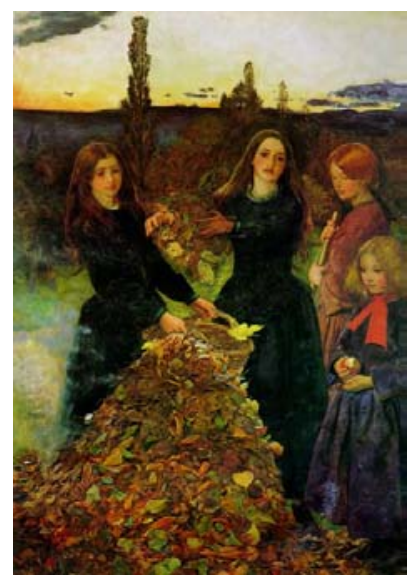

Fig. 28. Hojas de otoño (1856) por Sir John Everet Millais.

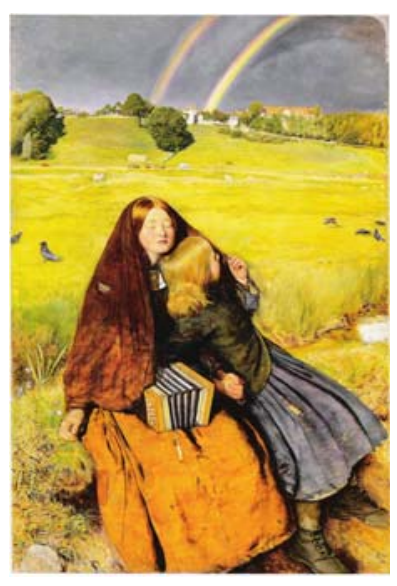

Fig. 29. La muchacha ciega (1854-56) por Sir John Everett Millais.

\footnotetext{
17 La ceguera de la joven, es también una ceguera espiritual, que halla la iluminación mediante el arcoiris, los cuervos y el burrito, todos ellos símbolos bíblicos. HARDING, Ellen. Op. cit., pág. 102.
} 


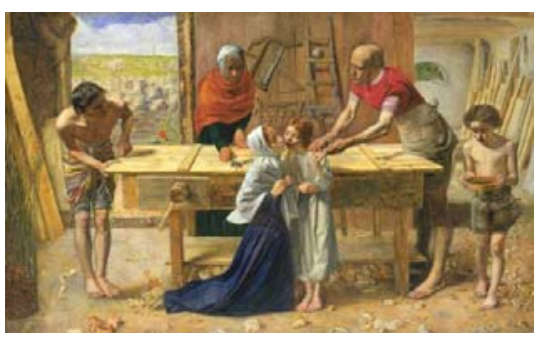

Fig. 30. Cristo en la casa de sus padres (1849-5) por John Everett Millais.

Algunos de sus trabajos iniciales y más cercanos a la fundación de la P.R.B, resultaron ciertamente escandalosos como Cristo en la casa de sus padres (1849-5), en el que Jesús es un niño con el cabello pelirrojo, sin embargo, con los años sus representaciones se fueron haciendo más «acordes al gusto del público», como señala Spielmann ${ }^{18}$. Este «acomodamiento» dio sus frutos en imágenes infantiles ajenas a polémicas y cosechadoras de éxitos populares avaladas por críticas favorables, como Mi primer sermón (1863), del que The Art-Journal ${ }^{19}$ señalaría ese mismo año: «nada puede ser más deliciosamente simple ni más completamente artístico que la cara, la postura y el vestido de esta pequeña», así el siguiente año esta opinión sería corroborada cuando afirmaba de Mi segundo sermón (1864) como un encantador retrato «de los más fascinantes y adorables estados de los años de la infancia» ${ }^{20}$. Ambos trabajos a pesar de superficial belleza, indagan sin embargo, en busca de una respuesta moralizadora entre la confrontación de la naturaleza inocente de la infancia frente a las expresiones rituales de la religión institucionalizada, un problema también contemporáneo respecto a la enseñanza religiosa de los niños. Años más tarde, Henry Blackburn ilustraría la portada de la revista Grosvenor Notes de 1881, con Los ojos mas dulces que jamás haya visto (1881) de Millais, que había sido expuestos en Burlington House y en Grosvenor Gallery en Londres y que sería calificada de «adorable» por Lewis Carroll.

\footnotetext{
18 Catálogo de su exposición retrospectiva de 1889. SPIELMANN, Marion H. Millais and His Works. London: Blackwood, 1898, pág. 86.

${ }^{19}$ The Art -Journal, June $1^{\text {st }}, 1863$, pág. 109.

20 Íd., pág. 163.
} 


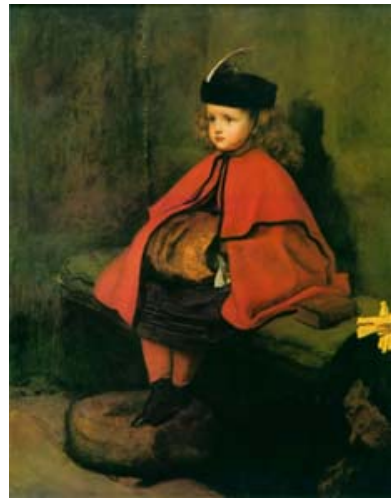

Fig. 31. Mi primer sermón (1863) por John Everett Millais.

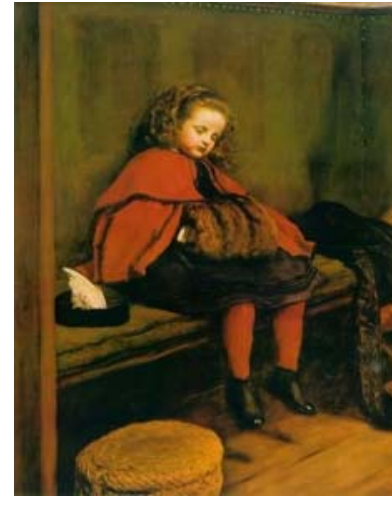

Fig. 32. Mi segundo sermón (1864) por John Everett Millais.

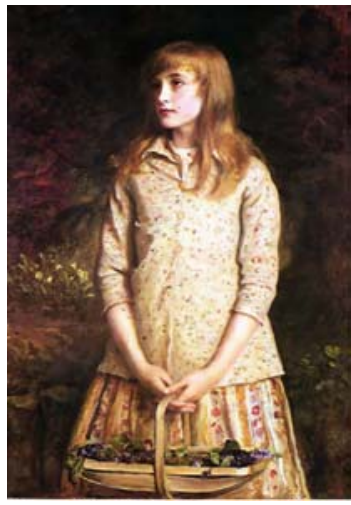

Fig. 33. Los ojos mas dulces que jamás haya visto (1881) por John Everett Millais.

La influencia del estilo de Fray Angélico y del primer Renacimiento se evidenciaría en las composiciones hieráticas de cierto primitivismo y un aire naíf ${ }^{21}$, en el color de las composiciones de vírgenes y santas de Marianne Stokes ${ }^{22}$ (1855-1927). La preadolescente se transfigura en el rostro juvenil de la Virgen María ${ }^{23}$ en Madonna y niño (1907-98) y se acentúa su naturaleza inocente, pura y casi angelical en Sta. Isabel de Hungría hilando para los pobres (1895), en la que se acentúa su virtud mediante la imagen del rostro de Cristo sobre ella, como también la representarían orante y piadosa, autores como Charles Allston Collins (1828-1873) en La devoción de Santa Isabel de Hungría (1852). Algunos autores

\footnotetext{
${ }^{21}$ MARSH, Jan; GERRISH NUMM, Pamela. Pre-Raphaelite Women Artist. New York: Thames and Huston, 1999, pág. 148.

22 Nació en 1855 en Graz, Austria. Estudió Arte en París. Con Bagnan-Bouveret estudió «la pincelada cuadrada» y el Naturalismo con Bastien Lepage. En 1883, pintando con los artistas plein-air británicos conoce a su futuro marido Adrian Stokes. Debutó en el Salón de 1884 y ese mismo año contraería matrimonio.

${ }^{23}$ MARSH y GERRISH señalan el parecido de la Madonna y niño con las madonnas y Cristo bebé de Julia Margaret Cameron. Op. cit., pág. 148.
} 
interpretaron la imagen de la santa en términos menos piadosos. En Isabel (1889) de P. H. Calderon, se la representa excepcionalmente desnuda, enfatizando la completa renuncia, mediante un acto de desnudez frente al altar pero también ofreciéndonos una singular escena del desnudo de una joven monja iluminado por un haz de luz que atraviesa uno de los ventanucos de la capilla a los ojos del resto de las monjas. Arnold Hauser, lo describiría como una «lamentable obra pornográfica» ${ }^{24}$.

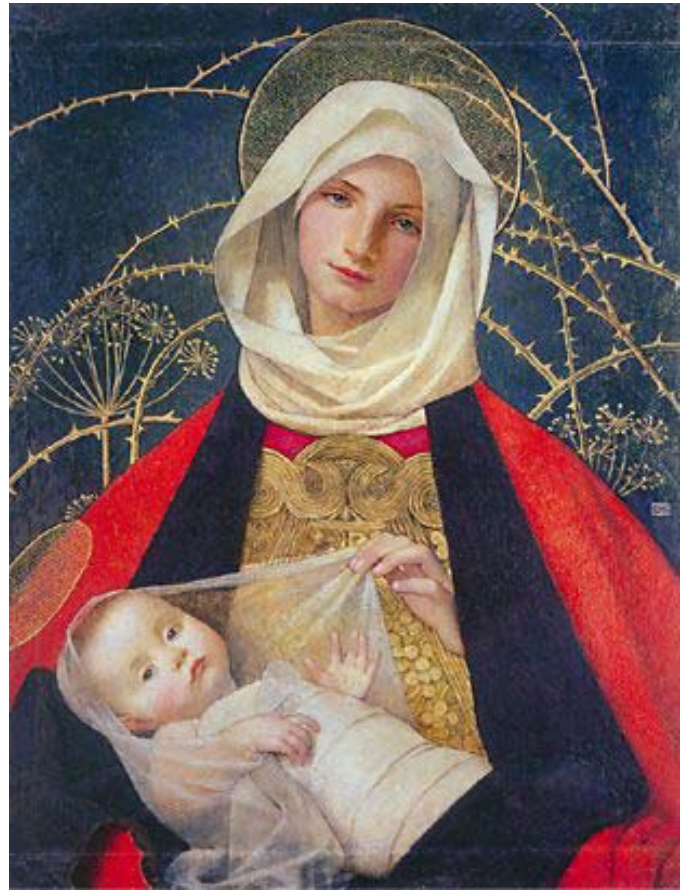

Fig. 34. Madonna y niño (1907-98) por Marianne Stokes.

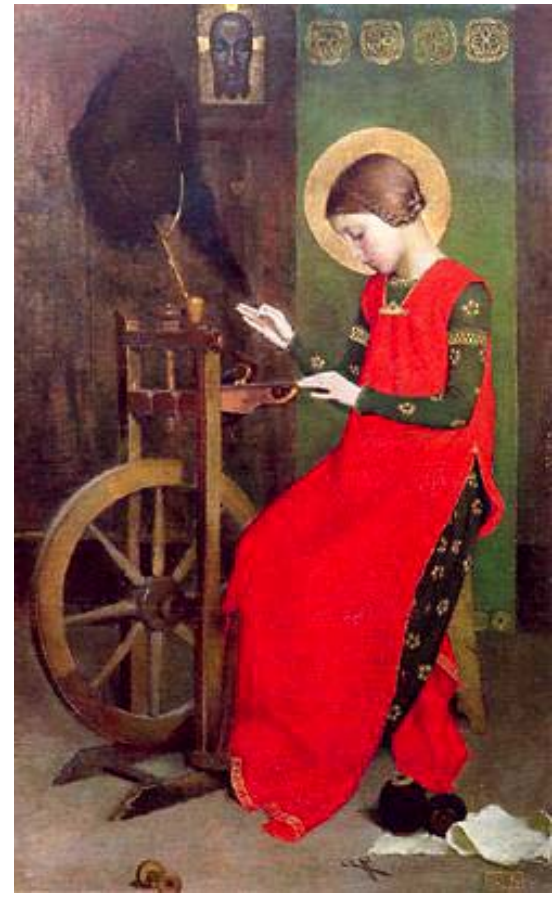

Fig. 35. Santa Isabel de Hungría hilando para los pobres (1895) por Marianne Stokes.

\footnotetext{
${ }^{24}$ HAUSER, Arnold. Historia social de la literatura y el arte. vol. 3. Madrid: Guadarrama, 1989, pág. 137.
} 


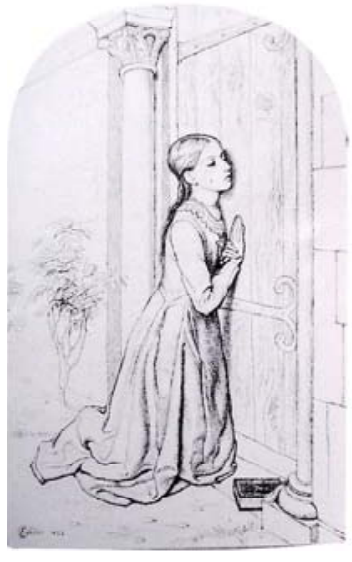

Fig. 36. La devoción de Santa Isabel de Hungría (1852) dibujo de Charles Allston Collins.

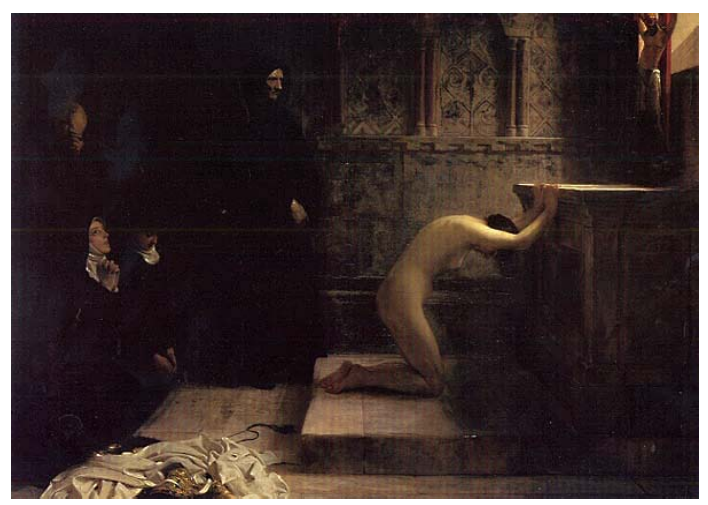

Fig. 37. Isabel (1889) por P. H. Calderon.

Este tipo de imágenes se desarrolló profusamente bajo la influencia de la renovación evangélica de la Iglesia Anglicana y en general la Protestante, de la que las artes se haría partícipe mediante la difusión de los preceptos morales propios para las niñas y las jóvenes, que mostraban las conductas ejemplares y piadosas a inculcar en las hijas pero mediante la función y participación mediadora de las madres, como muestra Al acostarse [Bed Time] (1862) de Arthur Hughes.

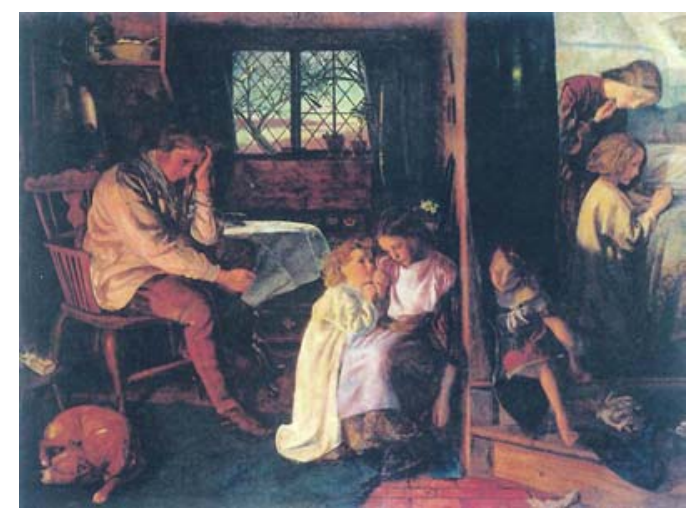

Fig. 38. Al acostarse (1862) por Arthur Hughes. 
Thomas Cooper Gotch ${ }^{25}$ (1854-1931) por su parte nos ofrece un estilo influenciado también por las formas del temprano Renacimiento con una imagen de la preadolescente marcada por el simbolismo, el decorativismo y el ideal romántico. La niña entronizada (circa 1894), en la que utiliza como modelo a su hija Phillys -y que resultó ser una obra de gran éxito en su momento ${ }^{26}$, va vestida ceremoniosamente con suntuosos ropajes y brocados, sentada inmóvil en un trono. Se hace evidente la idolatría hacia la imagen de preadolescente como si se tratase de la mismísima Virgen María, otorgándole no sólo un halo de santidad sobre su cabeza, sino que la entroniza casta y virginal, y le otorga un reino y un poder terrenal. El culto a la infancia se hace verdaderamente evidente con esta representación. De modo menos suntuoso, pero igualmente icónico entroniza a la niña de nuevo en $\mathrm{Mi}$ corona y mi cetro [My crown and sceptre] (1891).

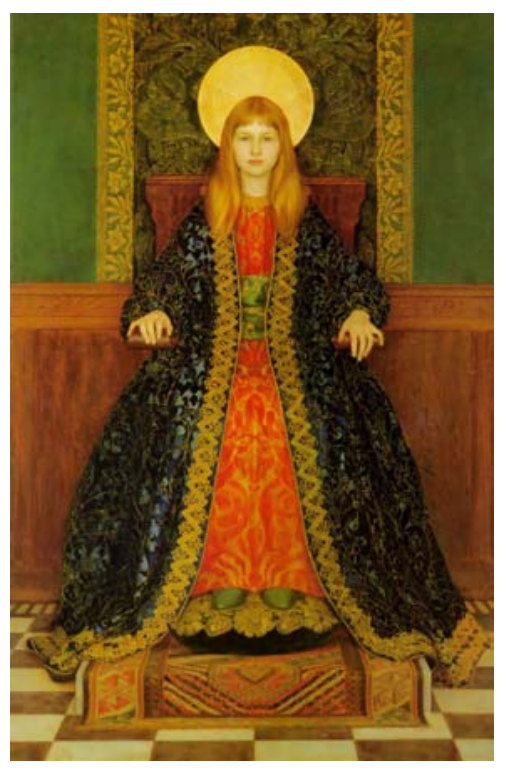

Fig. 39. La niña entronizada (c. 1894) por Thomas Cooper Gotch.

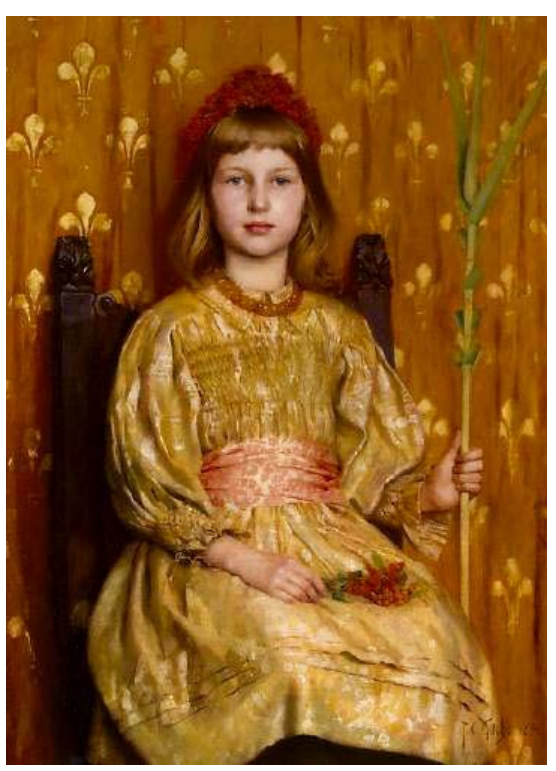

Fig. 40. Mi trono y mi cetro (1891) por Thomas Cooper Gotch.

\footnotetext{
${ }^{25}$ Fue Vicepresidente de la Royal West of England Academy.
}

${ }^{26}$ La pintura fue mostrada en la Royal Academy en 1892. 
Con el mismo motivo o identificando a la preadolescente con los ángeles de Dios, realizaría otras obras similares de grupo como Aleluya (circa 1896), El desfiles de niños [The Pageant of Childhood] (1895) o como representación individual e icónica en Una broma [A Jest] (s.a.) o La bandera (191?).

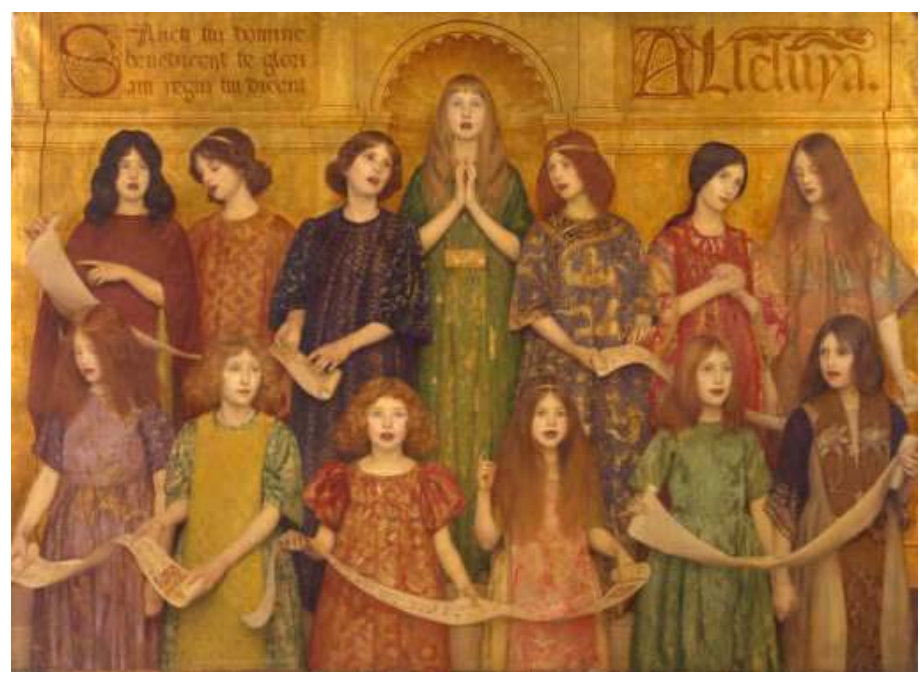

Fig. 41. Aleluya (c. 1896) por Thomas Cooper Gotch.

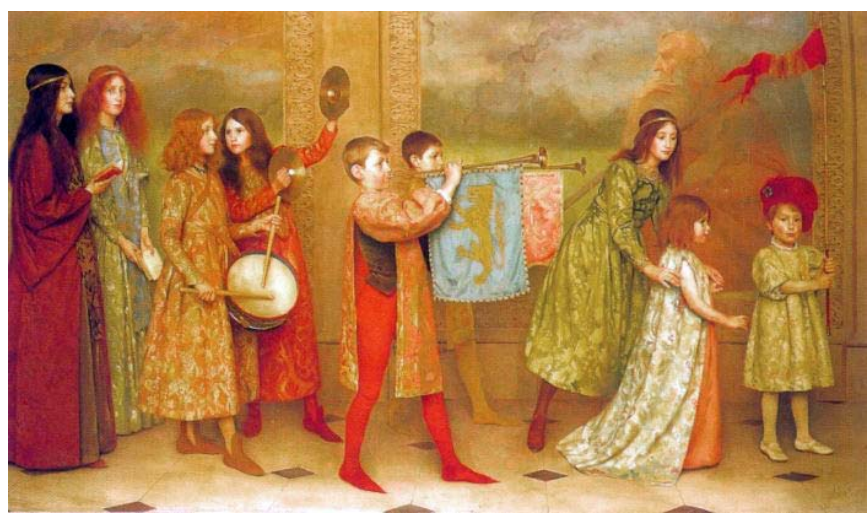

Fig. 43. El desfile de niños (1895) por Thomas Cooper Gotch.

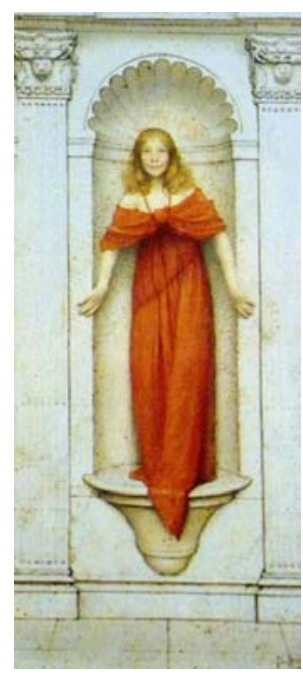

Fig. 42. Una broma (s.a.) por Thomas Cooper Gotch.

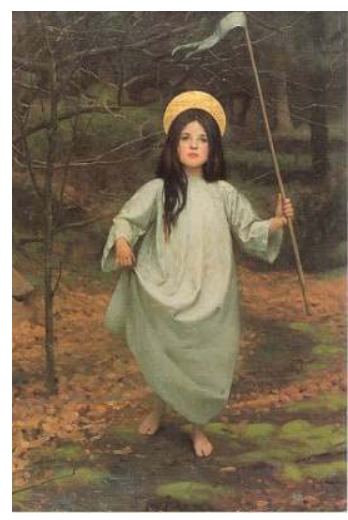

Fig. 44. La bandera (191?) por Thomas Cooper Gotch. 
Algunos pintores de finales del siglo XIX, como Paul Emile Chabas (1869-1937), ubicaron el desnudo infantil dentro del baño, semejantes a sirenas, hadas o ninfas de las aguas, en un ideal juego acuático en aguas tranquilas o lagos brumosos. La fragilidad y la candidez de las niñas son sólo la apariencia de la visión lujuriosa de la pintura simbolista.

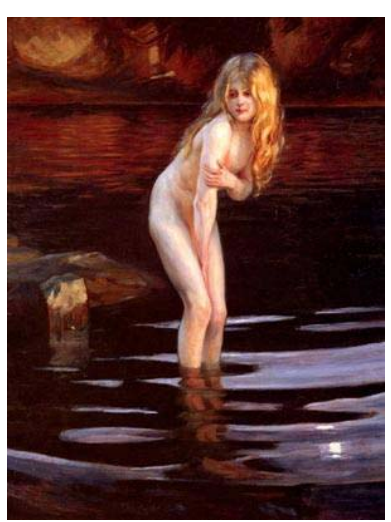

Fig. 45. La bañista (s.a) por Paul Emile Chabas.

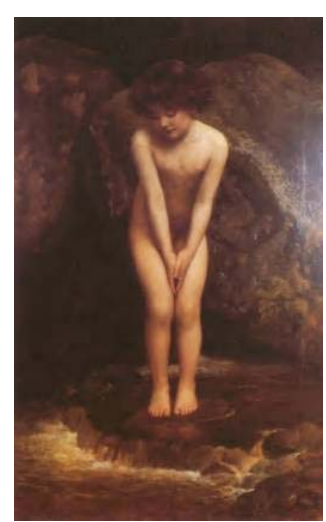

Fig. 46. El bebé de Agua [The Water Baby] (1890) por John Collier.

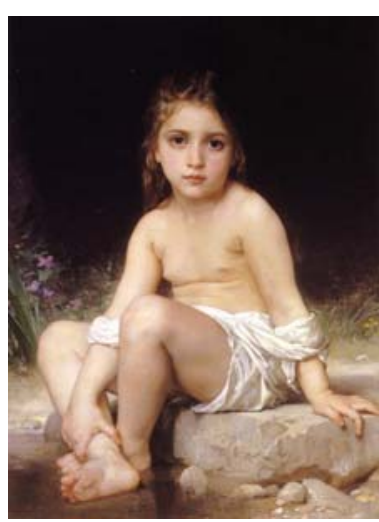

Fig. 47. Niña en el baño (1886) por Adolphe-William Bouguereau.

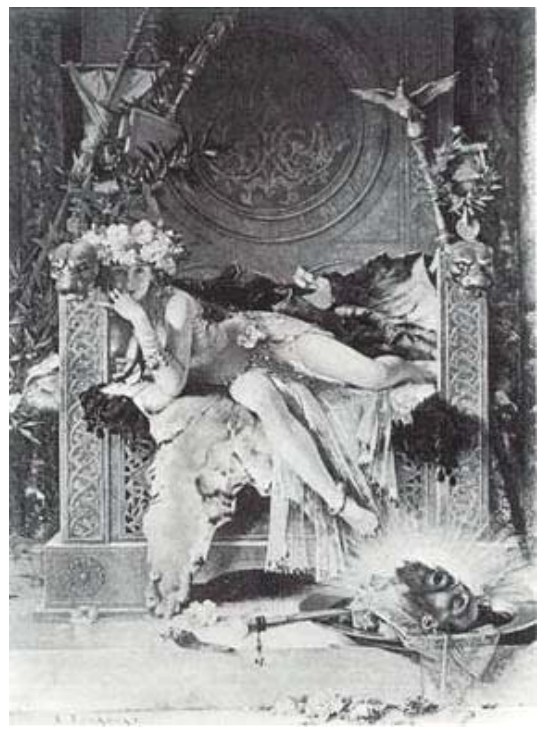

Fig. 48. Salomé triunfante (1886) por Édouard Toudouze.
Bajo la influencia del Simbolismo la sensualidad infantil, sucumbió ante la maldad femenina. Dentro de la representación simbolista encontramos la maldad manifiesta de la preadolescente con personajes de la tradición literaria o bíblica como Salomé triunfante (1886) de Édouard Toudouze (1848-1907), que nos presenta una Salome preadolescente, juguetona, de mirada curiosa $y$ penetrante, con la cabeza del Bautista a sus pies como si de un juguete usado o un regalo abierto se tratase. 


\begin{abstract}
Así, John Collier nos ofrece una poco habitual Lady Godiva (1898) pues su apariencia es la una joven de no más de quince años, desnuda sobre la montura de un caballo blanco, con su piernas largas y delgadas, carente de exhuberancias y con el cabello cubriéndole parcialmente la espalda y el pecho, que para el espectador
\end{abstract}

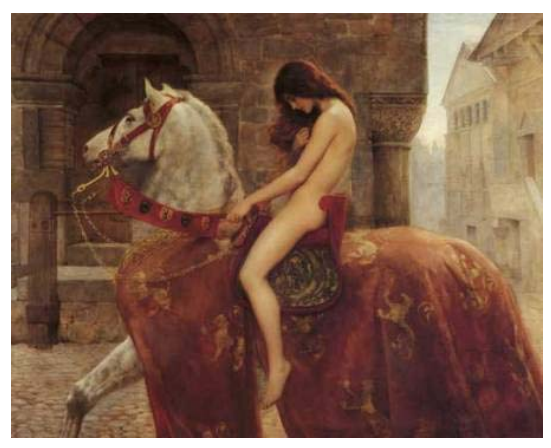

Fig. 49. Lady Godiva (1898) por John Collier.

permanece oculto. La metáfora zoofílica del caballo entre sus piernas, no es sólo la única, sino también la de la pérdida de la virginidad.

Esa provocación y la perversidad no siempre se hallaría en la evidencia del desnudo sino también en la sutileza de las expresiones del rostro como en el Autorretrato con la familia (c. 1903) de F. von Lembach, en la que el autor se retrata con su esposa y sus dos hijas, todas ellas de mirada perturbadora, pero es de destacar la mirada de la hija menor que fijamente observa al espectador, como una endiablada vampiresa, que nos conduce a la constante duda social respecto a la verdadera bondad de las niñas.

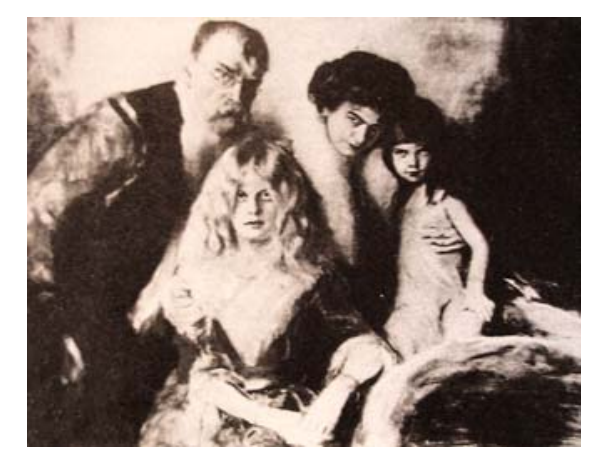

Fig. 50. Autorretrato con la familia (c. 1903) de F. von Lembach. 


\subsection{La ilustración victoriana.}

Anteriormente al siglo XVIII apenas existían libros ilustrados y menos todavía creados específicamente para un público infantil. Tan sólo a mediados de dicho siglo, se abrió progresivamente un mercado de literatura infantil hasta el siglo XIX en el que precisamente nacerían los grandes clásicos de la literatura infantil, como Alicia en el País de las Maravillas de Lewis Carroll o Mujercitas de Louisa May Alcott y con ella la publicación de numerosos libros ilustrados. Además, alrededor de 1860 hasta principios del XX, ya fuera en Europa o Estados Unidos, existía un extenso mercado que difundía tanto imagen idealizada como la imagen pornográfica ${ }^{27}$ de la preadolescente.

Se realizaban y se publicaban numerosos grabados de las obras pictóricas más populares del momento. Así ocurriría con las obras de los pintores prerrafaelistas, siendo John Everett Millais uno de los más reproducidos en las revistas, al que seguirían pintores y dibujantes como Dante Gabriel Rossetti, William Holman Hunt, Frederick Sandy, John Tenniel, ilustrador de Alicia en el País de las Maravillas y $A$ través del espejo de Lewis Carroll o George Cruikshank por sus ilustraciones para las obras de Dickens. Será gracias a la invención de la fotografía y de la cuatricromía, que la ilustración será considerada como uno de los primeros grandes medios de masas.

Paralelamente al desarrollo de la ilustración, se formaría una visión misógina de la naturaleza del género femenino, debida en parte a la nueva situación social de la mujer y a la enorme cantidad de enfermedades venéreas, que propiciaría indirectamente el tópico de la femme fatale ${ }^{28}$, dando lugar en numerosas ocasiones a representaciones

\footnotetext{
27 DIJKSTRA, Bram. Op.cit., pág. 193.

${ }^{28}$ Los simbolistas harían del tópico de la femme fatale uno de sus temas más recurrentes.
} 
femeninas tanto de atractivas jóvenes como de seductoras niñas indistintamente sin hacer apenas diferencia entre lo que verdaderamente constituía una imagen idealizada de la preadolescente y la imagen infantil en la pornografía. Los ilustradores victorianos contribuyeron a perpetuar tales concepciones de la naturaleza femenina y de su etapa infantil, pero sobre todo difundieron esos mismos estereotipos entre la gran masa popular que compraba los periódicos y revistas ilustradas, ajenos a las tendencias artísticas de las academias y las escuelas de arte. Los anuncios y la propaganda sacarían provecho del atractivo de las imágenes infantiles, en especial de las niñas.

Los trabajos pictóricos que trataban el desnudo infantil resultaron tan populares que se reproducían en las revistas o se versionaban por los ilustradores, así también se realizarían numerosos objetos y artefactos dedicados a la cultura infantil victoriana $^{29}$ con decoraciones con niños pequeños o bebés, alimentando la demanda por esta clase de artículos. La imagen infantil pues, se convertiría en un «hermoso» objeto de consumo del obsesivo y fetichista público adulto.

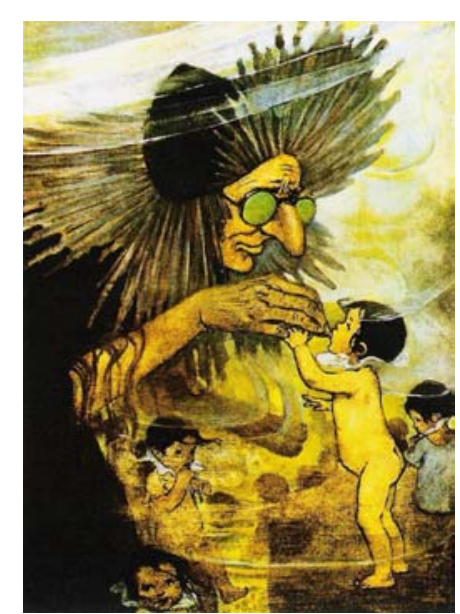

Fig. 51. Ilustración de Jessie Wilcox Smith para Los bebés de agua [The Water Babies] (circa 1863) de Charles Kingsley.

A pesar de que las imágenes de niñas tenía un numeroso público masculino, la gran mayoría era femenino, sobre todo influenciado por el ideal romántico y victoriano de feminidad. Así, la artista Kate Greenaway

\footnotetext{
${ }^{29}$ CALVERT, Karin. Children in the House: The Material Culture of Early Childhood. Boston: Notheastern University Press, 1992, pág. 7.
} 
(1846-1901) supo hacerse hueco dentro del sentimental público victoriano consiguiendo que rápidamente se difundiesen sus libros y álbumes ilustrados por varios países europeos. Sus ilustraciones obtendrían un gran éxito desde su primer libro infantil Bajo la ventana [Under the Window] (1878). Su Libro de cumpleaños para niños [Kate Greenaway's Birthday Book for Children] (1879) con versos de Mrs. Sale Barker, vendió tan sólo en Inglaterra 128.000 copias, 13.500 en Francia y 8.500 en Alemania. No todos supieron admitir el éxito de Miss Greenaway, como Frederick Locker-Lampson, que escribió sobre ella con desdén: «... se me ha ocurrido, que usted es la única artista inglesa que ha estado en la moda francesa».

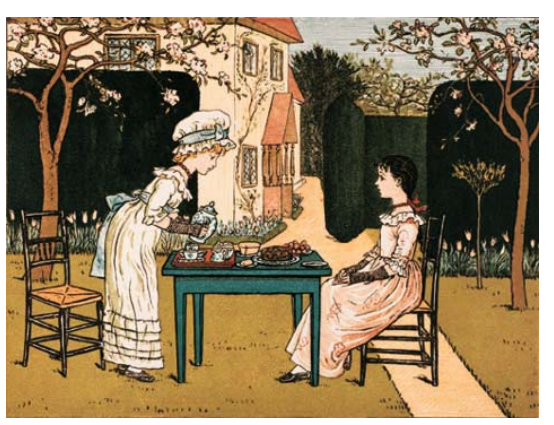

Fig. 52. Bajo la ventana [Under the Window] (1878) por Kate Greenaway.

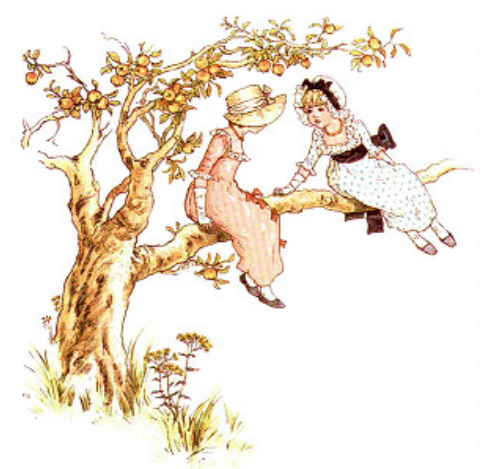

Fig. 54. El jardín de caléndulas [Marigold Garden] (1885) por Kate Greenaway.

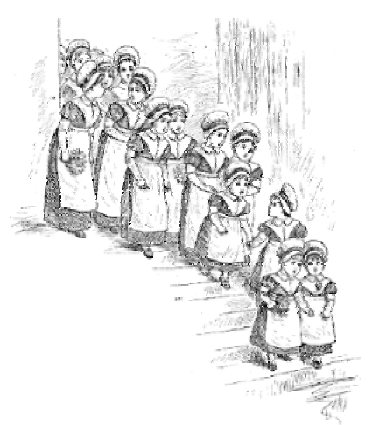

Fig. 53. Dejando el colegio [Leaving the School. St. Nicholas. Volume 6, No. 3 (Enero 1879) por Kate Greenaway.

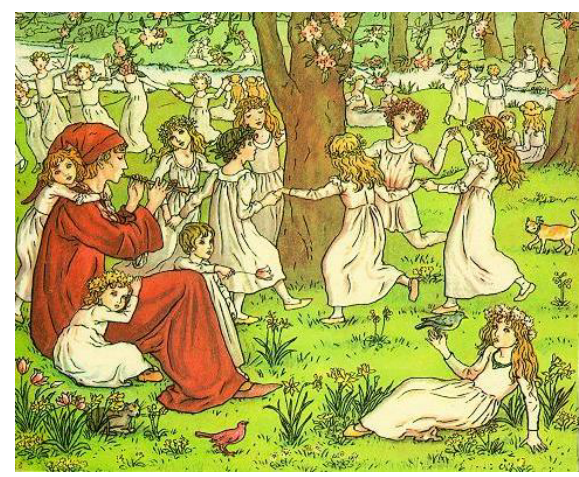

Fig. 55. El flautista de Hamelin [The Pied Piper of Hamelin] (1888) por Kate Greenaway. 
Sus escenas de infancia idealizada y didácticamente moralizadoras de niñas con cofia y vestidos con mangas abullonadas, fueron tremendamente populares en Estados Unidos. Edward William BoK $^{30}$ periodista norteamericano afirmaba que las ilustraciones de la «inaccesible» Miss Greenaway -como la calificaban sus propios editores $^{31}$-, eran el vivo reflejo de su casa y de la acaramelada forma de vida de su autora, que vivía en Queen Anne House en Hampstead Healt.

La escasez de encargos pictóricos que recibían los artistas prerrafaelistas, forzó a que algunos realizaran eventualmente trabajos mejor pagados como la ilustración, sobre todo de género sentimental o infantil o con referentes fantásticos muy del gusto popular. Uno de los artistas que sucumbió ante la demanda de imágenes infantiles, fue Sir John Everett Millais, que a pesar de declarar: «si el público quiere imágenes de niñas en las cofias, yo les daré imágenes», llegó a ganar entre 30.000 y 40.000 libras al año con éste tipo de imágenes. En 1879, la imagen más popular de Millais era Cerezas maduras [Cherry Ripe], que en 1880 se reprodujo en color en la página central de la revista Graphic Christmas Annual, del cual se vendieron unas 600.000 copias. En ella se representaba a una dulce niñita con cofia al estilo de Reynolds o Gainsborough. Y en 1886, por ejemplo, La pequeña Miss Muffet [Little Miss Muffet] (1886), fue usada para ilustrar la revista Illustrated London News. Otra de sus más famosas pinturas, Burbujas [Bubbles] (1886),

\footnotetext{
30 Edward William Bok viajó a Inglaterra con la intención de conseguir entrevistar a algunos de los más vendidos autores victorianos en los Estados Unidos de América como Lewis Carroll. Tras su fallida búsqueda de Lewis Carroll, obtuvo su entrevista con Kate Greenaway. Para lograr acceder a entrevistarla tuvo que convencerla de que el objetivo principal de su llegada a Inglaterra era verla y entrevistarla «en nombre de los miles de niños norteamericanos». AA.VV. XX Meeting a Reverse or Two [en línea]. Edward William Bok (1863-1930). The Americanization of Edward Bok, 1921. [ref. de 13 de septiembre del 2005]. Disponible en Web: http://www.bartleby.com/ 197/20.html

${ }^{31}$ Algunos de sus editores jamás la conocieron en persona. «Todos los tratos y negocios los realizamos por correspondencia», afirmaban.
} 
pronto se convirtió en la imagen que vendiera los productos de la marca Pears, de jabones, talcos, etc... y que utilizarían como imagen comercial durante décadas. Junto al Pears Soap, no sólo obtienes higiene corporal, sino que también satisfaces el ansia de un espíritu inmaculado. Este tipo de imágenes con ropas blancas y cofias, transmitirían con claridad y sin doblete el ideal de pureza victoriano.

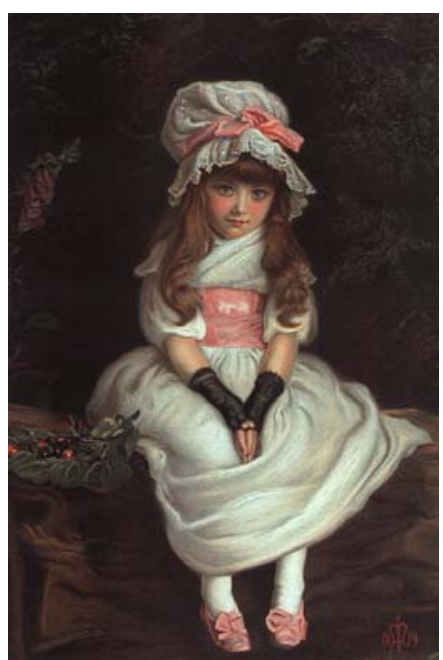

Fig. 56. Cerezas maduras (1879) por John Everett Millais.

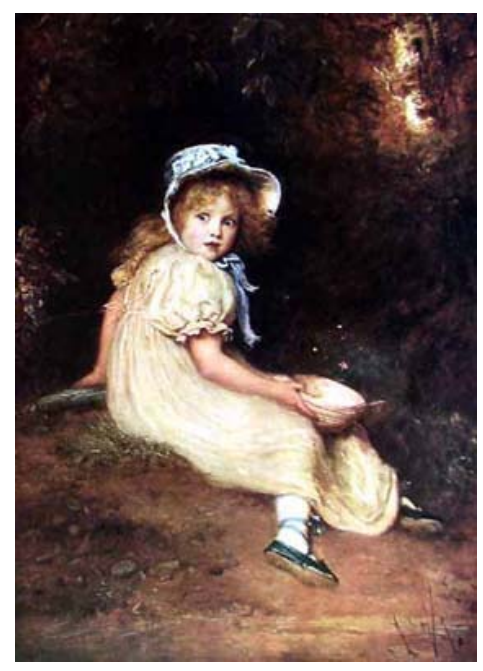

Fig. 58. La pequeña Miss Muffet (1886) por John Everett Millais.

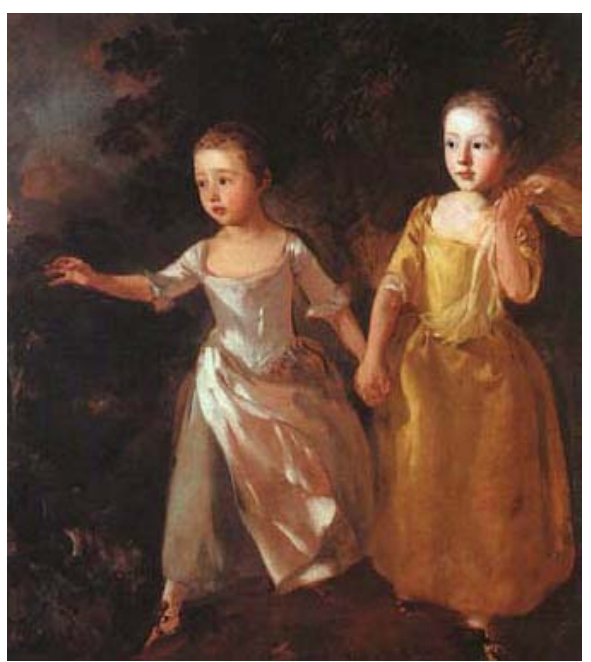

Fig. 57. Las hijas del pintor atrapando una mariposa (1756) por Gainsborough.

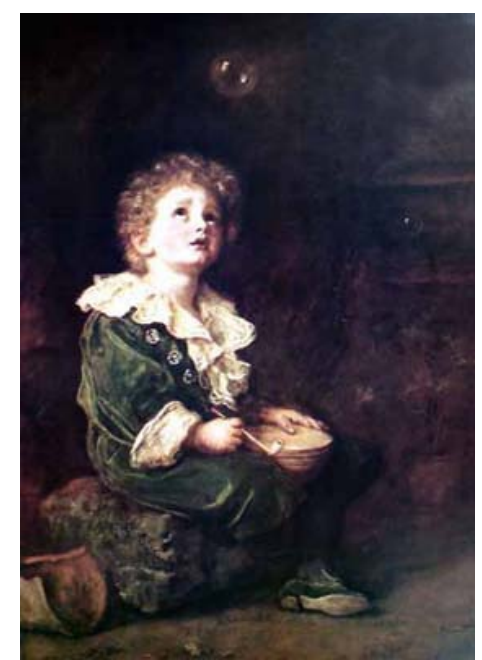

Fig. 59. Burbujas (1886) por John Everett Millais. 


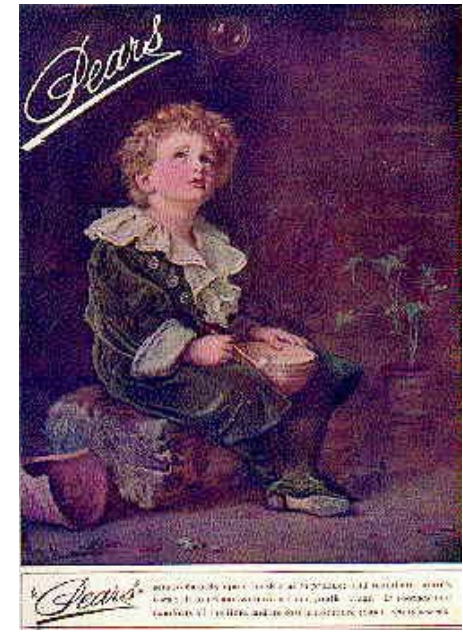

Fig. 60. Burbujas usado para Pear's Soap.
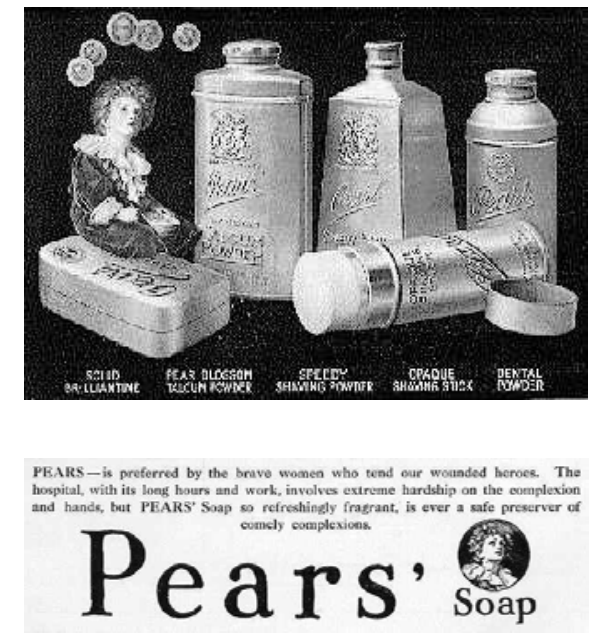

Fig. 61. Anuncios para Pear's Soap (c. 1914).

En cuanto a las ilustraciones de los cuentos de hadas las heroínas, salvo contadas excepciones, eran de una belleza extraordinaria e idealizada, por lo que su representación física e indumentaria respondía a los cánones de belleza de la época en que se realizaran.

La ilustraciones de Walter Crane (1845-1915) estaban influenciadas por las formas de William Morris y las Arts and Crafts, así como por las estampas japonesas que comenzaban a estar de moda en Europa, como se aprecia en sus dibujos de La Bella Durmiente para The Bluebeard Picture Book de 1875.

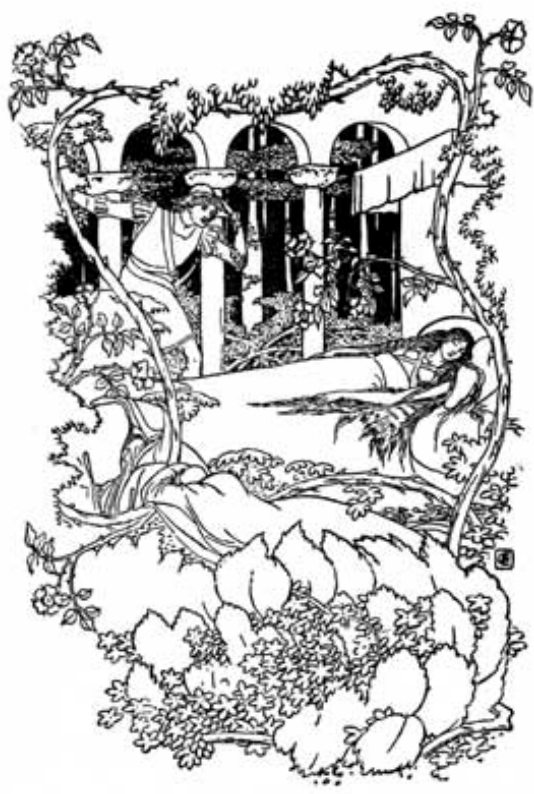

Fig. 62. La Bella Durmiente. Ilustraciones de Walter Crane para The Bluebeard Picture Book (1875). 
La representación de la muchacha «dormida» debe mostrar por un lado, la apariencia de muerte, por la que se la representa como era costumbre en la fotografía y en la pintura mortuoria de la época, como La muerte de Albine (1895) de John Collier y por otro, la belleza perenne de la muchacha bajo el hechizo del Hada Malvada.

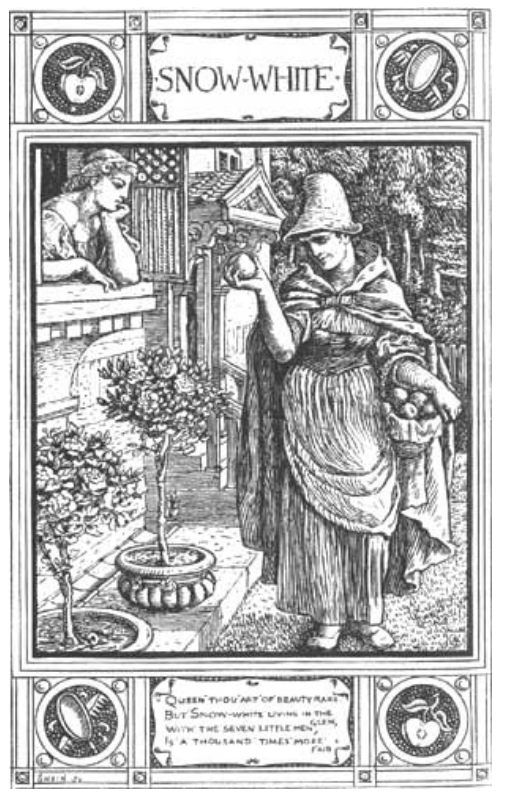

Fig. 63 y fig. 64. Blancanieves. Ilustraciones de Walter Crane para Household Stories from the Collection of the Brothers Grimm.
Las heroínas de los cuentos infantiles a pesar de ser en su mayoría descritas como preadolescentes, a menudo eran representadas como adolescentes e incluso como mujeres ya desarrolladas. Es el caso de Blancanieves pues se trata de una niña de siete años, pero la imagen que se hace de ella, no ha respetado la edad ofreciéndonos sin embargo ilustraciones de una joven de mayor edad. Obviamente los ilustradores, en su búsqueda por hacer más convincente y romántica a Blancanieves casándose con el príncipe pasaron por alto la imagen de una niña de siete años.

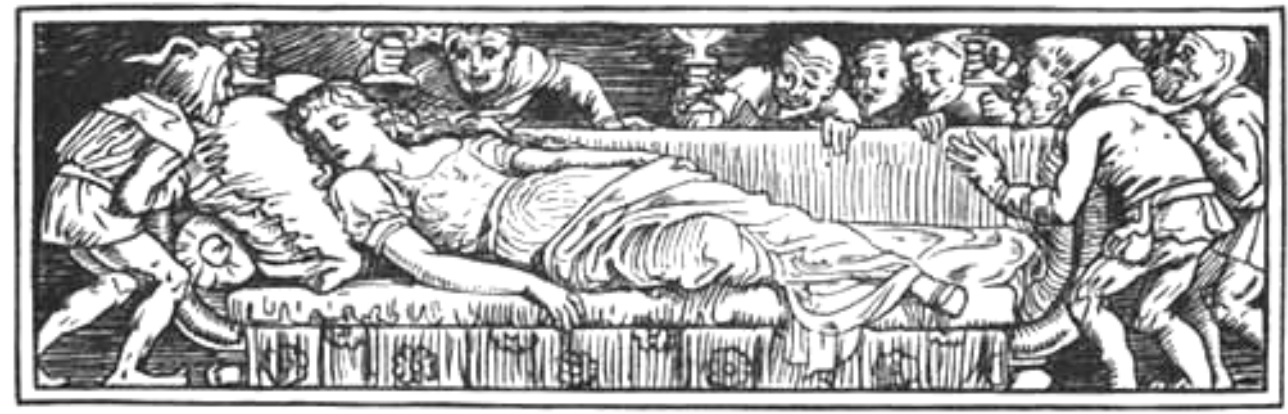




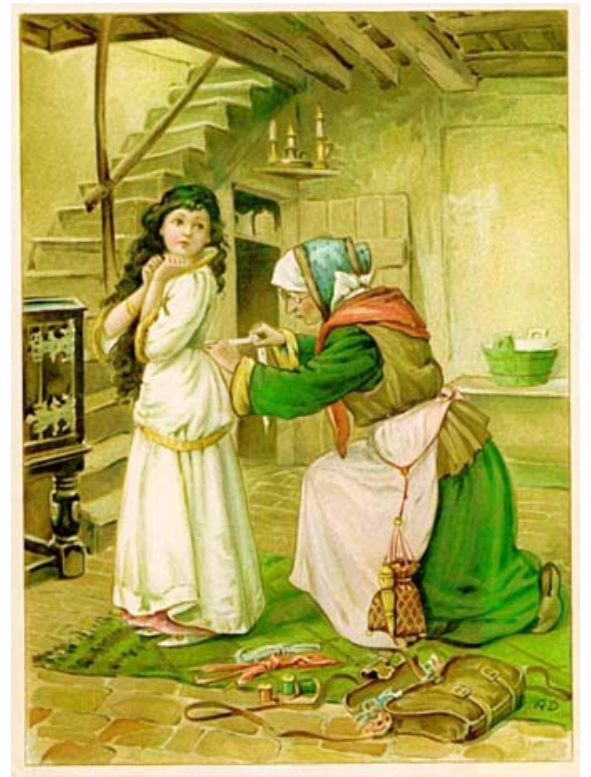

Fig. 65. Blancanieves y los siete enanitos. Ilustración de Ada Dennis y E. Stuart Hardy para Grimm's Fairy Tales.

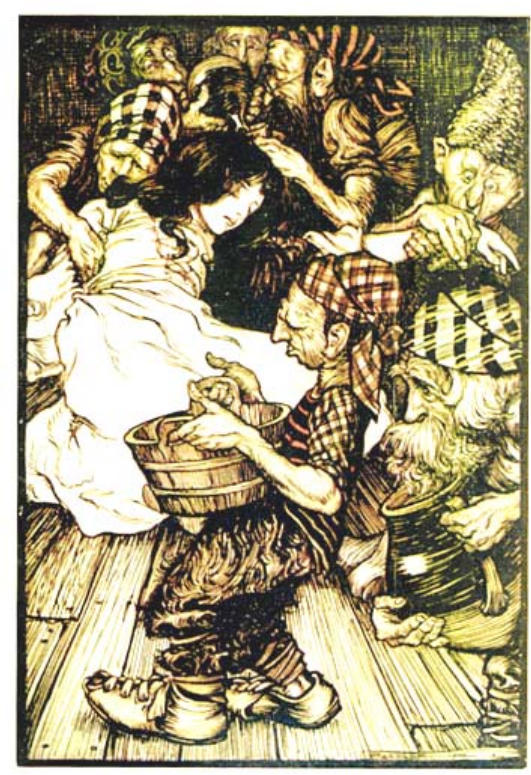

Fig. 66. Blancanieves. Ilustración de Arthur Rackham para The Fairy Tales of the Brothers Grimm.

Arthur Rackman (1867-1939) por su parte, nos ofrece en su visión de Blancanieves, una muchachita hermosa de cabello azabache y tez pálida protegida por una pandilla de enanos vestidos de bucaneros más que de enanitos del bosque, pero tampoco es fiel al aspecto simbólico de la niña que es Blancanieves es sus versiones literarias más antiguas.

El consagrado Gustave Doré realizaría ilustraciones para grandes obras de la literatura como la Biblia o la Divina Comedia de Dante Alighieri, pero también realizaría ilustraciones para cuentos infantiles como Caperucita Roja de Perrault, enfatizando las connotaciones sexuales sobretodo en la escena de la cama con el Lobo, en la que Caperucita parece encontrarse en un estado de fascinación y curiosidad, en contraposición a la pasividad del Lobo. 


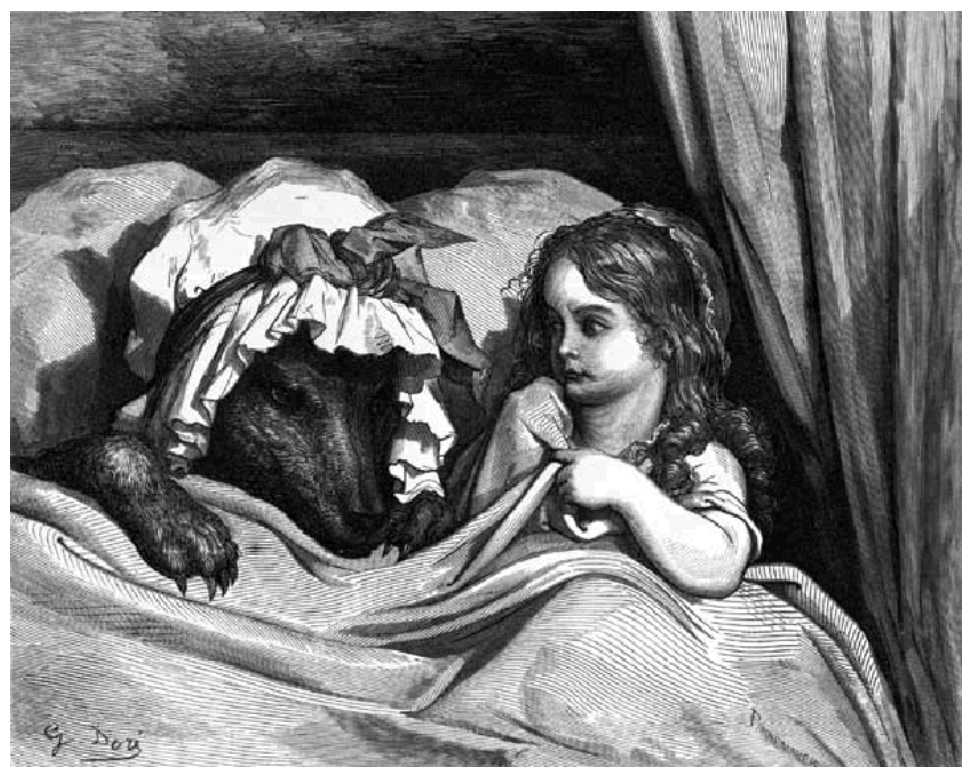

Fig. 67. Caperucita (1867). Ilustración de Gustav Doré para Les Contes de Perrault.

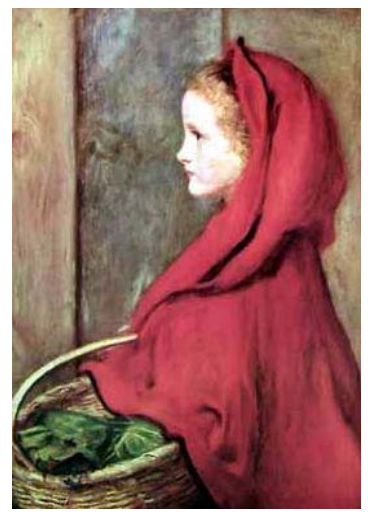

Fig. 68. Caperucita, (1865) por John Everet Millais.

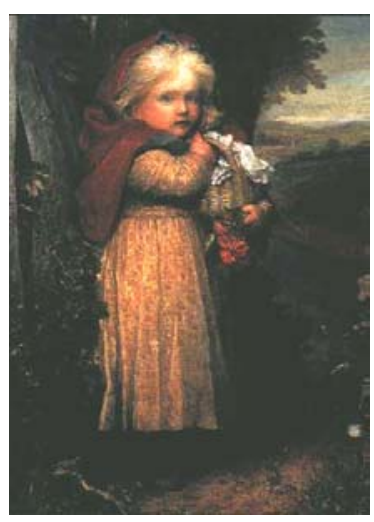

Fig. 69. Caperucita roja (s.a.) por George Frederic Watts.

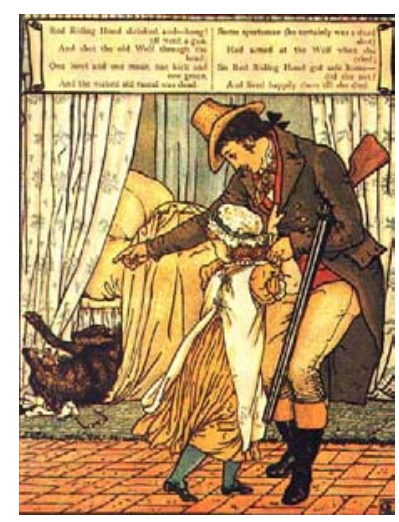

Fig. 70. Caperucita Roja.

Ilustración de Walter Crane para Little Red Riding Hood (1875).

Millais nos ofrece una Caperucita dentro de su estilo más convencional y comercial, por el contrario George Frederic Watts realizaría una Caperucita Roja de turbada mirada azul grisáceo que temerosa, aprieta contra ella la cestita al percatarse de que está siendo observada como si el pintor o el espectador fuese el Lobo que la 98 
sorprende en el bosque apartándose del camino que va a casa de su abuelita al distraerse con unas flores silvestres que lleva en la mano.

William Stephen Coleman (1829-1904), uno de los más prolíficos diseñadores victorianos de tarjetas de felicitación, dedicó gran parte de su obra como ilustrador y acuarelista a la ilustración de la preadolescente en escenas paradisíacas para tarjetas. Coleman estaba fuertemente influenciado por el ideal infantil romántico y así lo plasma representando a las niñas desnudas o semidesnudas cuidando cualquier evidencia de sexualidad o provocación sólo lejanamente evocada por los senos incipientes y las referencias inmediatas a odaliscas o a las escenas mitológicas recreadas por los pintores academicistas de la época como Lawrence Alma-Tadema ${ }^{32}$.
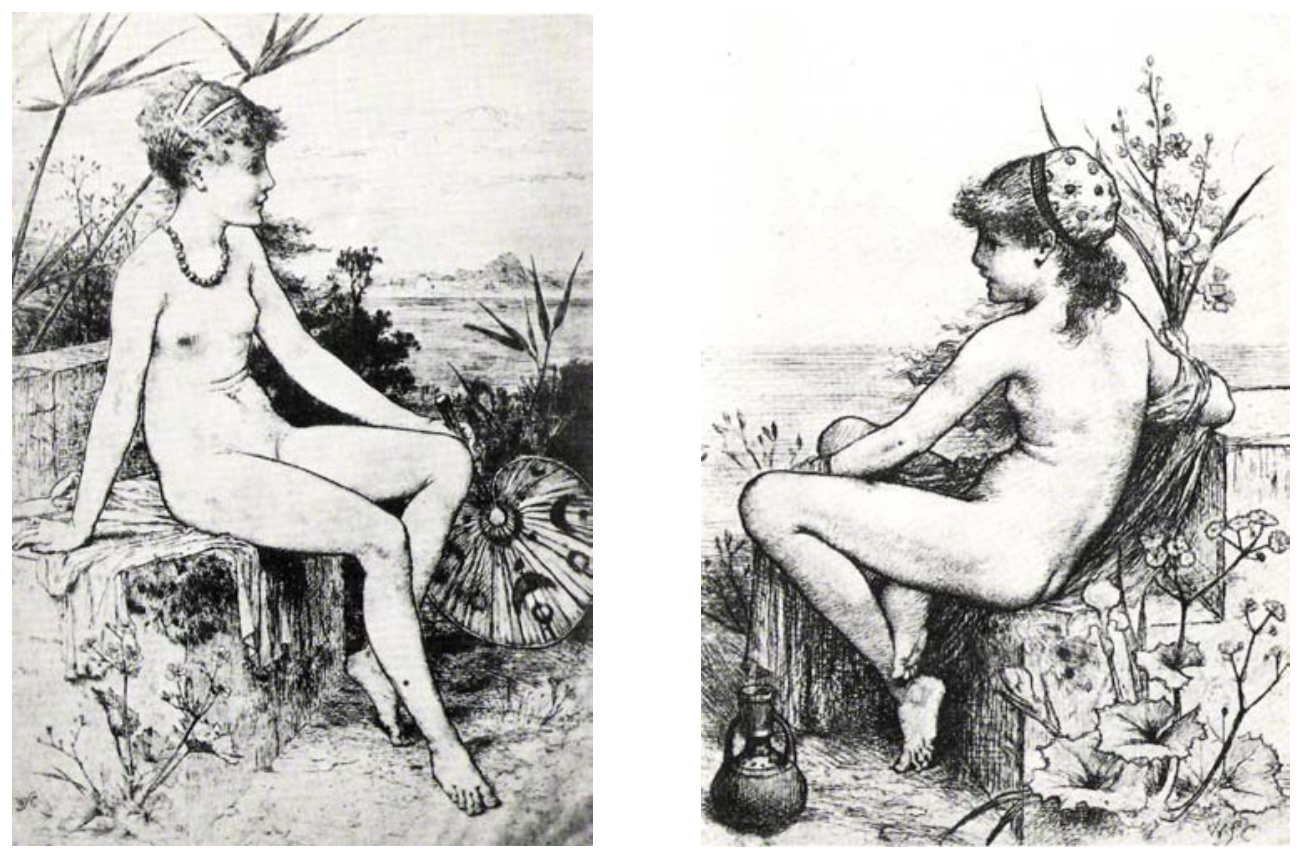

Fig. 71 y fig. 72. Tarjetas de felicitación ilustradas por William S. Coleman.

\footnotetext{
32 Erika Borney, apunta que estas imágenes eran un modo de pornografía camuflada, disfrazada de ideal de inocencia. BORNAY, Erika. Las hijas de Lilith. Cátedra: Ensayos Arte, Madrid, 1998, pág. 148.
} 

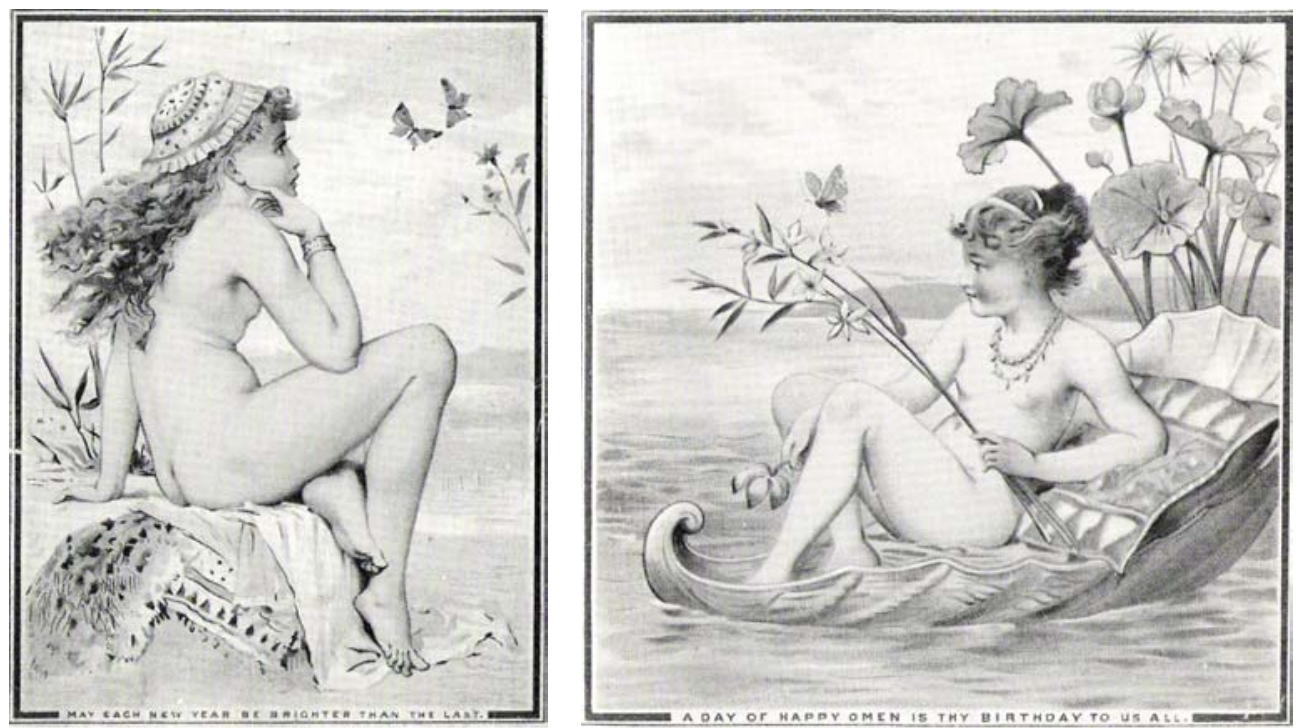

Fig. 73 y fig. 74. Tarjetas de felicitación ilustradas por William S. Coleman.

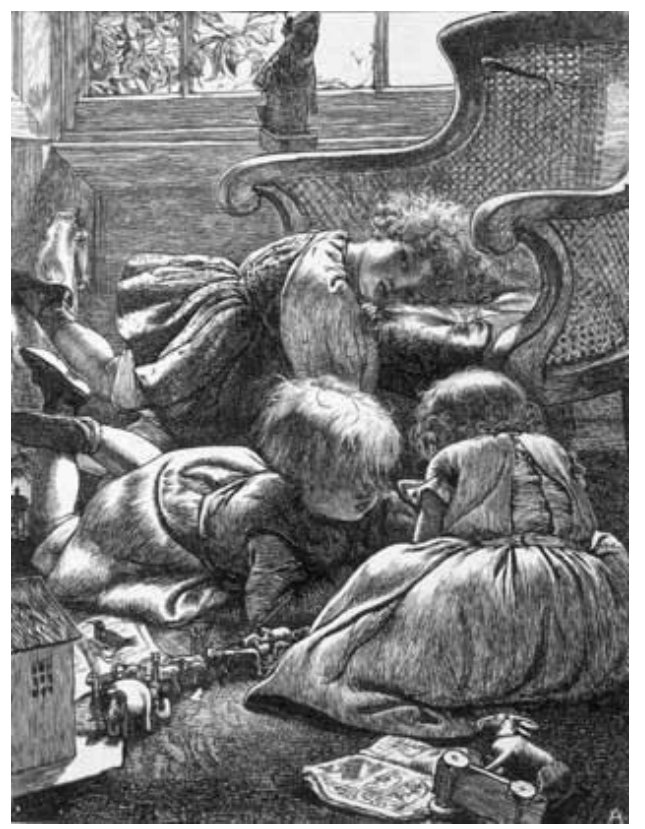

Fig. 75. El Arca de Noé. Grabado de Arthur Boyd Houghton para House Thoughts and Home Scenes (1865).

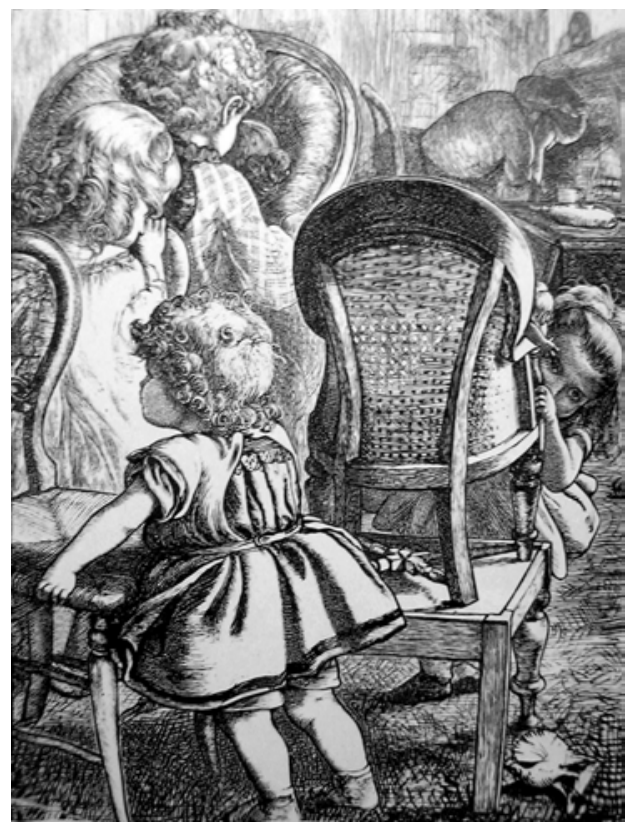

Fig. 76. El asiento del tren. Grabado de Arthur Boyd Houghton para House Thoughts and Home Scenes (1865). 
Arthur Boyd Houghton (1836-1875), al igual que William S. Coleman realizarían ilustraciones infantiles siguiendo los gustos del público. En los grabados realizados para House Thoughts and Home Scenes (1865), sus personajes infantiles son en su mayoría niñas pequeñas de cabellera rubia ordenada en tirabuzones, mostradas en escenas de juegos en la calidez del hogar victoriano, donde el entretenimiento infantil debe conjugarse con una educación cristiana, como el juego con figuritas que representan las parejas de animales entrando en la casita de muñecas que sirve de Arca de Noé.

Carl Larsson (1853-1919) es conocido como el ilustrador de la vida cotidiana de Suecia. Sus motivos eran las escenas familiares y todos los eventos en relación a la misma, fiestas de cumpleaños, fiestas al aire libre, comidas, o lectura bajo el candil. Esa cotidianidad, sin embargo, nos ofrece una falsa naturalidad de los detalles de la intimidad femenina que están siempre bajo un filtro embellecedor, que no sentimental o cursi como el de Greenaway. El interés de sus escenas costumbristas reside en la excepcionalidad de algunas de las ilustraciones en que traspasan la cotidianidad para crear un verdadero diálogo entre el personaje representado y el artista o espectador. Así en La habitación de las niñas [Mama's and the Little Girl's Bedroom] (c. 1895), una de las hijas del artista posa desnuda desinhibida, con tan sólo unas medias negras, una actitud no tanto de provocación como de la familiaridad con la que los nórdicos se relacionaban con el desnudo ${ }^{33}$, sin embargo la escena no deja de estar cercana límite del género pornográfico.

\footnotetext{
${ }^{33}$ Recordemos que el movimiento nudista actual tuvo como precursor los países del norte de Europa.
} 


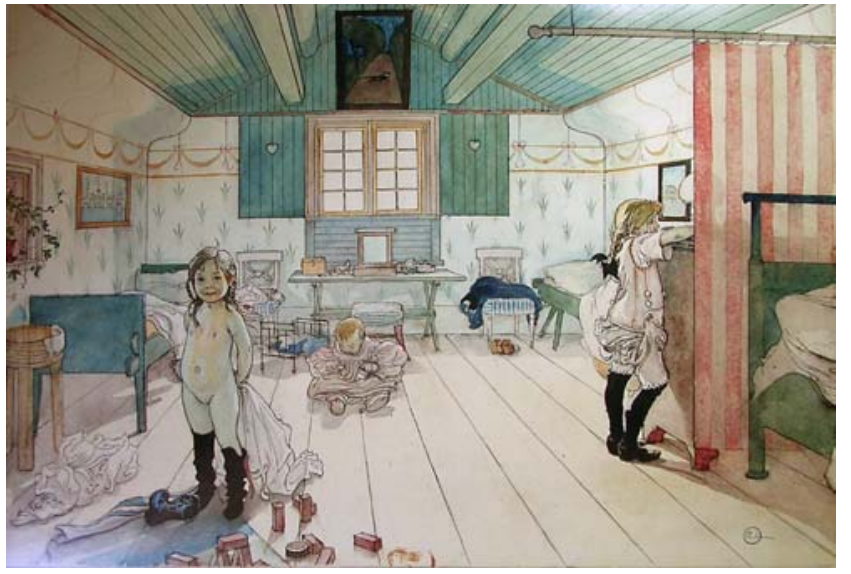

Fig. 77. La habitación de las niñas (c. 1895), acuarela de Carl Larsson.

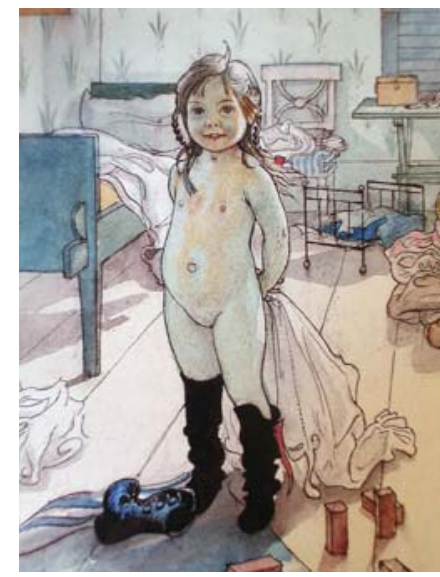

Fig. 78. Detalle. La habitación de las niñas (c. 1895), acuarela de Carl Larsson.

\subsection{La ilustración pornográfica.}

El género pornográfico, no fue calificado como tal hasta la segunda mitad del siglo XIX. Como forma de expresión de las temáticas prohibidas, obscenidades y parafilias, la cultura erótica y pornográfica, incluyó la imagen de la preadolescente como objeto de deseo pedófilo. El marqués Donatien Alphonse François de Sade (1740-1814), el más famoso pornógrafo de la historia y contemporáneo a la Revolución francesa, había explorado al extremo la sexualidad y establecido unos parámetros de relaciones eróticas basadas en escenas lésbicas, homosexuales o de pederastia habitualmente, dejando de lado en gran medida el «amor» heterosexual para contadas excepciones. Las mujeres -y también los niños-, eran bajo sus pervertidos preceptos, objetos sexuales para adultos generalmente del género masculino, a los que se podía dominar y esclavizar bajo la crueldad y la violación en el ámbito de lo privado. 
Algunos ilustradores victorianos como Aubrey Beardsley, contribuirían a crear un subgénero de ilustración centrado en la imagen erótica que era enormemente difundida, aunque tremendamente perseguida en los países de tradición judeo-cristiana. Entre 1840 y 1860, una buena parte del material pornográfico publicado fue confiscado y destruido, por lo que son escasos los grabados de este periodo en Gran Bretaña.

Estas escenas de abuso sexual infantil, generalmente eran representadas por padres o profesores, que actuaban violentamente o hacían uso de artilugios eróticos. El álbum [Die Grenouillère] (1907) del pornógrafo alemán Franz Von Bayros (1866-1924) y firmado bajo el pseudónimo de Choisy le Conin, contenía quince páginas y se imprimió en una edición de 525 copias. En él se recrean escenas lésbicas y de masturbación con diferentes protagonistas, mujeres adultas, jóvenes pero sobre todo preadolescentes.
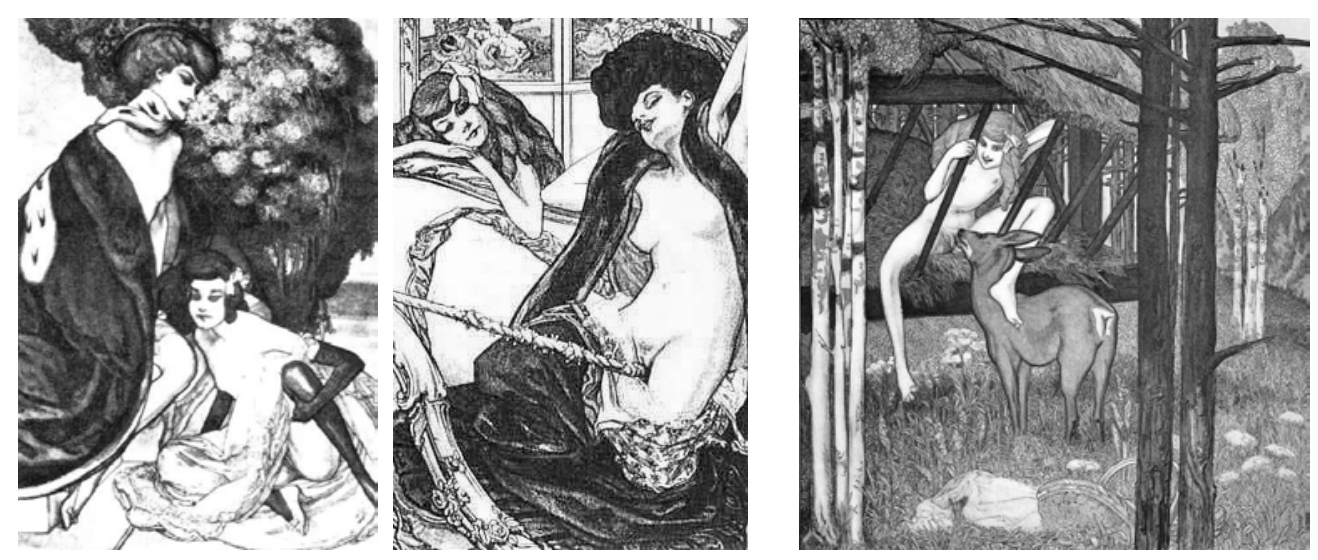

Fig. 79, fig. 80 y fig. 81. Die Grenouillère (1892) ilustraciones de Choisy le Conin (Franz Von Bayros). 

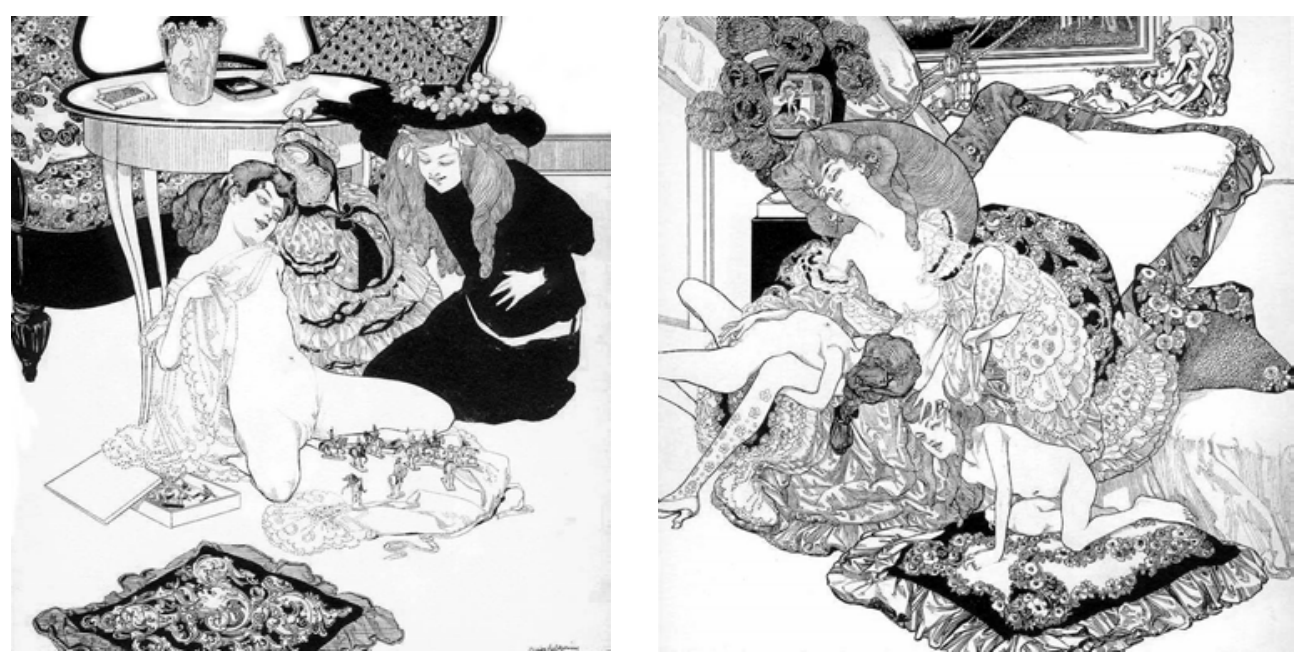

Fig. 82. y fig. 83. Die Grenouillère (1892) ilustraciones de Choisy le Conin (Franz Von Bayros).

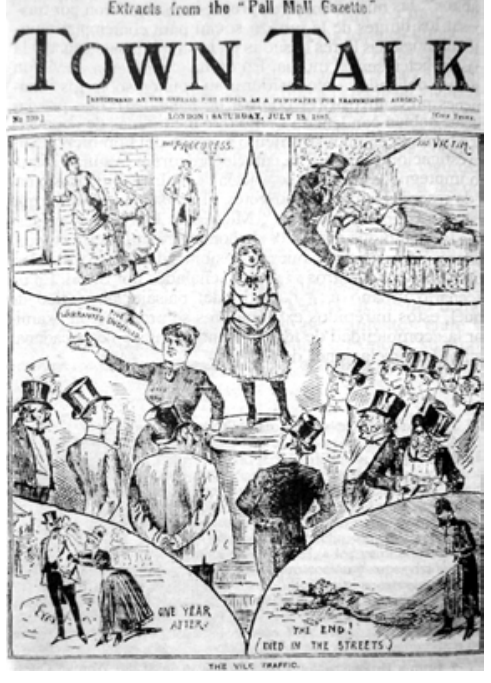

Fig. 84. Portada de la revista Town Talk, que ilustra la venta de una virgen y otras escenas, basadas en El tributo de las jóvenes doncellas en la moderna Babilonia de The Palm Mall Gazette.
Tras la publicación de El tributo de las jóvenes doncellas en la moderna Babilonia en julio de 1885 en la Palm Mall Gazette, y aprovechándose de la polémica generada, se publicaron numerosos dibujos y grabados en periódicos y revistas que describían las violaciones y perversiones relatadas en «El tributo», fomentando un interés morboso en el publico, que por otro lado aumentaría la venta de sus publicaciones. De repente se motivó un fenómeno paralelo de revistas e ilustraciones pornográficas que servían de soporte gráfico al relato de William Thomas Stead. 
El «Culto por los niños», verdaderamente llegó a ser tan evidente en todos los ámbitos, que un crítico llegaría a definir aquel fervor como de «baby disease», es decir, de «enfermos de bebés», de los niños, de las niñas y de todo aquello que hiciese referencia al mundo de la infancia y la inocencia, impregnando e «infectando» todas las artes ${ }^{34}$.

\footnotetext{
${ }^{34}$ AA.VV. The Cult of the Child. Images of Children in late $19^{\text {th }}$ Century Art [en línea]. [ref. de 3 de marzo de 2005]. Disponible en Web: http://www.artfund.org/main_site/artfundmags_archive.asp?id=551
} 



\section{FOTOGRAFÍA VICTORIANA.}

\subsection{La fotografía victoriana.}

La fotografía nació a la par que la concepción moderna de infancia, cuando las barreras entre niñez y adolescencia se fueron concretando y definiendo. Con la unión de ambos nacimientos la fotografía infantil se convirtió en un deseado objeto fetiche de gran valor y admiración.

Para los pintores prerrafaelistas, la fotografía no suponía un reto frente a la pintura ${ }^{1}$, sino más bien la usaban como una magnífica herramienta para el estudio analítico y la preparación compositiva de los cuadros, en tanto que sí admitían el reto de la fugacidad de la percepción visual y la posibilidad pues, de intentar captar el «ser interior» en lo humano, como se observa en la relación entre fotografía y los grupos espiritistas y teosóficos durante la $2^{a}$ mitad del siglo XIX. Por su parte los fotógrafos no pretendían que la fotografía supusiese una amenaza a lo pictórico sino una ejemplar mimesis, de modo que según afirmaba Peter C. Bunnell «los objetos delineaban ellos mismos y el resultado es verdad $y$ exactitud ${ }^{2}$. Sin embargo para muchos otros, el daguerrotipo resultaba completamente obsceno y vulgar, por su capacidad de representar con realismo ciertos temas, como el desnudo, que fotografiado era considerado obviamente «inmoral»³. Según el pintor William Newton -entusiasta del calotipo y que utilizaba para

\footnotetext{
${ }^{1}$ SELMA DE LA HOZ, J. V. Los Prerrafaelitas. Barcelona: Montesinos, 1991, pág. 97.

2 BUNNELL, Peter C. A Photographic Vision: Pictorical Photography, 1899-1923. Salt Lake City: Peregrine Smith Inc., 1980.

3 En Inglaterra, enviar «fotografías obscenas» estaba prohibido. SCHARF, Aaron. Arte y fotografía. Madrid: Alianza Forma, 1994, pág. 136.
} 
realizar bocetos previos a sus pinturas-, la fotografía era «químicamente bella», pero todavía no era «artísticamente bella» ${ }^{4}$.

Durante el periodo victoriano en el cual se manifestó la corriente prerrafaelista, un grupo de fotógrafos profesionales como Oscar Gustav Rejlander o Henry Peach Robinson y amateurs como Julia Margaret Cameron o Lewis Carroll entre otros, desarrollaron una fotografía que asumía las temáticas, esquemas compositivos y estilo de la Hermandad Prerrafaelista, sin embargo jamás se consideraron a sí mismos como creadores de una escuela de «fotografía prerrafaelista» ${ }^{5}$.

A pesar de la notable influencia de la pintura británica del momento en la fotografía, numerosos fotógrafos victorianos abusaban en exceso de los desenfoques y borrosidades. Tales efectos disgustaba tremendamente a gran parte de los pintores prerrafaelistas que buscaban por su parte el análisis casi botánico de las vegetaciones con minuciosos detalles. Sin embargo los fotógrafos siguiendo los pasos de los pintores, trabajaron la belleza femenina hasta la saciedad, pero sobretodo aprovecharon el potencial dramático de los personajes infantiles, creando escenas de indefensión, dulzura o sensualidad, más allá de la representación de la figura femenina adulta.

El apetito social por recoger y coleccionar, se fue alimentando gracias a la fotografía, que se prestaría como medio idóneo para documentar y comunicar así como por las diferentes narraciones y

\footnotetext{
${ }^{4}$ NEWTON, William. "Upon Photography in an Artistic View, and its relations to the Arts" en Journal of the Photographic Society, no 1. London: marzo, 1853.

5 La clara identificación de estos fotógrafos con el ideario de la Hermandad Prerrafaelista hace que en la actualidad numerosos autores los identifiquen como fotógrafos prerrafaelistas. "Introducción" de Graham OVENDEN, en Pre-Raphaelite Photography. London: Academy Editions, 1972 y MARSH, Jan; GERRISH NUMM, Pamela. Op cit., pág. 8.
} 
motivos que la sociedad demandaba, que irían desde los temas domésticos, pasando por el documento policial o criminal.

La representación de la infancia en la fotografía victoriana, siguió los patrones convencionales del género del retrato, que en general aportaron una estética de influencia prerrafaelista, algo almibarada, convencional y muy del gusto del público burgués, que hacía uso de los fotógrafos profesionales, cada vez con más frecuencia.

Helmunt Gernsheim, calificaría al fotógrafo sueco Oscar G. Rejlander (1813?-1875) y a Henry Peach Robinson (1830-1901) como los «Sacerdotes de la fotografía artística» ${ }^{6}$ por sus composiciones formalmente académicas, equilibradas y meditadas, sin dejar detalle a la improvisación pero también por sus formas afectadas. Así en Niña con espejo (c. 1860) o Niña sosteniendo un jarroncito (c. 1860) ambas por Oscar G. Rejlander, las modelos posan con carácter estereotipado e insípido, estilo con el que precisamente se hizo famoso. En ellas se utilizan elementos que tradicionalmente sugieren la belleza, la vanidad o la sensualidad de las niñas pero que poco aportan al enriquecimiento de la fotografía como incipiente forma de representación artística. El deseo por capturar la inocencia, la pureza o la sensualidad de las formas infantiles, que fotógrafos más amateurs buscaron de manera obsesiva, como Julia Margaret Cameron o Lewis Carroll, se perdió a favor de la profesionalidad y el dominio de la «ciencia» fotográfica, convirtiéndose en una barrera que mermara en cierto grado la creatividad de sus fotografías en favor de una agradable aceptación pública.

\footnotetext{
6 «The High Priests of Photografic Art». GERNSHEIM, Helmunt. Lewis Carroll. Photographer. New York: Dover, 1969 y JONES, Edgar Yoxall. Father of Art Photography: O. G. Rejlander, 1813-1875. New York: Greewich, 1973.
} 


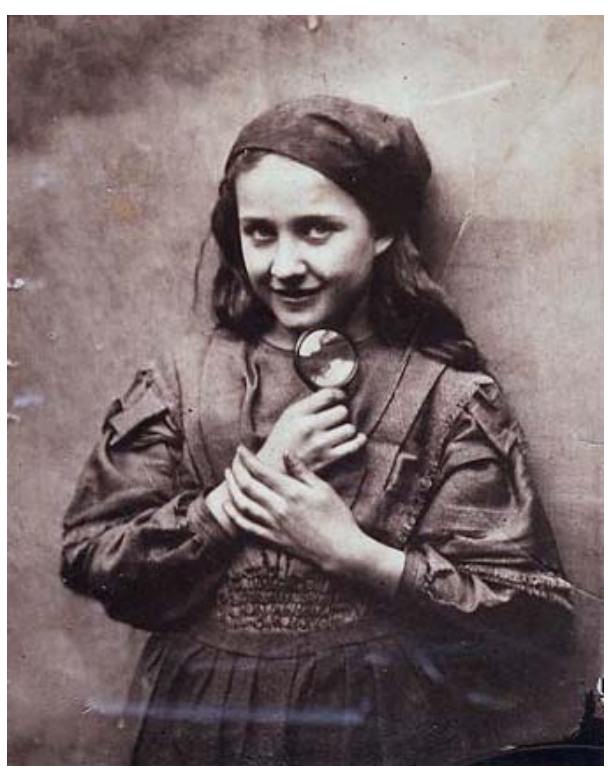

Fig. 1. Niña con espejo (1860) por Oscar G. Rejlander.

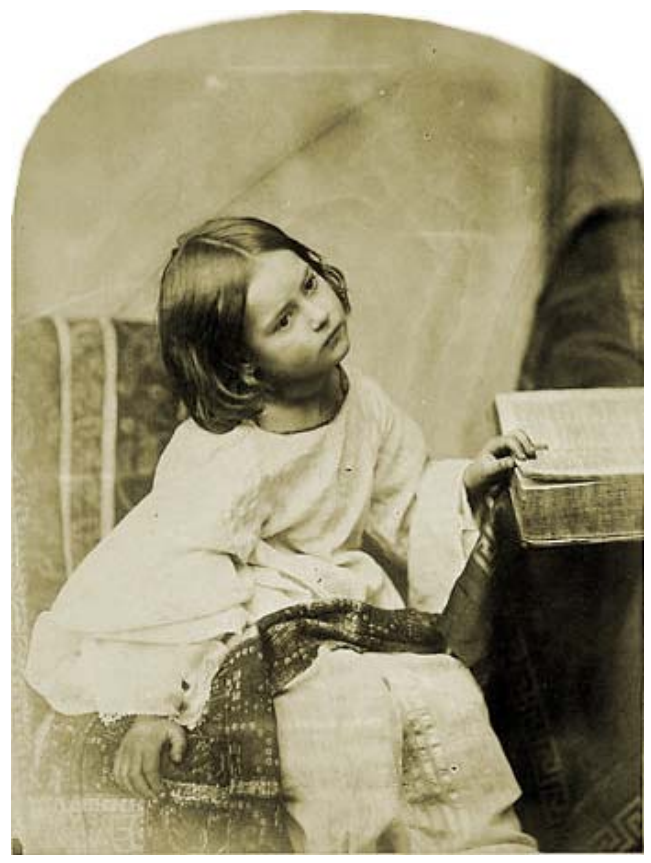

Fig. 3. Niña con la mirada perdida (1860) por Oscar G. Rejlander.

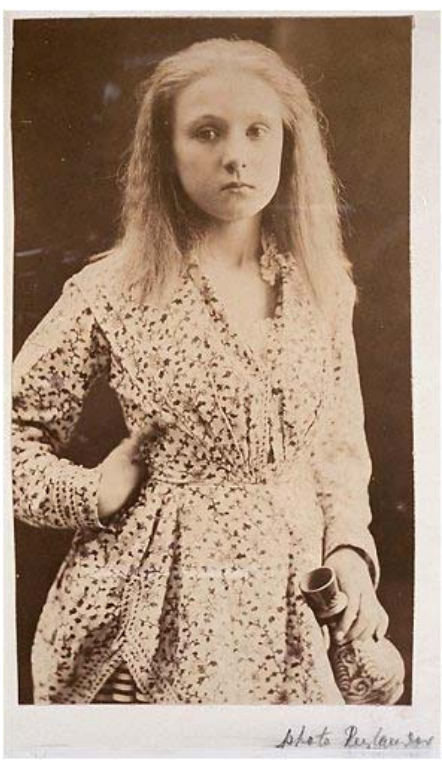

Fig. 2. Niña sosteniendo un jarroncito (1860) por Oscar G. Rejlander.

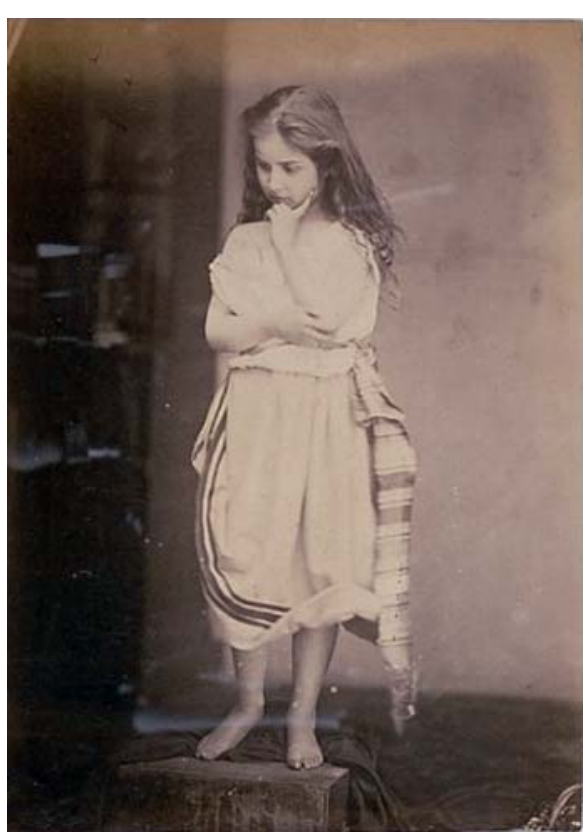

Fig. 4. Niña pensativa (1860) por Oscar G. Rejlander. 
Como el fotógrafo J. T White, Rejlander realizó algunas fotografías muy poco conocidas-, con niñas prostitutas, catalogadas de pornográficas y que se distribuían ilegalmente para su consumo. El material pornográfico fue severamente perseguido y al igual que la ilustración apenas se conserva material. Numerosos autores realizaban estudios de desnudos infantiles que en numerosos casos hallaban un hueco en el suculento mercado del «culto a la infancia», pero lo cierto es que las fotografía que mostraba el sexo de las niñas más explícitamente 0 que posaban con evidentes propósitos eróticos eran destinadas al mercado clandestino de pornografía infantil.

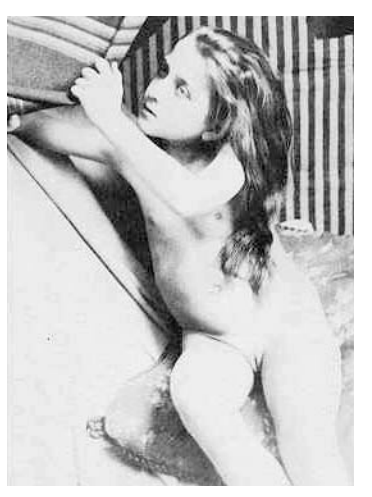

Fig. 7. Sin título

(finales del s. XIX), autor anónimo.

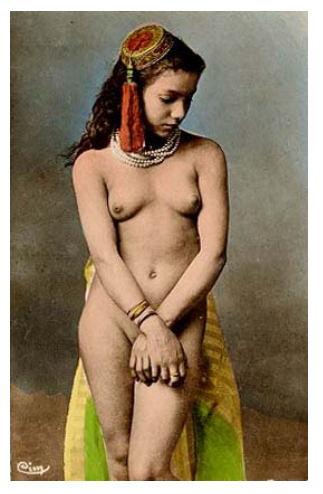

Fig. 8. Joven del norte de África (principios

s. XX), autor anónimo.

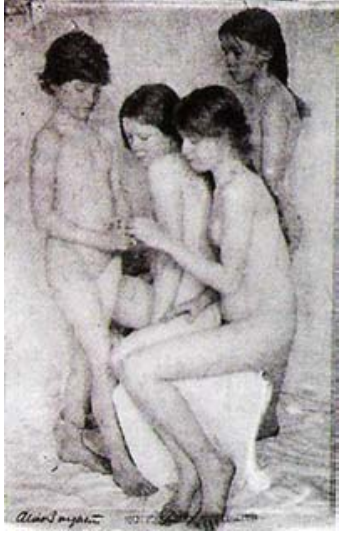

Fig. 3. Desnudo infantil

(1902) por Alice Boughton.

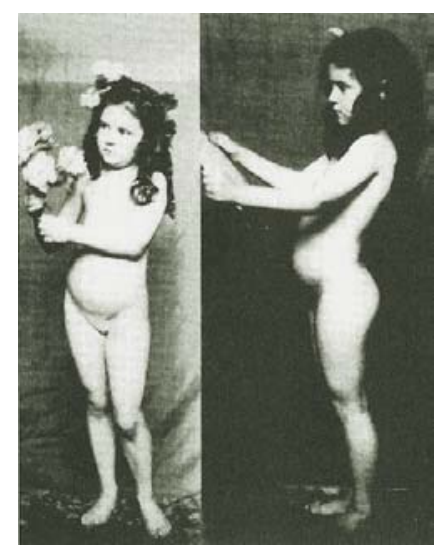

Fig. 4. Estudio de desnudo infantil publicado por Schench de New York (1880).

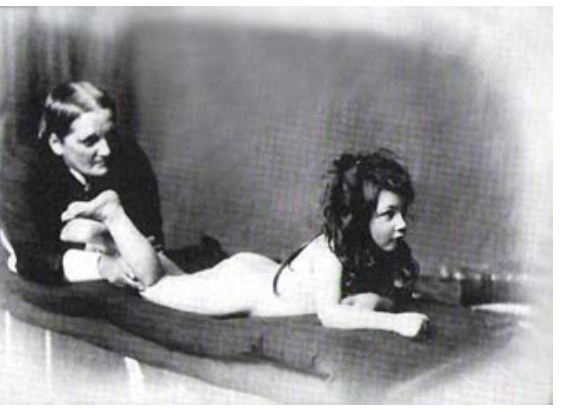

Fig. 9. Estudio infantil (1874) por Katie Morrison. 
Retomando la recurrente temática victoriana de la mujer, el sueño y la muerte, fueron numerosos los fotógrafos que repitieron el icono ubicándolo en lo profundo del bosque al estilo de La hija del leñador (1860) de Arthur Hughes ${ }^{7}$, enfatizando la fragilidad de las niñas con resonancias de cuento popular como Caperucita roja.

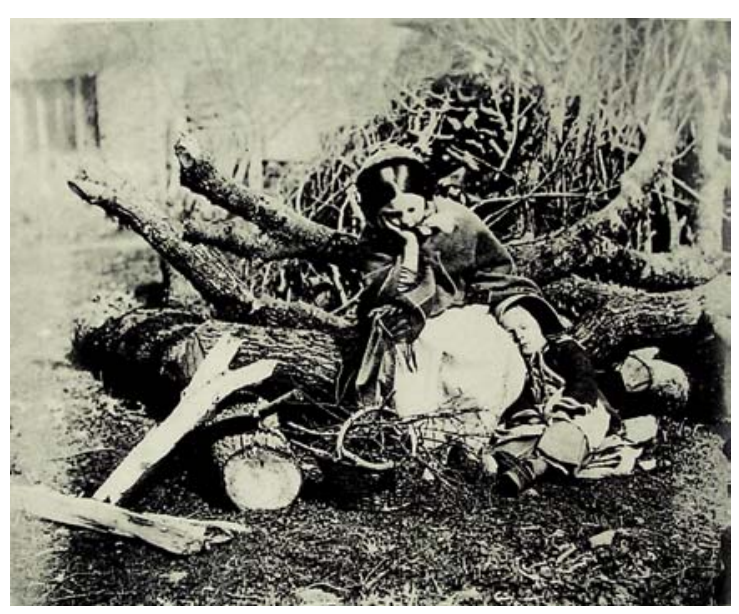

Fig. 10. Dormida (1855) por John Whistler.

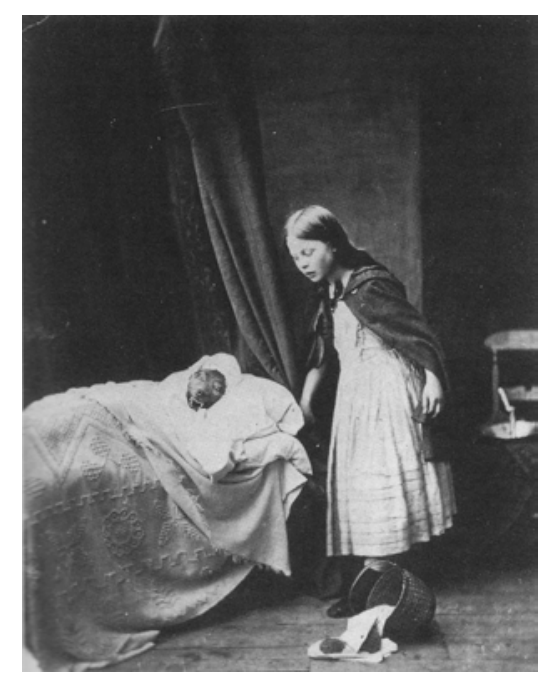

Fig. 11. Serie de Caperucita roja (1858) por Henry Peach Robinson.

Henry Peach Robinson, recreó también el tema del «sueño», desde un punto de vista más cercano a la fotografía post mortem como La dama de Shalott (c. 1860) o Dormidos (1858) basado en la fotografía de James Robinson, La muerte de Chatterton [The Dead of Chatterton] (1859) copia a su vez de la obra pictótica, Chatterton (1855-6) realizado por Henry Wallis. La copia o relectura de obras pictóricas por parte de los fotógrafos era común durante la época victoriana, pues la fotografía era un medio de representación todavía carente de temas o formas expresivas propias.

\footnotetext{
${ }^{7}$ V. pág. 77 , fig. 19 de la presente tesis.
} 


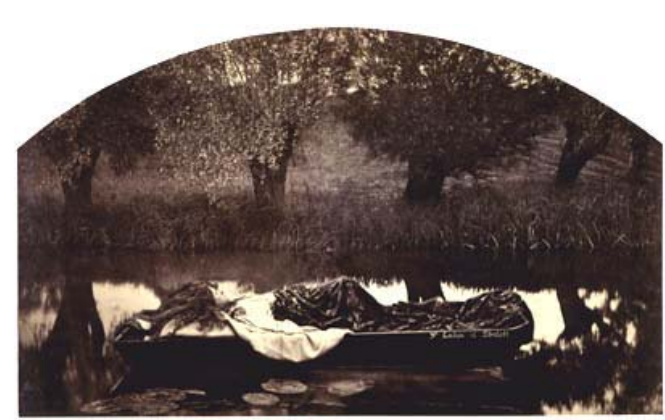

Fig. 6. La dama de Shalott (c. 1860) por Henry Peach Robinson.

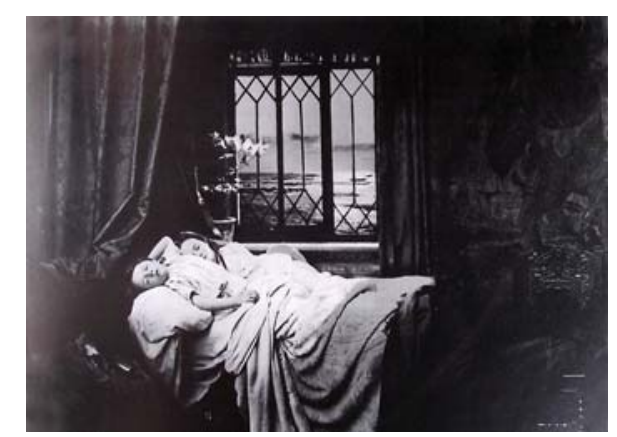

Fig. 5. Dormidos (1858) por Henry Peach Robinson.

De Henry Peach Robinson se diría que era un hombre «que amaba a las niñas» ${ }^{8}$. En sus memorias, afirmaba que «las más deliciosas modelos eran las niñas»: «(...) un brillo de felicidad corre a través de mi cuando pienso en algunas de mis pequeñas amigas. No conozco ocupación más encantadora que la de fotografiar niñas, de edades comprendidas entre los cuatro y los ocho o nueve años de edad. Tras esa edad, pierden su belleza poco a poco...»`. En una búsqueda por reunir el ideal infantil y su pertenencia ancestral a la naturaleza Henry Peach Robinson realiza Trayendo mayo al hogar [Bringing Home the May] (1862), una escenificación en la que las mujeres y las niñas personifican alegóricamente la llegada de la primavera y los propios frutos de la naturaleza y que bien pudiera tener como referente compositivo y temático Primavera [Spring. Apple Blossoms] (1856-9), de John Everett Millais.

\footnotetext{
8 HARKER, Margaret H. "Henry Peach Robinson: The Grammar of Art" en WEAVER, Mike. British Photography in the Nineteenth Century. The Fine Art Tradition. Cambridge: Cambridge University Press, 1989, pág. 137.

9 ROBINSON, Henry Peach. "Heads I Have Taken Off". The Mirror. 17 th January 1874. Citado por Margaret H. Harker. Henry Peach Robinson, Master of Photography Art, 1830-1901. Oxford: Basil Blackwell, 1988, pág. 57.
} 


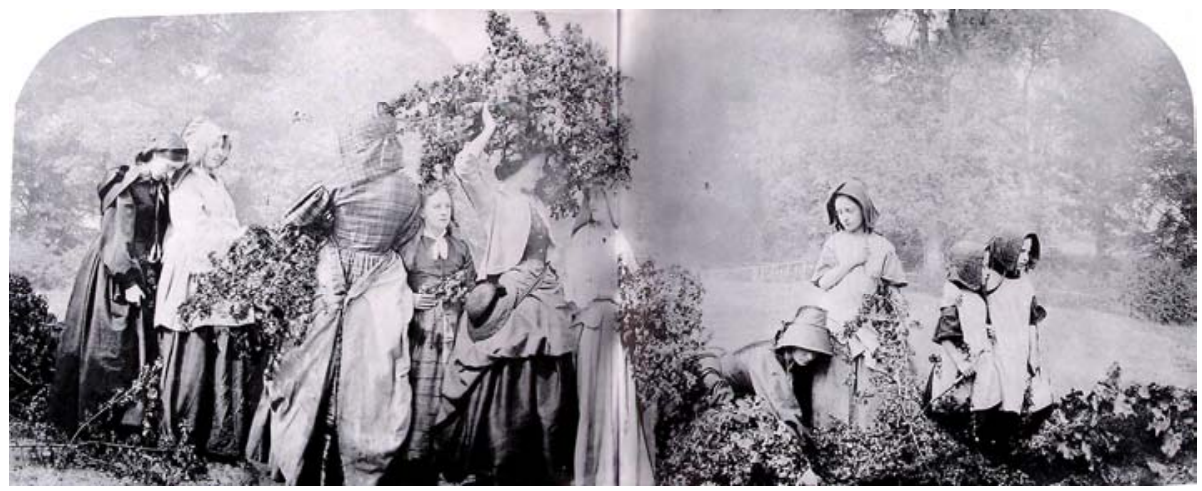

Fig. 7. Trayendo mayo al hogar (1862) por Henry Peach Robinson.

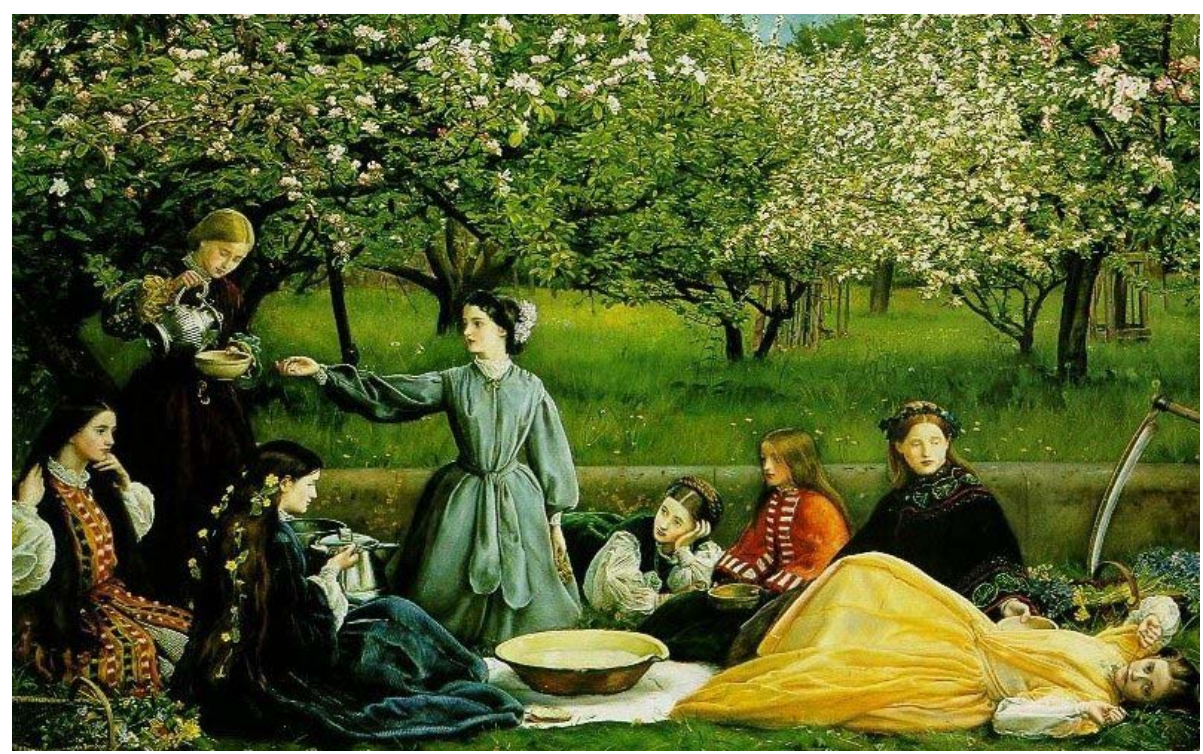

Fig. 8. Primavera (1856-9) por John Everett Millais.

El análisis por la vegetación -tan del interés de los prerrafaelistas-, se evidencia por el contrario en algunos fotógrafos como Rober Fenton, gran admirador de John Everett Millais, que combina compositivamente con la introducción del personaje o personajes infantiles, con el mismo propósito de enfatizar las características primigenias e intactas de la infancia. 


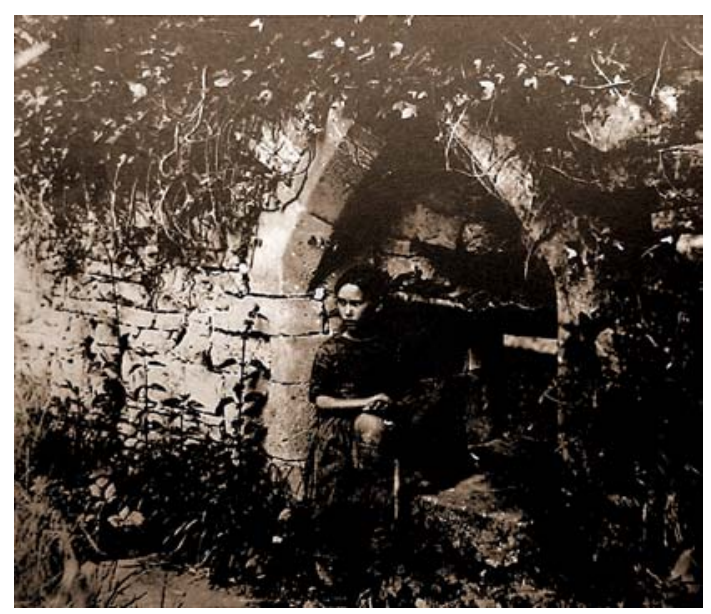

Fig. 9. Interior de Tintern Abbey (1850) por Rober Fenton.

\subsection{Fotografía post mortem.}

Son numerosas las fotografías post mortem que se realizaron durante el siglo XIX. Se trató de una práctica muy común en el siglo XIX y principios del $X X$, que debido a su alto reclamo se convirtió en uno de los principales géneros fotográficos. La mortalidad infantil era altísima y el propósito habitual era conservar una imagen del fallecido, la cual a menudo se trataba de la única fotografía que tenían de sus seres queridos. Pero en el caso de la fotografía infantil, hay un elemento que no se puede obviar, que es la inocencia y la pureza sin mancha que se le atribuye a la infancia. La puesta en escena de las mismas, requería de una última «interpretación» por parte de la niña o bebé difunto, que era colocado en actitud de descanso, dormido, tal vez recostado sobre el hombro de su madre, vestido con sus mejores ropas. No se trata de un interés o gusto aislado por la imagen infantil en relación con la muerte ${ }^{10}$. Dan Meinwald explica que «la fotografía post mortem es como la

\footnotetext{
${ }^{10}$ El fenómeno romántico que hallaba el deleite a través de lo horrendo se pone de relieve en éste gusto victoriano por la fotografía post mortem. Sobre la belleza de lo horrendo véase PRAZ, Mario. Op. cit., pág. 68 y 69.
} 
embalsamación, la preservación del cuerpo a la mirada del espectador» ${ }^{11}$. Como ya se ha visto, la visión y el contacto con bebés o niños pequeños difuntos, eran habituales tanto en la literatura como en el arte y convertidas en convención social. Se hicieron tan populares que llegaron a aparecer en las páginas de las revistas ilustradas Once a Week o Cornhill, aunque en general se mostraban únicamente en el ámbito familiar. Se tratan de fotografías con una escenografía muy preparada, de abrumadora belleza y de patetismo, que enfatizan en el ideal infantil victoriano.

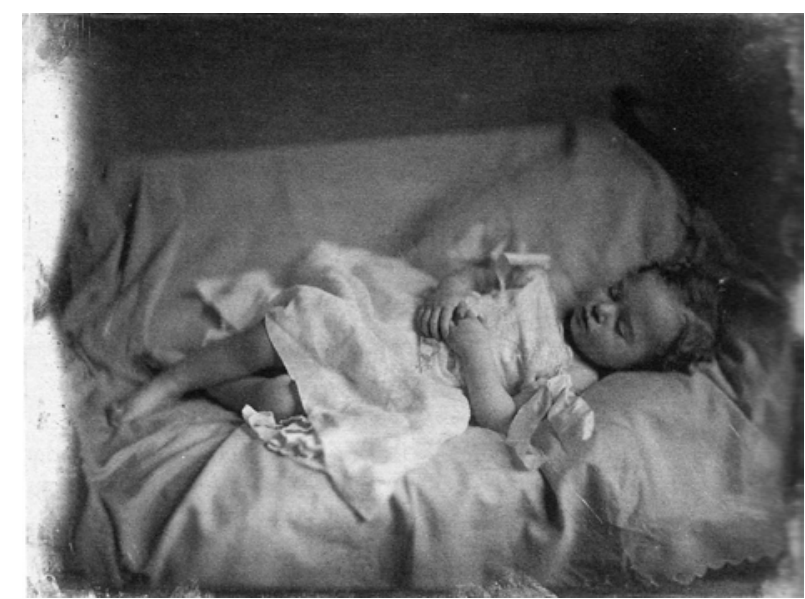

Fig. 10. Niña muerta (1865) por Southwares and Hawes.

Es posible, que «la muerte» hubiese hallado en la fotografía el medio ideal para ser representada. Como afirma Roland Barthes: «/o que se ampara indefectiblemente en la imagen fotográfica es la Muerte». La muerte se asocia a la fotografía, no sólo por ser un motivo a representar, sino por que la fotografía «recoge una interrupción del tiempo a la vez que construye (...) una "doble" realidad»"12. Es un «medio» de tremendo patetismo y melancolía.

\footnotetext{
${ }^{11}$ MEINWALD, Dan. Memento Mori: Death in Ninetheenth-Century Photography. Riverside: University of California, 1990, pág. 8.

12 BARTHES, Roland. La cámara lúcida. Notas sobre fotografía. Barcelona: Piados Comunicación, 1999, pág. 22.
} 


\subsection{Julia Margaret Cameron (1815-1879).}

Julia Margaret Cameron nació en Calcuta en 1815 y se casó en 1838. Fue madre de seis hijos y de tres más que adoptó, pero no fue hasta que sus tareas como madre ${ }^{13}$ se fueron progresivamente relegando que comenzara a fotografiar en 1863.

Desde su casa de la Isla de Wight (sur de Gran Bretaña), fotografió a algunos de los hombres más célebres de su época, como Tennyson, Thomas Carlyle, Charles Darwin o miembros de la P.R.B.

A pesar de que Julia Margaret Cameron era una fotógrafa amateur, repleta de excentricidades, defectos y errores técnicos ${ }^{14}$, en sus retratos emana el amor, la emotividad y la humanidad. Se recrean escenas de inspiración medieval y poesía lírica trovadoresca, como sus contemporáneos pintores prerrafaelistas, y comparte con ellos el ideal femenino. La compenetración y la amistad está latente entre fotógrafa y modelos ${ }^{15}$. Modelos que se ajustan al ideal de belleza de femenina victoriano, de rostros y gestos lánguidos pero sensuales. En este sentido, la observación y la influencia de la pintura prerrafaelista es

\footnotetext{
13 Dos años después de comenzar con la fotografía, a los 50 años de edad escribía, que «era la primera vez desde hacía 26 años, que no tenía un bebé en su seno». MARSH, Jan; GERRISH NUMM, Pamela. Pre-Raphaelite Women Artist. New York: Thames and Huston, 1999, pág. 40.

${ }^{14}$ Cameron, abusaba en exceso de los desenfoques, y se cuidaba poco de los acabados limpios, pero hallaba en ello unos resultados novedosos en una época en la que la fotografía resultaba una técnica de por si ya novedosa. En una ocasión, Lewis Carroll, pasó una temporada de vacaciones en la Isla de Wight, y tuvo la ocasión de visitar a Julia Margaret Cameron. Ella, que tan sólo llevaba unos pocos meses haciendo fotografía, le mostró a Carroll sus obras exultante y triunfal por los resultados «artísticamente notables» que había conseguido. Sin embargo Carroll poco admirador del desenfoque, criticó duramente el pictoricismo de las mismas. Helmunt Gernsheim, redescubridor de Cameron en el siglo $\mathrm{XX}$, señala que entre sus fotografías no habrían más de sesenta que pudieran considerarse obras de arte, considerando el resto «afectadas» y «ridículas». En GERNSHEIM, Helmunt. Julia Margaret Cameron, Her Life and Photographic Work. New York: Aperture, 1975, pág. 82.

${ }^{15}$ Su modelo más habitual fue Mary Hillier, que posó en innumerables ocasiones como Virgen María, entre otras doncellas.
} 
notable. Rossetti, supone un referente fundamental. El retrato femenino en primer término, el desenfoque, con los fondos difusos y los límites imprecisos y neblinosos son su mayor distintivo y sus señas de identidad, opuestas por completo al enfoque de H. P. Robinson o Lewis Carroll.

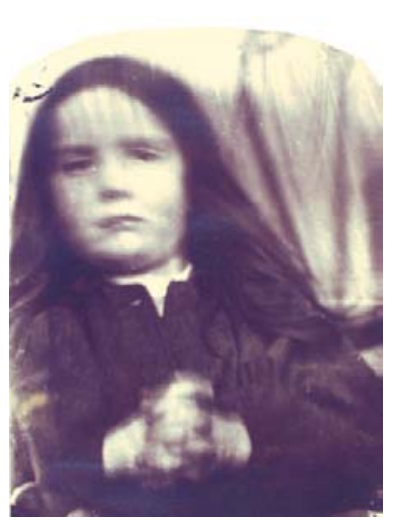

Fig. 11. Niña con los dedos entrecruzados (1864) por Julia Margaret Cameron.

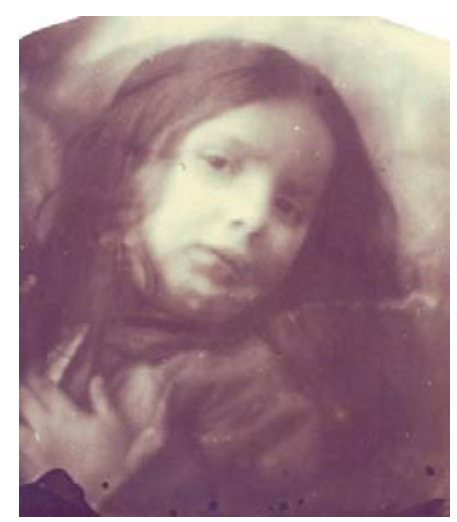

Fig. 19. Niña con la cabeza reclinada hacia el hombro (1864) por Julia Margaret Cameron.

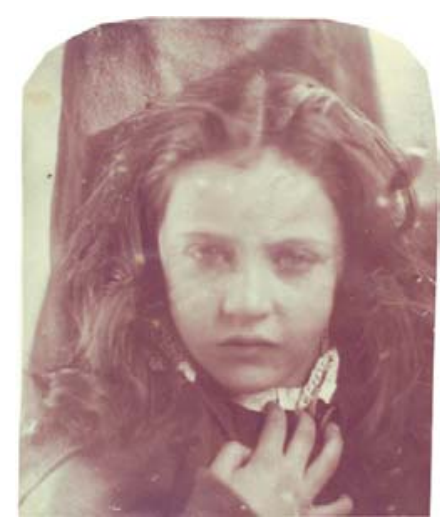

Fig. 20. Daisy Bradley (1864) por Julia Margaret Cameron.

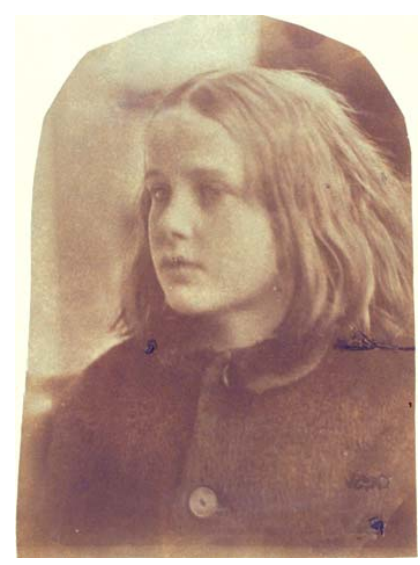

Fig. 21. Annie Philpott, mi primer éxito [My First Success] (1864) por Julia Margaret Cameron.
Se produce una relación familiar, entrañable entre las modelos y Julia Margaret Cameron, un trato maternal hacia todas ellas que se manifiesta en una fascinación mutua que la cámara registra en las interpretaciones y representaciones. Cameron escribiría tras su primera fotografía, «A mi pequeña y dulce Annie, de brillante cabellera» ${ }^{16}$, entusiasmada ante aquel primer resultado.

\footnotetext{
${ }^{16}$ CAMERON, Julia Margaret. "Annals of My Glass House". London: Camera Gallery, 1889.
} 
La teatralidad, y la puesta en escena son la clave de su composición fotográfica, ya sea en la construcción de grupos o retratos individuales. Entre la iconografía que baraja, se encuentran muchachas jóvenes que representan los personajes literarios de moda, como Elaine, en sus diferentes formas, La dama de Shalott, La doncella del Lirio de Astolat, pero sobre todo una amplia representación de personajes cristianos femeninos, madonnas, santas, ángeles $o$ querubines de influencia renacentista.

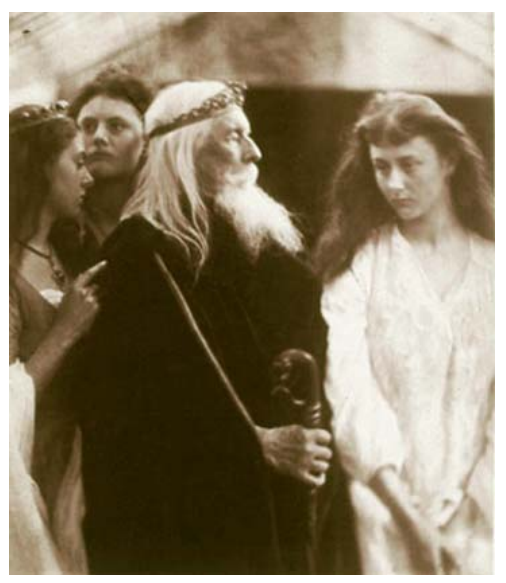

Fig. 22. El rey Lear repartiendo su reino entre sus tres hijas. ¿Que debe hacer Cordelia? Amar y estar en silencio. [King Lear allotting his Kingdom to his three daughters. 'What shall Cordelia do? Love and be silent] (1872) por Julia Margaret Cameron.

Como muchos fotógrafos de su época, Cameron también trabajó la fotografía de difuntos infantil. Tales fotografías alimentaban el gusto por lo morboso que provocaban este tipo de imágenes.

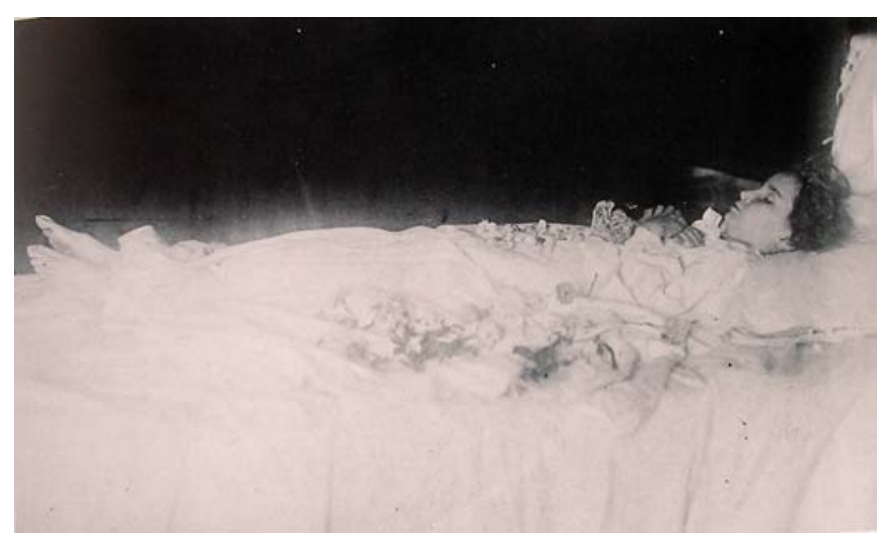

Fig. 23. Estudio de niña muerta (c. 1868) por Julia Margaret Cameron. 
La muerte en sí misma no suponía una visión terrible, pues las afectadas escenificaciones de los difuntos remitían a la apariencia de estar dormidos, de manera que incluso se utilizaban modelos vivos que aparentaran muertos, atestiguándose una vez más el estereotipo de belleza de los bebes y las niñas difuntas en las que muerte y sueño se confunden.
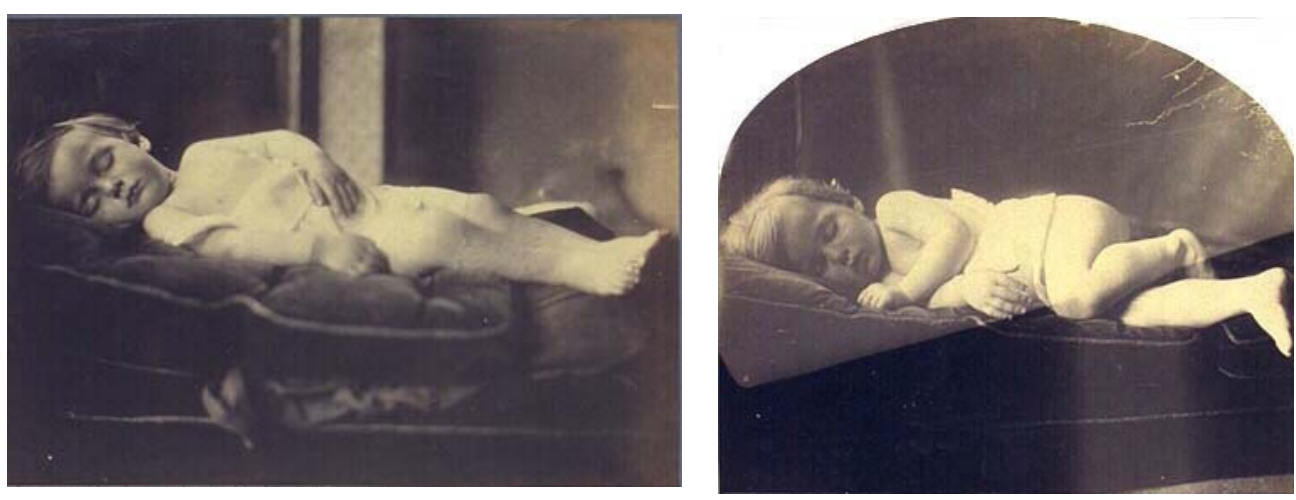

Fig. 24 y fig. 25. Mi nieto Archie, hijo de Eugene, nacido en Barbados el 25 de mayo de 1853. Dos años $v$ tres meses (1865) por Julia Maraaret Cameron.

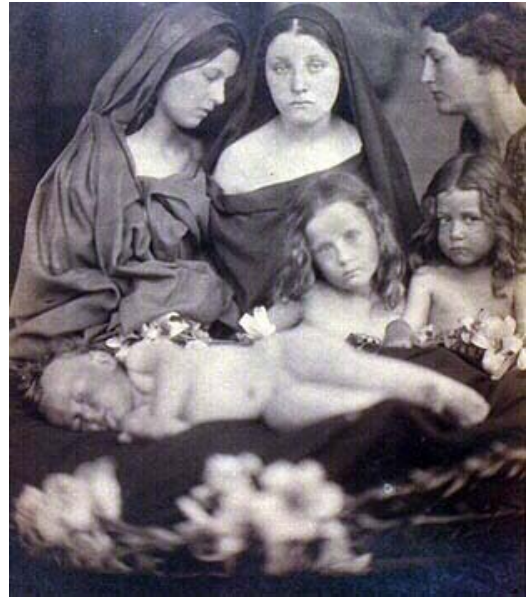

Fig. 26. Hermanas del alma (1867) por Julia Margaret Cameron.

Los bebés recostados de las fotografías de Julia Margaret Cameron, «interpretan» estar profundamente dormidos -si acaso no lo están-, como en Hermanas del alma [Sister Spirits] (1867), pero las semejanzas con la fotografía post mortem son tales, que sólo se distinguen por algunos rasgos en concretos, haciendo que las dificultades para diferenciar a los niños difuntos de los vivos, se conviertan en un morboso juego de búsqueda de muerte o aliento vital. 


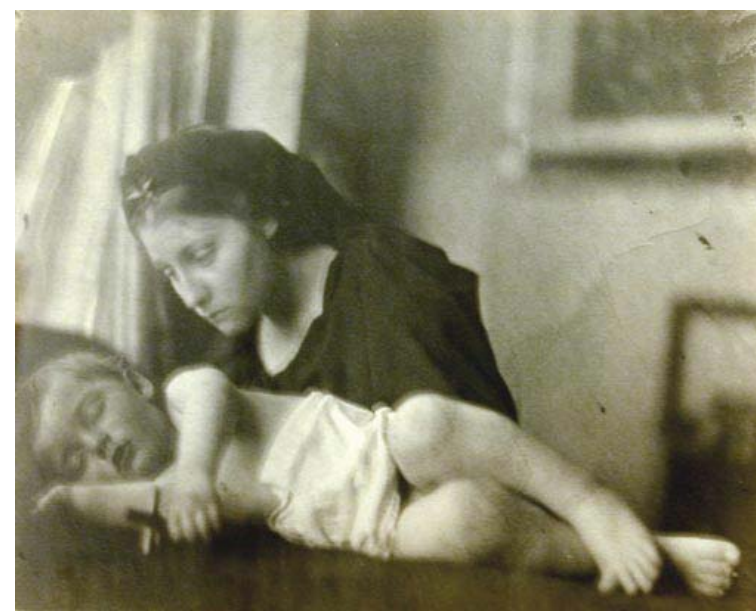

Fig. 27. La sombra de la Cruz (1865) por Julia Margaret Cameron.

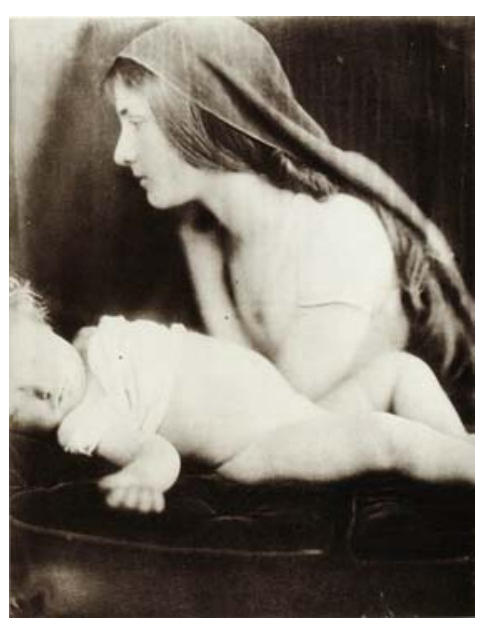

Fig. 28. La sunamita y su hijo muerto (1865) por Julia Margaret Cameron.

En La sombra de la Cruz [The Shadow of the Cross] (1865) el pequeño «difunto» que sostiene una cruz en su mano es Jesucristo tras ser bajado de la cruz con los pies colocados todavía uno sobre el otro, ante su madre, María, vestida de luto, triste pero serena. Para enfatizar la pureza de Jesús, en esta escena tras su muerte, vuelve a ser como un niño. El bebé de La sunamita y su hijo muerto [The Sunamite Woman and Her Dead Son] (1865) -escena basada en un episodio bíblico (2 Reyes 4:8-37) - , a pesar de la inmovilidad y los párpados sellados, se nos muestra en una postura de sutil sensualidad infantil, con el cuerpo estirado, la espalda arqueada y el vientrecillo abultado, dando una sensación de vida que no se da por el contrario en el bebé de Perfecta en paz [La Madonna Della Pace/Perfect in Peace] (1865) y Ferviente en el rezo [La Madonna Esaltata/Fervent in Prayer] (1865) en el que Mary Hillier, la modelo preferida de Cameron, permanece en ambas con el rostro serio, triste, pero paciente y fervoroso. Sin embargo en ambas el bebé permanece dolorosamente inmóvil, con los ojos cerrados, los labios prietos y la piel como de cera. La apariencia de difunto se hace morbosamente evidente. 


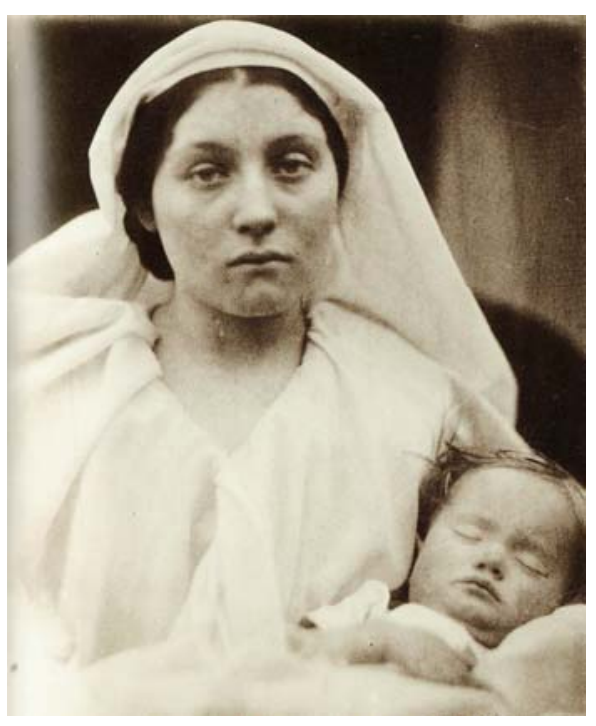

Fig. 29. La Madonna Della Pace/ Perfecta en paz (1865) por Julia Margaret Cameron.

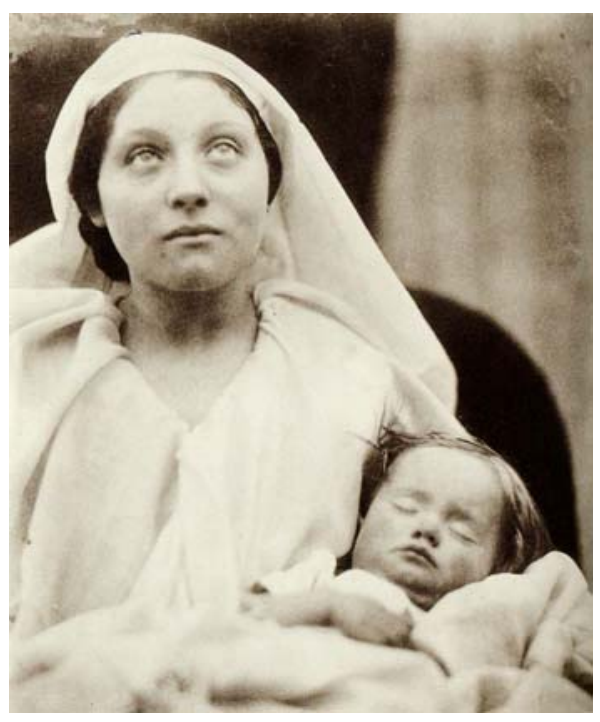

Fig. 30. La Madonna Esaltata/ Ferviente en el rezo (1865) por Julia Margaret Cameron.

Cameron, hace de las niñas unos personajes andróginos, cuando las utiliza indistintamente junto a niños para representar a ángeles asexuados o a niñas para personajes masculinos como Juan el Bautista ${ }^{17}$, sin embargo son pocas las ocasiones que utiliza a niños para representar a personajes femeninos ${ }^{18}$. Una de las pocas excepciones es la del pequeño «Paul», que posaría generalmente de querubín, de cupido o dentro de un grupo junto mujeres y niñas, en el que difícilmente reconoceríamos su sexo si no fuese por que conocemos la identidad de su modelos habituales.

\footnotetext{
17 En general, los artistas victorianos y posteriormente el cine tendrían la tendencia a simplificar el género infantil como femenino. Así, algunos personajes masculinos como Peter Pan, serían interpretados por niñas. MAVOR, Carol. Op. cit., pág. 25.

${ }^{18}$ La androginia, representa al ser primigenio, en el que se fusiona de manera perfecta los dos principios, femenino y masculino, que equivalen a la inteligencia y a la estética. "Discurso de Aristófanes" en El Banquete de Platón.
} 


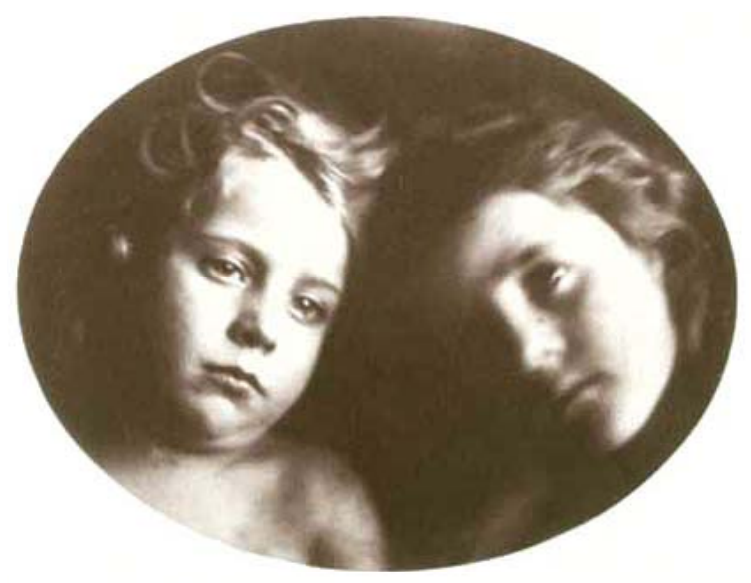

Fig. 31. Querubín y Serafín (c. 1864-66) por Julia Margaret Cameron.

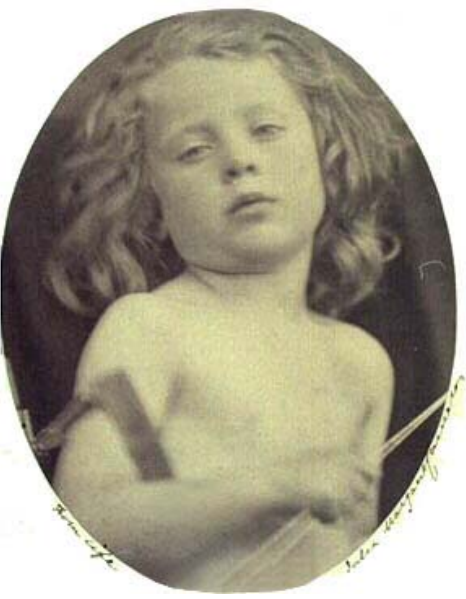

Fig. 32. Amor frívolo [Love in Idleness] (1866) por Julia Margaret Cameron.

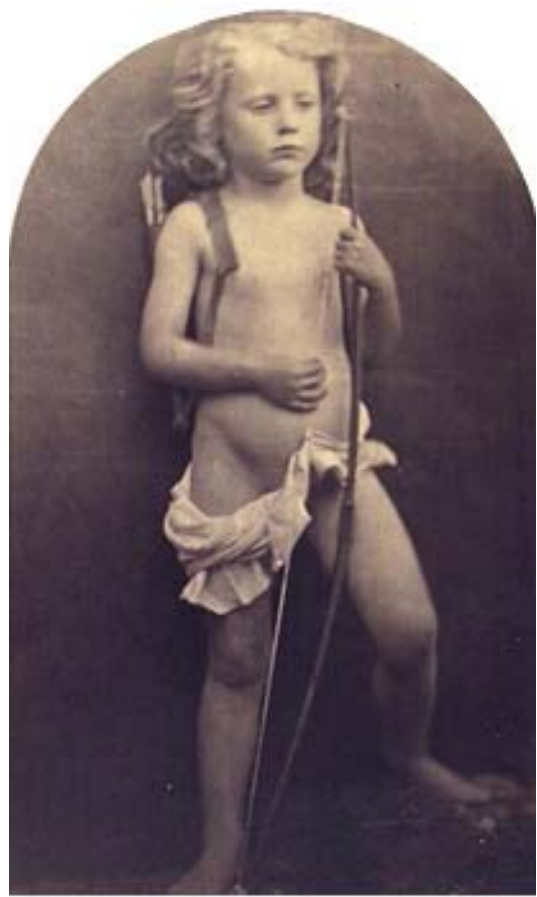

Fig. 33. Cupido en pie (c. 1867) por Julia Margaret Cameron.

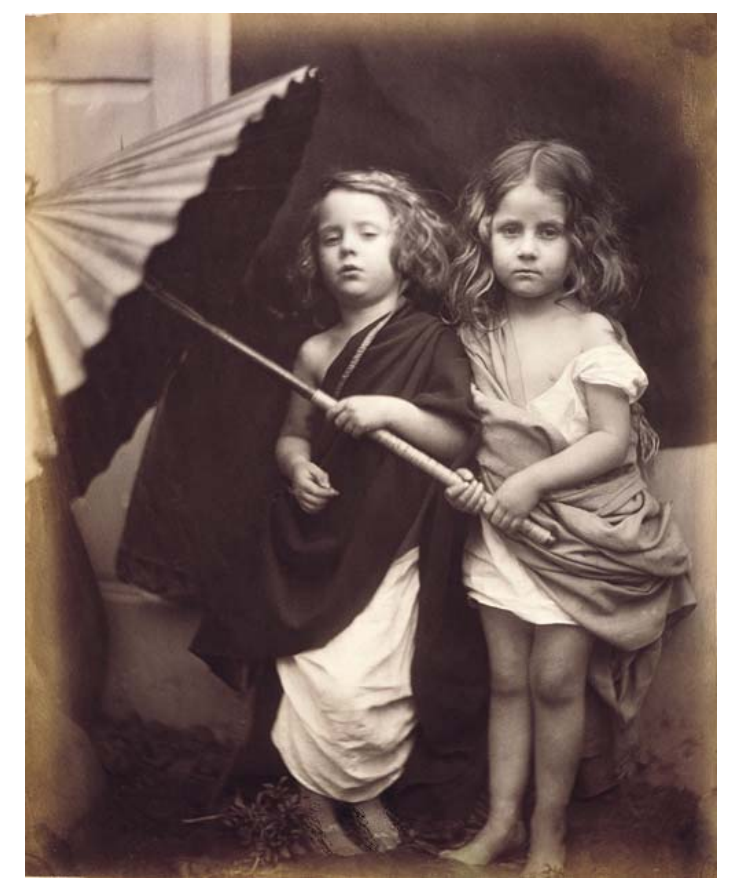

Fig. 34. Paul y Virginia (1864) por Julia Margaret Cameron. 


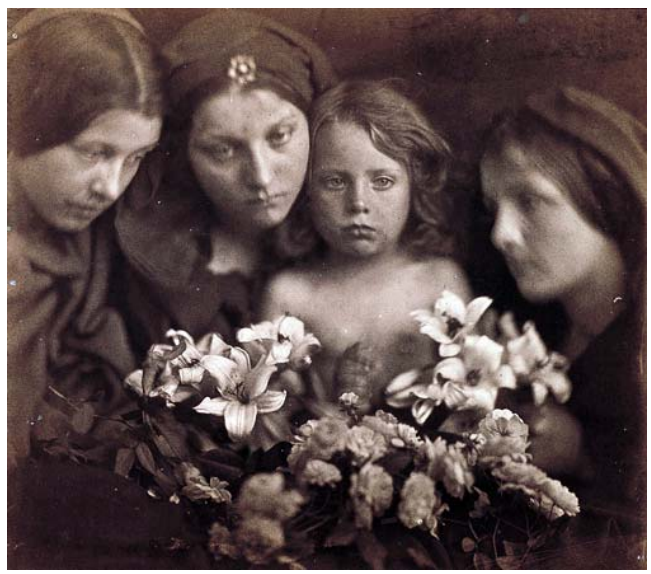

Fig. 35. Hijo, ¿por qué has hecho esto? He aquí que tu padre y yo te buscábamos angustiados [ 'Wist ye not that your father and I sought thee sorrowing?] (1865) por Julia Margaret Cameron.

La asexualidad de los niños y niñas más pequeños, de los bebés, tendrá especial relevancia para mostrar las sensaciones o los sentidos humanos, el fervor religioso o las virtudes mediante la personificación icónica en referentes infantiles con alegóricas escenas. La religiosidad está expresamente en la postura de rezo, orantes o meditativas de las niñas, que parecen invadidas por la gracia de Dios, en un estado de pureza incorrupta, angelical y resguardada del pecado adulto.

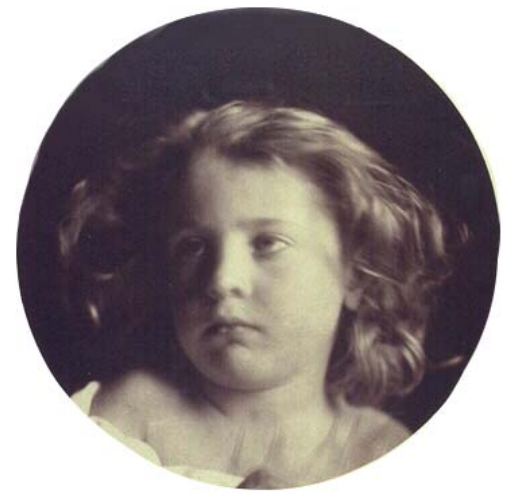

Fig. 36. La belleza de la santidad [The Beauty of Holiness] (1866) por Julia Margaret Cameron.

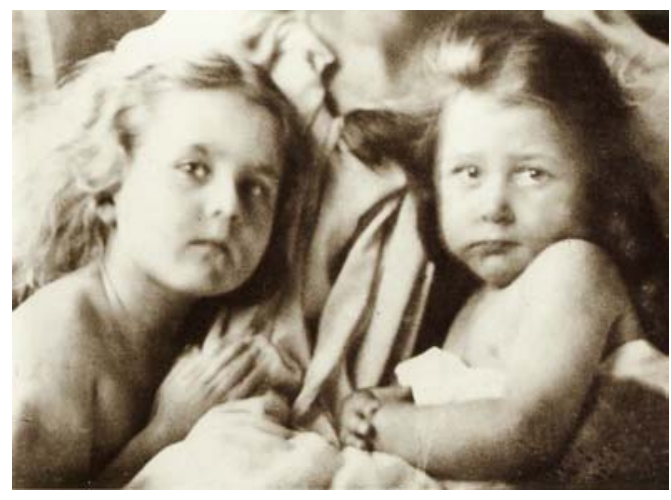

Fig. 37. Sus desconsolados bebés/ iLa madre se movió! [The Bereaved Babes/The Mother Moved!] (1864) por Julia Margaret Cameron. 


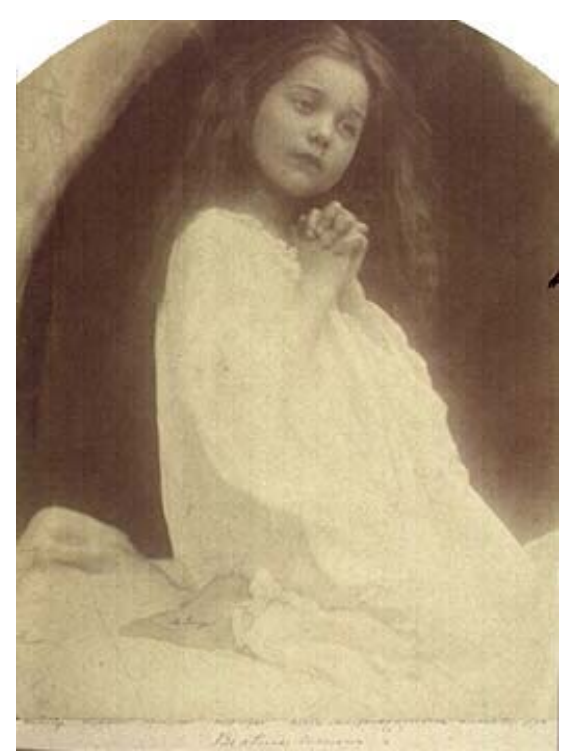

Fig. 38. Béatrice Cameron (1872) por Julia Margaret Cameron.

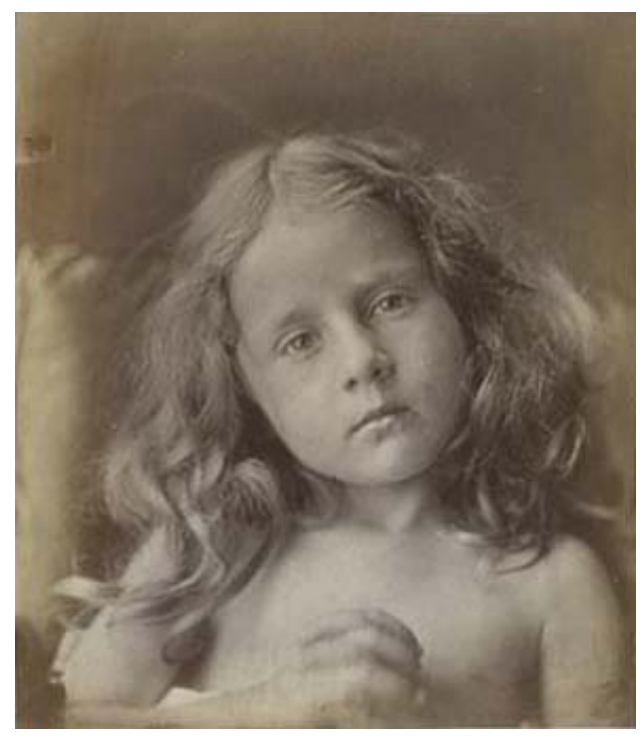

Fig. 40. El aniversario [The Anniversary] (1865) por Julia Margaret Cameron.

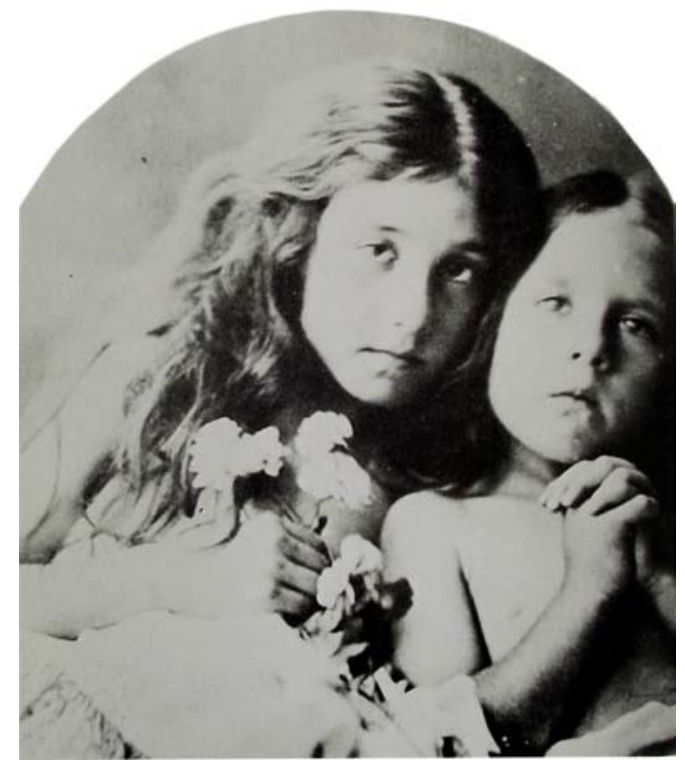

Fig. 39. Rosas rojas y blancas [Red and White Roses] (c. 1865) por Julia Margaret Cameron.

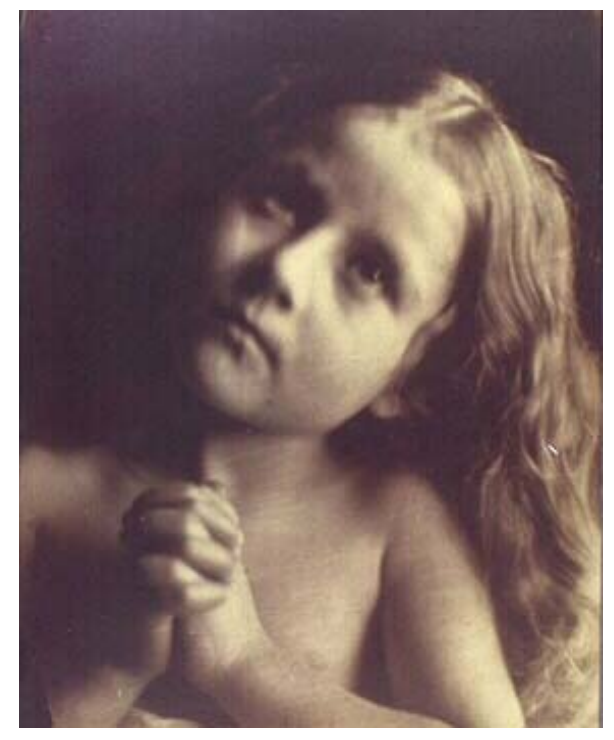

Fig. 41. Orante [Prayer] (c. 1866) por Julia Margaret Cameron. 


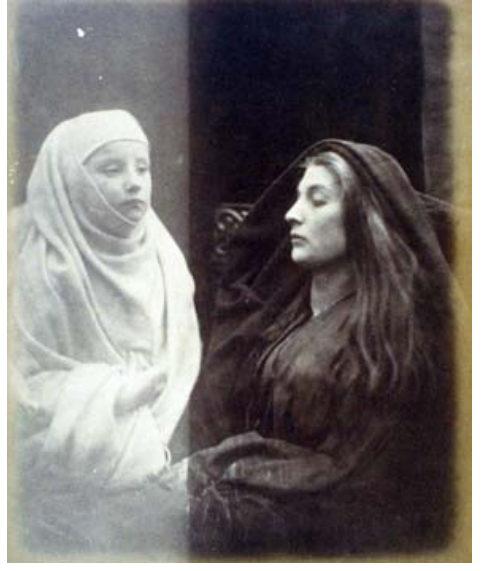

Fig. 42. La reina Ginebra y la pequeña novicia (1874) por Julia Margaret Cameron.
En La reina Ginebre y la pequeña novicia [Queen Guinevere and the Little Novice] (1874) -escena que pertenece a Los Idilios del Rey de Tennyson-, Cameron identifica la pureza y la virtud femenina en una jovencísima monja vestida con su hábito blanco y envuelta por un haz de luz, de santidad, con el rostro impasible en contraposición a una mujer adulta vestida de negro, una reina, con expresión melancólica, de enfermedad o quizás de maldad. El hábito

de la pequeña novicia no sólo se indica de su vida en castidad y santidad sino que es un anticipo de su propia mortaja. El antagonismo entre la doncella virginal -la pequeña novicia- y la mujer adulta y lóbrega -la reina en este caso- ya se había tratado anteriormente en los cuentos populares como la dulce y nívea Blancanieves y su madrastra la Reina Malvada.

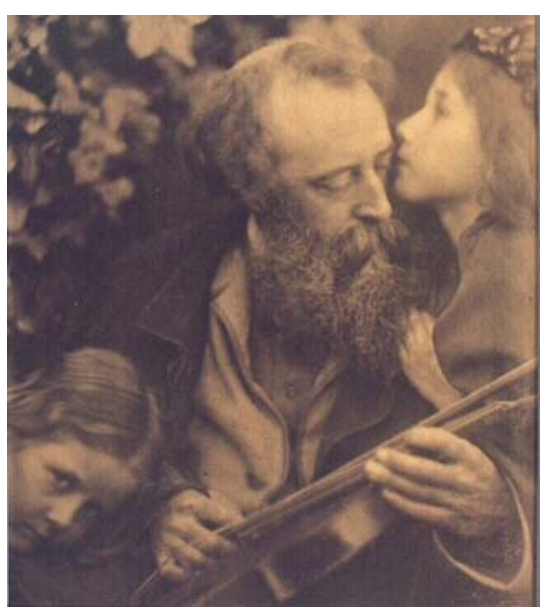

Fig. 43. El susurro de la musa (1865) por Julia Margaret Cameron.
La pureza de las niñas, resulta estimulante para los artistas de cualquier época, por ello las «Musas» inspiradoras del ingenio y de las artes del hombre, para Julia Margaret Cameron toman forma en la figura de preadolescentes, a las que como en El susurro de la musa [Whisper of the Muse] (1865) representa apareciéndosele al artista como duendecillos o formas evanescentes y espectrales, invisibles 
a la vista, asomando a penas su cabeza al espectador, lo suficiente para llegar al oído del músico fotografiado. Pero por encima de otros personajes o iconos, para Cameron las niñas encarnarían sin duda la figura asexuada de los ángeles.

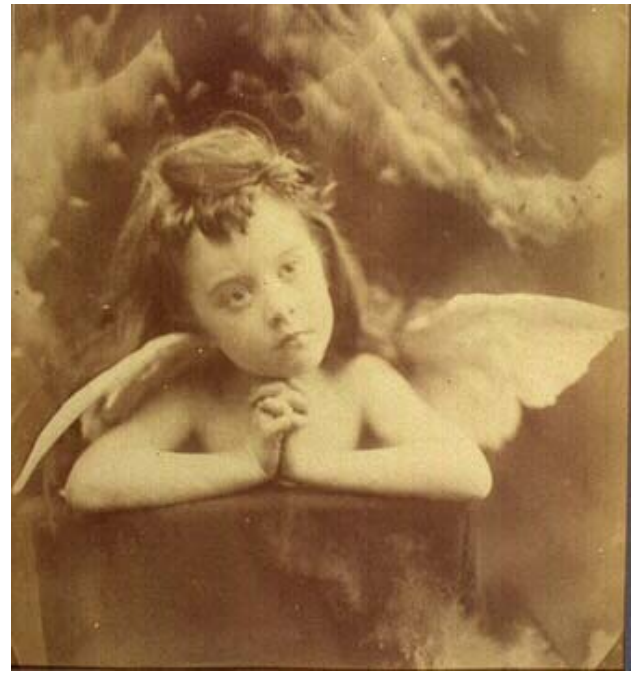

Fig. 44. Hágase tu voluntad [Thy will be Done] (1872) por Julia Margaret Cameron.

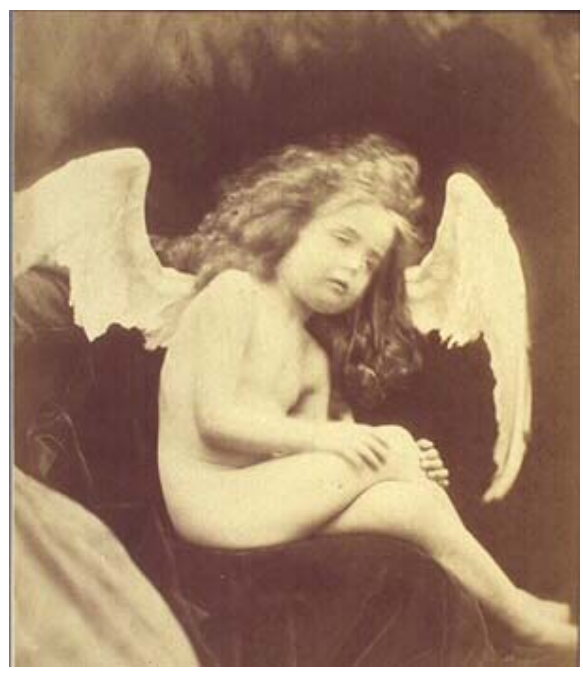

Fig. 46. Cupido pensando [Cupid Considering](1872) por Julia Margaret Cameron.

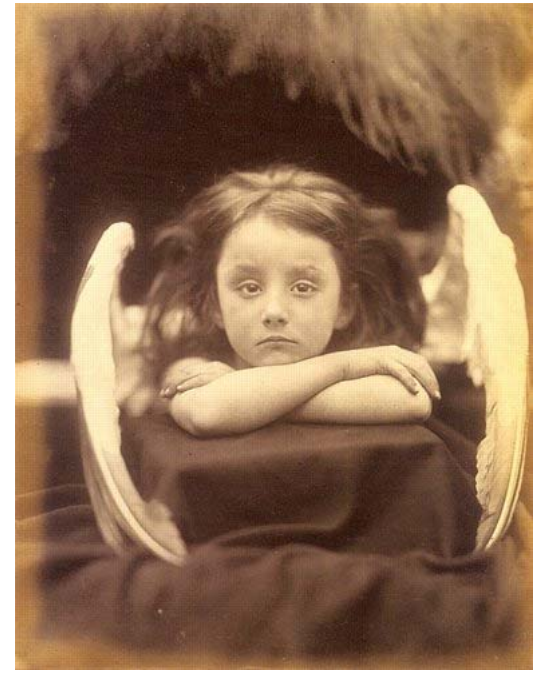

Fig. 45. Rachel Gurney. Espero [I Wait] (1872) por Julia Margaret Cameron.

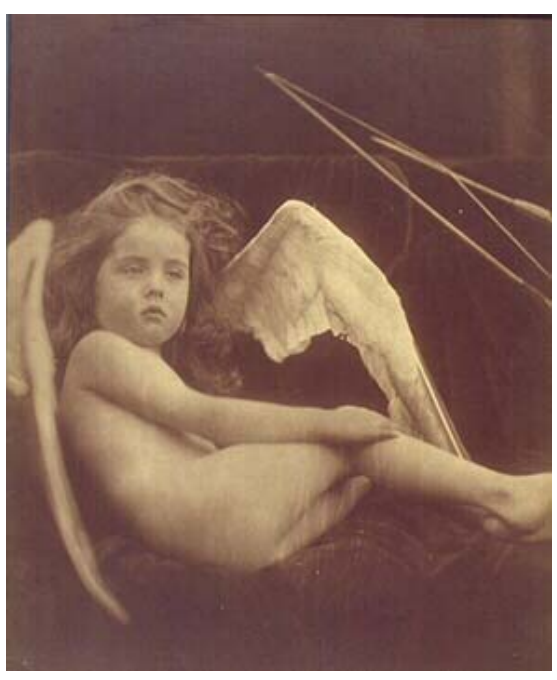

Fig. 47. Cupido descansando (1872) por Julia Margaret Cameron. 
Los ángeles de Cameron no están carentes sin embargo de un erotismo como se evidencia en algunas de las posturas que adoptan las niñas reclinadas sobre las telas de terciopelo oscuro como Cupido descansando [Cupid Reposing] (1872), en la que las nalgas se muestran parcialmente.

En la mayoría de composiciones de la Virgen María con Jesús y Juan el Bautista, las modelos femeninas se representan ambiguamente asexuales. Por ello el desnudo infantil ya sea de niño o de niña no implica sexualidad. Así en Primavera [Spring] (1855), se nos deja ver ligeramente los genitales bajo la pequeña pieza de ropa que cubre el cuerpecito de una de las niña que posa probablemente para Jesús o para Juan el Bautista.

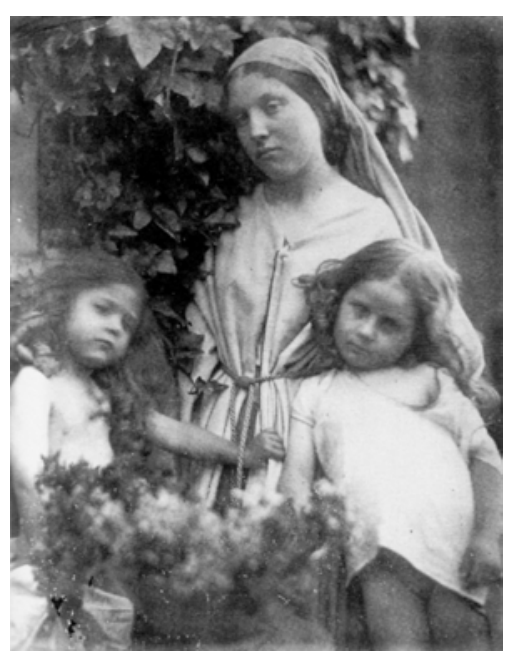

Fig. 48. Primavera [Spring] (1855) por Julia Margaret Cameron.

Mary Hillier, a menudo encarnaba a la Virgen María, junto a niñas que representaban a Jesús y a Juan El bautista, como parte de su pequeño cortejo celestial, como personificación de las Virtudes Teologales o como los Frutos del Espíritu Santo. Se tratan de escenas que no sólo ensalzan la belleza de los cuerpos infantiles, sino que gracias a su concepción de naturaleza inocente, se puede desarrollar una misión evangelizadora con el estudio y la meditación de las enseñanzas religiosas plasmadas en las fotografías, como lo hiciera durante siglos la pintura o la escultura. Tanto en Bondad [Goodness] (c. 1864), como en el resto de fotografías en las que se presentan al trío Mary Hillier, Elizabeth y Kate Kuhn, una de las pequeñas o ambas aparecen de nuevo con los dedos entrecruzados, en gesto de ruego o 
de rezo. Tales gestos aportan una sensación de humildad, fragilidad e indefensión, enfatizada por los hombros desnudos de las niñas o recogidas por el abrazo maternal de Mary Hillier.

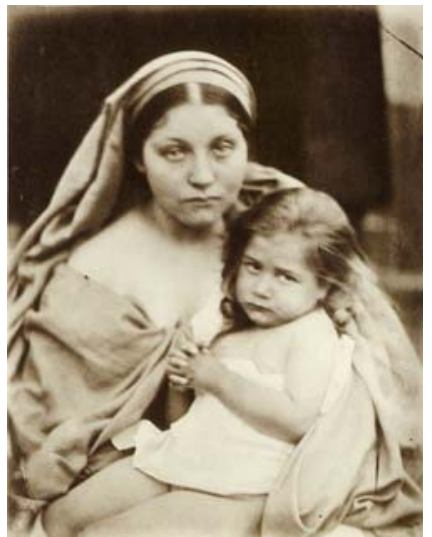

Fig. 49. Bondad [Goodness] (c. 1864) por Julia Margaret Cameron.

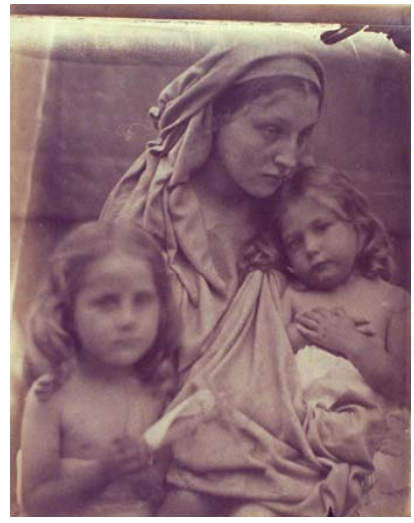

Fig. 52. Amor [Love] (1864) por Julia Margaret Cameron.

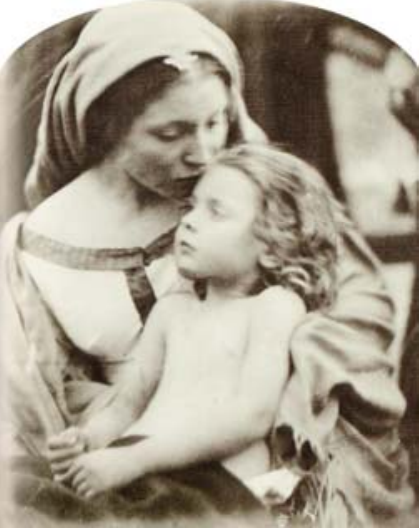

Fig. 50. Bendiciendo y bendecido [Blessing and Blessed] (1865) por Julia Margaret Cameron.

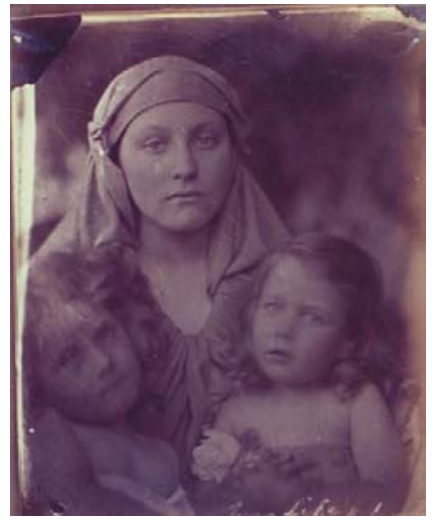

Fig. 53. Mary Hillier, Elizabeth and Kate Kuhn. Sagrada Familia [Holy Family] (1864) por Julia Margaret Cameron.

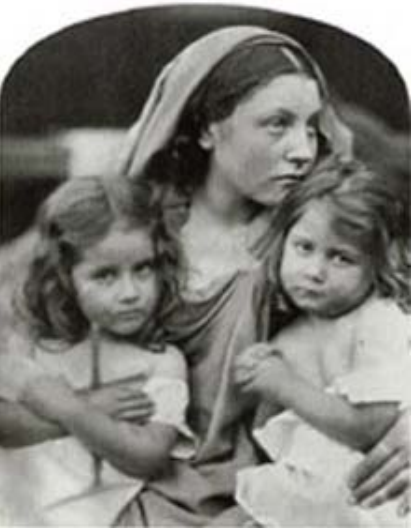

Fig. 51. Fe [Faith] (1864) por Julia Marqaret Cameron.

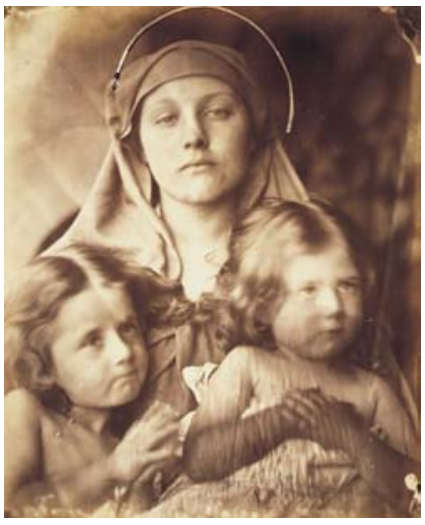

Fig. 54. Mary Hillier, Elizabeth and Kate Kuhn. Sagrada Familia [Holy Family] (1864) por Julia Margaret Cameron. 
Para el personaje de Juan el Bautista, utiliza a la niña Florence Fisher, en Florence Fisher. Estudio para San Juan Bautista [Study of a St. John the Baptist] (1872) que vestida con una piel polvorienta, deja al descubierto la pálida piel de su hombro, brazo y la parte mas alta del pecho, representación del santo compartida por J.W. Waterhouse.

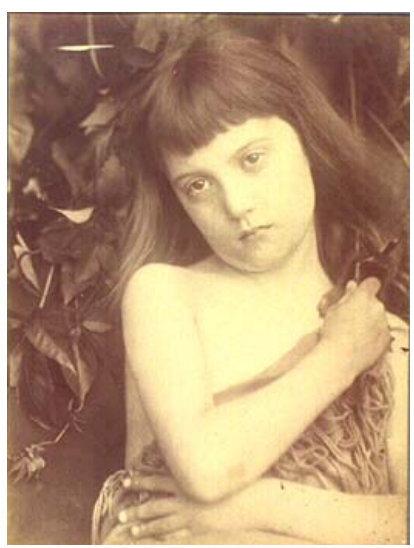

Fig. 55. Florence Fisher. Estudio para San Juan Bautista (1872) por Julia Margaret Cameron.

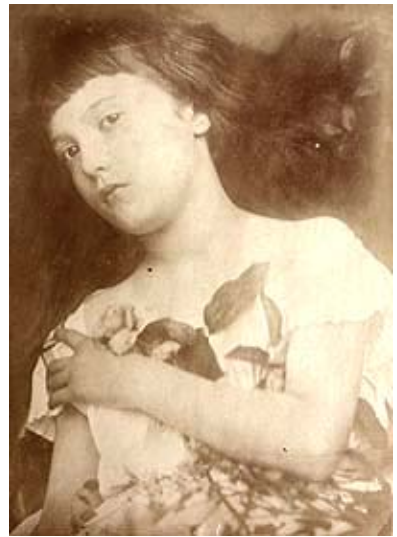

Fig. 56. Florence Fisher (1872) por Julia Margaret Cameron.

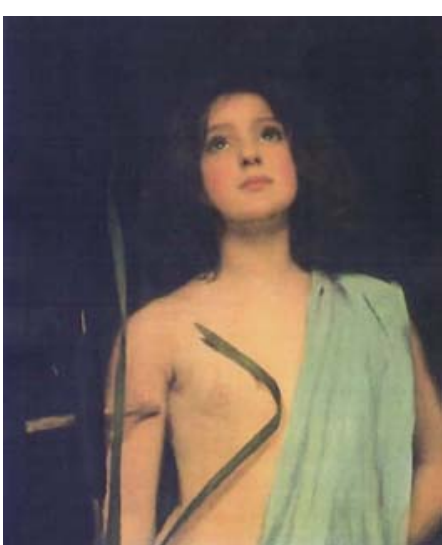

Fig. 57. San Juan (s.a.) por John William Waterhouse.

Sus personajes seducen a la cámara con sus pieles aniñadas, sus rostros angelicales, miradas perdidas y distintivos conformes al erotismo propio de la época, sin embargo la obra de Cameron escapó, señala Mavor $^{19}$, de la «etiqueta» de perversa. A ello contribuyó tal vez su condición de madre de familia numerosa y heterosexual, la libraba de la sospecha y le daba «respetabilidad». La fotografía de Julia Margaret Cameron se vio resguarda por la opinión victoriana que la definieron de infantil, inocente y maternal. El erotismo lésbico ni siquiera se prestó a opinión a pesar de que los grupos femeninos eran frecuentes en sus composiciones, o como en La doble estrella [The Double Star] (1862), en la que dos niñas que se besaban en los labios, como si lo hicieran

${ }^{19}$ MAVOR, Carol. Op. cit., pág. 22. 
bajo el agua o en medio de un profundo sueño. De hecho se trata de composiciones que tienen referentes pictóricos renacentistas y de la iconografía cristiana.

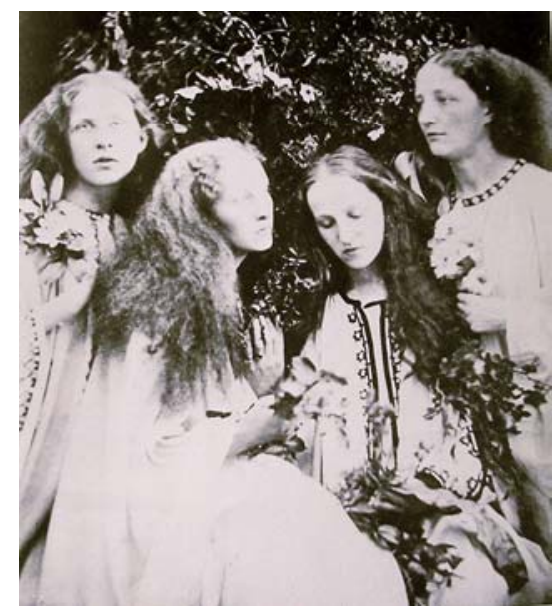

Fig. 58. La rosaleda de muchachas [The Rosebud Garden of Girls] (1870) por Julia Margaret Cameron.

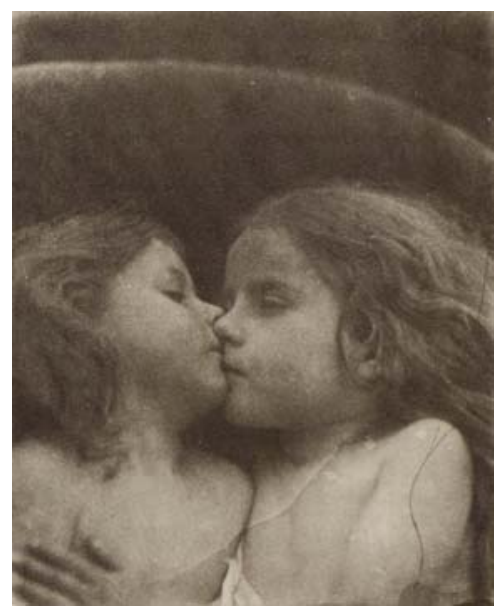

Fig. 59. La doble estrella (1862) por Julia Margaret Cameron.

El conjunto de su obra nos presenta un «ideal de belleza que se identifica trascendentemente con la verdad ${ }^{20}$, y que logra manifestar a través de la temática principalmente femenina, una infancia y una maternidad idealizada, así como los valores domésticos y religiosos victorianos que toda mujer debiera poseer. Pero su visión moralizadora no sólo estaba enfocada hacia cuestiones de fe o decoro sino que entraría en cuestiones sobre el valor estético o artístico de la imagen femenina durante la infancia, cuando afirmaba que «ninguna mujer debería jamás dejarse fotografiar entre los dieciocho y los ochenta años de edad» ${ }^{21}$.

\footnotetext{
${ }^{20}$ A.A.V.V. Cameron: The Work and the Career. New York: International Museum of Photography at George Eastman House, 1986, pág. 15.

21 Afirmación de Julia Margaret Cameron, según Hester Thackeray (hija de Anne Thackeray). THACKERAY, Hester F. Three Freshwater Friends: Tennyson. Watts and Mrs. Cameron. Newport: Hunnyhill Pubns, 1933, pág. 36. Citado en AA.VV. Cameron: The Work and the Career. Op. cit. pág. 27.
} 


\subsection{Fotografía del trabajo infantil.}

Tal vez el fotógrafo Lewis Hine haya sido desde su contribución con la fotografía, uno de los más prominentes abanderados de la lucha contra la explotación laboral infantil de principios del siglo XX.

Nació en Oshkosh, Wisconsin, EEUU, en 1874. Era profesor de escuela y reformador social. Algunas de sus fotografías más conocidas son las que retratan la dramática situación de los inmigrantes europeos, en la llamada puerta de los Estados Unidos, la Isla de Ellis en Nueva York, así como las de la construcción del famoso Empire State Building.

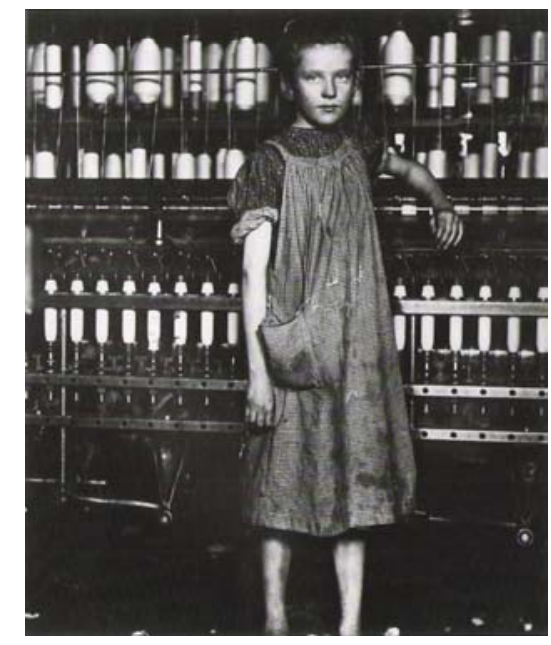

Fig. 60. Hilandera en una factoría de algodón en Nueva Inglaterra. North Pownal, Vermont, Estados Unidos (1913) por Lewis Hine.

Su visión de la infancia era completamente contrapuesta a la de sus contemporáneos y predecesores europeos de la Inglaterra victoriana que envueltos por el «Culto a la infancia», desestimaron la realidad vital de los niños y niñas de la sociedad industrial y rural. Al igual que en Europa, Estados Unidos utilizaba niños como mano de obra barata para el trabajo agrícola o en la industria. Lewis Hine, procuró acercarse a esa situación laboral de un modo realista llevando su cámara a los lugares propios donde vivían y desempeñaban sus trabajos, en las plantaciones, en las fábricas, en los talleres o en las casas. No hacía diferencias de género, todos ellos, niños y niñas, independientemente de que trabajasen en empleos diversificados según el sexo de sus adultos, ya 
fuera en las minas o en las fábricas, eran víctimas de unas condiciones de vida precarias, prácticamente en situación de esclavitud o de extrema pobreza. Su propósito se centraba en dar a conocer las condiciones reales de la infancia de su país, en conocer la injusticia laboral y conseguir la movilización de la sociedad entera, como hicieran los grupos reformistas y feministas británicos, en demanda de leyes que protegiesen a los menores.

La pequeña Edith o Rosie, no son modelos, ni hijas de los amigos del fotógrafo, como las de Julia Margaret Cameron. Son las protagonistas reales del drama documentado por Lewis Hine, que sin embargo, se nos muestra con sencillez, sin morbosidad. En ellas no hay simulación, interpretación o teatralidad. No responde a las estéticas victorianas ni a la visión post-romántica del arte prerrafaelista, sin embargo si que hay una mirada «enamorada» hacia sus anónimas protagonistas.

Dr. Barnardo escribió la falsa leyenda que leía: «Una pequeña de seis años desamparada, recogida de las calles», con la finalidad de provocar la compasión y la conmiseración del espectador. La madre de las niñas Holder las llevó al estudio del doctor. No eran fruto de una familia adinerada,

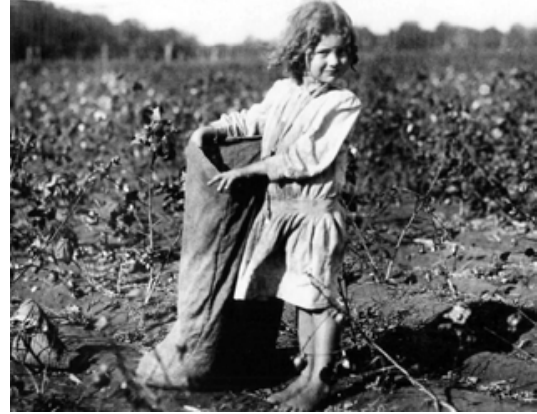

Fig. 61. Edith, cinco años de edad (c. 1910) por Lewis Hine.

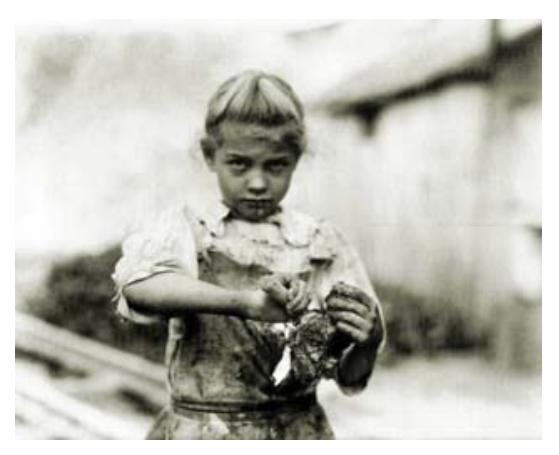

Fig. 62. Rosie, siete años de edad, una experimentada extractora de ostras. Bluffton, Carolina del Sur, Estado Unidos (1913) por Lewis Hine. 


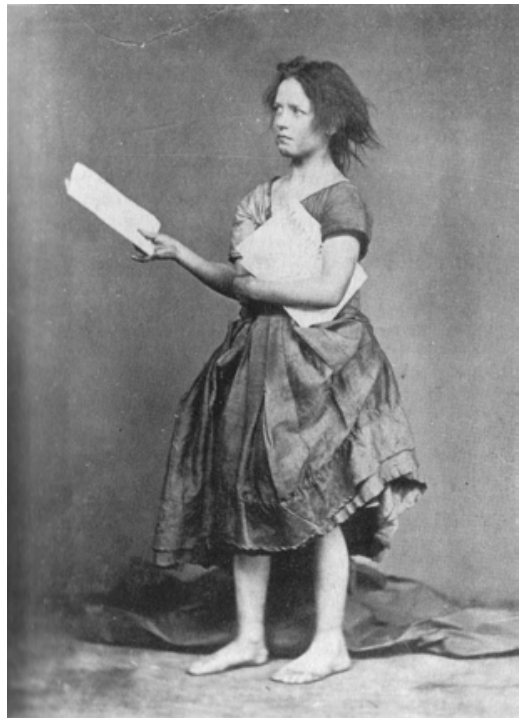

Fig. 63. Florence Holder (1876) por Dr. Barnardo.

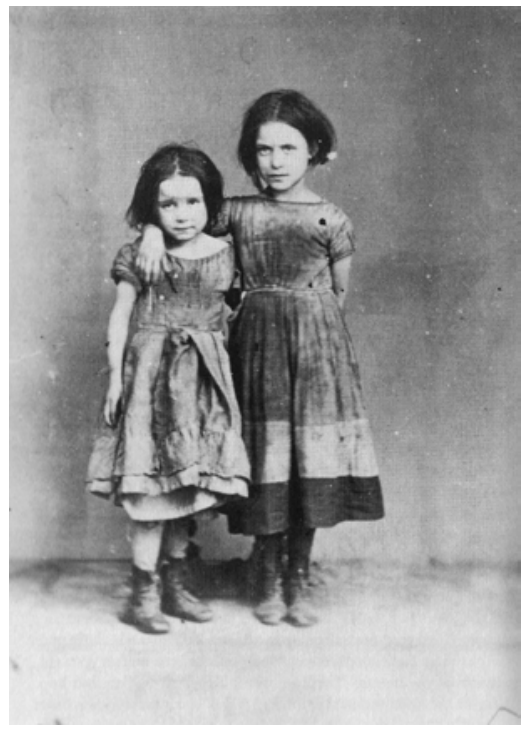

Fig. 65. Florence y Eliza Holder (1876) por Dr. Barnardo. pero tampoco eran indigentes, sin embargo, la «ficción artística» fue para muchos autores victorianos la única forma de acercarse a la lamentable realidad de las condiciones infantiles, recreando una idealización dramatizada que quedaba muy lejos de la comprensión de las clases adineradas.

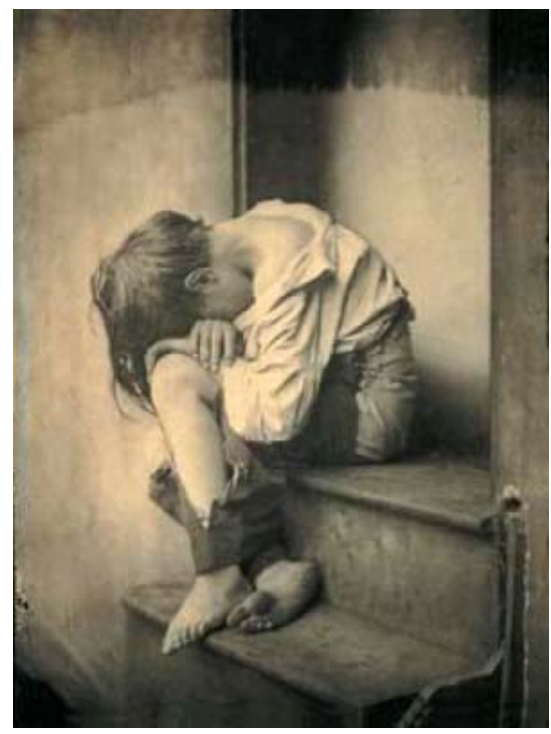

Fig. 64. La noche en la calle del sinhogar [A night out homeless] (c. 1892-3) por Oscar G. Rejlander. 


\section{LEWIS CARROLL.}

\subsection{Lewis Carroll, pseudónimo de Charles Lutwidge Dodgson.}

Lewis Carroll ${ }^{1}$, era el pseudónimo de Charles Lutwidge Dodgson (1832-98), autor del archiconocido cuento «para niños», Alicia en el país de las maravillas. Su reconocimiento se debe más a su obra literaria y fotográfica que a la de su alter ego, el reverendo Dodgson, un hombre neurótico y nostálgico, profesor de matemáticas ${ }^{2}$. Sin embargo, la cantidad de información que poseemos de Dodgson en la actualidad nos hace replantearnos el interés de Lewis Carroll de manera integral. Los testimonios nos presentan a Charles L. Dodgson como un hombre remilgado, altivo, quisquilloso y tremendamente aburrido durante las lecciones y reuniones, pero también a un hombre de constitución física hermosa, alta, con un andar erguido incluso en exceso que vestía siempre de negro, tartamudo, sordo de un oído, inventor de toda clase de artilugios y juegos que ideaba para sus incontables amistades con niñas. Mr. Dodgson y Lewis Carroll son un portmanteau ${ }^{3}$ de un mismo hombre. Es decir que para conocer al autor de Alicia y sus fotografía es necesario conocer al misterioso Charles Dodgson.

Nació el 27 de enero de 1832, en Daresbury, Manchester, Inglaterra, siendo el mayor de cuatro hermanos y siete hermanas.

\footnotetext{
${ }^{1}$ Utilizaremos ambos nombres: Charles Lutwidge Dodgson o su pseudónimo, Lewis Carroll, según su conveniencia en el contexto en el que se le haga referencia.

${ }^{2}$ Algunos autores señalan, como Kathleen Baker en el Centenario de la muerte de Carroll en 1998, que «lo que Charles Dodgson hizo era menos interesante que lo que escribió Lewis Carroll». BAKER, Kathleen. Play, Games and Sport: The Literary Works of Lewis Carroll. Ithaca \& London: Cornwell University Press, 1974, pág. 11.

3 Portmanteau, son dos palabras, dos significados, que se unen en una sola palabra «nueva», las llamadas «palabras maletín». Lewis Carroll usó el portmanteau como neologismo, valiéndose del procedimiento que ya usaban Aristófanes o Swift, y que más tarde usarían los dadaístas o Derrida entre otros. En francés portemateau, significa perchero, hallando una metáfora entre Dodgson y Carroll. Dodgson es la percha de Carroll y viceversa.
} 
Charles L. Dodgson, era un hombre de arrebatada imaginación y creatividad que había cultivado desde niño cuando ideaba y creaba marionetas y juegos para su numerosa familia. Realizó algunas revistas familiares como El paraguas de la rectoría o Cajón de sastre 4 .

En 1850 comenzó a estudiar en el Christ Church Collage de la Oxford University. Resultó ser siempre un excelente estudiante y tras acabar sus estudios y lograr el grado de bachiller en 1855, obtuvo la beca $B . A^{5}$, de la Christ Church, volviendo en enero para comenzar a dar allí mismo clases como tutor de matemáticas ${ }^{6}$. En junio de ese mismo año, el dean del college, Henry G. Liddell y su familia, se mudaron a las habitaciones contiguas de Charles Dodgson.

Fue Edmund Yates ${ }^{7}$, director de la revista The Train quién en 1855 , le sugirió a Charles L. Dodgson un cambio de nombre. Con su habitual ingenio inventó su pseudónimo mediante la latinización y la inversión de sus dos nombres propios Charles Lutwidge ${ }^{8}$. Así en 1856 apareció publicado su poema Soledad [Solitude] por primera vez con su nom de plume como Lewis Carroll. Fue precisamente cuando comenzó a hacer uso de su pseudónimo, cuando comenzó también a fotografiar. Su primera cámara la compró en marzo de ese mismo año. Por aquel entonces él tenía 24 años. La fotografía se convirtió en un medio de relacionarse con los círculos artísticos y a grandes personalidades de la

\footnotetext{
${ }^{4}$ The Rectory Umbrella, escrita entre 1845-1850 y Mischmasch (1855) respectivamente.

${ }^{5}$ La beca B.A, por la que obtuvo los cargos de Master of the House y sub bibliotecario de la Christ Church, le comprometía según los términos de la escolaridad y del alumnado, a permanecer soltero y proceder a la orden sagrada, perdiendo dicha beca en el caso de que contrajese matrimonio. En 1861 fue ordenado diácono de la Iglesia Anglicana pero jamás fue ordenado sacerdote.

${ }^{6}$ Actividad que realizó hasta 1881 .

7 Charles L. Dodgson, había publicado anteriormente en la revista Comic Times, dirigida por Edmund Yates. Al poco tiempo la revista desapareció y Yates sacó la revista The Train.

${ }^{8}$ Su nombre, mediante un juego de palabras y su latinización pasa de Charles Lutwidge a Carolus Ludovicus, que traspasados, trasladados y traducidos de nuevo al inglés son Lewis Carroll.
} 
cultura, como el fotógrafo O. G. Rejlander, del que era amigo y gran admirador, al cual pediría consejo en varias ocasiones.

Entre sus historias Alicia en el País de las Maravillas y A través del espejo, que se convertirían en clásicos de la literatura del siglo XIX, escribió numerosos poemas, artículos, tratados de matemáticas y lógica, así como inventos y juegos.

\subsubsection{Charles Lutwidge Dodgson y el arte victoriano.}

Lewis Carroll mantuvo una estrecha relación con los artistas prerrafaelistas y en su afición compartida por la fotografía, llegó a desarrollar -sin más ambición que la de disfrutar y la de realizar obsequios a sus jóvenes modelos- de un particular icono de preadolescencia femenina que trascendería a diferentes áreas como literatura, pintura, fotografía y cine desde finales del siglo XIX hasta la actualidad.

Dodgson gozaba con la vida cultural victoriana que le ofrecía conferencias, representaciones teatrales de las cuales era un tremendo aficionado, ópera, la cual consideraba -a pesar de la oposición religiosauna fuente de entretenimiento edificante, así como de exposiciones de fotografía y pintura en la Royal Academy de Londres, Burlington House, Grosvenor Gallery o en colecciones menores de las que difícilmente se perdía alguna, como constatan sus abundantes anotaciones en sus diarios de las que daba cuenta de sus impresiones. Conoció y trabó amistad con los más importantes autores victorianos como Ruskin y con los artistas prerrafaelistas como Dante Gabriel Rossetti.

En su afición por la imagen de las niñas, probablemente indagaba buscando los más sugerentes retratos infantiles populares de la época. 
Sin embargo y contrariamente a lo que se pensaba, Carroll también disfrutaba con retratos de muchachas y adolescentes, a pesar de su predilección por las formas infantiles. En 1868, visitó la Royal Academy y se fijó en unas pinturas que mostraba una escena de niñas. Escenas que sin duda le recordaban a las que él recreaba en sus fotografías. Quedó particularmente encantado ante las pinturas tituladas: No lloréis, damas [Sigh No More, Ladies] (circa 1867) de Arthur Hughes, Virgen tonta [Foolish Virgin] de Westmacott, Caperucita roja [Red Riding Hood] de Mrs. Anderson y un par de pinturas de Schlesinger, tituladas La labor aburrida [The Tedious Task] y En desgracia [In Disgrace] ${ }^{9}$. Varias décadas más tarde, en el verano de 1883 escribiría en su diario a propósito de una visita a la Grosvenor Gallery, en la que menciona su admiración por Las criadas del Faraón [Pharaoh's Handmaidens] (1883) de John Collier, en la que aparecen unas jóvenes criadas con el torso visiblemente desnudo y de formas juvenil, propias de la adolescencia.

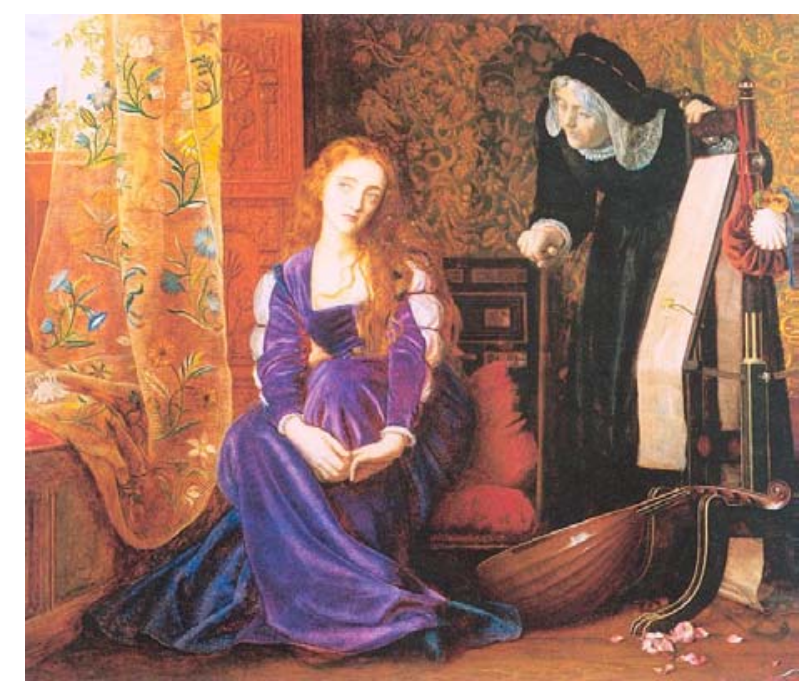

Fig. 1. No lloréis, damas (c. 1867) por Arthur Hughes.

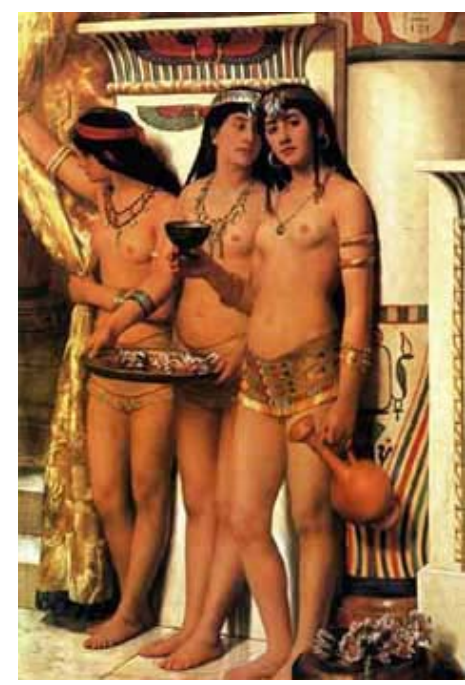

Fig. 2. Las criadas del Faraón (1883) por John Collier.

9 PEARSALL, Ronald. Op. cit., pág. 144. 
Charles Dodgson y el pintor Arthur Hughes compartían la misma admiración por la inocencia de las niñas, por su belleza y fragilidad. Dodgson precisamente, poseía un óleo sobre tabla de su amigo Hughes titulado, La dama de las lilas [The Lady of the Lilacs] realizado en 1863. Se trata de un trabajo menor que representa a una joven envuelta en perfumados ramilletes de lilas, el cual colgó sobre la chimenea de su estudio de la Christ Church.

Dodgson era de carácter reservado «con los adultos»-pero no con las niñas- y jamás se sintió demasiado cómodo con el hecho de que lo identificaran como el autor de Alicia, identidad que sólo revelaba discretamente a sus amistades, molestándose enormemente ante las visitas inoportunas a las puertas de sus habitaciones. Tal era su disgusto que incluso negaba ser Lewis Carroll ante los desconocidos. Así Edward William Bok ${ }^{10}$, relataba su visita a Oxford con la intención de entrevistar al autor de la famosa Alicia con la sorpresa de que el reverendo Dodgson que vivía en las habitaciones de Tom Quad del Christ Church Collage de Oxford, negaba ser Lewis Carroll. Se sabe que en cierta ocasión abandonó una fiesta en la que se reveló que él era el autor de Alicia o que devolvía como destinatario desconocido las cartas que le llegaban a su dirección ${ }^{11}$. Del mismo modo, la Reina Victoria, tras leer encantada Alicia en el País de las Maravillas, escribió a Lewis Carroll pidiéndole una copia personal del mismo, a lo cual Dodgson resolvió enviándole un ejemplar de Tratado elemental de determinantes [An Elementary Treatise on Determinant], escrito por C. L. Dodgson.

10 AAA.VV. XX Meeting a Reverse or Two [en línea]. Edward William Bok (1863-1930). The Americanization of Edward Bok, 1921. [ref. de 13 de septiembre del 2005]. Disponible en Web: http://www.bartleby.com/ 197/20.html

${ }^{11}$ COLINGWOOD, Stuart Dodgson. The Life and Letters of Lewis Carroll. C. L Dodgson. London: T. Fisher. Unwin, 1898, págs. 272-3. 
Por otro lado, era un hombre comprometido desde la sombra con diferentes causas de su época. Se oponía por completo a la vivisección ${ }^{12}$ de animales, abogó por la ventajas de la vacunación, así como cuando donó unos 2.000 libros de Alicia a diferentes hospitales e instituciones para niños, entre algunas de sus actividades altruistas.

Para Dodgson sus historias no sólo debían de tratar de divertir, sino de moralizar, así como para su coetáneo John Ruskin y los prerrafaelistas, el arte y también la literatura, debían aspirar a mayores y más elevadas pretensiones que el logro estético. Dodgson como profesor que era utilizaba sus historias y acertijos con pretendido sentido edificante. Con tal intención escribió Silvia y Bruno durante los últimos años de su vida, la cual pasó bastante desapercibida en comparación con Alicia.

Tras la publicación de el polémico artículo El tributo de las jóvenes doncellas en la moderna Babilonia en la Palm Mall Gazette, el 6 de julio de 1885, numerosos lectores de la gaceta, escribieron indignados al director de la misma, criticando, unos el carácter sensacionalista del artículo y otros, escandalizados por el contenido. En este sentido, Lewis Carroll, que consideraba que los detalles que en él se ofrecían sobre la prostitución infantil eran repugnantes, escribió en respuesta a «El tributo», una carta a la St. James Gazette con el título: "¿Quién escandalizaría a una de esas pequeñas?"13. Sin duda Carroll, acomodado en el seguro ambiente universitario de Oxford, no podría creer ni imaginar, que los hechos que se narraban en el artículo, eran una realidad para muchas de sus «idealizadas» niñas de las calles londinenses.

\footnotetext{
${ }^{12}$ Disección de un animal vivo. Esta tendencia se vio frenada a mediados del s. XIX con la aparición del fisiólogo francés Claude Bernard.

13 "'Whoso Shall Offend One of These Little Ones?", en St. James Gazette, 22 de julio de 1885.
} 


\subsubsection{Las niñas, sus mejores amistades.}

El coleccionismo era una de las facetas más destacables de la personalidad de Dodgson, que disfrutaba reuniendo todo tipo de objetos y libros en sus habitaciones de Oxford. Se ha buscado semejanza con el hecho de mantener numerosas amistades con niñas como si las «coleccionara».

Mantenía con niñas relaciones de amistad marcadas por el sentimiento de nostalgia hacia la inocencia y la sencillez de la infancia, su numerosa correspondencia con ellas así lo manifiesta. Algunos autores han justificado esa misma nostalgia como la causa de que sus amistades sólo duraran unos pocos años, hasta que las niñas se convertían en muchachas y para entonces Dodgson, ya no deseaba su compañía.

En una ocasión, Dodgson besó a una joven de diecisiete años acompañada por su padre. El padre no comentó nada sobre el incidente en esa ocasión pero si su madre y Dodgson al saber la edad, se horrorizó de él mismo pues pensaba que era una menor de edad, de manera que sintiéndose tremendamente avergonzado, sacó el suficiente coraje como para escribirles una carta sugiriéndoles le enviasen a la joven para fotografiarla. Morton Cohen señala que: «para él las niñas encarnaban la esencia de lo romántico, admiraba su belleza natural, apreciaba su espontaneidad, estimaba su inocencia sin límites.(...) Le encantaba hacerlas reír, inventaba juegos para jugar con ellas, las estimulaba (...) sencillamente las adoraba» ${ }^{14}$.

\footnotetext{
${ }^{14}$ COHEN, Morton N. Lewis Carroll. Barcelona: Anagrama, 1998, pág. 16.
} 
Michael Holquist considera primordial establecer que para Lewis Carroll, la palabra «niño» ${ }^{15}$ significa en realidad «niña», pero además, una niña de entre los diez y los trece años de edad, bonita, bien vestida y educada, inteligente y perteneciente a la clase media-alta.

El rechazo de Dodgson hacia una relación sexual adulta, se manifiesta en numerosos episodios de su vida. Su condición de soltero, y sus extravagantes relaciones con niñas, han ayudado a reforzar la leyenda de una homosexualidad reprimida y una desviación pedófila.

¿Podemos afirmar con seguridad que ese amor por las niñas era un síntoma de represión sexual? La polémica respecto a su sexualidad, ha dado como resultado opiniones diversas como la que nos ofrece Dijkstra, que especula respecto a la probabilidad de que Dodgson se liberara de la represión y la frustración sexual mediante el trato con niñas, con sus juegos y con las fotografías que tomaba de ellas ${ }^{16}$. Por el contrario, Morton Cohen encuentra en tales opiniones, una búsqueda de pensamientos y comportamientos «oscuros», en base a un tipo de obsesiva y fantasiosa $^{17}$ psicología más propia de la sociedad contemporánea que la del victoriano mister Dodgson.

Hacia 1960, Cohen realizó unas entrevistas a algunas ancianas señoras que en su infancia habían sido amiguitas de Mr. Dodgson, y que a pesar de no dar detalles, afirmaron siempre unánimemente que

\footnotetext{
${ }^{15}$ «Niño», child en inglés, se refiere tanto al género masculino como al femenino. Su opinión hacia los niños, en género masculino, resulta ambigua, en un escrito puntualiza sobre «el temperamento violento de los niños» y en otra ocasión escribiría: «Piensan que estoy loco por los niños. Pero no soy omnívoro como un cerdo, sino que selecciono...».

${ }^{16}$ Dijkstra considera que su fascinación por el mundo infantil era para escapar de las pasiones adultas. DIJKISTRA, Bram. Op. cit., pág. 189.

${ }^{17}$ Calhoun, Ada. The Man Who Loved Little Girls [en línea]. Austin Chronicle, 10-12-98. [ref. de 29 de marzo de 2002]. Disponible en Web: http://www.weeklywire.com/ww/10-12-98/austin_arts_ feature1.html
} 
su trato era impecable, amable, cariñoso, encantador, «más que ningún otro hombre que hubiesen conocido jamás». Es decir que Cohen no halló nada reprochable en su conducta ${ }^{18}$.

A pesar de la defensa de autores como Cohen e incluso de aquéllas que hubiesen podido argumentar una personalidad pervertida en su contra y no lo hicieron, las suposiciones respecto a la posible pedofilia han persistido, haciendo de Dodgson-Carroll un personaje enigmático. La última de las amistades infantiles de Carroll, Mrs. Shawyer, declaró una vez que «la mentalidad victoriana veía con malos ojos la asociación entre una niña de doce años con un hombre de sesenta $y$ tres» ${ }^{19}$. Probablemente esa mentalidad victoriana, no sea en el fondo más que la raíz de la mentalidad de la sociedad de masas del siglo XX y XXI, que señala Cohen ${ }^{20}$.

Sin embargo, en los últimos años y tras el Centenario de la muerte de Lewis Carroll, han salido a la luz nuevos datos que nos permiten dar una nueva visión del enigmático Lewis Carroll. Autores como Karoline Leach aseguran que la visión que se ha tenido durante el siglo XX de Lewis Carroll es distorsionada y restringida, pues está basada en las transcripciones de los manuscritos de las herederas de Charles L. Dodgson y que pasaron sus cartas y diarios a Roger Lancelyn Green, que estaban repletas de omisiones ${ }^{21}$. Muchas de esas

\footnotetext{
${ }^{18}$ Morton Cohen observa que es probable que Carroll hubiese deseado casarse con algunas de ellas. Sin embargo murió célibe. Citado en CALHOUN, Ada. Op. cit.

19 PEARSALL, Ronald. Op. cit., pág. 606.

${ }^{20}$ V. n. 13, pág. 140.

21 Se han encontrado unas 100 omisiones respecto a sus impresiones en el terreno artístico y cultural. Del material original que constaba de trece diarios, que cubrían desde 1855 hasta su muerte, han sobrevivido nueve volúmenes que fueron editados por las sobrinas de Dodgson, Violet Dodgson y Frances Menella Dodgson. Cuatro volúmenes desaparecieron tras su muerte, entre los años 1898 y 1932. Por otro lado hay numerosas páginas cortadas, lo que nos hace preguntarnos si fueron cortadas
} 
omisiones atañen al tipo de relación que tenía con las niñas y jóvenes ${ }^{22}$, como el hecho de que mostrase un entusiasmo por las jóvenes cantantes de opereta y bailarinas de espectáculo. Entre sus amistades infantiles, había un gran número de niñas, pero también mujeres jóvenes actrices que conocía en las sesiones teatrales a las que acudía, como la actriz de dieciséis años Isa Bowman, que llegó a ser una de sus más fieles amigas. Lo cierto es que con el paso de los años, Dodgson fue abriendo el abanico de edades femeninas con las que le agradaba entablar amistad como revela una carta a su editor MacMillan en 1877 en la que le escribe que veinte o treinta años atrás prefería a las niñas de diez años: «Ahora veinte o veinticinco años, es la edad justa. Algunas de mis más queridas amigas tienen treinta o más» ${ }^{23}$. Al respecto también escribiría en 1879 una carta a Mrs. Poole, diciendo que «las niñas eran un mundo delicioso, pero que debía confesar que las que están más crecidas eran más interesantes» ${ }^{24}$. Incluso se corrieron rumores en Oxford durante una temporada de una supuesta relación con la niñera de las hijas del deán Liddell, que jamás se confirmó. Con casi sesenta años, Dodgson afirmaría que su sentimiento romántico ya había muerto y que un hombre de su edad aceptaba la visita de damas de «cualquier» edad.

por el propio Carroll o por sus herederas y que información contenía. Los diarios supervivientes fueron donados al British Museum en 1969.

22 De las 1292 cartas de Lewis Carroll publicadas en 2 volúmenes en 1979 por Morton Cohen y Roger Lancely Green, 581 son a amistades femeninas, de esas, 147 son a niñas de 1 a 13 años de edad, 184 a chicas o jóvenes de entre 14 y 19 años, y 250 a mujeres mayores de 20 años (quedan excluidas las cartas a familiares, negocios o madres de niñas a menos que se demuestre que se tratasen de amistades principales antes que con las hijas). Esto implica que las cartas a niñas suponen tan sólo un $11 \%$ del total.

${ }^{23}$ COLINGWOOD, Stuart Dodgson. Op. cit., pág. 364.

${ }^{24}$ LEBAILLY, Hugues. "Charles Lutwidge Dodgson's Infatuation wih the Weaker and More Aesthetic Sex-Re-Examined" [en línea]. [ref. de 18 de febrero de 2006]. Disponible en Web: http://www.lookingforlewiscarrol.com 
Probablemente sus herederas omitieron tales pasajes con la mejor de las intenciones, en un intento por preservar una visión inocente propiamente pre-freudiana, sin embargo contribuyeron $y$ reforzaron en cierta medida la reputación de exclusivo admirador de bellezas impúberes, pervertido y pedófilo y así se le presenta en la mayor parte de sus biografías y sobretodo en Internet donde se le presenta como el «santo patrón de los pedófilos» ${ }^{25}$.

A pesar de los nuevos descubrimientos respecto a su gustos femeninos -más extensos de lo que se pensaba-, no deja de ser menos cierta la clara predilección por las niñas. No sólo evidenciado en las cartas en las que les mandaba besos y abrazos, como a Gertrude Chataway -cuando tenía 10 años-, sino en todos aquellos gestos $y$ acciones que propiciaban el encuentro y la amistad con niñas, conocidas y desconocidas.

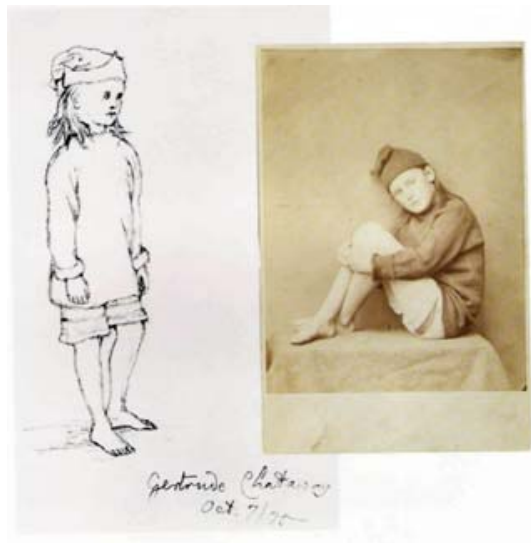

Fig. 3. Dibujo y fotografía de Annie Gertrude Chataway (1876) por Lewis Carroll, a la que le dedicó La Caza del Snark.

Como el maletín con el que viajaba siempre repleto de juguetes y curiosidades con las que entretener a las niñas que pudiera conocer, la estancia que tenía en sus habitaciones de Tom Quad, repleta de juguetes, muñecas, disfraces y cajas de música o el estudio fotográfico acristalado que se hizo construir sobre el tejado para poder realizarles fotografías con suficiente luz a cualquier hora del día y ofrecerles un lugar donde sentirse cómodas durante las sesiones fotográficas.

\footnotetext{
${ }^{25}$ LEBAILLY, Hugues. Op. cit.
} 


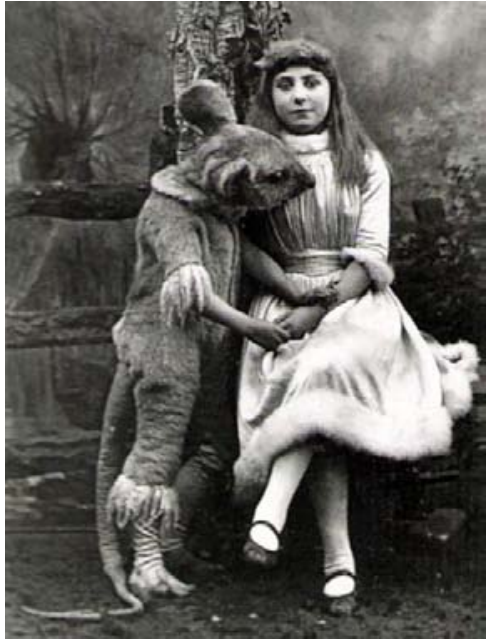

Fig. 4. Phoebe Carlo interpretando a Alicia en la adaptación teatral de Henry Savile Clarke, estrenada la Navidad de 1886.
Así pues, Mr. Dodgson se nos presenta tanto como un reprimido y un romántico, obsesionado por las niñas durante sus primeros años, como tutor de matemáticas o como «Don Juan» los últimos años de su vida, en un ir y venir de innumerables visitas femeninas a sus habitaciones de Tom Quad. Sin embargo, ninguna información desdice el hecho de que permaneció siempre célibe.

\subsubsection{Alicia en el País de las Maravillas.}

El 4 de julio de $1862^{26}$, sucedió uno de los acontecimientos cruciales en la vida de Charles Lutwidge Dodgson. Fue precisamente ése día de «tarde dorada» cuando él y las tres hermanas Liddell ${ }^{27}$ junto al Reverendo Duckworth realizaron un agradable paseo en barca por el Isis -afluente del río Támesis-, cuando Charles Dodgson contó por primera vez las aventuras de «Alicia», dedicándolas a su pequeña amiga Alice

\footnotetext{
${ }^{26}$ El 4 de julio de 1862, Dodgson escribiría en su diario: «He realizado una excursión río arriba hasta Godstowe con las tres Liddells, tomamos el té allí, en la orilla y no llegamos a Christ Church hasta las ocho y cuarto; entonces las llevé a mis habitaciones para que viesen mi colección de microfotografías y las devolvimos a la residencia del decano poco antes de las nueve». Siete meses más tarde escribiría al respecto: «en esta ocasión les conté el cuento de hadas de Aventuras Subterráneas de Alicia que me comprometí escribir para Alice».

27 William Blake Richmond realizó el triple retrato de las hermanas Liddell, Las 3 hermanas (fig. 5) en 1864. Lorina "Ina", la mayor (en el centro) tenía 15 años. Edith May (izquierda) 10 años de edad, murió en 1876. Alicia (derecha) de 12 años, la predilecta de Lewis Carroll, se convertiría en la famosa protagonista de Alicia en el País de las Maravillas.
} 
Pleasance Liddell -segunda de las tres hijas de Henry George Liddell, deán de la Christ Church y vicerrector de la Oxford University- y dando por resultado un primer escrito con el título de Aventuras Subterráneas de Alicia [Alice's Adventures Underground] ${ }^{28}$ y más tarde Alicia en el País de las Maravillas [Alice's Adventures in Wonderland] ${ }^{29}$.

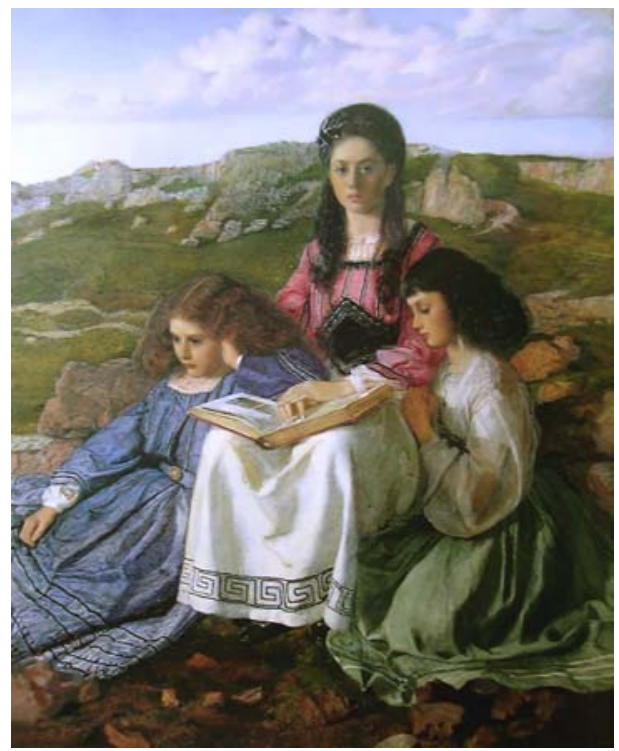

Fig. 5. Las 3 hermanas (1864) por William Blake Richmond.

Carroll conoció a Alice Liddell en 1856, cuando se encontraba buscando modelos para fotografiar. La niña era vecina suya en Christ Church desde 1855 y por aquel entonces contaba con tan sólo cuatro años de edad. No fue hasta 1857 que Carroll hiciese referencia en sus diarios sobre ella por su nombre propio, con motivo de su quinto cumpleaños en el que le hizo un regalo.

\footnotetext{
${ }^{28}$ El relato manuscrito se lo entregó a Alice como regalo de Navidad el 26 de noviembre de 1864 .

${ }^{29}$ Alicia en el País de las Maravillas [Alice's Adventures in Wonderland] se publicó por primera vez con MacMillan el 4 de julio de 1865, aniversario de la famosa excursión en barca de 1862. Las ilustraciones las realizó John Tenniel.
} 
La complicidad de Carroll con las niñas Liddell llegaba a extremos de familiaridad que difícilmente entenderíamos si no fuese por la abundante información que disponemos. Se trataba de un círculo pequeño y reducido en el que fácilmente se reconocían a sí mismas en las historias que inventaba. Así Carroll ubica a sus tres amigas como personajes de Alicia en el País de las Maravillas. Llamaba a Alice con el nombre de «Secunda» y también hace referencia a ella mediante Alicia, la protagonista; Edith como «Tertia» y en el personaje del aguilucho, Eaglet-; Lorina como «Prima $»^{30}$ y con el loro, -Lory-; o a el mismo Dodgson como el Dodo, por su apellido que a menudo pronunciaba «DoDo-Dodgson» debido a su tartamudez.

Alice Liddell ha sido considerada por muchos como la musa inspiradora de Carroll así como su amor romántico. En el verano de 1863, Dodgson y la familia Liddell rompieron su amistad, sin que conozcamos las causa de tal ruptura. Se ha apuntado a que la causa de la misma fuese que Dodgson pidiese a Alice Liddell en matrimonio ${ }^{31}$, que entonces contaba con unos once años, aunque otros creen más probable que lo hiciera a su hermana mayor Lorina ${ }^{32}$, que por aquel

\footnotetext{
${ }^{30}$ Prima, Secunda y Tertia, remarcando el orden de edad de las tres hermanas Liddell.

${ }^{31}$ Morton Cohen y Martín Gardner entre otros, han especulado sobre tal posibilidad pero no de que se tratase de una petición formal sino como una sugerencia, confiando en que en el futuro «si la amistad con Alice o incluso con cualquiera de las hijas de los Liddell prosperase en un sentimiento mayor, podría tal vez esperar ser correspondido...». Tales especulaciones nacen de algunas afirmaciones y rumores como el de la Sra. Margaret Woods, hija de George Grandville Bradley, amigo de Charles, que escribió: «Cuando la Alicia del cuento creció hasta convertirse en una encantadora jovencita, él pidió permiso al padre de ella, a la vieja usanza para cortejarla»; o de los comentarios escritos de Lord Salisbury a Lady John Manners el 25 de agosto de 1878: «se dice que Dodgson casi ha perdido el juicio como consecuencia de haber sido rechazado por la verdadera Alice (Liddell). Eso parece». En "Oxford in Seventies". Fortnightly Review, no 150, 1941, págs. 276-282 y Hatfield House. MSS 3M/D XIII/101, citados por COHEN, Morton N. Op. cit., pág. 137.

32 En agosto de 1862, un mes más tarde de la famosa «tarde», Dodgson escribe en sus diarios que Ina probablemente ya no podría reunirse junto a él y sus hermanas por mucho más tiempo, pues ya estaba demasiado crecida para estar a solas junto a un hombre adulto, según las convenciones sociales. Así el
} 
entonces contaba con 14 años, una edad mucho más acorde con la mayoría de edad legal de la época que todavía era entonces a los doce años, o que utilizaba a las niñas incluso para cortejar a la institutriz de las niñas, como se rumoreó durante un tiempo incluso por parte de la señora Liddell. Sin embargo no tenemos ningún dato fehaciente que así lo atestigüe firmemente pues, las páginas de sus diarios que se refieren a esa época, están arrancadas o resultan ambiguamente esclarecedoras $^{33}$. La señora Liddell, ya mostró su hostilidad hacia la amistad de las niñas con Mr. Dodgson desde 1856 y en 1864 les prohibió definitivamente las excursiones en común, así como que destruyera todas las cartas que Dodgson escribiera a Alice.

Tras su ruptura con los Liddell, Dodgson apenas tuvo trato con Alice, produciéndose un distanciamiento. En 1865 se refiere a ella, que ya tenía doce años, diciendo: «Alice parece notablemente cambiada, aunque harto dudoso que sea para mejor. Probablemente está entrado en la fase de la pubertad». Como se ha comprobado, es más que probable que el interés de Dodgson por Alice Liddell se limitara a una encantadora y emotiva amistad infantil que a un verdadero deseo sexual o de compromiso matrimonial. Aunque años más tarde, cuando Alice ya

17 de abril de 1863, Dodgson escribe respecto a una visita que hiciera a Ina, en la que comenta lo «alta que está» y señala que era la primera vez que Mrs. Liddell insistió en que llevara carabina.

${ }^{33}$ Las páginas que debieran dar causa de su ruptura fueron arrancadas, así como los diarios que van del 18 de abril de 1858 al 8 de mayo de 1862. Karoline Leach, autora de una de las últimas revisiones biográficas de Lewis Carroll, escudriñando en los archivos de Guilford (el archivo familiar de Dodgson), encontró un pedazo de papel supuestamente revelador que podría hacer referencia a las causas por las que Dodgson rompió con la familia Liddell durante el verano de 1863. Los archivos de Guilford sugieren causas bien distintas. El sumario que corresponde al vol. 8 que está perdido (en concreto a las fechas del 27 y 29 de junio de 1863), se dice que Charles sabe que la señora Liddell piensa que él utilizaba a las niñas para cortejar a la institutriz de las niñas, Miss Prickett, e incluso que corteja a Ina. Independientemente de si esto era cierto o no, las sospechas de la señora Liddell sin duda debieron resultarle verdaderamente molestas. Respecto al rumor escribiría: «... para proteger a la señorita Prickett de ulteriores situaciones embarazosas, no prestaré en el futuro más atención a las niñas en público a no ser que surja una ocasión que no deje ningún lugar a dudas». 
era la Sra. Hardgraves, Charles le confesaría en una carta fechada el 1 de marzo de 1885, que ella había sido su «amiga ideal» ${ }^{34}$, describiéndola como su inspiración. La huella de su primera amiguita no dejaría de hacer sombra a muchas y muy buenas amistades posteriores, como afirma Morton Cohen, «la preciada imagen de la verdadera Alicia, nunca dejó de existir en el recuerdo de Charles ni de provocarle angustia por su pérdida» ${ }^{35}$.

Alicia $^{36}$ y Alice Liddell se funden y confunden en una doble personalidad tanto en las fotografías como en los escritos de Carroll, con el mismo juego de doble personalidad entre Charles Dodgson y su alter ego Lewis Carroll. Pero, tal vez, hacer una diferencia entre ambas personalidades, como hacen algunos estudiosos como Dereck Hudson, quizás sea un error. Antes que considerarlo como un Dr. Jeckyll y un Mr. Hyde, sería más conveniente, entenderlo en sentido global, como un hombre del Renacimiento ${ }^{37}$.

Alicia en el País de las Maravillas es una de las obras más interpretadas por el psicoanálisis freudiano, dando por resultado significados singulares $y$ explicaciones extravagantes completamente ligados al erotismo y al sexo, como la afirmación de William Empson de que Alicia representa una batalla entre lo carnal y lo intelectual o que Alicia trata del parto de una mujer, o como el pasaje en el que Alicia corre tras el conejo blanco y al caer por el agujero, le parece muy

\footnotetext{
${ }^{34}$ También lo escribiría Carroll en su diario en otra ocasión: «La imagen en mi corazón de aquella que fue mi ideal amiga-niña a través de tantos años, está más clara que nunca. Desde aquella época he tenido docenas de amigas-niñas, pero con ellas todo ha sido diferente».

${ }^{35}$ COHEN, Morton N. Op. cit., pág. 602.

36 «Alicia», hace referencia al personaje de Alicia en el País de las Maravillas, «Alice» es Alice Liddell.

37 Carlos Miquel Sánchez-Rodrigo, entra en desacuerdo respecto a las consideraciones que establecen dos personalidades diferenciadas entre Charles Dodgson y Lewis Carroll. Prólogo para El paraguas de la rectoría. Cajón de Sastre. (Ed., trad. y notas de Carlos Miguel Sánchez-Rodrigo). Barcelona: Parsifal Ediciones, 1998.
} 
profundo, lo que Goldschmidt define como «lo más parecido al símbolo coital» ${ }^{38}$ sugiriendo el deseo de Carroll por practicar el coito y para rematar, que Alicia es un falo.

Pero Alice, resulta en ciertas ocasiones una amistad y una modelo casi perversa, por la que Carroll se sentía profundamente subyugado. Un cierto descaro ante la cámara, en la compañía de Mr. Dodgson $^{39}$. En los libros de Alicia, se revelan ciertos deseos sádicos de los niños, algo que ciertamente ocurre en las versiones más antiguas y originales de numerosos cuentos infantiles. En Alicia en el País de las Maravillas, Alicia es una niña educada, entre ignorante y marisabidilla que intenta seguir las normas de cortesía y las reglas sociales enseñadas por sus mayores, que prudentemente intenta poner en práctica, como cuando lee con atención la palabra BÉBEME, en un frasquito y recuerda que por imprudentes otras niñas bebieron veneno. Pero en $A$ través del espejo, su comportamiento es más descortés ${ }^{40}$. A este respecto en una carta $\mathrm{Mr}$. Dodgson se refiere a ella llamándola «Malice ${ }^{41}$, con uno de sus habituales juegos de palabras.

Alicia es como la expresión simbólica de la infancia romántica de la obra de William Blake, a la que Carroll le añade características del género de aventuras, del nonsense ${ }^{42}$ inglés y de la parodia. Carroll

\footnotetext{
${ }^{38}$ GOLDSCHMIDT, A.M.E. "Alice in Wonderland Psycho-Analyzed". The New Oxford Outlook, vol. I, no 1, may 1933, pág. 70.

39 Paul Adam afirmaba en un artículo titulado "Des Enfants" de 1895, acerca de las características eróticas y perversas de la mujer que se acentuaba en las niñas. Había observado que la niñas de entre los 8 y los 13 años, «encontraban placer perverso en observar a hombres sedentarios de mediana edad mientras se exhibían ante ellos por unos pocos peniques». ADAM, Paul. "Des Enfants". La Revue Blanche, 9, 1895, pág 350-53. V. también sobre la maldad femenina de Caesar LOMBOSO, y William FERRERO. Op. cit., n. 29, cap. 2. Sexualidad Victoriana, pág. 64.

40 MAVOR, Carol. Op. cit., pág. 8.

${ }^{41}$ Realiza un juego de palabras entre el nombre de «Alice» y la palabra inglesa «malice», malicia.

42 «Sin sentido» 0 «absurdo».
} 
escribiría: «...lo que el niño desea antes que nada es que el mundo en que vive tenga sentido...». El mundo subterráneo, representa el mundo del subconsciente humano, de la ensoñación, en ocasiones de pesadilla kafkiana y de atmósfera claustrofóbica.

Su biógrafo Morton Cohen, afirma que Alicia, es el resultado de su compromiso con la infancia, su autodisciplina, su reprimida vida emocional y su inagotable fuente de energía ${ }^{43}$.

Con la confrontación de contradicciones, Carroll/Dodgson, se ha convertido en una de las figuras más apasionantes y victimizadas del siglo XIX, no sólo por su -sin lugar a dudas- particular personalidad, sino también a través de un proceso interminable de interpretaciones, filtros, tendencias psicoanalíticas del siglo XX, que han hecho de «todo» él, de su vida y su obra, un cúmulo de sospechas bajo la sombra de la perversión, la depravación o como señala Douglas R. Nickel ${ }^{44}$, «un lobo con piel de cordero».

Los últimos años de su vida, se dedicó por completo al estudio del Cálculo y la Lógica. Moriría de pulmonía en Guilford en 1898. Alice Liddell, más tarde Mrs. Hardgraves, llegó a vivir la celebración del Centenario del nacimiento de Lewis Carroll en 1932 para la cual viajó a Nueva York.

\footnotetext{
${ }^{43}$ COHEN, Morton N. Op. cit., pág. 163.

${ }^{44}$ NICKEL, Douglas R. Dreaming in Pictures: The Photography of Lewis Carroll. San Francisco: San Francisco Museum of Modern Art. Yale University Press, 2002, pág. 110.
} 


\subsection{Las ilustraciones para su obra.}

Tras la publicación de Alicia en el País de las Maravillas, Alicia se hizo tan popular, que aparecieron numerosos productos inspirados en ella como sellos, latas, etc ${ }^{45}$.

\section{Lewis Carroll sabía bien cuales} eran las características que debían cumplir las niñas de sus ilustraciones. En aquella primera copia que escribió de Aventuras Subterráneas de Alicia, las ilustraciones las realizó el propio Carroll y terminaba con una fotografía oval de Alice Liddell, a la que dedicaba el relato.

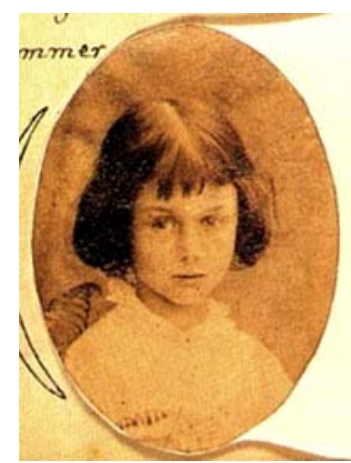

Fig. 6. Fotografía oval que aparecía en el manuscrito de Aventuras Subterráneas de Alicia.

Carroll siempre había dibujado desde que de niño ilustrara la revista de ámbito familiar El paraguas de la rectoría. Pero sus dibujos destacaban más por su ingeniosidad que por su trazo. Incluso John Ruskin llegó a reprocharle su incapacidad para el dibujo. A pesar de sus dudosas capacidades como dibujante, Morton Cohen señala respecto a sus ilustraciones de niñas, que «las dibujaba con naturalidad» ${ }^{46}$. No existe en ellas sofisticación sino una simplicidad ejecutada con cierta ingenuidad. Sin embargo, Auerbach llega a afirmar $^{47}$, que las ilustraciones de Carroll para Alicia, «emanan una sensualidad bajo una aparente pureza».

\footnotetext{
${ }^{45}$ MAVOR, Carol. Op. cit.

${ }^{46}$ COHEN, Morton N. Lewis Carroll, Photographer of Children Four Nudes Studies. New York: Clarkson N. Potter Inc., 1979, págs. 4, 30.

47 AUERBACH, Nina. Woman and the Demon: The Life of a Victorian Myth. Cambridge: Harvard University Press, 1982, pág. 167.
} 

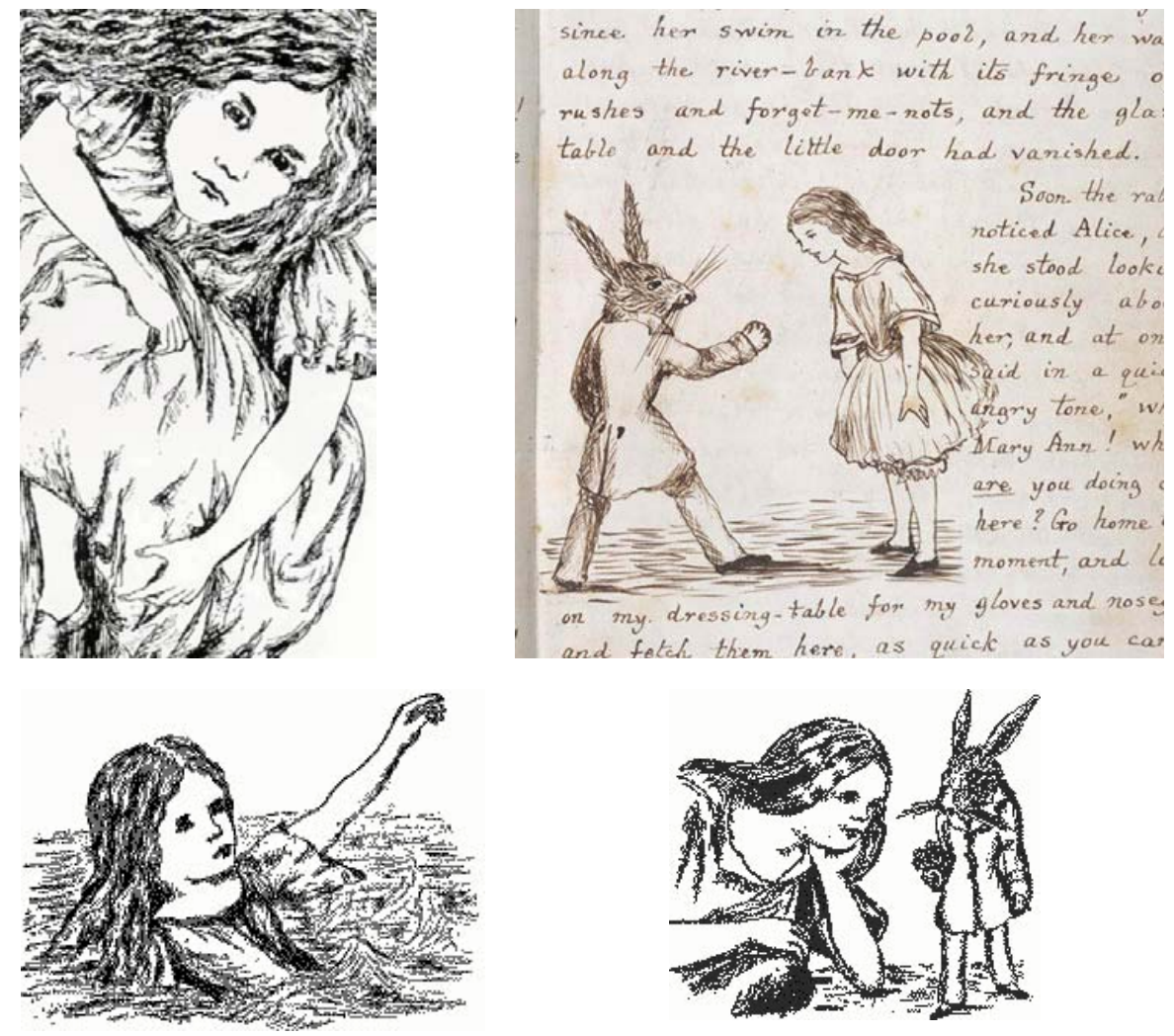

Fig. 7, fig. 8, fig. 9 y fig. 10. Ilustraciones de Lewis Carroll para el manuscrito de Aventuras Subterráneas de Alicia.

Sir John Tenniel fue el encargado de ilustrar la primera edición de Alicia en el País de las Maravillas y más tarde $A$ través del espejo. Aunque era un conocido ilustrador antes de que Carroll le encargase sus ilustraciones, su trabajo es básicamente conocido por los libros de Alicia.

La intención de Carroll era ilustrar él mismo el libro, como hiciera con el manuscrito de Aventuras Subterráneas de Alicia, pero tras la insistencia de John Ruskin, dejó la ilustración en manos de Tenniel, resultando el libro con las ilustraciones de Tenniel un rotundo éxito. 
Lo más probable es que la niña Alice Liddell tuviese su importancia únicamente en el hecho de ser ella la que dio su nombre a la protagonista y por ser la precursora de que Carroll se tomara el interés por escribir el relato que contara en la excursión en barca. Lo cierto es que ni las ilustraciones que Carroll realizara para la versión manuscrita, ni las que realizara Tenniel, se corresponden con el físico de Alice Liddell. De hecho, se sabe que Tenniel se basó en unas fotografías que le mandara Carroll de otra de sus modelos, May Hilton Badcock.
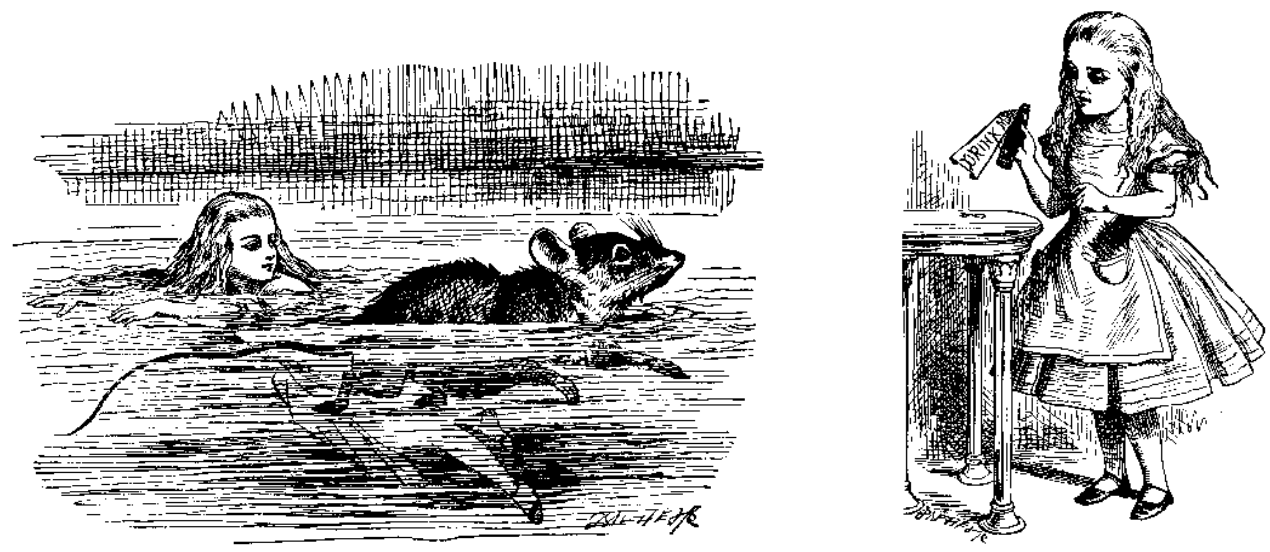

Fig. 11 y fig. 12. Ilustraciones de John Tenniel para Alicia en el País de las Maravillas.
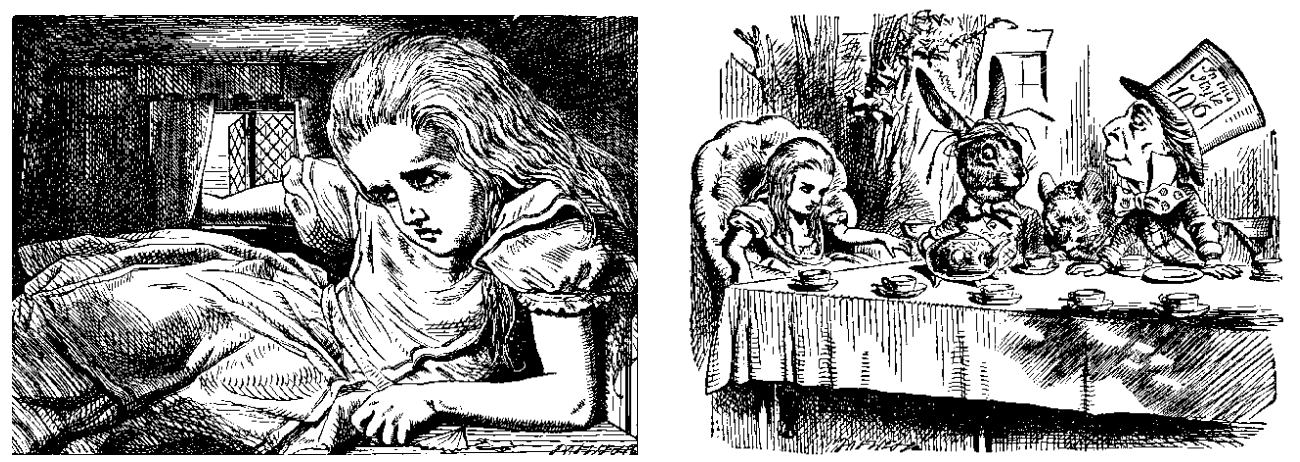

Fig. 13 y fig. 14. Ilustraciones de John Tenniel para Alicia en el País de las Maravillas. 

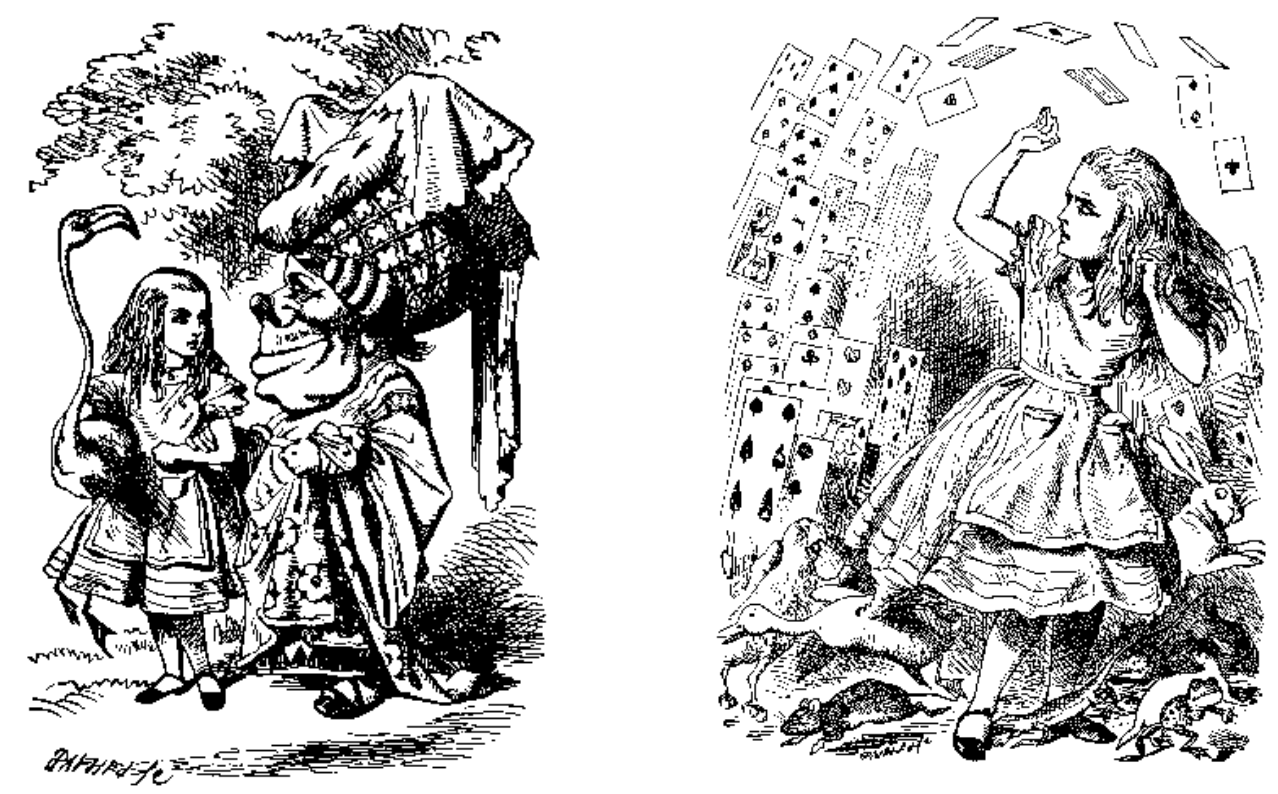

Fig. 15 y fig. 16. Ilustraciones de John Tenniel para Alicia en el País de las Maravillas.

Su relación con Tenniel aunque cortés resultó ciertamente incómoda. Carroll hacía un seguimiento constante de las ilustraciones de Tenniel, haciendo sugerencias e incluso mandando su propios dibujos para que los tomara como referente ${ }^{48}$. Carroll se quejaba de que Tenniel no había conseguido reproducir lo que él imaginaba. Durante su realización, Carroll sostuvo diversas discusiones con su editor Macmillan y con Tenniel al que a menudo se le presenta como la víctima de las exigencias de Carroll.

\footnotetext{
${ }^{48}$ En una carta a Tomas Taylor, Carroll escribiría: «Si (el Sr. Tenniel) ... estuviese dispuesto a encargarse (de las ilustraciones) ..., le enviaría el manuscrito para que le echara un vistazo, no para que se ajuste en todo a mis dibujos, sino simplemente para darle una idea del tipo de cosa que quiero». Fechada el 20 de diciembre de 1863.
} 
Para A través del espejo, Alicia adquirió un aspecto más delicado. Seguía llevando el cabello largo y rubio pero adornado con una cinta negra alrededor de la cabeza.
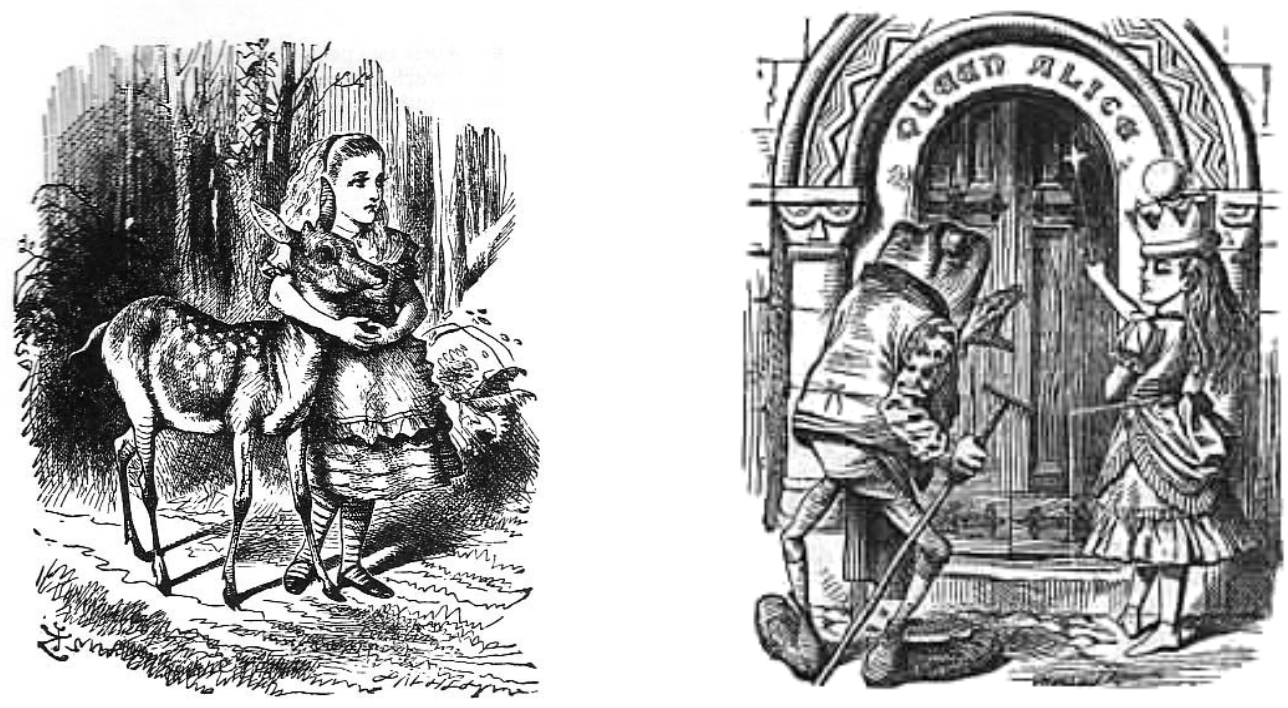

Fig. 17 y fig. 18. Ilustración de John Tenniel para A través del espejo.

Al parecer Carroll comentaría al ilustrador Harry Furniss, que no le agradaba ninguno de los personajes creados por Tenniel a excepción de Humpty Dumpty. Furniss afirmaba que Tenniel, se habría negado en rotundo a volver a ilustrar ninguna historia de Carroll, tras realizar sus ilustraciones para $A$ través del espejo. Su relación con los ilustradores de sus obras nunca resulto fácil. Lo cierto es que Furniss tampoco sostuvo un trato cómodo con Carroll que lo calificaba de «insufrible», como: «una persona aguda, un caballero pelmazo y un egoísta» ${ }^{49}$. No es menos cierto que Carroll abrumaba con sus sugerencias y que a menudo resultaba inflexible con los detalles, sin embargo, de la poca correspondencia que se conserva de su colaboración para Silvia y

\footnotetext{
${ }^{49}$ FURNISS, Harry. The confessions of a caricaturist. vol. 2. Toronto: W. Briggs, 1902.
} 
Bruno, y de otros cartas, se revela a un Harry Furniss de carácter tumultuoso e impulsivo frente a un Lewis Carroll, paciente y amable tanto con Furniss como con Tenniel. Carroll, no dudaba en alabar los trabajos de sus colaboradores cuando encontraba unos buenos resultados e incluso llegaría a pagar de su propio bolsillo los gastos de una nueva tirada de Alicia en el País de las Maravillas, tras la $1^{\text {a }}$ edición, pues Tenniel había protestado insistentemente por la mala impresión de sus ilustraciones.

Arthur Rackman (1867-1939), realizaría décadas más tarde, nuevas ilustraciones para los libros de Alicia. Son acuarela en tonos grises y sepias enfatizando en las líneas del dibujo. Sin duda, las ilustraciones de Tenniel le eran muy conocidas pero su estilo responde más al gusto de la ilustración de los libros de hadas de principios del siglo XX. Alicia ya no es una niña victoriana con miriñaque, ni tampoco está idealizada como si fuera un ángel, sino que su aspecto es el de una niña bonita, esbelta, con un sencillo vestido estampado y con un par de medias negras.
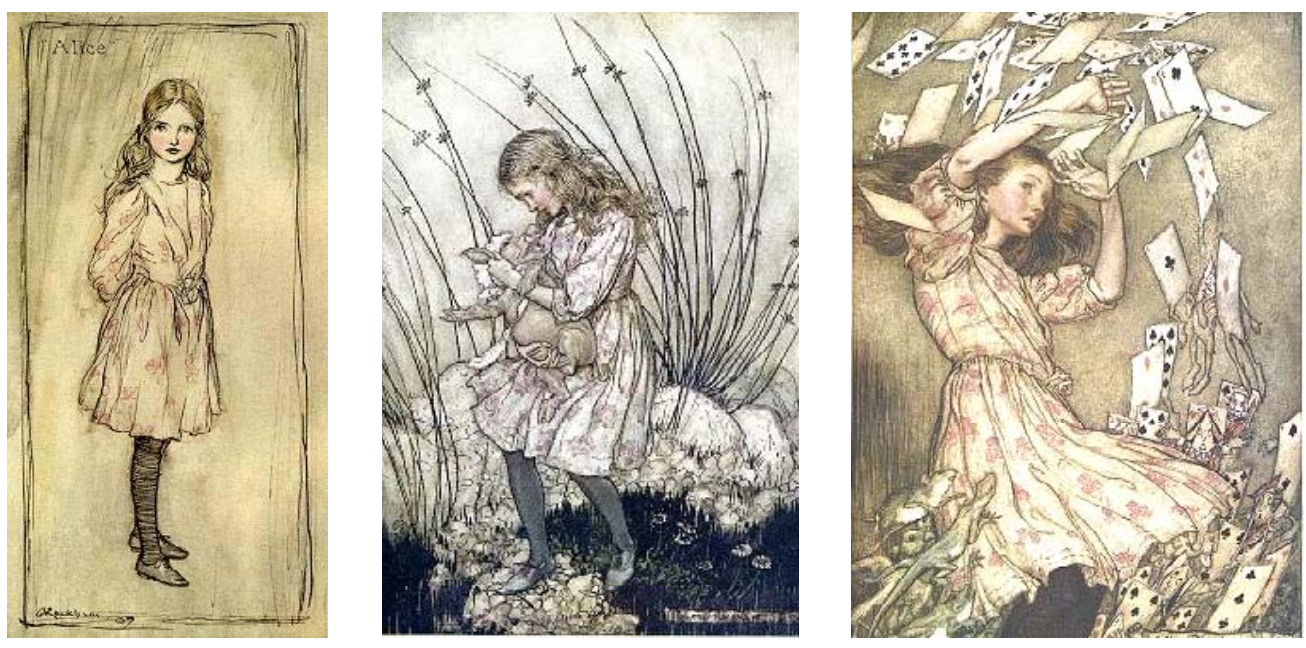

Fig. 19, fig. 20 y fig. 21. Ilustraciones de Arthur Rackman para Alicia en el País de las Maravillas. 
Cuando a Harry Furniss le encargaron las ilustraciones para Silvia y Bruno [Sylvie and Bruno] (1889-93), Carroll le escribió una carta, en la que explicaba que Silvia y Bruno, no son hadas en sentido estricto, ni tampoco niños. «Estoy encantado con su idea de vestirla de "blanco": se ajusta perfectamente a la idea que tengo de ella; quiero que sea una especie de encarnación de la Pureza», le explicaba en una de sus cartas. No debían tener «alas» y deberían vestir con ropas normales, «como cualquier niño londinense» ${ }^{50}$. Así que Carroll, a pesar de su vaga técnica, dibujó él mismo a Silvia para mostrárselo a Furniss y añadió: «¿Ojalá me atreviera a prescindir de toda ropa; las niñas desnudas son perfectamente puras y adorables, pero Mrs. Grundy se enfurecería, nunca podrá ser». Silvia, debía de vestirse como una encarnación de la pureza y para ello el vestuario más adecuado sería un vestido blanco e incluso transparente. La carta proseguía dando detalles de cómo debían ser las piernas, los pies y cómo detestaba los tacones altos ${ }^{51}$.

Con sus indicaciones, a menudo caía en la contradicción. Carroll describe una escena de esta manera: «Silvia estaba reclinada, con su codo hundido en el musgo y la sonrosada mejilla apoyada en la palma de la mano y Bruno estaba tumbado a sus pies con la cabeza en su regazo». Esta escena es imposible pues si Bruno está tumbado a los pies de Silvia, su cabeza no puede estar en su regazo. Furniss resolvió la escena ignorando parcialmente la descripción de Carroll. En otra descripción, Silvia debe medir ocho cabezas de altura respecto a una liebre muerta, sin embargo la ilustración primera que Furniss realizara medía unas seis cabezas, que más tarde solucionó.

${ }^{50}$ PEARSALL, Ronald. Op. cit., pág. 431.

${ }^{51}$ Ibíd. Lo recoge Harry FURNISS. Op. cit. 

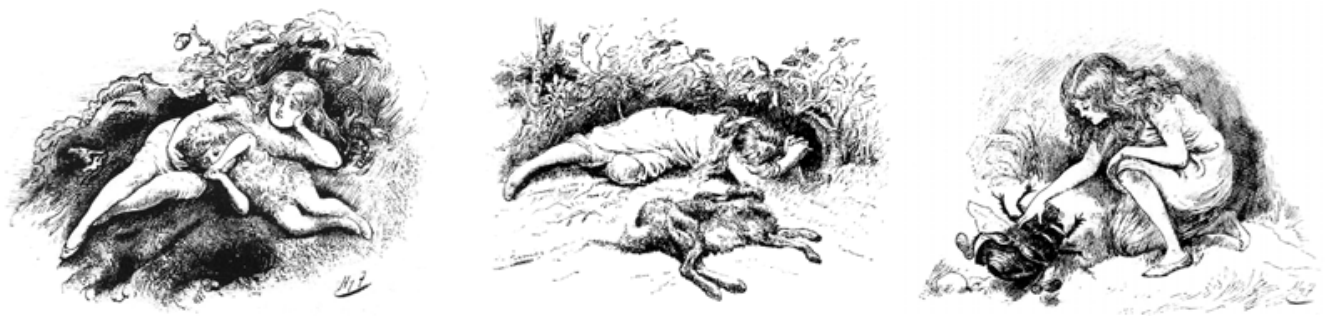

Fig. 22, fig. 23 y fig. 24. Ilustraciones de Harry Furnis para Silvia y Bruno.

Carroll controlaba al detalle el aspecto que debían de tener sus personajes, a sabiendas que el desnudo no siempre era aceptable en todos los contextos y prefería anteponer el decoro a la importancia estética, si las imágenes iban a tener una reproductibilidad masiva, como hacía notar a A. B. Frost, ilustrador de su libro de poemas ¿Rima? y ¿Razón? [Rhyme? and Reason?] (1889): «me gustaría que el Cupido estuviera cubierto -una túnica le iría muy bien-, pues si no está bastante vestido, los críticos se echarán sobre mi enseguida. Su "rostro" debería de ser, si es posible, un retrato de la pequeña Sallie Sinclair (...) mi ideal de belleza es una chica de 12 años» ${ }^{52}$.

Las ilustraciones para su libro de versos póstumos Tres atardeceres $y$ otros poemas [Three Sunsets and Other Poems] (1898), fueron realizados por Gertrude Thomson. En Tres atardeceres se cuenta la historia de un anciano que rememora un amor de juventud no correspondido. En esta ocasión las hadas, a diferencia de Silvia en Silvia y Bruno, no debían de llevar vestido alguno, es decir que debían aparecer desnudas.

${ }^{52}$ COHEN, Morton N. Op. cit., pág. 284. 

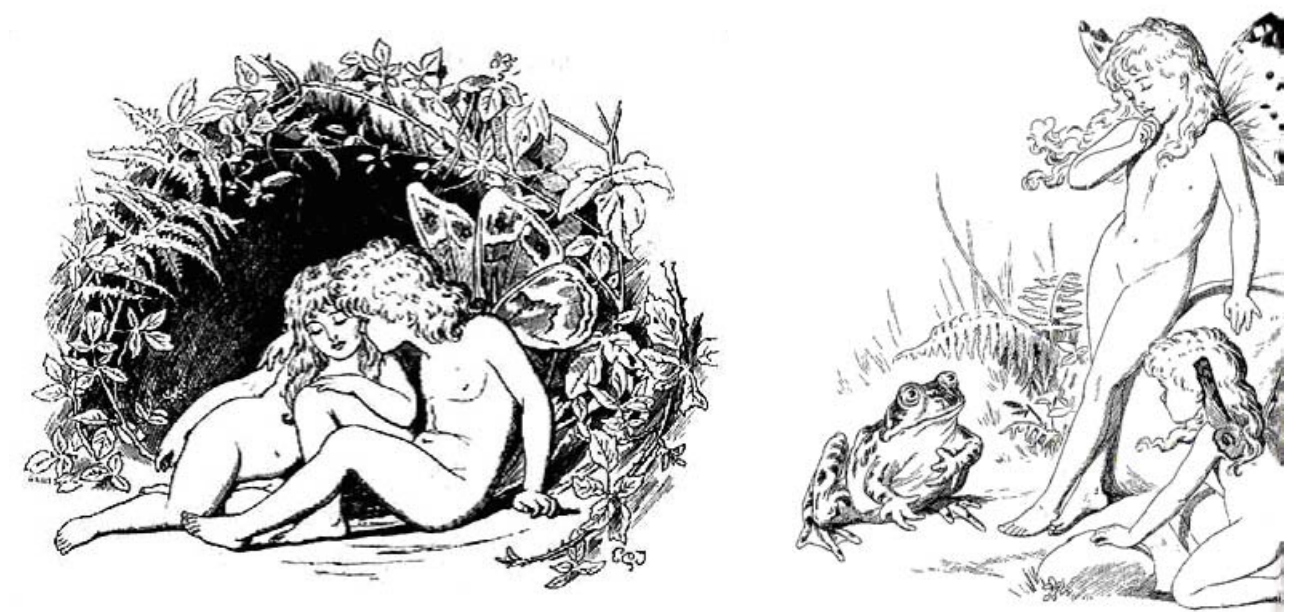

Fig. 25, fig. 26. Ilustraciones de Gertrude Thomson para Tres atardeceres (1898).

En sus libros de Alicia, así como en Silvia y Bruno, Lewis Carroll sostiene su visión sobre la naturaleza infantil según la concepción romántica de Coleridge, que busca perpetuar la inocencia el mayor tiempo posible, así como la indefensión de los niños, víctimas de la brutalidad del mundo adulto, sin embargo, él no identificaría jamás a sus personajes con niñas de clase baja, sino de clase alta. A pesar de ello, su concepción romántica sobre las niñas era menos sentimentalizada que la de sus contemporáneos y entraba en contradicción con lo que otros autores mostraban en sus representaciones endulzadas. Por ello, la idealización de las niñas en formas angelicales de Furniss o las afectadas niñitas de Gertrude Thomson, no acabaron jamás de complacer las exigentes expectativas de Lewis Carroll. 


\subsection{Fotografías de niñas.}

Hasta mediados del siglo XX, se desconocía la faceta fotográfica de Lewis Carroll. Fue el historiógrafo de fotografía Helmunt Gernsheim, quién en 1949, identificó a Lewis Carroll como el autor de un álbum de un fotógrafo victoriano amateur ${ }^{53}$.

Entre sus casi 3000 negativos -que realizó durante unos 24 años-, nos encontramos un género, el del retrato infantil, el de las niñas, para las cuales únicamente escribía, fotografiaba y dedicaba su vida. «La muerte y la resurrección más allá de lo real, la detención del tiempo, la infinita prolongación del tiempo, la presencia de lo ausente, la ausencia de lo presente, todas las paradojas las vivió una y mil veces al hacer sus fotos» ${ }^{54}$, escribiría Brassaï sobre la fotografía de Lewis Carroll.

Si para los pintores de su época el erotismo femenino se hallaba en la palidez, en la fragilidad y en la mirada enigmática, en Carroll este estereotipo se transforma en la apariencia la infancia femenina, en las niñas. Su ideal de belleza inscrito en el ideal romántico de infancia está en una pureza terrenal, sin mancha y libre de pecado. Las «niñas» confesó- «eran tres cuartas partes de su vida» ${ }^{55}$ y como si de un poema sobre la infancia femenina, Carroll realizaría ${ }^{56}$ un listado de 107 niñas por su nombre cristiano ordenado alfabéticamente: «Alices, Agneses, Beatrices,...», incluyendo en algunos casos la fecha de nacimiento.

\footnotetext{
${ }^{53}$ A su muerte (1898), dejó 33 álbumes de los que sólo 12 de ellos contenían fotografías. Contienen una 700 fotografías de las que sólo se han publicado unas 100 .

${ }^{54}$ Introducción de Brassaï en CARROLL, Lewis; BRASSAÏ. Niñas. cartas y fotografías. Estudio preliminar de Brassaï. Pocas Palabras. Barcelona: Lumen, 1998, pág. 14.

${ }^{55}$ COVENEY, Peter. The Image of Childhood. The Individual and Society: a Study of the Theme in English Literature. London: Penguin Books, 1967, pág. 242-3.

${ }^{56}$ El listado lo realizó el 25 de marzo de 1863.
} 
El mundo infantil es un mundo aparte, diferente al de los adultos, ni siquiera lo comparten con la sociedad. Susan Sontang, describiría su fotografía como una «extremada obsesión privada» ${ }^{57}$. Mediante la cámara, entramos en el mundo «oculto» de las niñas, como Alicia lo hace a través de la madriguera del conejo blanco al mundo subterráneo. Independientemente de las patologías que pudiera tener Lewis Carroll, su fotografía es exponencialmente fundamental para entender el erotismo infantil. Entender la fotografía de Carroll es entender su visión creadora y la de sus contemporáneos victorianos, de manera diferenciada a como la interpretamos un siglo más tarde.

\subsubsection{Las niñas como protagonistas.}

A menudo, Lewis Carroll tomaba como modelos a las hijas de sus amigos más allegados ${ }^{58}$, incluyéndolos a ellos incluso en las propias fotografías como en Arthur Hughes y su hija Agnes de 1863. Al igual que en otras ocasiones, el muro de piedra de un jardín sería el elemento escenográfico primordial. Parece más el resultado de un idea tejida entre dos colegiales, Mr. Dodgson y Mr. Hughes, que habiendo especulado y fantaseado con la visión idílica entre padre e hija, hubiesen tratado de plasmarla en el placa fotográfica. A pesar del abrazo cariñoso y protector de Arthur Hughes a su hija, ésta se nos muestra con gesto obligado o de disconformidad, de pie sobre el banco, parcialmente apoyada sobre su padre pero con el tronco erguido, prefiriendo tal vez juguetear en el jardincillo a ser la muñeca de unos hombres de mediana edad.

${ }^{57}$ SONTANG, Susan. Sobre la fotografía. Barcelona: Edhasa, 1996.

${ }^{58}$ Siempre realizó las fotografías bajo el consentimiento de sus padres, incluidos por supuesto los desnudos. 


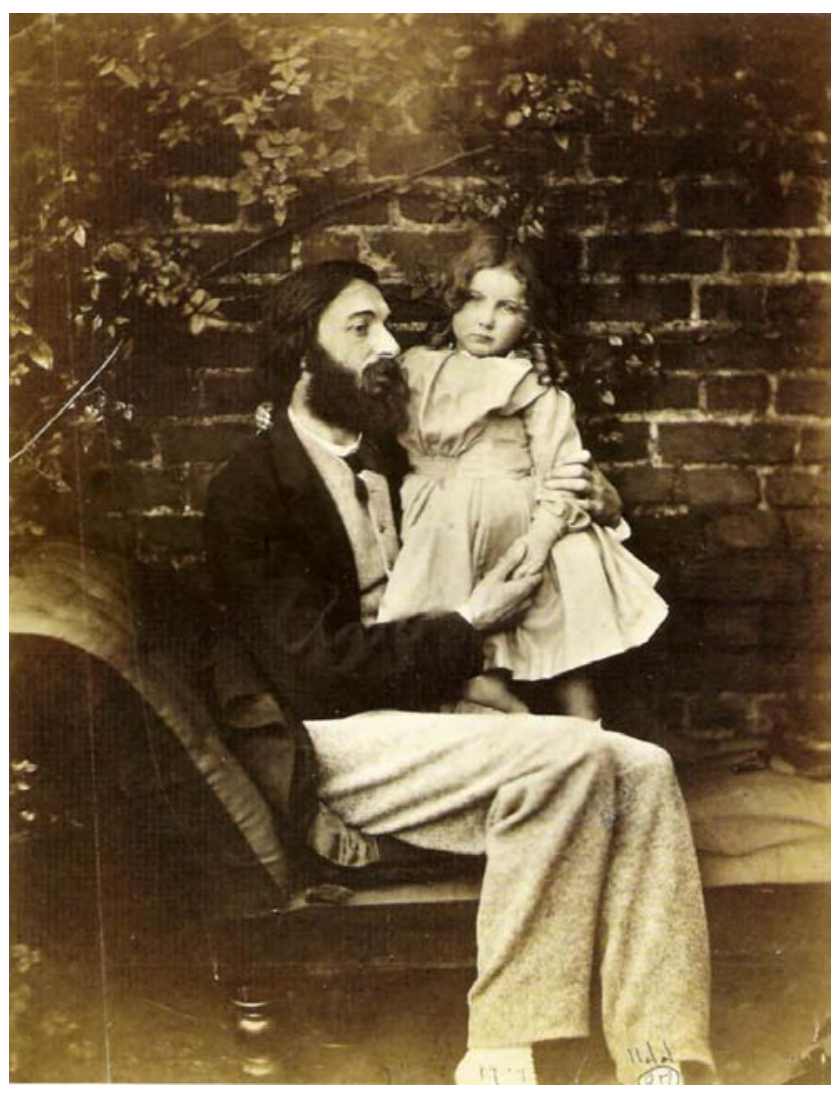

Fig. 27. Arthur Hughes y su hija Agnes (12 de octubre de 1863).

Se ha considerado que el carácter reprimido de los victorianos permitía poder llevar una vida clerical, como era el caso de Mr. Dodgson con una actividad fotográfica enfocada a la temática de las niñas, llevando una conciencia limpia y sin remordimientos: «los padres victorianos compartían la visión de Carroll y permitían a sus inocentes vástagos juguetear en el cálido clima sin ropa alguna, en particular en la costa, además estaban acostumbrados a ver desnudos infantiles asexuados, como en los objetos de decoración, en libros ilustrados y 
tarjetas de felicitación ${ }^{59}$. A este respecto Morton Cohen afirma que «sólo un ser humano reprimido, podría haber vivido esa paradójica vida y trabajado con niñas con una clara conciencia cristiana» ${ }^{60}$.

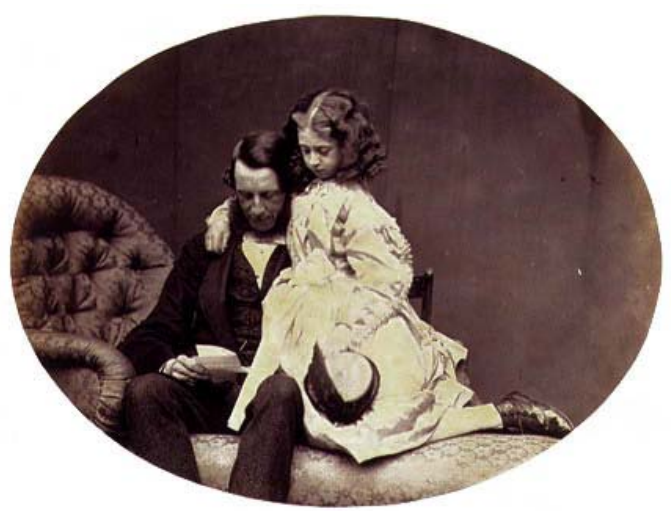

Fig. 28. Reverendo R. Gandell and Florence (1862).

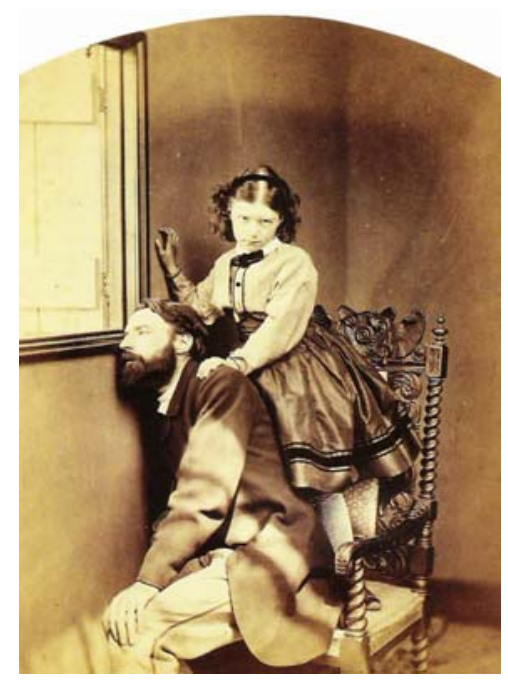

Fig. 39. Barker y su hija May (6 de junio, 1864).

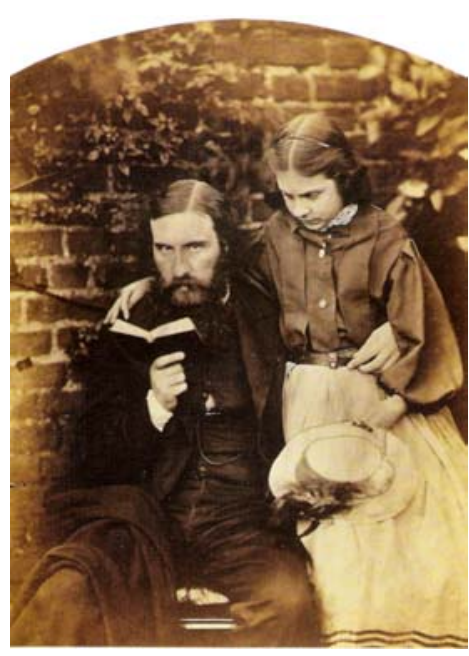

Fig. 30. El novelista George MacDonald y su hija Lilia "Lily" en Kengsington (Octubre 14, 1863).

\footnotetext{
59 COHEN, Morton N. Lewis Carroll, Photographer of Children Four Nudes Studies. Op. cit, págs. 6-7, citado a su vez por MAVOR, Carol. Pleasures Taken. Performances of Sexuality and Loss in Victorian Photography. Op. cit., pág. 9.

${ }^{60}$ COHEN, Morton N. Lewis Carroll, Photographer of Children Four Nudes Studies. Op. cit,. pág. 5.
} 
Se ha argumentado que existía una «naturalidad» hacia el desnudo infantil, sin embargo esa visión asexuada, difiere bastante de los resultados inequívocamente eróticos de muchas de las representaciones de la preadolescente. A este respecto Carol Mavor se pregunta si no existe una gran diferencia entre el desnudo infantil en las playas -como un gesto de incipiente vida naturista, influencia de los países del norte de Europa- y «sentarse delante de la cámara de un hombre en su estudio» ${ }^{61}$.

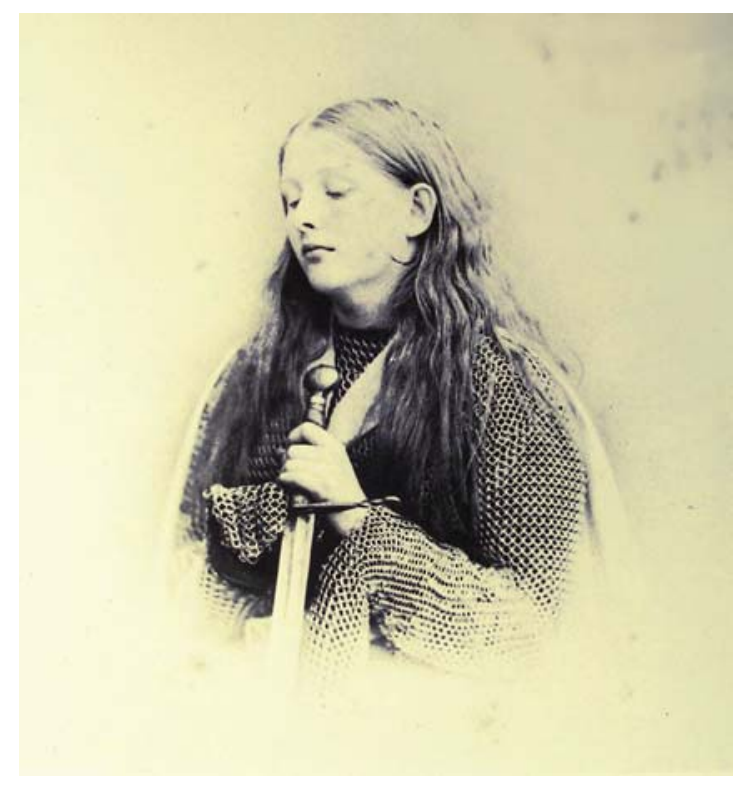

Fig. 31. Phoebe "Effie"Newall (1871).

A pesar de la influencia prerrafaelista y el medievalismo, la preadolescente en la fotografía de Lewis Carroll, es más cercana al retrato infantil de las obras de Charles Dickens que al ideal romántico de Alfred Lord Tennyson con temas y personajes literarios o de la tradición popular. En el caso del retrato de Phoebe "Effie" Newall (1871) se la representa disfrazada con una cota de malla metálica, como si de una

${ }^{61}$ MAVOR, Carol. Op. cit., pág. 9. 
asexuada virgen Juana de Arco se tratase, agarrando con una mano la empuñadura, con la otra el filo de la espada, tal vez encomendándose a Dios antes de la batalla.

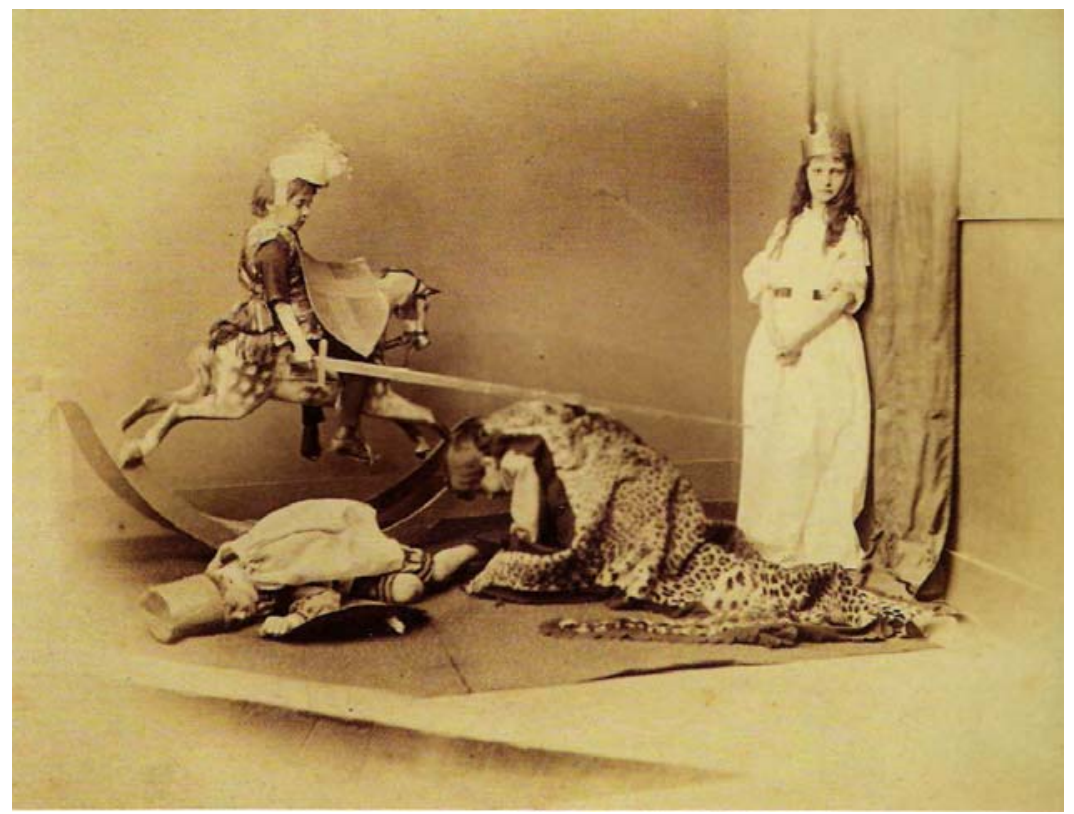

Fig. 32. San Jorge y el Dragón (c. 1874).

La fotografía de niñas de Carroll trascienden la teatralidad representada y nos permite observar más allá de la sesión de estudio fotográfico, introduciéndonos en la complicidad entre el fotógrafo y su modelo durante una tarde de juegos, disfraces, interpretación y hora del té. En sus fotografías se congela la mirada privada, amorosa y humana del tímido profesor ${ }^{62}$. Ciertamente su escenografía resulta amateur al comparar con las elaboradas composiciones de Julia Margaret Cameron o de otros fotógrafos victorianos ${ }^{63}$ como las de su admirado Oscar G. Rejlander, sin embargo, Carroll logra mostrarnos la amistad existente en

\footnotetext{
62 OVENDEN, Graham. Op. cit., pág. 10.

${ }^{63}$ Lewis Carroll, desdeña el pictoricismo y el desenfoque de Julia Margaret Cameron, que considera poco fiel al medio, prefiere las tomas claras como las de Lady Hawarden.
} 
la intimidad con las niñas modelo de clase alta a través de una mirada completamente distinta del mundo de las niñas.

Generalmente utilizaba los disfraces, sin embargo prefería la naturalidad frente a la cámara, haciéndolas posar despeinadas y de manera excepcional desnudas ${ }^{64}$. Un observador diría que Carroll «nunca las dejaba (a las niñas) posar a su gusto y le importaba un comino que tuvieran el cabello alborotado, de hecho lo prefería» ${ }^{65}$. Es precisamente en esta simplicidad donde Carroll elabora sus mejores escenografías con elementos concretos, un espejo, una bicicleta, un diván o unos libros. En ciertas ocasiones, el pintor Henry Holiday ${ }^{66}$, realizaba dibujos de niñas que más tarde Carroll estudiaba y utilizaba para sus fotografías ${ }^{67}$. Las composiciones y la organización de las niñas frente a la cámara no eran sin embargo, fruto de la casualidad o de la naturalidad. En otras ocasiones tomaba por ejemplo pinturas que le llamaran la atención en un momento dado y las versionaba con sus propias modelos, incluso posando desnudas. Carroll controlaba las escenas y muy pocas eran fruto de la pura improvisación, como atestiguan sus propias recomendaciones a su amiga Gertrude Thomson: «Me parece que usted no sabe sujetar a una niña inquieta para fotografiarla (...) Yo la arrincono en la esquina de una habitación, si la fotografía es en posición vertical; o en el extremo de un sofá, si está echada» ${ }^{68}$. Estas referencias explican muy bien el por qué de la cantidad de escenas en las que aparecen las niñas tumbadas -Agnes Hugues o Xie, Kitchin, entre otraso de pie apoyadas prácticamente en la pared.

\footnotetext{
${ }^{64}$ OVENDEN, Graham. Op. cit., pág. 151.

65 "Lewis Carroll Interrupts a Story". Children's Newspaper. 7 de febrero de 1931.

${ }^{66}$ Henry Holiday le ilustró La caza del Snark y la primera edición de $A$ través del espejo.

67 DJKISTRA, Bram. Op.cit., pág. 189.

${ }^{68}$ Carta fechada el 2 de octubre de 1893. CARROLL, Lewis; GREEN, Roger Lancelyn (ed.) The Diaries of Lewis Carroll. 2 vols. London: Cassell, 1953.
} 


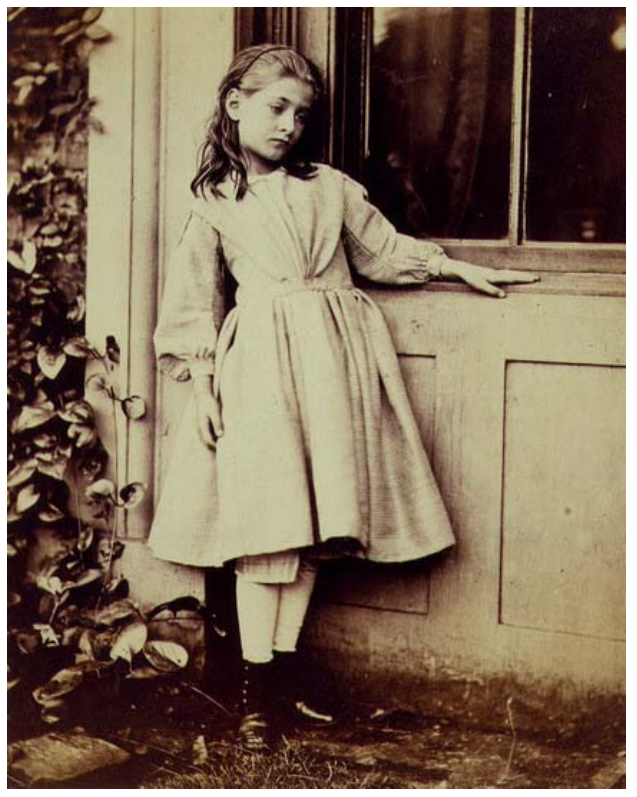

Fig. 33. Gertrude Dykes (1862).

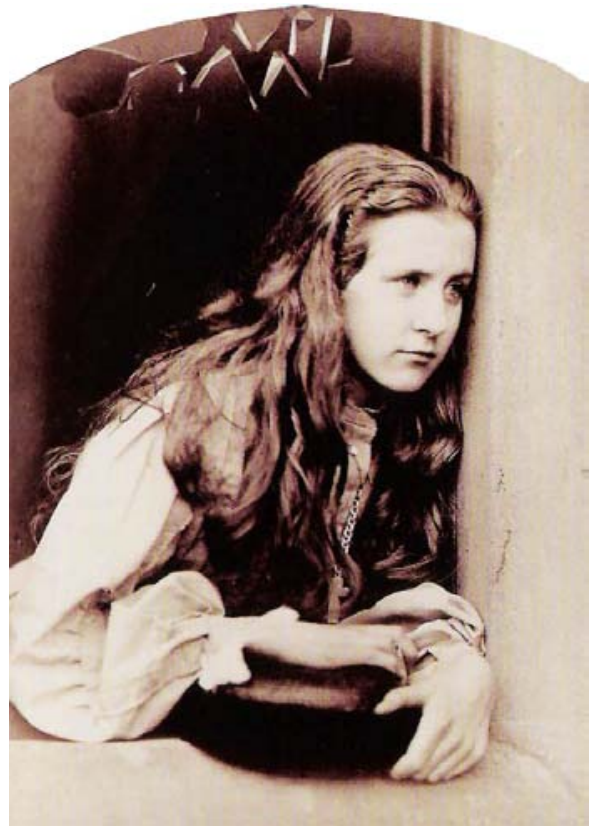

Fig. 35. Florence Bickersteth (c. 1865-66).

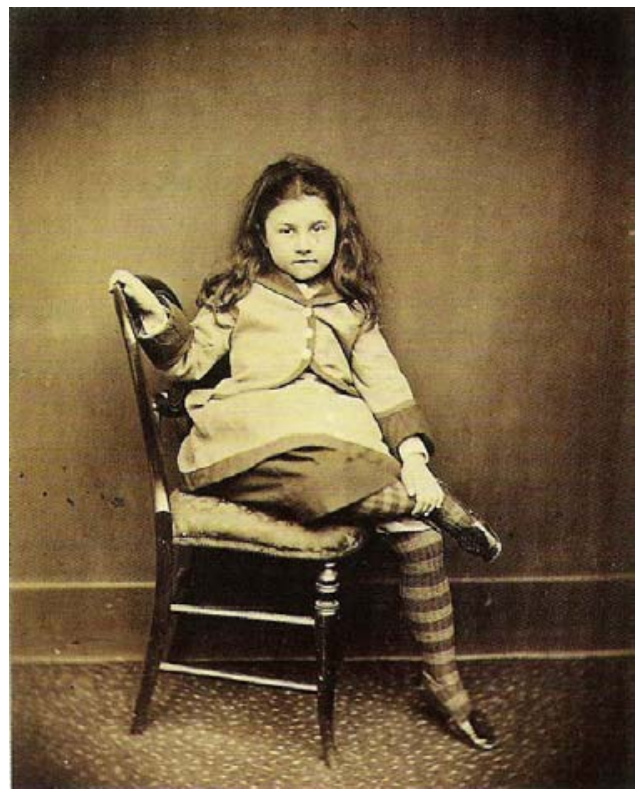

Fig. 34. Beatrice Hatch (24 de marzo, 1874).

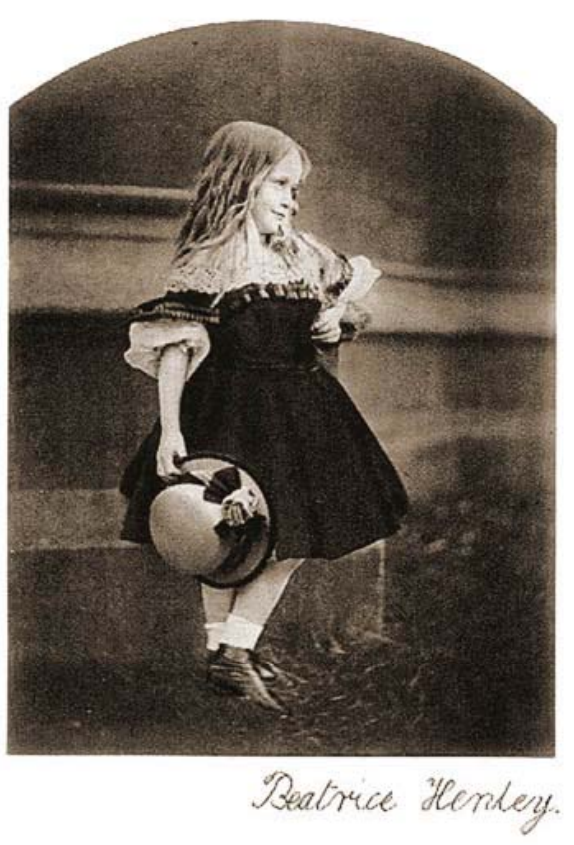

Fig. 36. Beatrice Henley (1875). 


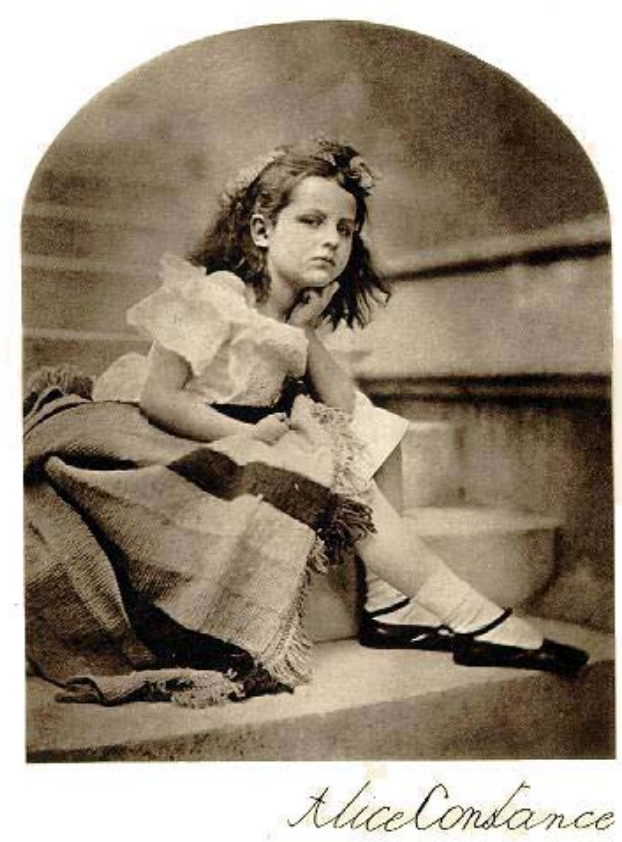

Fig. 37. Alice Constance Westmacott (s.a.).

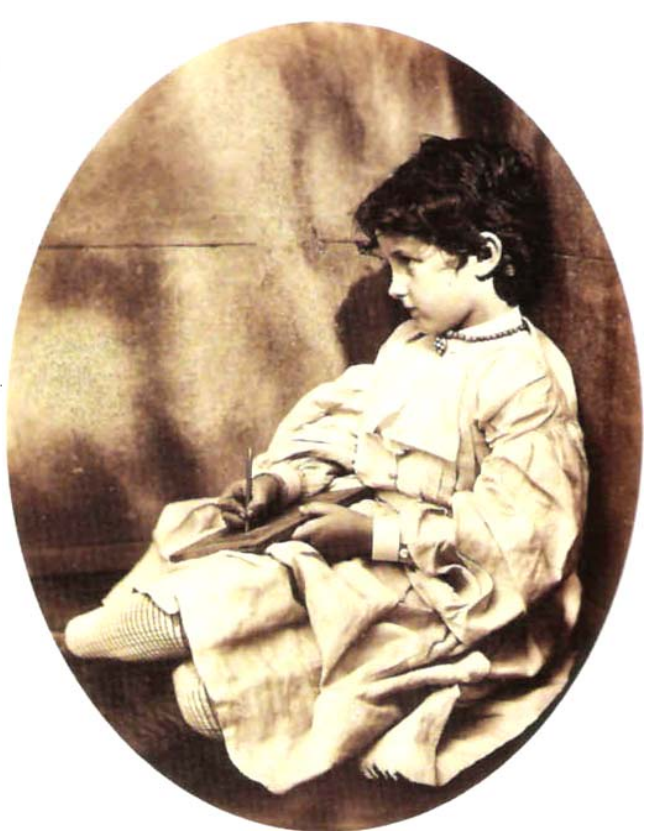

Fig. 38. Effie Millais (1865).

La belleza de las niñas ejercía una extraña fascinación en Carroll. Una fascinación que Helmunt Gernsheim describe ${ }^{69}$ como un «amor inocente». $Y$ es que la belleza infantil para Carroll representaba la inocencia misma. «Él adoraba su naturalidad, su intacta belleza», afirma Cohen ${ }^{70}$, que lo enlaza dentro de la tradición romántica.

La sexualidad sin embargo se hace obvia, incluso en aquellas fotografías que no son de desnudos. Carol Mavor se contrapone a la pretendida inocencia que señalan algunos autores como Morton Cohen indicando que las fotografías de Carroll «cuestionan el valor de la inocencia humana» ${ }^{71}$.

\footnotetext{
${ }^{69}$ GERNSHEIM, Helmunt. Lewis Carroll. Photographer. New York: Dover, 1969, pág 18.

${ }^{70}$ COHEN, Morton N. Lewis Carroll, Photographer of Children Four Nudes Studies. Op. cit., págs. 4, 30.

${ }^{71}$ MAVOR, Carol. Op. cit., pág. 8.
} 
Antes de morir, Carroll destruyó gran parte de tales fotografías de las cuales se conservan sólo unas pocas. Resulta sospechoso el arrebato de Dodgson al destruir las fotografías de desnudos de niñas $^{72}$. Un posible sentimiento de culpabilidad, tras unas críticas despectivas hacia el hecho de que fotografiara niñas desnudas parece haber sido el desencadenante de tal acción. Se podría ver en ese gesto un arrepentimiento -por algo que en su momento Dodgson consideró completamente inocente y «natural»- que nos indica tal vez, que tras la aparente mirada de inocencia y amabilidad, se escondía una visión mucho más erotizada de las niñas de lo Cohen nos insiste.

Dodgson tenía una clara predilección hacia el denudo infantil femenino que no por el masculino, como evidencian sus cartas. En una ocasión escribiría: «Las niñas desnudas son perfectamente puras y adorables..., confieso que no admiro a los niños desnudos. Siempre me parece que necesiten ropas, mientras que uno apenas ve el por qué las adorables formas de las niñas debieran cubrirse» ${ }^{73}$. A pesar de su favoritismo Dodgson jamás condenó el desnudo femenino adulto, como lo hiciese por el contrario Ruskin, que hallaba en el desnudo masculino una desdeñada inclinación hacia la decadencia del arte griego.

\footnotetext{
72 Destruyó la mayoría de los negativos y copias antes de morir y mandó a sus albaceas que destruyeran las que quedaran.

${ }^{73}$ «Naked children are so perfectly pure and lovely... I confess I do no admire naked boys. They always seem to me to need clothes, whereas one hardly sees why the lovely forms of girls should ever covered up» (trad. de la autora). Carta a Harry Furniss. COHEN, Morton N.; LANCELYN GREEN, Roger (ed.). Op. cit., pág. 947 y GERNSHEIM, H. Op. cit., pág. 21.
} 
A pesar de que son pocos los desnudos que se conservan ${ }^{74}-\tan$ solo cuatro han salido a la luz ${ }^{75}$, hay en ellos una visión explícitamente sexual, como en Retrato de Evelyn Hatch (c. 1878), en el que la pequeña de unos seis o siete años, posa tumbada como una odalisca de Ingres, en un sobrio y casi espartano escenario, sin ornamentos o telas, mirando fijamente a la cámara y esbozando una leve sonrisa. Su rostro está menos iluminado que el resto de su delgado cuerpecito y las pupilas de sus ojos están retocadas con dos pequeños puntos blancos, como «los ojos de un zorro reluciendo en la oscuridad de la noche» ${ }^{76}$. Evelyn es como un animalillo salvaje, como un gatito que se estira en toda su longitud, sin vergüenza a mostrar sus genitales. Auerbach equipara esta «animalidad» a la sexualidad animal pero también de pureza de la cual -asegura-, Carroll es completamente conciente ${ }^{77}$. Hay una promiscuidad animal, una disponibilidad sexual, acentuada por la pasividad, constituyendo un tabú victoriano como el de la mujer-animal que viene abalada por una representación del erotismo femenino en las artes, perfectamente determinado por los criterios masculinos, como han señalado numerosas historiadoras feministas como Linda Nochlin o Giselda Pollock.

\footnotetext{
${ }^{74}$ La primera fotografía de desnudo de la que se tiene constancia es de Beatrice Hatch, una de sus modelos favoritas junto a su hermana pequeña. Referencia del 21 de mayo de 1867, hallada en un diario. GERNSHEIM, Helmunt. Lewis Carroll. Photographer. New York: Dover, 1969, pág. 65.

${ }^{75}$ Tan sólo se conservan 4 desnudos fotográficos de Lewis Carroll que se encuentran en el Museo Philip \& A.S.W. Rosenbach de Filadelfia y están reproducidas en COHEN, Morton N. Lewis Carroll, Photographer of Children Four Nudes Studies. New York: Clarkson N. Potter Inc., 1979.

${ }^{76}$ MAVOR, Carol. Op. cit., pág. 11.

77 Nina Auerbach afirma que ese animal latente, nos hace pensar en su poder oculto y en el temor victoriano hacia el alma animal en la mujer, como ser mitológico, comparable al comportamiento histérico o al de una prostituta. "Falling Alice, Fallen Women, and Victorian Dream Children", en AUERBACH, Nina. Romantic Imprisonment: Women and Other Glorified Outcast. New York: Columbia University Press, 1986, pág. 168.
} 


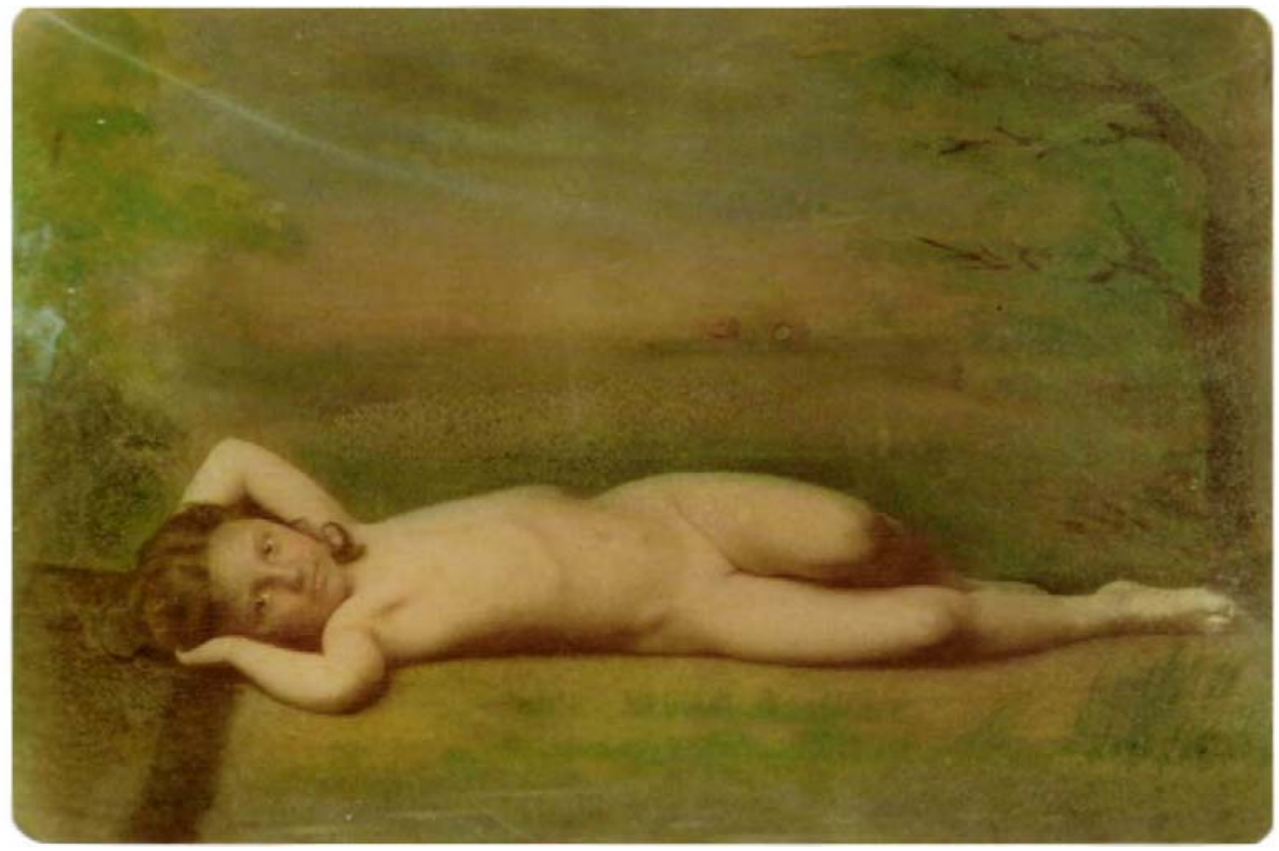

Fig. 39. Retrato de Evelyn Hatch (c. 1878), coloreada.

Carroll siempre guardó la máxima discreción y decoro respecto a los desnudos que tomaba y jamás realizó ninguno, si no tenía la suficiente familiaridad, así como tampoco regalaba tales fotos o las mostraba si no se trataban de personas de su confianza. "Si tuviese que dibujar o fotografiar a la niña más preciosa del mundo y notase en ella una pudorosa resistencia -por ligera y fácil de vencer que fuese-, a quedarse desnuda, consideraría un solemne deber para con Dios renunciar "por completo" a semejante petición», escribiría. Comenzaba tanteándolas, comprobando si se sentían cómodas, descubriéndoles los pies o tumbándolas en camisón o con ropas más ligeras, como relata en su diario el 8 de julio de 1866, sobre una serie que tomó de Ella, hija de sir Monier-Williams -catedrático de Sánscrito-, «de la que hice varios retratos sin más ropa que un ceñidor, a la manera de los salvajes», o el 21 de mayo de 1864 en el que escribió «... la señora 
Latham (vecina de Oxford) trajo a Beatrice y tomé una foto de las dos y varias de Beatrice sola "sans habillement"». La sorpresa de Carroll sería comprobar que las niñas ponían menos objeciones a ser fotografiadas desnudas de lo que él mismo consideraba con la consecuente satisfacción por parte de Carroll: «La señora Henderson trajo a Annie y Frances (...) me sorprendió descubrir que estaban dispuestas a desvestirse todo lo que yo quisiera, y que les encantaba que yo les permitiera corretear desnudas. Fue un privilegio tener como modelo a Annie: un rostro "muy" lindo y una buena figura (...)».

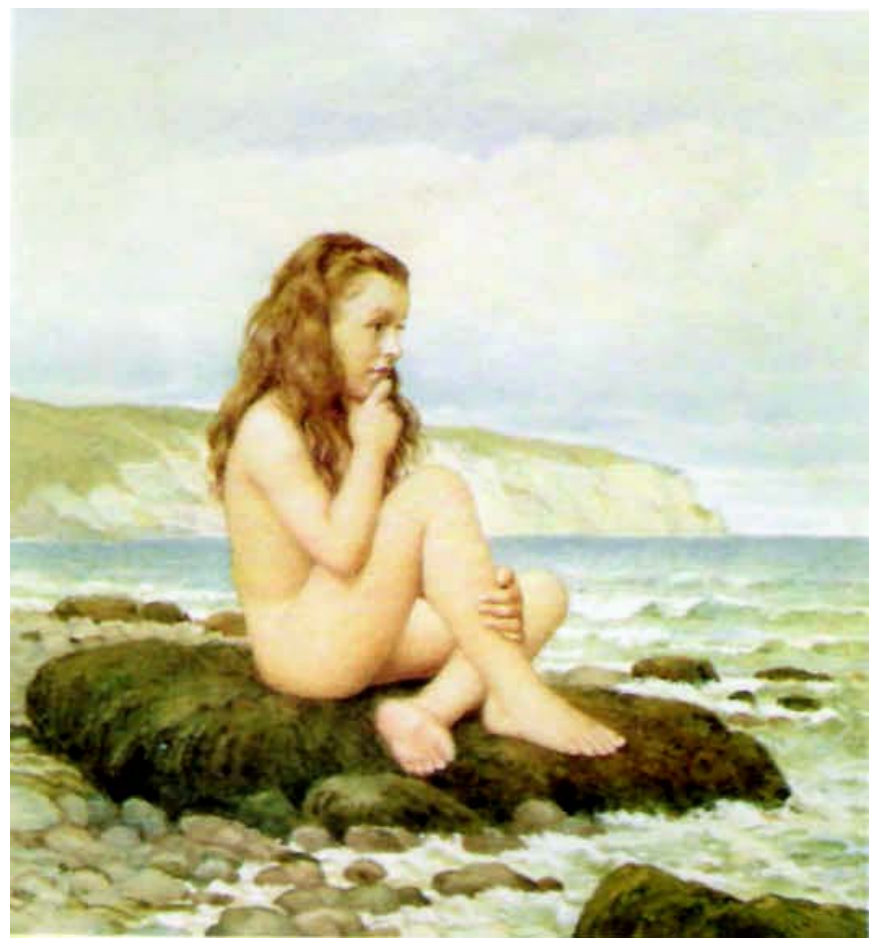

Fig. 40. Beatrice Hatch (1873), coloreada por Anne Lydia Bond.

Algunos de estos desnudos estaban coloreados por el propio Carroll «para así lograr un buen parecido» ${ }^{78}$ afirmaba, pero la gran

${ }^{78}$ COHEN, Morton N. Lewis Carroll. Op. cit., pág 127. 
mayoría estaban realizados por profesionales que les incluían fondos específicos como en la fotografía de Beatrice Hatch (1873), en la que Anne Lydia Bond le añade un fondo de acantilados propios de la costa sur de Inglaterra, confiriéndole un aspecto de Venus «británica». En Evelyn Hatch (circa 1879), la niña está situada junto a un arroyo como la hija de una familia gitana, como se aprecia al fondo donde se encuentra su caravana, recurriendo a la visión romántica y poco realista de la mendicidad, las vida en las calles o bohemia como hicieran otros autores de su época. La cuarta fotografía que se conserva es la de Annie y Frances Henderson con disfraces a lo Robinson Crusoe, o como Náufragos (circa 1880).

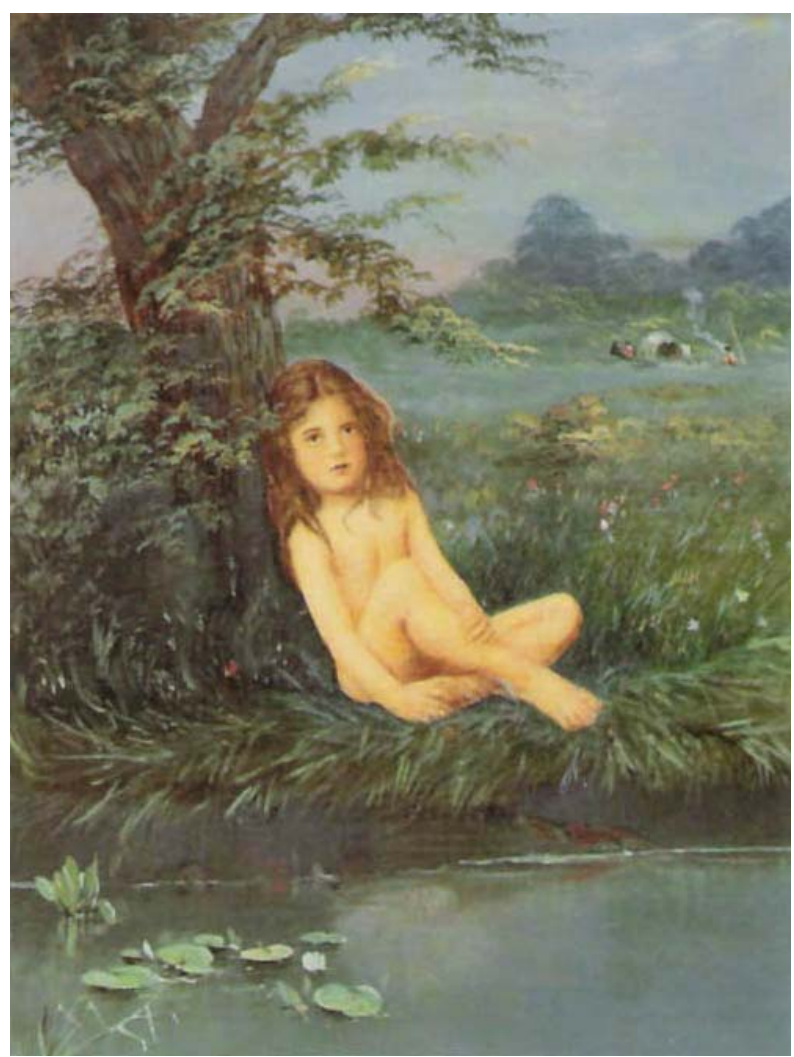

Fig. 41. Evelyn Hatch (c. 1879), coloreada. 


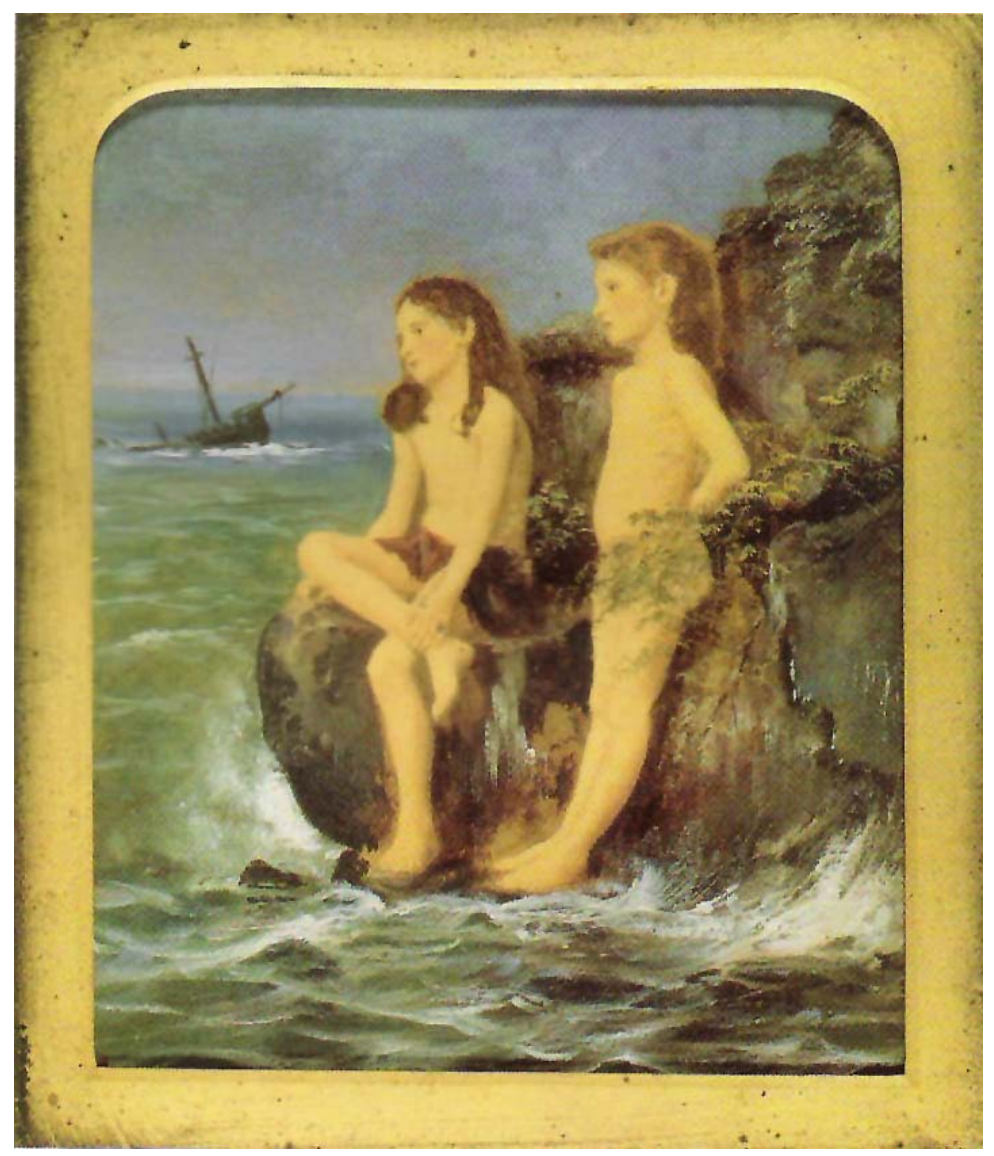

Fig. 42. Annie y Frances Henderson con disfraces a lo Robinson Crusoe o como Náufragos (c. 1880), coloreada.

Lewis Carroll era perfectamente consciente de que sus desnudos infantiles no eran vistos por todo el mundo de la misma «inocente» manera que pudiera hacerlo él, como se advierte en la carta que enviara a la Sra. Henderson a propósito de las fotografías de sus hijas $^{79}$.

79 En una carta del 21 de junio de 1881 a la Sra. Henderson escribe diciendo: «le escribo para preguntarle si le gustaría tener algunas copias más de las fotografías frontales de las niñas. Tengo 2 ó 3 copias de cada una de ellas, pero mi intención es destruir todas excepto una de cada. Éstas las quiero para mi y (aunque las considero completamente inocentes) realmente no hay "ningún" amigo al que desearía darle estas fotografías que tan abiertamente desafiarían las normas convencionales». 
El desnudo infantil no era en principio motivo de polémica desde el punto de vista social, como ya se ha comprobado en el difundido uso decorativo y comercial, sin embargo había una franja de edad susceptiblemente problemática. Así lo afirma Margaret, hija de un don ${ }^{80}$ de Oxford: «Mi madre no puso ninguna objeción a que mi hermana menor de unos seis o siete años, fuese fotografiada desnuda, o muy ligera de ropa..., pero cuando (Dodgson) le pidieron permiso para fotografiar a su hija mayor, que debía tener entonces unos 11 años, de la misma forma, el estricto victoriano sentido del decoro de mi madre se escandalizó y la amistad cesó inmediatamente» ${ }^{81}$.

La misma «animalidad» del Retrato de Evelyn Hatch (circa 1878), la hallamos en la mirada de Agnes Grace Weld como Caperucita Roja [Agnes Grace Weld as Little Red Riding Hood] (1857), que parecen los ojos del propio Lobo, que ha tomado forma de la niña, ahora se nos descubre entre el follaje, misteriosa, amenazadora, peligrosa incluso sexualmente, con la cestita destapada, mostrando su contenido sugerentemente ${ }^{82}$. Carroll, nos ha cambiado la consecución narrativa, pues difícilmente sabemos que ocurrirá a continuación. También realizaría una escena peculiar disfrazando a la niña Alice Donkin. La fuga [Elopement] (1862), que vestida de Caperucita Roja, se encuentra a punto de bajar por una escalera de cuerda que cuelga desde una ventana. Curiosamente Lewis Carroll tituló a esta fotografía como Elopement, que significa «fugarse para casarse», lo que implica que Alice Donkin ${ }^{83}$ no es una Caperucita habitual, sino una amante

\footnotetext{
${ }^{80}$ Categoría de profesor, considerados algo excéntricos y que contaban con gran autonomía.

${ }^{81}$ HUDSON, Derek. Lewis Carroll: An Illustrated Biography. New York: Clarkson N. Potter, Inc., 1977, págs. 322-26. Citado en COHEN, Morton N. Lewis Carroll. Op. cit., pág. 217.

82 Íd., pág. 11.

${ }^{83}$ Curiosamente, Alice Donkin se casó con Wilfred Dodgson, hermano de Charles.
} 
irrefrenable que hará todo lo posible para reunirse con su amado, no sabemos si será el Lobo o el cazador.

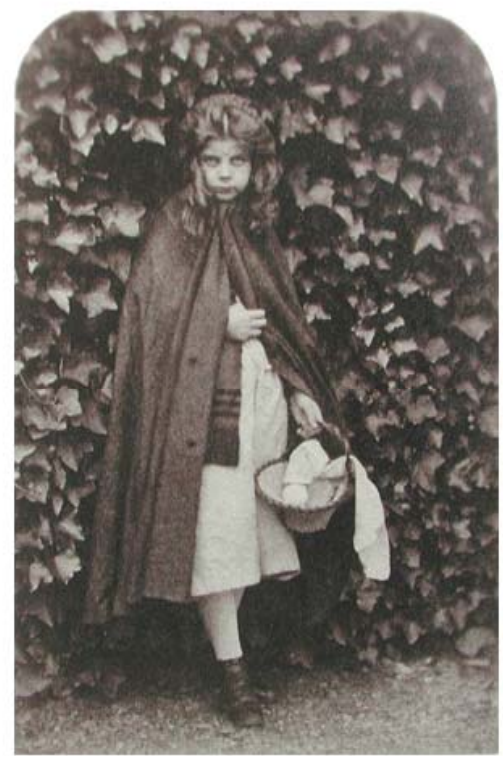

Fig. 43. Agnes Grace Weld como Caperucita roja (1859).

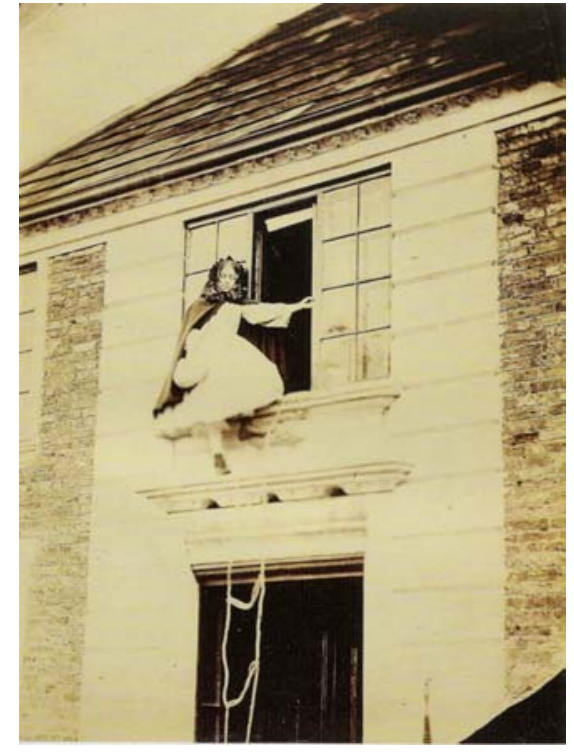

Fig. 44. Alice Donkin. La fuga (1862).

Al estilo de la Olimpia (1863) de Manet, posan algunas de las pequeñas, recostadas sobre un diván, somnolientas, relajadas o leyendo como niñas educadas de clase alta como Agnes Hughes (c. 1863) o Alexandra "Xie Kitchin" (1873).

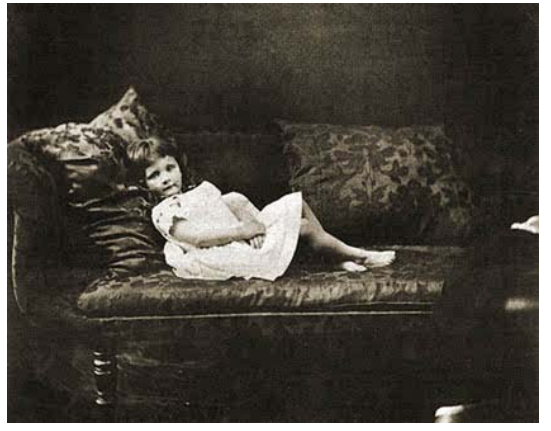

Fig. 45. Agnes Hughes (c. 1863).

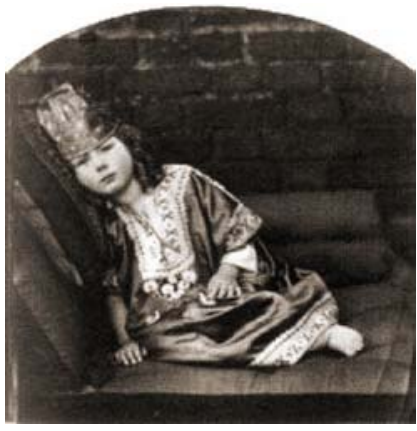

Fig. 46. Agnes Hughes (c. 1863). 


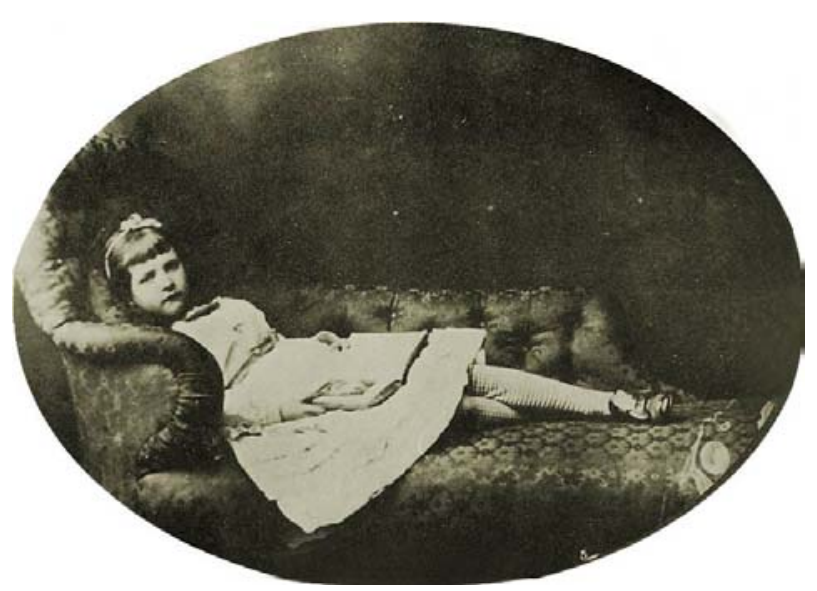

Fig. 47. Alexandra "Xie Kitchin" (1873).

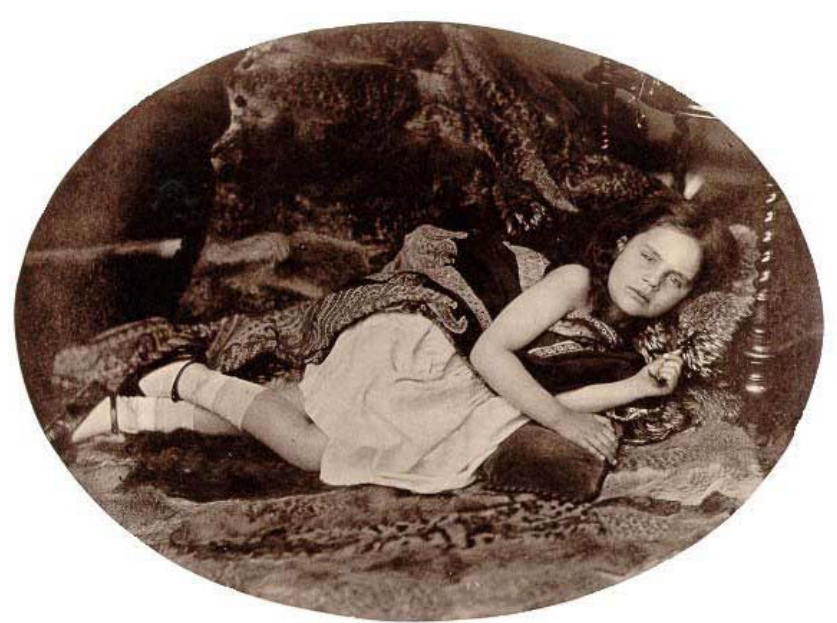

Fig. 48. Irene MacDonald (1863).

Por el contrario, Irene MacDonald (1863) ha entrado en un escenario bien diferente, envuelta entre telas orientales y mantas de piel de leopardo, como una odalisca, como una concubina de un bazar turco, con los hombros descubiertos. Sólo la falda, los calcetines blancos y los zapatitos negros, nos indican verdaderamente el origen occidental de la modelo. La inocencia de Irene MacDonald se transmuta en una coqueta y sugerentemente criatura. Carroll maneja con decoro y corrección el lenguaje erótico. Sin resultar vulgar o 
deshonroso para las niñas. El recorte ovalado refuerza la visión voyeurista que tenemos de la escena. Carroll realizaría otros retratos de Irene MacDonald como «No se alisa» [It Won't Come Smooth] (1863), en el que la niña en camisón y con el cabello despeinado y erizado sostiene con una mano un cepillo y con la otra un espejito apoyado a su vez en una silla. Una escena mundana y de la vida íntima como lograr alisar el cabello por las mañanas se convierte en una deliciosa imagen sobre la vanidad infantil.

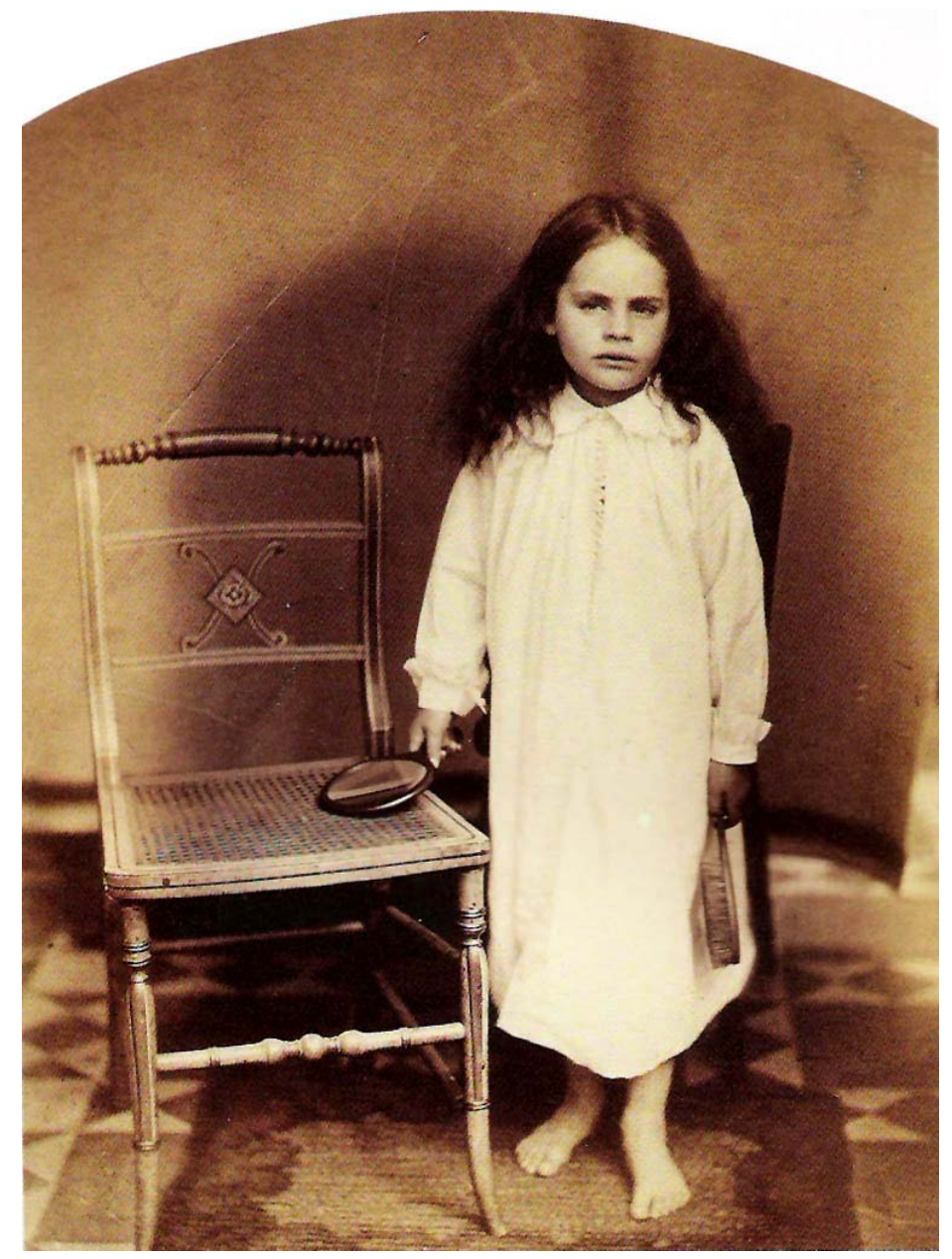

Fig. 49. Irene McDonald. «No se alisa» (1863). 
Algo más enigmática resulta la fotografía de Julia Arnold (s.a) ${ }^{84}$, que posa de costado vestida con un enorme camisón blanco mirándose a un espejo -de mayor tamaño que el de la fotografía de Irene MacDonald-, que ella eleva con las manos y que apoya a su vez sobre una mesita. Es casi más una imagen espectral que una escena de tocador, en la que a pesar de mirarse en el espejo, el reflejo de la niña parece inexistente, enfatizando la sensación fantasmal o de muerte que provoca el largo del

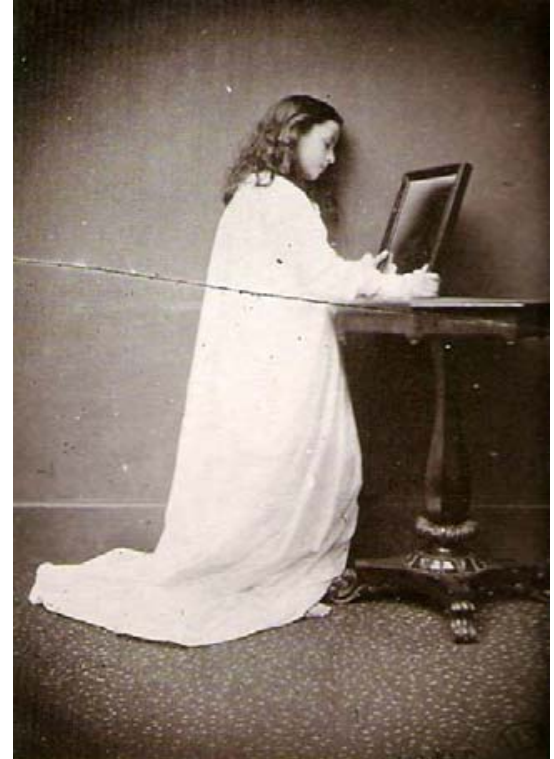

Fig. 50. Julia Arnold (s.a). camisón apoyado sobre el suelo.

En Alexandra "Xie Kitchin" (c. 1874) repite la escena de 1873, en la que posa recostada en el diván decorosamente vestida sosteniendo entre sus manos un libro, pero en esta ocasión nos «ofrece» una visión bien distinta, con los hombros y piernas al descubierto y los pies deliciosamente descalzos a lo largo del diván, los pies o las piernas al descubierto son tan importantes en estos retratos como si se tratara del rostro de un desnudo. Xie Kitchin está dormida, indefensa, como una joven prostituta de burdel. Al igual que el desnudo del Retrato de Evelyn Hatch (c. 1878), la niña se convierte en un exquisito fetiche. Numerosos autores afirman que sus fotografías no son pornográficas pero que sin embargo sus imágenes guardan demasiado parecido con los daguerrotipos eróticos franceses que circulaban en aquella época.

\footnotetext{
${ }^{84}$ Julia Arnold casó con Leonard Huxley en 1885 y sería madre del famoso Aldous Huxley.
} 


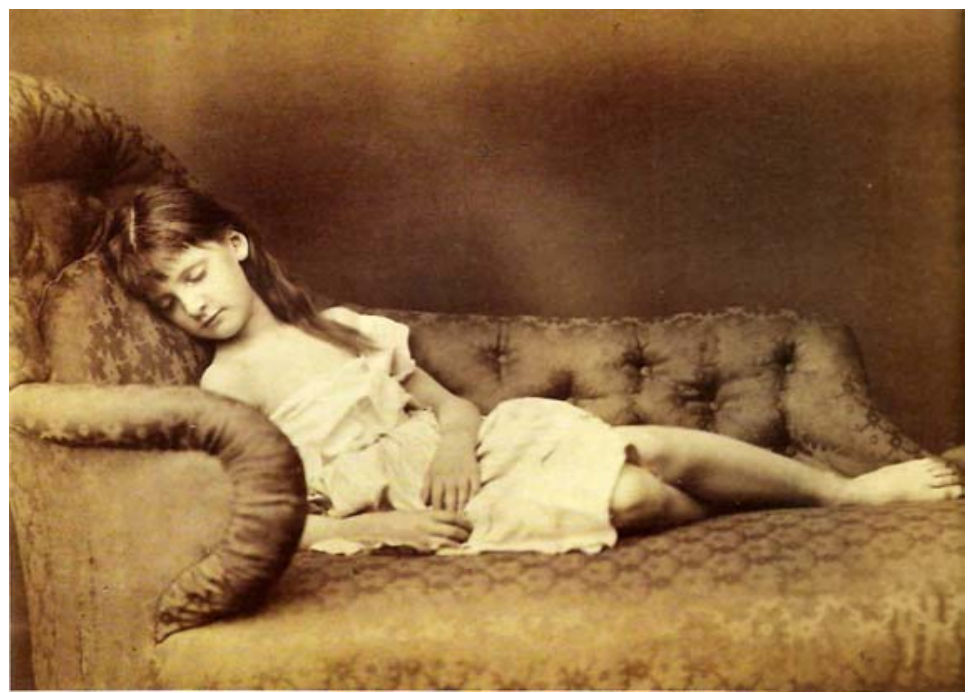

Fig. 51. Alexandra "Xie Kitchin" (c. 1874).

Carroll busca en la tradición pictórica, recuperando el orientalismo de Delacroix o Ingres en las representaciones con disfraces turcos o chinos, como manifiesta su gusto por el teatro, en el uso de disfraces de trajes típicos de diferentes países con los que viste a las niñas.
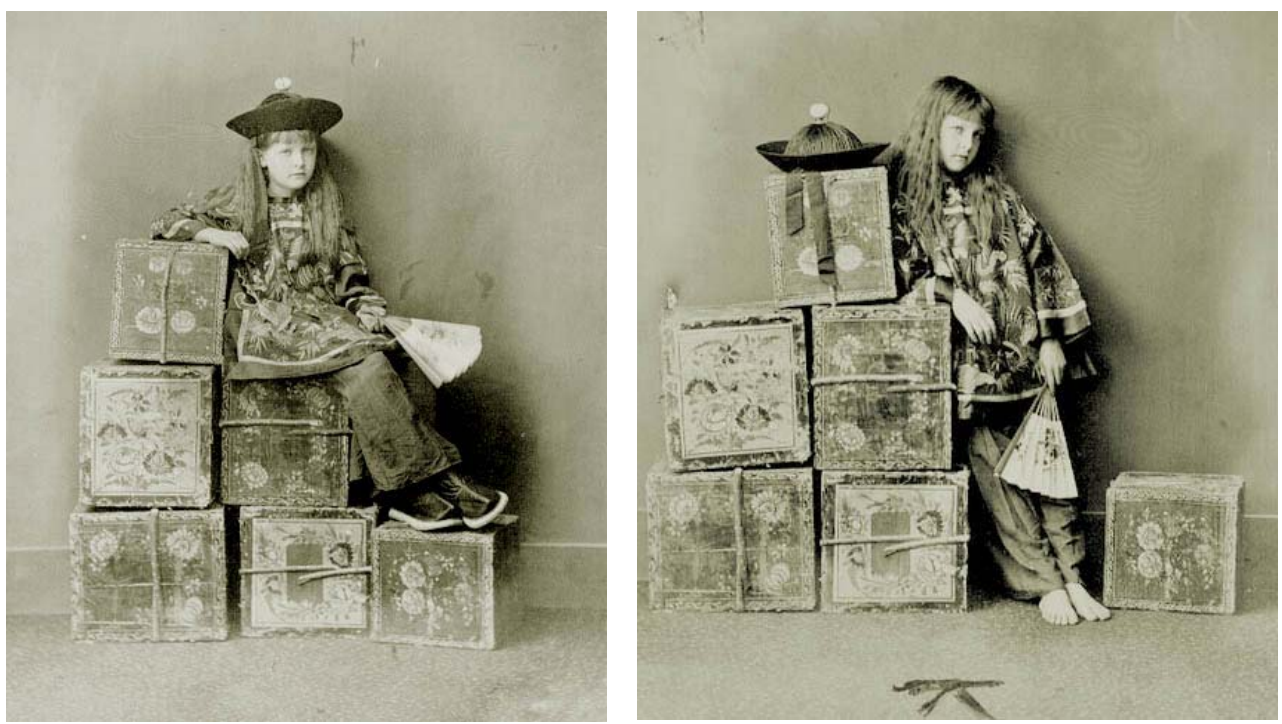

Fig. 52 y fig. 53. Xie Kitchin disfrazada de chino (1873). 


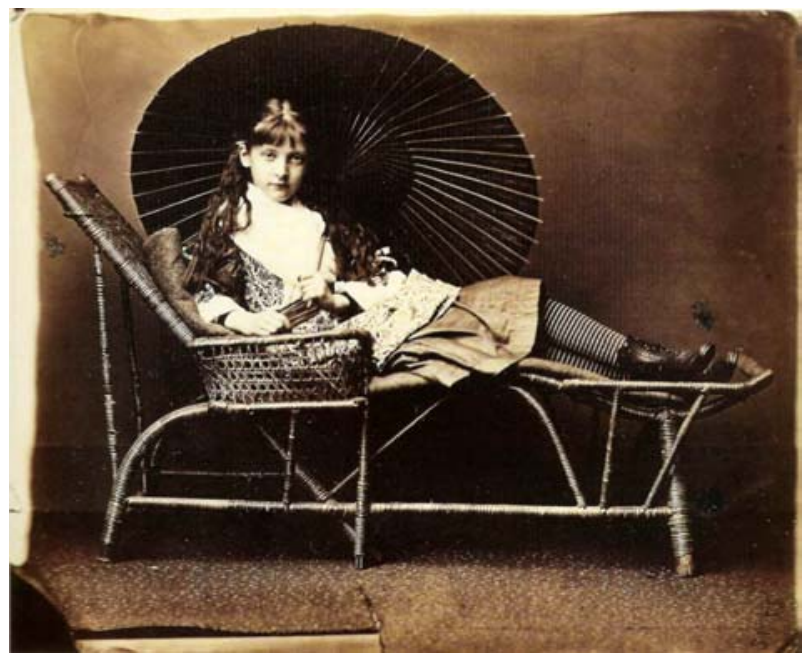

Fig. 54. Xie con parasol (1876).

Alexandra Xie Kitchin, se convertiría en una de sus modelos favoritas de la que realizó numeroso retratos y composiciones hasta que cumplió unos quince años, edad habitual a la que dejaba de fotografiar a sus amiguitas.

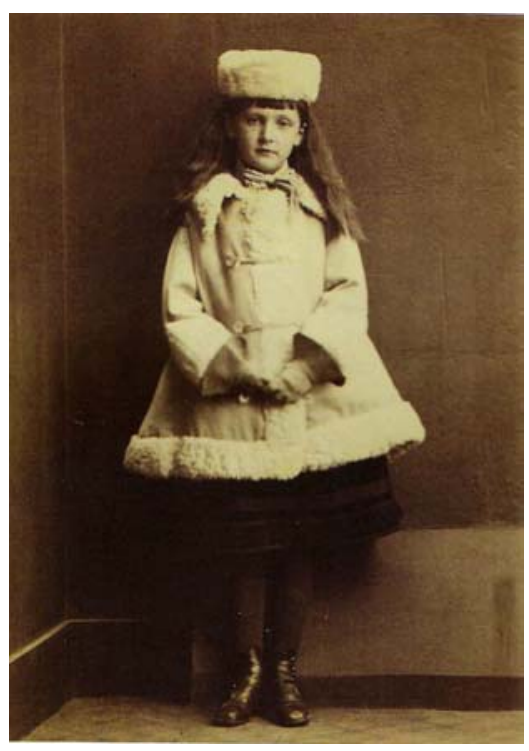

Fig. 55. Xie vestida de Escandinava (1873).

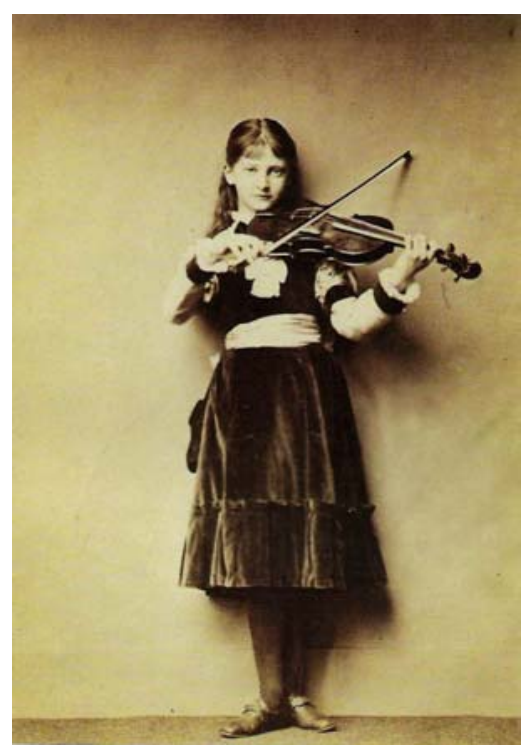

Fig. 56. Xie como violinista (1876). 


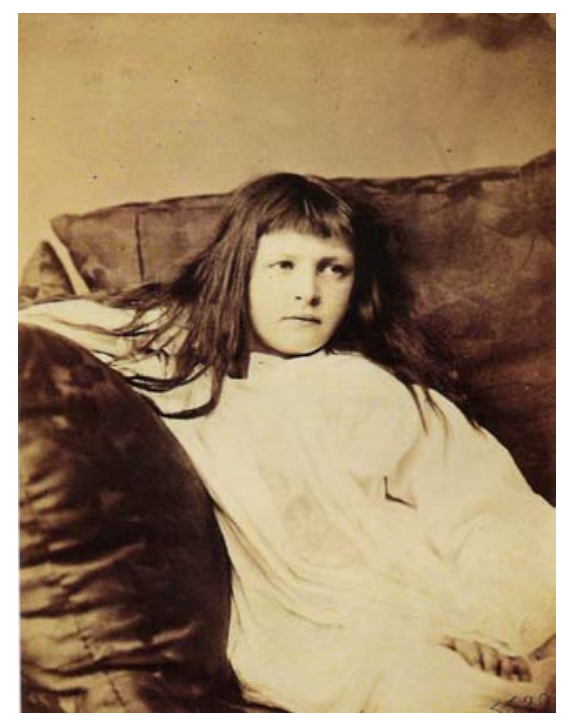

Fig. 57. Xie Kitchin. En vela (1874).

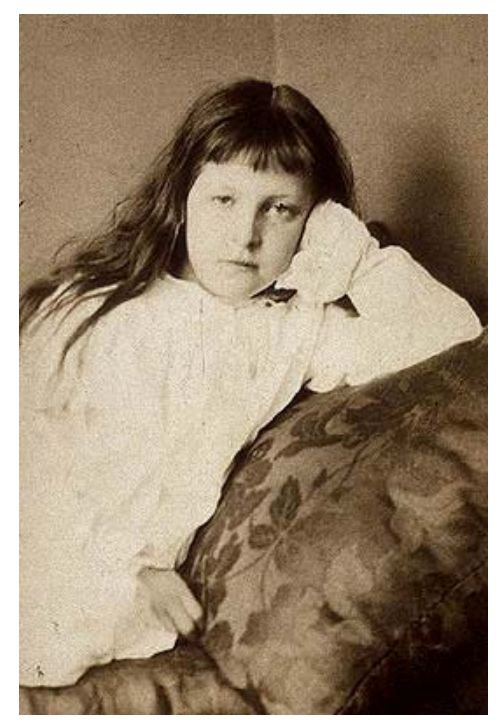

Fig. 58. Xie Kitchin. Una noche de verano (1874).

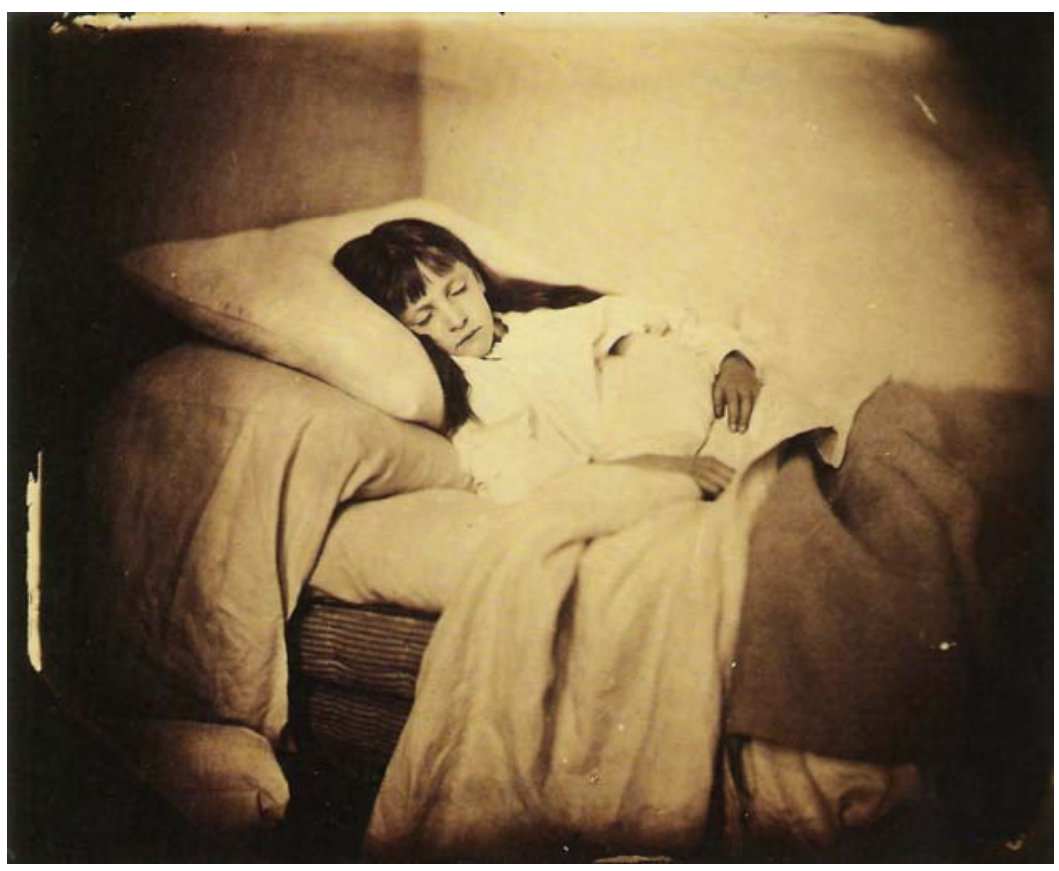

Fig. 59. Xie Kitchin durmiendo (1873). 
En Xie Kitchin durmiendo (1873) la niña duerme entre las sábanas, y es en ese momento con el que se expresa todo el mundo de fantasía que Carroll atribuye a las niñas.

Reinterpretando el retrato de Penelope Boothby (1788) de Sir Joshua Reynolds, se nos muestra a Xie Kitchin mirando a la cámara penetrantemente, llevando una cofia con una cinta negra y unos mitones de encaje negro, mientras apoya ligeramente la barbilla sobre su mano derecha, más como una femme fatale que como la ingenua niñita de Cerezas maduras (1880) de John Everett Millais, que también se basó en esta misma pintura ${ }^{85}$.

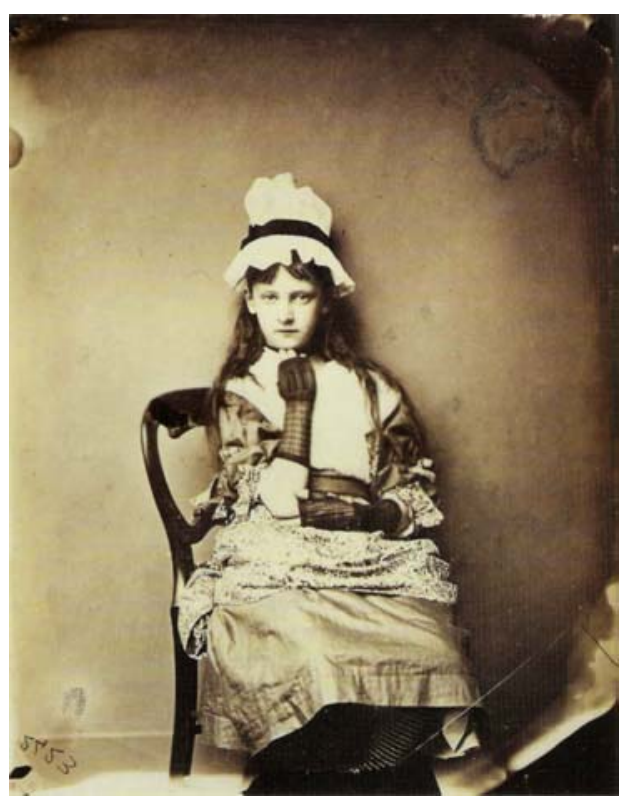

Fig. 60. Xie Kitchin como Penelope Boothby (1879).

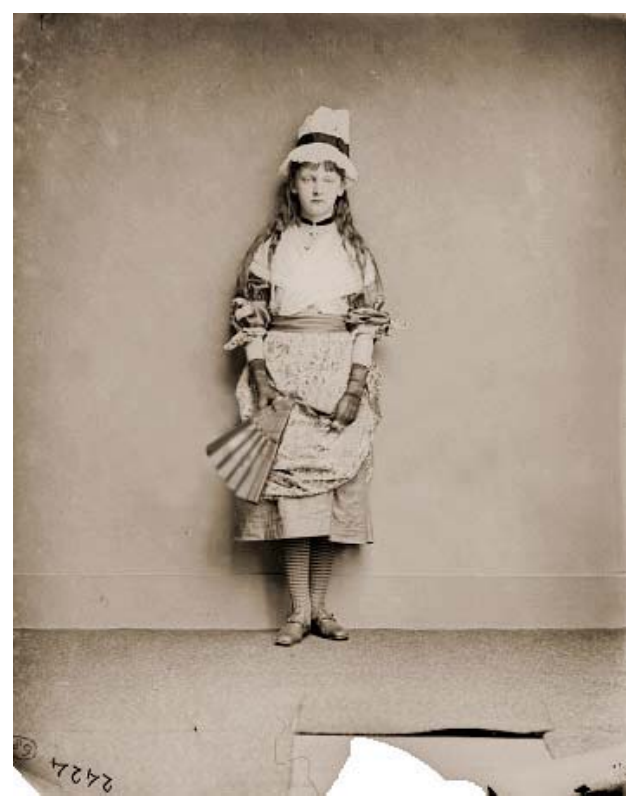

Fig. 61. Xie Kitchin como Penelope Boothby (1879).

${ }^{85}$ Como Sir John Everett Millais o Henry Fuseli entre otros autores, Lewis Carroll, reinterpretaría casi 100 años después, el retrato que realizara Sir Joshua Reynolds de Penelope Boothby (1788). Penelope Boothby (1785-1791), hija de Sir Brooke Boothby -perteneciente al círculo literario de Rousseau-, murió cuando tan sólo contaba con seis años, convirtiéndose en un romántico icono de la inocencia y la muerte trágica. El escultor Thomas Banks, realizó su escultura funeraria de la que decían que no estaba muerta sino viva. La propia reina Charlotte y las princesas al ver su escultura lloraban. 


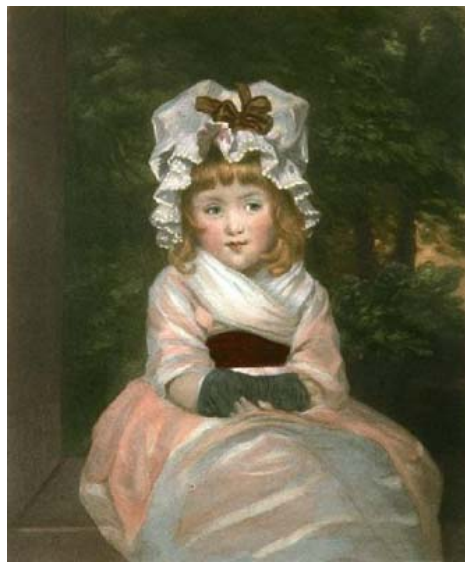

Fig. 62. Penelope Boothby (1788) por Joshua Reynolds.

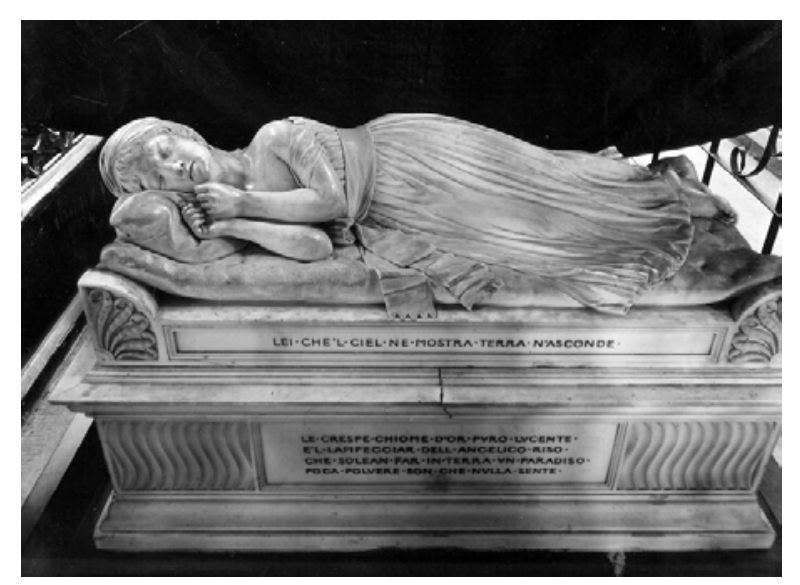

Fig. 63. Penelope Boothby (1791), escultura funeraria por Thomas Banks

Carroll, fotografiaría a cientos de niñas, sus modelos que eran minuciosamente listadas alfabéticamente tendrían diferentes fechas de nacimiento, durante diferentes décadas pero todas ellas fueron fotografiadas por un breve espacio de tiempo, pues cuando su rostro y su cuerpo tomaba formas femeninas, dejaba de fotografiarlas y de enviarles cartas, a excepción de un reducido número,...

La fotografía implicaba la captura de esa infancia que pronto acabaría. La carencia de «sexualidad» infantil, por tanto, la juventud eterna, es capturada en la emulsión de plata, preservando esa inocencia que moriría al crecer. La infancia se convierte en una fantasía fetichista. $Y$ con esas fotografías, se obtienen verdaderos fetiches de las niñas convertidas en un pequeño objeto, en versiones de bolsillo. El fetichismo en términos psicoanalíticos, señala Carol Mavor, suponen una «castración simbólica» y una protección frente a la pérdida. Lógicamente Carroll, disponía de las imágenes de las niñas para siempre, incluso cuando ellas estuviesen casadas y con hijos, él las seguiría teniendo siempre con la misma edad. 
A pesar de tratarse de un fotógrafo amateur -él se consideraba a sí mismo como tal-, ha pasado a ser considerado como uno de los pioneros del naturalismo fotográfico y del retrato ${ }^{86}$. Dejó la fotografía en 1880, al parecer airado y molesto por los comentarios peyorativos respecto a sus fotografías de niñas desnudas. Por otro lado consideraba que los avances técnicos en la fotografía iban en detrimento de su criterio artístico.

\subsubsection{Alice, como primer icono de la preadolescente.}

Fueron muchas las niñas con las que Charles Lutwidge Dodgson compartió amistad, cartas, fotografías, juegos, tardes de té y recomendaciones moralizadoras. Pero sin duda Alice Liddell ha sido destacada sobre todas las demás no sólo por ser la niña que dio nombre a Alicia en el país de las Maravillas sino porque se convirtió en una de sus modelos más importantes sobre todo durante los primeros años de su actividad como fotógrafo y que sirviera para cimentar su «amor por las niñas». Tal vez la fotografía más conocida de Alice sea Alice Liddell como mendiga [Alice Liddell as a Beggar-girl] de 1858 aproximadamente ${ }^{87}$. Se trata de una de las doce fotografías -conocidas- que realizaría de Alice Liddell y a sus hermanas.

En esta fotografía, Carroll recoge la tradición prerrafaelista por el análisis de la naturaleza, la vegetación enfocada, crepitante y borrosidades mínimas. Sin embargo se desmarca del resto de fotógrafos de su época en este singular retrato. Carroll nos introduce

\footnotetext{
86 OVENDEN, Graham. Op. cit., pág. 183.

${ }^{87}$ N. B. los comentarios de Vladimir Nabokov respecto a las fotografías de Lewis Carroll. N. 36, cap. 8. Lolita de Vladimir Nabokov, pág. 254.
} 


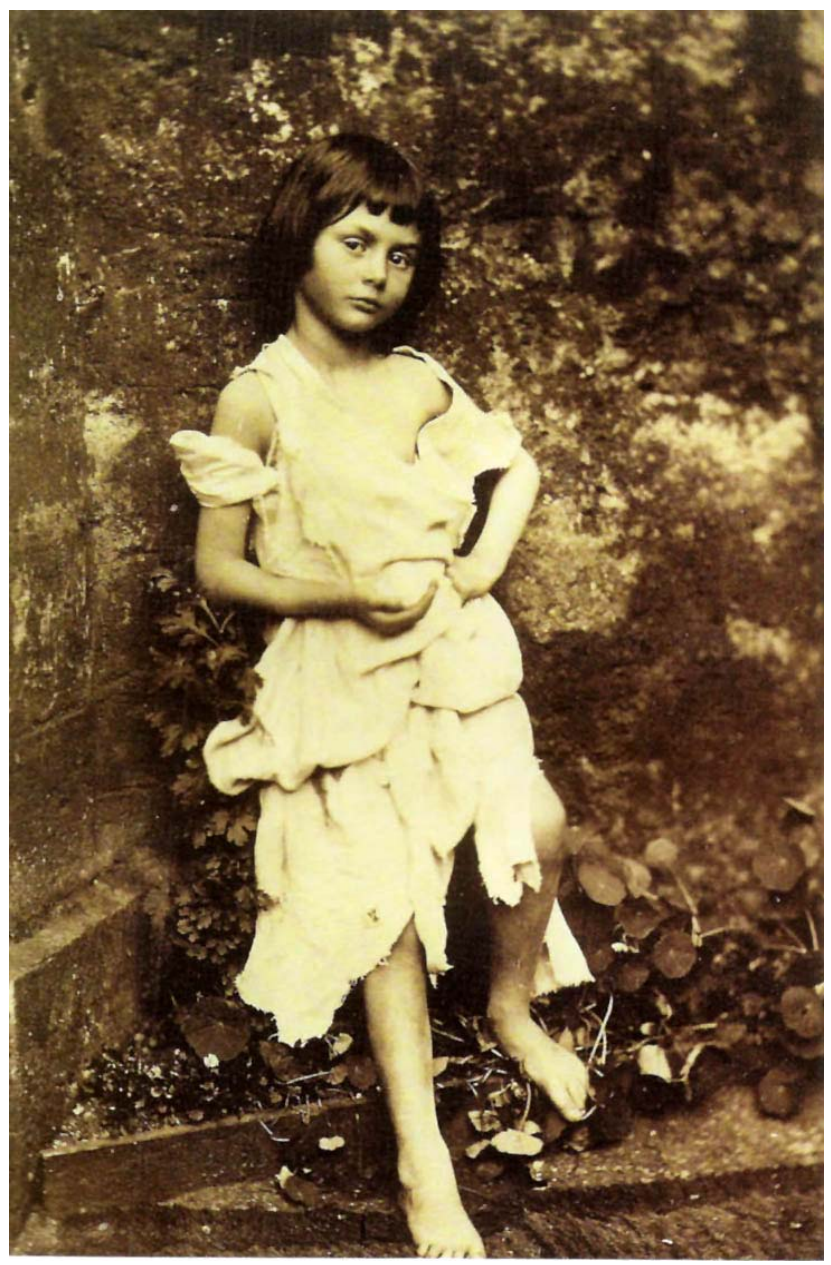

Fig. 64. Alice Liddell como mendiga (c. 1858).

en un personaje erotico camuflado de mendiga, que nos plantea numerosas «dudas». La mirada de Alice es enigmática, penetrante y escrutadora incluso hacia su fotógrafo, que hace de ella una víctima del ojo adulto que la observa a través de la cámara. Su vestido de harapos deja al descubierto sus hombros, recreando el aspecto que se supone tiene una mendiga, como una «Cenicienta» ${ }^{88}$. Se trata de una visión

${ }_{88}^{88}$ N. las similitudes entre Alice como mendiga (c. 1858) y Florence Holder (c. 1876) del Dr. Barnardo. MAVOR, Carol. Op. cit., pág. 39. 
idealizada y romántica de la mendicidad. Mavor señala que «sólo un rico podría creer esta imagen ${ }^{89}$, y es que Carroll sólo tenía amistades con niñas de clase media y alta del pequeño grupo de Oxford y del círculo cultural prerrafaelista, lo que implicaba una ignorancia respecto a la realidad infantil, bien diferente a la aproximación que realizaba Lewis Hine. «Alice-Cenicienta», puede simular ser una mendiga porque no lo es. Es esa irrealidad o «ficción artística» la que le atrae a Carroll y no la verdadera realidad de la pobreza. Él ni siquiera se plantea esa problemática. Alice se viste de mendiga como lo hace Xie Kitchin de griega o de china, se trata tan sólo de un juego.

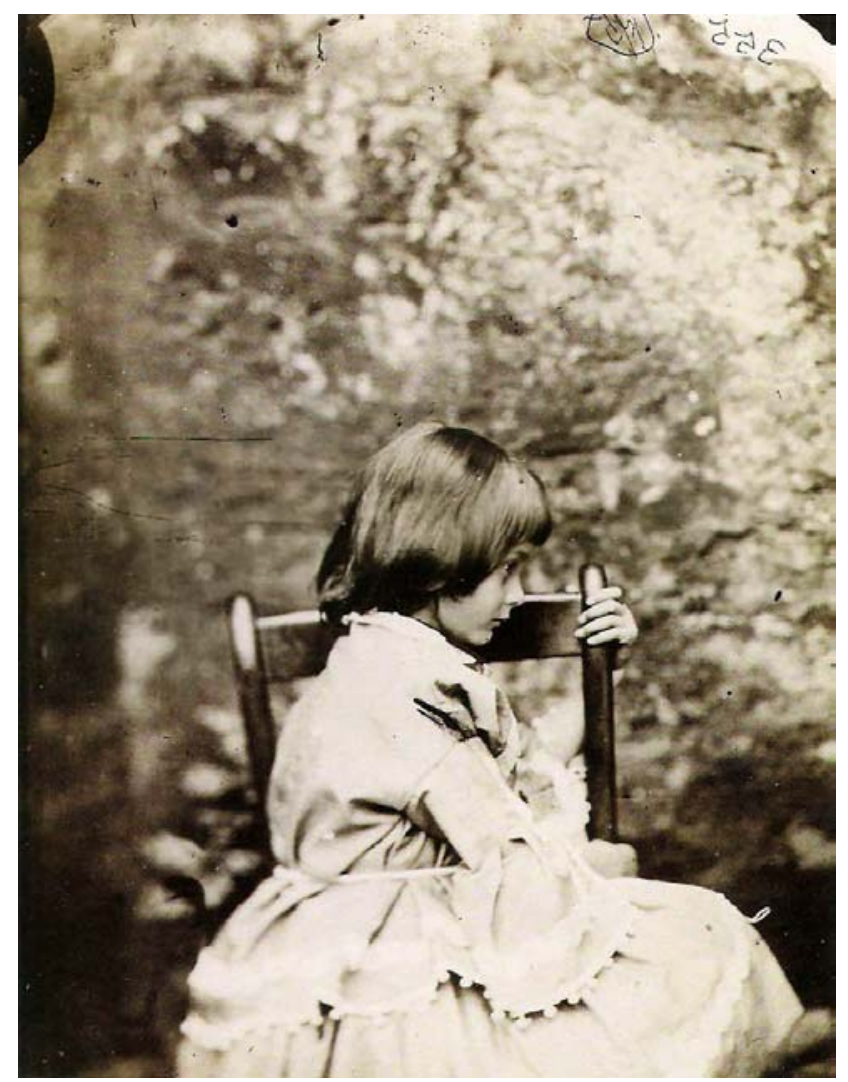

Fig. 65. Alice Liddell (1858).

\footnotetext{
89 Íd., pág. 35.
} 
Realizaría varios retratos más de Alice sola, posando sentada, pensativa con una corona de flores en la cabeza o recostada en el suelo como durmiendo con un sombrero de paja negra en las manos, que remite claramente a la fotografía de difuntos. En ellas se observa la delicadeza y la ternura con la que Carroll se acerca a la belleza natural de las niñas que sería posteriormente su seña de identidad en los retratos de niñas.

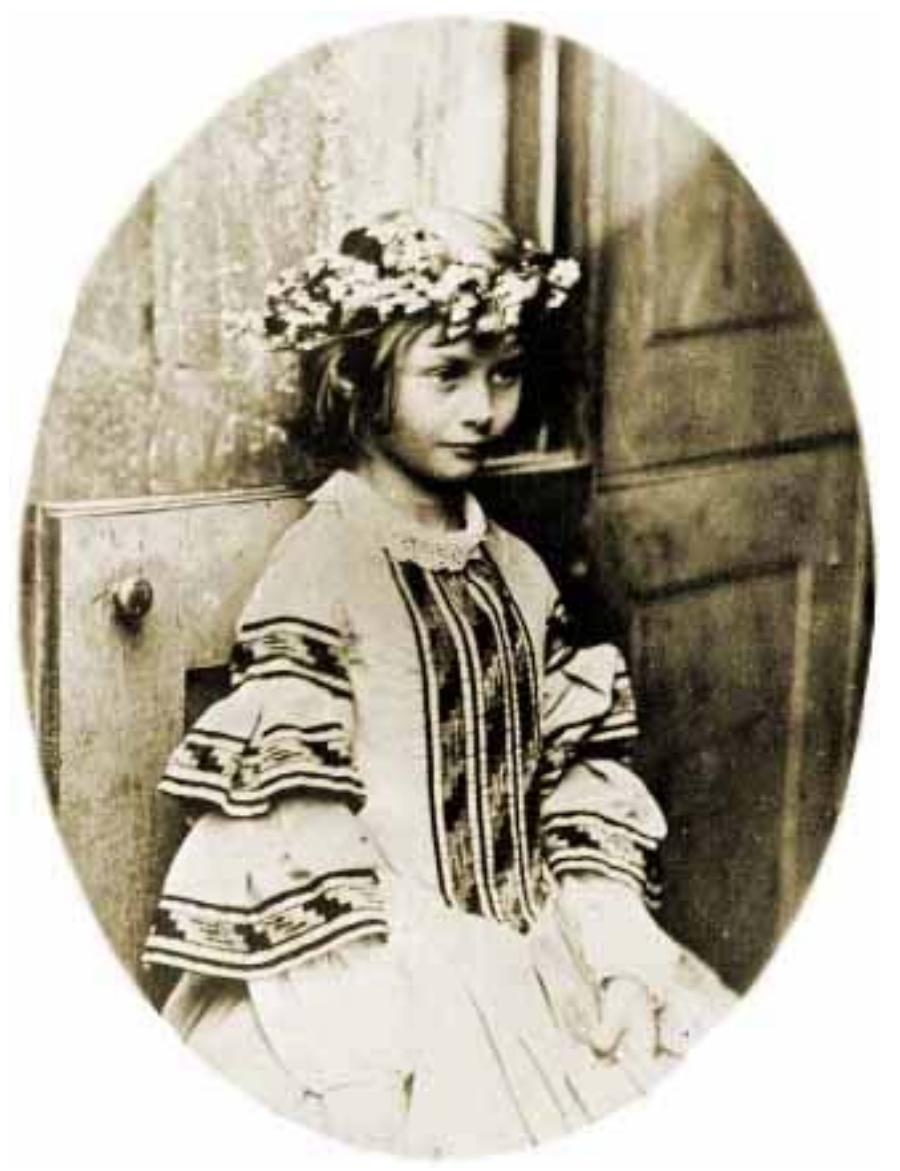

Fig. 66. Alice Liddell (c. 1860). 


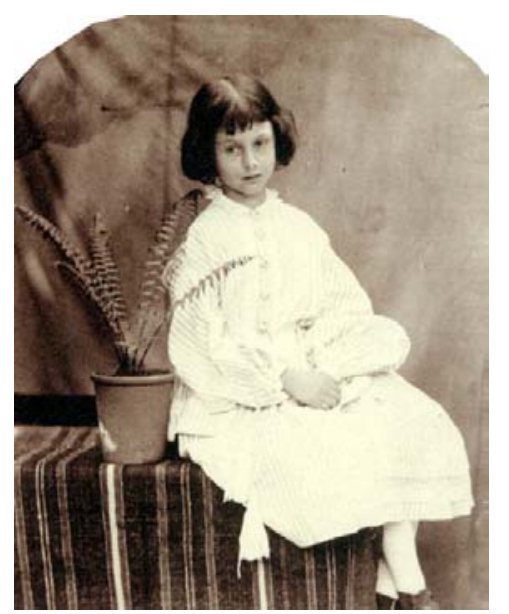

Fig. 67. Fotografía de Alice que utilizaría para el manuscrito de Aventuras Subterráneas de Alicia (1864).

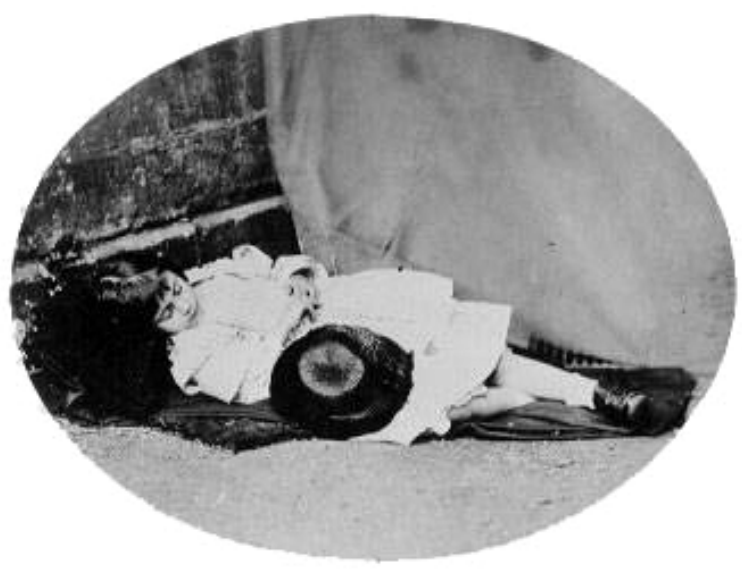

Fig. 68. Alice Liddell (s.a.).

Tal vez la primera fotografía que realizara de las Liddell sea en la que se encuentran sentadas frente a la casa familiar en la Christ Church de Oxford, en la que las niñas apenas se distinguen del conjunto por sus vestidos y sombreritos blancos.

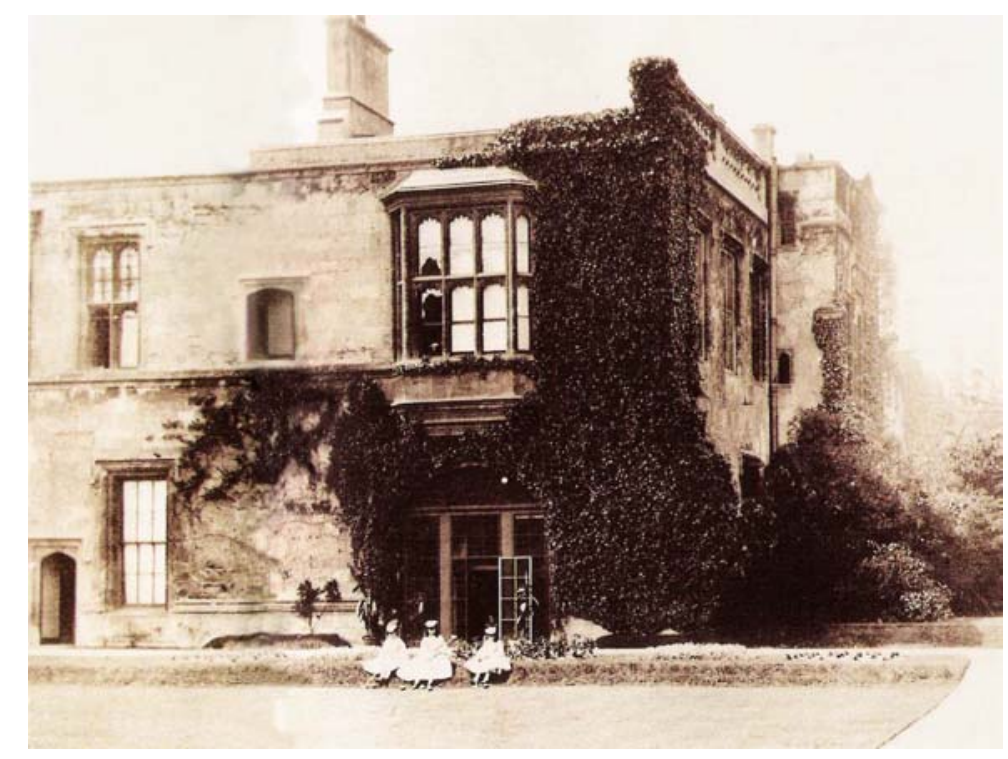

Fig. 69. Las 3 hermanas Liddell en el jardín del Dean en Christ Church (1856). 
Con Las cerezas. Abre la boca y cierra los ojos [The Cherry Group. Open your mouth and shut your eyes] (julio de 1860), realiza una fotografía de las tres hermanas Liddell, en la que Lorina sostiene unas cerezas mientras Alice con los ojos cerrados intenta cogerlas con los labios como si se tratara de un juego y junto a ellas sentada sobre una mesa, permanece pensativa Edith, la pequeña, con un montoncito de cerezas sobre el regazo.

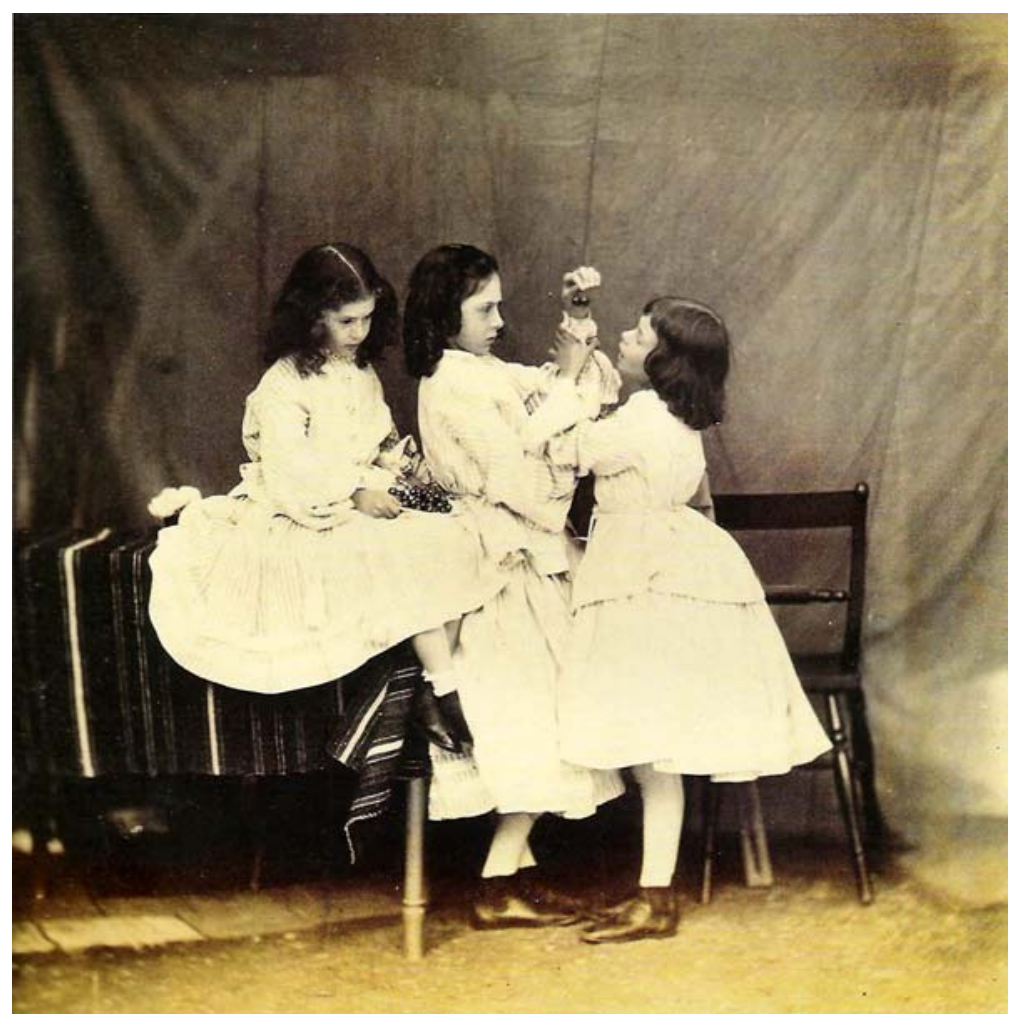

Fig. 70. Las cerezas. Abre la boca y cierra los ojos (julio de 1860).

En la foto de grupo Edith, Lorina y Alice Liddell (1859), las tres hermanas posan recostadas sobre un diván con los vestidos revueltos, colocando a Lorina, la mayor, en el centro y al lado izquierdo a Edith mirando de frente a la cámara apoyándose en su hermana y al otro lado, 
Alice, mirando a la cámara de $3 / 4$ y con las piernas flexionadas dejando ver parcialmente la piel de sus pantorrillas. Carroll repite la pose que ya hubiera utilizado apenas dos años antes en 1857, con las niñas Mary y Charlotte Webster y Margaret Gatey, en un exterior de Keswick.

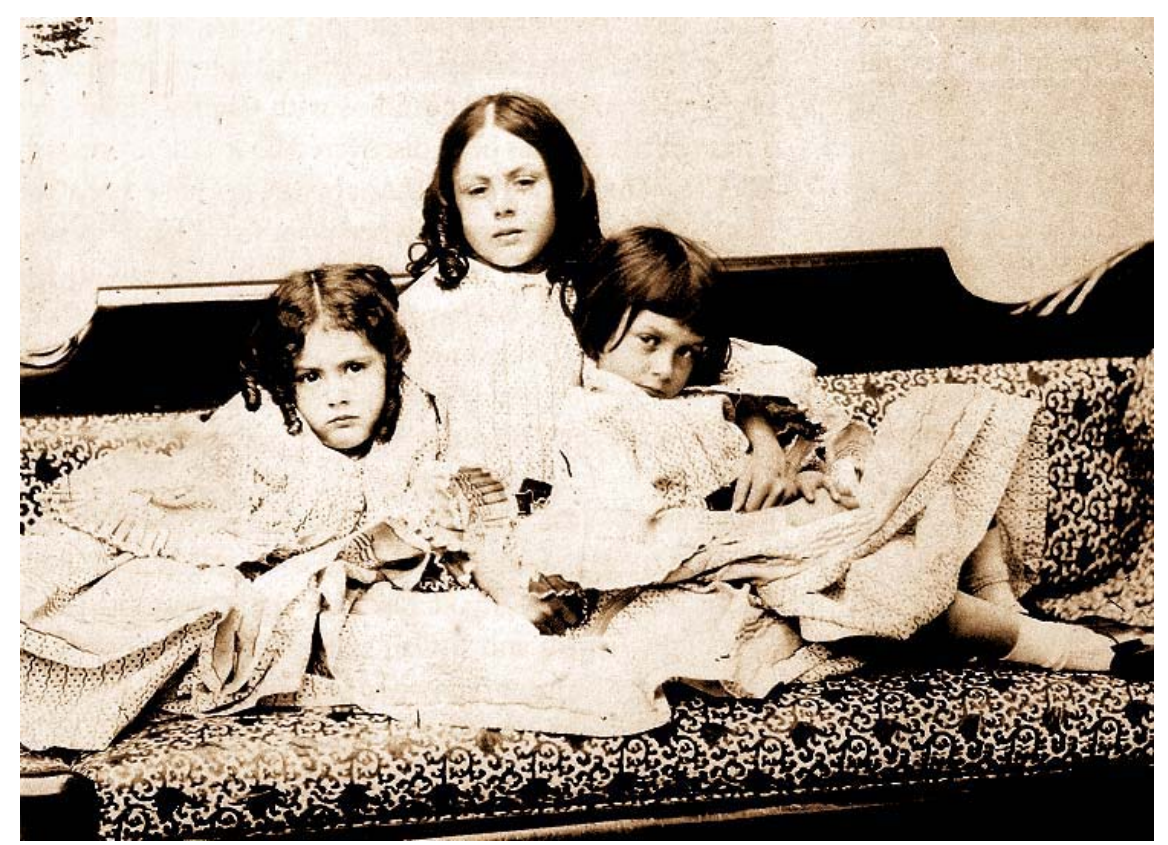

Fig. 71. Edith, Lorina y Alice Liddell (1859).

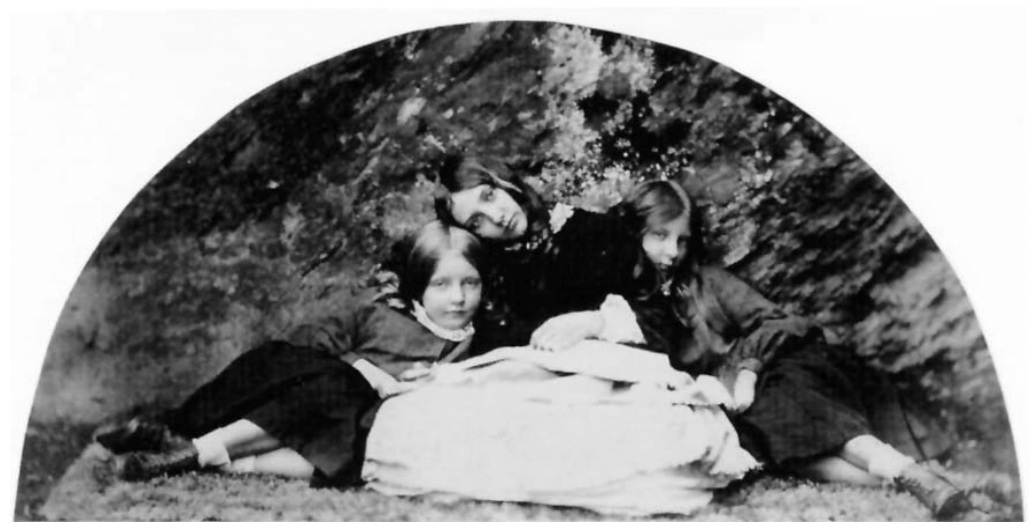

Fig. 72. Mary y Charlotte Webster y Margaret Gatey, Keswick (1857). 
En su afición por los disfraces, obtendría una fotografía de Lorina y Alice vestidas de chinas, ambas tocadas con bonete mandarín y portando una gran sombrilla china. Alice, prácticamente sentada en cuclillas sobre un sillón típicamente victoriano mira fijamente a la cámara, con una mirada consciente de ser fotografiada, de complicidad, mientras que Lorina sin embargo, permanece junto a ella de pie con la mirada perdida. El fondo es sobrio como era su costumbre, compuesto único por una tela en tono neutro.

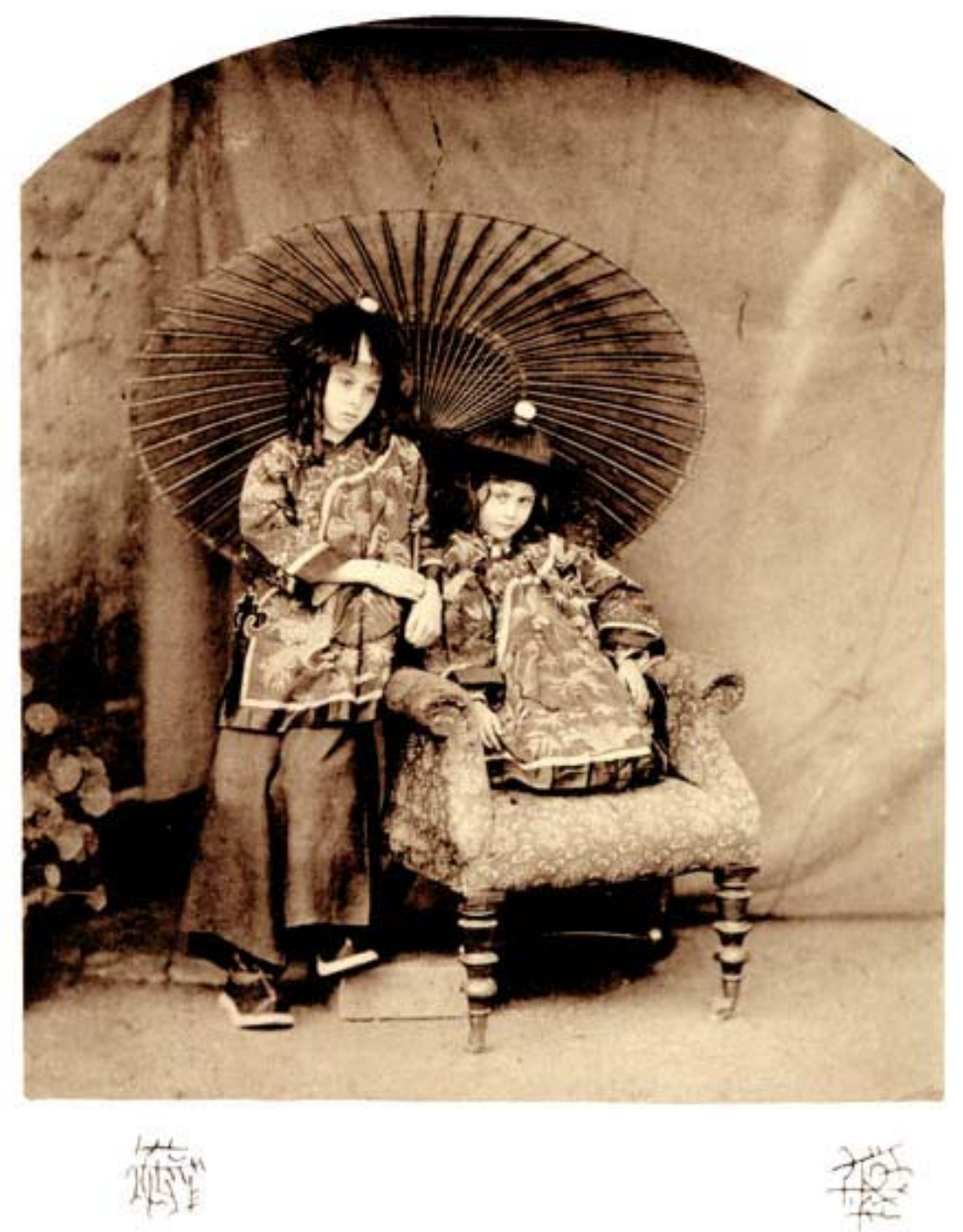

Fig. 73. Lorina y Alice Liddell disfrazadas de chinas (1860). 

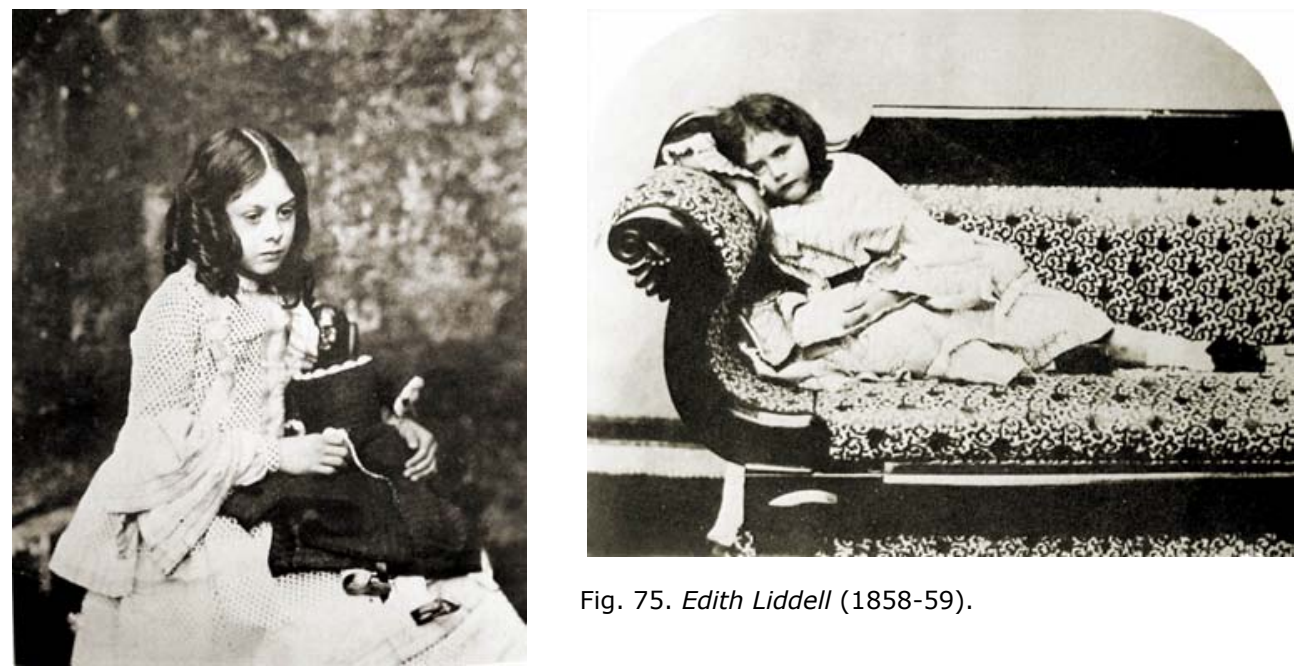

Fig. 75. Edith Liddell (1858-59).

Fig. 74. Lorina Charlotte Liddell (1858-9).

\section{Durante muchos años Carroll} dejó de tener contacto con Alice Liddell. Alice había crecido y la ruptura con la familia Liddell, los distanció irremediablemente. En 1870 realizaría una última fotografía de Alice convertida ya en una joven mujer ${ }^{90}$, así como de su hermana Lorina. Son retratos de estudio, en la que poco se puede ver ya de la amistad que unía a las niñas con el excéntrico Charles L.

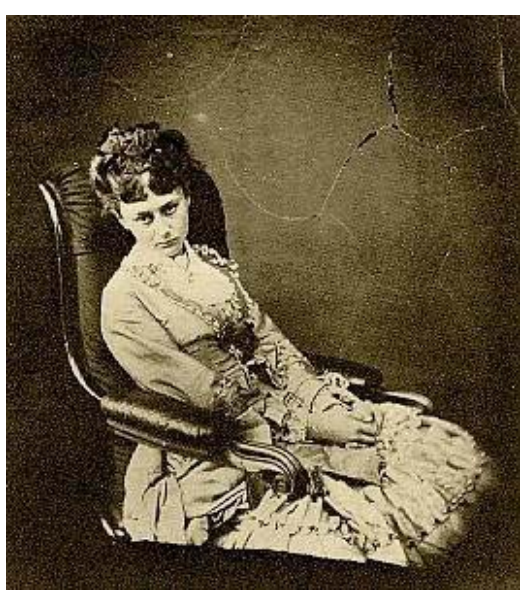

Fig. 76. Alice Liddell (1870). Dodgson.

\footnotetext{
90 Alice Liddell se casó casualmente con un ex alumno de Dodgson, Reginald Hardgraves, convirtiéndose en Mrs Hardgreaves en 1888. Sabemos que durante un tiempo tuvo un romance con el príncipe Leopold, hijo menor de la reina Victoria. La relación que resultaba del agrado para la señora Liddell fue coartada por la reina Victoria que evidentemente esperaba casar a su hijo con una noble.
} 



\section{6. «LAS NiñAS DEL CELULOIDE». LA PREADOLESCENTE EN EL CINE A COMIENZOS DEL SIGLO XX.}

La iconografía misógina y los tópicos femeninos, constituyeron una tradición perdurable en las nuevas formas de arte como el cine, que pronto se convirtió en un lenguaje internacional, difusor de los estereotipos femeninos occidentales.

El cine, desde sus inicios, ha condicionado y se ha visto condicionado por los avatares de la sociedad, convirtiéndose durante el pasado siglo $\mathrm{XX}$, en el instrumento más importante de transmisión de la historia y la cultura y sirviéndonos de referente respecto a la percepción que tiene el ser humano del mundo.

Si en la Inglaterra victoriana, los parámetros entre edad infantil y edad adulta no estaban delimitados claramente, en el siglo XX, ese proceso de búsqueda y definición permanecerá abierto, no siendo tanto la edad biológica la que marcase los criterios de infancia o adolescencia como la apariencia física de las jóvenes lo que contribuiría a crear iconos de feminidad y juventud basados en la ambigüedad entre la inocencia y el erotismo.

A diferencia del resto de las artes, el cine desde sus comienzos siempre ha dado importancia a los personajes infantiles. Jamás los ha obviado u olvidado durante su siglo de vida y es en este marco de la imagen en movimiento donde se han desarrollado $y$ «desgastado» las categorías de la preadolescencia y adolescencia, que en la actualidad se establecen y que han caracterizado los comportamientos y los roles sociales de la preadolescente durante el siglo XX. Tras la hipocresía y la represión sexual victoriana que mantenía oculta la prostitución infantil, la industria cinematográfica hollywoodiense 
tomaría como tema recurrente el erotismo de las niñas que se gestara durante el siglo XIX.

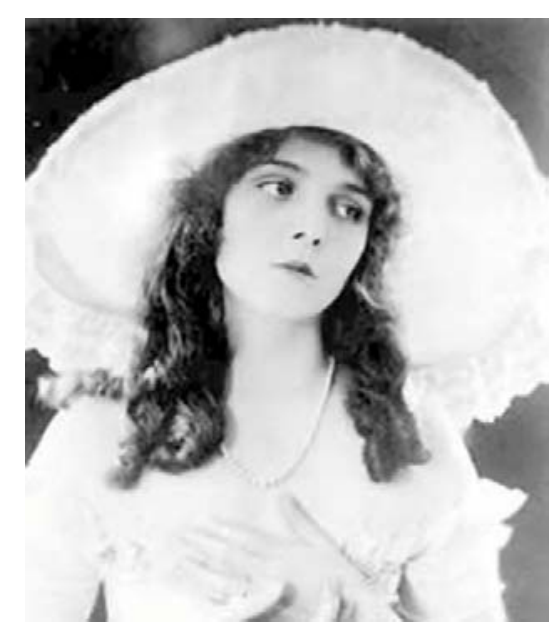

Fig. 1. Fotografía promocional de Olive Thomas.
Las primeras estrellas infantiles y adolescentes del cine norteamericano, cumplían los cánones físicos de la preadolescente o joven del siglo XIX y con el fervor de la nueva $y$ revolucionaria industria del cine, multitud de jovencitas marchaban a Hollywood con ansias de obtener una oportunidad profesional y de convertirse en estrellas del cine mudo, en imágenes, en iconos mediáticos, niñas jugando a ser adultas. Tal fue el caso de Olive Thomas (1894-1920),

que empezó a los 16 años y moriría a los 25 de sobredosis. Hollywood se convirtió en un Edén para cocainómanos, maníacos sexuales y pervertidos, en el que se vendía la imagen de mujeres-niñas eternas, de moralidad dudosa.

La vida privada de las jóvenes estrellas salió a la luz en numerosos casos, ante la atónita y estupefacta mirada pública que contemplaba cómo sus ídolos del celuloide se veían envueltos en escándalos. En 1912, la actriz y bailarina Virginia Rappe, de 25 años murió tras una salvaje fiesta organizada por el exitoso cómico del momento Roscoe Fatty Arbuckle, el cual fue acusado de la muerte de la actriz ${ }^{1}$. Tras tres juicios, fue absuelto pero la opinión pública lo declaró culpable. La prensa se cebó con la insinuación de que la

\footnotetext{
${ }^{1}$ Virginia Rappe llevaba una oscura vida en la que ejercía de prostituta ocasional. Se le habían realizado varios abortos, al parecer incluso uno pocos días antes de su muerte.
} 
muerte de la joven se produjo en una mezcla de sobrepeso y un apetito sexual desbordado y depravado del obeso Fatty. Casi una década más tarde, en enero de 1920, entre una larguísima lista de sospechosos y sospechosas por el asesinato del conocido director William Desmond Taylor, se encontraban las actrices Mabel Normand Mary Miles Minter y la madre de ésta, a las que se las relacionaba sexualmente con el difunto ${ }^{2}$.

Era conocida la obsesión del director David W. Griffith y del actor y también director Charles Chaplin entre otros, de perseguir adolescentes dentro y fuera de la pantalla. Además, la promiscua moralidad de la nueva joven de la década de 1920, chocaba con el físico aniñado, incluso ambiguamente masculino de las muchachas, las llamadas flappers ${ }^{3}$ que fumaban y bailaban $\mathrm{Hot}^{4}$.

Tras las futuras estrellas del celuloide se encontraba no solamente la figura del corruptor de menores de la industria del cine sino las ambiciosas madres deseosas de ver a sus hijas triunfar, fomentando la precocidad sexual y el sex-apple, como ocurriera con Judy Garland o inventando extrañas estratagemas para introducirse en el mundo del cine, como el anecdótico comienzo de la carrera de Mary Miles Minter (1902-1984). Durante su aparición en The Little Rebel (1911), llamó la atención de la Gerry Society ${ }^{5}$-sociedad que protegía los derechos de los niños actores-, la cual consideró que la entonces todavía llamada Juliet Shelby, era demasiado joven para trabajar la jornada completa y la sacaron de la producción. Pero su madre, hizo pasar el certificado de nacimiento de una hija suya fallecida a los 8 años

2 ANGER, Kenneth. Hollywood Babilonia, (vol. I y II). Barcelona: Editorial TusQuets, 1985, 1986.

3 Flappers es el nombre que se le daba a las jóvenes de la década de 1920, de carácter rebelde, gustaban de llevar una vida alocada, se cortaban el cabello, fumaban, bebían alcohol y bailaban Hot.

${ }^{4}$ El Jazz de principios del siglo XX que evocaba sonidos rítmicos y expresivos con influencia del Blues.

${ }^{5}$ El nombre oficial era New York Society for the Prevention of Cruelty to Children. 
por el de esta, llamándose entonces como su hermana fallecida, Mary Miles Minter, ahora con 16 años en lugar de ser Juliet Shelby de 11 años de edad.

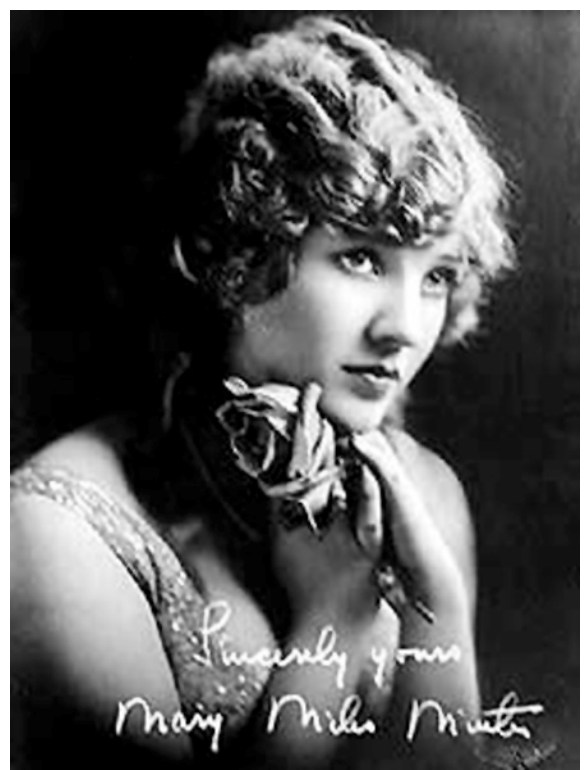

Fig. 2. Fotografía promocional dedicada de Mary Miles Minter.

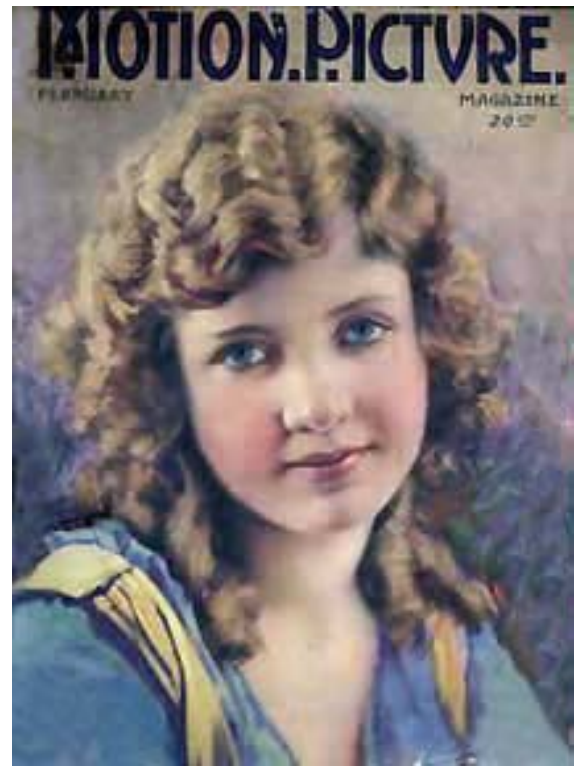

Fig. 3. Mary Miles Minter para la portada de la revista Motion Picture.

En esta combinación de inocencia y virtud frente a pecado, perversión, drogas y sexo, Hollywood fue recreando en sus producciones cinematográficas, iconos femeninos con características perversas como hicieran los artistas simbolistas, con Salomé o Pandora, favoreciendo la imagen femenina a través de icónicas vampiresas hollywoodienses. Sin embargo, tanto Europa como EEUU seguían todavía sumergidas en la moralidad victoriana, proliferando grupos y sociedades puritanas que luchaban contra el pecado y actuaban de censura.

Durante los comienzos del cine, la interpretación infantil no estuvo claramente establecida, pues fueron pocas las actrices que contaban con la edad de los personajes que interpretaban. En la 
mayoría de los casos sobrepasaban dicha edad, con lo que para dar verosimilitud, se caracterizaban con apariencia aniñada e infantil. Incluso los nombres artísticos de muchas de ellas, solían contener palabras relativas a la infancia y la inocencia, como Arline Pretty o Blanche Sweet. Las actrices pioneras del cine mudo, como Mary Pickford, Lillian y Dorothy Gish o Mary Miles Minter, interpretaría en la pantalla el estereotipo de personaje femenino indefenso que se presentaba en la literatura y el teatro del siglo XIX.

Un claro ejemplo es el personaje de Lilian Gish (1893-1993), en Lirios rotos $^{6}$ (1919) dirigida por David W. Griffith. La película cuenta el amor idealizado de un chino inmigrante en la Inglaterra de comienzos del siglo XX, por una jovencita maltratada -Lilian Gish-, que vive aterrorizada por la crueldad y brutalidad de su padre, un boxeador. El desenlace del drama finaliza con el de la muerte de la chica bajo el puño de su padre.

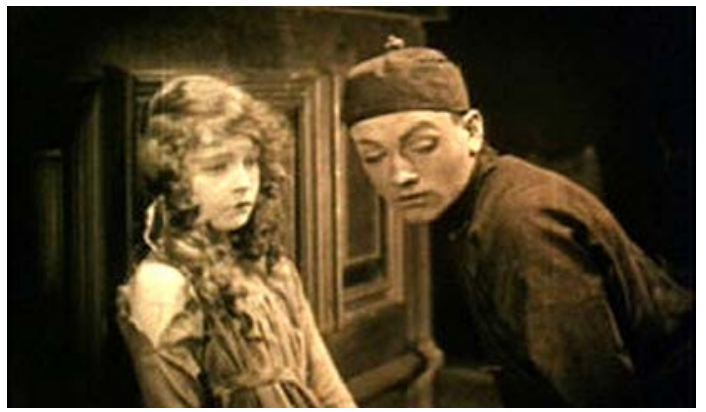

Fig. 4. Lilian Gish en Lirios rotos (1919).

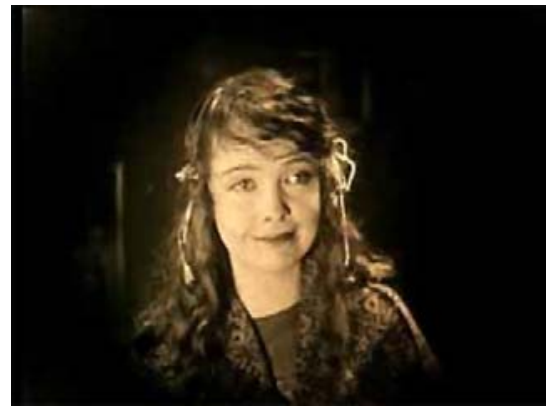

Fig. 5. Lilian Gish en Lirios rotos (1919).

El tópico se repetiría en innumerables películas de la época en las que los personajes de Charles Dickens sirvieron de referente fundamental para desarrollar aquellas primeras producciones del cine

\footnotetext{
${ }^{6}$ Lirios rotos o La culpa ajena (Broken Blossoms; The Yellow Man and the Girl; David W. Griffith, 1919).
} 
mudo de David W. Griffith, con protagonistas que vivían en la pobreza o la brutalidad del mundo adulto, en las que los agresores eran representados por hombres de mediana edad, apariencia sanguinaria, de raza negra o asiática y de nacionalidad alemana o francesa, lo que le llevó a ser acusado de chovinista y racista. Los efectos fotográficos y los ángulos de cámara acentuados eran recursos cinematográficos que ayudaban a empequeñecer el tamaño de las protagonistas y a crear la imagen de desprotección infantil que los personajes femeninos requerían.

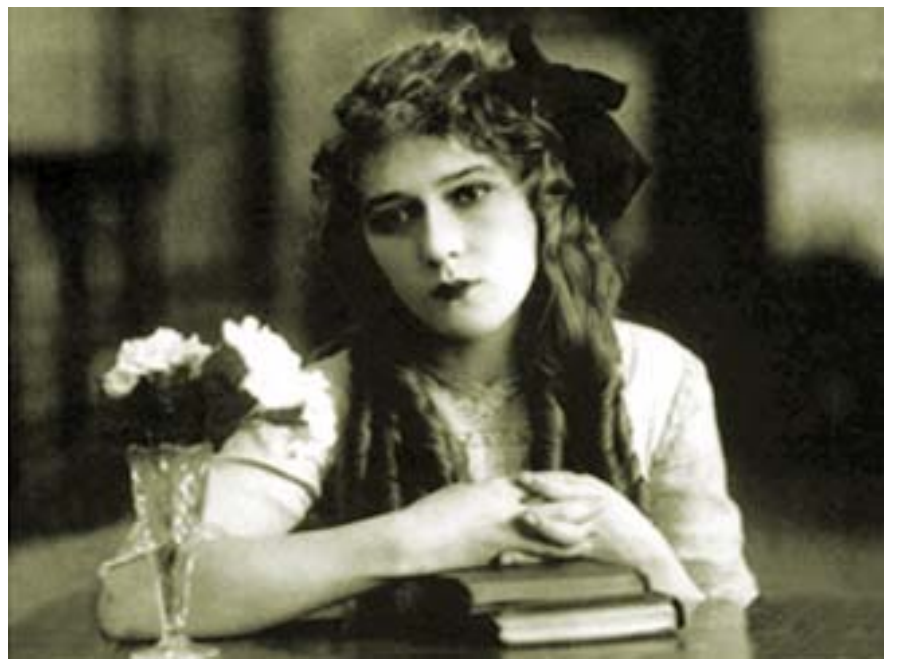

Fig. 6. Mary Pickford en Pobre niña rica (1917).

Mary Pickford (1893-1979), apodada la «Novia de América» [«America's Sweetheart»] fue la más famosa intérprete de papeles infantiles con un cuerpo adulto. Su nombre original era Gladys Smith, nacida en Toronto, Canadá. Comenzó su carrera a los 16 años y continuó haciendo papeles infantiles hasta los 20. Su vida privada, como la del resto de las actrices y actores de la época, era de dominio público. Tras divorciarse de Owen Moore, se casó en 1920 con Douglas Fairbanks. Ambos recreaban el matrimonio perfecto de belleza, éxito y dinero. 
Trabajó numerosas ocasiones con David W. Griffith, pero finalmente lo abandonó considerando que los papeles que éste le ofrecía eran un insulto para ella y su público. Consecuentemente, en 1919 creó su propia productora, United Artist ${ }^{7}$, de esta manera pudo dirigir, producir e interpretar sus propias historias. Su carrera, que duró cerca de dos décadas, comprende unos 50 largometrajes tales como Pobre niña rica ( $A$ Poor Little Rich Girl; Maurice Tourneur, 1917), Papa Piernaslargas (Daddy Long-Legs; Marshall Enhilan, 1919) o Pollyanna (Paul Henry Walter; 1920). En 1929, la diva de largos tirabuzones, se cortó el cabello, abandonando la pantalla, como ella misma explicaría: «Dejo la pantalla porque no quiero que me suceda lo que a Chaplin». Muchas de las estrellas del cine mudo, no sobrevivieron al cine sonoro. De ahí la decisión de Mary Pickford, de abandonar la pantalla antes de perder su imagen de estrella ante el público.
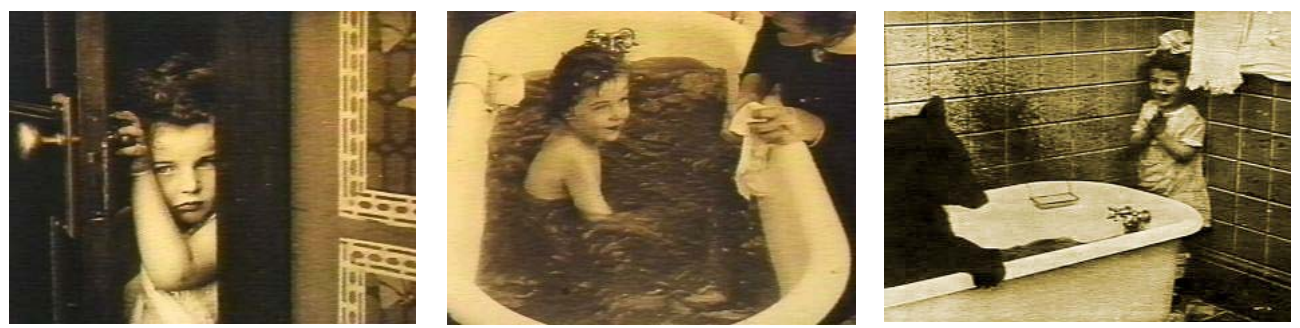

Fig. 7, fig. 8 y fig. 9. Baby Mary Osborne en varios fotogramas de Little Mary Sunshine (1916).

Las actrices infantiles del cine mudo, se convertían habitualmente en la principal fuente económica de su grupo familiar. Así sucedería con la pequeña de nombre artístico Baby Mary Osborne (1911), descubierta mientras jugaba en el Balboa Studio, por el actor y director Henry King, que escribiría para ella Little Mary Sunshine (1916) con la que comenzaría

\footnotetext{
7 United Artist fue fundada en 1919 por Charles Chaplin, Mary Pickford, Douglas Fairbanks y D. W Griffith.
} 
a considerarse la estrella infantil favorita de la audiencia norteamericana durante la $1^{\text {a }}$ Guerra Mundial.
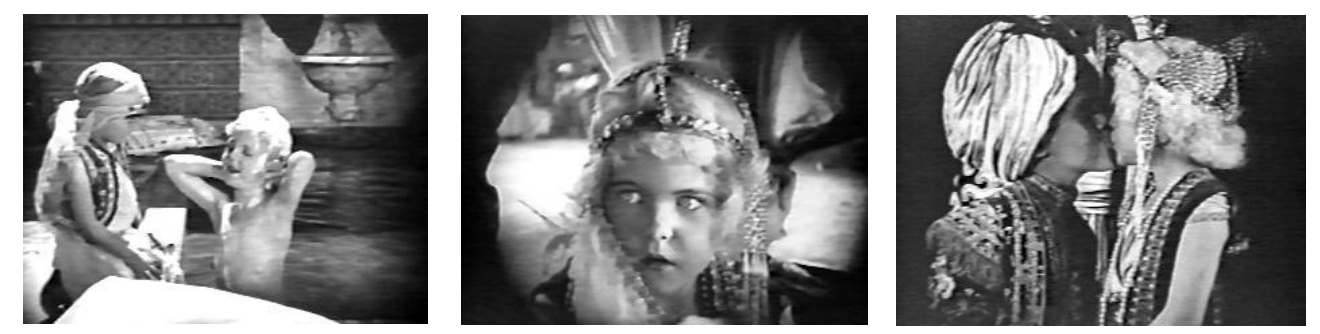

Fig. 10, fig. 11 y fig. 12. Virginia Lee Corbin en Aladino y la lámpara maravillosa (1917).

Virginia Lee Corbin (1910-1942) resultó tener unas dotes interpretativas excepcionales para los personajes emotivos 0 dramáticos, de hecho se la llamaba la «Dresden Dol/ ${ }^{8}$ de las películas» o «la más joven estrella emocional» ${ }^{9}$. En 1916 firmaba con la 20th Century Fox para la que realizaría cuatro producciones infantiles, con las que se convertiría en una de las primeras estrellas verdaderamente infantiles. Seguiría trabajando en el cine con papeles de flappers al alcanzar la adolescencia y en espectáculos de vodevil hasta su muerte tras una larga enfermedad a los 31 años de edad. Las interpretaciones de las niñas serían una mímesis del mundo adulto adaptado a sus pequeños cuerpos lo que implicaba que al igual que sus colegas adultas, ellas también interpretaban escenas de seducción o de drama, en las que repetían los roles femeninos adultos. Así Virginia Lee Corbin aparecía bañándose como una princesa oriental o besando a su amado en Aladino y la lámpara maravillosa (Aladdin and the Wonderful Lamp; Chester M. Franklin, Sydney Franklin, 1917) o la pequeña Baby Peggy (1918) -otra de las estrellas infantiles favoritas del cine mudo- siendo besada en los

\footnotetext{
${ }^{8}$ Dresden Doll una variedad de rosal enano.

${ }^{9}$ «The Dresden Doll of the Movies» $\mathrm{y}$ «The Youngest Emotional Star» respectivamente.
} 
labios «amorosamente» por un maduro capitán de barco que cuida de ella en El capitán alegría (Captain January; Edward F. Cline, 1924).
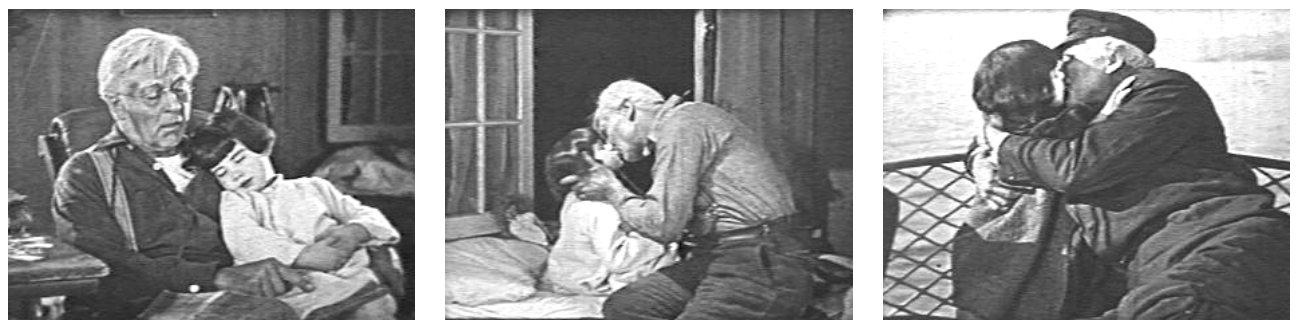

Fig. 13, fig. 14 y fig.15. Baby Peggy en El capitán alegría (1924).

Poco a poco la industria cinematográfica introdujo en papeles estelares a las jóvenes actrices como Shirley Temple, Margaret O'Brian o Elizabeth Taylor. Este fenómeno se dio principalmente en las décadas de 1930 y 1940, sin embargo en la década de los veinte, sirvieron de ensayo para lo que acontecería más tarde con las actrices preadolescentes de las siguientes décadas. Sus personajes se definían dentro de interpretaciones que iban destinadas sobre todo al género melodramático, donde las niñas mostraban sus capacidades artísticas de canto y baile, hasta el género dramático. No eran personajes creados para un público infantil, sino para uno adulto que como ocurriera durante el siglo XIX con la fotografía y la ilustración infantil, «consumía» la imagen infantil, desarrollada ahora en iconos cinematográficos de moda.

Si durante las dos primeras décadas del siglo XIX las actrices jóvenes interpretaban papeles infantiles, generando una imagen de la inocencia ambiguamente sensual en cuerpos adultos, será durante la década de 1930, cuando esos mismos papeles que contenían escenas de seducción y que no suponían un problema para las actrices -pues eran ya adolescentes o adultas-, comenzaron a ser interpretados por niñas 
de la edad representada. Fue precisamente durante ésa misma década, que apareció uno de los iconos infantiles más populares del cine de todos los tiempos, la pequeña Shirley Temple (1928), la niña prodigio de tirabuzones rubios. «Miss Curly Top ${ }^{10}$, como se le conocía de apodo, protagonizó numerosos remakes de los clásicos de Mary Pickford, como Pobre Niña Rica (Poor Little Rich Girl; Irving Cummings, 1936), Rebecca of Sunnybrook Farm (Alna Dwan, 1938), La princesita (The Little Princess; Walter Lang, 1939). Durante unos años se convirtió en la persona más fotografiada del momento, recibía unas 500 cartas al día y se fabricaban juguetes, muñecas, jabones y otros tantos productos con su imagen. De modo significativo, Shirley Temple era la estrella favorita del público adulto y no la del público infantil. A menudo, sus actuaciones eran básicamente parodias o imitaciones de un prototipo de sexualidad y de coquetería femenina adulta, que la precoz niña ejecutaba seduciendo a hombres de mediana edad, en combinación con números musicales y de baile. La serie Baby Burlesks (1932) de Charles Lamont es un buen ejemplo de sus comienzos, en los que la virginal Shirley Temple actúa a lo Marlene Dietrich, intentando crear un icono de sexualidad infantil femenina que el público gustaba de ver en la pantalla. El novelista Graham Greene señalaría que sus principales admiradores eran los hombres de mediana edad y los clérigos ${ }^{11}$. En Wee Willie Winkey (1937) de John Ford, Shirley Temple «emana una sensualidad adulta disfrazada bajo la apariencia de niña», afirmaría Greene ${ }^{12}$. Bajo esas mismas pautas de coquetería, realizaría sus interpretaciones en Kid 'in' Africa (Jack Hays; 1932), como Madame Craddlebait, una bella misionera en

10 «Señorita tirabuzones», apodada así por la película Una Pequeña Cupido (Curly Top: Irving Cummings, 1935).

11 WOOD, Bret. "Lolita Syndrome". Sight and Sound. June, 1994, pág. 34.

12 «Infancy with her is a disguise, her appeal is more secret and more adult... her neat and welldeveloped rump twisted in the tape dance: her eyes had a sidelong searching coquetry». WOOD, Bret. Ibíd. 
pantalones cortos en la selva africana, guiando una expedición para «domesticar» a los caníbales y que es salvada de ser cocinada en un gran caldero por Tarzán. En War Babies (Charles Lamont; 1932) interpreta a un camarera francesa en tiempos de guerra. En esta película Shirley Temple recibiría su primer beso cinematográfico. Incluso llegaría a interpretar el papel de prostituta en Polly Tix in Washington (Charles Lamont, 1933), con tan sólo 4 años.

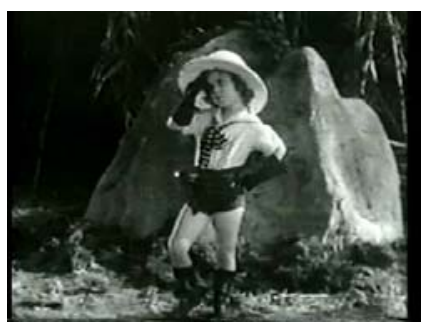

Fig. 16. Shirley Temple en Kid 'in' Africa (1932).
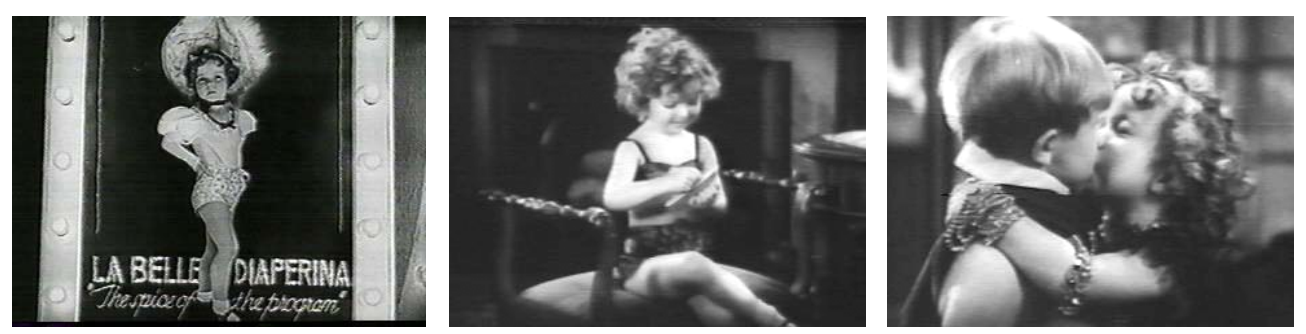

Fig. 19, fig. 20 y fig. 21. Shirley Temple en Baby Burlesks (1932).

Shirley Temple se retiraría definitivamente del cine en 1949, pues la precocidad que la había convertido en estrella inigualable e insustituible de la 20th Century Fox durante la década de los 40, crecería inevitablemente convirtiéndose en una adolescente, que ya sólo obtenía papeles secundarios, en películas que sin embargo alcanzarían un buen resultado de taquilla y crítica como Fort Apache (John Ford; 1948) o la comedia El solterón y la menor (The Bachelor 
and the Bobby-Soxer; Irving Reis, 1947). En ésta última, Shirley Temple interpreta a Susan Turner, una joven adolescente que vive con su hermana mayor, la jueza Margaret Turner. Susan conoce al atractivo pintor Richard Nayer -Gary Grant- durante una conferencia que éste imparte en el instituto de la adolescente, e inmediatamente se enamora de él. Decide entrar en el apartamento de «Dick» diminutivo de Richard- con el propósito de posar como modelo para él, pero la situación se vuelve comprometida para Dick, que acaba en la sala de justicia de la jueza Margaret Turner, la cual ya lo conocía por ser un habitual en peleas y escándalos en clubs nocturnos. Comprendiendo que la situación había sido creada por el encaprichamiento de la joven, la jueza dictamina que Richard, debe salir de vez en cuanto con Susan, para que se desanime y termine su enamoramiento juvenil por un hombre adulto. En palabras del tío Matt, psiquiatra del juzgado, se trataría de una «medida terapéutica vital», a lo que Dick responde con ironía: «recomendado para niñas...», refiriéndose a sí mismo. Curiosamente el título que se le dio a la película en castellano, alude significativamente al estado civil de los personajes, más rotundamente que los títulos originales en inglés. A pesar de tratarse de una enrevesada comedia aparentemente superficial con los actores más carismáticos del momento, como eran Cary Grant, Myrna Loy y Shirley Temple, el guión de Sidney Sheldon -Oscar la mejor guión original de 1947-, nos muestra en clave de comedia el ingenuo modo de entender las relaciones amorosas/sexuales entre adultos y menores. Es significativo el primer encuentro de ambas hermanas durante el desayuno, cuando Susan le pregunta a Margaret respecto a la pena que le impuso al «viejo que se fugó con una chica de 16 años», a lo que ésta contesta: «Tres años». He aquí la pena que impone la justicia por tal delito, pero la conversación va más allá cuando Margaret pregunta a la sirvienta 
cual es su opinión respecto al tema, a lo que ésta contesta: «yo le hubiese echado diez años», y es aquí cuando la respuesta se hace eco de lo que verdaderamente opina la sociedad sobre este tipo de relaciones.
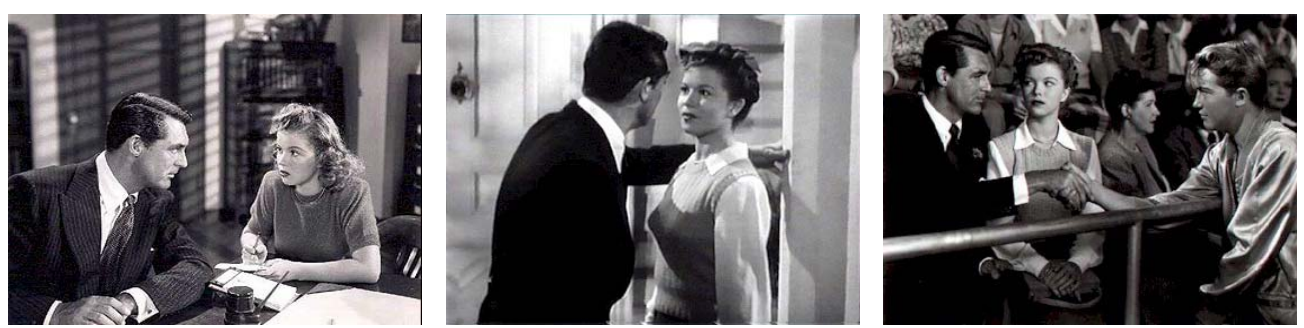

Fig. 22, fig. 23 y fig. 24. Shirley Temple y Cary Grant en El solterón y la menor (1947).

Margaret O'Brian (1937), a diferencia de Shirley Temple, carecía verdaderamente de dotes de canto y baile. Fue su locuacidad, su carácter impetuoso, su facilidad para los acentos, sus dotes interpretativas como comediante o sus exagerados llantos infantiles ninguna otra actriz infantil resultaría más convincente llorando ante las cámaras-, los que la convirtieron en una de las estrellas infantiles imprescindibles del momento.

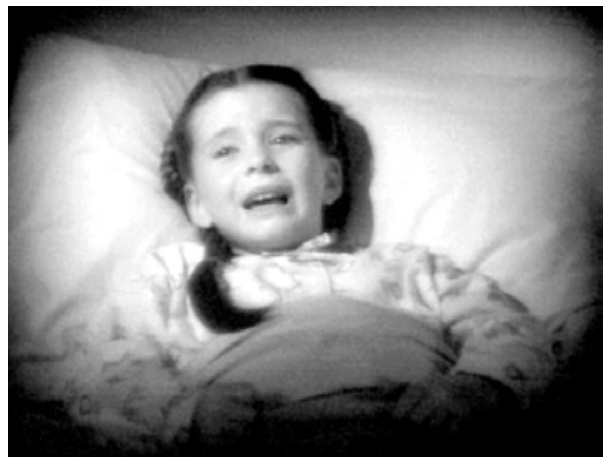

Fig. 25. Margaret O'Brian en Lost Angel (1943).

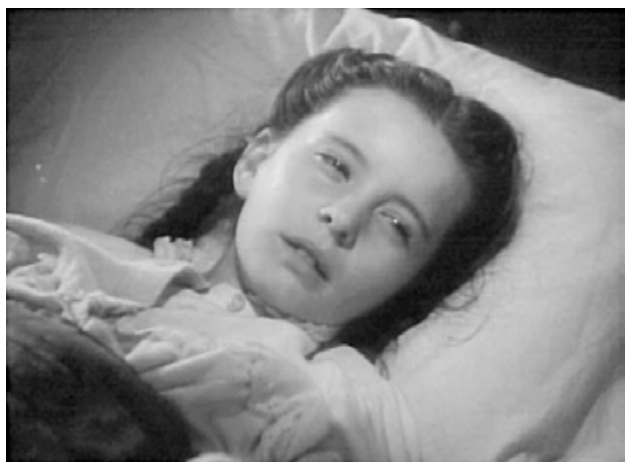

Fig. 26. Margaret O’Brian en Bad Bascom (1946). 
Comenzó como modelo, pero pronto la contrató la MGM. Cuando con tan sólo seis años de edad, trabajó en Cita en St. Louis (Meet Me in St. Louis; Vincente Minnelli, 1944), su madre le explicó a Minnelli, que «la manera de hacer que la niña llorara, era que alguien le dijera que iban a matar a su perrito y que si esto no bastaba, se le podía contar con detalle las atrocidades que le harían y lo mucho que sufriría el animalito». La histeria infantil, la obsesión por la muerte, la enfermedad, las heridas, la maldad y las diabluras infantiles son las características de Margaret O'Brian en ésta película en el que interpreta a Tootie, la hija menor de una familia de clase media-alta, que esperan con impaciencia la Exposición Universal de 1903 en la ciudad en la que viven, St. Louis. La obsesión con la que Tootie habla de las enfermedades de su muñequita, de manera precoz y con morboso interés nos indican el carácter neurótico de la niña. Además de ser potencialmente peligrosa con el tipo de travesuras que comete, como hacer descarrilar el trolebús. Sólo el ataque de cólera de Tootie, contra los muñecos de nieve la noche de Navidad, hace que finalmente el padre cambie de opinión respecto a la mudanza y cambio de residencia a la ciudad de Nueva York. Es aquí donde se observa la confrontación de la visión de la fragilidad infantil frente al «poder» que pueden ejercer las niñas en las decisiones de los adultos.
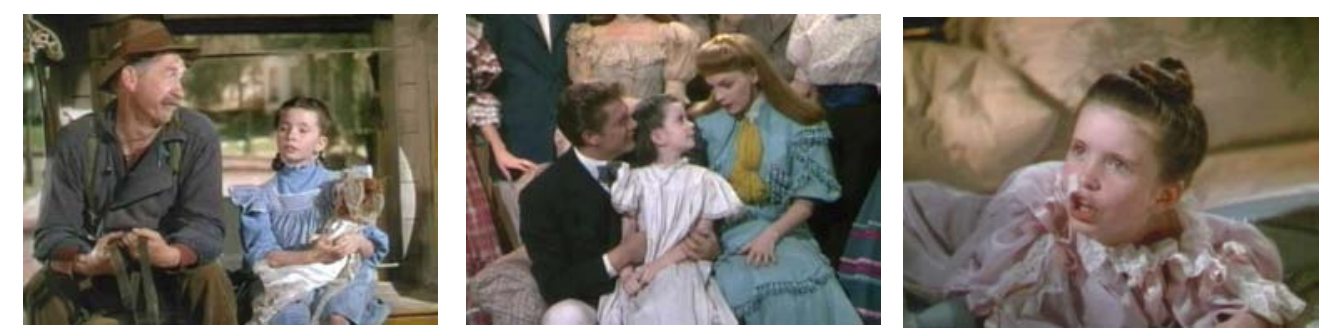

Fig. 27, fig. 28 y fig. 29. Margaret O'Brian en Cita en St Louis (1944). 


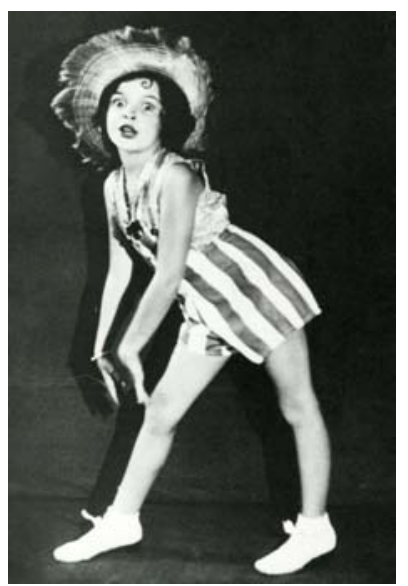

Fig. 30. Fotografía promocional de Baby Gum (1929).

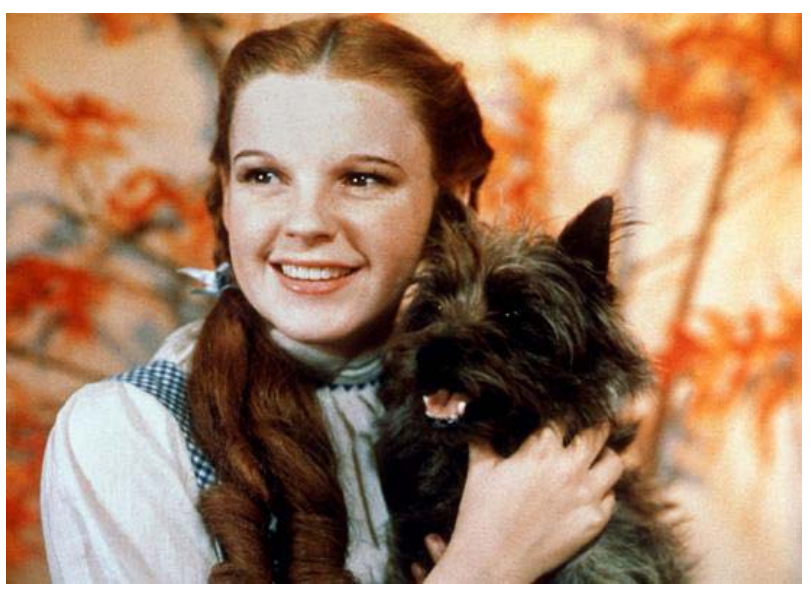

Fig. 31. Judy Garland en El Mago de Oz (1934).

Por aquel entonces Judy Garland (1922-1969), compañera de reparto de Margaret O'Brian en Cita en St. Louis, ya era una artista de reconocido prestigio. En sus comienzos infantiles, su nombre artístico era el de Baby Gumm. Las hermanas Virginia, Sue y Frances Gumm, que formaban el conjunto artístico de las «Gumm Sisters», cambiaron su apellido por el de «Garland» y Frances cambió su nombre por el de «Judy». Al igual que la madre de Margaret O'Brien, la madre de Judy, utilizaba métodos y trucos similares para hacer llorar a la pequeña o la amenazaba con abandonarla, cosa que hacía con sus otras dos hijas. A pesar de contar con una voz estupenda, Judy no se caracterizaba por su belleza física, todo lo contrario, cuando llegó a la Metro Goldwyn Mayer la sometieron completamente a cambios estéticos, desde enderezarle los dientes, hasta someterla a cirugía y a tratamientos de adelgazamiento con píldoras, dietas. Cuando contaba con catorce años, ya corrieron rumores de un romance entre ella y Louise B. Mayer, directivo de la Metro. El sentimiento de inferioridad, su constante búsqueda de aceptación y cariño y su problema con las drogas, la 
acompañarían durante toda su vida. Judy fue conocida principalmente por su personaje de Dorothy en El Mago de Oz (The Wizard of Oz; Victor Fleming, 1934), para el cual se pensó inicialmente en alguien mucho más joven, que no era otra sino Shirley Temple que tenía diez años, pero estaba contratada por la 20th Century Fox. Judy tenía entonces dieciséis años, y tuvo que ser caracterizada como una joven de menor edad, lo que creó una ambigua imagen de preadolescente. Sin embargo este elemento de irrealidad, no nos resulta tan irracional pues el público estaba acostumbrado a ver actores y actrices que no se correspondían con la edad de los personajes como ocurriera con las primeras actrices del cine mudo, Mary Pickford o Lilian Gish.
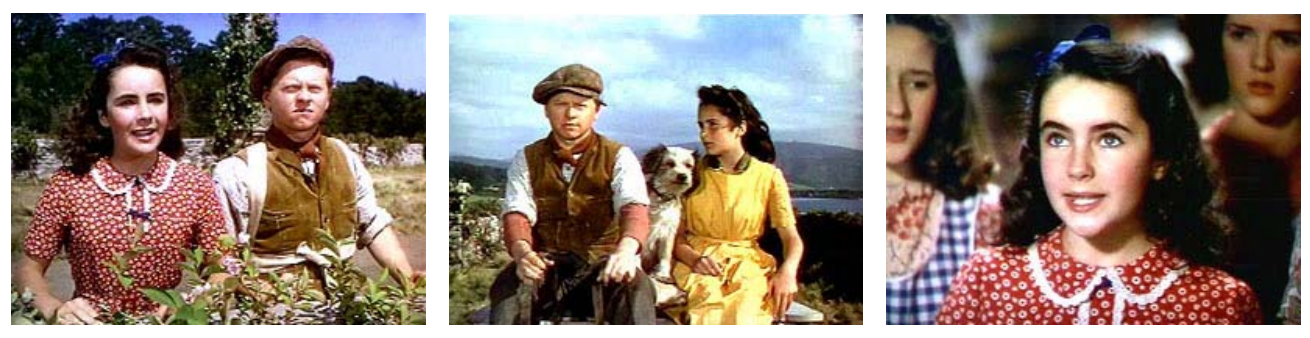

Fig. 32, fig. 33 y fig. 34. Judy Garland junto a Mickey Rooney en Fuego de Juventud (1944).

Elizabeth Taylor (1932), no llegó a ser considerada verdaderamente una gran actriz hasta que no llegó a la adolescencia. Cierto es que, gracias a su físico de muñeca y sus ojos color violeta, Elisabeth se convirtió en la niña más bella del celuloide, pero los papeles que se le ofrecían únicamente ensalzaban su físico como elemento decorativo en películas infantiles y con animales. Se la comenzó a conocer sobre todo por sus papeles en Lassie (Lassie Come Home; Fred M. Wilcox, 1943) o Fuego de Juventud (National Velvet; Clarence Brown, 1944). Liz creció relativamente pronto y cuando todavía era una adolescente, los papeles que se le ofrecieron fueron los de femme fatale o mujeres de fuerte carácter. 


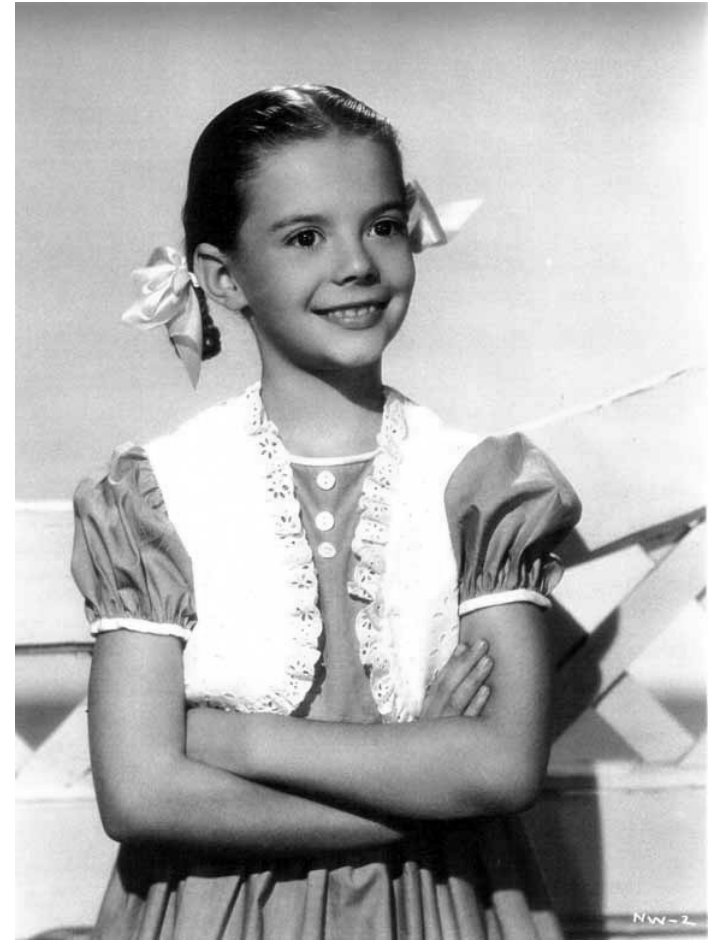

Fig. 35. Fotografía promocional de Natalie Wood, a finales de la década de 1940 .

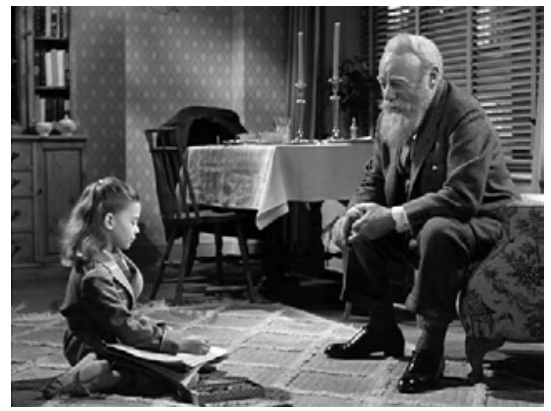

Fig. 36. Natalie Wood en Milagro en la calle 34 (1947).

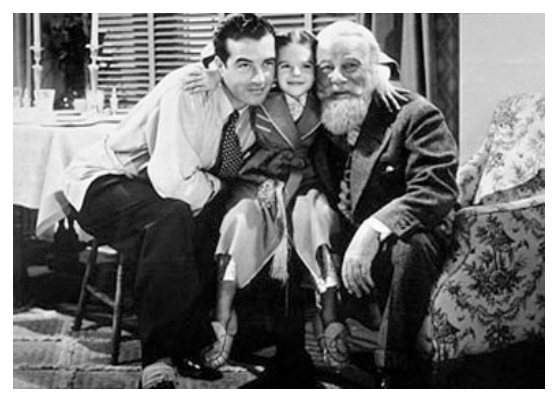

Fig. 37. Natalie Wood en Milagro en la calle 34 (1947).

Natalie Wood (1938-1981), sin embargo desde sus comienzos obtuvo un gran reconocimiento a pesar de su juventud. Comenzó su carrera cinematográfica como extra con cuatro años de edad por el entusiasmo hollywoodiense de su madre, una bailarina clásica de origen ruso. Pero su capacidad interpretativa con personajes frágiles y enternecedores se vio pronto recompensada con numerosos premios y críticas favorables como el ser considerada en 1947, la «actriz infantil con mayor talento del año» por la revista Parents Magazine, o en 1949 elegida la «estrella infantil del año» por el Children's Day Council de Nueva York, gracias a sus interpretaciones en películas como Mañana es vivir (Tomorrow is Forever; Irving Pichel, 1946) interpretando a una refugiada vienesa rescatada por Orson Welles, o Milagro en la calle 34 
(Miracle on 34th Street; George Saeton, 1947). Su carrera se prolongó durante su edad adulta hasta su dramática muerte -ahogada en el mar en extrañas circunstancias- con algunas de las más famosas películas del siglo XX, como Rebelde sin causa (Rebel Without a Cause; Nicholas Ray, 1955) Esplendor en la hierba (Splendor in the Grass; Elia Kazan, 1961) o West Side Story (Jerone Robbins; Robert Wise, 1961).

Las dificultades de las actrices adolescentes para conseguir buenos papeles o papeles que fueran del gusto del público a medida que iban creciendo, provocaron que sólo unas pocas actrices infantiles como Judy Garland o Elizabeth Taylor pudieran mantenerse como estrellas taquilleras durante toda su carrera cinematográfica sobreviviendo al éxito de sus infancias.

Algunas obtendrían un gran éxito sólo durante su más tierna infancia, como Baby Sandy (1938) que durante su corta carrera -que finalizaría a los 4 años de edad-, llegaría a ser portada de la revista Life, a ser el «Bebé del año» para la Parents Magazine en 1940 y a tener su propia butaca con su nombre en rojo en el

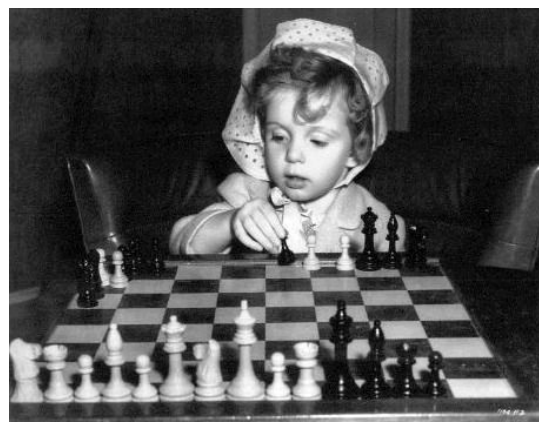

Fig. 38. Baby Sandy en Bachelor Daddy (1941). plató de la Universal Pictures.

En el caso de las actrices Deanna Durbin (1921) o Gloria Jean (1926) lograron grandes éxitos de taquilla durante sus años de adolescencia como iconos de la juventud de manera momentánea. Tras esa etapa, muchas de ellas, no lograban sobreponerse a los antojos del público y del mercado cinematográfico y sólo conseguían trabajos menores, anuncios de televisión o empleos ajenos al mundo 
cinematográfico como Shirley Temple o Margaret O'Brien, que prolongaron sus carreras durante una década aproximadamente con papeles secundarios. La carrera fulgurante de éstas niñas, a menudo era tan sólo el preámbulo de una vida adulta repleta de alcoholismo, drogadicciones, rupturas amorosas y matrimoniales o problemas médicos. El éxito a tan temprana edad, la opulencia, codeándose con las revistas más glamorosas dedicadas a las estrellas, como Modern Screen y Photoplay, hacía que estas niñas vivieran una vida ajena a su naturaleza infantil, convirtiéndose en las trabajadoras que realmente mantenían a sus familias.

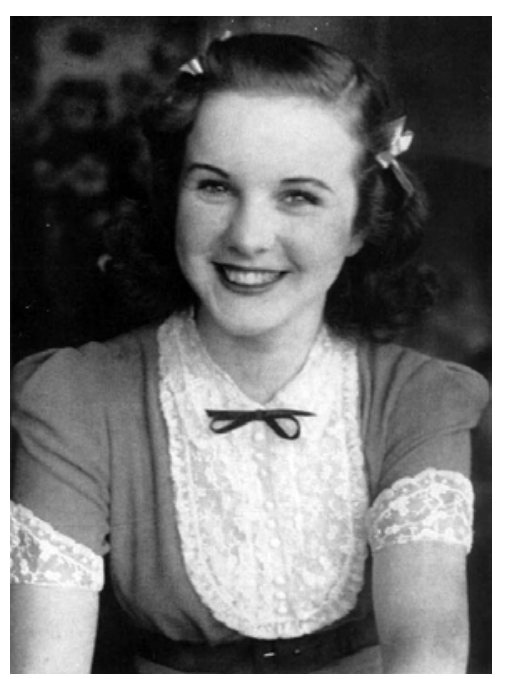

Fig. 39. Fotografía publicitaria de Deanna Durbin en 1936.

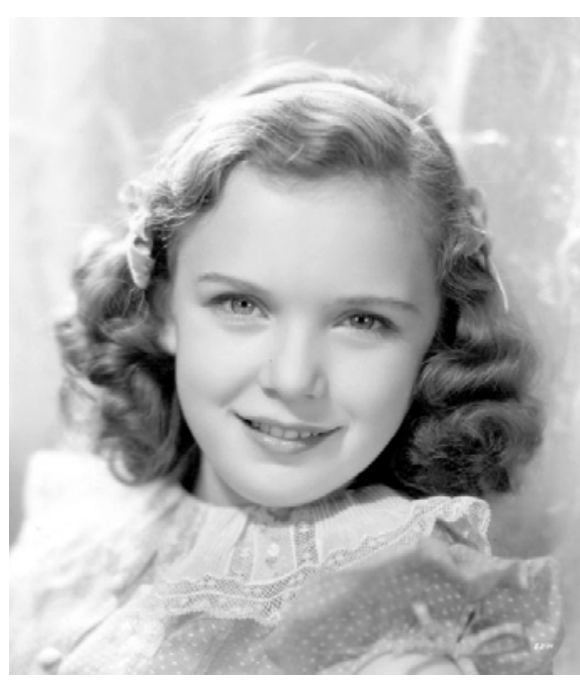

Fig. 40. Fotografía publicitaria de Gloria Jean, a finales de la década de 1940. 



\section{BALTHUS.}

\subsection{Sobre Baltasar Klossowski de Rola.}

Analizar la representación de la preadolescente en la pintura de Baltasar Klossowski de Rola, Balthus (1908-2001), se convierte en una apasionante y absorbente odisea de uno de los pintores más longevos del siglo XX. Es una obra que va más allá de los iconos femeninos y los simbolismos superficiales, en la que el trabajo del pintor en su taller da lugar a un diálogo entre perturbadoras imágenes de niñas desnudas y la búsqueda sincera de la belleza bajo una concepción religiosa de la pintura.

Nació en París, pero durante su infancia y juventud viviría en Berlín, Berna y Ginebra. Sus padres, ambos artistas e intelectuales contaban con un nutrido grupo de amistades del mundo del arte y la cultura. Tuvo una formación artística autodidacta, haciendo copias en los museos y estudiando a los primitivos italianos como le aconsejara Pierre Bonnard y Maurice Denis tras mostrarles sus pinturas y dibujos. Encontraría apoyo y ayuda por parte del poeta Rainer Maria Rilke que a comienzos de la década de 1920, mantenía una relación sentimental con su madre, la artista llamada Baladine Klossowska -Elisabeth Dorothea Spiro $^{1-}$. Durante la primera mitad del siglo $\mathrm{XX}$, diseñó numerosas escenografías teatrales y cinematográficas, mientras su pintura se mostraba en diferentes galerías y museos como la exposición del Museo de Arte Moderno de Nueva York en 1957. En 1961 fue elegido director de la Villa Médicis de Roma de la que se hizo cargo hasta 1977. Ese mismo año se instalaría en un antiguo chalet en Rossinière, Suiza, una casa en la que hasta el día de su muerte, alternaba el concienzudo

\footnotetext{
${ }^{1}$ Sería precisamente Raine Maria Rilke, quién aconsejara a Balthus que adoptara el pseudónimo de «Baltusz», como le llamaban de niño.
} 
trabajo de taller con las numerosas visitas de amigos y admiradores desde el director de cine Federico Fellini, al cantante Bono del grupo de rock $U 2$.

Durante gran parte del siglo $X X$, su obra encontró el reconocimiento oportuno gracias a un grupo de incondicionales intelectuales, coleccionistas o artistas como André Derain o Albert Camus. Jamás se identificó con ninguna de las vanguardias, permaneciendo en un estilo propio, ajeno a las tendencias artísticas del siglo, resultando ser un pintor atípico e inclasificable ${ }^{2}$, la «antivanguardia», como le llamaban en la década de 1930. Su amigo el poeta surrealista Antonin Artaud, lo clasificaría en un realismo a medio camino entre el Quattrocento y el clasicismo más elaborado y diría al respecto que: «La pintura de Balthus es una revolución irrebatiblemente dirigida contra el surrealismo, mas también contra el academicismo en todas sus formas. Más allá de la revolución surrealista, más allá de las formas del academicismo clásico, la pintura revolucionaria de Balthus alcanza una especie de misteriosa tradición ${ }^{3}$.

\subsection{La pintura de Balthus. Temas y símbolos.}

\subsubsection{Las niñas.}

Comenzó a pintar niñas semidesnudas o desnudas alrededor de 1940. El erotismo y el misterio impregnaron desde el principio la obra de Balthus. William Blake y Lewis Carroll fueron algunos de sus escritores favoritos y fuente de inspiración al trabajar los retratos y desnudos de

\footnotetext{
2 Balthus se haría eco de las afirmaciones de Charles Péguy: «"solo la tradición era revolucionaria" y decididamente moderna». BALTHUS; VIRCONDELET, Alain (ed.). Memorias. Barcelona: DeBolsillo, 2003, pág. 15.

${ }^{3}$ YUSTI, Carlos. Balthus, pintor de lolitas a plena luz. Enfocarte.com. Arte y cultura en la red [en línea]. [ref. de 17 de julio de 2006]. Disponible en Web: http://www.enfocarte.com/1.9/articulo.html
} 
niñas bajo una concepción de la infancia romántica y post-romántica. Balthus consideraba de Carroll que tanto en su libro de Alicia en el País de las Maravillas como en sus fotografías de niñas, había logrado captar lo desconocido, lo secreto, lo oculto, lo inocente y lo primitivo de la naturaleza infantil. Llegaría a afirmar que fue gracias a Carroll que pudo plasmar «el encanto de la infancia» ${ }^{4}$.

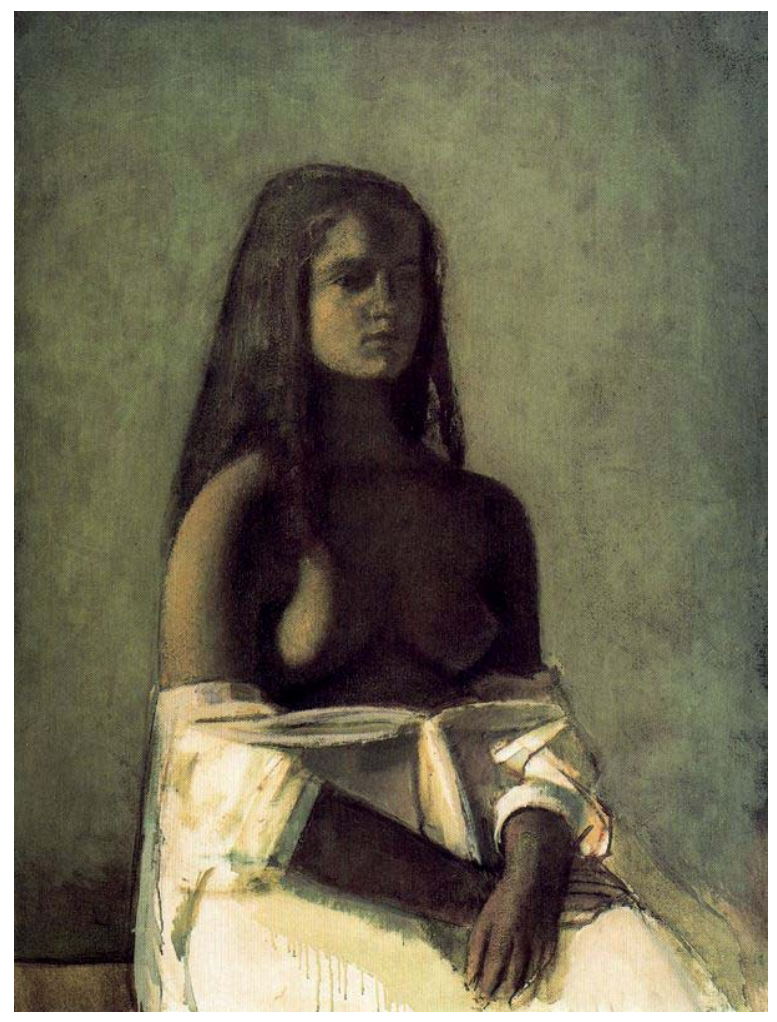

Fig. 1. Muchacha con camisa blanca [Jeune Fille à la chemise blanche] (1955).

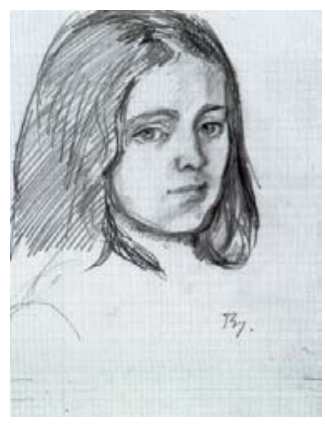

Fig. 2. Frédérique (1954).

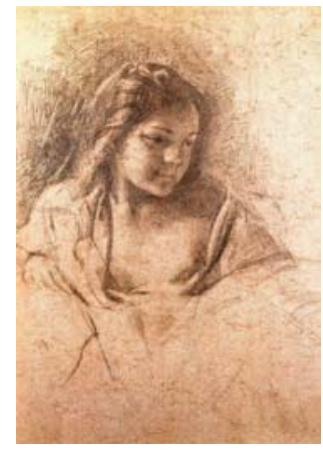

Fig. 3. Busto de mujer joven (1960-70).

Captar la infancia, implica poder reencontrarse una y otra vez con la «gracia» de la inocencia infantil que se esfuma rápidamente. Ello conllevaría a Balthus a desarrollar un disciplina exigente, reiterándose en las variaciones de los rostros y en las posturas de las niñas

${ }^{4}$ BALTHUS; VIRCONDELET, Alain (ed.). Op. cit., pág. 120. 
reclinadas y somnolientas, por ello algunos de los motivos de sus temas se repiten una y otra vez en múltiples versiones de manera obsesiva. «Los cuadros que retomo una y otra vez» aseguraba Balthus, «son en cierto modo fruto de mi descontento. Si estuviera satisfecho, no haría más versiones $»^{5}$ las niñas, los instrumentos musicales, los espejos, la vanidad, los gatos...; como las series Tres hermanas (c. 1954-64), Gato en el espejo (1977-94) o Salón [Le Salon](1941-43).

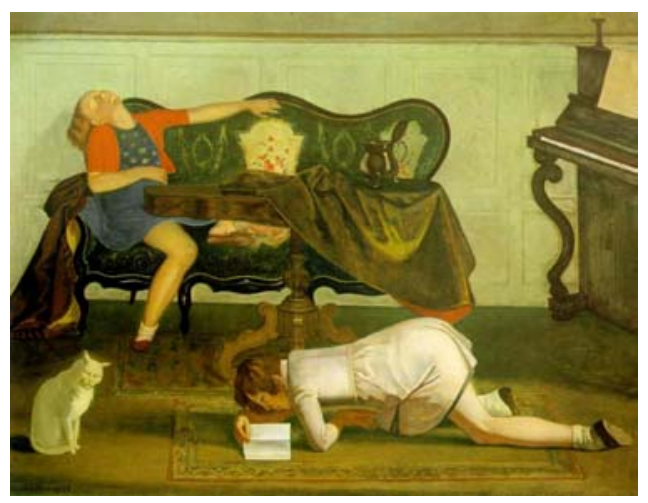

Fig. 4. Salón II [Le Salon II] (1942).

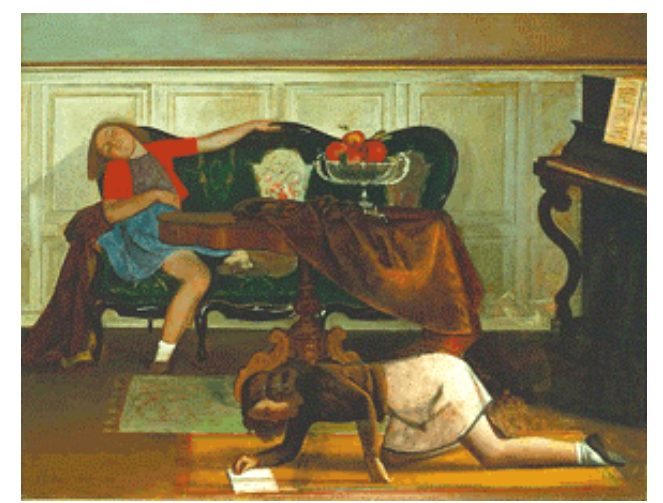

Fig. 5. Salón III [Le Salon III] (1943).

Las niñas dormidas, tumbadas, «sus ángeles soñadores y ensimismados» como las calificaba, destacan por sus posturas provocadoras que sin embargo están tratadas con la rigidez propia de los primitivos italianos ${ }^{6}$, como se aprecia en las articulaciones de los brazos y las piernas angulosas y los contornos destacados de las niñas de la serie Salón (1941-43), o como en La falda blanca [La jupe blanche] (1937) en la que destaca el acabado anguloso de los pliegues de la falda o los detallados bordados dorados de las zapatillas.

\footnotetext{
${ }^{5}$ NÉRET, Gilles. Balthus. Köln: Taschen, 2003, pág. 64.

${ }^{6}$ Estilo influenciado por la admiración y las numerosas copias que realizaría de Piero della Francesca. 


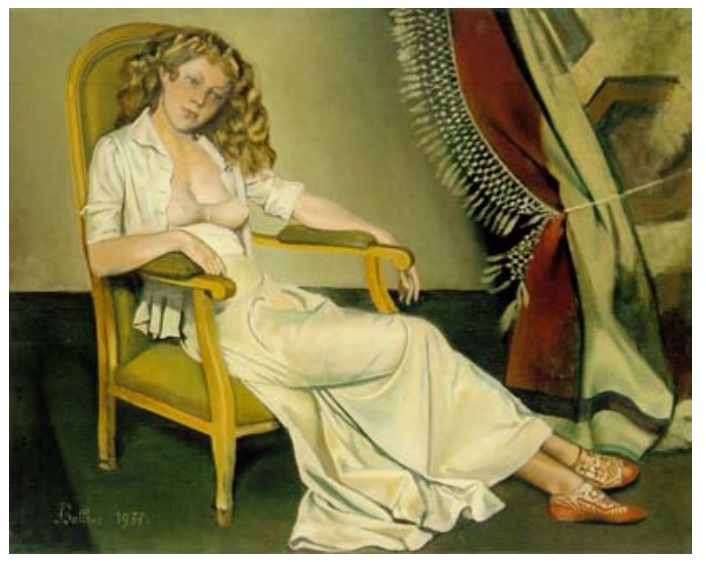

Fig. 6. La falda blanca (1937).

Muchos de sus personajes aparecen leyendo, La muchacha [Jeune fille lisant] (1957), Katia leyendo, [Lecture de Katia] (1968-70), o durmiendo, sentadas con los brazos cruzados, etc, lo que para Balthus no es más que una representación de un modo de «entrar en el secreto de la existencia» ${ }^{7}$, capturando un momento único.

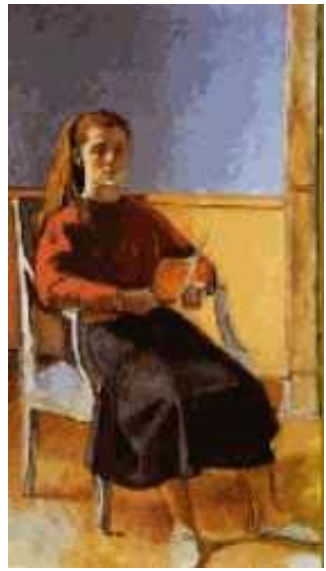

Fig. 7. La muchacha [Jeune fille lisant] (1957).

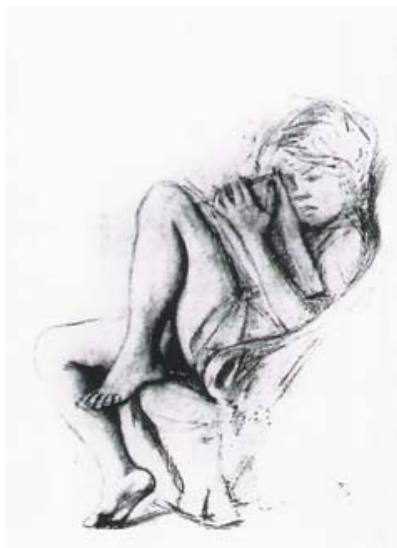

Fig. 8. Katia leyendo, [Lecture de Katia ] (1968-70), dibujo preparatorio.

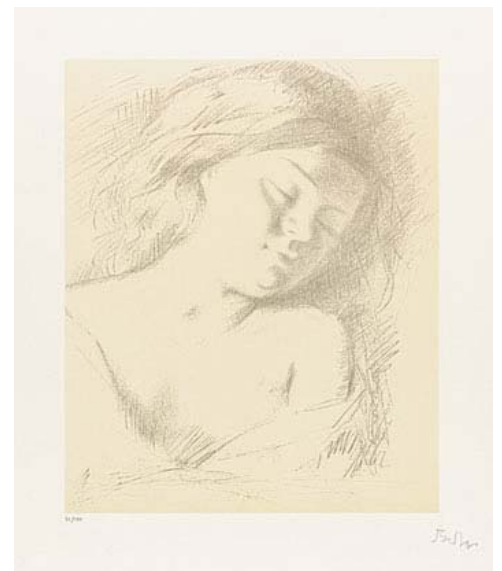

Fig. 9. Muchacha adormecida [Jeune fille endormie], (1994).

${ }^{7}$ BALTHUS; VIRCONDELET, Alain (ed.). Op.cit., pág. 118. 


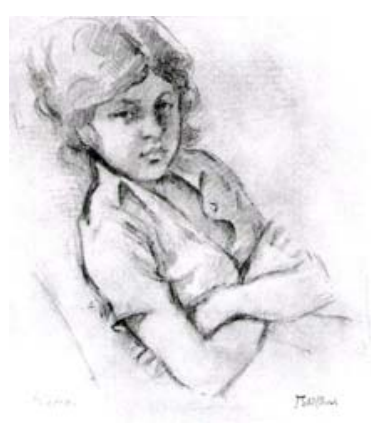

Fig. 10. Katia con los brazos cruzados [Katia aux bras croisés] (c. 1970).

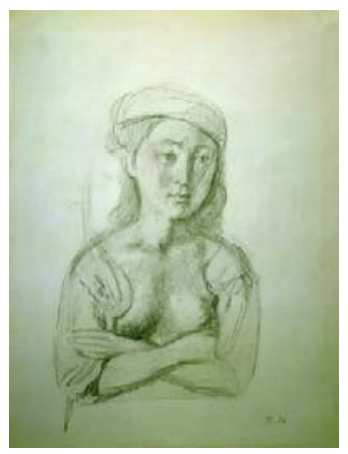

Fig. 11. Muchacha con sobrero [Fille avec un béret] (1963).

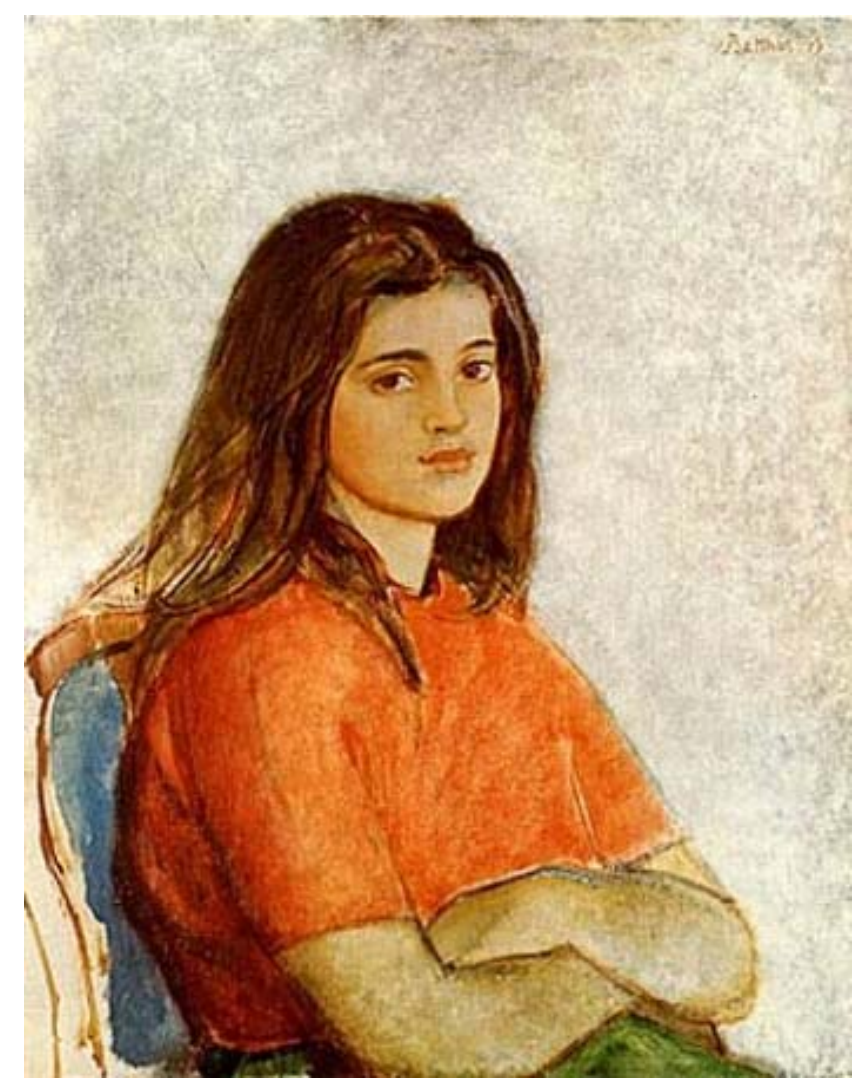

Fig. 12. Muchacha con los brazos cruzados [Jeune fille aux bras croisés] (1955).

La complicidad con las niñas era pues necesaria y formaba parte del trabajo pictórico; Natalie de Noailles, Michelina, Katia, Frédérique,... Algunas de ellas en lugar de posar preferían juguetear, como Katia o Michelina -hijas de un empleado de la Villa Medicis-, por lo que Balthus debía recurrir a bocetos y fotografías como en El pintor y su modelo [Le Peintre et son Modèle] (1980-81), de la que había tomado años antes una fotografía de Michelina arrodillada con los codos sobre una silla y leyendo un cómic de Tintín. 


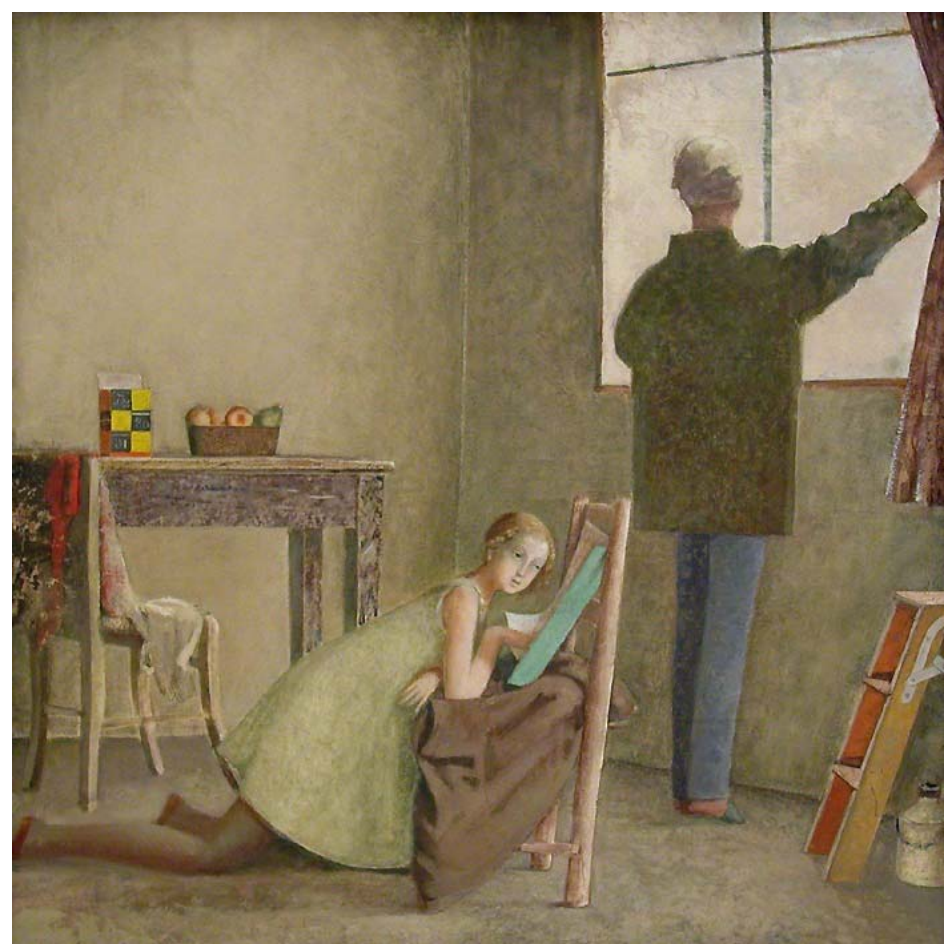

Fig. 13. El pintor y su modelo (1980-81).

Las tres hermanas franco-mexicanas, Marie-Pierre Colle, Sylvia Lorant y Béatrice Saalburg, posaron para el pintor en 1954, cuando tenían 11, 12 y 14 años respectivamente. Se encontraban en el Salón Azul de la mansión de la playa de Biarrtiz. Balthus tardó más de una década en terminar la serie Tres hermanas [Les Trois Sœurs] (c. 195464), para la cual las muchachas posaron. Años después, las ya mujeres, recordaban la experiencia considerando que en Balthus había un amor platónico por las niñas ${ }^{8}$. Lo recordaban como un hombre silencioso que las observaba penetrantemente, y al cual consideraban como a un padre. Al igual que con Lewis Carroll, esa inocente complicidad sería objeto de conjeturas más o menos perversas.

\footnotetext{
${ }^{8}$ BALTHUS. Balthus, las tres hermanas. Milán: Landucci Editores, 2000.
} 


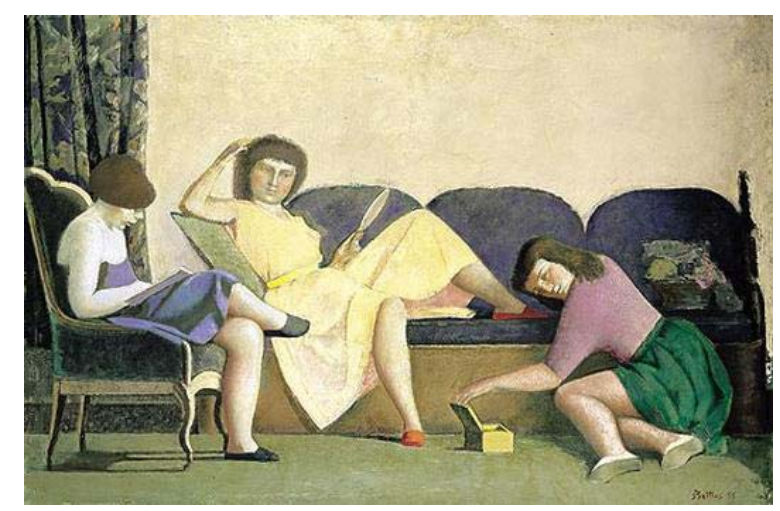

Fig. 14. Tres hermanas (1955).

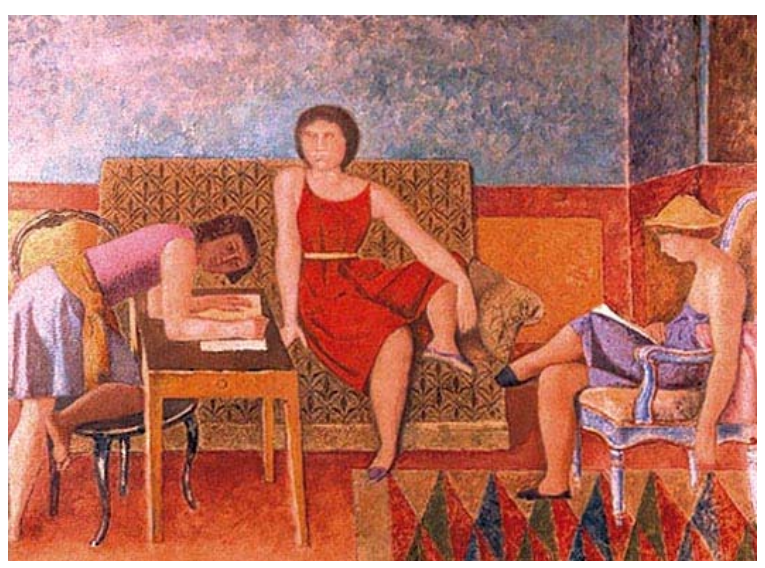

Fig. 15. Tres hermanas (1964).

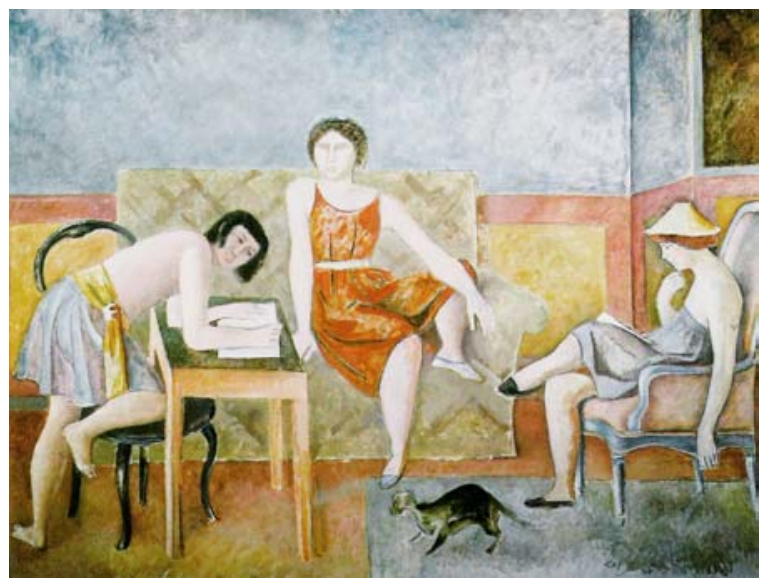

Fig. 16. Tres hermanas (1964). 
La complicidad y la misteriosa relación con las niñas emana en las formas $\mathrm{y}$ actitudes de sus personajes que permanecen en un enigmática introspección, resultando entre ellos desconocidos. Las muchachas de sus escenas parecen esperar algo, mudas, ausentes, con entretenimientos infantiles casi aburridos, tumbadas sobre el sillón, leyendo en posturas insólitas, distraídas con juegos hedonistas y envueltas en un clima de autoseducción silencioso frente a un espejo, con el cuerpo semidesnudo o desnudo, como anticipo de una escena perversa todavía por ocurrir. A pesar de la brutalidad o del dolor o del sufrimiento que puedan padecer sus personajes, siempre parecen aislados, ensimismados, como si la acción que acontece en la representación fuese la única.

\subsubsection{Los gatos.}

Los gatos, son uno de los elementos más característicos junto con el erotismo. Con ellos se reitera la dificultad de abordar «lo misterioso», como el propio «temperamento» independiente y extraño de los felinos a los que Balthus siempre se sintió ligado e incluso con los que se identificaba, lo que él Ilamaba su «pertenencia secreta, misteriosa, al mundo de los gatos»?

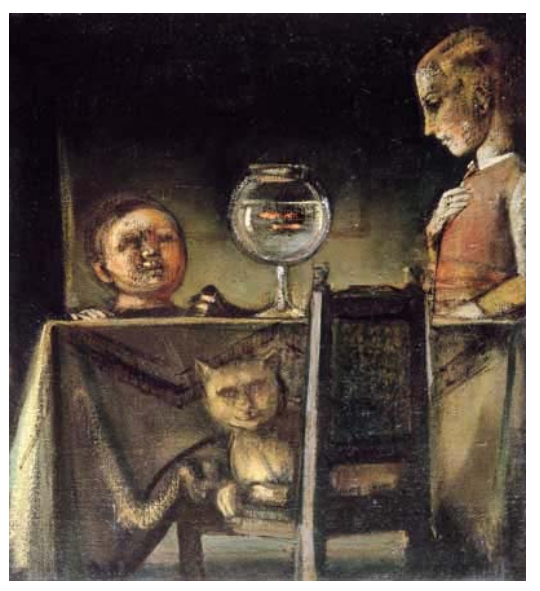

Fig. 17. Los peces rojos [Les Poissons Rouges] (1948).

\footnotetext{
9 Balthus siempre vivió rodeado de gatos. En su juventud tuvo un gato llamado Mitsou al que tras su muerte le dedicó unas cuarenta ilustraciones. BALTHUS; VIRCONDELET, Alain (ed.). Op. cit., pág. 45 y NÉRET, Gilles. Balthus. Köln: Taschen, 2003, pág. 31.
} 


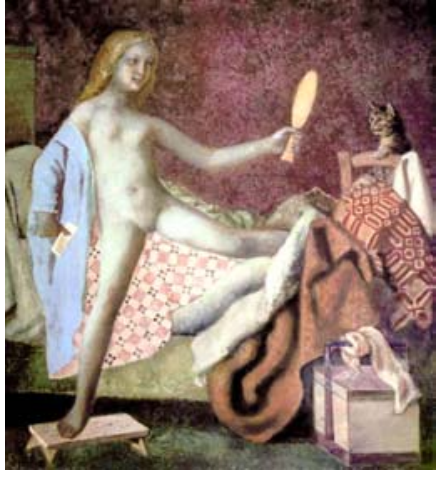

Fig. 18. Gato en el espejo (19771980).

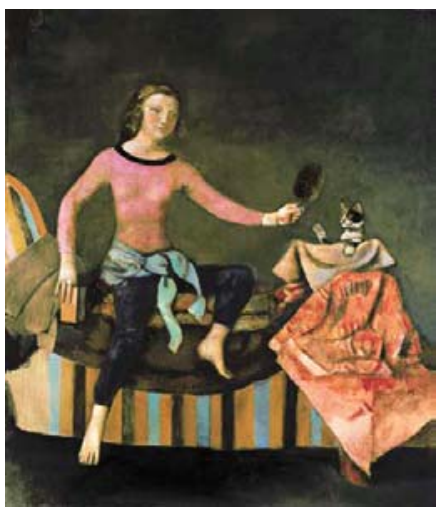

Fig. 19. Gato en el espejo II (1986-1980).

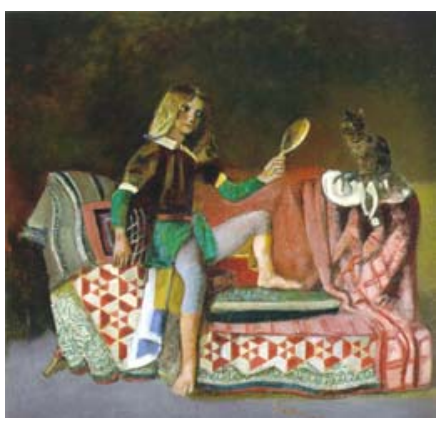

Fig. 20. Gato en el espejo III (1989-1994).

${ }^{10}$ NÉRET, Gilles. Balthus. Op. cit.
En la serie Gato en el espejo [Le Chat au miroir] (1977-94), la niña coloca un espejo frente a un gato para que vea su reflejo. Balthus diría que había pintado esa peculiar escena en la que «...el gato se queda estupefacto ante la imagen que le devuelve el espejo. Es un cuadro polémico, quería burlarme de quienes escriben sobre pintura» ${ }^{10}$. Sin embargo, su intencionalidad crítica también subraya sobre la reflexión que debería hacer el ego, el Yo, sobre sí mismo, de modo que como el gato, el Yo se sorprende de sí mismo. Lo curioso es que es una niña la que acerca el espejo al gato, como si se tratase de una pequeña Alicia en el País de las Maravillas ofreciéndole al risueño Gato de Cheshire una nueva visión de sí mismo. Por otro lado, el personaje de la niña ha variado notablemente en cada versión, comenzando con un desnudo para más tarde ser pintada con ropas, lo que sugiere el anecdotismo del desnudo como elemento erótico dentro de la temática de la obra, puesto que prescinde de él en posteriores versiones. 


\subsubsection{Los instrumentos de música.}

Entre las numerosas formas, objetos y símbolos de la iconografía erótica tradicional como la desnudez, el espejo, la cama, el diván, etc, los instrumentos musicales sugieren metafóricamente formas sugerentes y eróticas, a los que se les atribuyen características fálicas o de uso masturbatorio. Balthus retoma estos elementos de la tradición e introduce la guitarra o la mandolina como objetos generadores de sensualidad femenina.

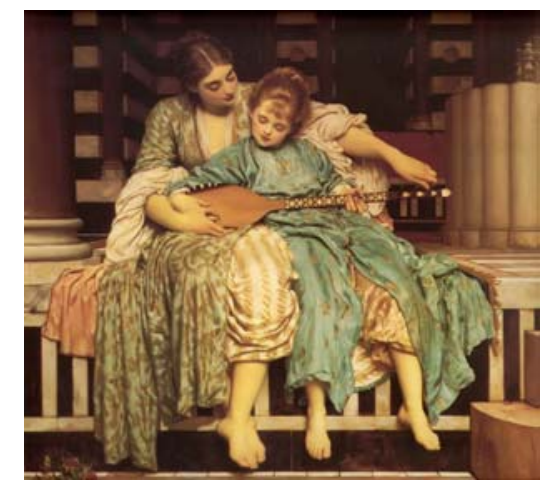

Fig. 21. La lección de música (1877) por Frederick Leighton.

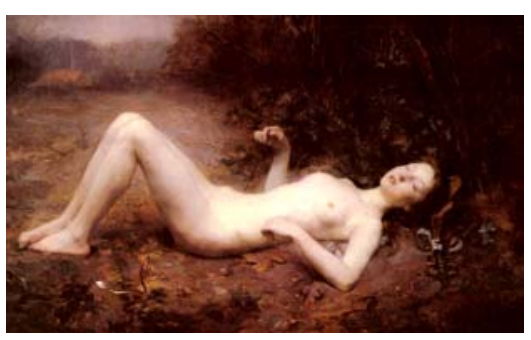

Fig. 23. Desnudo con mandolina (1873) por Georges Callot.

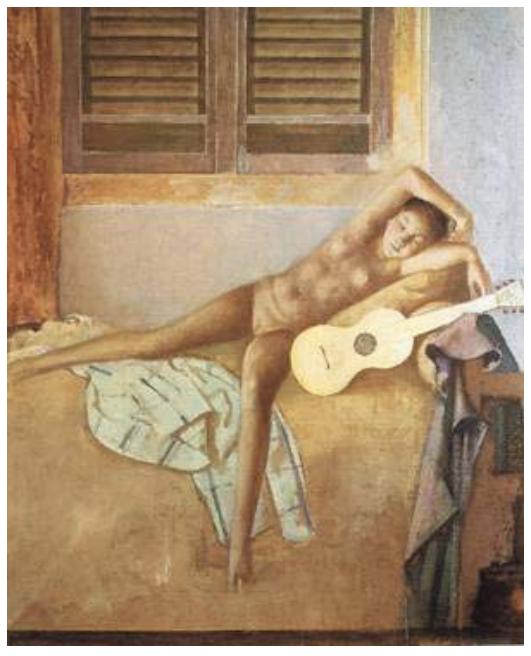

Fig. 22. Desnudo con guitarra [Nu à la guitare] (1983-86).

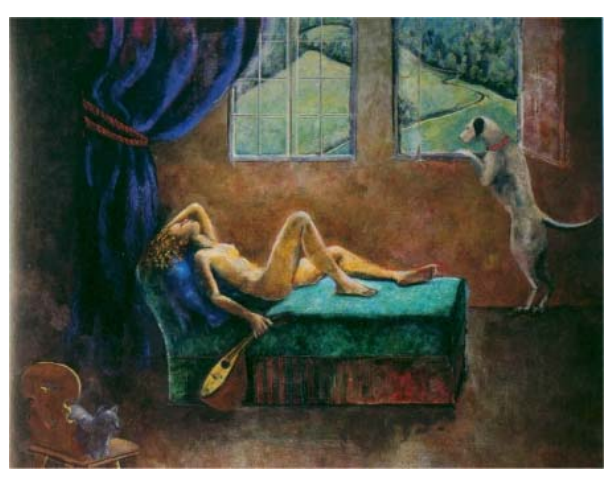

Fig. 24. Muchacha con mandolina [Jeune fille à la mandoline] (2000-2001). 
La lección de guitarra [La Leçon de guitare] (1934) destaca sobre el resto de versiones que realizara el pintor sobre el tema, por la violencia de la escena. Balthus buscaba escandalizar con esta pintura que se basaba compositivamente en la Pietà de Villeneuve-lesAvignons (c. 1470) de Enguerrand Quarton ${ }^{11}$. En La lección de guitarra se muestra a una madre o maestra de música -se advierte una guitarra en el suelo y un piano de pared-que sostiene violentamente sobre sus rodillas a la joven alumna haciendo de su delgado cuerpo el instrumento musical en cuestión. La niña tiene la falda levantada dejando ver el sexo infantil, que la maestra se dispone a tocar como si las cuerdas fuesen insinuadas por los surcos que forman el pubis ${ }^{12}$, mientras que con la otra mano estira del cabello de la niña, lo que sería el extremo del mástil de la guitarra. Por otro lado, la maestra lleva la camisa abierta dejando un pecho descubierto. La niña parece agarrarse con una extraña sutileza de la camisa de la maestra con los dedos colocados en forma de pellizco $^{13}$ y su rostro expresa un completo abandono a la violación, como en éxtasis o desmayo. Del mismo modo, el rostro ambiguo y casi plácido de la maestra -que debiera expresar furia-, contrasta con el sadismo del momento. La lección musical se convierte en un acto sexual. Lo que perturba de la escena son las pervertidas insinuaciones que se plantean como un pequeño compendio de obscenidades: violación, pederastia, sadomasoquismo o incesto.

\footnotetext{
${ }^{11}$ Balthus mismo declararía que la intención había sido buscar el escándalo y la provocación. V. pág. 239 de la presente tesis. La lección de guitarra se mostró por primera vez en la Galería Pierre Loeb de París en 1934. Cuando en 1984, se realizó una retrospectiva de Balthus en el Centre Pompidou y en el Museo de Arte Moderno de París, la obra se prohibió. Por fin, se volvería a mostrar en el 2001 en una retrospectiva en el Palazzo Grazzi de Venecia. NÉRET, Gilles. Balthus. Op. cit., pág. 15-20. 12 Íd., pág. 20.

${ }^{13}$ Néret afirma que la niña pellizca el seno de la maestra como en las escenas lésbicas representadas en la tradición de la Escuela de Fontainebleau. Ibíd.
} 


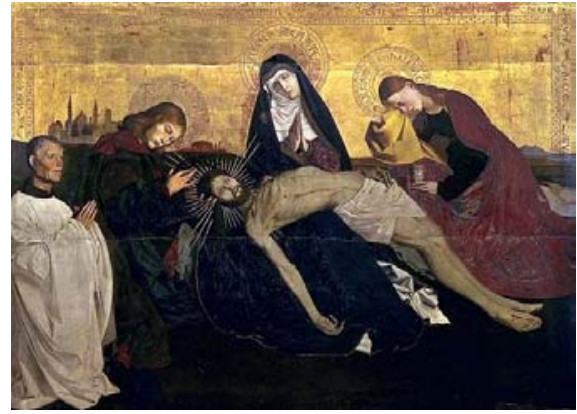

Fig. 25. Pietà de Villeneuve-les-Avignons (c. 1470) por Enguerrand Quarton.

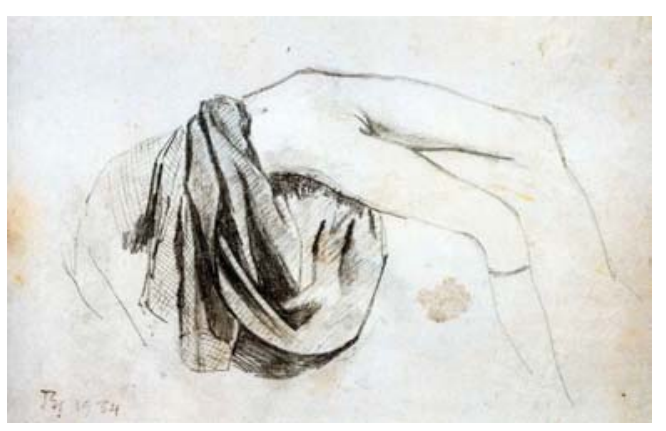

Fig. 26. Estudio para La lección de guitarra (1934).

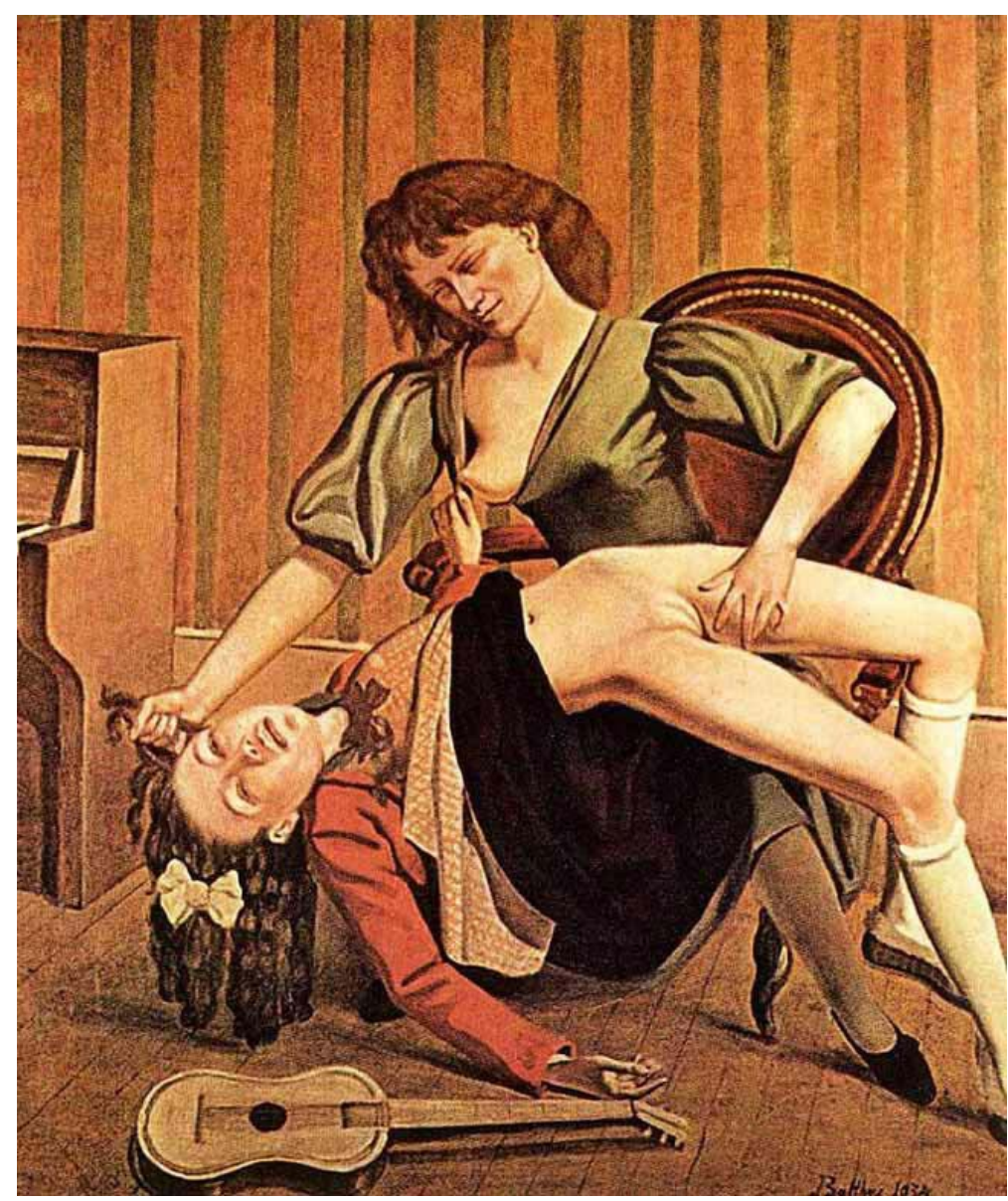

Fig. 27. La lección de guitarra (1934). 


\subsubsection{Erotismo y religiosidad.}

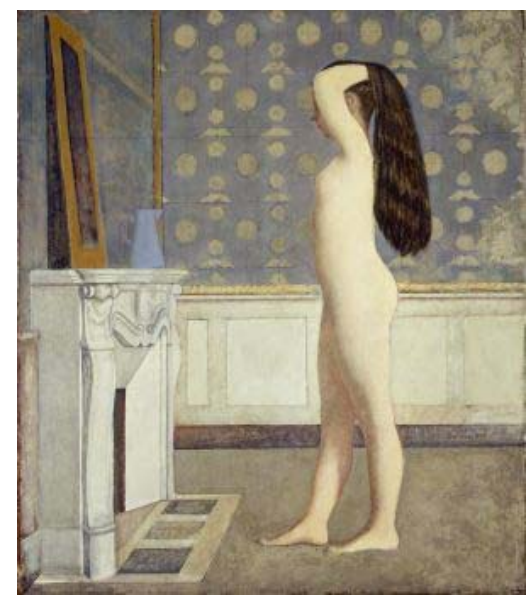

Fig. 28. Desnudo frente a la chimenea [Nu devant la cheminée] (1955).
La componente sexual en su obra ha sido considerada en numerosas ocasiones presuntamente pedófila. Balthus siempre negó la componente «pervertida» en sus obras y mucho menos pedófila. Como muchos otros autores, argumentaría que tal perversión se halla en los ojos del que mira y las consideraciones sobre sus preadolescentes como «lolitas» ${ }^{14}$, disgustaban a Balthus que detestaba ése término, negando las lecturas eróticas.

«Creer que ser molestado por la representación de una jovencita en situaciones de provocación y perversión sexual es discutible, poco menos que por una crítica negativa, es considerado el equivalente a una desaprobación del erotismo mismo» ${ }^{15}$. Por otro lado, Linda Nochlin, cuestiona el discurso del erotismo femenino desde la perspectiva masculina, el cual establece correspondencias entre fetichismo femenino y discurso erótico, haciendo de la sexualidad femenina un icono del erotismo universal, en base a la supuesta vulnerabilidad y sensualidad ${ }^{16}$. En este sentido, la iconografía erótica de Balthus es universal. Las niñas son para Balthus como delicados ángeles, «seres llegados de fuera, del cielo, de un ideal» ${ }^{17}$, retomando así el ideal icónico de las niñas de herencia romántica y victoriana. Y sin embargo su iconografía es en gran

\footnotetext{
${ }^{14}$ V. cap. 8. Lolita de Vladimir Nabokov, pág. 245.

${ }^{15}$ Texto de Sabine Rewald para el catálogo Balthus. New York: Metropolitan Museum of Art and Harry N. Abrams, 1984.

${ }^{16}$ NOCHLIN, Linda. Women, Art and Power, and Other Essays. Colorado-Oxford: Icon Editions, 1999, pág. 32.

${ }^{17}$ BALTHUS; VIRCONDELET, Alain (ed.). Op. cit., pág. 49.
} 
medida la de la preadolescente erotizada o en actitud sexual. Como diría Camus, sus cuadros desbordan «erotismo negligente», y es que es en la carnalidad reprimida de las sutiles formas femeninas, incluso deformes o desproporcionadas de las niñas, donde se halla una muestra de la sensualidad casi exhibicionista e incluso pornográfica de los cuerpos en crecimiento.

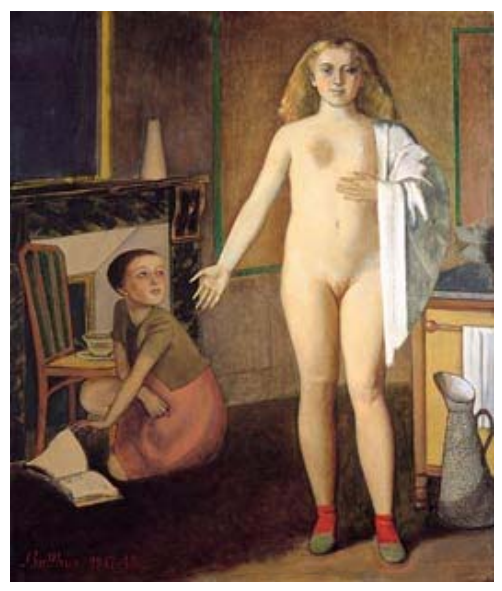

Fig. 29. La habitación [La chambre] (1947-48).

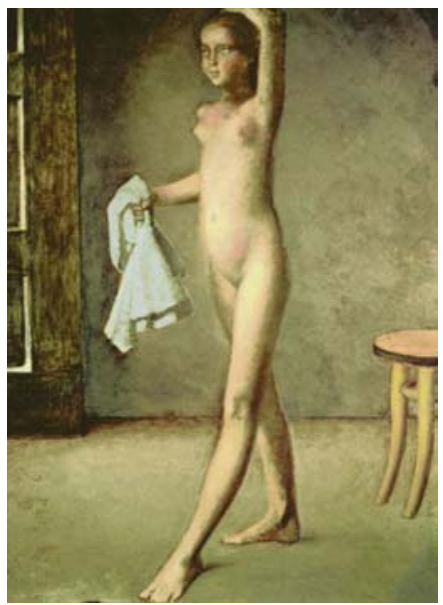

Fig. 31. Desnudo con foulard [Nu au foulard] (1981-1982).

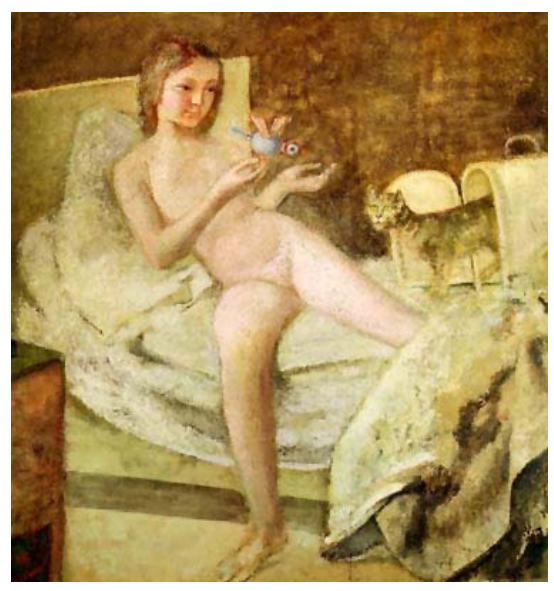

Fig. 30. Amanecer [Le Lever] (1975-78).

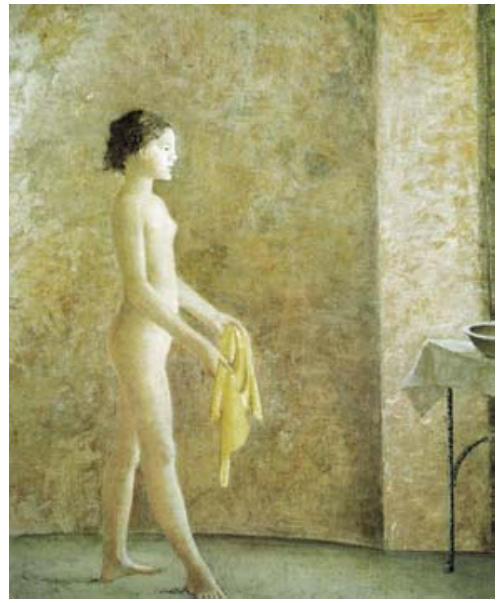

Fig. 32. Desnudo de perfil [Nu de profil] (1973-1977). 


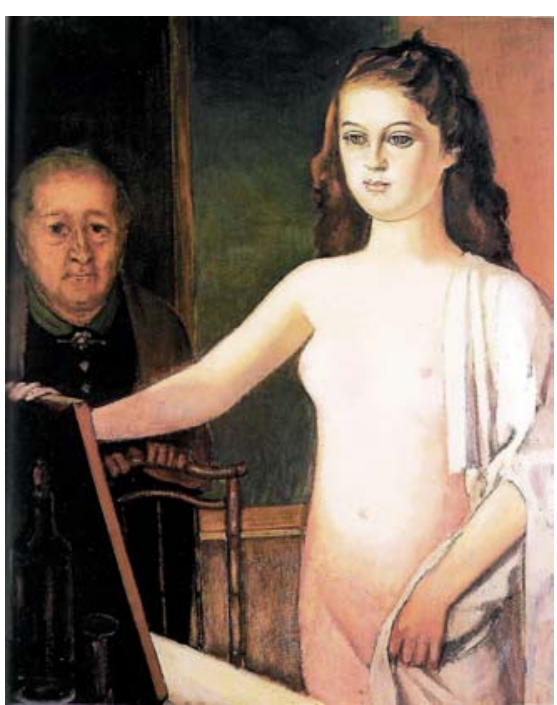

Fig. 33. Joven ante el espejo [Fille devant le miroir ] (1948).

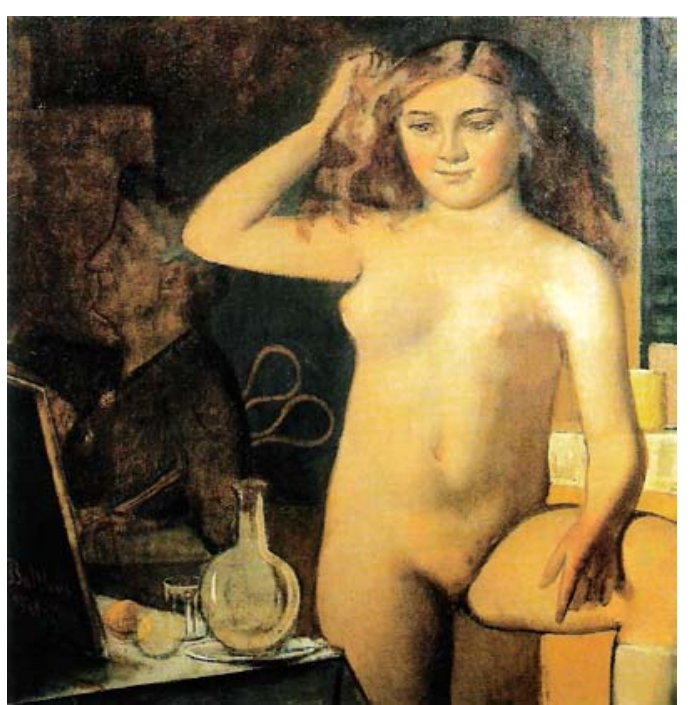

Fig. 34. Georgette aseandose [La toilette de Georgette] (1948-49).

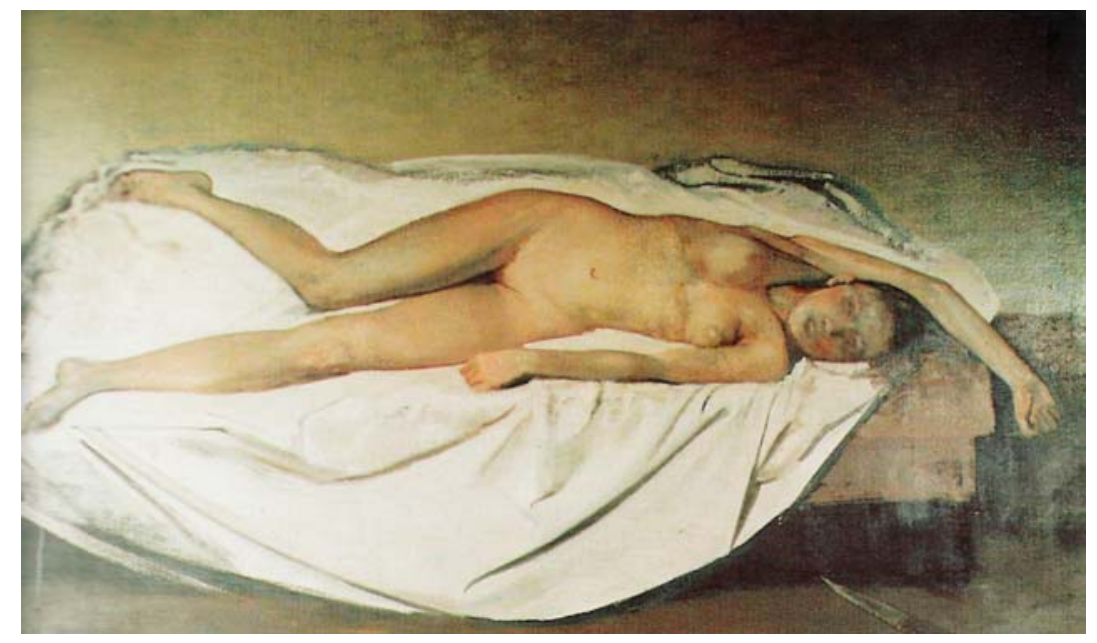

Fig. 35. La víctima (1939-1946).

Hay en su obra un abandono de las niñas y jóvenes a la voluntad de los adultos, hombres o mujeres, que se manifiesta en algunos casos en forma de castigo, incluso asesinato como en La víctima [La victime] (1939-1946) en el que una muchacha desnuda aparece tumbada sobre 
unas sábanas con el cuerpo completamente estirado con un brazo extendido sobre la cabeza ${ }^{18}$ y en el suelo hay un gran cuchillo. No se trata de una escena sangrienta y sin embargo la tragedia y la violencia se adivina, incluso en un acto de auto-agresión inflingida.

El abandono es también expresado con una languidez placentera ${ }^{19}$, en el sentido victoriano de extenuación erótica o de fragilidad enfermiza, en estado de sueño o en apariencia de muerte como las heroínas de los cuentos populares, Blancanieves o La Bella Durmiente.

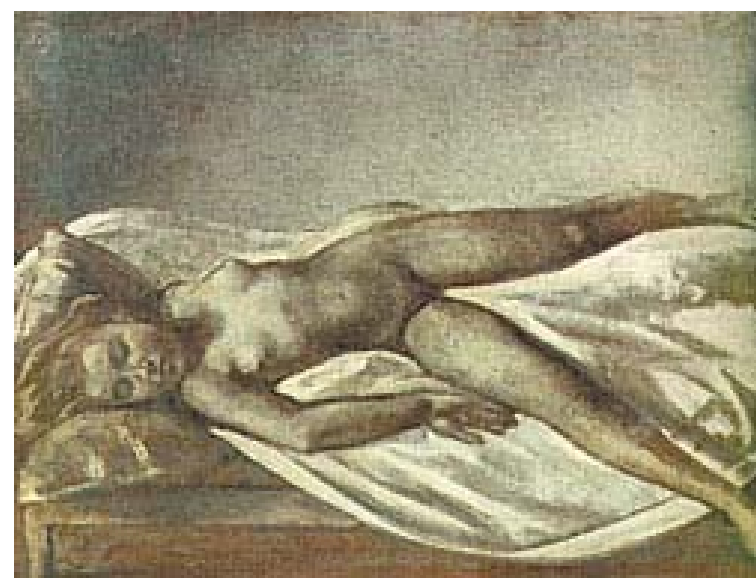

Fig. 36. Desnudo reclinado [Un couché] (1945).

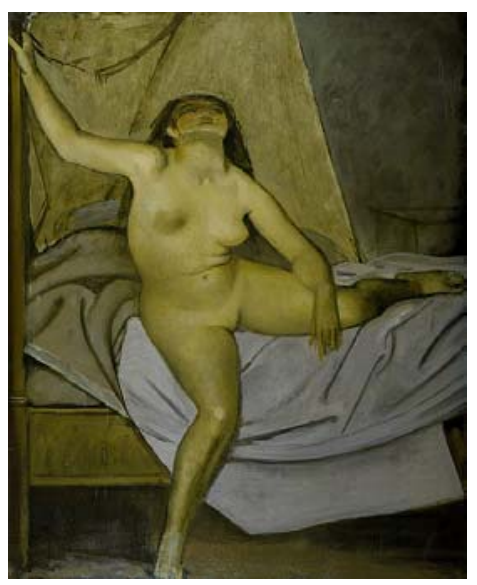

Fig. 37. Amanecer [Le Lever] (1955).

En Los días felices [Les Beaux Jours] (1945-46) la joven se estira sensualmente sobre un diván ante su propia imagen reflejada en un espejito de mano, con un gesto de autoerotismo, mientras al fondo un hombre atiza el fuego de una chimenea. Los espejos abundan en su pintura, a menudos como una aparente forma de vanidad de las niñas, sin embargo, Balthus utiliza los espejos con una significación platónica,

\footnotetext{
${ }^{18} \mathrm{Cf}$. con las poses de la niñas de las fotografías de Lewis Carroll (capítulo 5. Lewis Carroll) y el Retrato de Evelyn Hatch (c. 1878), fig. 39, pág. 173.

${ }^{19}$ Cf. con La lección de guitarra [La leçon de guitare] (1934) fig. 27, pág. 229.
} 
es decir, como una forma que búsqueda de ideal elevado del alma, de modo que las niñas al reflejarse en el espejo no buscan alimentar la vanidad, ni fantasear con juegos de autoseducción, sino «ahondar al máximo en lo más profundo de su ser» o hacer del espejo «un tragaluz abierto al sueño, a la imaginación ${ }^{20}$. En este sentido, tanto los espejos como los gatos por su misterioso temperamento, tienen un carácter «mediador» entre las niñas y la búsqueda interior que Balthus explora insistentemente.

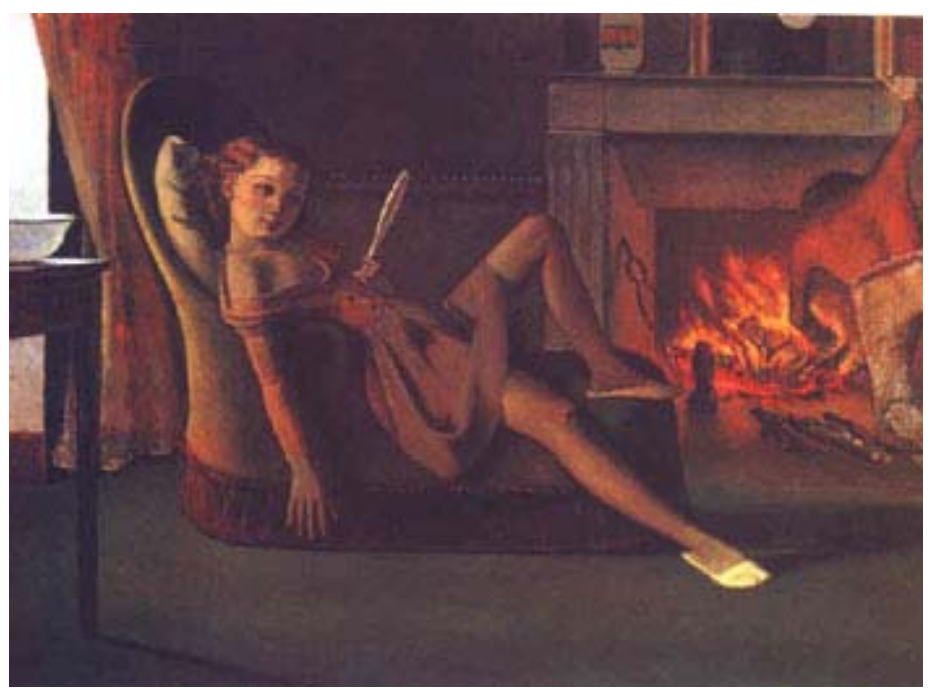

Fig. 39. Los días felices (1944).

La sensualidad está fuera de dudas en sus personajes femeninos, y aunque Balthus pretendiera trascender el sentido erótico hacia una visión romántica de la inocencia, la turbadora visión de niñas y adolescentes dejando ver sus braguitas o retorciéndose sobre su propia columna con los pechos al descubierto y la piernas entreabiertas sugieren un erotismo semejante al de las niñas soñolientas y semidesnudas de las fotografías de Lewis Carroll, como un «deseo expresado pero reprimido» ${ }^{21}$.

\footnotetext{
${ }^{20}$ BALTHUS; VIRCONDELET, Alain (ed.). Op. cit., págs. 182-83.

${ }^{21}$ RUEDA, Gerardo. "Balthus y las Lolitas". Arte y Parte, no. 1 febrero-marzo, 1996, pág. 148.
} 


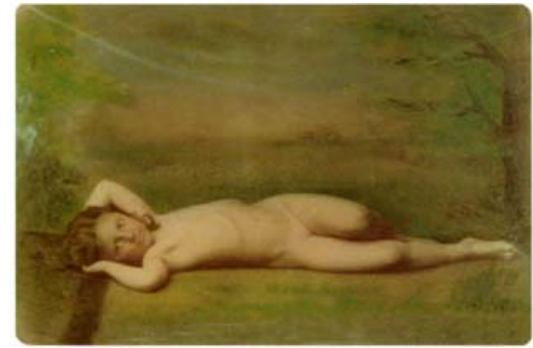

Fig. 40. Retrato de Evelyn Hatch (c. 1878), fotografía de Lewis Carroll.

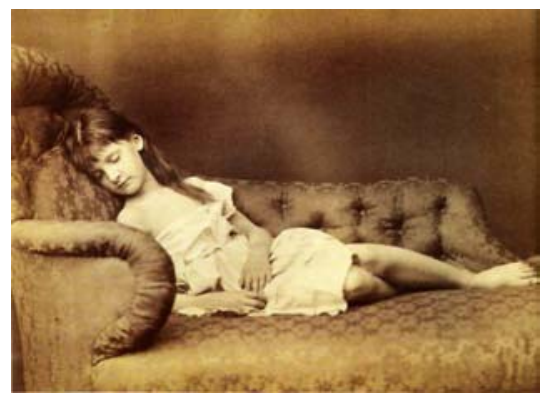

Fig. 41. Alexandra Xie Kitchin (c. 1874) fotografía de Lewis Carroll.

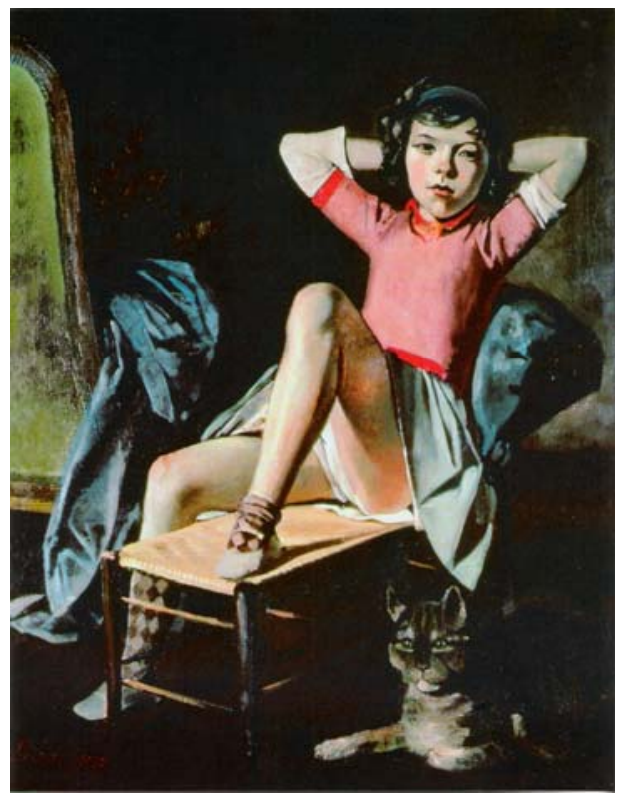

Fig. 43. Niña con gato [Jeune fille au chat] (1937).

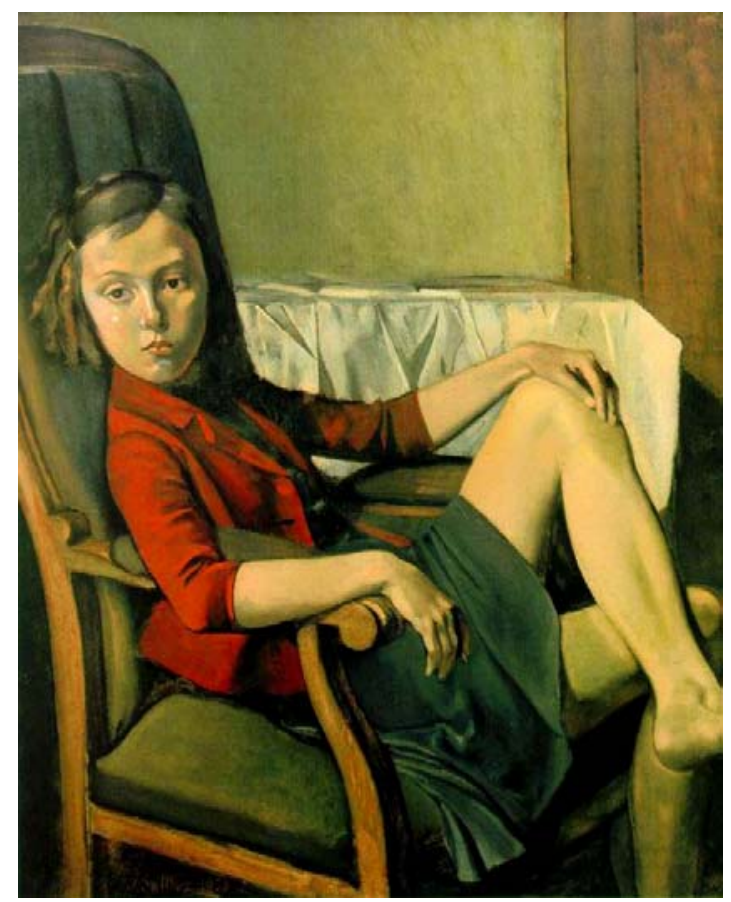

Fig. 42. Thérèse (1938).

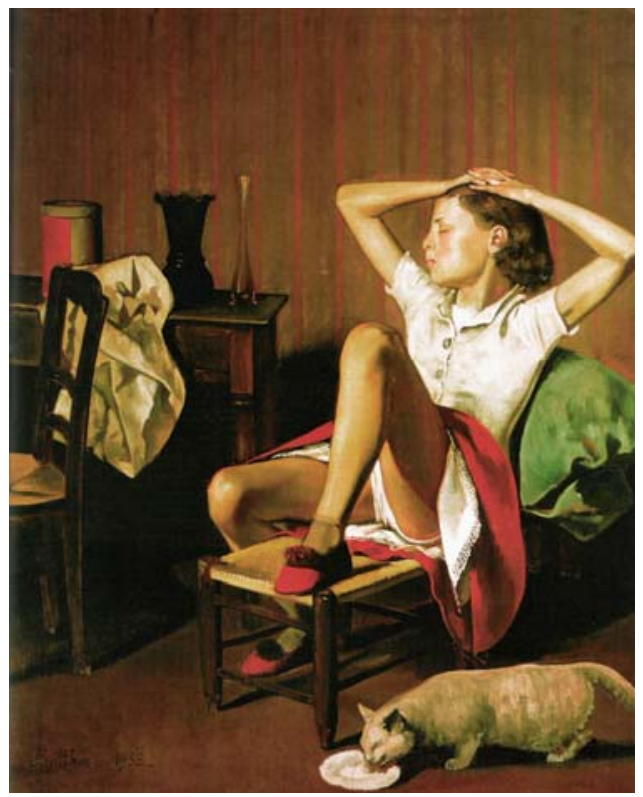

Fig. 44. Thérèse soñando [Thérèse sommeil] (1938). 


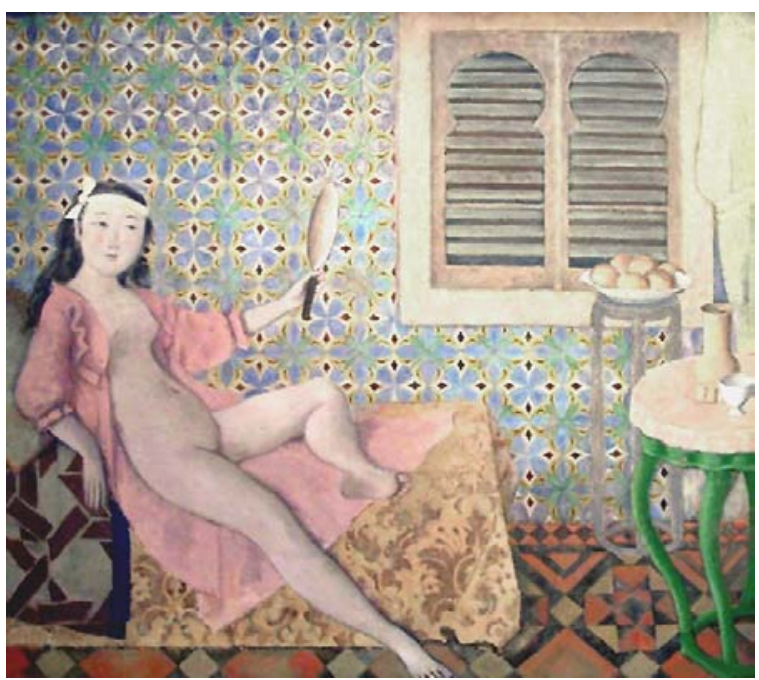

Fig. 45. La habitación turca [La chambre turque] (1963-66).

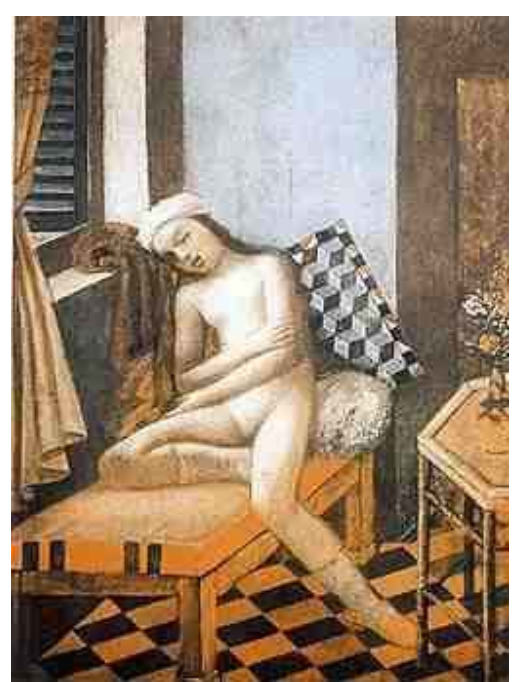

Fig. 46. Desnudo adormecido [Nu assoupi] (1980).

La violación y la agresión son expresados en términos sexuales pero no desde la mirada del pornógrafo, que no deja lugar a equívoco, al contrario, las niñas están envueltas de una enigmática mirada entre el absurdo, lo obsceno y lo religioso.

En La calle [La rue] (1933) se muestra lo que parece preceder a la violación de una adolescente con chaqueta roja ante una concurrida calle de ensimismados viandantes. Giles Néret identifica a esta jovencita con una «especie de Alicia en el País de las Maravillas» siendo abordada por Tweedledum, mientras su hermano gemelo Tweedledee -al que identifica con el hombre del centro-, intenta tocar el pubis de la mujer que viste de oscuro y que extiende la mano con intención de abofetearle ${ }^{22}$. Así en La habitación [La Chambre] (1952-54) $)^{23}$ se muestra el interior de una estancia, en la que se encuentra una

\footnotetext{
${ }^{22}$ NÉRET, Gilles. Op. cit., pág. 13. Como referente compositivo, Balthus se inspiró en La leyenda de la Vera Cruz de Piero della Francesca y en unas ilustraciones para el Cascanueces y el rey de los ratones de Heinrich Hoffmann-Donner, 1851.

${ }^{23}$ Balthus se inspiró en La pesadilla (1781) de Henry Fuseli.
} 
muchacha desnuda tumbada sobre un diván con las piernas entreabiertas y contorsionada sobre su espalda, que es iluminada por la luz que penetra a través del cortinaje oscuro de la ventana que un pequeño, ridículo y desagradable personaje femenino aparta, como si mostrara «la entrada del Espíritu Santo en el cuerpo de la Virgen», o los vestigios de una «adolescente violada», o para hacernos partícipes de una inminente violación ${ }^{24}$. El gato, espera en la penumbra sabedor de que el sexo de la joven es un modo de cruzar al otro lado del espejo, como señala Alain Vircondelet ${ }^{25}$.

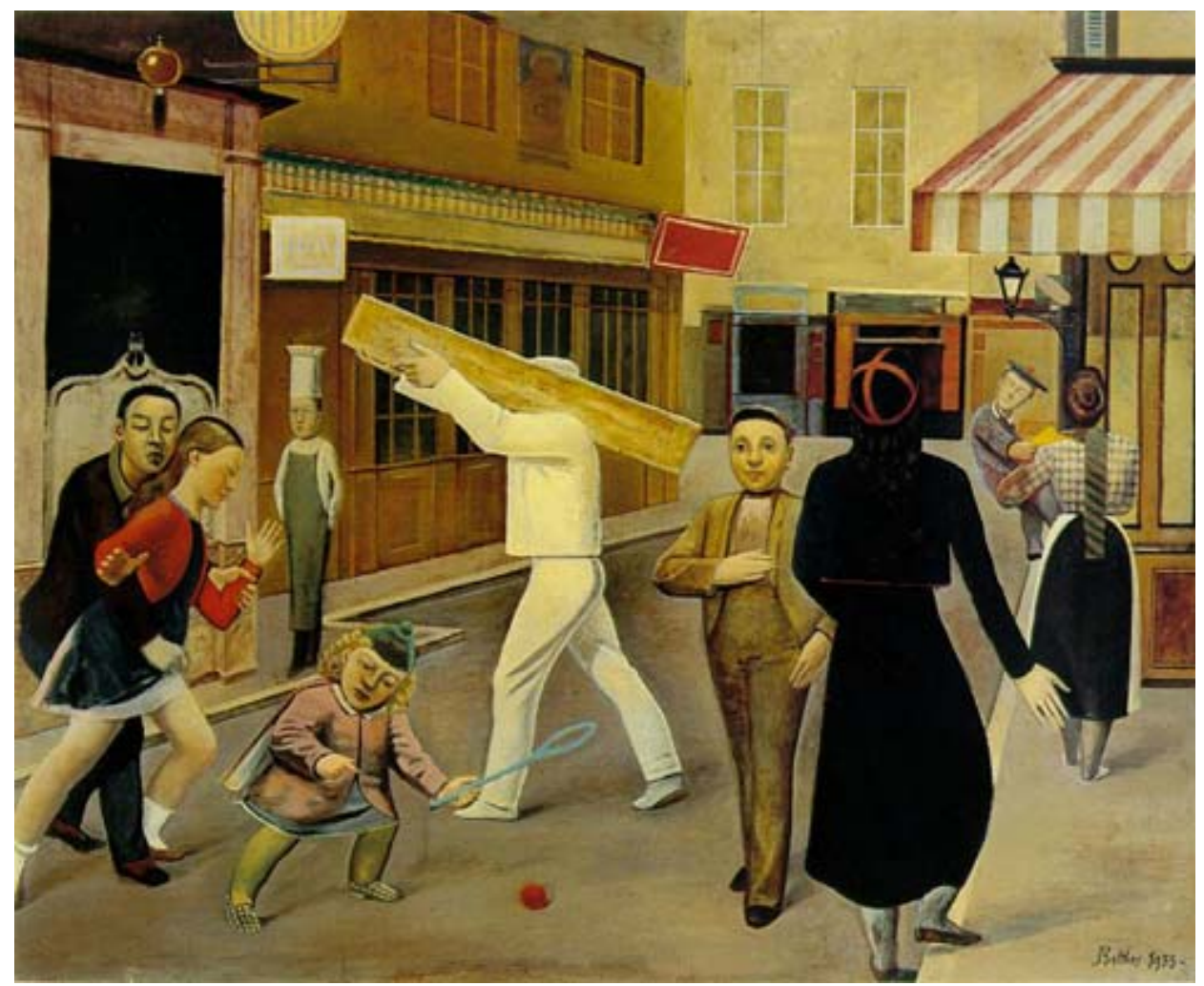

Fig. 47. La calle (1933)

${ }^{24}$ VÁZQUEZ, Xesús. "La carne, la luz, el tiempo". Arte y Parte, no. 1 febrero-marzo, 1996.

${ }^{25}$ Alain Vircondelet en Les Chats de Balthus. Paris: Flammarion, 2000. Cit. en NÉRET, Gilles. Óp. cit., pág. 38. 


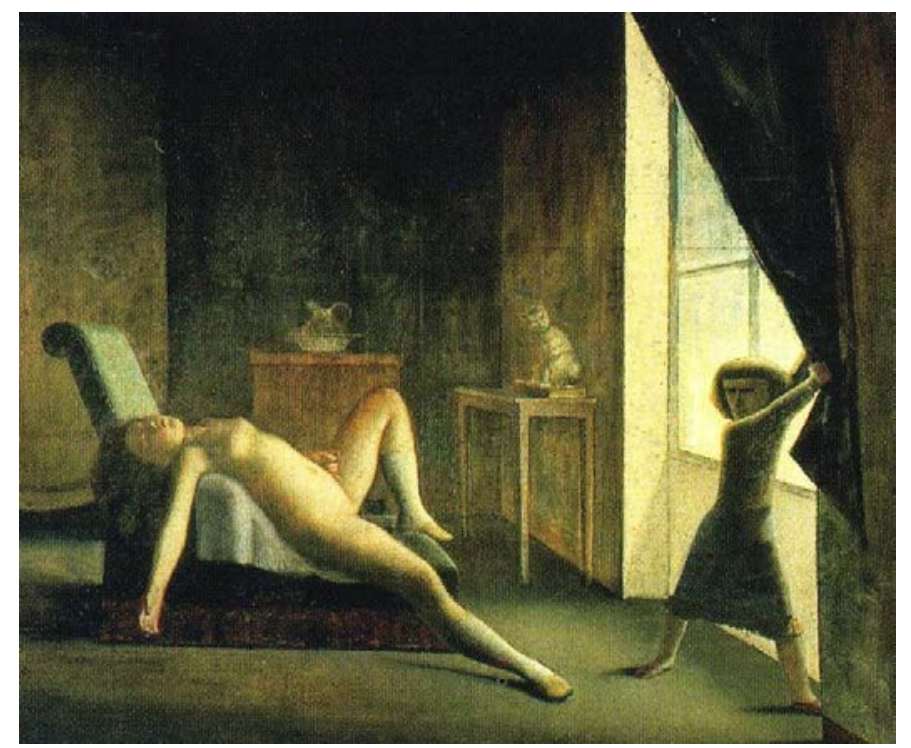

Fig. 48. La habitación [La Chambre] (1952-54).

El pintor busca captar los etéreos y fugaces momentos, como por sorpresa, retirado y oculto, observa a las niñas como ángeles dormidos o en el éxtasis de la contorsión. No pretende evocar o mostrar el sueño de las niñas, sino las niñas soñando, sin pasado, ni futuro, enclavadas en un momento atemporal.

Vicente Molina Foix, define sorprendentemente la obra de Balthus bajo una concepción religiosa, no sin una grave ironía: «¿No es, al fin y al cabo, la religión el ejercicio de una mirada fija y persistente a un punto inalcanzable? El culo misterioso de las niñas» ${ }^{26}$.

Es inevitable volver una y otra vez sobre el erotismo en su obra, y preguntarnos porqué Balthus halla en una convención erótica, la de la enfant fatale, una trascendencia y una religiosidad que aunque se

${ }^{26}$ Cit. SANTIAGO, Pablo. Alicia en el lado oscuro. La pedofilia desde la antigua Grecia hasta la era Internet. Madrid: Imagine ediciones, 2004, pág. 96. 
asemeja a la visión prerrafaelista, va más allá, aproximándose hacia lo más profundo de la espiritualidad humana en su relación con lo divino.

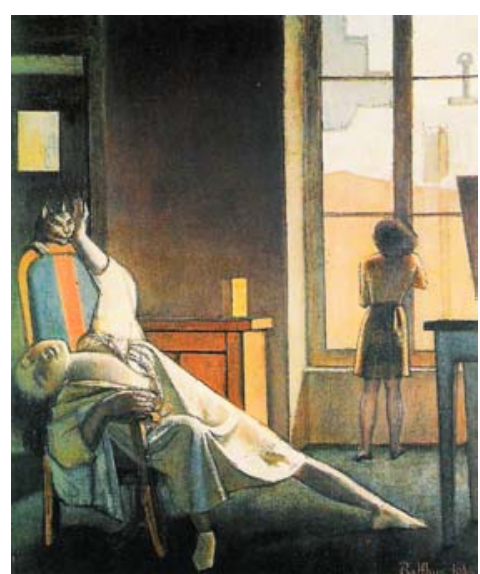

Fig. 49. Para las calendas griegas [La Seimaine des quatre jeudis] (1949).

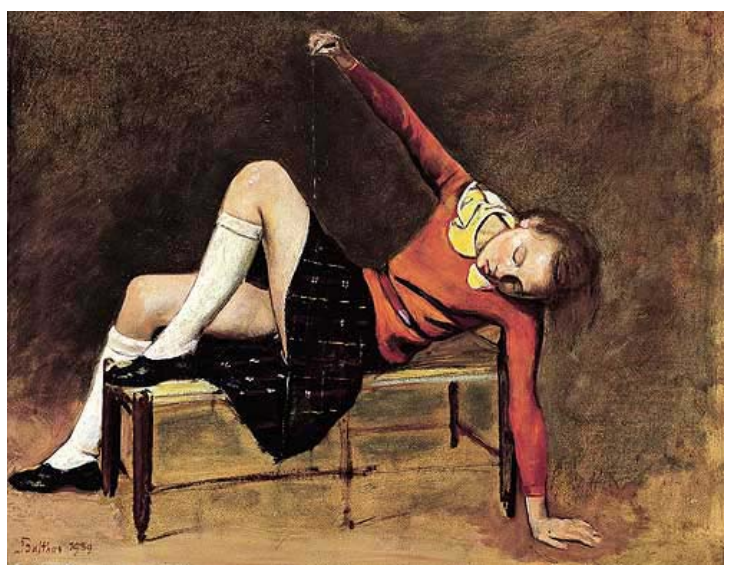

Fig. 50. Thérèse sobre un banco [Therese sur une banquette] (1939).

Pero definir el erotismo como tema principal de Balthus, obviando la espiritualidad global que el pintor le adjudica a su obra, es tomar lo anecdótico y lo superfluo como tema principal. La intencionalidad erótica sólo sería un pretexto ocasional. Únicamente tuvo el propósito provocador en 1934, con los cuadros expuestos en la galería Pierre Loeb, Alice (1933), La calle (1933), La toilette de Cathy $(1933)^{27}$ y sobretodo La lección de guitarra. A propósito de la polémica generada a partir de La lección de guitarra, que tenía un claro sentido masturbatorio, Balthus señalaría la poca importancia del tema: «Era la única forma de atraer la atención [...] El tema es una excusa. Lo que más me interesa son las imágenes reconocibles, el efecto pictórico, que

\footnotetext{
${ }^{27}$ La toilette de Cathy (1933) fue pintada tras realizar ese mismo año, dieciséis dibujos a plumilla y tinta china para ilustrar Cumbres borrascosas, de Emily Brontë -que jamás llegó a publicarse-, y entre los dibujos se encontraba ésta escena que años más tarde llevara a la pintura.
} 
decía Braque. El contenido no interesa para nada» ${ }^{28}$. El contenido es lo que él reconoce como narrativo y lo narrativo es anecdótico. Centrarse en lo anecdótico del erotismo, sería ignorar la sincera búsqueda de la verdadera inocencia, dejando al pintor como un simple voyeur, exteriorizando perversiones pedófilas inconscientemente, muy al contrario, Balthus considera que el erotismo en su obra es la manifestación del Yo único del individuo ${ }^{29}$, «liberando su naturaleza fabulosa, mitológica y onírica».

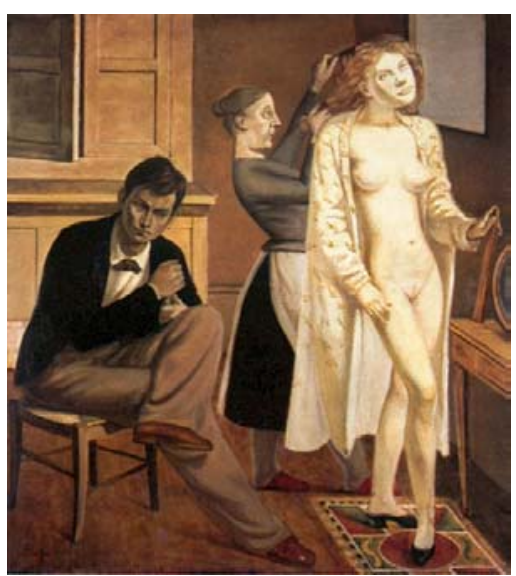

Fig. 51. La toilette de Cathy (1933).

Balthus, plantea en su pintura una visión espiritual y moral del ser humano a través de la naturaleza, en concreto mediante el cuerpo desnudo y el erotismo, de modo que manifiesta su rechazo por la sociedad industrializada y el materialismo alienante, como revela la correspondencia que mantenía con Antoinette de Watteville entre 1928 y 1937 -su primera esposa y protagonista del desnudo en La toilette de Cathy $(1933)^{30}$-. Sostiene que es en el erotismo, en la desnudez de la piel, donde reside la verdadera vida espiritual. La niñez y la adolescencia femenina son para Balthus sinónimo de las mujeres que en potencia son y es precisamente esa

28 Tras el escándalo de la presentación de ésta obra en una exposición colectiva, comenzó a ser conocido. CARRILLO DE ALBORNOZ, Cristina. "Balthus un artista marginal y exquisito". Descubrir el ARTE. Año III, no 3, septiembre, 2001, pág. 39.

${ }^{29}$ Al respecto, Balthus hace referencia a lo que su hermano Pierre Klossowski llama «el enigma», como un fondo invariable dentro de todo hombre, que ni siguiera el propio individuo conoce, lo que Eckhart llama «fondo abisal». BALTHUS; VIRCONDELET, Alain (ed.). Op. cit., pág. 125.

30 QUIÑONERO, Juan Pedro. "Las cartas de Balthus y su primera mujer escarban en el erotismo del pintor". $A B C$, septiembre, 2001. 
inmadurez, ese «aún no», lo que envuelve misteriosamente a las niñas y que las mujeres ya hechas carecen. Las largas sesiones frente a las niñas, frente a sus modelos, hacían salir la «dulzura del alma», manteniendo un diálogo fantástico y emocionado ante las formas de las mejillas, los labios,... transformándose del «estado de ángeles al estado de niñas», bajo la contemplativa mirada de Balthus ${ }^{31}$. En Jinete montando a caballo blanco [Ecuyère montant au cheval] (1941), el universo interior se materializa en la desnudez de la niña que monta sobre un caballo blanco. Su vaporoso tutú de bailarina no esconde sus nalgas desnudas sobre el lomo del caballo como Lady Godiva. La niña es como una crisálida en permanente cambio enfatizado por el vestido transparente semejante a las alas de una mariposa. El desarrollo físico de las niñas, de la infancia a la adolescencia a menudo se compara con la metamorfosis de los insectos y en concreto con el de la oruga a la mariposa ${ }^{32}$.

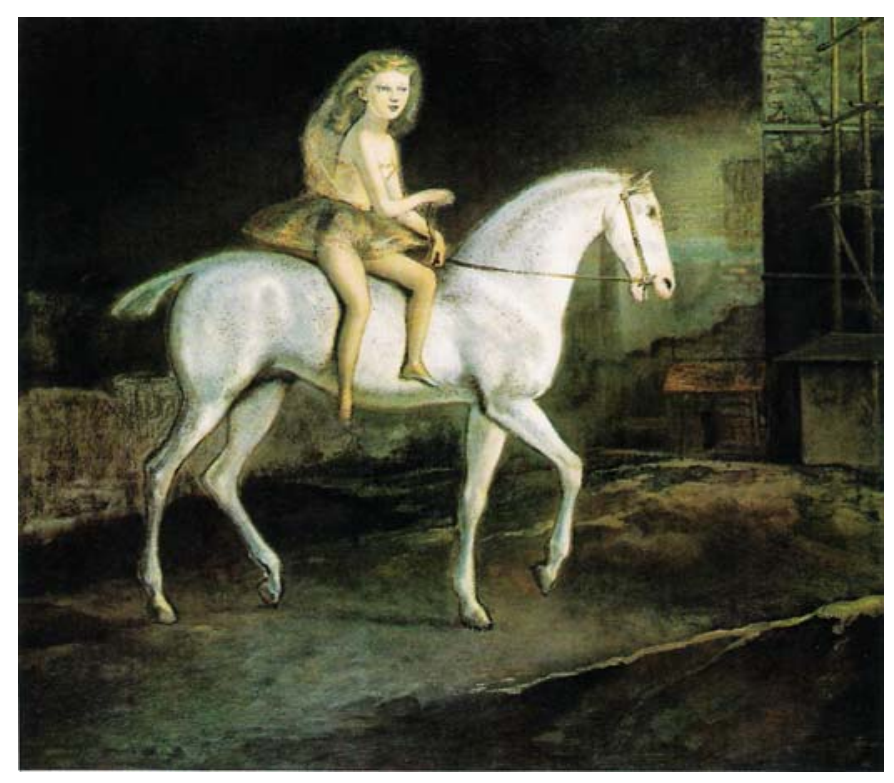

Fig. 52. Jinete montando un caballo blanco (1941, modificado en 1946).

\footnotetext{
${ }^{31}$ BALTHUS; VIRCONDELET, Alain (ed.). Op. cit., pág. 74.

${ }^{32}$ V. capítulo 8. Lolita de Vladimir Nabokov, pág. 249.
} 


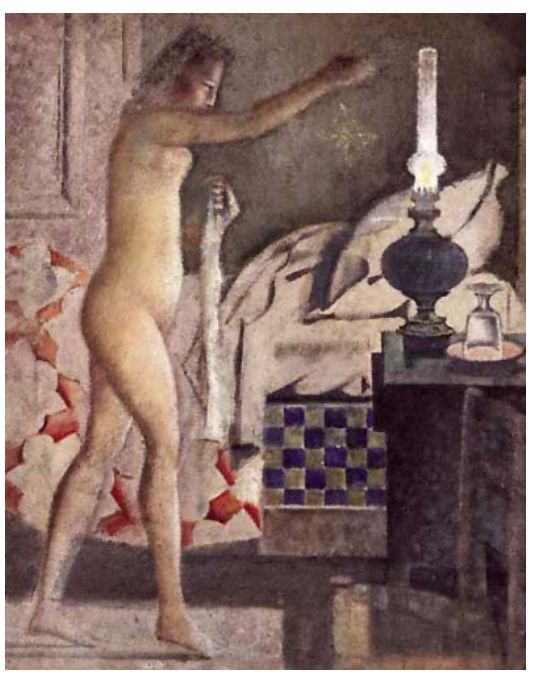

Fig. 53. La falena (1959).
En La falena [La phaléne] (1959), una mariposa está a punto de morir quemada al acercarse en exceso a un candil encendido. La muchacha desnuda intenta evitar lo inevitable, del mismo modo que será inevitable su propio crecimiento, desarrollando sus formas de mujer, que comienzan a percibirse como sus pechitos abultados iluminados por la luz tenue del candil y que sólo el pintor puede intentar capturar mediante la representación del cuerpo de la preadolescente.

Por otro lado, esa vida espiritual, se desarrolla pictóricamente mediante un ejercicio carente de todo ego, sin personalidad -la cual consideraba el mal de los pintores de su época-, en el silencio meditativo del taller, convirtiéndose el pintor en una herramienta confiada a la providencia de Dios, el único creador que no el pintor ${ }^{33}$ : «Los pintores se interesan más en expresar su personalidad que en la pintura misma, y eso es absurdo. La pintura está muerta. El que pinta, intenta salir de sí mismo y se acerca así al que crea [...] Al pintar, uno debe dejar al lado su ego y en ese momento se siente al lado de una luz que es Dios. La mente y la mano no son más que instrumentos que escuchan lo que deben hacer [...] Mi pintura es una forma de oración para celebrar la belleza divina» ${ }^{34}$. Para Balthus no hay diferencia entre un cuadro y una oración.

\footnotetext{
${ }^{33}$ Desdeña la palabra artista y desconfía de la creatividad, por lo que el pintor inventa pero no crea.

${ }^{34}$ CARRILLO DE ALBORNOZ, Cristina. Op. cit., pág. 39.
} 
Ciertamente se definía a sí mismo como un pintor religioso ${ }^{35}$, y al igual que los artistas prerrafaelistas se consideraba «un artesano puro al estilo de la Edad Media», pues sólo de ese modo y a través del análisis de la naturaleza, se puede expresar algo «más profundo», el «misterio de Dios».

Así, la oración contemplativa ante el erotismo y la fragilidad de las púberes es el medio que Balthus elige para transgredir lo material y representar lo inmaterial, la idea de belleza divina, «la cosa en nosotros y fuera de nosotros», por lo que el pecado en su pintura no es tal, asegura Paul Lombard, pues su religiosidad es una celebración del deseo, como aliento del alma, revelado a través de sus modelos: «Hizo del erotismo un cántico, para decepción de mirones y papanatas» ${ }^{36}$.

\footnotetext{
35 Balthus se declaraba un ferviente y exigente católico practicante, aunque no se definía como un «pintor católico». BALTHUS; VIRCONDELET, Alain (ed.). Óp. cit., págs. 21, 29 y 86.

${ }^{36}$ LOMBARD, Paul. "El pintor en el espejo". Introducción para BALTHUS; VIRCONDELET, Alain (ed.). Íd. págs. 8-9.
} 



\section{LOLITA DE VLADIMIR NABOKOV.}

El escritor ruso Vladimir Nabokov (1899-1977) está considerado uno de los más importantes escritores del siglo XX. Sus primeras obras las escribió en lengua rusa, pero sus obras más famosas las escribió en inglés. Los críticos han hallado numerosas similitudes entre Vladimir Nabokov y Lewis Carroll, pues ambos destacan por su impresionante erudición, un cierto esnobismo, un estilo artificioso, el agrado por los portmanteau, así como por su afición al coleccionismo. Por otro lado, Nabokov fue el primero en traducir Alicia en el País de las Maravillas al ruso. La figura de Nabokov condicionaría seriamente las interpretaciones post-freudianas que se harían de Lewis Carroll precisamente por la influencia del psicoanálisis que todavía era latente en la literatura de Nabokov y en concreto en su novela más conocida Lolita, escrita en inglés.

Nabokov escribiría Lolita a principios de $1950^{1}$, cuando recorría el Oeste de los Estados Unidos en coche, acompañado de su esposa en busca de nuevos especimenes de mariposas para su colección. La novela fue rechazada varias veces antes de ser publicada en París por la editorial The Olympia Press en 1955.

\footnotetext{
${ }^{1}$ Nabokov escribió hacia 1939 un relato corto titulado El hechicero, que serviría de base para Lolita. «La nínfula ahora con una gota de sangre irlandesa, era prácticamente la misma zagala, y también subsistía la idea básica del matrimonio con su padre; pero, por lo demás, todo era nuevo (...)». Cit. en "Primera nota del autor". NABOKOV, Vladimir. El hechicero. Barcelona: Anagrama, 1999, pág. 9. Según Michael Juliar, biógrafo de Nabokov, la inspiración para escribir Lolita, le vendría de una acontecimiento insólito referido en un artículo periodístico sobre un dibujo a carboncillo realizado por un chimpancé llamado Cookie, en el Jardin des Plantes, a finales de 1939 o principios de 1940. Cf. con las acusaciones de plagio, n. 5, pág. 247.
} 


\subsection{Lolita, la novela.}

Lolita o Las Confesiones de un viudo de raza blanca ${ }^{2}$, es la confesión de Humbert Humbert, el cual espera para ser juzgado por el asesinato del dramaturgo Clare Quilty, pero también, es una confesión para el lector, sobre su verdadero «crimen», el deseo y la relación incestuosa con su hijastra, Lolita. Humbert Humbert ${ }^{3}$, es un profesor y escritor de origen francés, que viaja a los Estados Unidos para dar clases, y allí se «enamora» de Lolita, una niña de doce años, hija de Charlotte Haze, una viuda dueña de la casa donde se aloja en la localidad de Ramsdale, Nueva Inglaterra.

Para permanecer cerca de Lolita, decide casarse con la vulgar Charlotte y planea el modo de deshacerse de ella y quedarse con Lolita, la cual a los ojos de Humbert Humbert no es una niña cualquiera, sino una nínfula ${ }^{4}$, una «criatura escogida», de naturaleza «no humana», sino «demoníaca». Lolita es enviada a un campamento de verano y mientras Humbert Humbert idea el modo de asesinar a su nueva esposa, pero ésta descubre sus diarios y en ellos la confesión de su deseo por Lolita y su repugnancia hacia ella, a la que llama «la gorda puta, la vaca vieja, la mamá abominable». Horrorizada ante la lectura, Charlotte sale corriendo de su casa y al cruzar la calle es atropellada por un automóvil. Humbert Humbert pues, queda de repente viudo y único custodio de Dolores Haze. Empezará entonces una sórdida relación pederasta hasta que Lolita, asqueada de los

\footnotetext{
2 De éste modo comienza el prólogo de la novela. NABOKOV, Vladimir. Lolita. Barcelona: Anagrama, 1995, pág. 9.

3 A propósito del nombre de su personaje «Humbert Humbert», Nabokov declararía que «la repetición estruendosa era muy asquerosa y sugestiva, un nombre odioso para una persona odiosa». Declaraciones de Vladimir Nabokov a la revista Playboy en 1964. Cit. en NABOKOV, Vladimir. The Annotated Lolita. New York: Mc Graw Hill, 1970, n. 3/3, pág. 319.

${ }^{4}$ Cf. 8. 2. Lolita y las nínfulas, pág. 248.
} 
apetitos sexuales de Humbert Humbert, escapa marchándose «enamorada» de otro hombre maduro, Clare Quilty, también de gustos pederastas y pervertidos, que sin embargo tiene cautivada a Lolita. Humbert Humbert emprende la búsqueda de Lolita durante unos años, y finalmente la encuentra, ahora llamada Dolly Schiller, casada y embarazada, la cual le confiesa con quién se fugó. Humbert Humbert, todavía enamorado de Lolita, pero consciente de que no es esa la niña que él amó, decide asesinar a Clare Quilty, al que considera culpable de la pérdida de la inocencia de la niña ${ }^{5}$.

\footnotetext{
${ }^{5}$ El 18 de marzo de 2004, el periódico alemán Frankfurter Allgemeine Zeitung publicaba en sus páginas la posibilidad de que Vladimir Nabokov, plagiara Lolita de otra novela del escritor y periodista alemán Heinz von Lichberg, titulada La Gioconda maldita [Die Verfluchte Gioconda] la cual fue publicada en 1916 por la editorial Falken, de Darmstadt. El diario alemán, que mostraba una comparación de ambas obras, aseguraba que era más que probable que Nabokov conociese la narración de Lichberg, pues ambos vivieron durante quince años en Berlín y las coincidencias entre La Gioconda maldita y Lolita son numerosísimas. En el relato corto de Lichberg -18 páginas-, un hombre de mediana edad realiza un viaje a España y allí se instala en una pensión de Alicante buscando tranquilidad, hasta que conoce a la hija del dueño, Lolita -Loti, Löttchen en el original, del nombre Lotte-, la cual es descrita así: «El amable y hablador posadero me asignó una habitación con bellísimas vistas al mar y nada se interponía en mi camino hacia una semana de tranquilidad inalterable. Hasta que, el segundo día vi a Lolita, la hija de Severo. Era muy joven según nuestro concepto nórdico, y a sus sombreados ojos sureños acompañaba un extraño cabello con matices rojos y dorados. Su cuerpo era blando y flexible, de una delgadez pueril (...). Pero no sólo me cautivó su belleza, sino el enigma que ella encarnaba y que se apoderaba de mí en las noches de luna llena». Cit. en SÁNCHEZ, Rosalía. "«Lolita» sedujo a Nabokov desde las páginas de «la Gioconda maldita», de Heinz von Lichberg". ABC, 20 de marzo, 2004; Cf. , EFE. "Nabokov, acusado de plagiar «Lolita» a un periodista alemán". ABC, 19 de marzo, 2004; SUAREZ, Beatriz. "Nabokov podría haber plagiado «Lolita» a un periódico alemán" [en línea]. La Razón digital. [ref. de 20 de marzo de 2004]. Disponible en Web: http://www.larazon.es/noticias/noti_cul03.htm A propósito de la acusación de plagio, Dmitri Nabokov, hijo del escritor, declararía en un escrito el diario The Guardian: «Al contrario de lo que un montón de escritorzuelos están diciendo, no hay similitudes entre las dos obras, excepto el nombre, y el argumento forma parte de ese puñado de temas en el que se basa toda la literatura». Cf. ESTEBAN, Iñaki. "La jovencita que sedujo a Nabokov" [en línea]. La biblioteca de Mafaldas. [ref. de 26 de junio de 2006]. Disponible en Web: http://www.espacioblog.com/mafaldas/post/2006/03/24/la-jovencita-sedujo-nabokov
} 


\subsection{Lolita y las nínfulas.}

Humbert Humbert nos hace de Lolita una breve descripción en el momento de conocerla ${ }^{6}$ :

« (...) una oleada azul se hinchó bajo mi corazón y vi sobre una esterilla, en un estanque de sol, semidesnuda, de rodillas, a mi amor de la Riviera que se volvió para espiarme por encima de sus gafas de sol. Era la misma niña: los mismos hombros frágiles y color miel, la misma espalda esbelta, desnuda, sedosa, el mismo pelo castaño. Un pañuelo a motas anudado en torno al pecho ocultaba a mis viejos ojos de mono, pero no a la mirada del joven recuerdo, los senos juveniles. (...) Poco después (...) ella, esa "nouvelle", "esa" Lolita, "mi" Lolita, habría de eclipsar por completo a su prototipo»?.

Nabokov «inventa» el término nínfula partiendo de la palabra ninfa ${ }^{8}$, para definir la naturaleza del «inmortal demonio que se distingue de las niñas» ${ }^{9}$ de la que su principal materialización es la preadolescente Dolores Haze, Lolita, apropiándose de los significados mitológicos y zoológicos del término «ninfa», pues según la mitología griega es el nombre de cada una de las deidades femeninas que pueblan los campos, los bosques y los mares, existiendo categorías y nombres diferentes según el lugar donde éstas habiten. También se entiende por «ninfa», aquella joven de gran belleza y gracia, y por extensión para calificar a una cortesana o prostituta. Sin embargo, el significado que más entra en relación con la «nueva» palabra nínfula, es la de «ninfa» como el

\footnotetext{
${ }^{6}$ NABOKOV, Vladimir. Lolita. Op. cit., pág. 48.

7 El prototipo es la difunta Annabel Leigh. Cf. pág. 254.

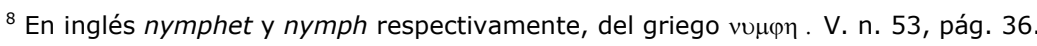

9 BRONFEN, Elisabeth. Over her Dead Body. Death, Feminity and the Aesthetic. Manchester: Manchester University Press, 1993, pág 377.
} 
estado transitorio entre la larva y el imago -insecto adulto que ha completado su desarrollo y que puede reproducirse- de los insectos con metamorfosis completa. De hecho, en su afición por la lepidopterología ${ }^{10}$, Nabokov clasificó una mariposa conocida como Nínfalo de Nabokov (Cyllopsis pyracmon), clasificada dentro de la familia de las nymphalidae. El interés por relacionar a Lolita con las mariposas reside en la comparación metamórfica de los lepidópteros con el proceso en constante metamorfosis de la niña, como de los acontecimientos mismos de la novela.

A través del personaje masculino Humbert Humbert, establece los parámetros que definen a una «nínfula»:

" Entre los límites de los nueve y los catorce años, surgen doncellas que revelan a ciertos viajeros embrujados, dos o más veces mayores que ellas, su verdadera naturaleza, no humana, sino nínfica (osea demoníaca); propongo llamar "nínfulas", a esas criaturas escogidas ${ }^{11}$.

\footnotetext{
${ }^{10}$ Especialidad de la entomología que se dedica al estudio de las mariposas.

${ }^{11}$ El texto continúa con una extensa explicación de la naturaleza nínfica, que a continuación se reproduce: «Se advertirá que reemplazo términos espaciales por temporales. En realidad, querría que el lector considerara los "nueve" y los "catorce" como los límites - playas espejeantes, rocas rosadasde una isla encantada, habitada por esas nínfulas mías y rodeada por un mar vasto y brumoso. Entre esos límites temporales, ¿son nínfulas todas las niñas? No, desde luego. De lo contrario, quienes supiéramos el secreto, nosotros, los viajeros solitarios, los ninfulómanos, habríamos enloquecido hace mucho tiempo. Tampoco es la belleza una piedra que toque; y la vulgaridad o al menos lo que una comunidad determinada considera como tal no daña forzosamente ciertas características misteriosas, la gracia letal, el evasivo, cambiante, anonadante, insidioso encanto mediante el cual la nínfula se distingue de esas contemporáneas suyas que dependen incomparablemente más del mundo espacial de fenómenos sincrónicos que de esa isla intangible de tiempo hechizado donde Lolita juega con sus semejantes. Dentro de los mismos límites temporales, el número de verdaderas nínfulas es harto superior al de las jovenzuelas provisionalmente feas, o tan solo agradables, o «simpáticas», o hasta «bonitas» $y$ «atractivas», comunes, regordetas, informes, de piel fría, niñas esencialmente humanas, vientrecitos abultados y trenzas, que acaso lleguen a transformarse en mujeres de gran belleza (pienso en los toscos pudines con medias negras y sombreros blancos que se convierten en deslumbrantes
} 
La nínfula pues, debe tener una edad de entre los nueve y los catorce años. Humbert Humbert establece unos rígidos cánones de belleza para las nínfulas, que no sólo lo rompen las mujeres adultas, sino incluso la mayoría de «niñas esencialmente humanas». Al hablar de belleza, se refiere a términos que van más allá de «atractiva», «bonita» o de la belleza como perfección. Los adjetivos que se le atribuyen al cuerpo de mujer adulta son despectivos, «pienso en los toscos pudines con medias negras», lo que refleja la falta de atracción física y sexual de Humbert Humbert por las mujeres y por lo tanto una incapacidad para establecer relaciones sexuales adultas. Las consideraciones sobre el rechazo masculino o falta de atracción sexual hacia el cuerpo femenino maduro en favor de la atracción por cuerpos de las púberes y las niñas, ya se observaba en la conducta sexual de un gran número de hombres victorianos, dando lugar al «culto por la infancia» ${ }^{12}$.

Lolita deja de ser la nínfula que fue cuando se convierte en esposa y en futura madre. Humbert Humbert confiesa que se enamoró de Lolita para siempre. Pero Dolores ya no será jamás Lolita. No puede serlo con un esposo en su cama y el hijo de éste en su vientre. Lolita, su imagen mental con todas las connotaciones que le atribuye Humbert Humbert, es el fetiche de Dolores Haze, la niña, la muchacha y más

estrellas cinematográficas). Si pedimos a un hombre normal que elija a la niña más bonita en una fotografía de un grupo de colegialas o «girl-scouts», no siempre señalaría a la nínfula. Hay que ser artista y loco, un ser infinitamente melancólico, con una burbuja de ardiente veneno en las entrañas y una llama de suprema voluptuosidad siempre encendida en su sutil espinazo (ioh, cómo tiene uno que rebajarse y esconderse!), para reconocer de inmediato, los signos inefables -el diseño ligeramente felino de un pómulo, la delicadeza de un miembro aterciopelado y otros indicios de la desesperación, la vergüenza y las lágrimas de ternura me prohíben enumerar-, al pequeño demonio mortífero entre el común de las niñas; $y$ «allí está», no reconocida e ignorante de su fantástico poder». NABOKOV, Vladimir. Lolita. Op. cit., págs. 23 y 24.

12 Recuérdese a Lewis Carroll o John Ruskin entre otros, los cuales tenían estrechas amistades infantiles, en lo que se refiere a relaciones personales entre un adulto y una menor. Eran relaciones si no verdaderamente pedófilas, sí al menos platónicas con las niñas, convirtiéndolas en relaciones seguras, inocentes, ingenuas y sin las exigencias sexuales de un cuerpo adulto femenino 
tarde esposa, que debe seguir creciendo pero que no lo hará jamás en el recuerdo de Mr. Humbert.

Si consideramos a Lolita como una femme fatale, entonces tal vez deberíamos remontarnos a precedentes más antiguos, y contemplar en las fuentes bíblicas el poder sexual de la preadolescente hija de Herodías, Salomé, que doblega la voluntad de su licencioso padrastro Herodes y conseguir la cabeza del «Bautista». Algunos autores señala otras jóvenes predecesoras como Julieta de William Shakespeare, Justine del Marqués de Sade, Haydée en Don Juan de Lord Byron, Cathy en Cumbres borrascosas de Emily Brontë, Gigi de Colette, en las que la inocencia se ve corrompida brutalmente.

Una de las representaciones populares de nínfula de Navokov pudiera ocultarse bajo la apariencia de la heroína del cuento infantil de Caperucita roja. Resultan curiosos los paralelismos existentes entre la estructura de relaciones en Caperucita y en Lolita, como lo es con los relatos de otros escritores ${ }^{13}$. Siguiendo un orden comparativo entre los personajes de ambas historias, observamos en primer lugar al personaje femenino principal, Lolita, que ha perdido la inocencia sexual -una Caperucita sin caperuza roja ${ }^{14}-$, y que del mismo modo que Caperucita que desobedece las recomendaciones de su madre de no apartarse del camino en su visita a la abuelita, Lolita descubre la sexualidad adulta en apariencia como un juego infantil- apartándose del camino principal y tomando un sendero peligroso. Por otro lado, ninguna de las dos niñas tiene padre. El de Lolita ha fallecido y el de Caperucita es omitido, nada se nos dice de él, ni tampoco aparece para rescatarla cuando es comida

${ }^{13}$ Cf. La Gioconda maldita [Die Verfluchte Gioconda] de Heinz von Lichberg, n. 5, pág. 187, así como con los diferentes autores a los que hace guiños y referencias, como Edgar Alan Poe.

${ }^{14} \mathrm{El}$ simbolismo de la caperuza roja como representación de la menstruación y de las pasiones sexuales, según Bruno Bettelheim y Erich Fromm. Cf. cap. 1. Antecedentes literarios del icono de la preadolescente como fenómeno artístico, pág. 31. 
por el Lobo. Como figura materna nos encontramos con su madre Charlotte Haze. En el caso de Caperucita, cuenta con dos predecesoras, madre y abuelita que se funden sin embargo en el personaje de la abuelita. Continuando con la identificación, Humbert Humbert actúa como Lobo, ya que desde el principio siente el deseo por Lolita pero reprime sus impulsos del mismo modo que el Lobo conoce a Caperucita en el bosque cuando ésta se aleja del camino, pero no la ataca. Para que Humbert Humbert pueda hacer realidad sus deseos, es necesario que desaparezca la figura materna, Charlotte Haze ${ }^{15}$. Primero posee a la madre casándose con ella y luego ésta muere de modo que se convierte legalmente en el único responsable de Lolita. Así, el Lobo se come a la abuelita ${ }^{16}$, para más tarde disfrazado de abuelita ${ }^{17}$ poder comerse a Caperucita. En las versiones originales de Caperucita, la niña se mete dentro de la cama de la abuelita junto al Lobo, como si una escena de seducción se tratase ${ }^{18}$. Comparativamente Humbert Humbert lleva a Lolita a el hotel El cazador encantado ${ }^{19}$, donde tras dormir juntos en la misma cama, Lolita aborda a Humbert Humbert que se deja arrastrar por los juegos sexuales de Lolita. El Lobo se come a Caperucita, como Humbert Humbert logra poseer a Lolita sexualmente. Lolita permanece atrapada en la relación pedófila oculta tras la intimidad doméstica, como

\footnotetext{
${ }^{15}$ Cf. pág. 37 la tesis, donde se señala el Complejo de Edipo/Complejo de Electra. Para que Humbert Humbert posea a Lolita, Charlotte debe morir. Para que el Lobo pueda comerse a Caperucita la abuelita también debe morir.

${ }^{16}$ «Comer» como metáfora de violación. V. pág. 35 de la tesis.

${ }^{17} \mathrm{Cf}$. el disfraz de abuelita que provoca confianza a Caperucita con la inocente apariencia de Humbert Humbert como bondadoso y protector padrastro de Lolita.

${ }^{18} \mathrm{~V}$. pág. 37 de la tesis.

${ }^{19}$ En la traducción al castellano se traduce en singular el nombre en plural del hotel The Enchanted Hunters, Los cazadores encantados. Alfred Apple Jr., señala que el plural hace referencia Humbert Humbert, a Quilty y en última instancia a el propio Nabokov. NABOKOV, Vladimir. The Annotated Lolita. New York: Mc Graw Hill, 1970, n. 108/2, pág. 375. Más tarde Lolita actúa en una obra teatral escrita por Clare Quilty y titulada Los cazadores encantados. En el texto original el título de la obra está escrito incorrectamente a propósito, The Hunted Enchanters -cambiado el orden de las palabras-.
} 
la encerrada en el vientre del Lobo, esperando que alguien, cualquiera, pero en este caso Clare Quilty, en Caperucita el cazador, las libere. Nabokov irónicamente llama al hotel donde sucede el primer encuentro sexual y el primer encuentro con Clare Quilty como El cazador encantado ${ }^{20}$, pues es Quilty el verdadero «cazador encantado».

\subsection{Humbert Humbert y Lolita.}

Tras la publicación de Lolita, el personaje de Humbert Humbert ha sido profusamente expuesto a debate ¿Es un loco como afirma Nabokov? ¿un enamorado, un artista? ¿un criminal? o ¿una víctima?

Humbert Humbert habla de Lolita como en un sueño, como algo lejano, como Edgar Allan Poe lo hace de sus amadas ya difuntas, como si Lolita estuviese muerta ${ }^{21}$. Al verla sentada junto a él en el coche, sintió verla «como al pequeño espectro de alguien a quién había dado muerte ${ }^{22}$. Ciertamente Lolita muere poco antes de que lo haga Humbert Humbert, pero antes de su «declaración» o historia. Alfred Appel Jr. sugiere que Lolita es «una parodia de la muerte con un sufrimiento real» ${ }^{23}$, que enfatiza en la presencia ausente de Lolita.

\footnotetext{
${ }^{20}$ Cazador en inglés es «hunter». Cuando Humbert Humbert sigue el rastro para encontrar a Lolita tras su fuga, encuentra en los registros de los moteles, en múltiples nombres todos escritos del mimo puño y letra. Uno de ellos es «Ted Hunter, Cane, N.H.», que es el anagrama de «cazador encantado», «Enchanted Hunter», es decir, que es uno de los múltiples pseudónimos que utiliza Clare Quilty. Cuando Humbert Humbert por fin encuentra a Lolita, su dirección de casada es Hunter Road, «calle del cazador». NABOKOV, Vladimir. The Annotated Lolita, Op. cit., págs. 196, 200-202, 268 y n. 196/1, pág. 402. ${ }^{21}$ Su idealización de Lolita es comparable a la que hace Dante de Beatriz, Mérimée de Carmen, o Poe de su esposa Virginia Clemm en Annabel Lee. BRONFEN, Elisabeth. Op. cit., pág. 377.

${ }^{22}$ NABOKOV, Vladimir. The Annotated Lolita, Op. cit., pág. 153.

${ }^{23}$ «A parody of death with suffering in it». APPEL, Alfred Jr. (ed.). (1970) op. cit., Cit. por BRONFEN, Elisabeth. Op. cit., pág 371.
} 
La muerte enmarca la personalidad de Lolita. Lolita llega a ser «mi Lolita» por la necesaria y previa muerte de tres mujeres en la vida de Humbert Humbert ${ }^{24}$ : su madre, que murió cuando él tenía 3 años; su esposa, Charlotte Haze, la madre de $L^{2} \operatorname{lita}^{25}$ y su primer amor adolescente, Annabel Leigh ${ }^{26}$. Todas ellas mueren prematura y dramáticamente. Si bien cada muerte es diferente, ambas madres parecen ser necesariamente eliminadas. La figura materna supone un problema para que Humbert Humbert pueda estar junto a sus amadas, primero junto a Annabel y muchos años después con Lolita. Annabel Leigh es «Annabel Lee» ${ }^{27}$ de Edgar Allan Poe. Nabokov insiste en relacionar sus protagonistas con las jóvenes de la poesía de Poe. En un momento dado esta referencia se hace explícitamente cuando Annabel Leigh es llamada «la pequeña iniciática Miss Lee» ${ }^{28}$. Humbert Humbert recuerda con la presencia ausente de Lolita, que a su vez existe gracias a la todavía más ausente Annabel Leigh, que verdaderamente evoca a la amada idealizada en una exaltación erotico-necrófila propia de Poe y del arte prerrafaelista. Si nos remitimos al primer boceto de Lolita, titulado El hechicero, se perfila la relación entre un hombre adulto y una niña, en el cual no existía ningún tipo de justificación para el deseo pederasta, más aún resultaba innecesario.

Al detenernos en la observación de algunas obras literarias en las que aparezcan temáticas vinculadas a la pedofilia, en todas ellas, la

\footnotetext{
${ }^{24}$ Elisabeth Bronfen, señala la necesidad de entender la existencia de Lolita remarcando la muerte de estas 3 mujeres en BRONFEN, Elisabeth. Op. cit., pág. 372.

${ }^{25} \mathrm{~N}$. B. el paralelismo entre la muerte de su madre en un «extraño accidente» y la muerte de Charlotte atropellada al salir corriendo de su casa tras el incidente del descubrimiento del diario.

${ }^{26}$ Algunos estudios, identifican a «Colette», una niña que Vladimir Nabokov conoció en una playa de Biarritz y que cita Nabokov en sus memorias. Al parecer ella inspiraría su libro Primer amor y sus Trece cuentos rusos.

27 Virginia Clemm la esposa de Edgar Allan Poe, que recordaba en su poema Annabel Lee, murió de tuberculosis. Nabokov hace que su Annabel Leigh muera de la misma manera.

${ }^{28}$ BRONFEN, Elisabeth. Op. cit., pág. 375.
} 
presencia infantil se manifiesta como una imagen desdoblada, como un reflejo, especular y siniestro, al cual Fraser Morris identifica como una visión feérica del niño o la niña encarnando la eternidad. Y frente a ellos estaría la figura aparentemente bondadosa e incluso «asexual» en algunos casos, de un hombre adulto o viejo que en la llamada «inversión narcisista» se proyecta al exterior mediante el deseo por los niños del mismo o distinto sexo, para resolver un Complejo de Edipo que arrastraran desde la infancia ${ }^{29}$. Así, bajo estos criterios hallamos a Humbert Humbert y Lolita, a Aschenbach y Tazio en Muerte en Venecia de Thomas Mann, Peter Pan, un adulto que no quiere crecer y permanece en su propio cuerpo infantil y a su propio autor J. M. Barrie y su obsesión con los niños, y por supuesto a Lewis Carroll con su Alicia.

Pero Lolita no es Annabel y aunque joven, Lolita dista mucho del recuerdo idealizado de la inocente Annabel, pues ella va ligada a una vida oculta, de sexualidad prohibida, censurable, de perversión y subyugación. Lolita no está idealizada, pero sí es imaginada por Humbert Humbert. Su recreación mental de la niña es más real que la propia Lolita ${ }^{30}$. Es una novela sobre la imaginación y el deseo. Ese deseo en Humbert Humbert es el que hace que Dolores Haze, una ninfa -una oruga-, se convierta en Lolita, una nínfula -en una hermosa mariposa-. Una transformación que numerosos autores han identificado con la más que afición, pasión de Nabokov por las mariposas.

Pero la cuestión es si Lolita es verdaderamente perversa, si esa naturaleza es la de las lujuriosas ninfas o la de la sensual y sádica Salomé. No lo cree así Vladimir Nabokov: «Lolita no es una niña

${ }^{29}$ MORRIS, Fraser. The Death of Narcissus. London: Secker and Warburg, 1976. Citado en el Prólogo de la edición de Manuel Garrido de CARROLL, Lewis. Alicia en el País de las Maravillas. A través del espejo. Op. cit. ${ }^{30}$ Humbert Humbert cuenta que al volver a ver a Lolita tras la muerte de su madre, en el campamento de verano, le pareció «que su rostro era menos bonito que la huella mental» BRONFEN, Elisabeth. Op. cit., pág. 378 y NABOKOV, Vladimir. Lolita. Op. cit., pág. 122. 
perversa. Es una pobre niña que corrompen y cuyos sentidos nunca se llegan a despertar bajo las caricias del inmundo señor Humbert: ¿Siempre viviremos así, haciendo toda clase de porquerías en camas de hotel?» ${ }^{31}$. Lolita es una colegiala americana de 12 años, algo vulgar, que bajo «la imaginación del triste sátiro» Humbert Humbert, es convertida en criatura mágica, mitológica. Tan trivial y normal es Lolita en su género, dice Nabokov, como lo es Mr. Humbert de poeta frustrado y no existe Lolita, ni existen las nínfulas, si no es a través de la obsesión de Humbert Humbert ${ }^{32}$.

Podremos distinguir a Lolita entre los nombres del poema-lista de clase de Lolita que escribe Humbert Humbert, como a Alice Liddell de entre el listado ${ }^{33}$ de niñas fotografiadas por Lewis Carroll. Una «Lolita» o una «Alice», carece de la esencia que verdaderamente la define pues la naturaleza demoníaca es inherente a la nínfula, no se adquiere sino que sólo algunos «locos» podrían descubrir de entre el resto de niñas ${ }^{34}$.

Las diferencias entre Lolita y Alice, son mínimas, que no entre Humbert Humbert y Lewis Caroll/Mr. Dodgson ${ }^{35}$. En Lolita como en Alicia

\footnotetext{
${ }^{31}$ Entrevista realizada a Vladimir Nabokov en Programa Apostrophes presentado por Bernard Pivot de la Televisión francesa en 1975. Vladimir Nabokov-Apostrophes. Entrevista a Vladimir Nabokov. Programa Apostrophes presentado por Bernard Pívot [Vídeo]. Editagrama. Videoteca de la memoria literaria, Ediciones Trasbals Multimedia, mayo de 1975.

${ }^{32}$ Ibíd.

${ }^{33}$ N. 56, pág. 162 del cap. 5. Lewis Carroll.

${ }^{34}$ Numerosos autores encuentran claras conexiones entre Carroll y Nabokov como Elizabeth Prioleau "Humbert Humbert Through the Looking-Glass". Twentieth Century Literature 21, no 4, decembre, 1975, págs. 428-37.

35 En septiembre de 1966, Alfred Appel Jr. realizó una entrevista Nabokov. Decía que siempre le había tenido mucho cariño a Lewis Carroll y que Carroll «tenía una patética afinidad con Humbert Humbert, pero que algunos extraños sin escrúpulos le prevenían de aludir en Lolita a su perversión y a sus ambiguas fotografías que él tomó en oscuras habitaciones». Él se escapó de esto, como otros victorianos se salieron impunes de la pederastia y la ninfomanía. "Sus flacuchas y tristes pequeñas nínfulas, sucias y a medio vestir o semidesnudas, como si participaran en alguna polvorienta y terrible charada». En esta afirmación parece referirse a la fotografía de Alice Liddell como mendiga de Lewis
} 
hay una atracción por la infancia fugaz y la inadaptación por comprender el mundo adulto de sus protagonistas. La pasión por las niñas les invade a ambos, no obstante, las niñas-nínfulas de Humbert Humbert, son criaturas deseables carnalmente, sexuales. Por el contrario Lewis Carroll descubre que con las niñas se siente a salvo precisamente de eso, de la sexualidad y el erotismo adulto ${ }^{36}$ y consecuentemente la maldad no es maldad sino travesura en las niñas, pues son inocentes y puras, algo que se pierde con la madurez.

\subsection{Diferencias entre el pedófilo, el ninfulómano y el artista.}

Nabokov, observa la naturaleza de las nínfulas y de Lolita desde el sentimiento estético de «lo sublime», en lo que se ha venido a llamar «la paradoja de lo sublime», como un sentimiento ambivalente de atracción-repulsión. Por un lado, Humbert Humbert detesta su actitud, su deseo por Lolita, «la turbación de la quietud debida a su anormalidad ${ }^{37}$, pero por otra no desea evitar su deseo pedófilo y lo lleva a último término. Es pues un pederasta que reconoce su patología y que se justifica en términos psicoanalíticos, al remitirse a otras mujeres como las causas de su «obsesión». Pero el pederasta desea de manera indiscriminada a las niñas o niños, como el personaje de Clare Quilty, el escritor, por quién Lolita se siente realmente enamorada y con el que urde una trama para escapar de su padrastro Humbert Humbert.

Carroll, fig. 64, pág. 188 de la presente tesis. Entrevista publicada en AA.VV. Winsconsin Studies in Contemporary Literature. vol. III, no 2, spring 1967.

${ }^{36}$ Posicionamiento que atiende a las consideraciones del Morton Cohen.

37 DE LA CALLE, Román. Lineamientos de Estética. Valencia: Nau Llibres, 1985. 
El término pedófilo ${ }^{38}$, es continuamente omitido. Vladimir Nabokov plantea mediante sus personajes una problemática no sólo moral o psiquiátrica respecto a la patología sexual de la pederastia sino que se remite a consideraciones estéticas o artísticas cuando incluye y equipara al «artista» dentro del grupo de «locos» buscadores de nínfulas. Consideremos pues las diferencias entre el pedófilo, el ninfulómano y el artista, a través de una serie de proposiciones:

- Primero, que acaso la naturaleza nínfica que Humbert Humbert reconoce en Lolita, no existe, y por tanto, tal naturaleza únicamente es una invención imaginaria creada en base a una persona concreta, la niña Dolores Haze, para poder justificarse frente a su propia moral, sus deseos pedófilos, que de manera indiscriminada no podría hacerlo.

- Segundo, en caso contrario, reconozcamos que realmente sí que existe dicha naturaleza nínfica, demoníaca, de la cual el ninfulómano, tiene indicios de su existencia, diferenciada de la naturaleza humana del resto de las niñas. Ciertamente su deseo es único y discriminado, pues se centra en la figura de Lolita, lo que le diferencia ya de por si de la figura del pedófilo. Se le atribuye a éste una variable diferente a la del deseo sexual, que es la del enamoramiento, la de la locura de amor. Sin embargo no deja de ser un pedófilo pues su deseo final es el disfrute sexual.

- Tercero, que independientemente de la existencia real o no de la naturaleza nínfica, se encuentra la visión del artista, del creador, del autor, Vladimir Nabokov, que al igual que el ninfulómano, vislumbra la naturaleza diferente y sublime de algunas niñas en su estado transitorio hacia la adolescencia. Pero que a diferencia del ninfulómano, su objetivo

\footnotetext{
${ }^{38} \mathrm{~N}$. B. la diferencia entre el pedófilo, que es el adulto, hombre o mujer, que siente atracción sexual por niños o niñas y el pederasta, que es el adulto que abusa sexualmente de menores, es decir que comete el delito de pederastia.
} 
final no es el disfrute sexual, sino el de utilizarla como estímulo para la creación como experiencia estética. Y por último sería necesario incluir la figura del espectador, del lector que participa del objetivo final del artista, el objeto fetiche, la nínfula. 



\section{EL ICONO DE LOLITA. LA PREADOLESCENTE EN EL CINE.}

Tras la publicación de Lolita, el personaje de la preadolescente sufrió cambios significativos y modificaciones de modo que incluso el propio Vladimir Nabokov se preguntaría veinte años después, por el problema de la «tonta» degradación ante la sociedad de masas del personaje de la nínfula que él inventara en $1955^{1}$, y es que la imagen que tenemos de las adolescentes y preadolescentes es la de una «Lolita» o «nínfula», de naturaleza erótica y algo perversa.

Lolita ha sido interpretada desde el punto de vista de la iconografía de la femme fatale simbolista, de este modo, Lolita es perversa, como una ambigua «ninfa» sin escrúpulos, que embauca al erudito Humbert Humbert, como las ninfas del bosque, con lo que las características físicas de la nínfula se han exacerbado grotescamente, al igual que la perversidad de la «pobre criatura» ${ }^{2}$, que en lugar de ser la víctima de un degenerado hombre de mediana edad que la imaginaba sexual y malévola, pasa a convertirse en una auténtica Salomé de Oscar Wilde. Se trata de una errónea interpretación o falsedad provocada por la popularidad del personaje.

Por otro lado, la representación erótica de la preadolescente, ha sido considerada en su forma más superficial, dando lugar a la categoría surgida del nombre propio «Lolita», ahora nombre común «lolita» definiendo precisamente el estereotipo de adolescente actual que ciertamente el cine ha ayudado a recrear, sin duda el resto de los medios de masas ha consolidado como «icono de Lolita», que el espectador espera ver en las pantallas de los cines.

${ }^{1}$ Vladimir Nabokov-Apostrophes. Op. cit.

${ }^{2}$ Ibíd. 
Durante las décadas posteriores a la publicación de la novela de Nabokov, el físico y la edad de Lolita o las muchachas que eran identificadas o consideradas como «lolitas», eran las jóvenes de 20 años o más que las publicaciones ilustradas de todo el mundo mostraban. «Pavas, gatas callejeras, modelos baratas o simples delincuentes de largas piernas, son llamadas «nínfulas» 0 «lolitas» en revistas italianas, francesas, alemanas, etc», afirmaba Nabokov indignado respecto a las representaciones visuales que se hacían de Lolita con la apariencia de una Brigitte Bardot. Incluso en las cubiertas de las traducciones turcas o árabes, Lolita es representada como una joven de curvas opulentas y melena rubia que se contrapone contundentemente a las descripciones que en la novela se hacen de la misma. «El colmo de la estupidez», señalaría el famoso presentador francés Bernard Pivot ${ }^{3}$.

Entre las premisas a tener en cuenta respecto a la representación icónica de la preadolescente y que remarcan el tratamiento superficial de la cuestión expuesta, está la consideración actual de que una «lolita», es una adolescente precoz, atractiva tanto para jóvenes de su edad como para adultos, con necesidades y capacidades sexuales, que si bien es protegida por la ley por su condición de menor contra la ito. La premisa radica, en que Lolita, no es una adolescente, es todavía pederastia, el acto sexual con otros adolescentes no constituye del una niña y por lo tanto, aunque sí que tiene una sexualidad infantil propia, no tiene todavía la capacidad ni el deseo sexual adulto. Sin embargo la turbación se produce porque a pesar de ser lo anterior cierto, Lolita -el personaje- se comporta en el ámbito sexual como una adulta y utiliza ese comportamiento sexual para obtener lo que desea, pero también, con su condición de

\footnotetext{
${ }^{3}$ Ibíd.
} 
huérfana, es la única manera que sabe para sobrevivir y convivir con su padrastro que la desea sexualmente. Es por ello que el término «Lolita» se convirtió en sinónimo de pederastia. En Holanda por ejemplo, hasta 1970 aproximadamente, se publicaba Lolita Magazine, una revista en la que su contenido abordaba las relaciones sexuales con menores incluso de tipo incestuoso.

\subsection{El icono de la preadolescente en el cine. El cine tras la publicación de Lolita.}

Durante el siglo $\mathrm{XX}$, el cine ha explotado parcialmente el estereotipo de la inocencia infantil con el icono de la preadolescente erotizada, en particular con una representación más cercana a la imagen de la adolescente que de la preadolescente, elaborándose un icono en términos principalmente sexuales o maléficos. En este sentido, Lolita, ha permitido a los medios de masas y al arte, legitimizar ${ }^{4}$ las explicaciones de los mecanismos de funcionamiento de la seducción y la sexualidad en la preadolescente. La novela de Lolita inaugura con nombre propio la imagen de la preadolescente que el cine intuyera a comienzos del siglo $X X^{5}$ y que lanzara a las pantallas cinematográficas como la enfant fatale, no sin antes enfrentarse, escritor y novela a las acusaciones de pornografía y pederastia.

La escabrosidad de algunos argumentos fílmicos, hacían que la interpretación de ciertos papeles infantiles, fueran interpretados por

\footnotetext{
4 STONEY, Elizabeth. Alice Does: The Erotic Child of Photography [en línea]. [ref. de 16 de noviembre de 2004]. Disponible en Web: http://www.ahcca.unimello.edu.aa/ screenscape/alice.htm

${ }^{5}$ Se toma como referente de estudio el cine producido en Hollywood, pero se hace referencia al cine europeo, sobretodo el que se realizara las últimas décadas del siglo XX. V. cap. 6. «Las niñas del celuloide». La preadolescente en el cine a comienzos del siglo XX, pág. 197.
} 
actrices de mayor edad. En esta ocasión no tanto por una falta de tradición interpretativa infantil como por lo polémico que resultaban tratar ciertos temas tabú para la puritana sociedad estadounidense que disponía de numerosas instituciones que actuaban de censura. La producción cinematográfica norteamericana se había visto regida desde 1930 por el baremo de moralidad que imponía el llamado Código de Ética y que nació a partir de la propuesta inicial del sacerdote católico Daniel Lord. La Motion Pictures Producers and Distributors of America (MPPDA), también conocida como la «Oficina Hays» se encargaba de aplicar el Código de Ética junto a otras organizaciones de carácter religioso, como la llamada «Legión de la Decencia» ${ }^{6}$, llegando incluso a boicotear las películas que habían pasado la censura, las cuales no siempre se les aplicaba estrictamente la censura por tratar algunos temas o vicios demasiado comunes en la sociedad estadounidense, pero no para la Legión de la Decencia. Así, la actuación eclesiástica extendía su prohibición a temas como el exceso de violencia, mestizaje, drogas, prostitución, adulterio, desnudos o posturas insinuantes o exaltación sexual. Por el contrario, el cine debía propiciar el patriotismo, la religión y las instituciones de la familia y el matrimonio. En 1934, se creó la Production Code Administration, PCA, dirigida por Joseph Breen, en sustitución de la MPPDA -que resultó insuficiente para la Legión de la Decencia y la Iglesia Católica-, con lo que a partir de entonces no se proyectarían películas que no llevasen el sello de la PCA. A pesar de ello, los directores y guionistas lograron sacar a la luz, no si esfuerzo, con mucho ingenio y con evidentes censuras iniciales, su películas, explotando cada vez más la sexualidad de la preadolescente de manera cada vez más explícita.

\footnotetext{
${ }^{6}$ Legion of Decency.
} 


\subsubsection{La «lolita».}

La representación de la preadolescente necesitaría de un bautismo cinematográfico de perversión versus moralidad para que la heroína preadolescente de Alicia en el País de las Maravillas, enmascarada bajo los galimatías, enredos y disparates del país subterráneo recreado por Lewis Carroll en la Inglaterra victoriana, rompiese sus lazos con el ideal romántico de pureza virginal y se convirtiese en amada y diablillo de Humbert Humbert, de aquel que la descubriera sucumbiendo a los encantos de la nínfula de la novela de Vladimir Nabokov, Lolita. La encarnación de la Lolita «perversa»o niña sexualizada, toma forma ya no sólo en la inocente Alicia, o en la sensualizada Shirley Temple, sino también en las heroínas de la factoría Disney, ya fuera en la dulce Blancanieves que como Eva come de la manzana, como la resuelta Wendy, la pequeña Hada Campanilla o las sirenas de Nunca Jamás en Peter Pan, todas ellas cautivadoras e inconscientes de su propio poder.

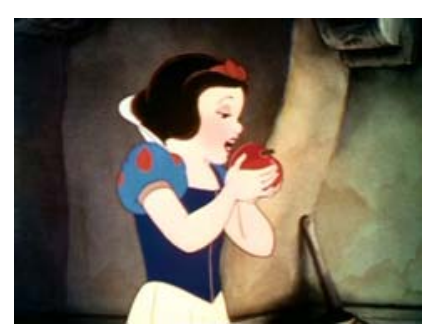

Fig. 1. Blancanieves y los 7 enanitos (Snow White and the Seven Dwarfs; Walt Disney, 1937).

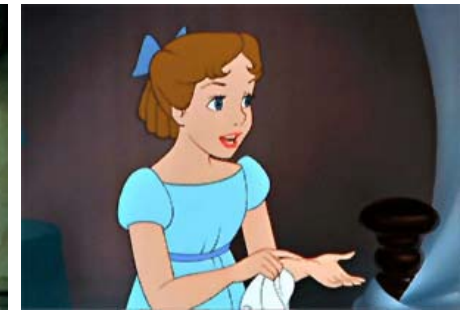

Fig. 2. Wendy en Peter Pan (Clyde Geromini; Wilfred Jackson; Hamilton Luske, 1954).

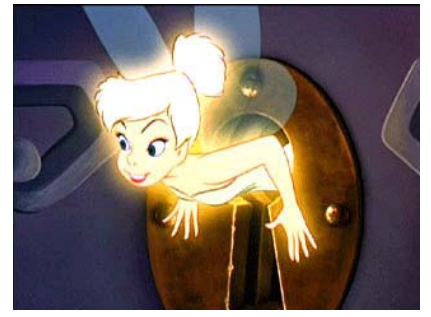

Fig. 3. Campanilla en Peter Pan (Clyde Geromini; Wilfred Jackson; Hamilton Luske, 1954).

Las exitosas producciones infantiles de Walt Disney, dieron a conocer a algunas jóvenes actrices protagonistas de comedias y musicales -verdaderas nínfulas en la vida real-, que no pudieron 
deshacerse de la etiqueta de «chica Disney» como Carol Lynley o Hayley Mills, a pesar de encarnar papeles de «lolitas».

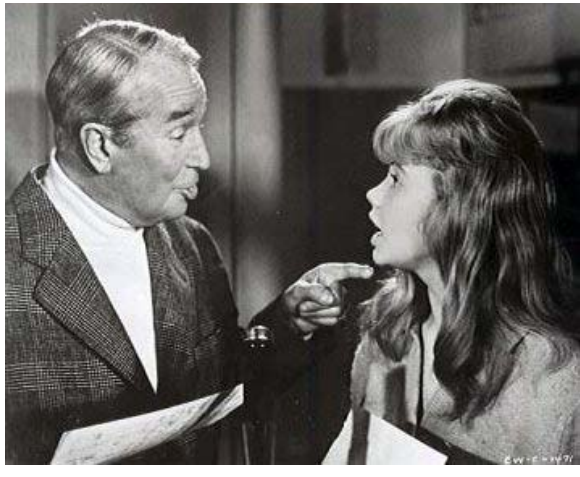

Fig. 4. Hayley Mills y Maurice Chevalier en Los hijos del Capitán Grant (1962).

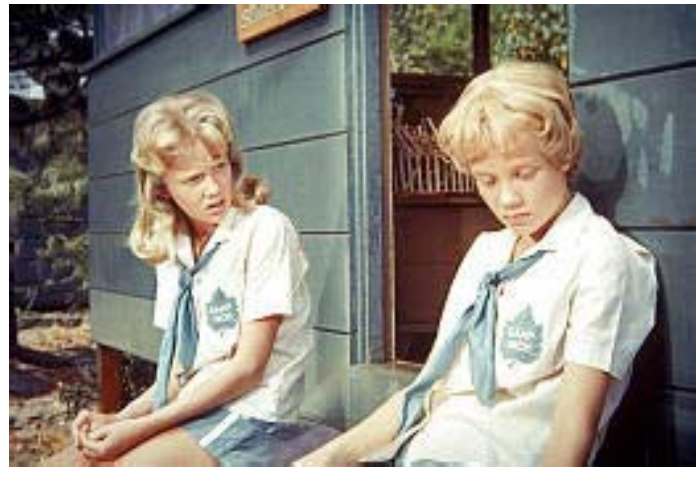

Fig. 5. Hayley Mills en Tú a Boston y yo a California (1963).

Hayley Mills (1946) comenzaría en el cine con papeles que ya interpretaran en su momento Mary Pickford o Shirley Temple como Pollyanna (1960) y que enfatizaban el carácter inocente y bondadoso de las niñas. Un año después y por partida doble interpretó el papel doble de las gemelas Sharon y Susan separadas al nacer en la comedia Tú a Boston y yo a California (The Parent Trap; David Swift, 1961), que inicialmente intercambia su identidad y luego mediante engaños $y$ travesuras tratan de unir de nuevo a sus padres divorciados. El veterano Maurice Chevalier, que había trabajado con ella en Los hijos del Capitán Grant (In Search of the Castaways; Robert Stevenson, 1962) -y como cantara Thanking Heaven for Little Girls, «agradeciendo al Cielo por haber creado a las niñas, pues algún día serán bellas mujeres» en Gigi (Vincente Minnelli; 1956)-, ahora auguraba en la figura de Harley Mills, un futuro en el que se convertiría en una de las actrices inglesas más populares y atractivas de la pantalla, sin embargo al crecer, su vida fue objeto de escándalo cuando aún adolescente se casó con el productor de 52 años Roy Boulting. 
En 1956, Elia Kazan dirigió la película Baby Doll , basada en la obra teatral del autor norteamericano Tennessee Williams y guión del propio Williams, que nos sitúa en el estado de Mississippi. Con Baby Doll, Carroll Baker ${ }^{8}$ (1931) se convertiría en uno de los grandes mitos eróticos de adolescentes de su época, interpretando a una menor de 19 años, cuando ella en realidad ya había cumplido los 25. «Baby Doll», es un personaje complejo. Su físico es acorde a su edad, pero su juego entre inocencia y sensualidad, no se debe a un juego consciente, sino a el retraso de la muchacha, que actúa de manera infantil, duerme en una cunita, habla aniñadamente y se chupa el pulgar.

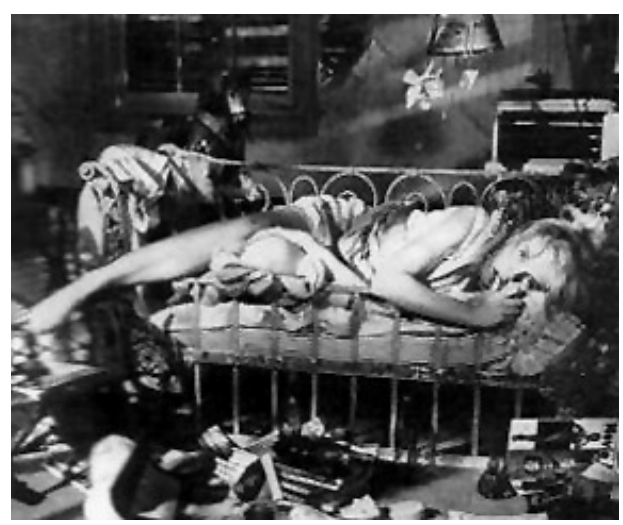

Fig. 6. Carroll Baker en Baby Doll (1956).

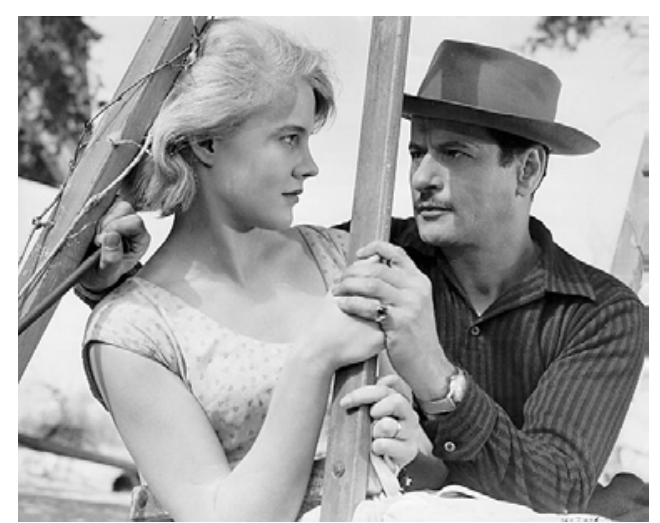

Fig. 7. Carroll Baker y Eli Wallach en Baby Doll (1956).

«Baby Doll» es una muchacha sureña, que aunque casada, permanece virgen, pues su marido, Archie Lee Meighan -Karl Malden-, prometió a su suegro no consumar al matrimonio hasta que ella cumpliese la mayoría de edad a los 19 años. La película arranca el día antes de que se cumpla ese plazo. A su vez, el nuevo jefe del sindicato

\footnotetext{
7 Las palabras inglesas baby o babe, no sólo significan bebé, sino también pequeño/a, nena, chica, cariño, que se pueden combinar con otras palabras como pretty baby, baby vamp o como en este caso, baby doll, muñequita.

${ }^{8}$ Carroll Baker , Mildred Dunnock -actriz de reparto- y el guión, fueron nominados a los Oscar ${ }^{\circledR}$ de 1956.
} 
algodonero, Silva Vacarro -Eli Wallach- planea vengarse de Archie, culpable de la quema de sus almacenes, seduciendo a «Baby Doll». Archie debe reprimir sus impulsos sexuales y obsesionado, la observa mientras duerme a través de un agujero de la pared, como si de un pervertido se tratase y no de su marido. El matrimonio entre Archie y «Baby Doll» es una farsa sexual, un contrato entre el difunto suegro y el marido, en la que aparecerá un tercero en discordia, Silva Vacarro, que mediante la seducción despierta la sexualidad de «Baby Doll». Si Shirley Temple era una mujer en el cuerpo de una niña, «Baby Doll» es una niña en el cuerpo de una mujer. De hecho el papel de «Baby Doll» pudo haberlo interpretado Marilyn Monroe, la eterna niña en cuerpo de mujer, como pensó Elia Kazan en un principio. «Baby Doll» es la representación metafórica de la represión sexual, la sexualidad infantil y la decadencia de la moral norteamericana. La película fue duramente castigada durante su estreno por la Legión de la Decencia y la Iglesia Católica y clasificada por el cardenal Francis Spellman, como «una ocasión de pecado».

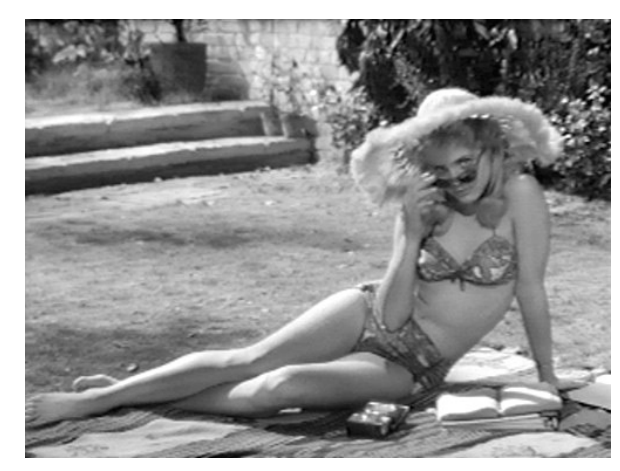

Fig. 8. Sue Lyon en Lolita (1962).

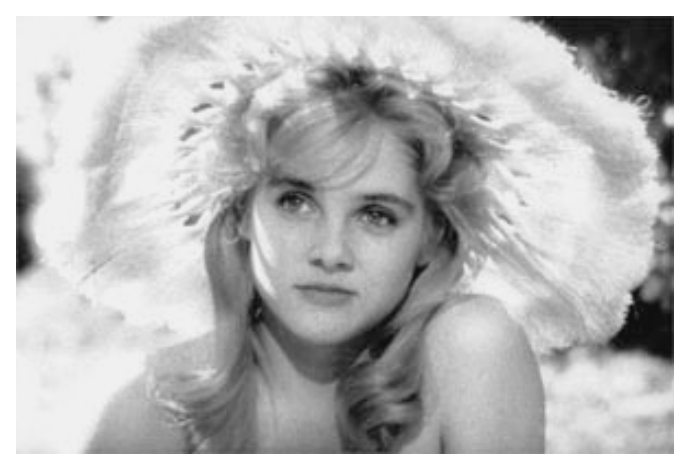

Fig. 9. Sue Lyon en Lolita (1962).

En 1962, Stanley Kubrick dirigió a la joven Sue Lyon (1946) de 16 años, en el papel de nínfula en Lolita. A pesar de basarse en la novela de Vladimir Nabokov y de participar éste de manera directa en el 
guión, la película se vio influenciada por la reciente Baby Doll. Stanley Kubrick conferiría a Humbert Humbert un carácter único y perverso en combinación con la actriz Sue Lyon, interpretando a Lolita, que vestida sofisticadamente, con tacones altos ${ }^{9}$, se aleja del aire de chiquilla vulgar de la novela. El poder de Lolita se manifiesta en una de las escenas más denigrantes para Humbert Humbert -James Mason-, cuando éste le pinta las uñas de los pies, mientras él le hace un listado a modo de reproche de todo lo que hace por ella como «ama de casa», pero que ella, Lolita, no sabe «apreciar». Precisamente es durante el comienzo de la película como fondo de los títulos de créditos, que aparece un anticipo de ésta escena con otra escena semejante en la que únicamente se ve cómo son pintadas las uñas de un pie. Simbólicamente, Humbert Humbert, se encuentra a los pies de Lolita, a su voluntad $^{10}$.

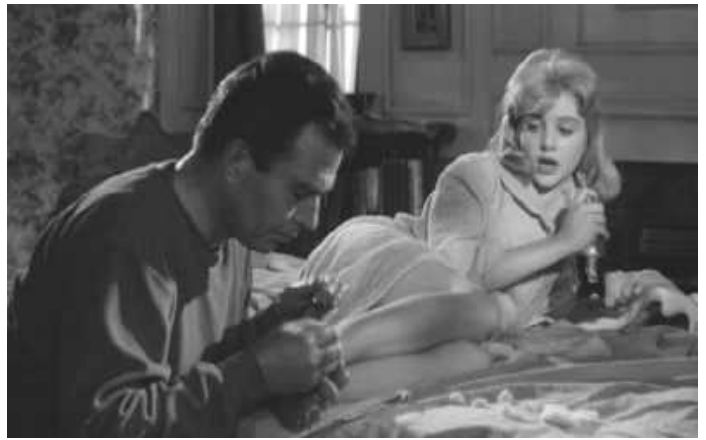

Fig. 11. Sue Lyon y James Mason en Lolita (1962).

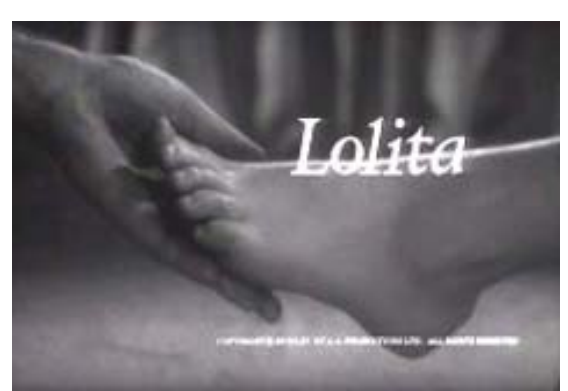

Fig. 10. Créditos iniciales de Lolita (1962).

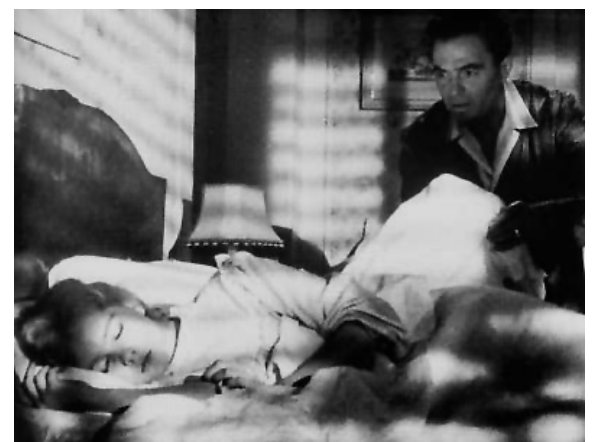

Fig. 12. Sue Lyon y James Mason en Lolita (1962).

\footnotetext{
${ }_{9}^{9}$ Marianne Sinclair señala, que sin embargo, esa era la manera de vestir de las niñas en los 50 . En SINCLAIR, Marianne. Hollywood Lolita. The Nymphet Sindrome In The Movies. London: Pexus, 1988, pág. 115.

10 ETXEBARRÍA, Lucía; NUÑEZ PUENTE, Sonia. En brazos de la mujer fetiche. Col. Imago mundi. Barcelona: Ediciones Destino, 2002.
} 
Los pequeños pies de la niña ejercen un atractivo sexual sobre Humbert Humbert, que tendido a sus pies, literal y simbólicamente, le pinta las uñas. Los pies ya se habían interpretado como elementos sexuales en la cultura china y su influencia en el cuento de la Cenicienta. Y ella, tras los patéticos reproches de su padrastro, se permite el lujo de contestarle : «iNo me quieres! iMe estás volviendo loca!».

La adaptación cinematográfica incrementa la perversidad de los personajes protagonistas, marcando sus rasgos sarcásticamente e incluso ridiculizándolos como en el personaje de Clare Quilty, interpretado por Peter Selles, que sin embargo repercutieron en la creación de una nueva concepción de las relaciones de poder y sexo entre el Humbert Humbert, Lolita y Clare Quilty, es decir en las figuras del ninfulómano, la nínfula y el pederasta.

Lolita supondría de manera definitiva, la concreción de un icono artístico y socio-cultural, con nombre propio y que el cine ya había apuntado desde sus comienzos con Mary Pickford o Shirley Temple. Lolita se había convertido en un icono de sexualidad infantil que difícilmente podía dejar de reconocerse no sólo en las estrellas del celuloide, sino también en la vida cotidiana de los espectadores al ver pasar a la coqueta vecinita del $3^{\circ}$ piso en minifalda o a la colegiala de uniforme, es decir, en cualquier muchacha atractiva de comportamiento sexual precoz o apariencia similar a Sue Lyon.

Escándalo en Villa Fiorita (The Battle of the Villa Fiorita; Delmer Daves, 1965) supuso el debut de Olivia Hussey (1951), que más tarde sería la musa del director italiano Franco Zeffirelli ${ }^{11}$. El argumento principal de la película trata cómo Moira -Maureen O’Hara-, una madre

${ }^{11}$ Con él rodaría en el papel de «Julieta» en Romeo y Julieta (1968) y de «María» en Jesús de Nazaret, (1977). 
y esposa inglesa abandona a su familia para irse a vivir a Italia con Lorenzo, un compositor viudo con una hija. Pero los hijos de Moira, Michael y Debby, junto a Donna, la hija de Lorenzo, harán todo lo posible para que se rompa esa relación y que todo vuelva a ser como antes $^{12}$. Sin embargo, en un segundo nivel se plantea el «poder» infantil sobre los adultos y el erotismo de la preadolescente mediante la comparación entre Debby y Donna -Olivia Hussey-. La primera representa a la niña que todavía no cuenta con ningún atractivo sexual y la segunda, a pesar de su juventud, ya lleva sujetador y presume de tener novio. Además su físico mediterráneo, hace de ella una atractiva Lolita, camuflada bajo la trama adulta, pero que el director no ha querido dejar de explotar, pues a diferencia del resto de los personajes cuenta con un tema musical propio interpretado con un saxofón, que resalta las cualidades lascivas y sensuales de ésta Lolita ${ }^{13}$.
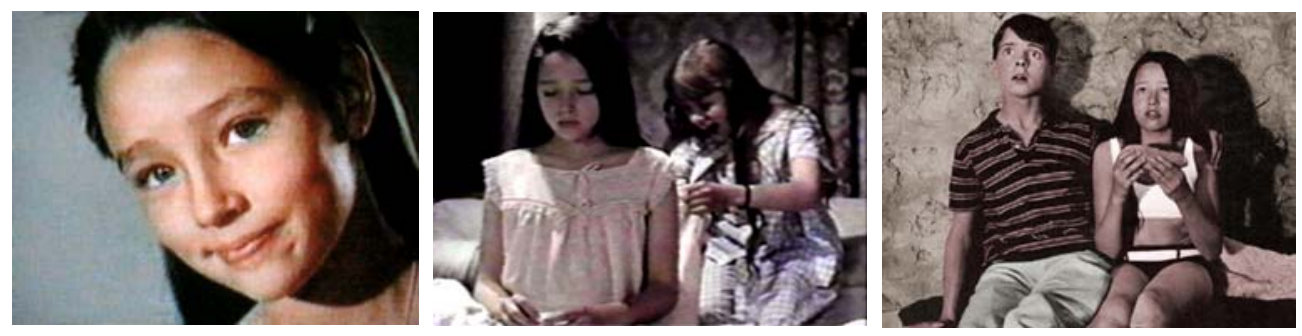

Fig. 13, fig. 14 y fig. 15. Olivia Hussey en Escándalo en Villa Fiorita (1965).

El cine y el público se sentía tremendamente atraído por el personaje de la «Lolita» en sus múltiples variantes que junto al personaje del hombre adulto, proponía unas seductoras relaciones «peligrosas» basadas en el juego entre erotismo y la inocencia.

\footnotetext{
${ }^{12}$ Cf. con la capacidad de manipulación de las niñas en Tú a Boston y yo a California (1963), pág. 266 de la tesis.

${ }^{13}$ Compuesta por el compositor ruso Mischa Spoliansky.
} 
Luna de Papel (Paper Moon; Peter Bogdanovich, 1973), se trata de una divertida comedia en blanco y negro ambientada en los Estados Unidos, durante la Gran Depresión en la década de 1930. Addie -papel con el que debutó Tatum O'Neal ${ }^{14}$ - es una precoz niña de 9 años que ha perdido a su madre y que debe marchar a vivir con su tía, pero en el funeral de su madre conoce a Moses - Ryan O'Neal, su padre en la vida real-, un aventurero vendedor de Biblias de lujo, al que ella cree su padre. Moses deberá llevar a la niña junto a su tía, no sin antes verse envueltos en aventuras y peripecias. Tatum O’Neal no volvería a interpretar ningún papel con tanta veracidad y éxito como con el de la pizpireta Addie, que viste como un muchacho, pero a su vez responde a las características de las flappers, en el corte de pelo, el sombrero o incluso en la manera de fumar de la menor que imita un estereotipo adulto de feminidad y seducción propio de las décadas de 1920 y 1930 del s. XX. Sin duda el éxito del personaje se debió a la enorme química que existía entre padre e hija en la vida real. Además del hecho de mantener la incógnita sobre su presunta paternidad en la ficción, hace que la relación entre ambos no sea la de un padre con su hija, sino la de un hombre desconocido con una niña.
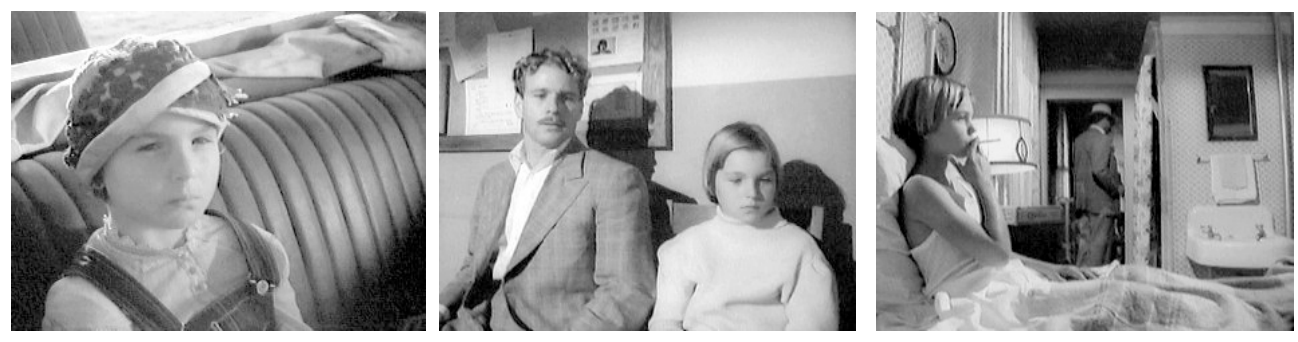

Fig. 16, fig. 17 y fig. 18. Tatum O'Neal en Luna de Papel (1973).

\footnotetext{
14 Tatum O’Neal obtuvo el Oscar ${ }^{\circledR}$ a la mejor actriz secundaria, convirtiéndose así en la actriz más joven de la historia que había obtenido dicho galardón. Ese mismo año, otra de las nominadas a mejor actriz secundaria era Linda Blair por su papel de Reagan, la niña poseída de El exorcista (1973).
} 
Las niñas «actuando» con modales y actitudes de mujer adulta, resultaban cómicas e incluso sugestivas al público, como ya ocurriera con Shirley Temple en la década de 1930, encandilando a galanes infantiles y a los espectadores adultos. En un intento de recuperar el espíritu de un mundo adulto con forma de niños, nació la producción musical Bugsy Malone, nieto de Al Capone (Bugsy Malone; Alan Parker, 1976), interpretada íntegramente por niños y adolescentes -como adultos miniaturizados- entre los que figuraba Jodie Foster (1962), en el papel de Tallullah, la novia de Fat Sam, el jefe de una banda de gansters, que en lugar de balas disparan tartas. Tallullah, coquetea sensualmente como un perfecta Gilda con el joven ganster Bugsy Malone, provocando los celos de la protegida de éste.

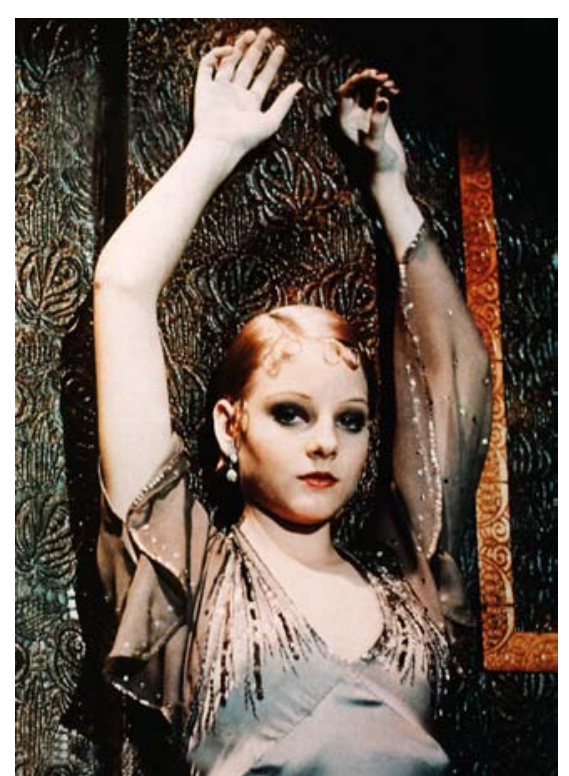

Fig. 19. Jodie Foster en Bugsy Malone, nieto de Al Capone (1976).

La polémica sobre la preadolescente y el erotismo llegaría de nuevo con la película del director francés Louis Malle, La pequeña (Pretty Baby; 1978), sobre la prostitución infantil en Nueva Orleáns a principios del siglo XX, sirviendo de filón comercial, como otras tantas películas que protagonizara la sex-symbol infantil Brooke Shields (1965). En ésta, interpreta a un niña, Violet, que vive junto a su madre, Hattie -Susan Sarandon-, una prostituta de un burdel de Nueva Orleans. Al alcanzar los doce años, la niña que ha vivido con toda naturalidad el ambiente de la prostitución, es subastada, bajo el consentimiento de su madre, entre los clientes del burdel para ser desvirgada. Pero, cuando su madre decide abandonarla para casarse con uno de sus clientes, Violet busca 
la protección en Bellocq -Keith Carradine-, un fotógrafo que ha realizado un reportaje fotográfico sobre las prostitutas del Barrio Rojo, con el que se casa, sin embargo y aun estando iniciada en el sexo, ella es todavía una niña. No sólo la temática sino los desnudos de Brooke Shields, provocaron una fuerte conmoción en esta primera incursión en el cine norteamericano del director francés. Dos años más tarde, considerada ya uno de los mitos sexuales infantiles de todos los tiempos, Brooke Shields, interpretaría El lago azul (The Blue Lagoon; Randal Kleiser, 1980) y a la que su incondicional público, incluido el propio Emperador de Japón, llegó a considerar como la «Princesa de América» y «la más bella mujer del mundo a la edad de once años».
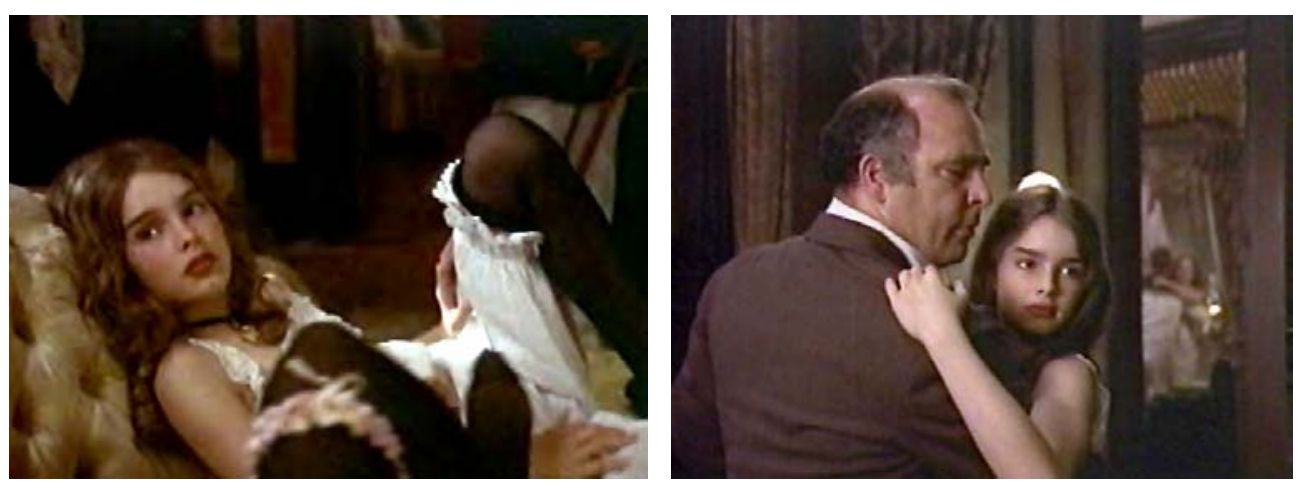

Fig. 20 y fig. 21. Brooke Shields en La pequeña (1978).
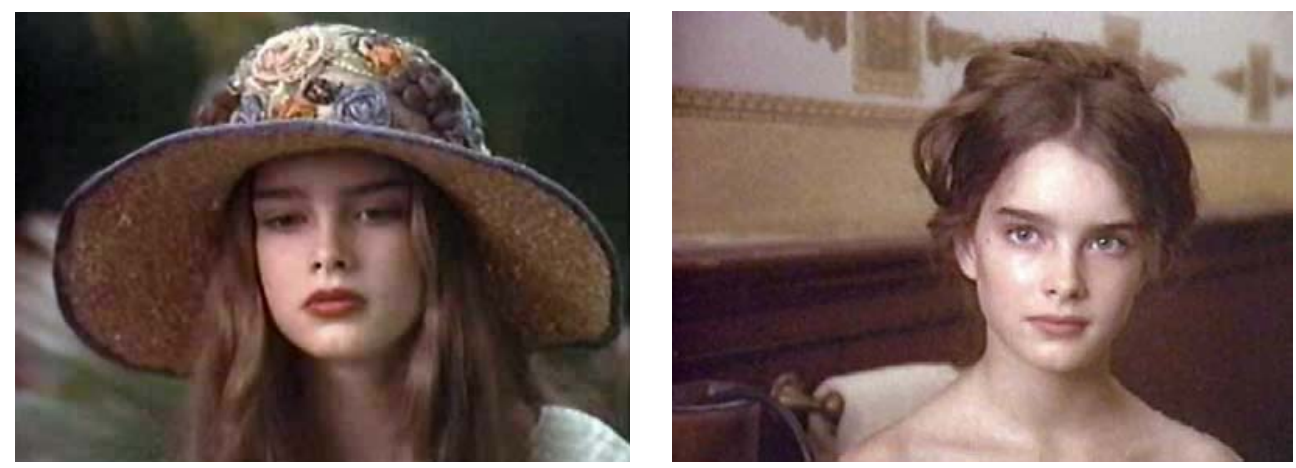

Fig. 22 y fig. 23. Brooke Shields en La pequeña (1978). 

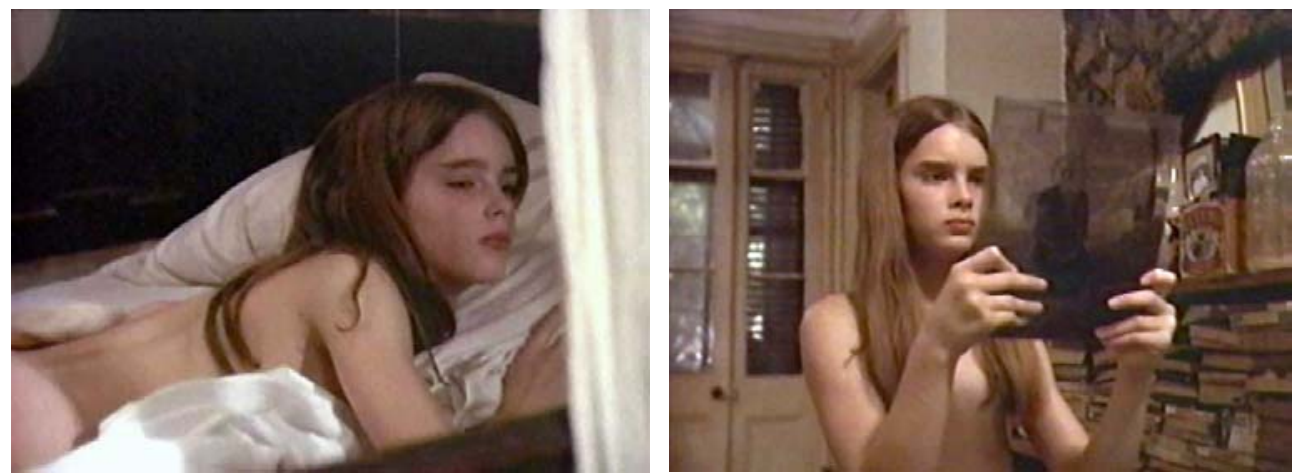

Fig. 24 y fig. 25. Brooke Shields en La pequeña (1978).
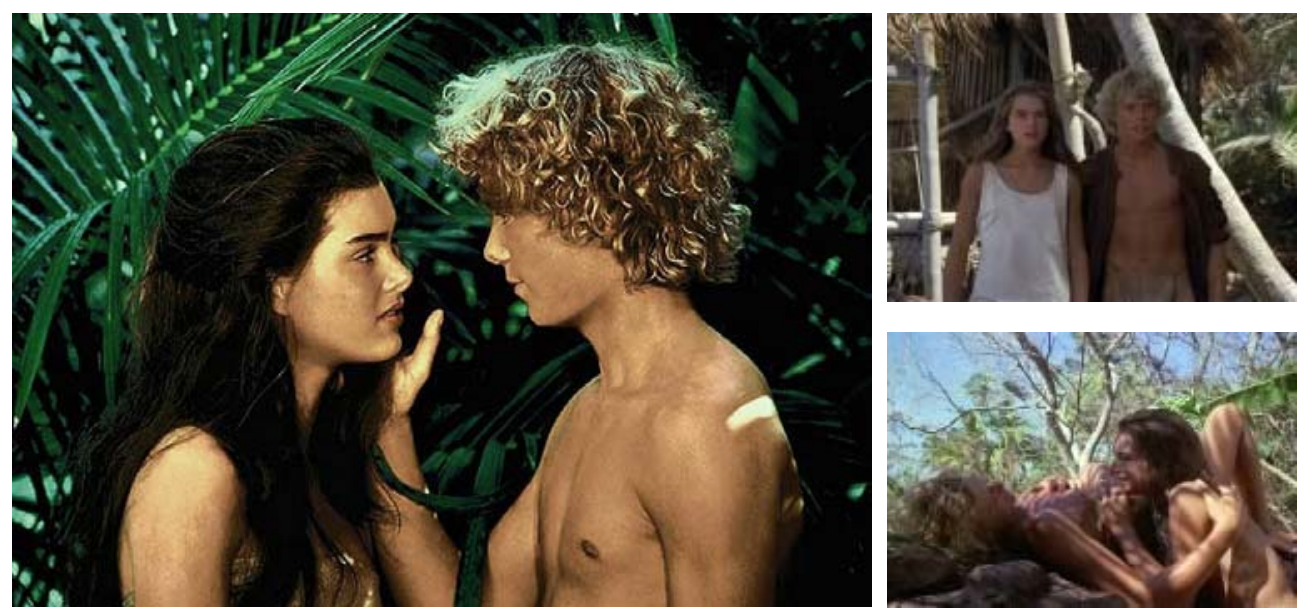

Fig. 26, fig. 27 y fig. 28. Brooke Shields y Christopher Atkins en El lago azul (1980).

Dos años antes, Jodie Foster ${ }^{15}$, también había encarnado el papel de Iris, una prostituta de catorce años de las calles de Nueva York en Taxi Driver (Martin Scorsese, 1976), en la que Travis Bickle -Robert de Niro-, un veterano de Vietnam que trabaja de taxista todas las noches observa la miseria y la amargura de las calles y decide tomarse la justicia por su mano. En su empeño intentará salvar a Iris de su «chulo», enfrentándose a éste. Pero la prostitución sólo fue el principio

${ }^{15}$ Para Jodie Foster, supuso su primer éxito cinematográfico pues fue nominada a los Oscar como mejor actriz secundaria. 
de incontables tópicos que el cine «ilustrara» como el alcoholismo, los desordenes mentales, el homicidio, el suicidio juvenil o el abuso sexual infantil, los niños perdidos, etc.

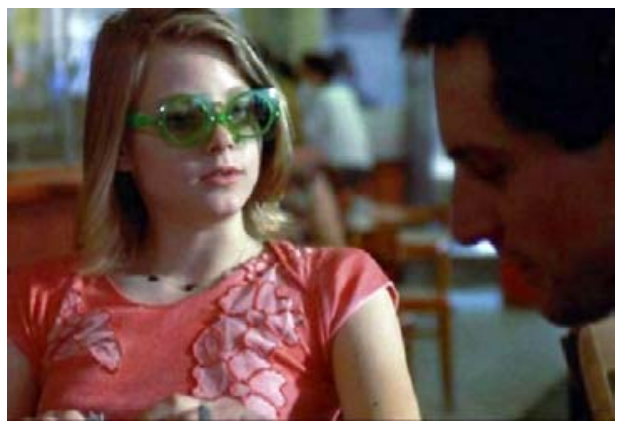

Fig. 29. Jodie Foster en Taxi Driver (1976).

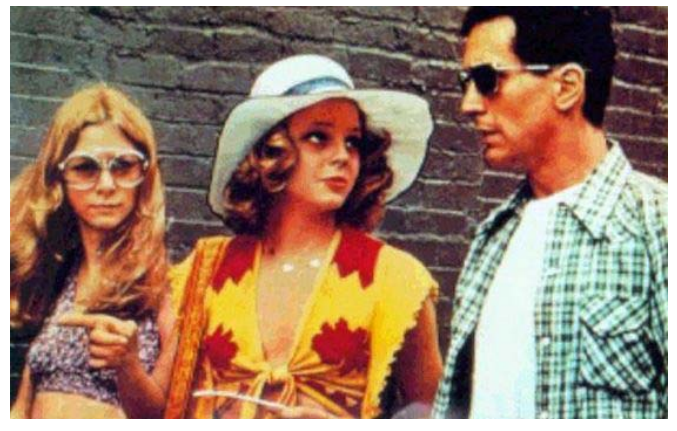

Fig. 30. Fotograma de Taxi Driver (1976).

Por otra parte, el cine europeo de la década de 1960 y 1970 del siglo XX, sobre todo el italiano y el francés, indagó en la sexualidad infantil sin verse demasiado afectado por las censuras de sus países como sí le ocurriera y sigue ocurriendo en el cine que se proyecta en Estados Unidos-, proliferando numerosas películas en las que se trataba el erotismo infantil y las relaciones sexuales y sentimentales entre menores y adultos, directa o indirectamente y recreándose en la relación «Lolita-Humbert Humbert» como algo real, como un hecho a analizar cultural y socialmente. Así en La rodilla de Clara (Le genou de Claire; 1970) de Erich Rohmer, se desarrolla un triangulo de seducción entre una preadolescente enamorada de un amigo de su madre que a su vez persigue a la hermana adolescente de la niña, Clara. También el fotógrafo David Hamilton, conocido sobre todo por sus desnudos de niñas y adolescentes, dirigiría entre otras Bilities (1977) y Tender Cousins (1980) o el director Roger Andrieux con La Petit Sirène (1980), en las que se insiste en el tópico de la preadolescente o adolescente y el descubrimiento de la sexualidad. Bertrand Blier, retomaría la historia de Nabokov, con Tú me hicistes mujer (Beau-père; 1981), en la que una 
muchacha de catorce años y su padrastro, mantienen una relación sentimental tras la muerte de la madre de la niña. De nuevo, se vuelven a tratar los temas de la pederastia y el incesto, pero Blier hace que en ésta ocasión, sea el deseo platónico de la niña por su padrastro, el que haga surgir el deseo sexual, que en principio no es correspondido por el padrastro.

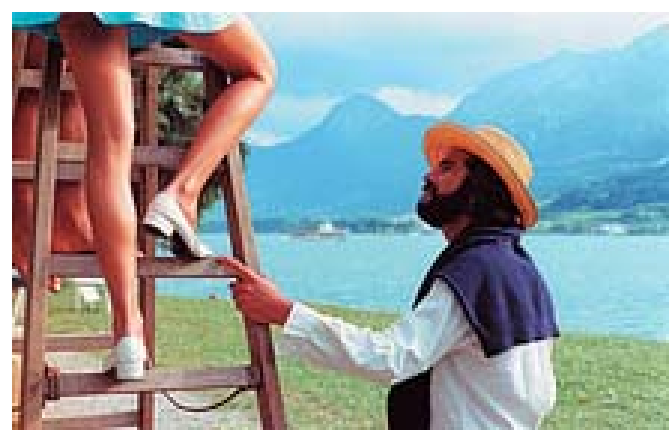

Fig. 31. Fotograma de La rodilla de Clara (1970).

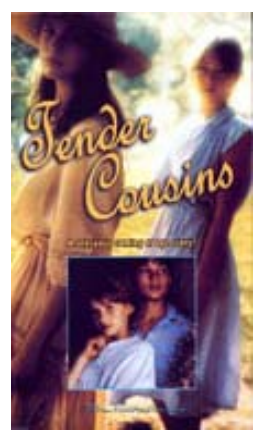

Fig. 32. Cartel de Tender Cousins (1980).

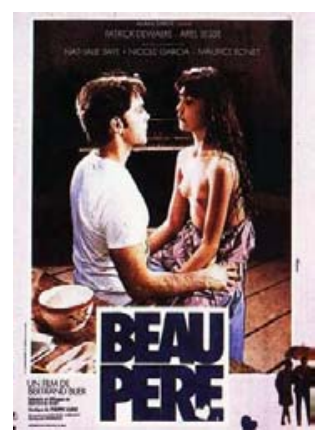

Fig. 33. Cartel de Tú me hicistes mujer (1981).

Las relaciones entre un adulto y una menor, se asociaron inseparablemente con una conciencia sexual, desde la visión adulta de la sexualidad en la adolescencia o la infancia hasta la pederastia, etc...

La cinematografía de la década de los noventa, se vería de nuevo plagada de variantes icónicas de la preadolescente y de la «lolita» demasiado preestablecidas y estereotipadas, de manera que la figura en algunos casos se vería descontextualizada y redefinida una y otra vez bajo los cambiantes criterios y exigencias de los medios de masas en conjunción con el público.

El amante (L'Amant; Jean-Jacques Annaud, 1992), la adaptación cinematográfica de la novela homónima de Marguerite Duras y basada en las experiencias biográficas de la propia escritora, narra la relación 

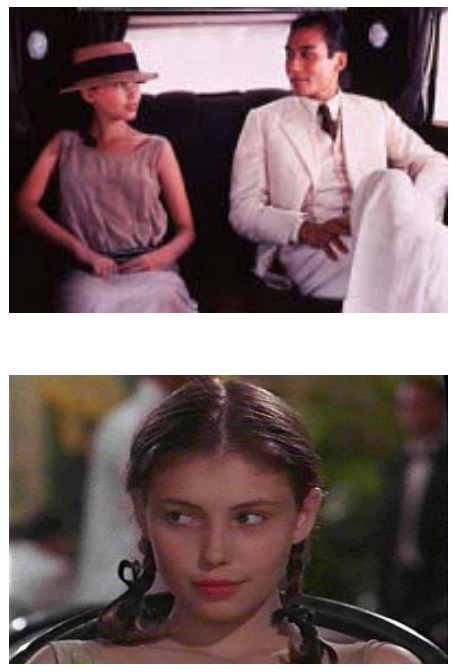

Fig. 34 y fig. 35. Fotogramas de El amante (1992). de amantes entre una adolescente pobre de origen francés y un rico hombre chino en Indochina a principios del siglo XX. La muchacha se siente atraída por el dinero de él pero también por el placer sexual que de él recibe en sus encuentros a escondidas en una habitación del barrio Chino de Cholen, en Saigón. Supuso la reaparición del icónico de «lolita» con aspecto de colegiala y sexualmente precoz encarnado en la actriz Jane March, hallando la polémica por sus escenas eróticas y la juventud de la actriz de 17 años.
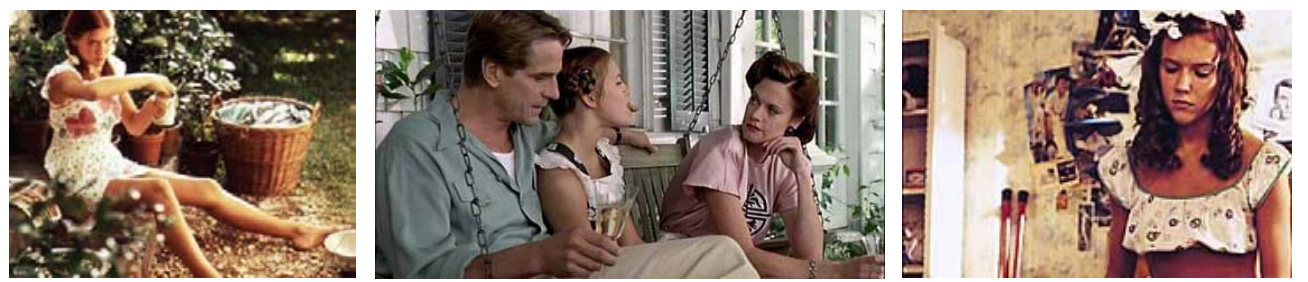

Fig. 36, fig. 37, fig. 38. Fotogramas de Lolita (1996).

Dominique Swain interpretaría con 15 años a Lolita, en Lolita (1996), versión dirigida por Adrian Lyne provocando un gran escándalo por el evidente erotismo como ocurriera pocos años antes con El amante (1992). Dominique Swain tenía prácticamente la misma edad que Sue Lyon en la versión de 1962, sin embargo no lograba la apariencia de «niña» que requería el personaje y que sí se logra en ésta segunda versión en la que Dominique Swain puede aparentar incluso unos 12 años de edad. A diferencia de la primera versión de 1962 de Stanley Kubrick, Adrian Lyne, concibe al personaje de Humbert Humbert como un loco enamorado digno de compasión, que permanece atrapado en su 
obsesión por Lolita sin percatarse de que Lolita, a pesar de poder ser más hermosa o más sexualmente promiscua que las demás, es una niña como el resto. Por otra parte Dominique Swain, la actriz que interpreta a Lolita, se acerca más a la edad de la protagonista.
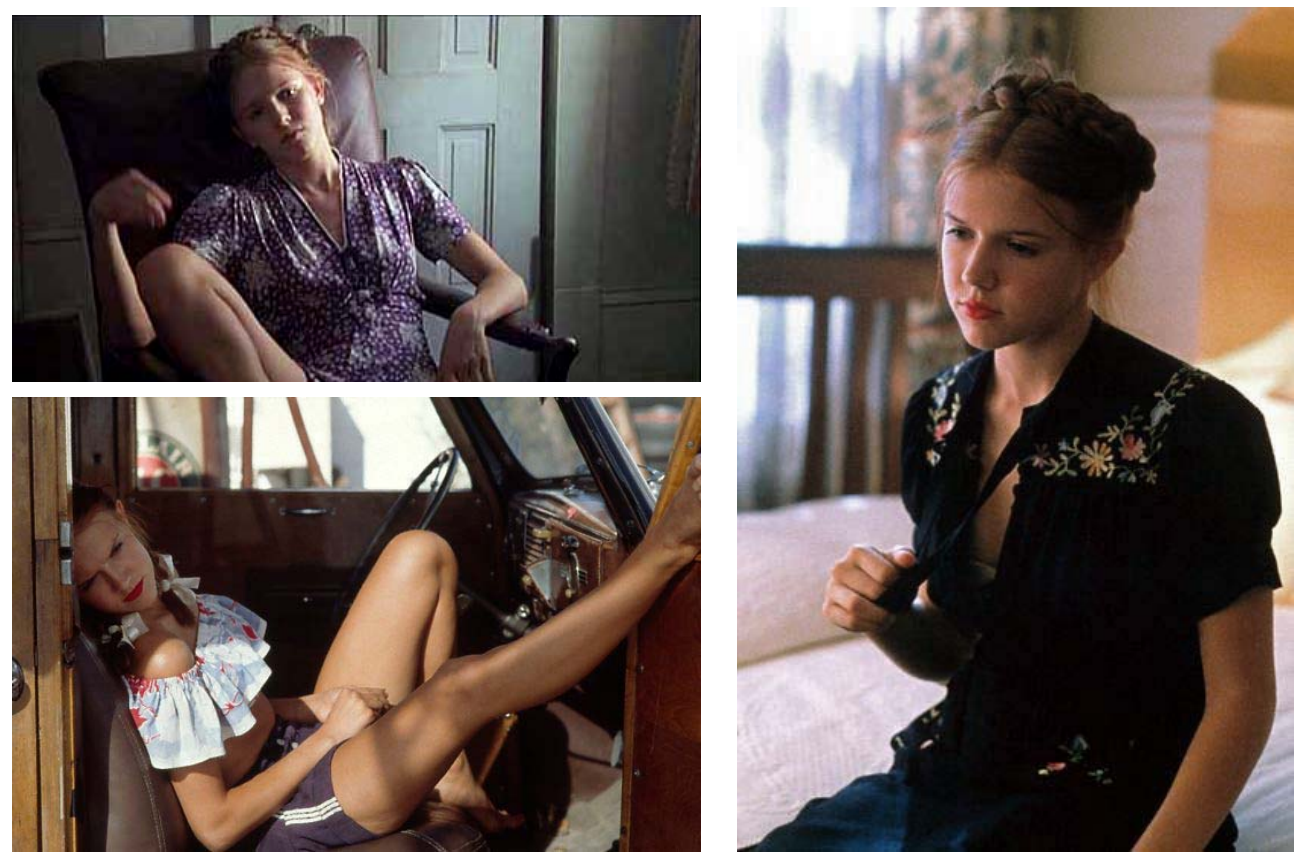

Fig. 39, fig. 40, fig. 41. Dominique Swain en Lolita (1996).

El fetichismo de pies se muestra también en esta versión como en la de 1962 a través de un constante goteo de detalles. Se convierten en un medio sexual de persuasión, con los que convencer a Humbert Humbert a que acceda a los caprichos de Lolita, como se aprecia en la escena en que la niña, tras pintarse las uñas y con el esmalte todavía fresco, coloca el pie en la entrepierna de Humbert Humbert -Jeremy Irons-, estableciéndose así un tira y afloja entre masturbaciones y concesiones ante las peticiones de «Lo» ${ }^{16}$. El pie constituye uno de los fetiches culturales más conocidos y en ambas Lolitas, el pie se convierte

16 Cf. con la escena de Lolita (1962), pág. 269 de la presente tesis. 
en metonimia de Lolita. En otra escena, Lolita pega un chicle sobre el diario de Humbert Humbert -chicle que con anterioridad no sólo había sido masticado por Lolita, sino manoseado y pegado a la rodilla- y éste para ocultar la travesura a la madre de Lo, se lo come. La ropa también es objeto de fetiche, como se aprecia en la escena en que Lo, deja su casa para ir al campamento de verano y Humbert Humbert se tira sobre la ropa de ella, colgada en el armario. El más mínimo objeto, suple el deseo por la niña. Si bien, el primer fetiche representativo en la película de Adrian Lyne, no es un referente a Lolita sino a Annabel, el amor infantil de Humbert Humbert, de la que conserva una cinta perteneciente a uno de sus vestidos. Lyne recrea las escenas con una estética fotográfica, que en ocasiones recuerda al fotógrafo y director David Hamilton, en detrimento del argumento, costándole innumerables críticas.

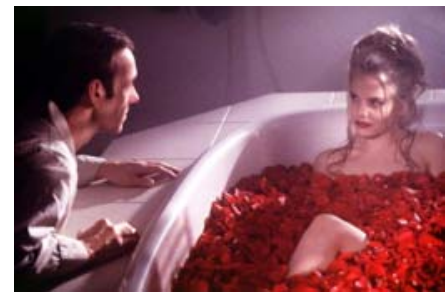

Fig. 42. Mena Suvari en American Beauty (1999).

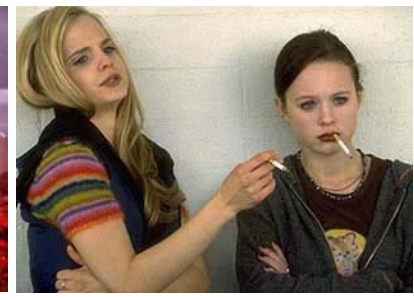

Fig. 43. Mena Suvari y Thora Birch en American Beauty (1999).

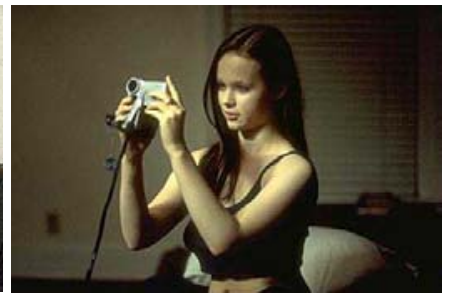

Fig. 44. Thora Birch en American Beauty (1999).

En American Beauty ${ }^{17}$ (Sam Mendes, 1999), a pesar de tratarse la problemática de los cambios surgidos en la sociedad estadounidense en la última década desde el punto de vista de una familia americana actual, se introduce el tópico de la Lolita y el hombre adulto como uno de los argumentos principales para definir el perfil psicológico del padre

\footnotetext{
17 Ganadora en los Oscar $^{\circledR} 2000$ de cinco galardones, entre ellos el de mejor película y el de mejor director.
} 
de la familia. Aquí, la actriz Mena Suvari interpreta un estereotipo de Iolita, que queda pretendidamente superficial respecto a la otra nínfula «camuflada», la actriz Thora Birch, que había interpretado en todas sus apariciones cinematográficas hasta el momento, papeles de niña «mona» en películas infantiles de aventuras como El retorno de las Brujas (Hocus Pocus; Kenny Ortega, 1993), Un ladrón de cuatro manos (Monkey Trouble; Franco Amurri, 1994) o como preadolescente con rellenos en el sujetador en Amigas para siempre (Now and Then; Lesli Linka Glatter, 1995).

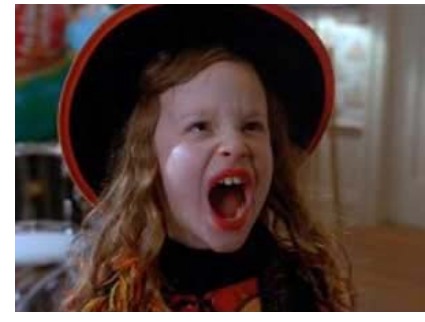

Fig. 45. Thora Birch en El retorno de las Brujas (1993).

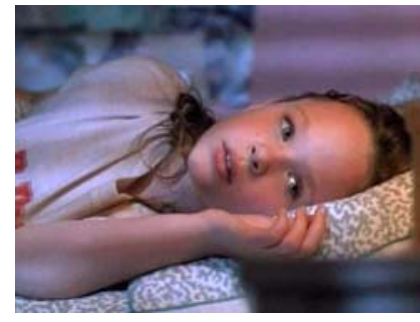

Fig. 46. Thora Birch en Un ladrón de cuatro manos (1994).

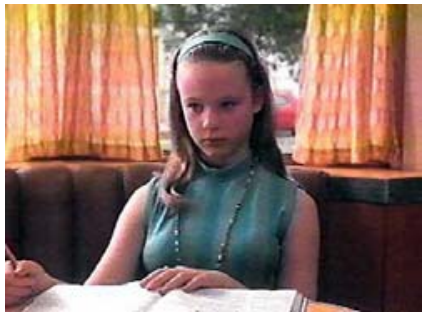

Fig. 47. Thora Birch en Amigas para siempre (1995).

Bajo las formas más tópicas del icono de la Lolita se han generado numerosas «estrellas fugaces» hollywoodienses, que merecen señalarse, como Alicia Silverstone en Clueless. Fuera de onda (Amy Heckerling, 1995), en la que se parodia el tipo de juventud norteamericana «pija» y consumista, o en las películas del género de terror para adolescentes con títulos como la trilogía planificada de Scream (Wes Craven, 1996-2000) o Se lo que hicisteis el último verano (I Know What You Did Last Summer; Jim Gillespie, 1997), Leyenda Urbana (Urban Leyend; Jaime Blanks, 1998) o Un San Valentín de Muerte (Valentine; Jaime Blanks, 2001) entre otras, en las que las heroínas o víctimas de las mismas como Neve Campbell, Drew Barrymore, Jennifer Love Hewitt, Sarah Michelle Gellar o Denise Richards, conforman el nuevo estereotipo de lo que socialmente es una 
Iolita, basando en la imagen de la adolescente de instituto, desarrollada sexual y físicamente en modo exagerado, que viste a la moda, con el comportamiento de una mujer fatal y en algunos casos con la ingenuidad de una niña de doce años, creándose el personaje de una heroína de finales del siglo XX. Es decir, que Lolita ya no es la nínfula de Nabokov, «reconocida tan sólo bajo la mirada del artista, del loco, de los seres infinitamente melancólicos». Lolita es en el siglo XXI, un bien común, un producto de consumo de masas, la fantasía sexual de cualquier hombre, «la tía buena», moral, social y culturalmente deseable, claramente diferenciada de lo que es una niña para no ser confundidos con los pederastas o consumidores de pornografía infantil.

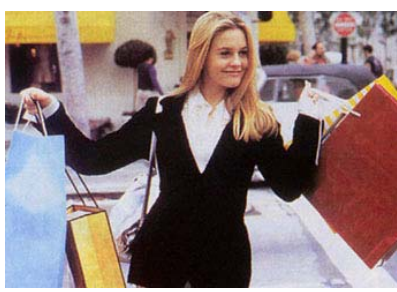

Fig. 48. Alicia Silverstone en Clueless. Fuera de onda (1995).

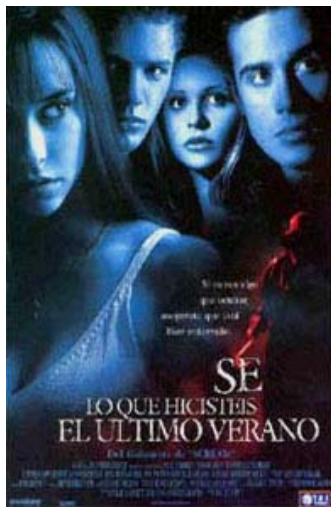

Fig. 51. Jennifer Love Hewitt en primer término. Cartel en castellano de Se lo que hicisteis el último verano (1997).

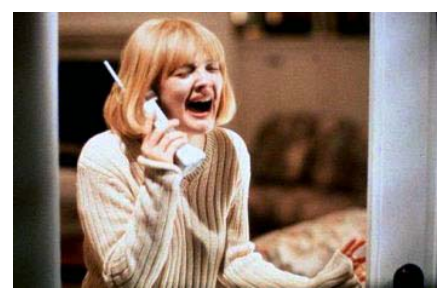

Fig. 49. Drew Barrymore en Scream (1996).
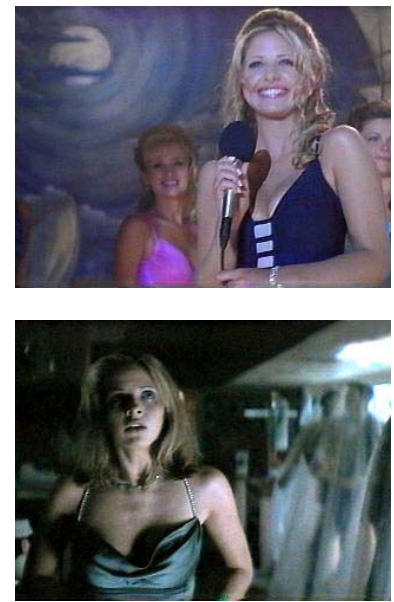

Fig. 52 y fig. 53. Sarah Michelle Gellar en Se lo que hicisteis el último verano (1997).

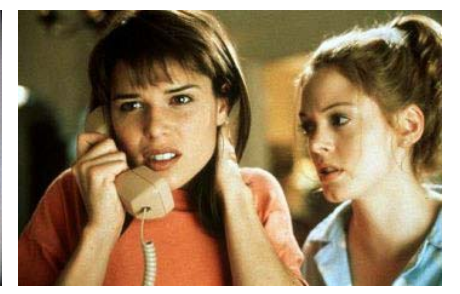

Fig. 50. Neve Campbell y Rose McGowan en Scream (1996).

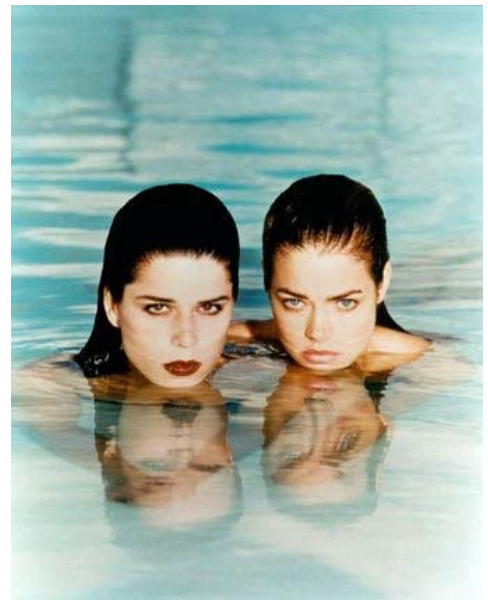

Fig. 54. Neve Campbell Denise Richards en Juegos Salvajes (Wild Things; John McNaughton, 1997). 
Frente al degradado concepto de la lolita en la década de 1990, algunos directores intentarían recuperar la sensibilidad «nabokoviana» carente de parodia que el cine europeo buscara en el personaje de la preadolescente durante las décadas de 1970 y 1980, como el director Manuel Pradal, con películas como Marie Baie des Anges (1997) en la que se recrean algunas escenas que no son sino un homenaje al icono de Lolita, en sí mismo. La protagonista de 16 años, Vahina Giocante, repetiría años más tarde con un personaje similar en Lila dice (Lila dit ça; Ziad Doueiri, 2004) afianzando el personaje de la nínfula adolescente.
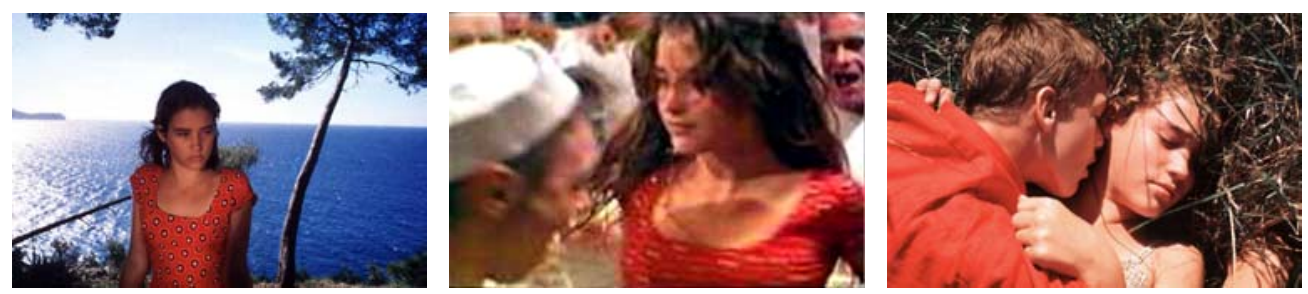

Fig. 55, fig. 56 y fig 57. Vahina Giocante en varias escenas de Marie Baie des Anges (1997).
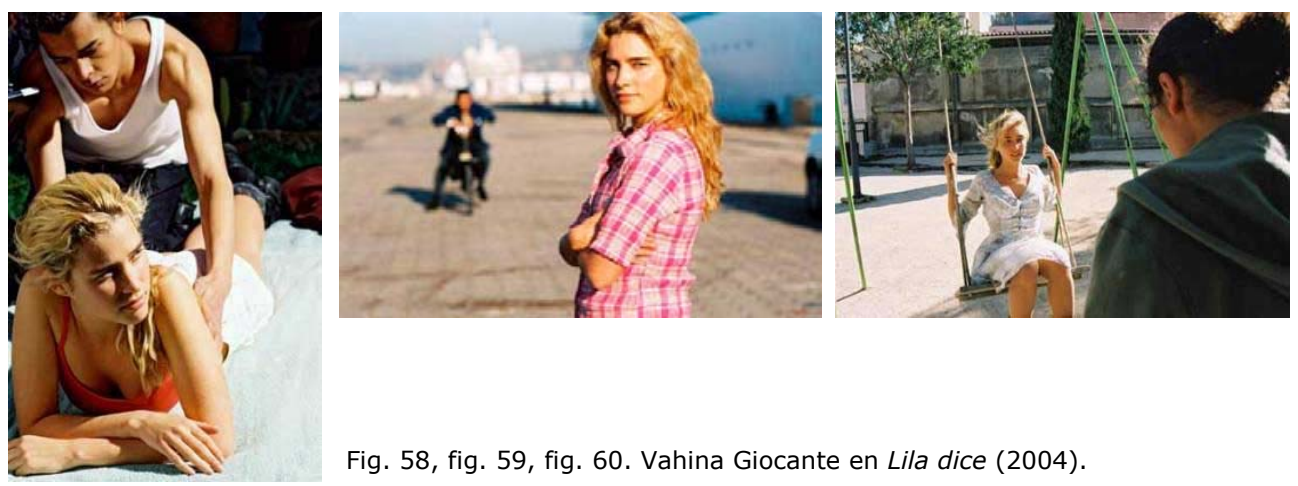

Fig. 58, fig. 59, fig. 60. Vahina Giocante en Lila dice (2004). 


\subsubsection{La preadolescente y el final de la inocencia.}

El final de la infancia, el deseo por mantenerla y el temor a crecer, son las circunstancias que sufren algunas de las preadolescentes del cine. El tratamiento no es sólo desde el punto de vista de lo fantástico, como pudiera darse en Alicia en el País de las Maravillas de Lewis Carroll o en Peter Pan de J. M. Barrie, en el que encontramos que el País de Nunca Jamás es el lugar donde escapar de la realidad adulta en la que no podemos comportarnos para siempre como niños. Es un lugar donde no existe la muerte, los roles sociales, el sexo, la conciencia adulta y las responsabilidades, al fin y al cabo, un lugar donde evitar la pérdida de la inocencia. Pero no sólo el País de Nunca Jamás, es un lugar de escape sino que en ocasiones la Muerte como tal, se considera una manera de no crecer, renunciando a la vida antes de abandonar la infancia o perder la inocencia.

La relación entre la preadolescente y la pérdida de la inocencia a través de la «Muerte» se desarrollaría en películas como Juegos prohibidos (Jeux interdits; René Clément, 1952)18. La acción está ambientada durante la $2^{a}$ Guerra Mundial, cuando Paulette interpretada por la niña Brigitte Fossey- pierde a sus padres mientras escapan de París. Entonces, es adoptada por una familia de campesinos. Al poco tiempo, la amistad entre Paulette y Michael -George Poujouly-, el menor de los hijos del campesino, se hace más estrecha y ambos descubren y comparten un mundo incomprensible para los adultos. Cuando Paulette comienza a comprender lo que significa la muerte -al morir su perrito-, su obsesión se intensifica en un deseo por enterrar a todos los animalitos muertos que encuentra y en construir cementerios para estos, absorta en la morbosidad que le produce la muerte. El ritual

${ }_{18}$ Juegos prohibidos, fue votada en 1979 por la Academia Francesa de Cine como una de las ocho mejores películas francesas jamás realizadas y ganó el Oscar ${ }^{\circledR}$ a la Mejor Película Extranjera. 
adulto frente a la muerte es copiado por los niños de manera grotesca, que hacen de sus vidas un acto de devoción por lo muerto y usurpando ellos mismos la autoridad de la iglesia.

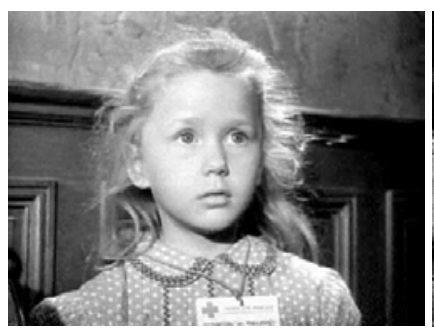

Fig. 61. Brigitte Fossey en Juegos prohibidos (1952).

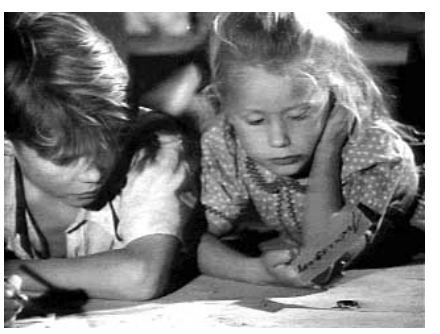

Fig. 62. Fotograma de Juegos prohibidos (1952).

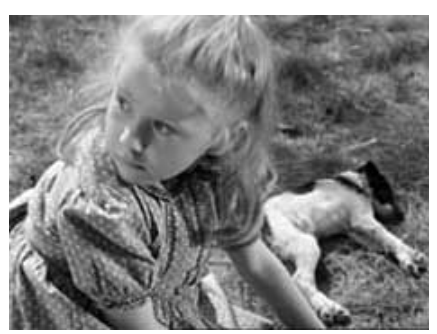

Fig. 63. Brigitte Fossey en Juegos prohibidos (1952).

En 1975, Peter Weir dirigió Picnic en Hanging Rock (Hanging Rock) adaptación de una novela de Joan Lindsay, pero basada en hechos reales que narra la misteriosa desaparición de un grupo de niñas de un internado y una de sus profesoras, durante una excursión el día de San Valentín a principios del siglo XX a Hanging Rock, una formación geológica emplazada en el desierto australiano. Sólo logran encontrar a una de las niñas que confusamente puede contar lo que les ocurrió. La montaña -que actúa simbólicamente como un gigantesco falo«devora» su ofrenda de vírgenes poseedoras de juventud, belleza e inocencia, haciéndolas desaparecer misteriosamente sin dejar rastro.
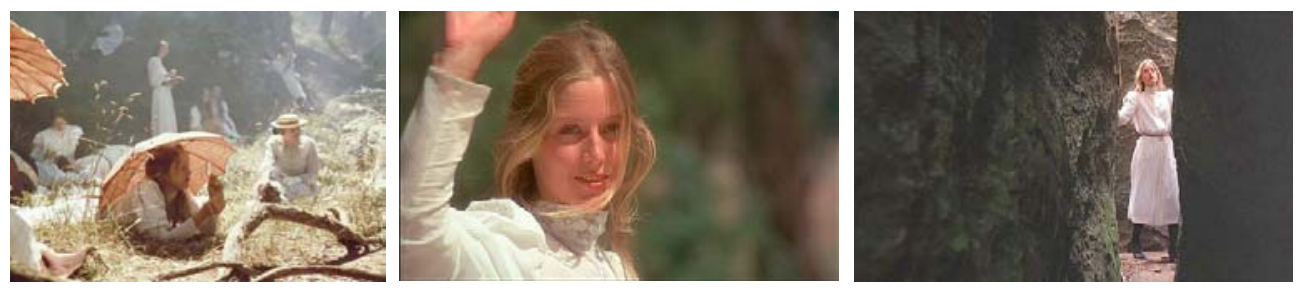

Fig. 64, fig. 65 y fig. 66. Picnic en Hanging Rock (1975). 
Picnic en Hanging Rock recoge el ideal femenino de tradición romántica e idealista de la infancia generado durante el siglo XIX, en el que la muerte y la vida, la belleza trascendente frente a la decrepitud o la decadencia de lo adulto frente a la juventud, son contrapuestos para aproximarse a la imagen de la preadolescente, como un ser que vive en un tiempo y espacio mínimo, glorioso, como si durante esos momentos, esos años, se dejase de ser humano, para formar parte de un mundo intermedio transitorio, donde la voluntad del ser adulto comienza a apreciarse, pero que se recrea indulgentemente en la existencia infantil y despreocupada ${ }^{19}$.

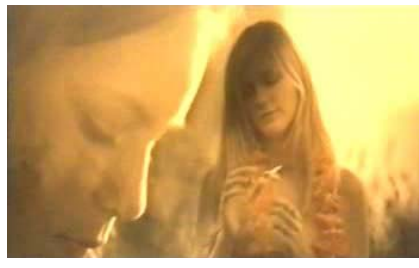

Fig. 67. Fotograma de Las vírgenes suicidas (1999).

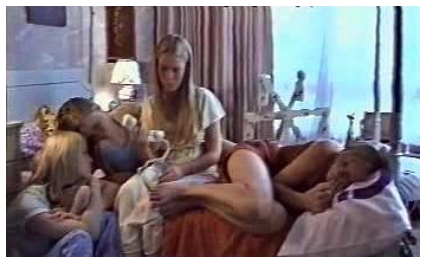

Fig. 68. Fotograma de Las vírgenes suicidas (1999).

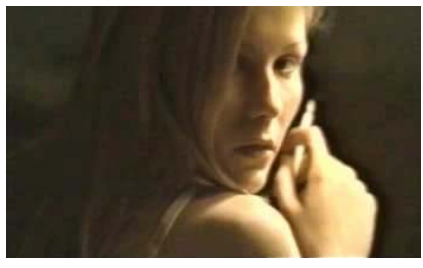

Fig. 69. Kristen Dunst en Las vírgenes suicidas (1999).

Bajo esta misma poética, Sophia Coppola llevó al cine Las vírgenes suicidas (The Virgin Suicides; 1999) la adaptación cinematográfica de la novela homónima de Jeffrey Eugenides. En ella se narran los acontecimientos que rodean los suicidios de cinco muchachas, las hermanas Lisbon, desde la visión de los muchachos del barrio. La educación que reciben de sus padres y de la sociedad les resulta

\footnotetext{
${ }^{19}$ En la adaptación cinematográfica homónima de la novela de Thomas Mann, Muerte en Venecia, la encarnación de la belleza está en la figura del andrógino muchacho Tadzio. Para Tadzio y para el propio actor que lo interpreta, Björn Andersen, ese verano, no sólo supone probablemente el final de la infancia, de la inocencia, sino que alegóricamente encarna al Ángel de la Muerte, para aquéllos que han entrado en un estado de decadencia vital. Tanto el joven Tadzio como la muchacha protagonista de Picnic en Hanging Rock, fig. 65, pág. 283. Son claros referentes a las Venus de Botticelli. Muerte en Venecia (Death in Venice; Luchino Visconti, 1971).
} 
opresiva y represiva. No pueden volver a la infancia y sin embargo tampoco se les permite crecer y ser jóvenes y disfrutar de todo lo que ello conlleva. El suicidio de las vírgenes, es la única salida «eficaz», al estancamiento vital en el que se ven forzadas a vivir, como lo era para Ofelia en Hamlet de Shakespeare o la Dama de Shalott de Tennyson.

\subsubsection{Alicia un siglo después.}

Desde que Lewis Carroll, escribiera Alicia en 1865 han sido numerosas las adaptaciones, primero teatrales y posteriormente -ya en el siglo XX-, cinematográficas desde la primera versión conocida de Alicia en el País de las Maravillas ${ }^{20}$ de 1903 a la conocida adaptación en dibujos animados de la Factoría Disney, Alicia en el País de las Maravillas (Alice in Wonderland; 1951) ${ }^{21}$, así como versiones para televisión que se han realizado de la fantasía de Alicia en el Mundo Subterráneo. Pero no todas las versiones se han ajustado al texto original.

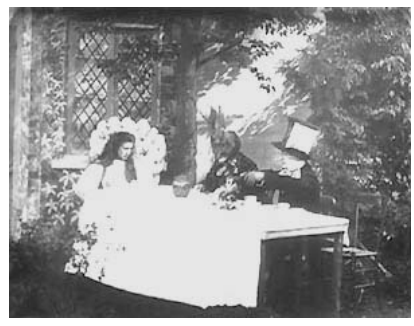

Fig. 70. Fotogramas de Alicia en el País de las Maravillas (1903).

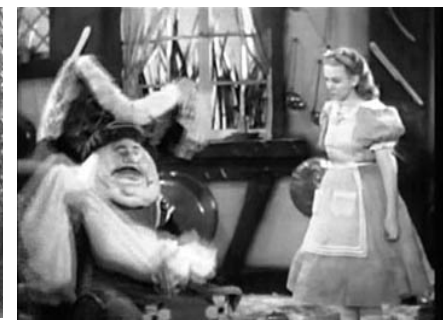

Fig. 71. Fotograma de Alicia en el País de las Maravillas (Norman Z. McLeod, 1933).

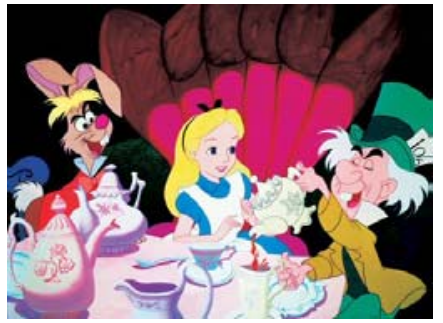

Fig. 72. Fotogramas de Alicia en el País de las Maravillas (1951).

En Dreamchild (1985) dirigida por Gavin Millar, nos ofrece una visión de Lewis Carroll -interpretado por Ian Holm- como la de un

\footnotetext{
${ }^{20}$ Dirigida por Percy Stow y Cecil M. Hepworth.

${ }^{21}$ Dirigida por Clyde Geronimi, Wilfred Jackson, Hamilton Luske y producida por Wat Disney.
} 
hombre que se auto-consume en el amor y el deseo por Alice Liddell, la «Alicia» de carne y hueso ${ }^{22}$. Dreamchild es una curiosa película en la que se recrea la vida del reverendo Charles Dodgson a través de los recuerdos de Alicia, ya anciana. No se trata tanto de una adaptación del texto de Carroll como la historia inventada de las reflexiones de Alicia tras analizar su relación con Mr. Dodgson. El resultado son unos recuerdos fantásticos en los que aparecen algunos de los seres del mundo subterráneo de Alicia en el País de las Maravillas y A través del espejo ${ }^{23}$, como interlocutores junto Mr. Dodgson y Alicia estableciendo un vínculo simpático de fantasía en medio de la temporalidad consciente y real. Pero la película va más allá, pues en las memorias que se nos presentan la propia Alicia se cuestiona y juzga su comportamiento con Mr. Dodgson. Alicia es recreada en sus relaciones personales con Mr. Dodgson, como una niña de carácter caprichoso, traviesa y marisabidillas que no dudaba en poner en ridículo al tartamudo Mr. Dodgson, que sin embargo permanece subyugado ante la presencia de la joven ninfa. Se indaga sobretodo en el poder que la niña ejerce sobre éste, más aún, Alicia es consciente de este poder y lo utiliza perversamente para comprometer y dominar a su amigo de manera semejante a como lo hiciera Lolita con Humbert Humbert ${ }^{24}$. A pesar de que tal comportamiento parecía olvidado por la anciana Alicia, ésta se absuelve, primero, ante sí misma pues al recordar sus memorias las observa como simples travesuras infantiles acompañadas de un verdadero y profundo cariño y segundo, con el sentimiento de

\footnotetext{
22 CALHOUN, Ada. Op. cit.

${ }^{23}$ Los seres fantásticos fueron creados por Frank Oz, creador de los famosos Teleñecos (Muppets Show).

${ }^{24}$ Recuerda sin duda a la perversidad observada por el articulista Paul Adam en «Des Enfants» de 1895. En cambio, en la novela de David R. Slavitt. Alicia a los ochenta, la ficción de Dodgson/Carroll lo presenta como un Mr. Hyde, un consumado pederasta y a Alicia como una anciana amargada, que ha guardado en secreto toda su vida, los horribles acontecimientos sucedidos en su infancia y que su hermana Edith delataría a su madre. SLAVITT, David R. Alicia a los ochenta. Barcelona: Laia, 1989.
} 
agradecimiento hacia el público del auditorio norteamericano en Harvard diciendo: «... gracias Mr. Dodgson, gracias».
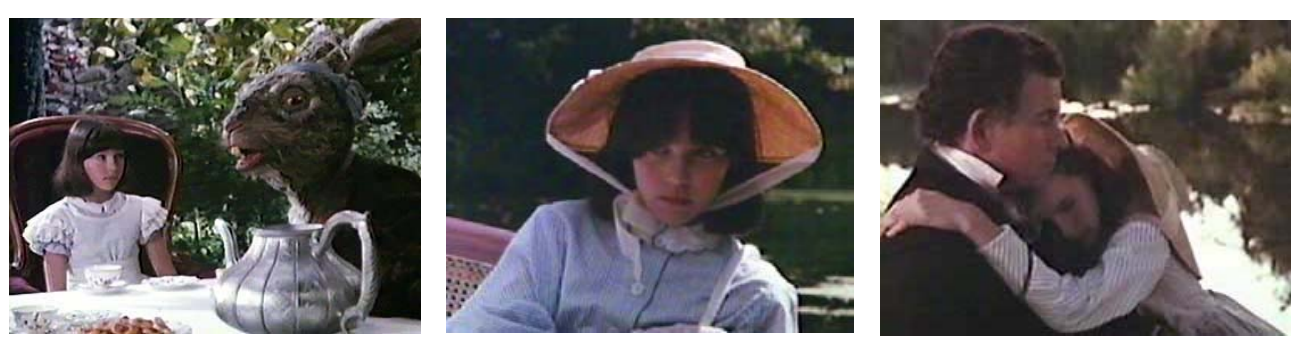

Fig. 73, fig. 74 y fig. 75. Fotogramas Dreamchild (1985).

El director checo Jan Švankmajer ${ }^{25}$, realizó en 1988 una excepcional, extraña y poco conocida adaptación de Alicia en el País de las Maravillas, titulada Alice (Nêco $z$ Alenky) en la que combina animación de títeres con la interpretación de la niña Kristyna Kohoutovà. Esta adaptación rompe la visión romántica que se tiene de la etapa victoriana y la visión dulcificada que nos dejó Disney en 1951, pues Alicia, parece introducirse en un subversivo mundo bajo tierra, más dantesco y sombrío que infantil. Alicia resulta ser una heroína, que se atreve a bajar a los infiernos, de seres inventados, ready-mades de muebles antiguos y carcomidos, platos rotos, serrín, latas, espinas de arenque ahumado del desayuno inglés, sin olvidar al imprescindible conejo blanco, que parece salido del sueño de un taxidermista. Pero uno de los aspectos más destacables de la película, es la elección de una niña de entre 8 y 10 años, para interpretar el papel de Alicia a diferencia de otras tantas películas, en las que los personajes infantiles eran interpretados por actrices que superaban la edad que la ficción precisaba. Recordemos a una exuberante Judy Gardland, interpretando

${ }^{25}$ Fue su primer largometraje, parcialmente financiado por Channel 4 Television y que gracias a la distribución realizada por British Films Institute, ha permitido que numerosas películas de Švankmajer, hayan sido mostradas internacionalmente. 
a Dorita en El Mago de Oz (Victor Fleming, 1934). Švankmajer, utiliza recurrentemente la animación de una muñeca de porcelana ataviada como Alicia, para representarla cuando esta se ve reducida en tamaño, después de haber bebido del frasquito que lee «bébeme». No es esta una personificación forzada sino todo lo contrario, pues de este modo, todos los elementos y seres que conviven en el País de las Maravillas pasan a ser de la misma naturaleza. $Y$ es en esos momentos en que Alicia es muñeca cuando deja de formar parte de la realidad y comparte espacio con la fantasía.
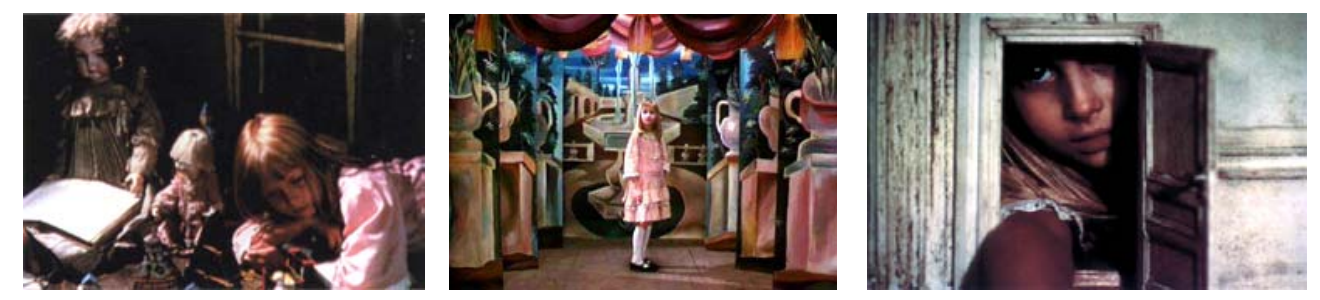

Fig. 76, fig. 77 y fig. 78. Fotogramas de Alice (1988).

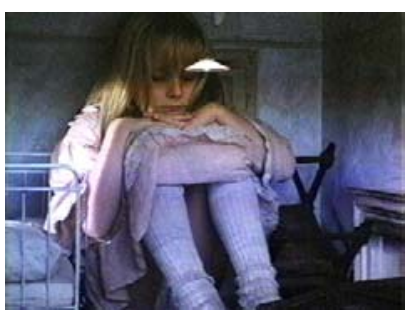

Fig. 79, fig. 80. Fotogramas de Alice (1988).

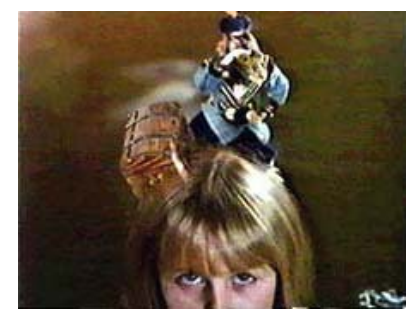

Fig. 81. Fotograma de Down to the Cellar (1983).

El tema de la «infancia» sería abordado por Jan Švankmajer numerosas veces en sus películas, como Jabberwocky (Zvahlav aneb Saticky Slameného Huberta; 1971) o Down to the Cellar (Do pivnice; 1983) en la que explora la psicológica infantil desde el punto de vista de una niñita. Tal vez, este personaje, sirviera como precursor de Alice (1988). La acción comienza con una puerta entreabierta y tras ella la joven heroína desciende unas escaleras, a mitad se encuentra un 
hombre que le ofrece un caramelo. En este caso el contenido sexual es más explícito que en Alice, en la que es velado bajo la historia de fantasía. Su reiterado uso de títeres y marionetas las convierte en un vehículo idóneo para relatar historias imaginativas e infantiles que a menudo relacionan la infancia con el horror, el miedo y la ansiedad infantil.

\subsubsection{Las niñas siniestras.}

El terror y el mundo infantil producen efecto de aprensión. Por un lado las niñas son las víctimas del elemento terrorífico convirtiéndolas en seres vulnerables y por otro, las niñas son la fuente de terror, el elemento terrorífico, capaces de asesinar y torturar pues es con la maldad, la perversión y la crueldad de los niños, cuando se muestra el lado oscuro de la inocencia. En el fondo son un reflejo de los deseos y temores adultos junto a la fascinante atracción por lo desconocido que hay en el ser humano, cambiando radicalmente los arquetipos preconcebidos del romanticismo y del post-romanticismo que idealizaba la infancia.

Las «niñas perversas o siniestras» tuvieron su apogeo sobre todo durante la década de los setenta y ochenta, de modo que el cine de terror enfatizaba la maldad en términos extremos como la desprotección o la pedofilia ${ }^{26}$.

El éxito de las series B hizo proliferar el género de Ciencia Ficción y Terror con películas como La mala semilla (The Bad Seed; Mervyn LeRoy, 1956), en la que Rhoda -Patty McCormack- es una niña buena y cariñosa pero que pronto dará rienda suelta a su verdadera naturaleza

\footnotetext{
${ }^{26}$ SINYARD'S, Neil. Children in the Movies. New York: St. Martin's Press, 1992.
} 
posesiva y asesina, o El pueblo de los malditos (Village of the Damned; Wolf Rilla,1960), en las que la maldad se ve personificada en los niños de un pueblo inglés ${ }^{27}$, en el que inexplicable toda una población experimenta una pérdida de conocimiento que dura 24 horas, y al despertar todas las mujeres en estado fértil descubren que han quedado embarazadas. Al nacer sus hijos todos poseen las mismas cualidades físicas, cabello albino, los ojos grises, etc. Pero a medida que crecen van desarrollando poderes que les permiten leer la mente de las personas y obligarlas a obedecer su voluntad.

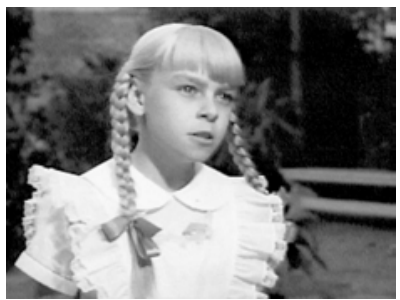

Fig. 82. Patty McCormack en La mala semilla (1956).

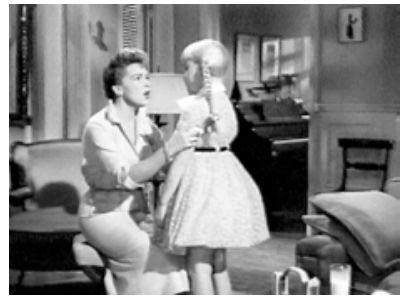

Fig. 83. Fotograma de La mala semilla (1956).

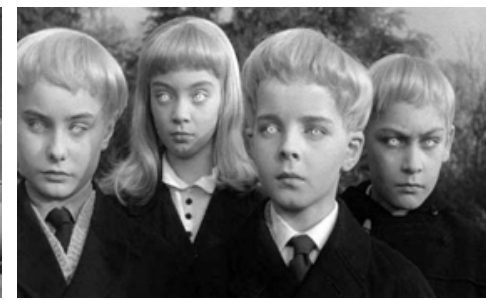

Fig. 84. Fotograma de El pueblo de los malditos (1960).

El exorcista (The Exorcist; William Friedking, 1973), resultó ser una de las más exitosas producciones del género de terror de todos los tiempos en el que el estereotipo de perversidad sexual se une al mal en sí mismo, dando lugar al icono de las «niñas siniestras» del cine. El argumento $^{28}$, nos sitúa en el caso de Reagan -Linda Blair-, una niña de 12 años poseída por el demonio, siendo ésta víctima y ejecutora del mal debido a la posesión satánica que se exterioriza con la degeneración del carácter civilizado de la niña, con el lenguaje obsceno, sadismo, crueldad, violencia, asesinato, masoquismo y exhibición genital, con

\footnotetext{
27 El cine español tuvo su propia versión de una población de niños asesinos en ¿Quién puede matar a un niño? (Narciso Ibáñez Serrador, 1976).

${ }^{28}$ Adaptación cinematográfica la novela homónima de William Peter Blatty que fue productor y guionista de la misma, basad en hechos reales.
} 
«auto-violación» satánica. La perversión sexual y la histeria son los elementos principales de la posesión demoníaca que contribuyen a la perdición de las almas de las jóvenes. $Y$ es que son las mujeres, las que principalmente se ven afectadas por posesión, especialmente las monjas y las niñas. El exorcista marcó el comienzo de una etapa cinematográfica marcada por el gran número de representaciones de «niñas siniestras» con películas como La endemoniada (Amando de Osorio, 1975), Carrie (Brian de Palma, 1975) o La monja poseída (To the Devil a Daughter; Peter Sykes, 1976) con Natassia Kinski y Christopher Lee.
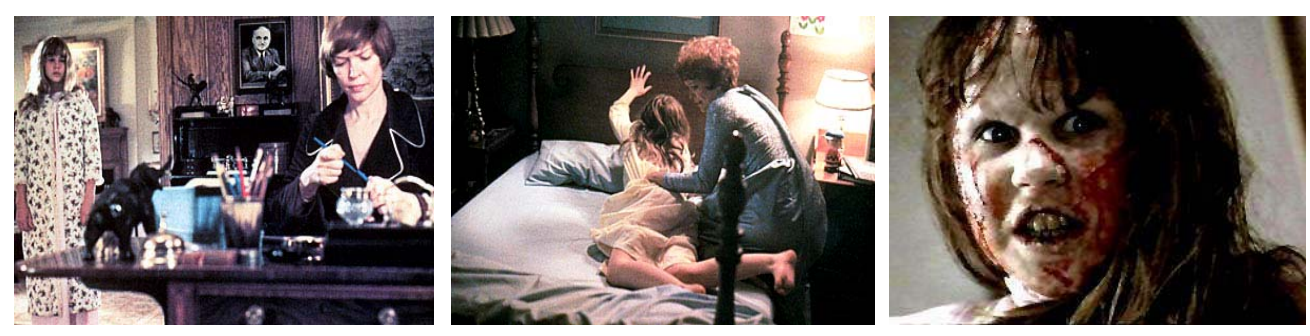

Fig. 85 y fig. 86. Fotogramas de El exorcista (1973).

Fig. 87. Linda Blair en EI exorcista (1973).

En las novelas de Henry James, los niños suelen mostrar siempre la dualidad de bondad y maldad, como cualidades humanas que tiene todo ser humano. En El celo (1999), dirigida por el español Antonio Aloy, -una adaptación de la novela de Henry James, Otra vuelta de Tuerca- y al igual que en la versión iSuspense! (The Innocents; Jack Clayton, 1961), el comportamiento de la niña Flora es angelical, sin embargo, el progresivo cambio de lenguaje, nos sugiere algo más siniestro en la naturaleza de la niña. La institutriz trata de exorcizar los espíritus demoníacos de los niños, pues según ella están poseídos. Pero en ambas versiones se plantea la duda respecto a si los niños están poseídos o son los fantasmas de la institutriz producto de una imaginación neurótica. 

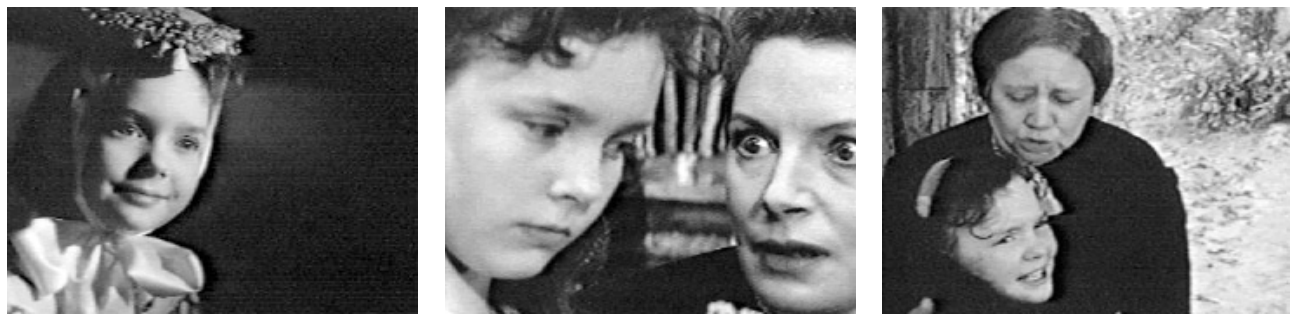

Fig. 88 , fig. 89 y fig. 90. Fotogramas de iSuspense! (1961).
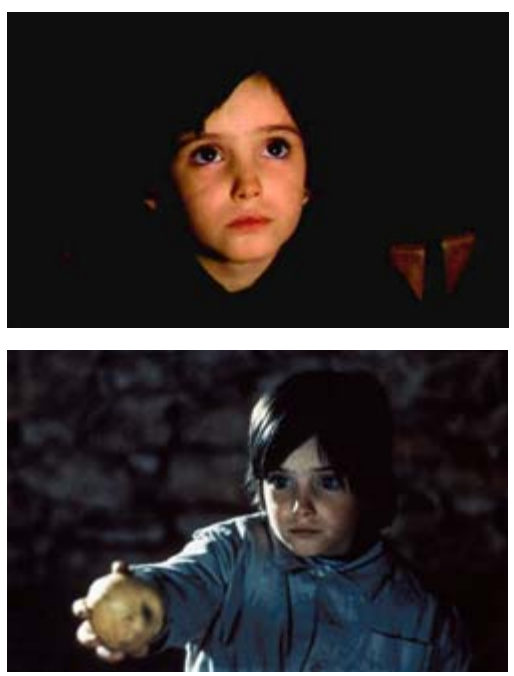

Fig. 91 y fig. 92. Ana Torrent en El espíritu de la colmena (1973).

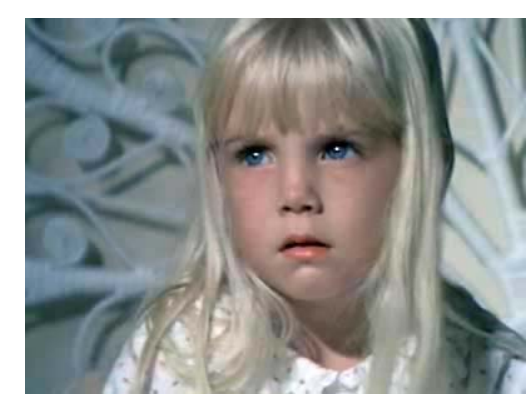

Fig. 93. Heather O’Rourke en Poltergeist (1982).
Los comportamientos extraños, diabólicos o paranormales en las niñas dieron por resultado películas en las que se indaga el miedo humano a lo desconocido a través de figuras de inocencia como la niña Ana Torrent en El espíritu de la colmena (Victor Erice, 1973) que trata del efecto que produce la película Frankenstein sobre la imaginación inocente de dos hermanas, las cuales no podrán dejar de obsesionarse con la existencia del monstruo, llegando a creer que realmente vive en un viejo cobertizo cercano a su casa; o la fallecida en extrañas circunstancias Heather O'Rourke, Carol Anne en Poltergeist (Tobe Hooper, 1982), una niña que desaparece en el armario de su propio cuarto tras sucederse ciertos fenómenos paranormales en su casa. 
En Las dos vidas de Audrey Rose (Audrey Rose; Robert Wise 1977), se plantea la posibilidad de la reencarnación en el caso de la niña Ivy Templeton -Susan Swift-, que es la reencarnación de Audrey Rose, una niña fallecida instantes antes del nacimiento de ésta. Elliot Hoover, el padre de la fallecida Audrey -Anthony Hopkins-, la rapta al reconocer en ella la reencarnación de su hija tratando de salvar su alma perdida, y a su vez la de la propia Ivy Templeton. Esta es una atractiva y extraña película de la saga de películas de niñas siniestras.

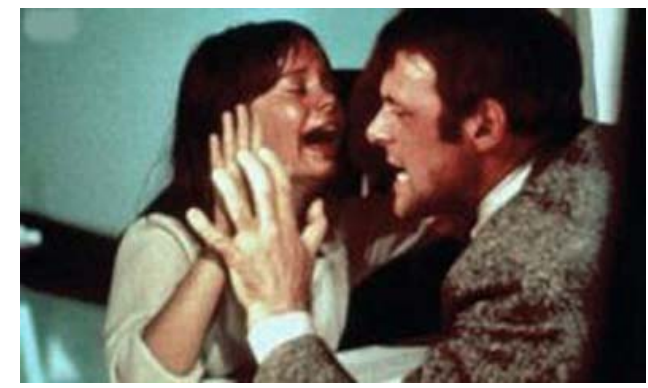

Fig. 94. Fotograma de Las dos vidas de Audrey Rose (1977).

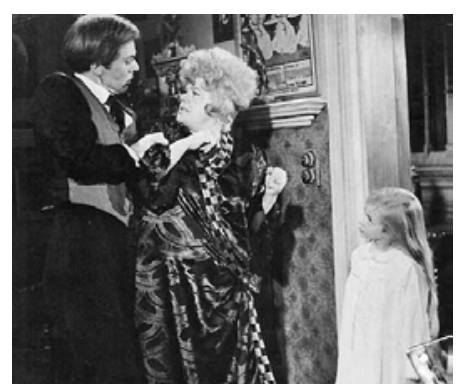

Fig. 95. Fotograma de ¿Quién mató a Tía Roo? (1971).

La niñas muertas en el cine, no sólo resultan inocentes, sino que enternecen, se vuelven «deliciosas» y «no huelen mal», señala Pilar Pedraza ${ }^{29}$, como la hija muerta de Tía Roo -Shelly Winters-, que es conservada en un féretro blanco en su habitación en ¿Quién mató a Tía Roo? ('Who Ever Slew Auntie Roo?; Curtis Harrington, 1971).

El erotismo necrófilo, el «cadáver exquisito» promulgado por las artes, fue heredado por el cine, sobretodo en el género fantástico o de terror. "Se debe evitar dar a las muertas un aire seductor», establecía el Código de Producción, también llamado «Código Hays» de 1930, en el apartado «temas reprochables», del no 3 , sobre la brutalidad o lo

\footnotetext{
${ }^{29}$ PEDRAZA, Pilar. Espectra. Op. cit., pág. 195.
} 
macabro. Así pues, las alusiones a la cópula entre un hombre y un cadáver quedaban prohibidas ${ }^{30}$.

Otras muertas, «viven» por su naturaleza no humana como las vampiras. En Entrevista con el vampiro (Interview with the Vampire: The Vampire Chronicles; Neil Jordan, 1994) la adaptación cinematográfica de las Crónicas vampíricas de la escritora de terror Anne Rice, nos encontramos con una de las más dolorosas manifestaciones de la niña fallecida. La vida de Claudia -interpretada por Kristen Dunst- es segada por un vampiro que la convierte también en vampira con tan sólo doce años de edad. Más que una conversión vampírica es un «nacimiento» a la naturaleza más inocente del vampirismo, terriblemente bella, infantil, impulsiva, caprichosa, como una feroz asesina chupa sangre, de instintos fetichistas entre la necrolatría y la necrofilia; es decir, a los ojos humanos, como un monstruo carente de conciencia humana. Claudia junto a sus compañeros Louis y Lestat, vive en las tinieblas de la perversidad. Pero tras décadas de niñez vampírica, Claudia, la niña eterna, desea cambios en su cuerpo que nunca llegarán, pues ella jamás envejecerá, ni será anciana, ni morirá, es decir que jamás crecerá, convirtiéndose en una adulta con cuerpo de niña para siempre. En ello radica la más profunda perversidad de su ser. Este hecho podría asociarse erróneamente con la figura de Peter Pan, pero Claudia no es como él, pues su deseo es crecer, mientras década tras década sigue en su cuerpo infantil, obligada a asesinar y a beber la sangre de sus víctimas para vivir. En ese conflicto, entre su naturaleza, su edad y su cuerpo, nace un deseo diferente al de la sangre que es el de codiciar lo que no se puede poseer, el cuerpo

\footnotetext{
${ }^{30}$ HAYS, R. P. Daniel Lord; MARTIN QUIGLEY, S.J.; HAYS, Will H. "Versión textual del célebre código de censura Hays en Hollywood". Cinemateca. Montevideo-Uruguay: n. 19, marzo de 1979, págs. 41-42.
} 
adulto y desarrollado de una joven criolla de los muelles de Nueva Orleáns. En un principio, su deseo es saciado quitándole la vida a la criolla, desposeyéndola de su aliento vital y desangrándola como al resto de sus víctimas. Pero ello no es suficiente, así que la lleva a su casa y la acomoda sobre su cama junto a sus muñecas de porcelana, convirtiéndola en su pútrido fetiche. Si no puede ser como ella, sólo le queda poseer a su muñeca muerta ${ }^{31}$.
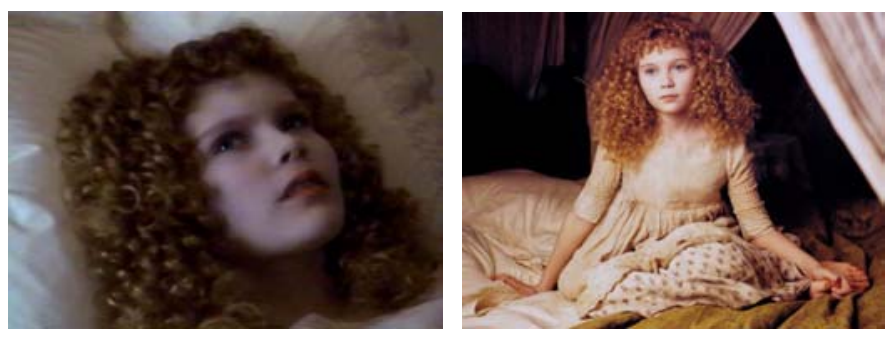

Fig. 96, fig. 97. Kristen Dunst en Entrevista con el vampiro (1994).

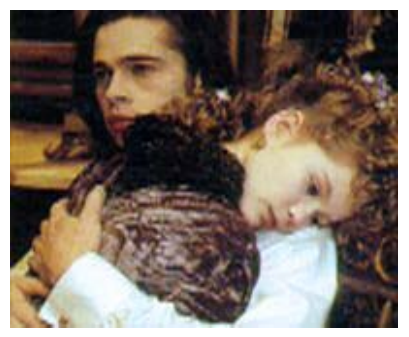

Fig. 98. Fotograma de Entrevista con el vampiro (1994).

Durante la década de 1990 y la llegada del siglo XXI, los temores y deseos adultos respecto a la naturaleza de la inocencia infantil se han desdoblado en dos corrientes distintas: por un lado, las niñas siniestras ligadas a los sobrenatural continuarían siendo las estrellas del cine de terror con películas como El exorcismo de Emily Rose (The exorcism of Emily Rose; Scott Derrickson, 2005) o Maleficio (An American Haunting; Courtney Solomon, 2006) y por otro lado, el thriller psicológico con The Hole (Nick Hamm, 2001) o Hard Candy (David Slade, 2005).

\footnotetext{
${ }^{31}$ Su forma de deseo es semejante a el de Búfalo Bill, el asesino sistemático de la película El silencio de los corderos, el cual ante la imposibilidad de someterse a una operación de transexualidad, decide fabricarse un cuerpo femenino con la piel de sus víctimas femeninas, proyectando así sus deseos frustrados y transformándolos en una satisfacción sucedánea. El silencio de los corderos (The Silence of the Lambs; Jonathan Demme, 1991).
} 


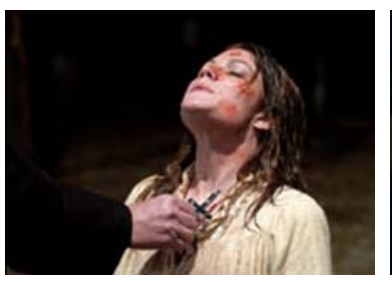

Fig. 99. Fotograma de El exorcismo de Emily Rose (2005).

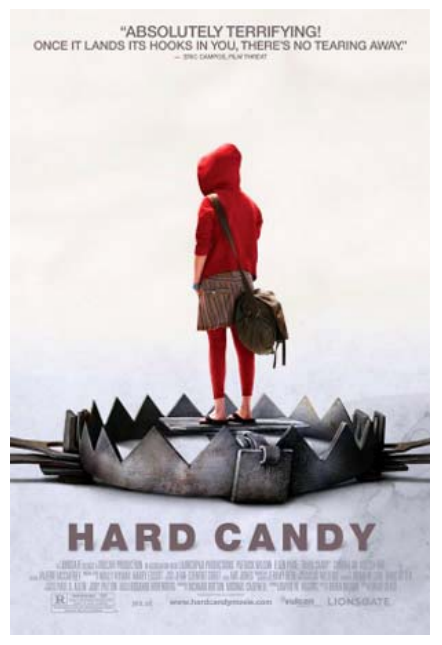

Fig. 102. Cartel de Hard Candy (2005).

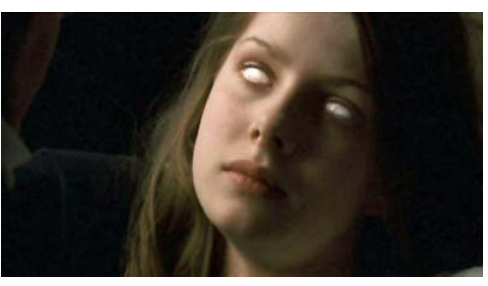

Fig. 100. Fotograma de Maleficio (2006).

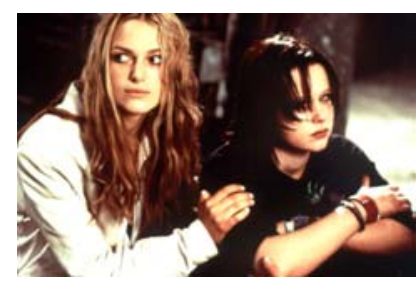

Fig. 101. Fotograma de The Hole (2001).

Hard Candy ${ }^{32}$ (David Slade, 2005) plantea los temores que surgen a raíz del nacimiento de Internet y de la facilidad que tienen los menores en caer en las manos de pornógrafos y pederastas a través de la red. Hayley -interpretada por Ellen Page-, es una adolescente de 14 años que se cita con un fotógrafo de 32 años llamado Jeff, al que ha conocido a través de un chat en Internet. Hayley, es una chica inteligente que conoce los peligros que éste tipo de citas conllevan, sabe que los menores no debe tomar bebidas que no hayan mezclado ellos mismos y otras recomendaciones de ese tipo, sin embargo se comporta insinuante. Por su parte, Jeff, aunque comedido, le sigue el juego y la invita finalmente a su casa para realizarle unas fotografías. Pero las cosas cambian al llegar allí. Jeff comienza a ser la víctima de la adolescente que se propone hacerle confesar su instinto pederasta y su implicación en la desaparición de una adolescente llamada Donna Mauer, maniatándole a una silla, más tarde a una mesa y amenazándole con realizarle una castración ella misma. El personaje

32 Ganadora del premio al Mejor Guión y Mejor Película del Festival de Sitges de 2005. 
de Hayley, toma el control y se convierte en la ejecutora y la vengadora de todas las niñas que han sido violadas y asesinadas, vestida como «Caperucita roja», actúa seductoramente inocente como una lolita mordiéndose los labios, haciendo que él se arrodille y le bese los pies, para desenmascarar al «Lobo» en su propia casa.
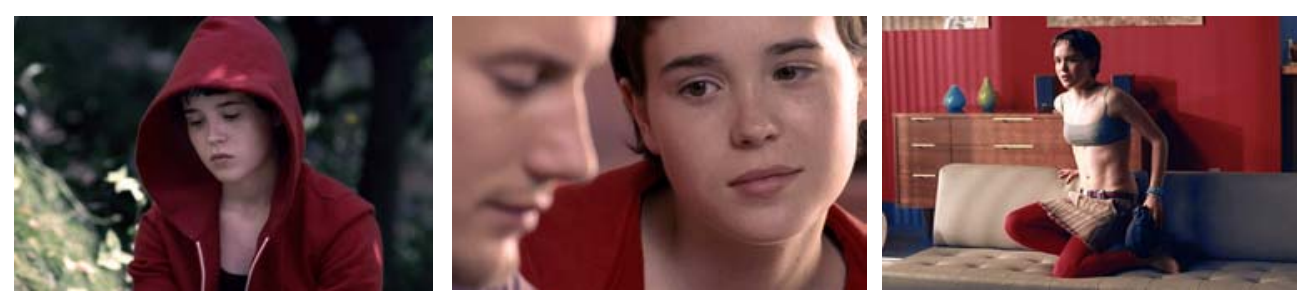

Fig. 103, fig. 104 y fig. 105. Fotogramas de Hard Candy (2005). 



\section{LA PREADOLESCENTE FOTOGRAFIADA.}

La fotografía comercial del siglo XX, repetiría los mismos tópicos infantiles de la pintura y la ilustración del siglo XIX, temáticas pastoriles, ángeles y hadas, en compañía de animales, como adultos miniaturizados o como la Virgen y el Niño ${ }^{1}$. Las fotógrafas Betsy Cameron o Anne Geddes entre otras, realizarían durante las décadas de 1980 y 1990, exitosas fotografías de niños y bebés bajo esta visión de inocencia infantil de espíritu romántico, comparándose en éxito de ventas con el que tuvieran Kate Greenaway o Jessie Wilcox Smith.

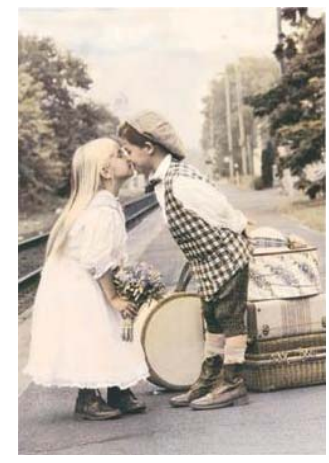

Fig. 1. Sin título (s.a.) por Betsy Cameron.

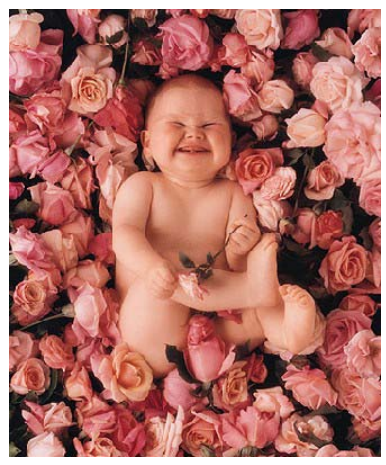

Fig. 2. Bebé de rosas (s.a) por Anne Geddes.

James R. Kincaid señala, que al igual que los victorianos Lewis Carroll o John Barrie y a juzgar por la televisión, las revistas y los anuncios de películas fotográficas de compañías como Kodak y Polaroid², tenemos la necesidad de fotografiar a los niños y a los bebés. La infancia pasa tan rápidamente, que es necesario preservarla con la velocidad de la cámara fotográfica. Pero esa necesidad por plasmar la

\footnotetext{
${ }^{1}$ HIGONNET, Anne. Pictures of Innocence: The History and Crisis of Ideal Childhood. Interplay. London: Thames \& Huston, 1998, pág. 76.

${ }^{2}$ Se refiere sobretodo a la publicidad de películas fotográficas desde comienzos de la $2^{\circ}$ mitad del siglo XX hasta finales de siglo. KINCAID, James R. Child Loving. The Erotic Child and Victorian Culture. New York: Routledge, 1992, págs. 227-28.
} 
inocencia, se asocia también con el erotismo y el sexo, que independientemente de los propósitos del fotógrafo, la interpretación sexual parece inevitable y es que en efecto, la fotografía, desde su creación ha sido uno de los medios más importantes de la difusión del erotismo infantil.

La sociedad de finales del siglo XX y principios del XXI, busca, identifica y califica el erotismo infantil de obsceno. Con la pornografía en Internet -que es un negocio «ilegal» muy rentable que devora la representación infantil-, se ha contribuido a generar una controversia respecto a la fotografía infantil independientemente de tratarse de fotografías cotidianas y familiares como de las artísticas, y que constantemente se equiparan en el mejor de los casos con la imagen erótica en el arte y en el peor con la pornografía pedófila.

La polémica respecto a la fotografía infantil y adolescente comenzaría alrededor de la década de los setenta con fotógrafos como Robert Mapplethorpe y durante la década de los ochenta y noventa, con fotógrafos como Sally Mann o Jock Sturges, los cuales se hicieron partícipes de la polémica con una fotografía que entraba de lleno en los tabúes del género y sobretodo en el desnudo de menores, como hiciera también el cine, siendo perseguidos por la censura de sus países o en aquellos donde se mostrara su obra.

Los desnudos infantiles de la fotógrafa Irina Ionesco también resultarían controvertidos. Ionesco, fotografiaría a su hija Eva hasta los catorce años. El estilo barroco y simbolista, envuelve a la joven modelo desnuda y seductora entre sedas, encajes, plumas y bisuterías en 
imágenes con reminiscencias de las divas del Moulin Rouge de París ${ }^{3}$. En 1977 apareció publicado Temple aux Miroirs, un libro de Alain Robbe-Grillet e ilustrado por Irina Ionesco con fotografías de su hija Eva como diosa y a la vez, víctima de un sacrificio en un mundo onírico. En el 2004, se publicaría el álbum Eva: Eloge de ma Fille de Irina Ionesco, que retoma parte de las fotografías realizadas en Temple aux Miroirs. Fue censurado y retirado en Estados Unidos, acusado de obscenidad y pornografía. La autora, reclamaría la libertad de «descubrir a su hija bajo la mirada inocente y amorosa que sólo una madre puede dar ${ }^{4}$, sin embargo, su mirada maternal es demasiado sexual para justificar una visión únicamente inocente. El carácter erótico de las fotografías no disminuye por el hecho de que la modelo sea su hija ni el que sea una menor, más bien al contrario, la juventud es parte de la componente erótica implícita en el desnudo, que por otro lado indaga en la feminidad como forma misteriosa $y$

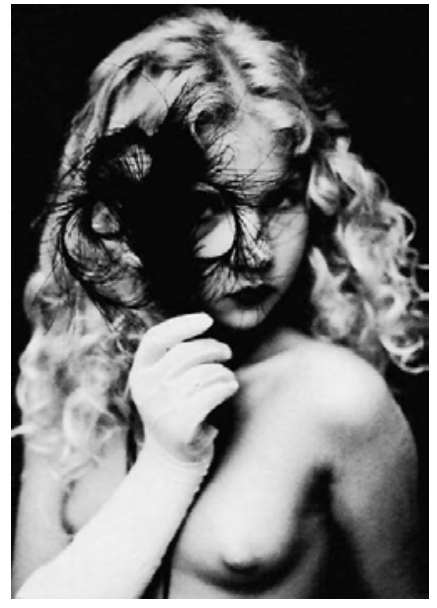

Fig. 3. Sin título (s.a.) del álbum Eva: Eloge de ma Fille de Irina Ionesco.

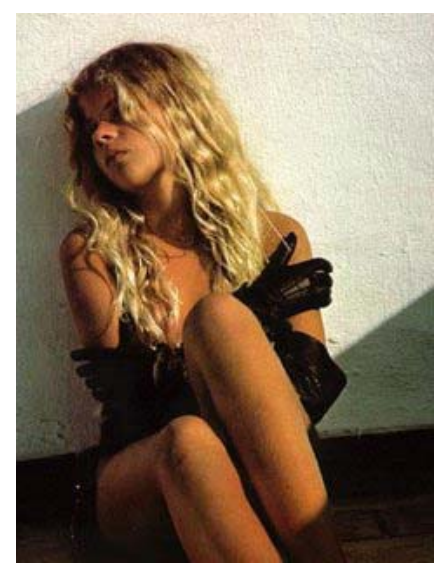

Fig. 4. Sin título (s.a.) del álbum Eva: Eloge de ma Fille de Irina Ionesco.

\footnotetext{
${ }^{3}$ La actriz erótica y modelo Sylvia Kristel (Emmanuel) o la vedet Norma Duval en su etapa del Moulin Rouge, fueron algunas de sus modelos predilectas antes del nacimiento de su hija Eva.

${ }^{4}$ Ensayos introductorios de Graham Ovenden, A. D. Coleman, Valer Martinenq y de la propia Irina Ionesco para IONESCO, Irina; COLEMAN, A. D. Eva: Eloge de ma Fille. S.I.: Alice Press, 2004.
} 
mística, haciendo de Eva Ionesco un icono infantil de sensualidad adulta $^{5}$, es decir una «Lolita» de carne y hueso.

David Hamilton indaga con obsesión en la iconicidad de la preadolescente virginal y erotizada tanto en su producción cinematográfica $^{6}$ como en su fotografía. «La virginidad es paradójicamente erótica» ${ }^{7}$. Su visión romántica y algo dulzona, enfatizada por los desenfoques ${ }^{8}$ y la luz aterciopelada, se recrea en la belleza del rostro femenino y en la juventud de la piel, sin buscar un erotismo diferente al propio que conlleva la juventud.

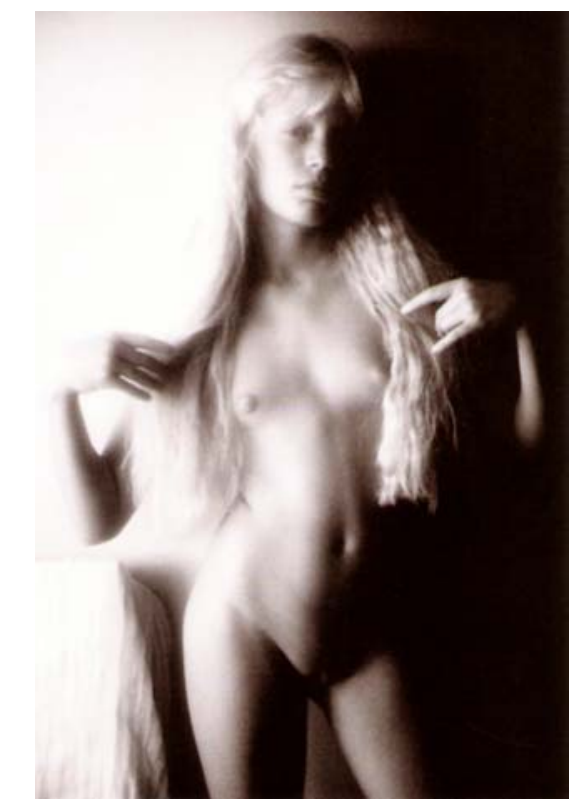

Fig. 5. Sin título (s.a.) del álbum The Age of Innocence por David Hamilton.

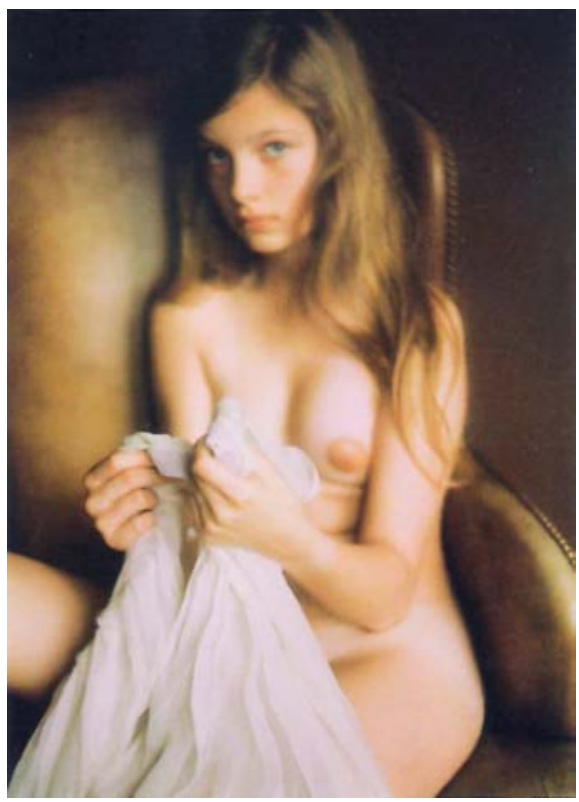

Fig. 6. Sin título (s.a.) del álbum The Age of Innocence por David Hamilton.

5 Durante aquellos años como modelo de su madre, Eva Ionesco realizaría algunos trabajos cinematográficos con papeles de «lolita». Aparecería en películas como Spermula (Charles Matton, 1977), El quimérico inquilino (Le Locataire; Roman Polanski, 1976) o Maladolescenza (P. G. Murgia, 1977). Posteriormente ha realizado numerosas apariciones en películas hasta la actualidad.

${ }^{6}$ Bilities (1977) y Tender Cousins (1980). V. 9. El icono de Lolita. La preadolescente en el cine, págs. 276 y 277.

${ }^{7}$ Introducción de Liliane James. HAMILTON, David. The Age of Innocence. London: Aurum Press, 1995.

${ }^{8}$ Influencia de la fotografía victoriana de Julia Margaret Cameron. 
Por su parte, el fotógrafo Bill Henson realiza una visión cruda y andrógina de la preadolescente, ubicándola en paisajes nocturnos industriales, desguaces, urbanizaciones iluminadas, etc. Son muchachas que parecen salir a escondidas de su casa para ocultarse en un desguace de coches donde poder mantener relaciones sexuales 0 drogarse. Sus rostros están casi desfigurados, enfermizos o drogados, como en plena resaca. La belleza o la sensualidad que buscan otros fotógrafos en la figura de la preadolescente es sin embargo, confrontada ante la desolación humana, violenta y seductora a la vez en las fotografías de Henson.
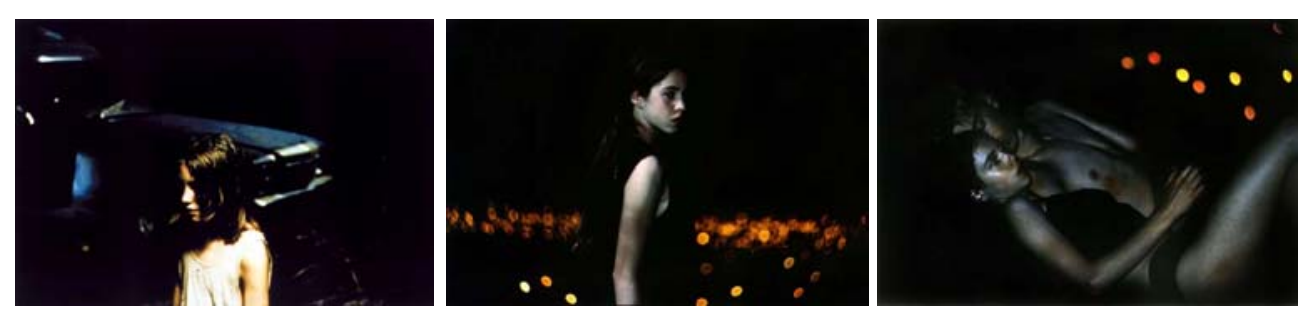

Fig. 7, fig. 8 y fig. 9. Sin título (1995-1996) por Bill Henson.

«La obscenidad»-afirmaría el fotógrafo Jock Sturges-, «está en los ojos que miran» ${ }^{9}$. A este respecto Román Gubern considera que «se da la paradoja de que lo que para unos sujetos activos ante el objetivo de la cámara es erotismo y ejercicio sexual de buena ley y no pornografía, para quien les mira es en cambio pornografía y desviación erótica» ${ }^{10}$. Sin embargo la neutralidad de la cámara condiciona la mirada del fotógrafo, conciliando difícilmente la imagen infantil con la interpretación de la misma por parte del autor o del espectador.

\footnotetext{
9 "The Right to Photograph Children Nude" en GINSBERG \& RICHEY; HARRIS, Melissa (ed.). The Body in Question. New York: Aperture Foundation, 1990.

${ }^{10}$ GUBERN, Román. La imagen pornográfica y otras perversiones ópticas. Barcelona: Anagrama, 2004. Cit. SANTIAGO, Pablo. Op. cit., pág. 338.
} 
La representación de la sexualidad infantil por medio del «nudismo», ha sido perseguida, censurada y castigada siendo la empresa librera Barnes \& Noble llevada a juicio por las autoridades de los estados norteamericanos de Alabama y Tennessee, por vender libros de fotógrafos conocidos por sus desnudos infantiles entre ellos Radiant Identities de Jock Sturges. Éste hecho es sólo uno de entre las múltiples persecuciones a las que se ha visto sometido Sturges, al que en abril de 1990, los agentes del FBI y la policía de San Francisco arrasó sobre su estudio, confiscando sus cámaras fotográficas, ordenador, fotografías y demás material fotográfico contenido allí.

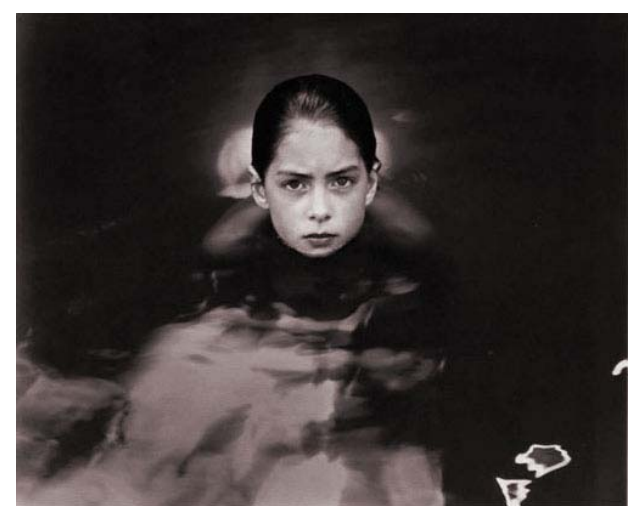

Fig. 10. Minna, norte de California (1978) por Jock Sturges.

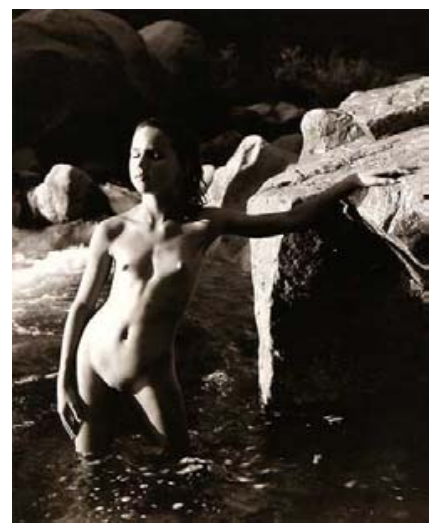

Fig. 12. Lisa C., norte de California (1981) por Jock Sturges.

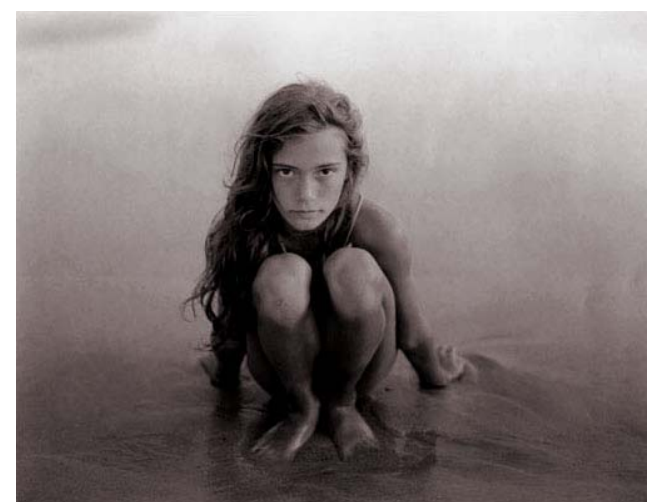

Fig. 11. Fanny, Montalivet, Francia (1995) por Jock Sturges.

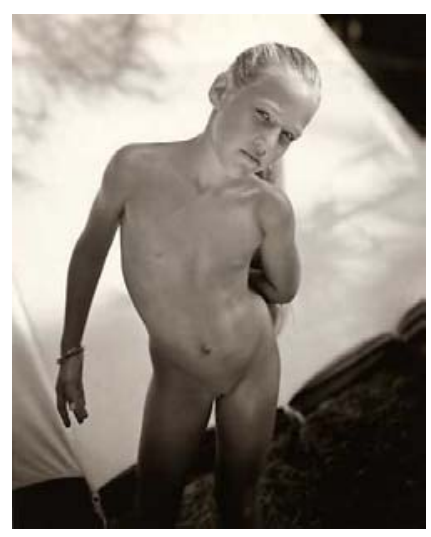

Fig. 13. Lotte, Montalivet, Francia (1995) por Jock Sturges.

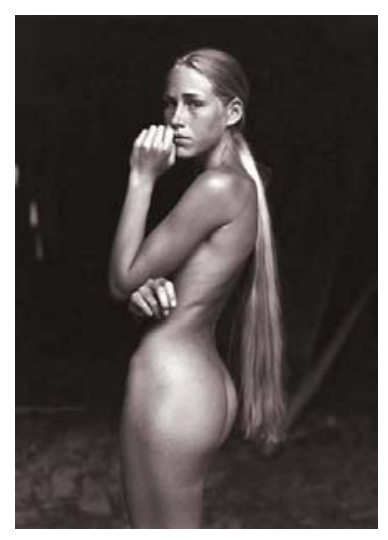

Fig. 14. Nikki, Montalivet, Francia (1997) por Jock Sturges. 
La fotografía de Jock Sturges se centra principalmente en la representación del cuerpo adolescente e infantil mostrando el desnudo integral en el entorno de la vida naturista y nudista de las playas francesas de Montalivet y las del norte de California. Sturges ha sido naturista la mayor parte de su vida y observa el desnudo sin ningún tipo de sentimiento pecaminoso, viviendo en una «maravillosa falta de vergüenza $y$ pudor ${ }^{11}$, así los genitales son sólo una parte más de la imagen fotografiada y no la imagen en sí, de esta manera, al no ocultarse y mostrarse con naturalidad, se desvanece la creación de intereses perversos, contemplando el cuerpo humano en toda su magnificencia.

El caso del fotógrafo Garry Gross, resulta excepcional dentro de la polémica surgida durante el último tercio de siglo XX. En 1981, Garry Gross fue llevado ante el Tribunal Supremo de Nueva York, por sus fotografías tomadas a Brooke Shields en 1975, cuando tan sólo tenía diez años de edad. La niña había posado desnuda y untada con aceite para el libro titulado Sugar and Spice, Surprising and Sensuous Images of Women ${ }^{12}$, publicado por Playboy Press. Terri Shields, madre de Brooke, demandó a Garry Gross, alegando que había dañado la reputación de su hija con tales fotografías. Su abogado diría:

«La retratan como vampiresa y una putita, una experimentada veterana sexual, una provocativa niña-mujer, un símbolo erótico y sensual del sexo, la Lolita de su generación ${ }^{13}$.

\footnotetext{
${ }^{11}$ STURGES, Jock. The Last Day of Summer. Photographs by Jock Sturges. New York: Aperture, 1994, pág. 86. ${ }^{12}$ AA.VV. Sugar and Spice, Surprising and Sensuous Images of Women. New York: Playboy Press, 1976.

13 «She [Brooke] is portrayed as a young vamp and harlot, a seasoned sexual veteran, a provocative child-woman, an erotic and sensual sex symbol, the Lolita of her generation». [Anón]. "Shields' Mother Fights Photos of Nude Brooke". Los Angeles Times. 26 de septiembre de 1981, sec. 1, pág. 22. Cit. HIGONNET, Anne. Op. cit., cita 35, pág. 150.
} 


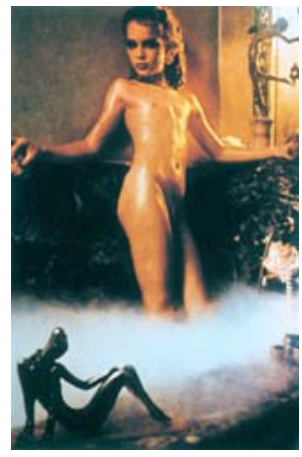

Fig. 15. Brooke Shields (1975) por Gary Gross.

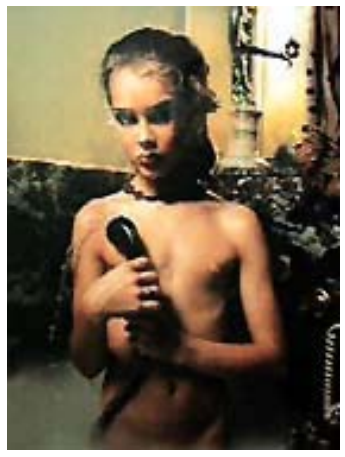

Fig. 16. Brooke Shields (1975) por Gary Gross.

Finalmente, la resolución descartó catalogar las fotografías como material pornográfico. El juez Pierre Leval, dictaminó que esas fotografías no eran fundamentalmente diferentes a los papeles que interpretaba habitualmente la niña ${ }^{14}$ y el juez Greenfield señaló que «sólo una mente perversa podría entenderlo así» ${ }^{15}$.

\subsection{Sally Mann.}

Hacia la década de los ochenta y los noventa, la fotografía de la estadounidense Sally Mann (1951), comenzó a hacerse conocida en Estados Unidos por la polémica generada al ser objeto de persecución por parte de la censura gubernamental y acusada de pornografía infantil.

\footnotetext{
${ }^{14}$ Por aquel entonces, Brooke Shields ya era considerada la sex-symbol de su generación. Contaba con una temprana trayectoria como modelo publicitaria y actriz y tras las fotografías para Sugar and Spice (1975), había realizado películas en las que aparecía desnuda o con una doble y de contenido sexual, como La pequeña (Pretty Baby; Louis Malle, 1978), El lago azul (The Blue Lagoon; Randal Kleiser, 1980) o Amor Infinito (Endeless Love; Franco Zeffirelli, 1981).

${ }^{15}$ A.A.V.V. El día del niño. La infancia como territorio para el miedo. Madrid: Valdremar, 2003, pág. 188.
} 
El polémico trabajo en cuestión, Immediate Family, consiste en un «álbum familiar» ${ }^{16}$ de fotografías de sus tres hijos -algunas de los hijos de sus amigos- realizadas durante unos doce años. Es en esa consideración, la de «álbum» y la de «familiar»-más propio del imaginario femenino- donde se halla la provocación en la fotografía de Sally Mann. A diferencia de la «fotografía de familia» de ámbito privado y de carácter sentimental con la que las familias construyen su identidad y su memoria, sus fotografías se hacen públicas, abriendo la controversia respecto al uso sensacionalista y con propósitos económicos -y artísticos- de la vida privada de sus hijos. Anne Higonnet, señala que la relación entre Sally Mann y sus hijos resulta polémica porque rompe con el todavía vigente ideal romántico de inocencia infantil, violando el espacio sagrado que conforma la vida doméstica ${ }^{17}$.

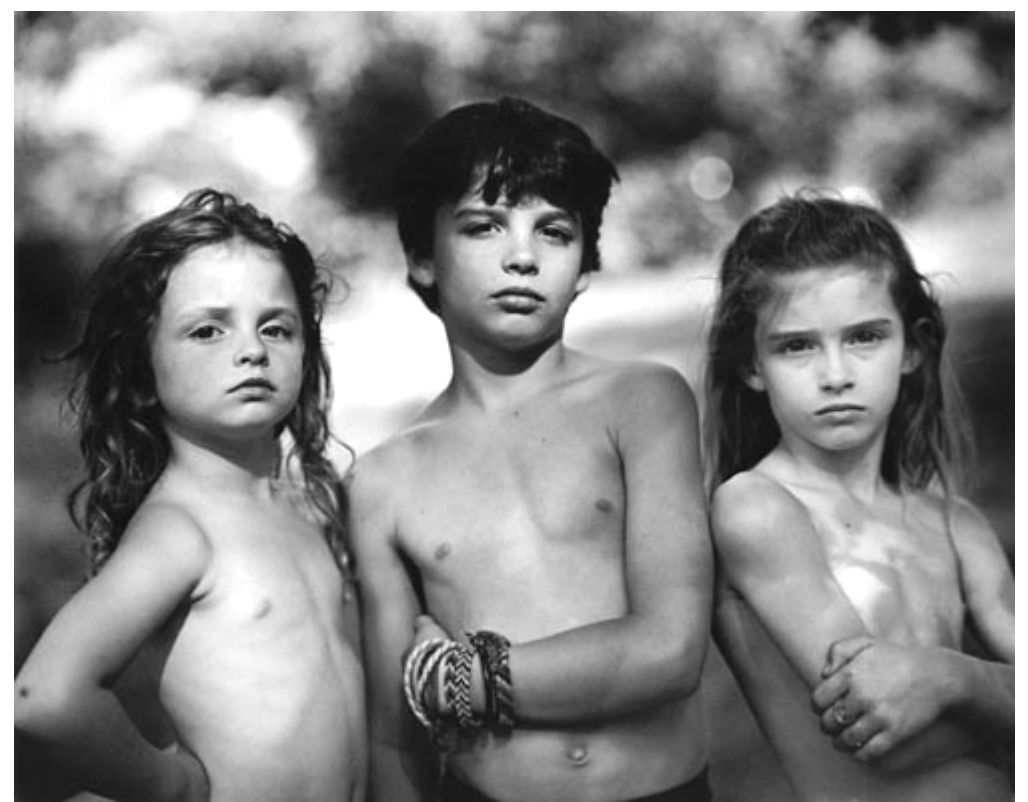

Fig. 17. Emmett, Jessie y Virginia (1989).

${ }^{16}$ MANN, Sally. Immediate Family. New York: Aperture, 1992.

${ }^{17}$ HIGONNET, Anne. Op. cit., pág. 196. 
La visión materna se abre al público para ofrecer la relación madre-hijos más allá de la imagen que sirve como recuerdo ${ }^{18}$. Sus dos hijas y su hijo, son sus modelos, pero modelos que viven además la intimidad de su desnudez según el estilo de vida naturista, en los que la falta de pudor hace de las escenas cotidianas una expresión de la sexualidad infantil en todo momento.

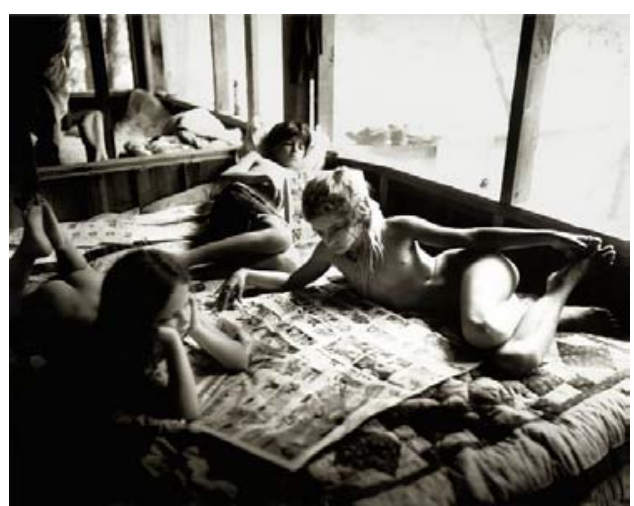

Fig. 18. Sunday Funnies (1991).

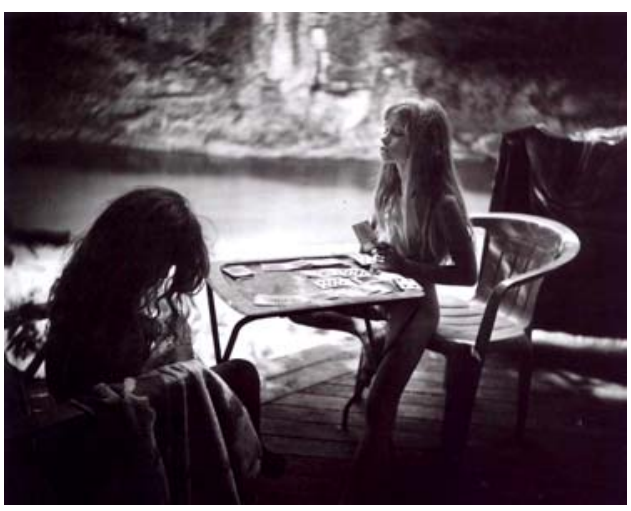

Fig. 20. Hermanas en guerra [Sisters at War] (1991).

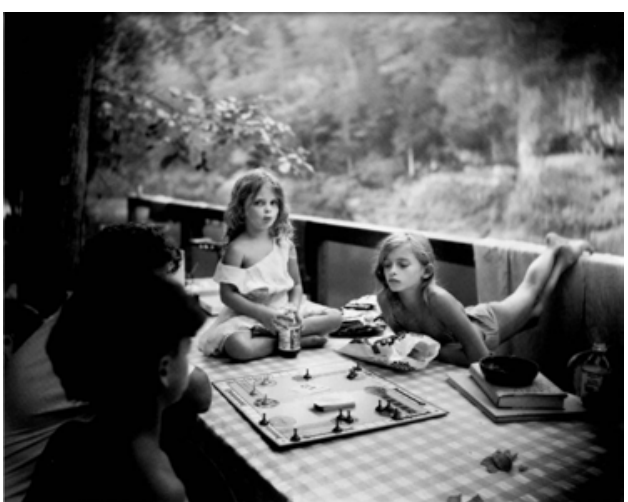

Fig. 19. Sorry! [Sorry Game] (1989).

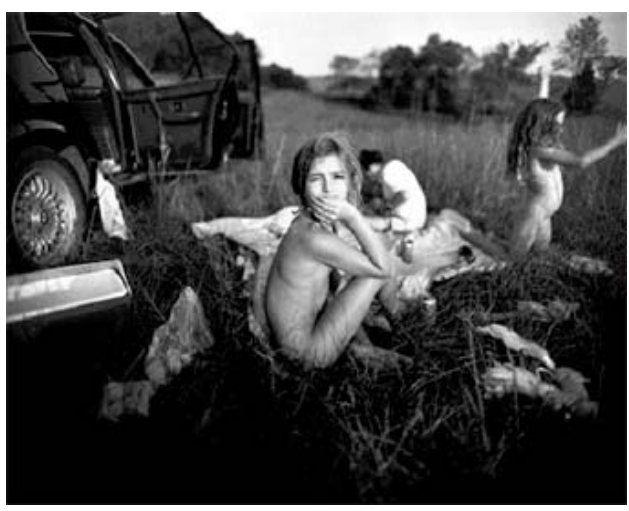

Fig. 21. Almuerzo sobre la hierba [Luncheon on the Grasses] (1991).

${ }^{18} \mathrm{Cf}$. con la también controvertida relación madre-hija, fotógrafa-modelo de Irina y Eva Ionesco. N. 4, pág. 303 de la tesis. 
En la trivialidad de la vida infantil y en la ausencia de la conciencia de desnudez se halla el erotismo. Los juegos infantiles de sus hijas son los propios juegos entre la imagen pornográfica y el poder sexual «latente» de la representación infantil. Hay una exteriorización de la sexualidad infantil, ligada al exhibicionismo -que aunque habitual en los niños-, ha sido asociado a la obscenidad y a la pornografía femenina según el imaginario masculino.

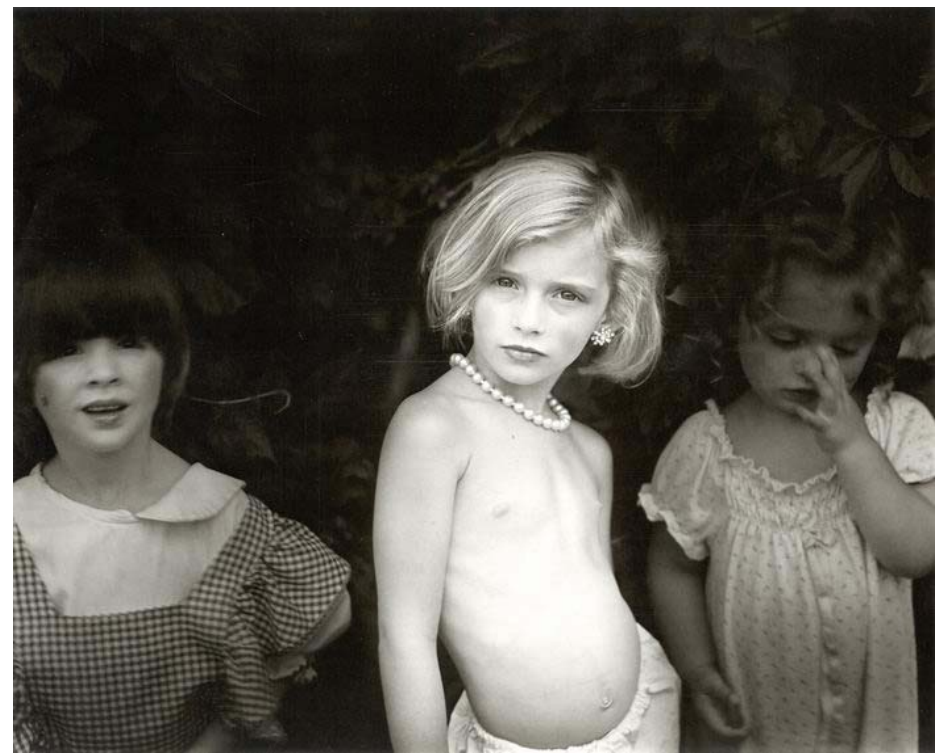

Fig. 22. Jessie a los cinco (1987).

En Jessie a los cinco [Jessie at Five] (1987) convergen dos mensajes contradictorios sobre la feminidad infantil. Jessie posa en el centro con el torso desnudo y andrógino, sin embargo, sus labios y sus mejillas está maquillados como los de una mujer adulta y luce un collar de perlas y los pendientes de mamá. En sí su aspecto es contradictorio, pero su presencia contrasta con la de las dos niñas que se encuentran a ambos lados en penumbra. La niña de la derecha, su hermana menor, Virginia, lleva un vestido infantil propio de su edad, pero al otro lado, la 
niña del cabello oscuro, lleva un vestido infantil varias tallas más grande y los labios pintados. Su aspecto como el de Jessie, es el de un disfraz, pues no es niña sino niño, Emmett, el hermano mayor. La imagen nos propone un entrecruzamiento de las relaciones de inocencia, erotismo y sexualidad adulta, a través del triangulo infantil que conforman los hijos de Sally Mann.

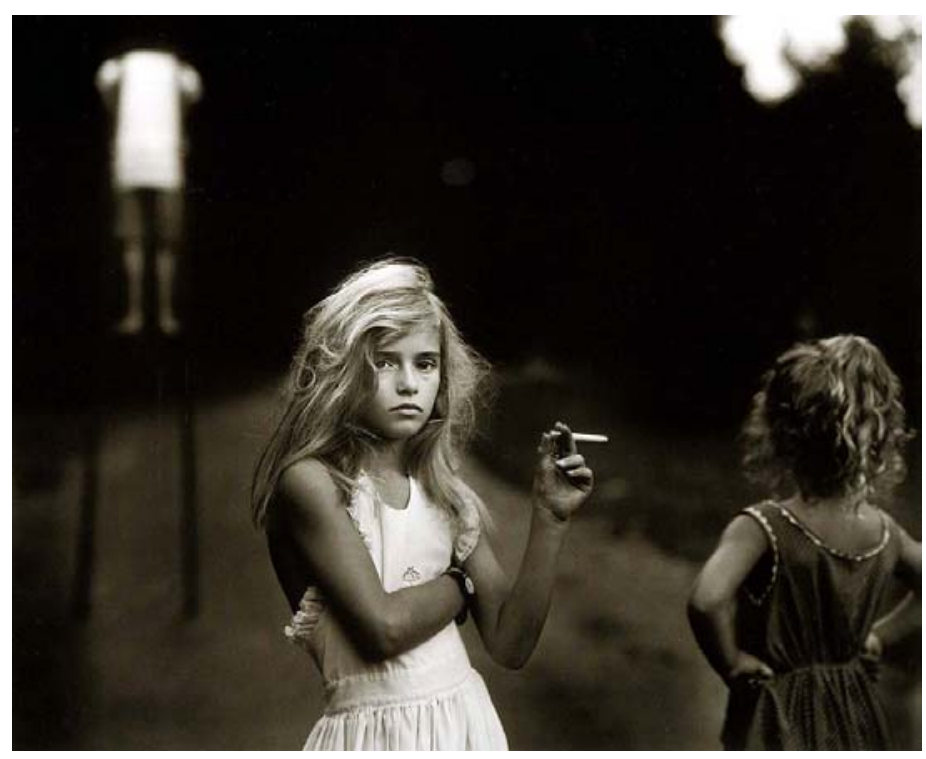

Fig. 23. Cigarrillo de caramelo (1989).

En otras ocasiones, esa «actuación» como adultos se hace más evidente mostrándose la acción misma en la que se maquillan o fumando, aunque sean cigarrillos de chocolate como en Cigarrillo de caramelo [Candy Cigarette] (1989) o en Las nuevas madres [The New Mothers] (1989) en la que entra en contradicción por un lado el hecho de que jueguen a las mamás con las muñecas y el carrito de bebé de juguete -como una muestra del desarrollo natural del sentimiento maternal en las niñas- y por otro el que fumen cigarrillos y lleven gafas 
de sol al estilo de Lolita $^{19}$, como si se tratasen de unas seductoras y estereotipadas femmes fatal cinematográficas o de modelos de un anuncio publicitario.

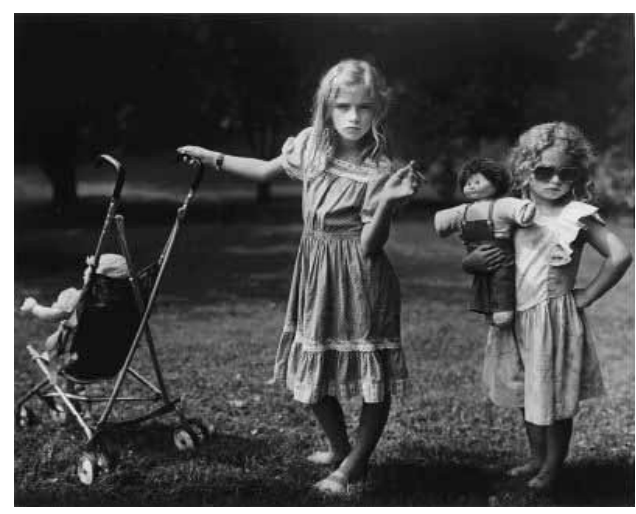

Fig. 24. Las nuevas madres (1989).

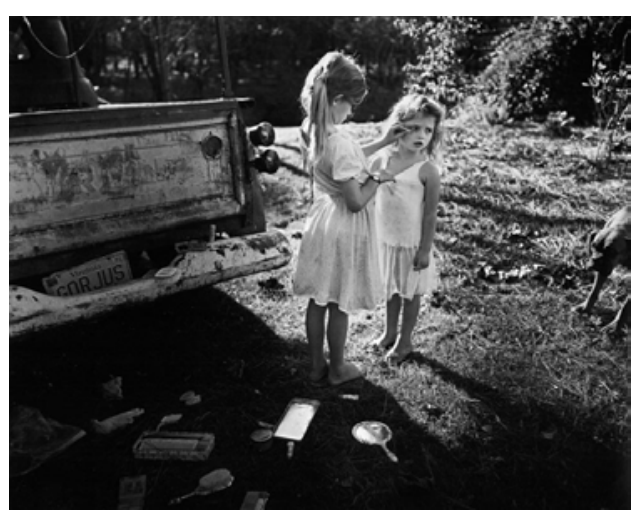

Fig. 25. Guapísima [ "Gorjus"] (1989).

La mirada de Mann como lo era la de Cameron, es una visión en la que maternidad y sensualidad van unidas. Pero a pesar de la condición de madre de Sally Mann y en modo opuesto a la fotógrafa victoriana de Cameron, su fotografía ha sido considerada erótica y pornográfica ${ }^{20}$.

La maternal visión se mezcla con la vida, casi salvaje de sus hijos. Es una mirada ausente de composturas sociales, que recuerda a la estética y a la crudeza de la fotografía de Lewis Hine, pero en los hijos de Mann, esa dureza sirve de contraste estético, la hermosura de las heridas, de la sábana orinada y los acontecimientos cotidianos de la tranquila vida rural.

\footnotetext{
${ }^{19}$ Nótese el estilo de las gafas de sol con forma de corazón, como llevaba Sue Lyon en la película Lolita (Stanley Kubrick, 1962), convirtiéndose en un objeto asociado a la figura de las «lolitas».

${ }^{20}$ BLACK, Louise. Page Two. [en línea]. Austin Chronicle [ref. de 3 de abril de 2002]. Disponible en Web: http://www.austinchronicle.com/issues/vol18/issue07/cols.pagetwo.html
} 

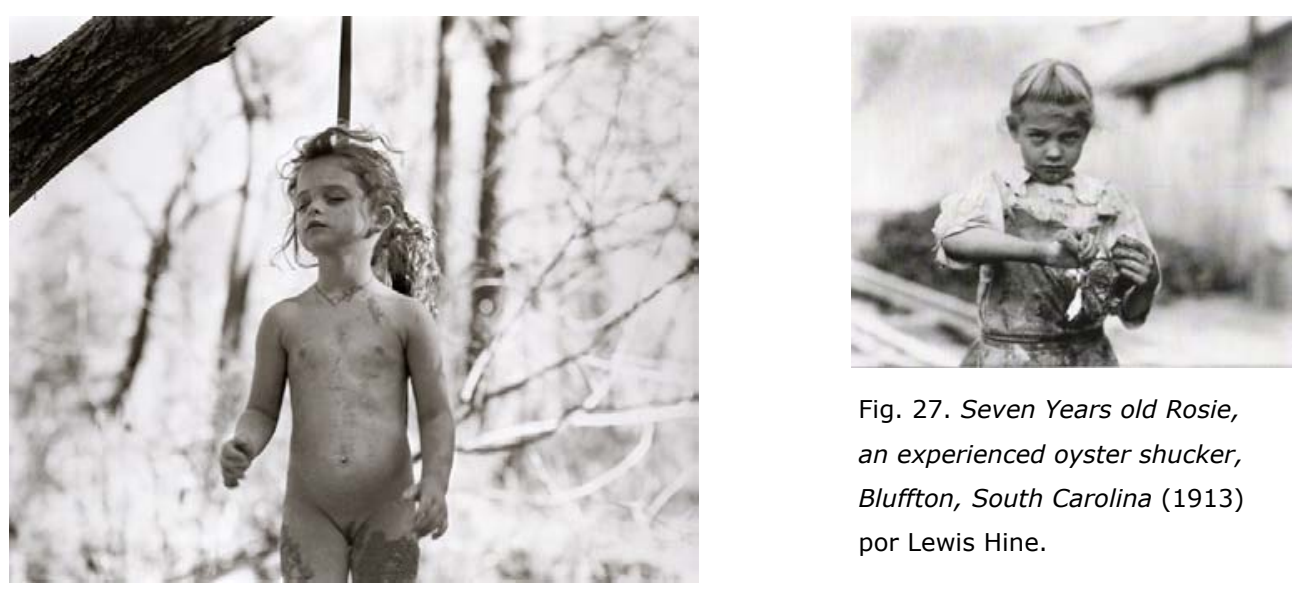

Fig. 27. Seven Years old Rosie, an experienced oyster shucker, Bluffton, South Carolina (1913) por Lewis Hine.

Fig. 26. La imagen terrible [The Terrible Picture] (1989).

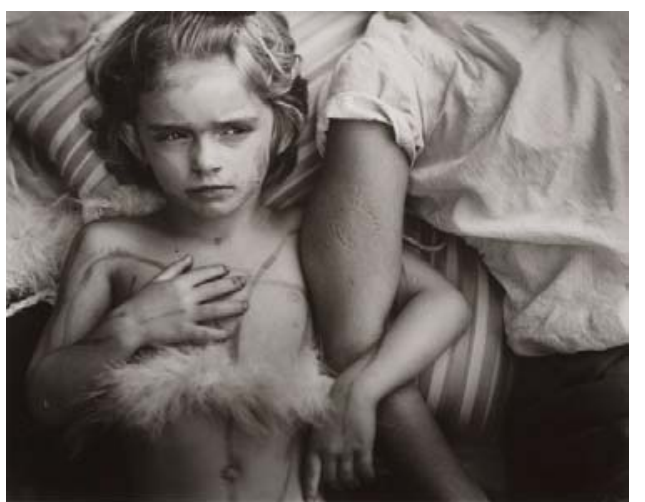

Fig. 28. Mordedura de Jessie [Jessie Bites] (1985).

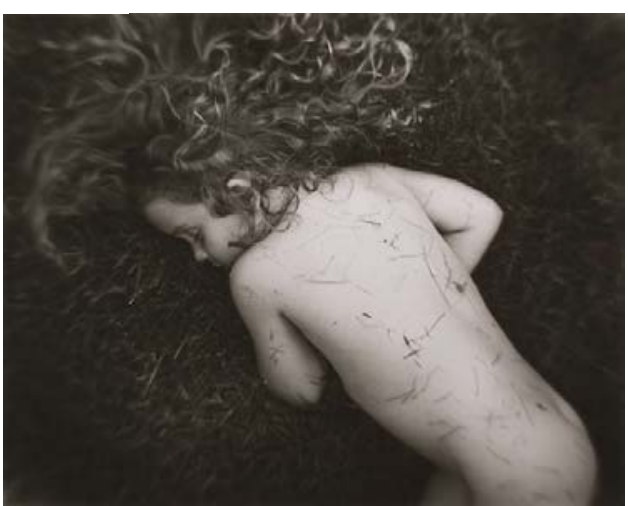

Fig. 29. Niña caída [Fallen Child] (1989).

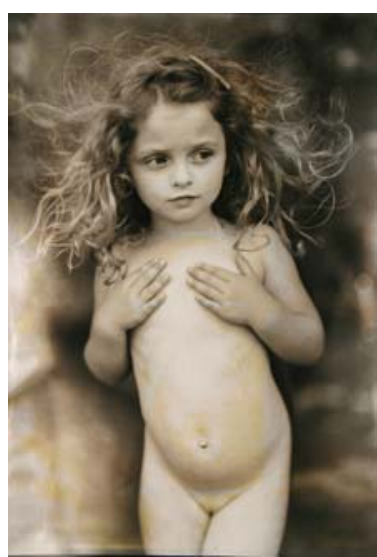

Fig. 31. La niña pudorosa [The Modest Child] (1988). 
Sus escenas triviales son enfatizadas y enmarcadas por el característico claroscuro de su fotografía, así como el uso de suavizados y borrosidades en las esquinas, semejante a la pintura y la fotografía prerrafaelista y sobre todo al estilo de Julia Margaret Cameron de la que hace algunas citas o al erotismo fetichista de las fotografías post mortem infantiles. Así, hallamos similitudes entre La cama mojada [The Wet Bed] (1987) en la que Virginia -la hija pequeña de Sally Mann- es mostrada desnuda mientras duerme, con La sunamita y su hijo muerto [The Sunamite Woman and Her Dead Son] (1865) de Julia Margaret Cameron o Retrato de Evelyn Hatch ${ }^{21}$ (c. 1878) de Lewis Carroll. Sin embargo y a pesar de la mancha de orina sobre las sábanas, que nos indican sobre la edad y la enuresis ${ }^{22}$, -acontecimiento propio dentro del núcleo familiar-, la sensualidad se enfatiza en La cama mojada mostrando claramente los geniales de la pequeña dormida sobre una cama de matrimonio y junto a la misma en el suelo, una muñeca -caída probablemente mientras dormía-, que lleva la falda levantada.

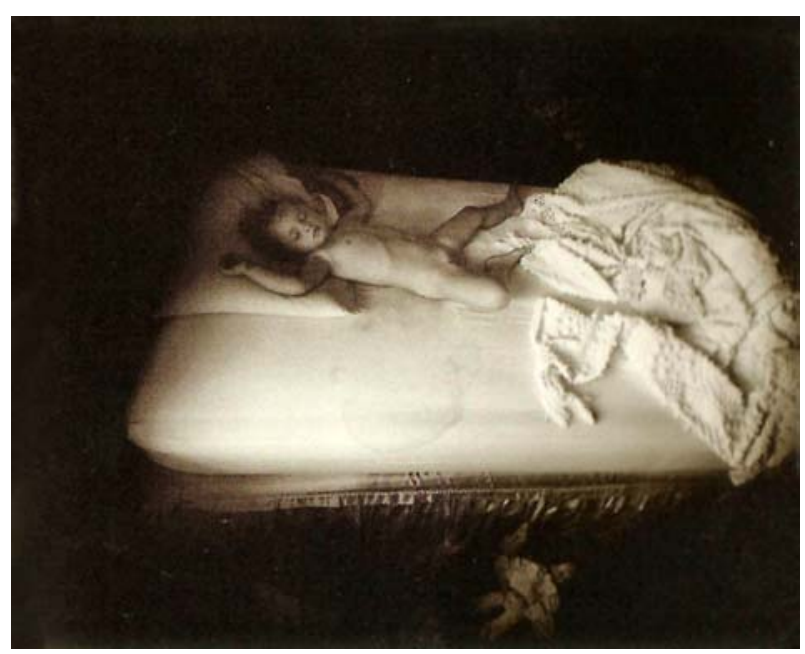

Fig. 32. La cama mojada (1987).

\footnotetext{
${ }^{21}$ V. cap. 5. Lewis Carroll, fig. 39, pág 173.

${ }^{22}$ Incontinencia urinaria infantil.
}

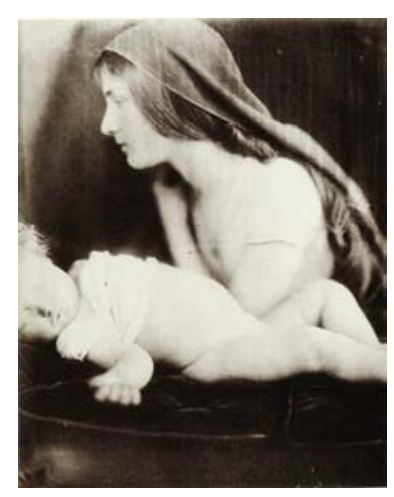

Fig. 33. La sunamita y su hijo muerto (1865) por Julia Margaret Cameron. 


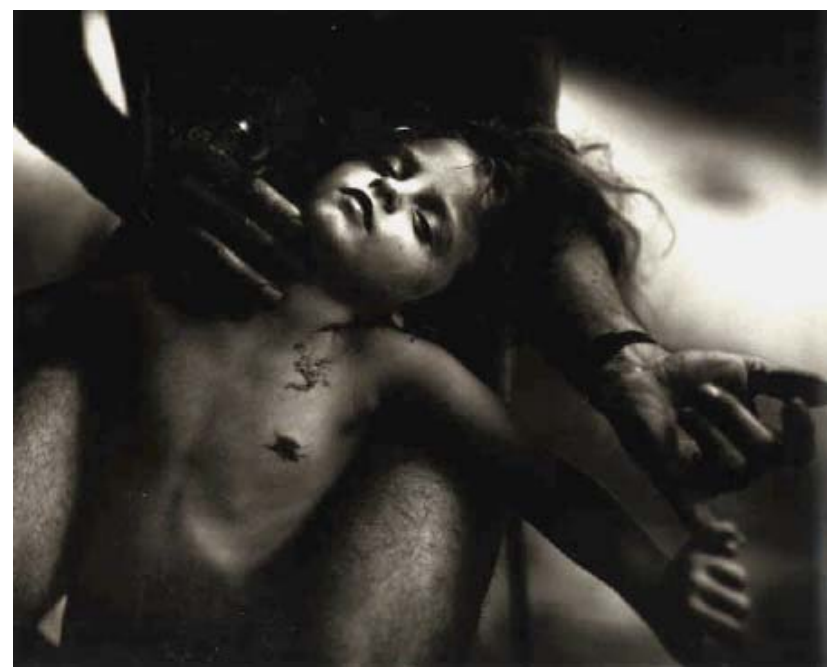

Fig. 34. La última luz (1990).

En La última luz [Last Light] (1990) la niña aparece con los brazos en cruz entre las piernas de un hombre aparentemente desnudo. El hombre tiene colocados sus dedos sobre la garganta de la niña como si le tomara el pulso pues parece desfallecida, enferma. Al explorar la infancia a través del dolor, la enfermedad o la muerte, se confiere al estado de inocencia un mayor grado de fragilidad y vulnerabilidad. De modo impactante, nos presenta en Gancho de Heno [Hayhook] (1989) el cuerpo infantil colgado a un gancho de heno como si se tratase de un pedazo de carne sacrificado del matadero, como un cuerpo martirizado. Jeffrey Eugenides, señala que la pequeña que se encuentra de pie, «recuerda a un querubín tocando su flauta, como ciertos angelotes de la pintura holandesa y los huevos rotos a sus pies -que simbolizan la pérdida de la virginidad- sustituidos por tubos de buceo (...) El resultado es un fantasma más vivo que la vida (...) destacando la iluminada vulva» ${ }^{23}$.

${ }^{23}$ EUGENIDES, Jeffrey. "Sally Mann: Hayhook, 1989 - black and white photograph". Art Forum, decembre 1994. 


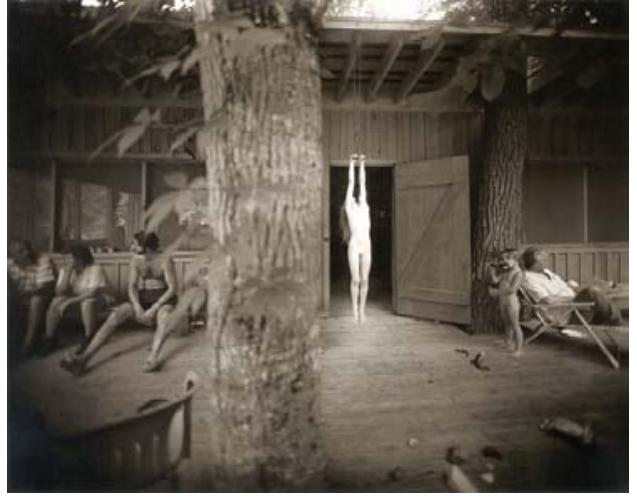

Fig. 35. Gancho de Heno (1989).

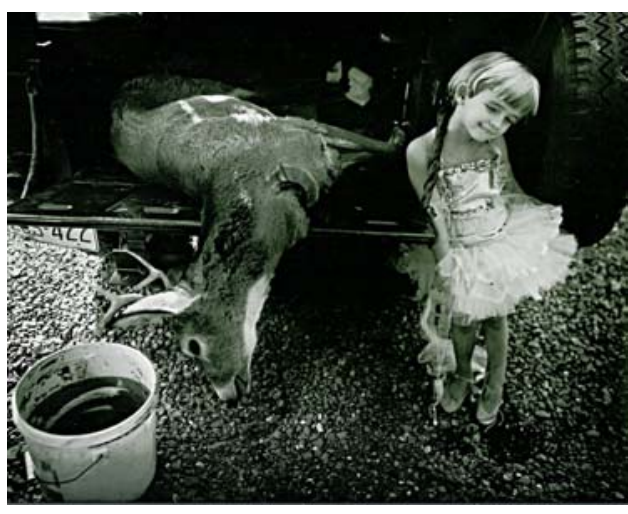

Fig. 36. Jessie y el ciervo (1985).

Sus fotografías indagan en las pesadillas maternas y las de los adultos respecto a los niños, fantaseando entre las relaciones que se establecen entre la figura infantil y el sexo, el dolor, la vejez o la muerte y transformándose en escenas turbadoras y sin embargo bellas. Así en Jessie y el ciervo [Jessie and the Deer] (1985), Jessie, vestida de bailarina con tutú se apoya coquetamente y con una inocente sonrisa, en la puerta abierta del maletero de un todo-terreno sobre el cual reposa el cadáver de un ciervo recién degollado y junto a él un cubo con la sangre del degüello.

En Las dos Virginias [The Two Virginias] (1988) las dos mujeres, anciana y niña se establece un paralelismo entre ambas mediante las semejanzas y las diferencias como el nombre de Virginia, el parentesco de abuela-nieta, las rodillas tapadas de una, descubiertas en la otra, la piel ajada de la anciana, las piernecitas carnosas y flexibles de la niña, la mano oscura y arrugada pero de uñas perfectas -metonimia del rostro de la anciana- apoyada cariñosa y protectora sobre la cabecita de la pequeña. 


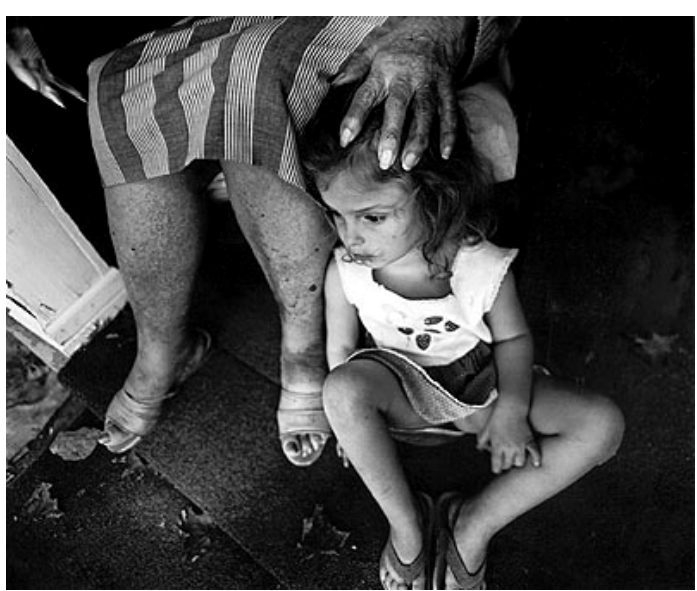

Fig. 37. Las dos Virginias (1988).

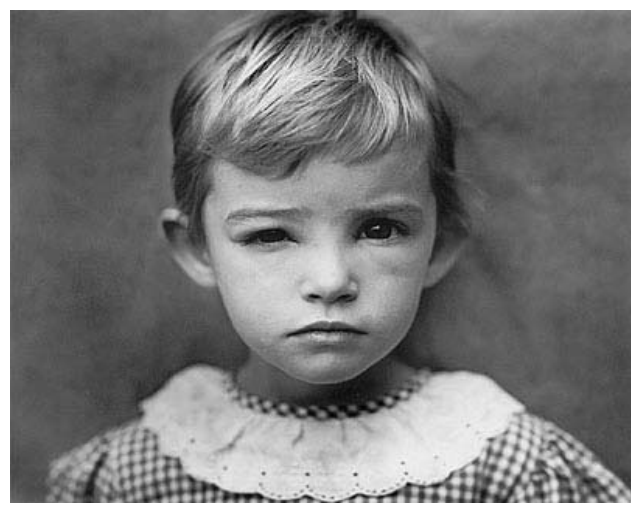

Fig. 39. Niña dañada (1984).

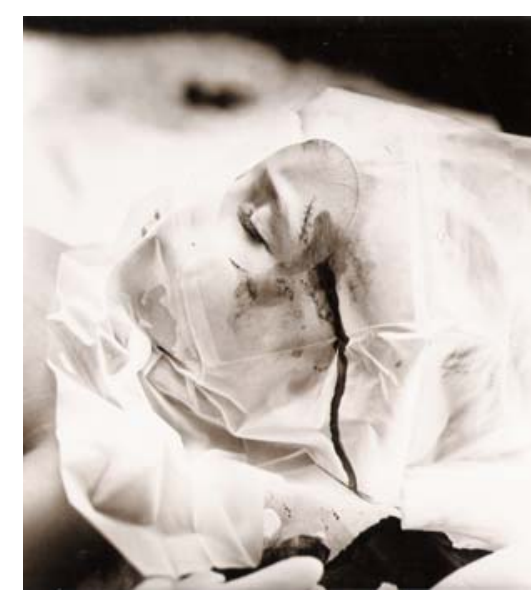

Fig. 38. El corte de Jessie [Jessie's Cut] (1985).

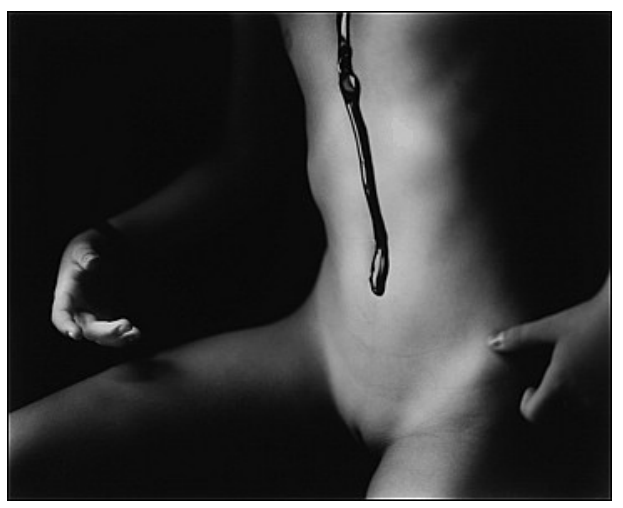

Fig. 40. Imagen divertida (1992).

A pesar del patetismo de algunas escenas como Niña dañada [Damaged Child] (1984), El corte de Jessie [Jessie's Cut] (1985) o Imagen divertida [Fun Picture] (1992), no están exentas de humor e ironía como Jessie sucia [Dirty Jessie] (1985), en la que la niña se encuentra tumbada como revolcada sobre el césped repleto de hojas, semidesnuda con las bragas varias tallas más grandes y unas botas de plástico, la cara y el cuerpo sucio, cubriéndose los pezones con ambas manos. El título no sólo hace referencia a su aspecto, sino que 
precisamente con la suciedad y el barro sobre su piel, tumbada sobre cualquier la tierra sugiere vulgaridad, promiscuidad y disponibilidad sexual, como si se tratase del desenlace del encuentro robado de una «putita» o de una violación.

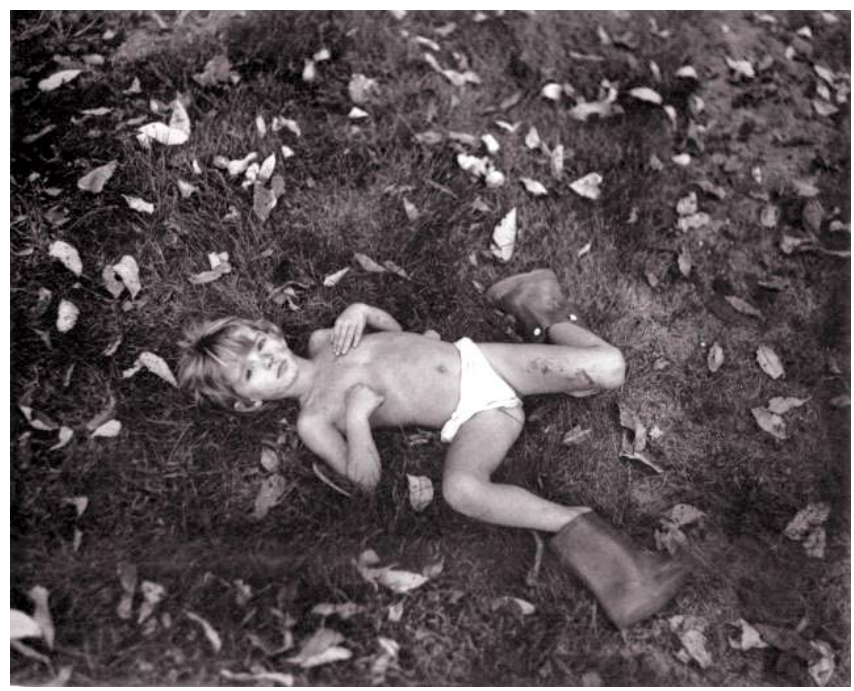

Fig. 41. Jessie sucia (1985).

Sally Mann, ha construido una imagen infantil a través de la maternidad como vehículo de deseo, como un «fetichismo maternal» ${ }^{24}$, pero un deseo entendido más allá de los términos sexuales, como una visión emocionada, exaltada y apasionada de la belleza del cuerpo infantil en los juegos y en los acontecimientos de la vida familiar.

Esa misma visión maternal se produce al observar el universo íntimo de la feminidad preadolescente y adolescente con su serie $A t$ Twelve ${ }^{25}-A$ los doce-, en la que se confronta la auténtico y lo artificial, la belleza y la vulnerabilidad o crudeza a través de una amorosa y respetuosa mirada en la vida de sus jóvenes protagonistas.

\footnotetext{
${ }^{24}$ HIGONNET, Anne. Op. cit., pág. 199 y MANN, Sally. Op. cit.

${ }^{25}$ MANN, Sally. At Twelve. Portraits of Young Women by Sally Mann. New York: Aperture, 1988.
} 


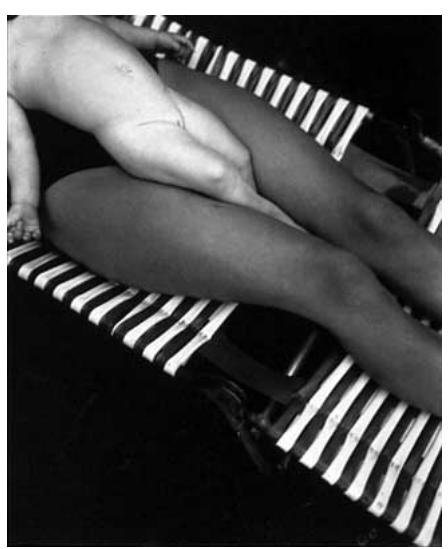

Fig. 42. Sin título (s.a), At Twelve.

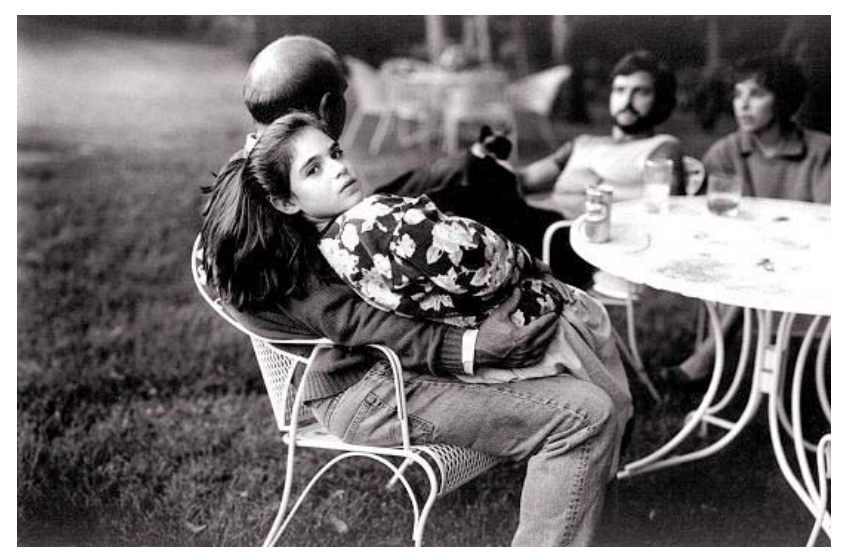

Fig. 43. Sin título (s.a), At Twelve.

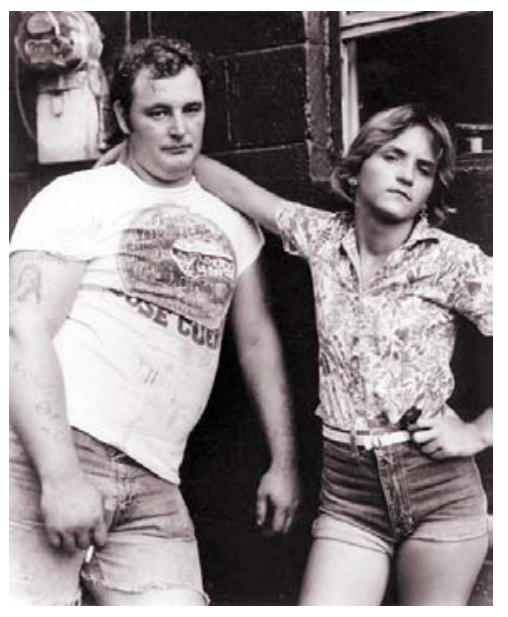

Fig. 44. Sin título (s.a), At Twelve.

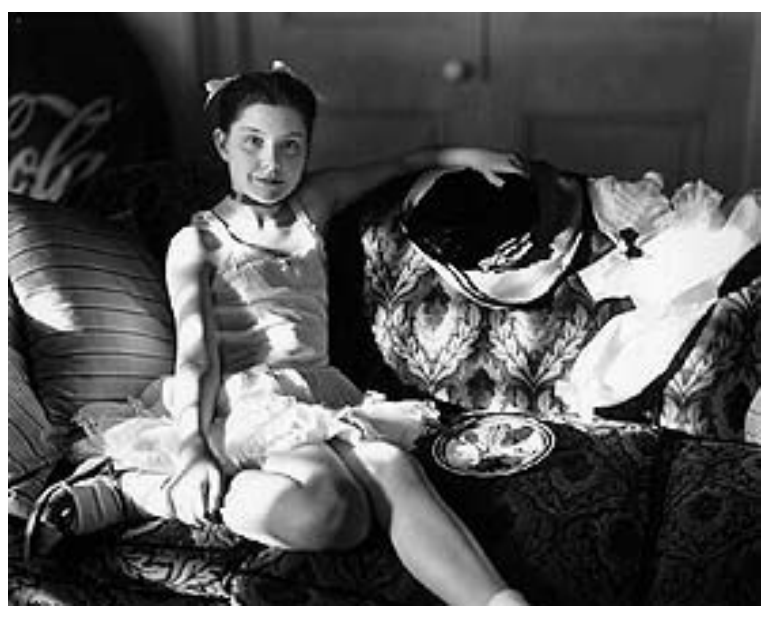

Fig. 45. Sin título (s.a), At Twelve.

\subsection{Graham Ovenden.}

El artista inglés Graham Ovenden (1943) se dio a conocer alrededor de las décadas de 1960 y 1970 en Londres. Muy pronto su obra fue considerada tanto en Europa como en EEUU como erótica y pornográfica. Precisamente en EEUU, sus fotografías han sido censuradas y calificadas de obscenas, así como en 1992, su monográfico 
States of Grace $^{26}$ fue acusado por el departamento de justicia de este mismo país de pornografía infantil. Ese mismo año, fue acusado por Scotland Yard de formar parte de una red de pornografía a nivel internacional.

Graham Ovenden, es un artista polifacético que retomaría la tradición prerrafaelista tanto a nivel literario como artístico. Su admiración por la Hermandad Prerrafaelista y su modo de entender el arte y la naturaleza, le llevarían en 1975 a crear junto a un reducido grupo de amigos artistas, la llamada Hermandad Ruralista -Brotherhood of Ruralist ${ }^{27}$-, como él mismo declararía, la Hermandad nacía como «parte de un esfuerzo por revivir no sólo las técnicas prerrafaelistas sino también el temprano modo de vida victoriano» ${ }^{28}$. Al igual que su admirado Lewis Carroll, Graham Ovenden comparte su actividad pictórica y fotográfica junto a la literatura o la arquitectura ${ }^{29}$, los juegos de palabra, la poesía, textos críticos o la publicación y edición de monográficos sobre fotografía e ilustración victoriana, etc...

Su fascinación por la fotografía victoriana sobre todo la de Lewis Carroll y su personaje de Alicia o de la fotógrafa Julia Margaret Cameron, se evidencia en sus dibujos, pinturas y fotografías de desnudos de niñas ${ }^{30}$.

\footnotetext{
${ }^{26}$ En la actualidad es prácticamente imposible encontrar ejemplares del mismo.

${ }^{27}$ En sus inicios estuvo formada por siete miembros: Ann Arnold, Graham Arnold, Peter Blake, Jan Haworth, David Inchaw, Graham Ovenden, Annie Ovenden. La Hermandad Ruralista admira la tradición artística británica representada en William Blake, Hermandad de los Ancianos -Brotherhood of Ancients- o la Hermandad Prerrafaelista.

${ }^{28}$ LUCIE-SMITH, Edward. Art in the Seventies. Oxford: Paidon Press Ltd., 1980, pág. 50.

${ }^{29}$ Diseña y construye su casa, Barley Splatt, de estilo Neo-gótico en el condado de Cornwall (Gran Bretaña), e inspirándose también en William Morris y Arts \& Crafts.

${ }^{30}$ A finales de la década de 1989, Graham Ovenden creó unas «falsas fotografías victorianas» que había realizado previamente dibujándolas a partir de unas copias de unas fotografías originales y posteriormente manipuladas con varias técnicas de impresión. Posteriormente las entregó a un
} 


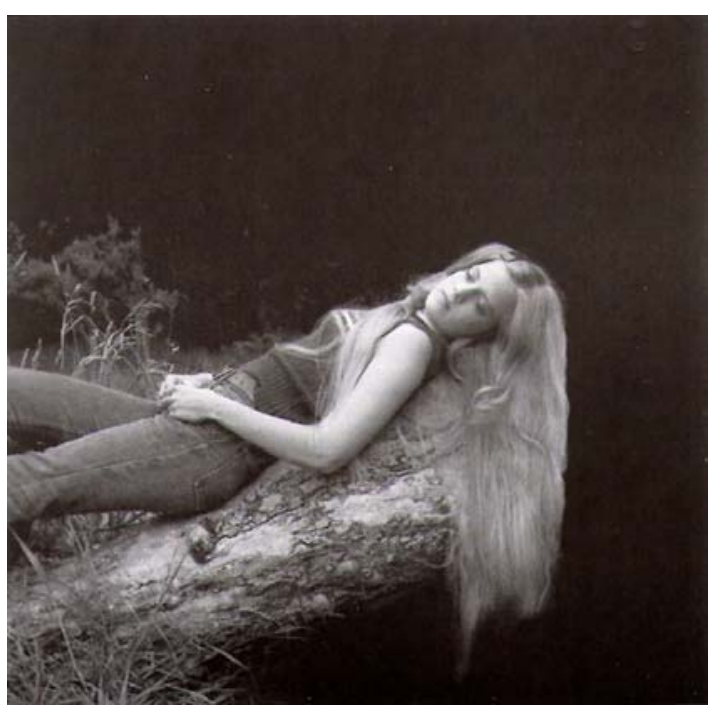

Fig. 46. April como Ofelia (1969).

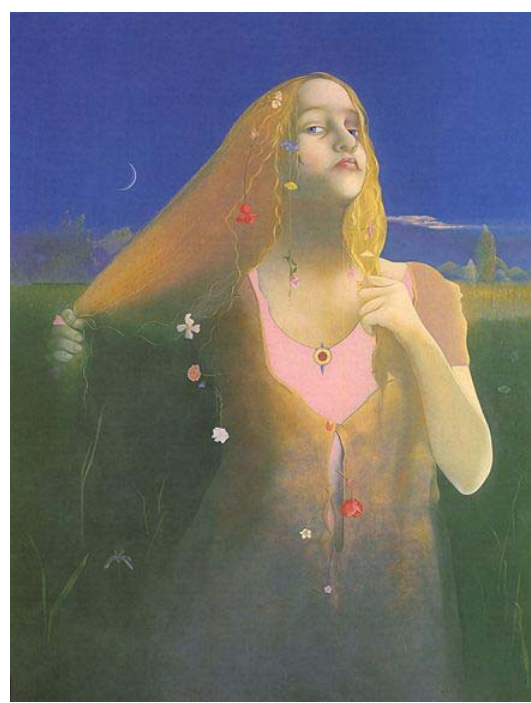

Fig. 47. Ofelia (1980-81). Óleo sobre lienzo.

Su fotografía es inseparable de su pintura, pues le sirve de referente para su posterior trabajo pictórico, así como para profundizar en su visión de las niñas a través de distintas disciplinas. Godfrey Pilkington describiría su pintura como devota de la figura y el paisaje ${ }^{31}$. Así en sus composiciones intenta integrar las formas de la naturaleza y del cuerpo de las niñas como una representación de la pureza y la Verdad de signo prerrafaelista. En ese sentido, la temática principal y más sugerente de Graham Ovenden es la de la preadolescente. Por un lado, contempla el ideal de inocencia angelical y la pureza de la infancia de tradición romántica y post-romántica, y por otro sin embargo, rechaza un concepto de infancia separado por completo de la vida de los adultos y los contempla como pequeños adultos, integrando las concepciones de preadolescencia infantil generadas a lo largo del siglo $\mathrm{XX}$, desde la visión erótico-mística de Balthus -al igual que Balthus,

marchant haciéndolas pasar por originales de un desconocido fotógrafo victoriano. Ovenden fue acusado de fraude pero posteriormente fue absuelto,

31 PILKINGTON, Godfrey. Art and Design. London: The Academy Group Ltd., 1985. 
Ovenden realizaría ilustraciones para Cumbres borrascosas, de Emily Brontë-, a la iconicidad del personaje de Lolita de Vladimir Nabokov para la que también realizó ilustraciones-.

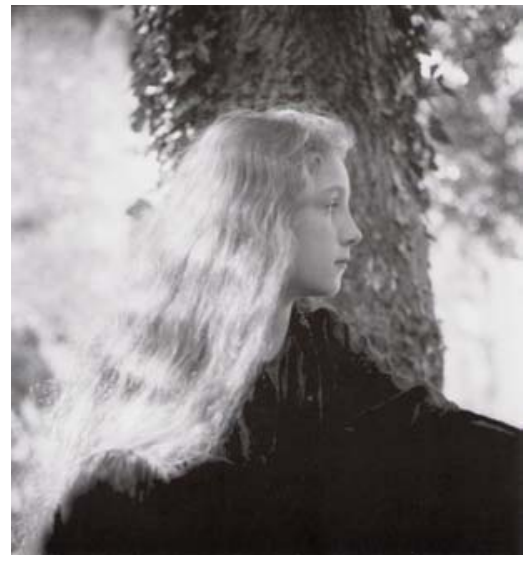

Fig. 48. Anouchka (2001).

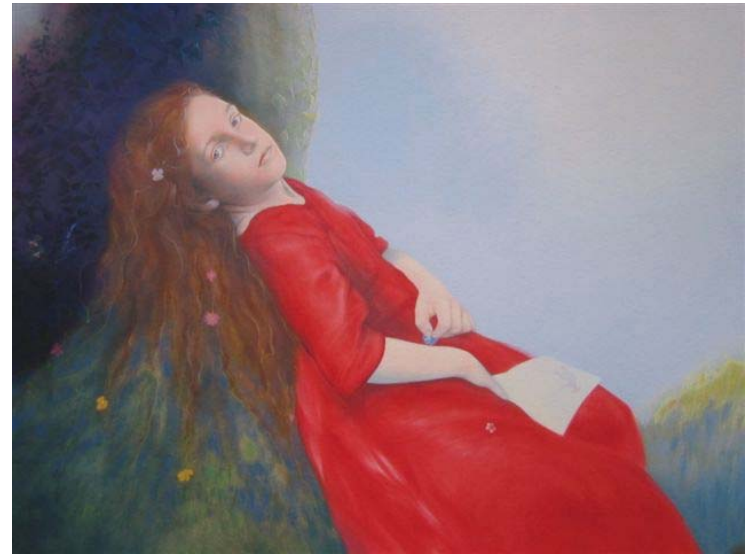

Fig. 49. Anouchka (2004). Óleo sobre lienzo.

La preadolescente, para Ovenden, forma parte orgánica de la naturaleza y la mística de la Arcadia que representan los campos y la vida rural británica ${ }^{32}$, y que también se recoge desde la concepción artística de la Hermandad Ruralista.

La representación de la preadolescente en Graham Ovenden es siempre tratada cuidadosamente bajo el velo de las suavidades y borrosidades - sin el uso abusivo que hace David Hamilton-, e influenciada por la fotografía victoriana en concreto de Julia Margaret Cameron, así como la pintura de Dante Gabrielle Rossetti o Millais. El retrato de la preadolescente, abarca un sin número de protagonistas femeninas que van desde la niña anónima, a las hijas de sus amigos, a

\footnotetext{
${ }^{32}$ Como señala Peter Nahum, «Los británicos son conocidos universalmente, [...] como una nación de jardineros». NORTHROP MOOR, Jerrold; LAURIE, Lee; NAHUM, Peter. The Ruralists. A Celebration. Bodmin, Cornwall: Ruralist Fine Art Ltd., 2003, pág. 7.
} 
personajes literarios archi-conocidos como «Ofelia», «Alice Liddell Alicia»-una de sus más tempranas obsesiones- 0 «Lolita» ${ }^{33}$.

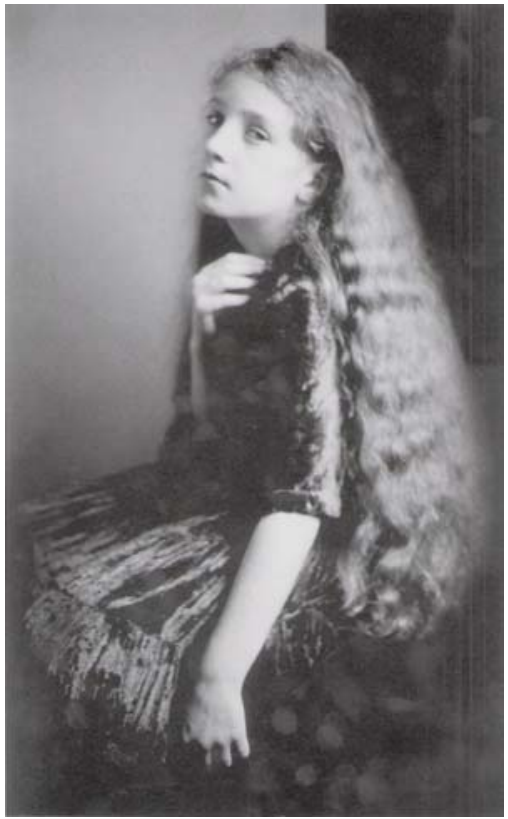

Fig. 50. Anouchka (2001).

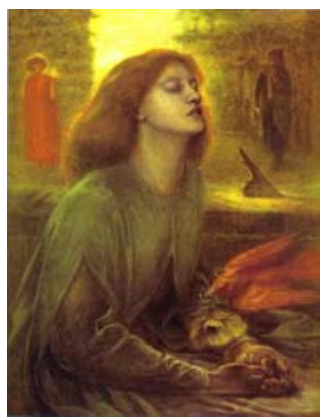

Fig. 52. Beata Beatrix (1864-1870) por Dante Gabriel Rossetti.

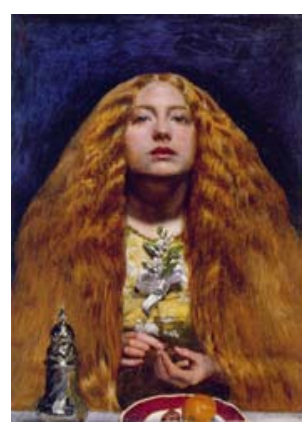

Fig. 53. La novia (1851) por Sir John Everett Millais.

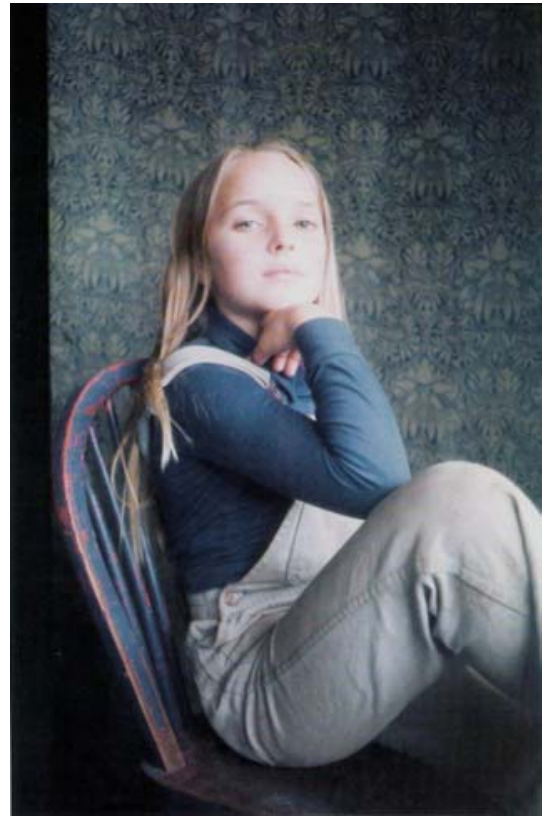

Fig. 51. Rebecca (1976).

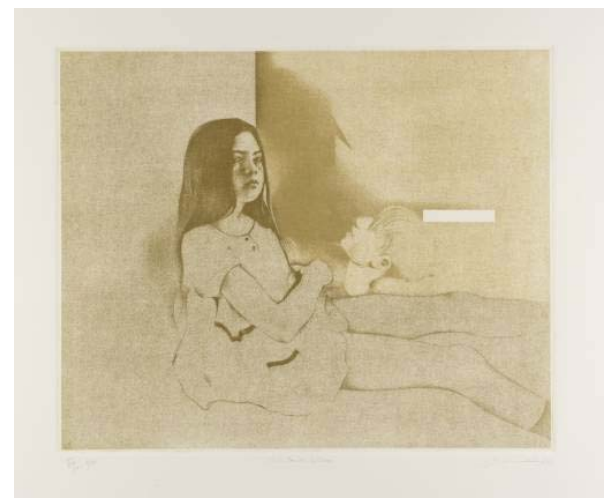

Fig. 54. Initial Rites (1974-5). Ilustración de Graham Ovenden para Aspects of Lolita.

${ }^{33}$ El estudio de estos personajes a menudo eran propuestas globales de trabajo de todos los miembros de la Hermandad Ruralista. 


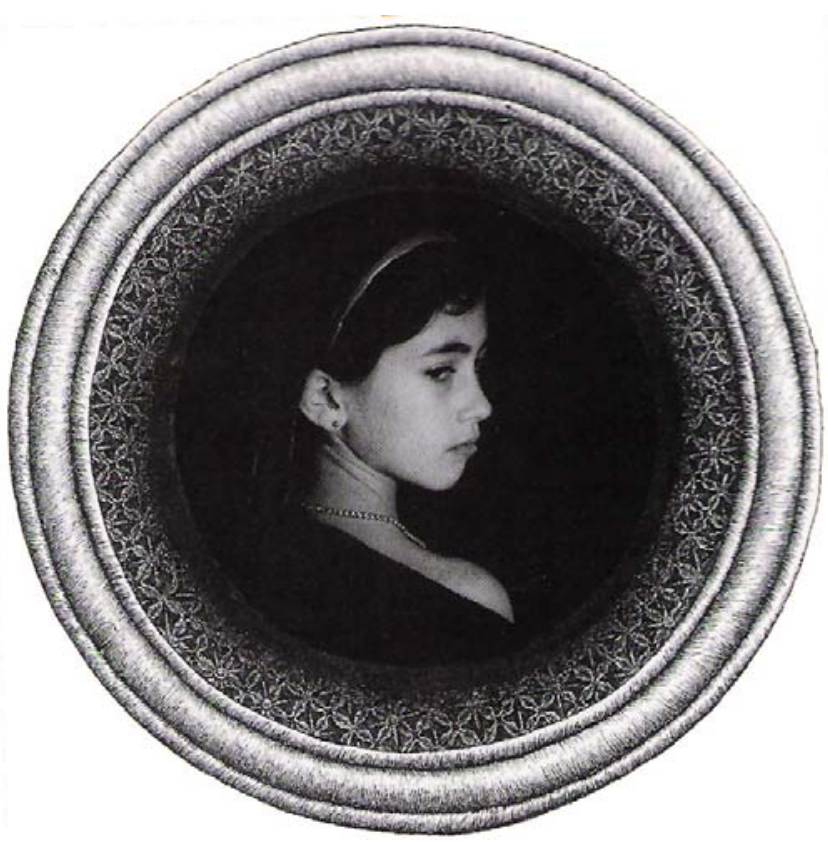

Fig. 55. Alice (1985).

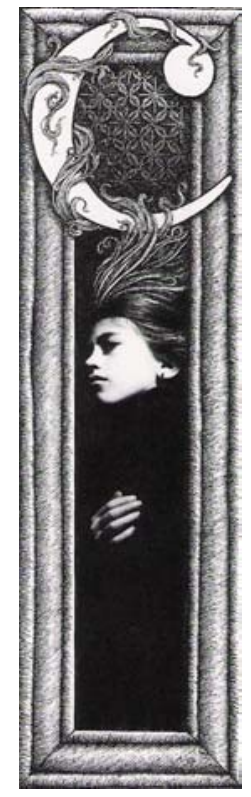

Fig. 56. Alice (1985).

La primera de sus series de trabajos fotográficos, Childhood Streets, no fue publicada hasta $1989^{34}$. En el se reproducen numerosas fotografías -tomadas entre 1956 y 1964- cuando Graham Ovenden todavía era un adolescente. En ellas se muestra una visión de la vida de los niños -sobre todo niñas-, hijos de padres de clase trabajadora de las calles de East End en Londres. En este sentido, su fotografía inicial era más cercana a la visión de infancia de Lewis Hine -fotógrafo que por aquel entonces le era desconocido-, y del que admiraría más tarde, la simplicidad, la humildad y la humanidad de su fotografía ${ }^{35}$.

\footnotetext{
34 OVENDEN, Graham. Childhood Streets. New York: Ophelia Editions, 1998.

35 J. Sir A.; IANTHE. An Interview with artist and photographer Graham Ovenden. [en línea]. $11^{\text {th }}$ September 1999 [ref. del 14 de septiembre de 2000]. Disponible en Web: http://duende. f2s.com/ovenden/ovenden.html
} 


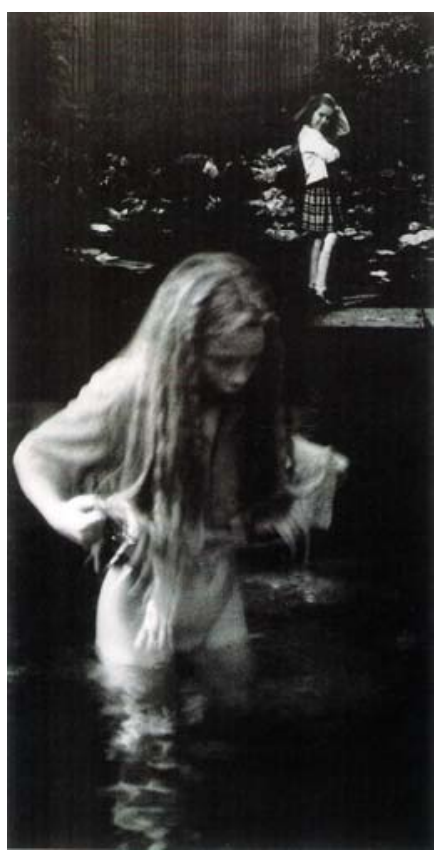

Fig. 57. Paddling, Regent Canal (1957).

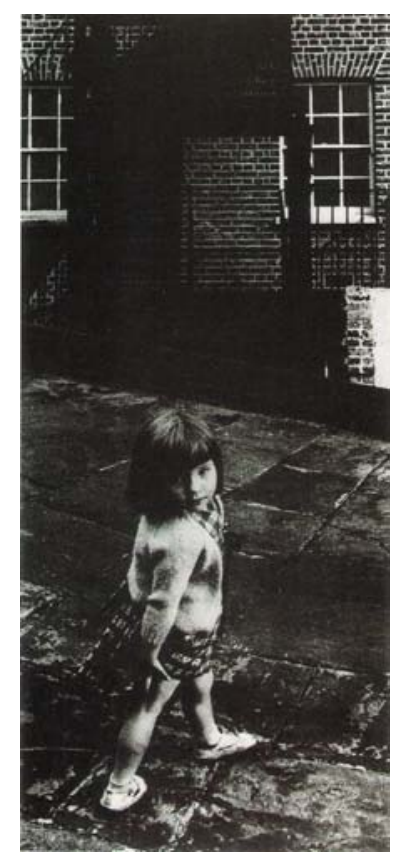

Fig. 58. Stepney (1957).

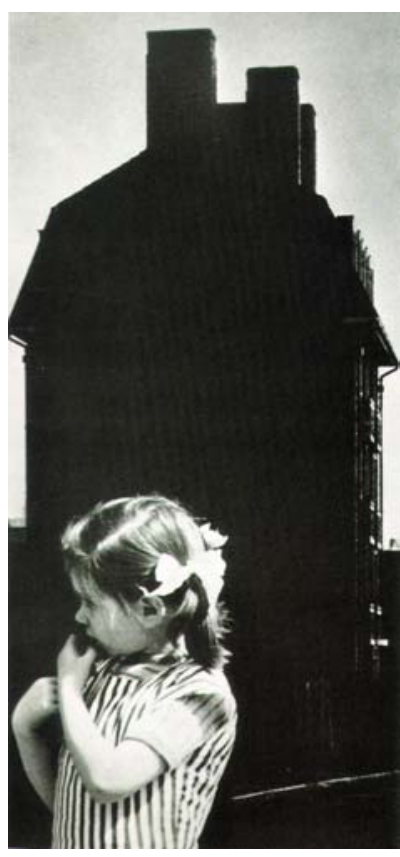

Fig. 59. Bloque de apartamentos, Shoreditch (1960).

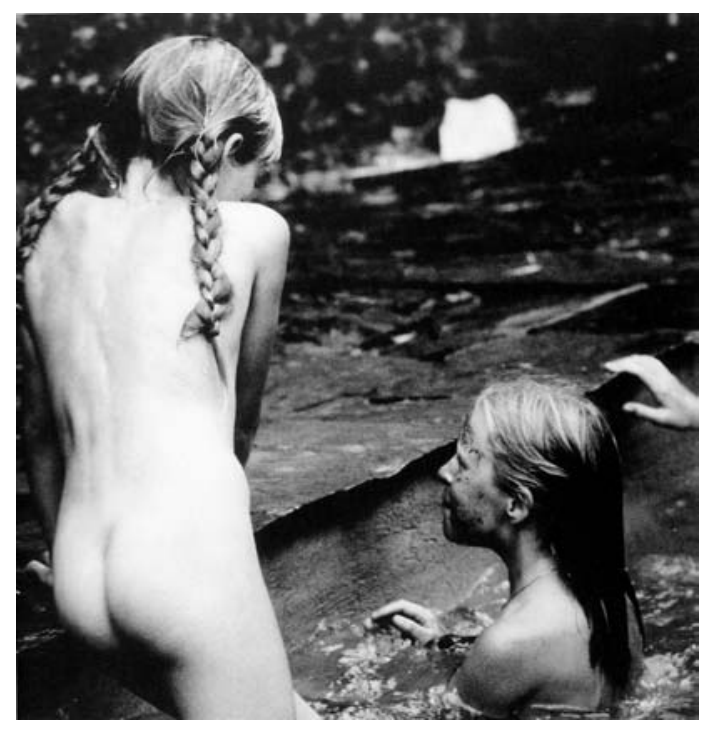

Fig. 60. Victoria Park (1961).

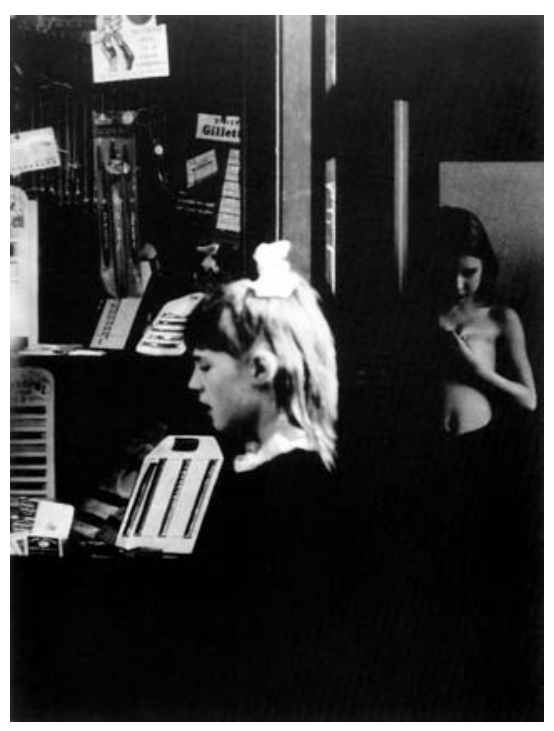

Fig. 61. Mile End (1961). 
A su visión de la arcadia rural ligada a la tradición celta y cristiana y al paisaje británico, se une un interés por el Jardín del Edén, lugar y «estado» de amoralidad, en el que la representación y desnudo de la preadolescente no se halla carente de valores negativos o pecaminosos, sino que más bien, se manifiesta en un estado inmaculado y de pureza, en un «estado de gracia». En su serie States of Grace $^{36}$, la inocencia humana sigue siendo el tema principal, hallándose el «Estado de Gracia» en el cuerpo de la «preadolescente», que es como el estado metamórfico de la ninfa ${ }^{37}$, hacia la adolescencia.

Las escenas de sus fotografías nos muestran a las niñas envueltas en sombras y luces de carácter simbólico y alegórico que provocan al espectador adulto que observa la sexualidad contenida de los cuerpecitos infantiles de las niñas, en las que se enfatiza la belleza de las formas y los estados de ánimo,

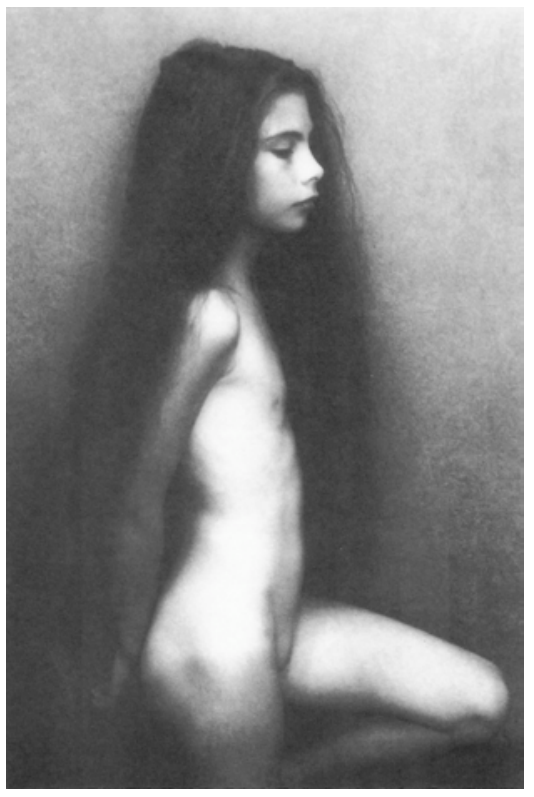

Fig. 62. Lorraine (1964). Serie States of Grace.

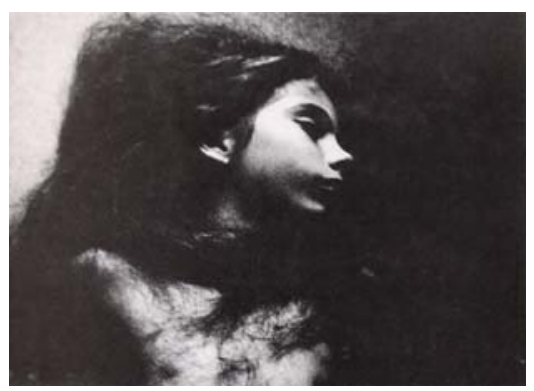

Fig. 63. Lorraine (1964). Serie States of Grace.

${ }^{36}$ OVENDEN, Graham. States of Grace. Photographs, 1964-1989. New York: Ophelia Editions, 1992.

37 V. Cap. 8. Lolita de Vladimir Nabokov, pág. 245. 
envueltos en una atmósfera enigmática y secreta. Graham Ovenden diría que encuentra en las niñas «una profunda e intensa complejidad de formas y líneas que se sostienen en las disciplinas del clasicismo» ${ }^{38}$.

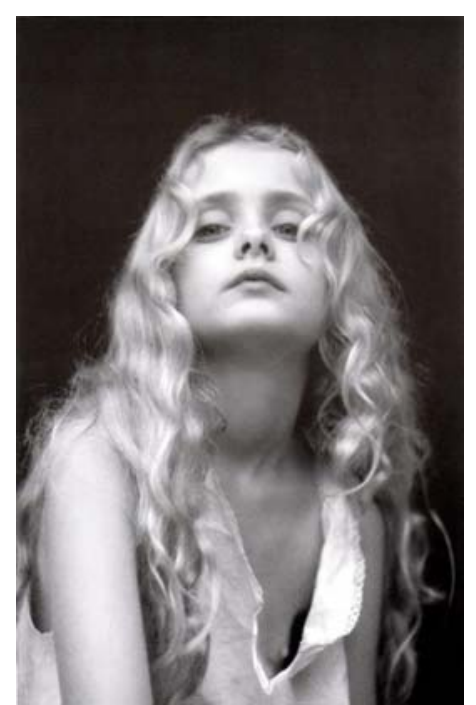

Fig. 64. Sam (1972).

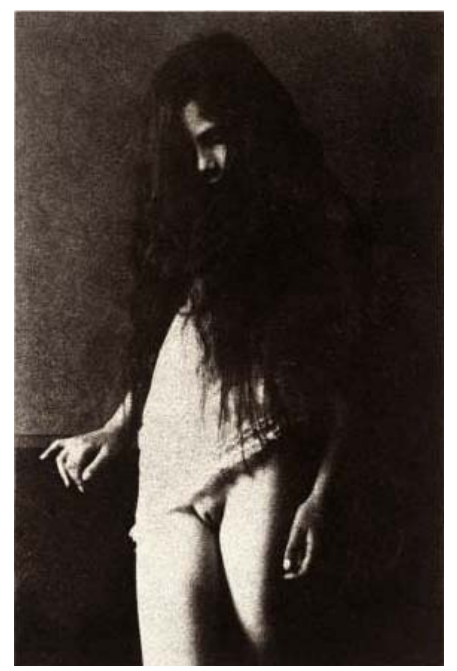

Fig. 66. Ashley (1970). Serie Five Girls.

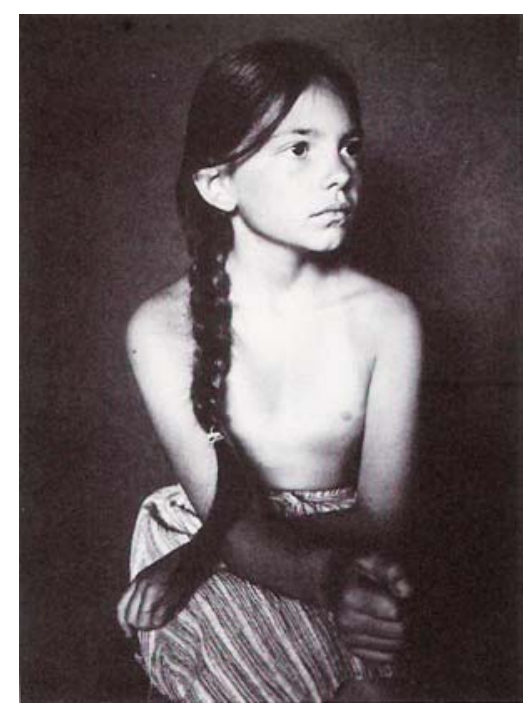

Fig. 65. Elinore (1981).

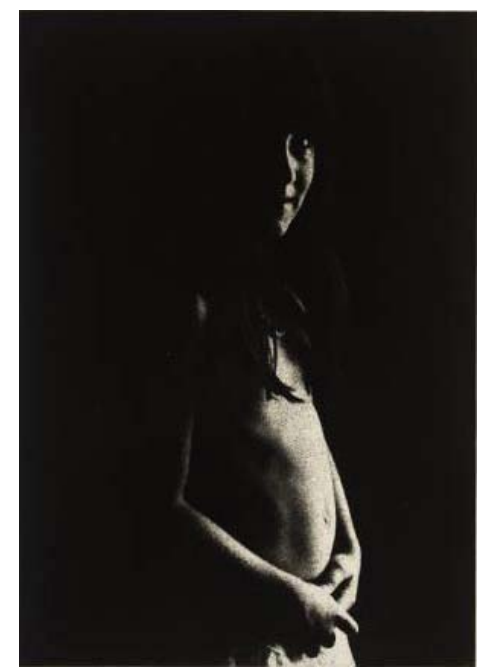

Fig. 67. Lorraine (1970). Serie Five Girls.

${ }^{38}$ LUCIE-SMITH, Edward. Op. cit., pág. 50. 


\section{ALCANCE DEL ICONO DE LOLITA.}

A pesar de los logros sociales en favor de la igualdad de la mujer en la sociedad occidental, la herencia de la iconográfica femenina de perfil machista, pervive hasta nuestros días en los iconos estéticos que se promulgan desde los medios de masas.

La imagen infantil es una imagen común en las revistas de moda, los spots publicitarios, las películas de Disney o en el Arte y a pesar de ello, casi siempre resulta controvertida. En ella se siguen encarnando los ideales románticos del siglo XIX, sin embargo la imagen actual de la infancia se ha precipitado irremediablemente hacia una crisis ligada a las nuevas condiciones sociales y culturales del mundo «desarrollado» en el que la imagen de los medios de masas y sobretodo Internet, promulgan unos nuevos estereotipos y formas de entender la infancia y la preadolescencia femenina en la cultura de finales del siglo $X X$ y principios del siglo XXI.

Ya en el siglo XIX, Ernest Dowson escribiría: «No hay nada más característico de nuestra época que la enorme importancia que los niños han asumido. En realidad, esto no es tan sorprendente en una época que es, después de todo, principalmente pesimista, una época que esta profundamente desilusionada, vuelve con un inmenso placer al constante encanto de la infancia» ${ }^{1}$. Éste es hoy en día un planteamiento todavía vigente. Stoney señala ${ }^{2}$, que lo que distingue a nuestro momento presente es una preocupación y ansiedad adulta respecto a cómo debe ser su relación con los menores, para no entrar en conflicto con el deseo por la imagen infantil. El ideal romántico de infancia

\footnotetext{
${ }^{1}$ DOWSON, Ernest. Op. cit.

2 STONEY, Elizabeth. Alice Does: The Erotic Child of Photography [en línea]. [ref. de 16 de noviembre de 2004]. Disponible en Web: http://www.ahcca.unimello.edu.aa/ screenscape/alice.htm
} 
protegido bajo el halo de inocencia asexuada, ha dado paso a una inocencia presuntamente sexual. $Y$ es que la infancia sugiere erotismo. Precisamente, Freud «descubrió» la sexualidad infantil en una época, en la que como en la nuestra, la preocupación por la naturaleza de la infancia era notable.

Anne Higonnet, señala que las interpretaciones que obtenemos de la observación de una imagen infantil «presuntamente» problemática, no son únicamente significados abstractos sino que en ellos vemos sus consecuencias reales, es decir, que imaginamos que los menores representados puedan ser objeto de algún mal físico o psicológico ${ }^{3}$ : maltrato, explotación, violación... La fotografía, por tratarse de un medio de representación realista o que provoca la apariencia de realidad, da como resultado imágenes que son tomadas como si fuesen lo mismo que la acción ${ }^{4}$.

¿Podemos seguir jugando como los victorianos a la asociación y contraposición de adjetivos aplicables a la niñez, como la inocencia, la pureza, la asexualidad frente al erotismo, sexualidad y perversión que dan origen a la ficción erótica del cuerpo inmaduro de las niñas?

\subsection{Arte y pornografía.}

Los artistas, han defendido y argumentado las diferencias ente «lo artístico» y la explotación pornográfica como ocurriera con las fotografías de Sally Mann o Graham Ovenden entre otros.

\footnotetext{
${ }^{3}$ HIGONNET, Anne. Op. cit., pág. 11.

${ }^{4}$ Desde un punto de vista semiótico, la fotografía sería considerada análoga a la realidad. Roland Barthes, sin embargo, calificaría de «efecto de realidad» el que provoca la imagen emulsionada sobre el papel fotográfico, que es diferente a la imagen análoga que se percibe en la retina de la realidad.
} 
Es necesario determinar lo que constituye lo obsceno en cuanto se refiere al desnudo femenino y en particular al desnudo de la preadolescente, siguiendo los criterios de la representación artística, el valor cultural, humano o político. Los juristas y expertos en leyes contra la pornografía diferencian entre la imagen infantil sexualmente explicita, es decir la pornografía infantil y la imagen infantil «inocente» posando con reminiscencias sexuales, es decir «erótica» 5 .

La iconicidad del desnudo femenino ha constituido la más evidente metáfora sexual en la representación. Cualquier tipo de «representación» condiciona y especifica el modo de ver. Es decir, que la representación y los iconos en el arte, son en principio cerrados ${ }^{6}$. La problemática surge cuando arte y pornografía se funden, en un límite difícil de establecer. «Realmente -explicaría Balthus- no entiendo la incapacidad de la gente para captar las diferencias esenciales entre erotismo o sexualidad y pornografía. Por ejemplo, la industria publicitaria es pornográfica, especialmente la de Estados Unidos donde se ve a una jovencita poniéndose un producto de belleza en la piel como si tuviera un orgasmo»?.

Lynda Nead señala que la obscenidad del cuerpo femenino sucede cuando produce excitación e intranquilidad ${ }^{8}$. Etimológicamente «obsceno», viene del latín scena, es decir, lo que está fuera, a un lado del escenario, más allá de la representación. Lógicamente, el «arte» es lo que puede verse, lo representado y lo «obsceno», lo que está fuera de la representación. Con esto, el desnudo femenino pone en

${ }^{5}$ SANTIAGO, Pablo. Op. cit., pág. 332.

${ }^{6}$ NEAD, Lynda. El desnudo femenino. Arte, obscenidad y sexualidad. Metrópolis. Madrid: Editorial Tecnos, 1998, pág. 13.

7 Citado en DRIBEN, Leila. Balthus el gran excéntrico [en línea]. Letras Libres, Mayo 2001 [ref. de 17 de octubre de 2006]. Disponible en Web: http://www.letraslibres.com/index.php?art=6820

${ }^{8}$ NEAD, Lynda. Op. cit., pág. 13. 
funcionamiento el engranaje de lo artístico marcando sus límites con la obscenidad $^{9}$. Esta diferencia es comparativamente visible en la distinción entre lo «bello»y lo «sublime» que hace Kant ${ }^{10}$. En lo «bello» hay un equilibrio, una limitación. En lo «sublime», el juicio se ve desafiado por formas que se insinúan más allá del límite de lo «bello».

Nos hllamos pues, ante la dificultad de afrontar la problemática de la sexualidad infantil, que lo artístico aborda en los límites de lo pornográfico y de lo pedófilo. La representación misma de la preadolescente supone una puesta en marcha de los mecanismos de lo «bello»y lo «sublime», desbordándose en multitud de ocasiones en lo «obsceno», y lo obsceno a su vez genera «deseo». Durante el siglo XIX, los victorianos utilizaron los engranajes de lo «bello» con un éxito tal que permitió hacer del «culto a las niñas», un icono fundamental en la representación artística sin transgredir los límites hacia lo pornográfico. La pornografía, estaría dentro de lo que Roland Barthes califica de fotografía unaria, es decir, una representación de la realidad sin doblez, sin dualidad, trivial, haciendo de estas características la «1a regla de la retórica vulgar». En ella no existe el deseo y el objeto, sino únicamente el objeto, es decir el «sexo» ${ }^{11}$. Estableciendo esta diferencia se entiende pues que la fotografía erótica es contrapuesta a la imagen pornográfica «alterada, fisurada, desdoblada y dual».

\footnotetext{
${ }^{9}$ Íd., pág. 47.

10 NEAD, Lynda. Op. cit., pág. 47. Sobre lo «bello» y lo «sublime» véase BAUDRILLARD, Jean. De la seducción. Cátedra, Madrid, 2000.

11 «Jamás un objeto secundario, intempestivo...», BARTHES, Roland. La cámara lúcida. Notas sobre fotografía. Barcelona: Paidós Comunicación, 1999, pág. 85.
} 


\subsection{Concepto de infancia. Desde mediados del siglo $X X$ a principios del siglo XXI.}

El impulso victoriano por fotografiar, por «capturar» la imagen infantil sigue vigente en la actualidad. En la fotografía hay un ansia por satisfacer deseos vouyeristas y fetichistas. Barthes, señala que la fotografía lleva a una dualidad inseparable, el bien y el mal, el deseo y el objeto.
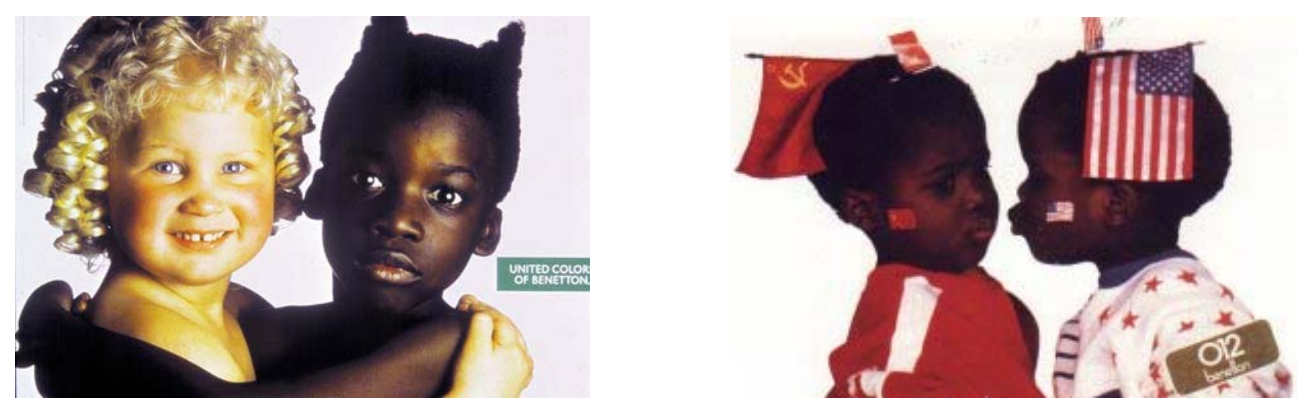

Fig. 1 y fig. 2. Fotografías de Oliviero Toscani para Benetton.

\section{Ese erotismo victoriano ligado}

a la pureza, ha sido difundido sobre todo por los medios de masas. El ideal de infancia victoriano, de desnudez/felicidad/bondad se retoma una y otra vez para la imagen publicitaria de marcas como Ivory Soap con slogans como: $\ll 99,44 \%$ pure!» ${ }^{12}$, o «The only leading shampoo that isn't mostly detergent... GOLD FORMULA BRECK» ${ }^{13}$ de 1974 , en la

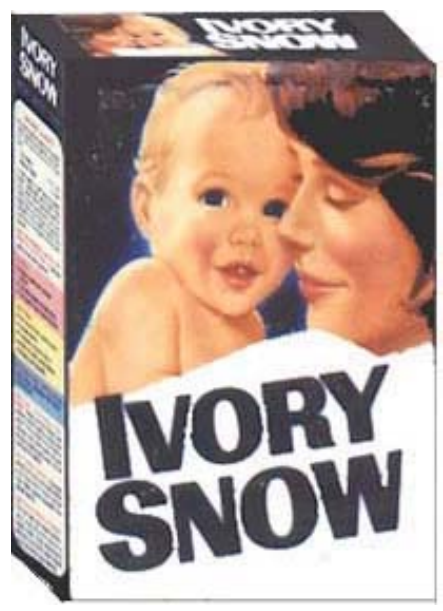

Fig. 3. Envase de Ivory Soap.

12 Francesco Scavullo fotografió en 1966 a Brooke Shields con tan sólo once meses para la publicidad del jabón Ivory.

13 «El único champú líder que no es sólo jabón... GOLD FORMULA BRECK». 


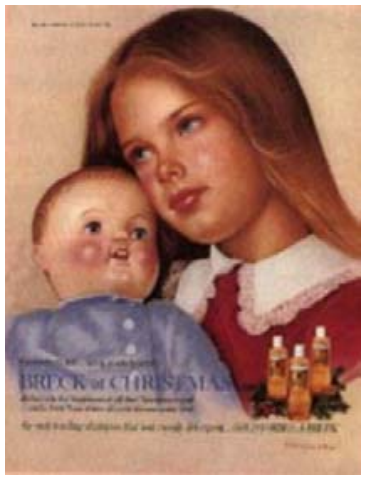

Fig. 4. Brooke Shields para GOLD FORMULA BRECK de Ivory Soap (1974). que Brooke Shields personifica el ideal de pureza que es conferido a su vez a las propiedades del producto. Brooke Shields ya había anunciado Coppertone al igual que la actriz Jodie Foster. Años más tarde protagonizaría semidesnuda las películas $L a$ pequeña (1978) o El lago azul (1980) entre otras o sería con quince años imagen en la campaña de jeans Calvin Klein con el slogan: «¿Sabes lo que hay entre mis Calvin y yo? iNada! ${ }^{14}$. Precisamente fue Calvin

Klein y sus polémicas campañas de ropa interior con jovencísimas modelos -como Kate Moss con diecinueve años en su campaña de $1995^{15}$ - o con niñas, el que promovió una imagen de juventud impregnada de contenido sexual explícito.

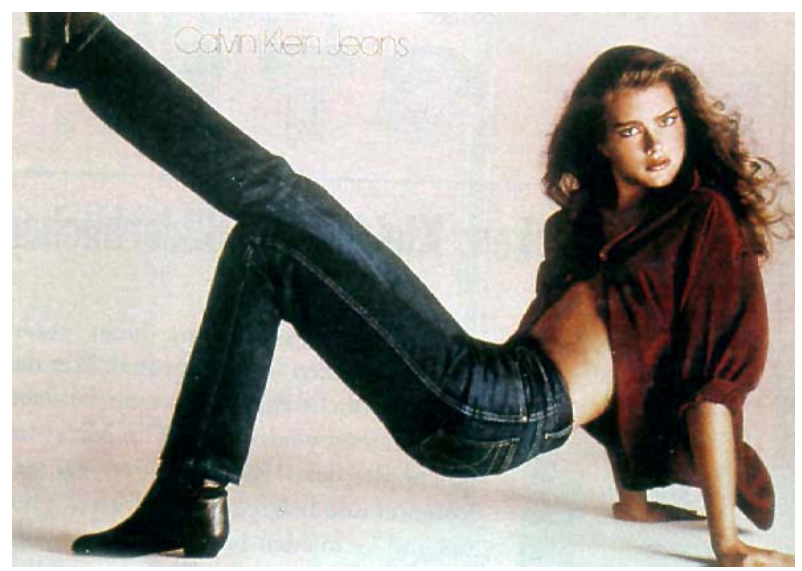

Fig. 5. Brooke Shields para la campaña de jeans Calvin Klein (1980).

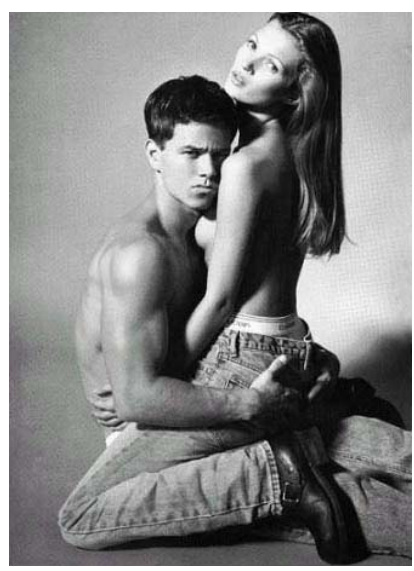

Fig. 6. Kate Moss para Calvin Klein (1995).

\footnotetext{
14 «'You know what comes between me and my Calvin's? 'Nothing!». Las fotografías para la campaña de Calvin Klein las realizó Richard Avedon.

${ }^{15}$ La campaña fue retirada en EEUU, señalando la supuesta explotación sexual de los jóvenes.
} 
Así pues, la noción de infancia actual muestra bien diferente a la concepción victoriana de inocentes niñitas con cofia de John Everett Millais, y se aproxima más a las enigmáticas y sugerentes Alice Liddell o Irene MacDonald de Lewis Carroll. Hugh Cunningham, afirma que si bien durante el siglo XIX se intentó categorizar la infancia, durante «la segunda mitad del siglo $X X$ ha habido un sentimiento de erosión 0 incluso desaparición de la infancia... mayormente relacionado con el influjo de los "mass media"... que fuerzan a convertirse a los niños en consumidores» ${ }^{16}$. El fetichismo, transformado en una forma de deseo sobrevalorado por la sociedad occidental, ha sido incentivado como fenómeno de consumo en dos direcciones. Por un lado, está el público adulto, que consume todo aquello que les hace sentirse de nuevo jóvenes y por otro, la propia juventud, incluidos los niños y las niñas, que gracias a sus «asignaciones semanales», se convierten en los mayores consumidores de productos que hablan de ellos, que les dicen cómo ser, como comportarse, en que creer, admirar y que desear.

Desde los medios de masas se bombardea la imagen idealizada de juventud-belleza ligada al éxito, ya sea sexual, profesional o familiar, dictando unos estereotipos tiránicos respecto a la imagen femenina. Esto implica que la apariencia de infancia y la juventud se extiende por un periodo de edad que se sitúa incluso más allá de la adolescencia física. Un claro ejemplo es la imagen femenina dominante desde el mundo de la moda. Se busca la apariencia de juventud con modelos de cara aniñada o de muñeca -Gemma Ward, Sasha Pivovaroval, Heather Marks o Natalia Vodianova- y extremadamente delgadas, si no escuálidas, lo que da lugar a un físico femenino, carente de curvas o pechos desarrollados propios de las adolescentes y las mujeres adultas.

\footnotetext{
${ }^{16}$ CUNNINGHAM, Hugh. Children and Childhood in Western Society Since 1500. London: Longham Group Limited, 1995, pág. 164.
} 
Sólo unas pocas privilegiadas top models han podido seguir considerándose como tales -Kate Moss, Claudia Schiffer, Naomi Campbell-, pasados los 30 años de edad, a pesar de no poseer ya un físico de adolescente.

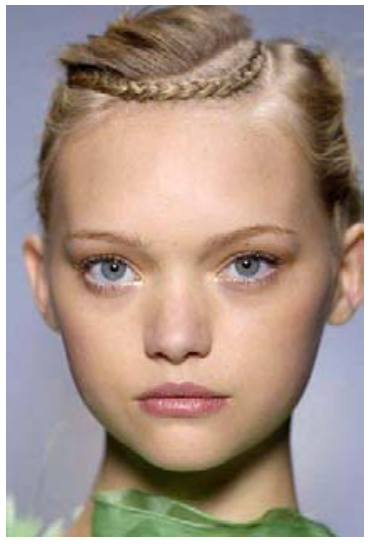

Fig. 7. Gemma Ward.

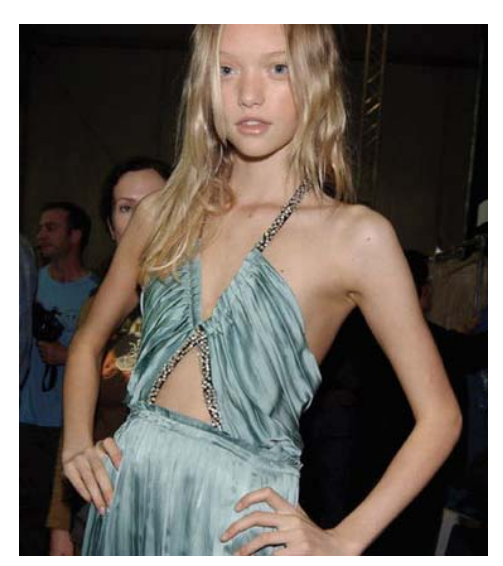

Fig. 8. Gemma Ward.

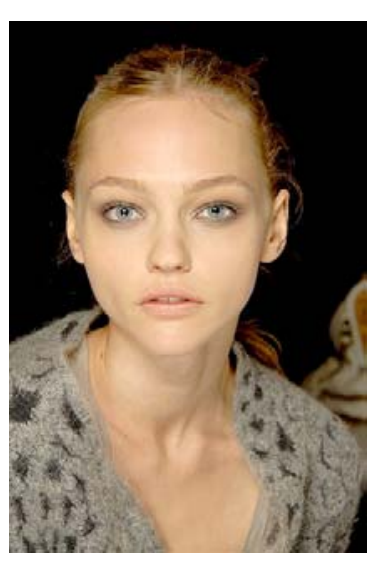

Fig. 9. Sacha Pivovarova.

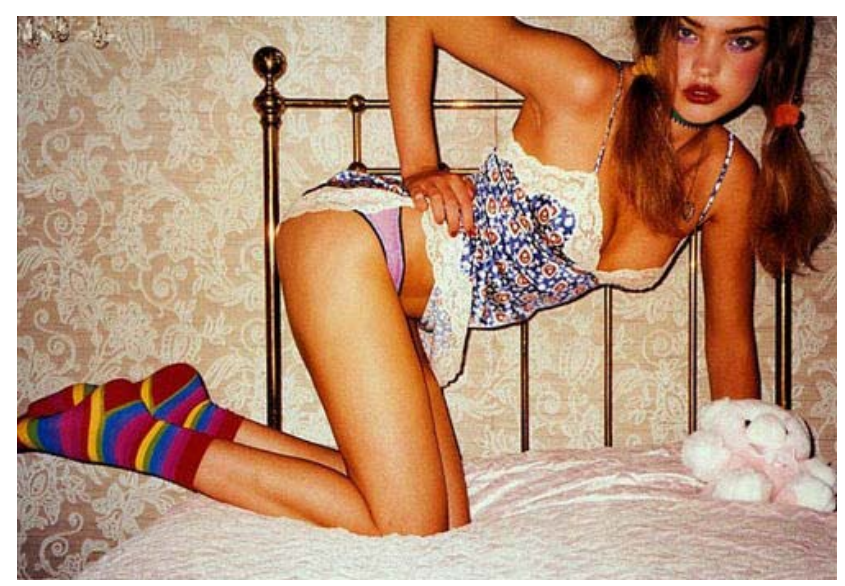

Fig. 10. Natalia Vodianova.

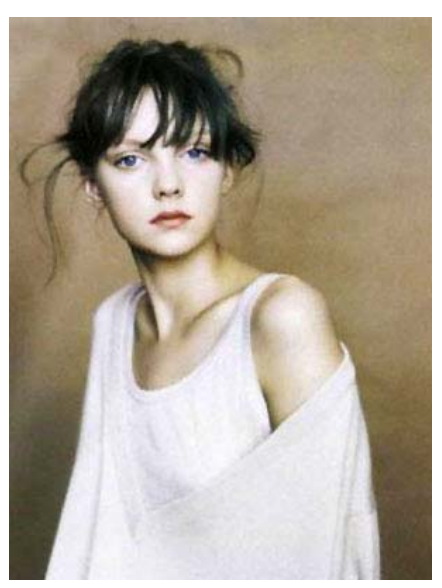

Fig. 11. Heather Marks.

Lolita, la nínfula, es ahora una imagen en la que confluyen todos esos deseos por la infancia y la juventud, de inocencia y sexualidad, de la alegría adolescente y de satisfacción pederasta. Su imagen es la de una muchacha, guapa, que no hermosa, que encarnan las cantantes de 
moda -las popstars- o las jovencísimas modelos de pasarela o de publicidad. Desde Brooke Shields enfundada en unos vaqueros, a Britney Spears contoneándose con un uniforme de colegiala con minifalda ${ }^{17}$ seduciendo «ingenuamente», las jóvenes estrellas mediáticas transmiten el ideal de belleza, éxito y dinero, pero sobre todo de promiscuidad sexual.

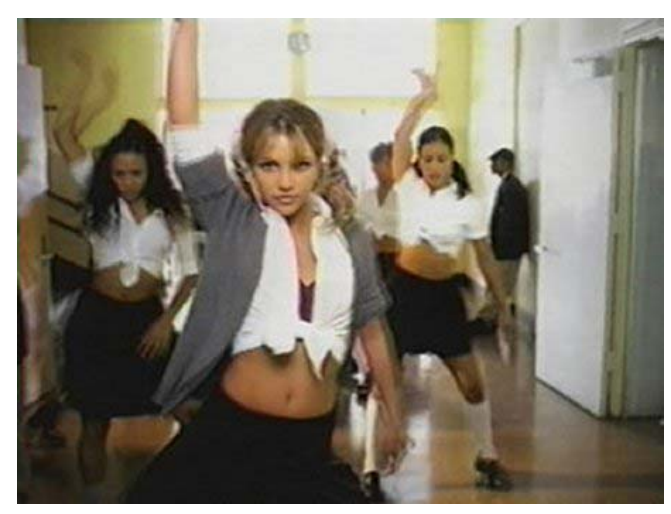

Fig. 12. Britney Spears en el video clip Baby One More Time (1998).

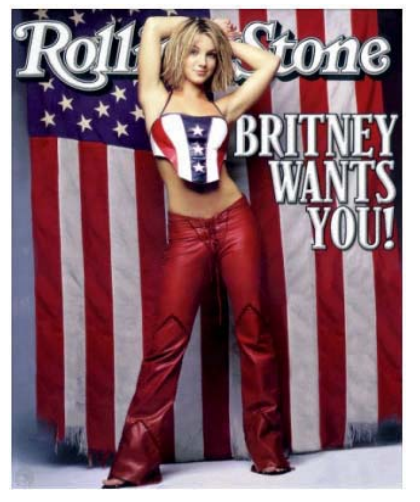

Fig. 13. Britney Spears para la portada de la revista Rolling Stone.

Al igual que Britney Spears, numerosas cantantes adoptarían la apariencia y el estilo ingenuo de colegiala como imagen característica, así como una letra pegadiza e insinuante, -en mayor o menor grado de provocación erótica- como estrategia agresiva de marketing musical. Así en el año 2000, debutó la cantante francesa Alizée Jacotey de dieciséis años, con la canción Moi... Lolita -Yo... Lolita-, con una apariencia marcada por el estilo lolita y una canción que no dejaba lugar a dudas

\footnotetext{
${ }^{17}$ La cantante norteamericana Britney Spears, se dio a conocer por sus pegadizas canciones pop y su famoso video musical Baby One More Time (1998), en el que aparecía con el pelo recogido con un par de coletas y uniforme de colegiala.
} 
sobre el tipo de imagen sensual-inocente que se asociaba a la joven cantante.

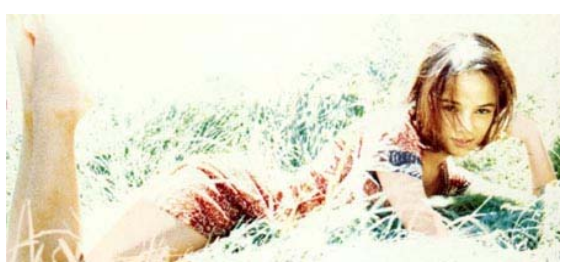

Fig. 14. Fotografía promocional de Alizée.
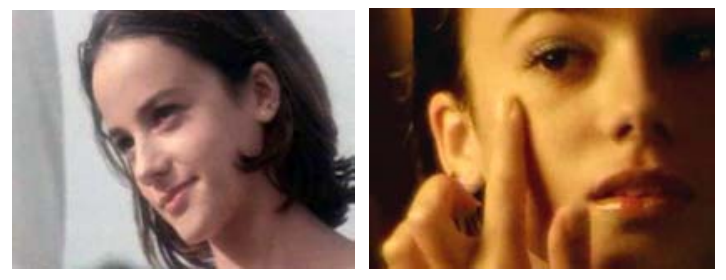

Fig. 15 y fig. 16. Fotogramas del vídeo clip Moi... Lolita (2000) de Alizée.

A mediados del año 2002, un dúo de muchachas rusas llamadas TATU, debutaban ${ }^{18}$ con la canción All The Things You Said, convirtiéndose en un éxito de ventas así como en objeto de controversia. Más allá de la calidad de su música, el éxito radicaba en el enfoque explícitamente sexual con la que se presenta a las dos jóvenes -Volkova Yulia Olegovna y Katina Elena Sergeevna- que eran menores de edad. Por un lado, aparecían en el vídeo clip de la citada canción besándose y abrazándose bajo una fuerte lluvia mientras un grupo de gente las mira reprobando la escena, que parece ocurrir es la oscuridad de un patio de colegio. Por otro lado, tanto la letra de sus canciones como su propio nombre -cuyas siglas significan en ruso «esta chica ama a esta otra»-, aludían al amor lésbico.
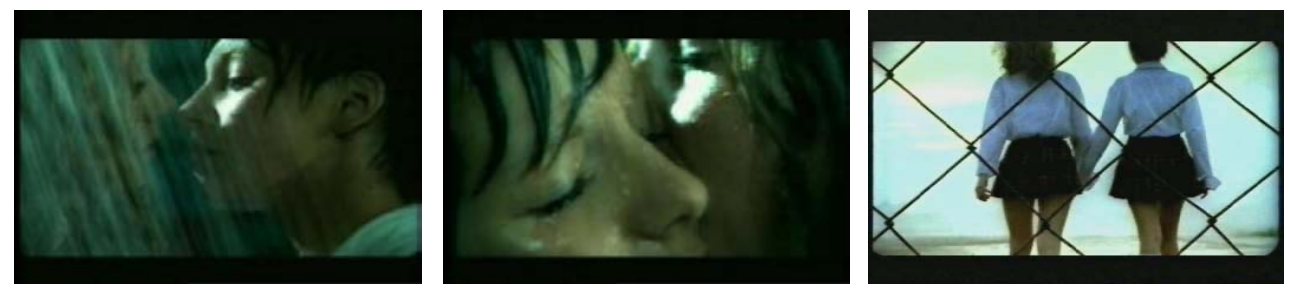

Fig. 17, fig. 18 y fig. 19. Fotogramas del vídeo clip All The Things You Said (2002) de TATU .

${ }^{18}$ En Rusia lo harían a mediados de 2001. 


\subsubsection{Sexo e infancia.}

La sociedad actual vive con una obsesión por la temática sexual infantil, que nos mantiene en constante alerta. Los noticiarios de las televisiones y periódicos, informan a diario de los abusos sexuales a menores, como la violación y la explotación sexual para el mercado de la pornografía o la prostitución infantil, ya sea vía Internet o en prostíbulos que llegan a formar parte de «rutas de turismo sexual» sobre todo en Indonesia, así como de las numerosas desapariciones de menores por diversas causas, que tienen su repercusión con la aparición de sus fotografías en los cartones de leche, método muy utilizado en Estados Unidos ${ }^{19}$.

Como consecuencia de este temor social y como reacción contra el mismo, han surgido controles legales, para prevenir las imágenes que puedan contener o sugerir sexo o explotación infantil. Pero por otro lado, Higonnet señala, este tipo de medidas han provocado unos efectos censores en la interpretación de las imágenes ${ }^{20}$. Por un lado, en nuestra sociedad hay una impaciencia por negar o suprimir el hecho de la sexualidad infantil, pero por el otro se provoca el efecto contrario, es decir, que tal vez se enfatiza esa sexualidad en la construcción de un atractivo sexual infantil ligado a un inevitable deseo pedófilo, como señala James R. Kincaid ${ }^{21}$. Según él, los victorianos, estaban más abiertos a tal posibilidad como hecho o como mito, a pesar de la incomodidad que estos temas provocaban socialmente. Parece ser que la concepción actual de sexualidad infantil es el resultado del psicoanálisis post-freudiano, el cual otorga

\footnotetext{
19 KINCAID, James R. Child Loving. The Erotic Child and Victorian Culture. New York: Routledge, 1992, pág. 25.

${ }^{20}$ HIGONNET, Anne. Op. cit., pág. 11.

${ }^{21}$ KINCAID, James R. Op. cit., pág. 26
} 
unos «poderes» sexuales a los niños y en especial a los bebés, convirtiéndolos rotundamente en un modelo de perversidad ${ }^{22}$.

Kincaid afirma que la diferencia sexual es de mínima importancia a la hora de percibir la pedofilia, que se define en términos de adulto/hombre o mujer frente a niños/niñas, mediante la separación que provoca la pubertad ${ }^{23}$. Ésta separación o diferencia fue de menor importancia durante el siglo XIX y anteriores, pues la pederastia es un fenómeno antropológico que ha estado presente en todas las culturas.

Desde mediados del siglo $\mathrm{XX}$, con la concepción claramente erótico-sexual del icono de Lolita, el artista se ha visto obligado a reformular el icono de la preadolescente heredado de la concepción victoriana de infancia -en la que el juego entre inocencia y erotismo encontró un equilibrio-, por una peligrosa interpretación que no sólo limita con el género pornográfico sino que se circunscribe consciente o inconscientemente en el «espacio moral» ${ }^{24}$ de los pedófilos. Esta imagen pornográfica es de componente fenomenológico es decir, que viene dictada por la complicidad del consumidor por el conocimiento de la misma en nuestra época ${ }^{25}$.

La imagen de la preadolescente de comienzos del siglo XXI se caracteriza por tratarse de un producto erótico de consumo, que se ha ido redefiniendo en la medida en que la sociedad del siglo XX ha ido cambiando, así como las formas de mass media han ido

\footnotetext{
${ }^{22}$ Entre otras razones, éste mismo motivo provocó el abandono de tales teorías. KINCAID, James R. Op. cit., pág. 26.

23 Íd., pág. 13.

24 Íd., pág. 3.

${ }^{25}$ El consumidor de la imagen pornográfica es el que mediante su experiencia subjetiva y con el conocimiento propio de la misma, interpreta y dictamina los significados de la imagen o del símbolo pornográfico.
} 
desarrollándose tecnológicamente, haciendo fecunda la difusión de un icono de preadolescencia completamente mediatizado y sexualmente explícito que se aproxima, si es que no lo es, al género pornográfico y pedófilo. Son imágenes vacías, que se desvinculan del erotismo sublime que destilaba Lolita de Nabokov, al tratar la perversidad por encima de los preceptos morales. Son visiones confrontadas que nos ilustran sobre la imagen de la preadolescente entre la realidad y la ficción, de lo deseable y de lo provocativo, mediante estrategias publicitarias y comerciales y convirtiéndose en un reclamo para la sociedad de masas, la sociedad del consumo, la sociedad del espectáculo.

\subsection{Pedofilia e Internet.}

Lolita ha tomado formas variadas y tal vez la pregunta clave sería, ¿qué es para nosotros una Lolita? ¿es Lolita el personaje de Vladimir Nabokov? ¿es cualquier niña? ¿tal vez lo es una quinceañera? ¿o quizás una de las modelos de la revista Cosmopolitan? Lo cierto es que basta con introducir en cualquier buscador de Internet el término Iolita, preteen, underage, sex child, para comprender que las «lolitas» son las grandes protagonistas del ciberespacio, en su mayoría de contenido pornográfico, que nos remiten igualmente a webs con nombres como Lolitas Land, Home Lolita, Lolitas Art, etc ${ }^{26}$.

\footnotetext{
${ }^{26}$ Lolita: 27.600.000; sex child: 122.000 .000 entradas. Búsqueda realizada en Internet a través de: http://www google.es [ref. de 1 de junio del 2006]. (Curiosamente, tan sólo 4 meses después de la anterior búsqueda de sex child, la cifra de entradas ha bajado a 79.100.000 [ref. de 17 de octubre del 2006]).
} 


\subsubsection{Pornografía infantil.}

Legalmente y según la Convención de Naciones Unidas sobre los Derechos del Niño, en su Artículo 1, «niño» es cualquier persona menor de 18 años de edad. Sin embargo los criterios para definir la pornografía infantil difieren por motivos socio-culturales, sexuales o religiosos en cada país. Por otro lado, el Consejo de Europa, establece que pornografía infantil es «cualquier material audio-visual que usa niños en contexto sexual» y el Protocolo Facultativo de la Convención sobre los Derechos del Niño relativo a la Venta de Niños, la Prostitución Infantil y la Utilización de Niños en Pornografía, la define como «toda representación, por cualquier medio, de un niño dedicado a actividades sexuales explícitas, reales o simuladas, o toda representación de las partes genitales de un niño con fines primordialmente sexuales» ${ }^{27}$.

Cualquier imagen infantil, sometida a interpretaciones subjetivas, podría sugerir sexualidad directa o indirectamente, e identificarse como pornografía infantil. Ante tal definición, un artista como Lewis Carroll o Balthus hubiesen sido fácilmente susceptibles de ser acusados de

\footnotetext{
27 En Australia, la legislación sobre pornografía infantil sólo se refiere a edades inferiores a 16 años. En algunas jurisdicciones de Estados Unidos, a partir de los 15 años los menores pueden consentir legalmente mantener relaciones sexuales con un adulto. En España, el Código Civil tipifica que el menor de edad, es toda persona que no ha cumplido los 18 años. $Y$ en la Legislación se entiende por pornografía, aquellos contenidos de características groseras, lúdicas o libidinosas, que persigan la excitación o satisfacción sexual, y en los que se verifique la carencia o casi inexistencia de valores artísticos, literarios, científicos o pedagógicos. La Comisión de la Unión Europea de febrero de 2001, definió el marco de referencia legal sobre la pornografía infantil, de acuerdo con las disposiciones de la Convención de las Naciones Unidas sobre los Derechos del Niño, especificando que los comportamientos punibles son la producción, distribución, difusión, transmisión, ofrecimiento, facilitación, adquisición o posesión de pornografía infantil. En octubre de 2002, los ministros de Justicia e Interior de la Unión Europea aprobaron la Decisión marco de la Comisión que tipifica los delitos de pornografía infantil y describe la pornografía infantil como todo material que represente de manera visual conductas sexualmente explícitas realizadas por menores, por personas simulando ser menores o en imágenes virtuales. "Informe sobre la pornografía infantil en Internet" [en línea]. ANESVAD [ref. de 31 de mayo del 2006]. Disponible en Web: http://www.anesvad.org/informe.pdf
} 
pornografía infantil. En cambio la INTERPOL la define más concretamente como «cualquier descripción visual de la explotación sexual de un niño, centrada en el comportamiento sexual del niño o sus genitales» ${ }^{28}$. En países como Estados Unidos, Australia o los Países Bajos, por ejemplo, la legislación ha criminalizado considerablemente el consumo de la imagen pornográfica infantil -pedopornografía-, es decir, su posesión y visionado, equiparándola generalizadamente con las condenas por explotación sexual de menores, o producción y distribución de material pedopornográfico. En 1996, entró en vigor la ley estadounidense que penalizaba y castigaba la creación y difusión de imágenes pedopornográficas, incluyendo también aquellas que fueran simuladas o creadas infográficamente sin la implicación de personas, que representaran menores desnudos o con connotaciones sexuales. Por lógica, las imágenes creadas analógicamente, pintura, dibujos, etc, también resultarían sospechosas de pornografía.

En el proceso de la aplicación de las leyes contra la pornografía infantil de numerosos países como los Estados Unidos, nos encontramos ante una acción legal que equipara la más «inocente» imagen de desnudo infantil con la pornografía pedófila. Esto implica que un laboratorio fotográfico podría ser denunciado por el revelado de fotografías en las que aparecieran menores desnudos o semidesnudos. Tan sólo podrían revelar imágenes con bebés en la bañera, pero más allá de un bebé de tres años sería completamente inaceptable, incluso por ley, deberían avisar a la policía si advirtieran en sus laboratorios imágenes con menores desnudos, en la piscina, el baño, etc... ${ }^{29}$

\footnotetext{
${ }^{28}$ SANTIAGO, Pablo. Op. cit., pág. 332.

29 MACQUARRIAE, Brian. "No Clear Focus on Nude Photos". Boston Globe. 6 de enero de 1996, págs. 1 y 6. Citado en KINCAID, James R. Op. cit., n. 69, pág. 191, KINCAID, James R. 'Is this child pornography? [en línea]. Salon.com [ref. De 4 de octubre de 2006]. Disponible en Web: http://dir.salon. com/story/mwt/feature/2000/01/31/kincaid/index.html
} 
La prohibición de imágenes de este tipo en Internet -la ciberpederastia-, no ha reducido la demanda de erotismo infantil sino que está dando paso a la alarma social y a la persecución, que engloba a todo tipo de imágenes infantiles, incluidas las de los artistas, lo que revela una tendencia de la cultura postmoderna a interpretar la imagen infantil prácticamente en términos sexuales. El periodista Pablo Santiago $^{30}$ afirma que «cuando hablamos de pederastia y pedofilia, el común de la gente piensa en abusos sobre niños, generalmente en relaciones homosexuales y en crímenes. Hay pedófilos que nunca tocaron ni tocarán a un niños: sus relaciones son meramente platónicas visuales» ${ }^{31}$.

La pedofilia en Internet, se manifiesta más allá de las evidencias sexuales, como el desnudo o los genitales. Algunos pedófilos coleccionan fotos de pies de niñas como el grupo Tyflas ${ }^{32}$ que en España tenía su réplica en un foro de Yahoo en el que se anunciaban como «Adoración de pies de niños, para aquéllos que su afrodisíaco son los pies de niños». Román Gubern argumenta que la pornografía en el ciberespacio es una «simulación» que favorece el fetichismo en los objetos o las visiones virtuales y es por ello que ahí se destapan las perversiones más extravagantes, con las mínimas consecuencias.

La pornografía infantil en Internet es un vasto territorio de géneros y subgéneros clasificados por rangos de edades, tipos de

\footnotetext{
30 En la actualidad, el periodista español, Pablo Santiago se encuentra en prisión acusado de pedopornografía y ciberpederastia. Ha pedido el indulto sin respuesta favorable, alegando en su defensa la investigación periodística de la que nace su libro Alicia en el lado oscuro. La pedofilia desde la antigua Grecia hasta la era Internet y para el cual tuvo que hacerse pasar por pederasta e internarse en una trama de ciberpederastia. Su caso recuerda al de William Thomas Stead, con su artículo «EI tributo de las doncellas en la moderna Babilonia», publicado en la Palm Mall Gazette en 1885.

${ }^{31}$ SANTIAGO, Pablo. Op. cit., pág. 164.

32 Ubicado hace un tiempo en la URL http://tyflas.org, citada en SANTIAGO, Pablo. Op. cit., pág. 332.
} 
perversión y medios de difusión que van desde el formato fotográfico, el vídeo streaming o a través de webcam. Como clasificación del tipo de pornografía con menores podemos distinguir los siguientes niveles según la edad ${ }^{33}$ :

- Young women: Mujeres jóvenes que rozan la mayoría de edad legal, de 18 a 21 años, según países.

- Teens: Adolescentes entre 15 y 18 años.

- Early Teens: Adolescentes tempranas de entre 13 y 15 años.

- Preteens: Preadolescentes de entre 7 y 12 años.

- Child: Niños y niñas de 4 a 6 años.

- Baby Sex: Bebés de 0 a 3 años.

- Fakes: Fotos falsas retocadas con caras infantiles y cuerpos adultos poco desarrollados.

- Dibujos, cómics, mangas, animaciones, imágenes en 3D o pornografía infantil escrita. Se trata de pseudopornografía, que no está castigada legalmente en numerosos países.

El mercado de la pornografía no se restringe a un público concreto consumidor de éste tipo de imágenes sexuales. Internet que es una herramienta sin fronteras, rápida y eficaz que nutre de millones de contenidos e información diversa a sus usuarios, también se ha convertido en el principal distribuidor de contenidos pornográficos y pedófilos ${ }^{34}$, que el usuario encuentra en la red apenas sin proponérselo, lo que incluye por tanto una accesibilidad masiva de carácter mundial no sólo del usuario adulto sino también del menor, víctima por partida doble si cabe del mercado de la pornografía infantil.

\footnotetext{
${ }^{33}$ Clasificación establecida en SANTIAGO, Pablo. Op. cit., pág. 338.

${ }^{34}$ CREIGHTON, Susan J. Child Pornography: Images of the Abuse of Children. Information Briefings November 2003 [en línea]. NSPCC The Online Child Protection Resource. [ref. de 3 de diciembre de 2004]. Disponible en Web: http:// www.nspcc.org.uk/inform
} 


\subsection{El «Complejo de Lolita» en la sociedad japonesa.}

Japón es el segundo mayor consumidor de pornografía infantil, seguido de Europa y sólo precedido por los Estados Unidos.

La globalización y los graves problemas internos de la sociedad y la cultura japonesa han generado unos fenómenos particulares en relación a la identidad de la preadolescente manifestándose en la degeneración del erotismo infantil.

En Japón, se utiliza el término Loli-con o Rorikon ${ }^{35}$, contracción japonesa del Ilamado «Lolita Complex»-Complejo de Lolita-, que significa «atracción sexual por las niñas». En general sirve para designar cualquier contexto o actitud que involucre adolescentes o niñas, en términos eróticos o sexuales, así rorikon son las niñas consideradas atractivas pero también sirve de sinónimo de pedófilo.

Las fotografías de niñas modelo -Loli photobooks- son muy populares en Japón. Sin embargo este tipo de fotografías están continuamente asociadas con la polémica sobre la explotación infantil que surge alrededor de la infancia. A pesar de que la ley japonesa castiga la producción y distribución de pornografía infantil desde 1999, la mayoría de estas modelos posan semidesnudas, mostrando las braguitas, tumbadas o con poses que bien pudieran resultar más propias de la fotografía pornográfica que de moda. Uno de los casos más controvertidos de junior models, como se las conoce, fue el de la niña japonesa Saaya Irie, modelo y cantante de varios grupos infantiles de música pop, que era entrevistada por la revista Playboy de Japón y que ejercería en el año 2005 de «embajadora de buena voluntad» en China para aliviar las tensiones entre ambos países,

35 También se escribe rori-kon con guión. 
gracias a sus atributos femeninos poco habituales en una niña de 11 años de edad. Es significativo también el caso de Ryo Shihono, que aparecía en la portada de su primer libro de fotografías también en el 2005 , vestida de colegiala y mostrando las braguitas.

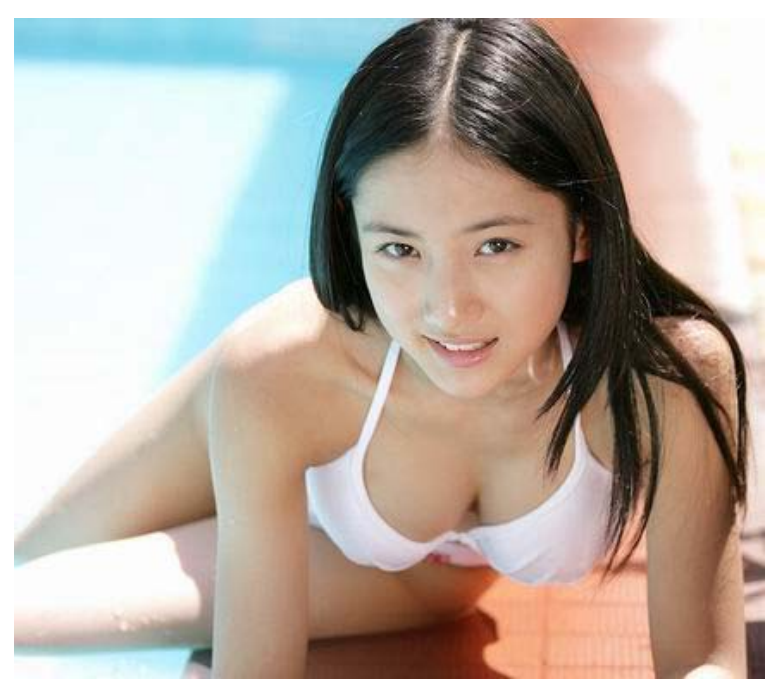

Fig. 20. La junior model Saaya Irie.

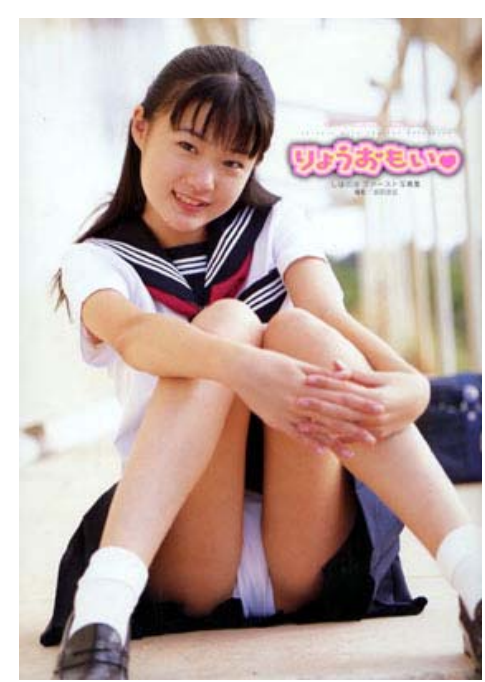

Fig. 21. Portada del Loli photobook de Ryo Shihono

El término rorikon, se utiliza también para referirse al género o temática de ciertos mangas -cómics- legales con dibujos de preadolescente -de entre 8 y 13 años de edad- con un alto contenido erótico o sexual en los que incluso se muestran relaciones sexuales con adultos de manera explícita. Existen multitud de géneros manga y anime, que abordan el «Lolita Complex». De hecho el género rorikon siempre ha estado ligado al mundo de los otaku ${ }^{36}$. Los géneros van desde el shojo, que significa «chica» y que se utiliza

\footnotetext{
${ }^{36}$ Otaku en japonés sirve para calificar al aficionado algo «fanático» del manga y del anime, pero también incluye a los aficionados de los ordenadores, coches, de sus cantantes favoritos, etc, y que viven su afición en modo reclusivo y antisocial. Su uso es generalmente despectivo pero en los últimos años se utiliza con orgullo.
} 
para referirse a los mangas para chicas con un contenido romántico, hasta el hentai ${ }^{37}$, en Japón más conocido como seiji manga o ecchi manga para adultos-, que es un manga más explícito y extremo en términos sexuales, es decir pornográfico. Se trata éste, de un producto de relativa accesibilidad. En agosto de 2003 por ejemplo, en las tiendas de DVD's para adultos de Akihabara, un barrio de Tokio, era habitual encontrar películas de animación de niñas impúberes semidesnudas. Tanto en los mangas como en las revistas o películas de animación -anime ${ }^{38}$ - de género hentai, las preadolescentes, principalmente las colegialas vestidas con uniforme son las protagonistas de todo tipo de abusos sexuales. Sin embargo se subdivide extensamente en subgéneros según su contenido loli-con, toddlerkon $^{39}$ o shōta-con ${ }^{40}$. Así encontramos mangas de temática heterosexual, gay -shonen-ai o yaoi ${ }^{41}$-, lésbica -shojo-ai o yuri ${ }^{42}$-, hermafroditas -futanari-, etc... En numerosos casos el género rorikon se combina con géneros hardcore ${ }^{43}$ como el ero-guro ${ }^{44}$, inequívocamente hentai y depravado.

\footnotetext{
37 Hentai significa literalmente pervertido o perversión y también transformación.

${ }^{38}$ Animación japonesa y más concretamente de dibujos animados.

${ }^{39}$ El toddlerkon es el hentai que muestra niñas o niños menores de 5 años, incluidos los bebés. Los lolicon comprenden ilustraciones de niñas de entre 5 y 15 años de edad.

${ }^{40}$ El subgénero shota-con es el equivalente masculino de loli-con. Comprende las relaciones entre un hombre y un niño o entre dos niños. También se incluye entre una mujer adulta y un niño. Así como el término loli-con viene de «Lolita Complex», Shota-con viene de la contracción de «Shotaro complex». ${ }^{41}$ Shonen-ai, en un manga amoroso que se centra en relaciones homosexuales masculinas. Es un subgénero del shojo manga. Yaoi significa «sin clímax, sin resolución, sin sentido». Comprende amor homosexual masculino, generalmente entre jóvenes y con contenido explícito.

${ }^{42}$ Shojo-ai, es un subgénero del shojo, que significa amor entre chicas. El yuri, trata el amor lésbico. como el yaoi, su contenido es sexualmente explícito.

43 Género extremo.

${ }^{44}$ Es un género pornográfico que comprende desde violaciones, gore, a perversiones escatológicas como la urofilia o la coprofilia, entre otras parafilias.
} 


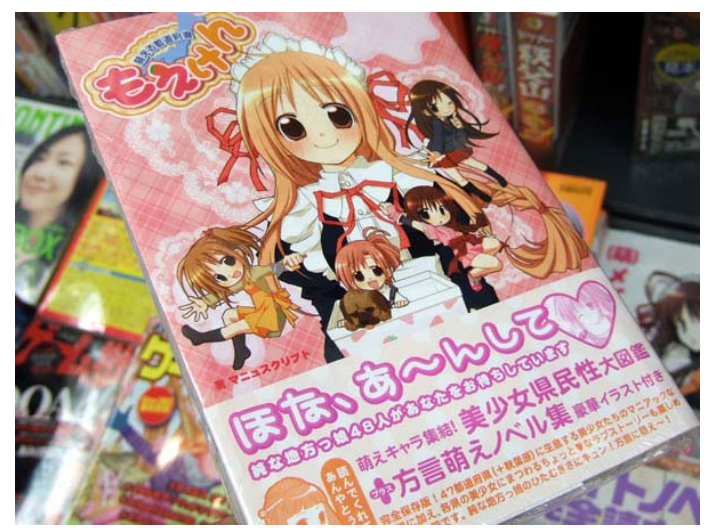

Fig. 22. Portada de un manga shojo.

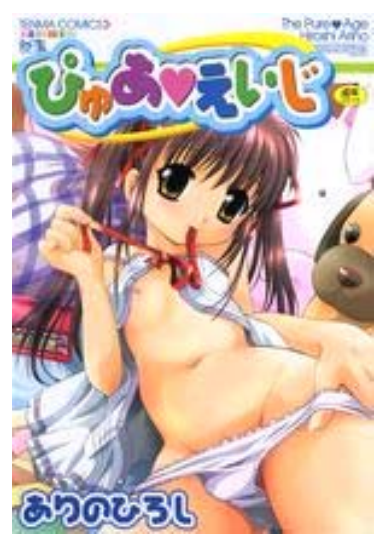

Fig. 24. Manga Iolikon.

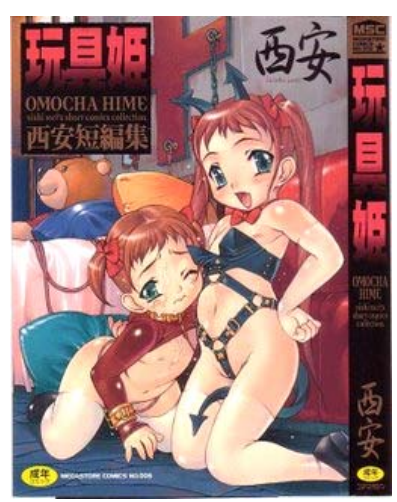

Fig. 27. Manga hentai.

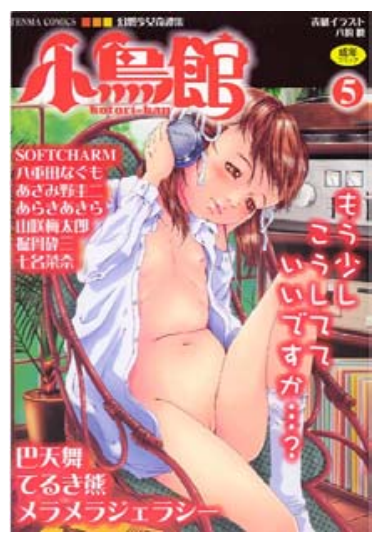

Fig. 25. Manga hentai.

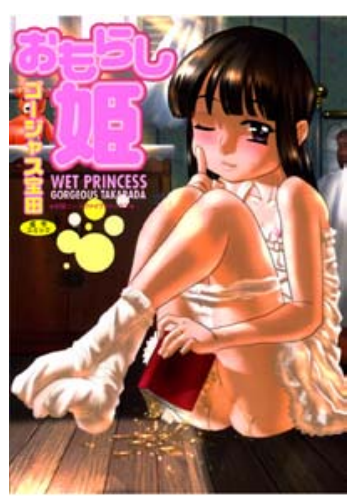

Fig. 28. Manga ero-guro.

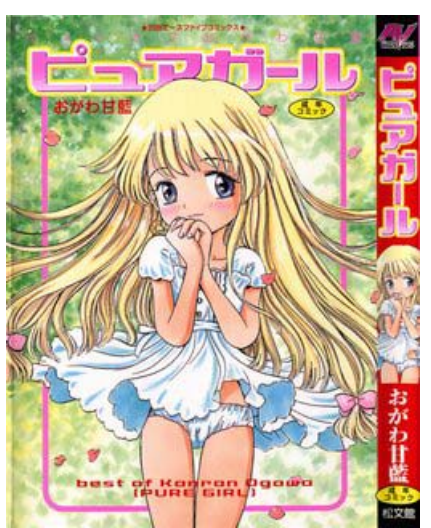

Fig. 23. Manga Iolikon.

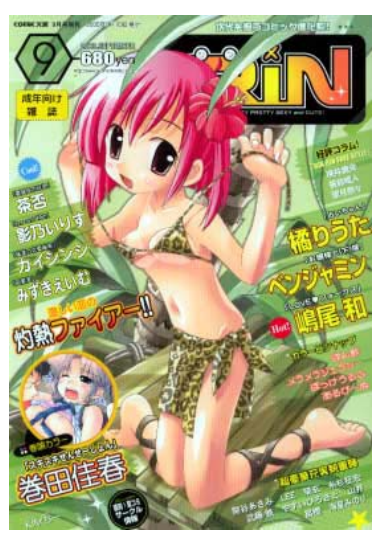

Fig. 26. Manga hentai.

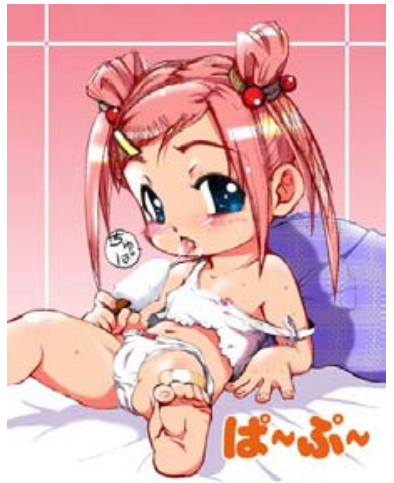

Fig. 29. Manga toddlerkon. 
Además de los mangas, vídeos y revistas, el estilo rorikon se ha adaptado a las exigencias del extravagante e imaginativo gusto consumista japonés, encontrándose así, desde figuras de porcelana o de resina con formas de los personajes femeninos de los diferentes géneros de manga; las esculturas del artista Takashi Murakami; las rori-dol/45, muñecas hiperrealistas con la apariencia y las medidas de una preadolescente de entre 10 y 12 años de edad fabricadas en hule espuma -se fabrican con una altura entre $140 \mathrm{~cm}$. y $150 \mathrm{~cm} .-$, demasiado naturales para ser encasilladas junto con las muñecas hinchables de los sex-shop, los productos inclasificables y fetichistas, como el buru-sera, braguitas que han sido utilizadas dos o tres días y que más tarde las adolescentes venden a las bloomer shops, junto con otro tipo de prendas usadas. Estas prendas, se han llegado a vender en máquinas expendedoras. En el envase de las mismas, a veces, aparece la fotografía de la joven y el tiempo que las ha utilizado o la escuela a la que ha ido, entre otros datos de interés.

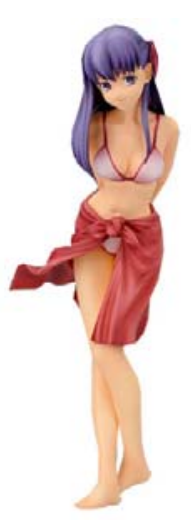

Fig. 30. Figura del anime Fate/Hollow Ataraxia.

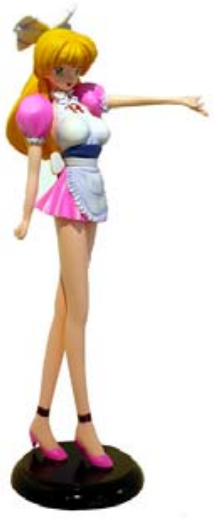

Fig. 31. Escultura del artista Takashi Murakami.

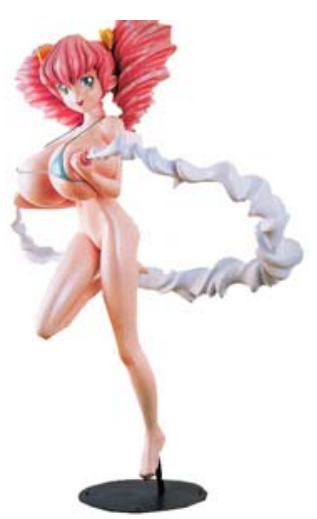

Fig. 32. Escultura del artista Takashi Murakami.

45 Doll Kan [en línea]. [ref. de 11 de octubre de 2006]. Disponible en Web: http://www.dollkan.com/top.asp, Lovely Fan Doll [en línea]. [ref. de 11 de octubre de 2006]. Disponible en Web: http://h.zansu.com/real/ o Orient Industry [en línea]. [ref. de 11 de octubre de 2006]. Disponible en Web: http://www.orient-doll.com/top.htm. Estos modelos incluyen una orificio vaginal útil. El modelo más polémico es Candy Girl Petit Soft que tiene las siguientes medidas: $140 \mathrm{~cm}$. de altura, $68 \mathrm{~cm}$. de busto, $57 \mathrm{~cm}$. de torso, $51 \mathrm{~cm}$. de cintura, $76 \mathrm{~cm}$. de cadera y $9 \mathrm{~kg}$. de peso. 

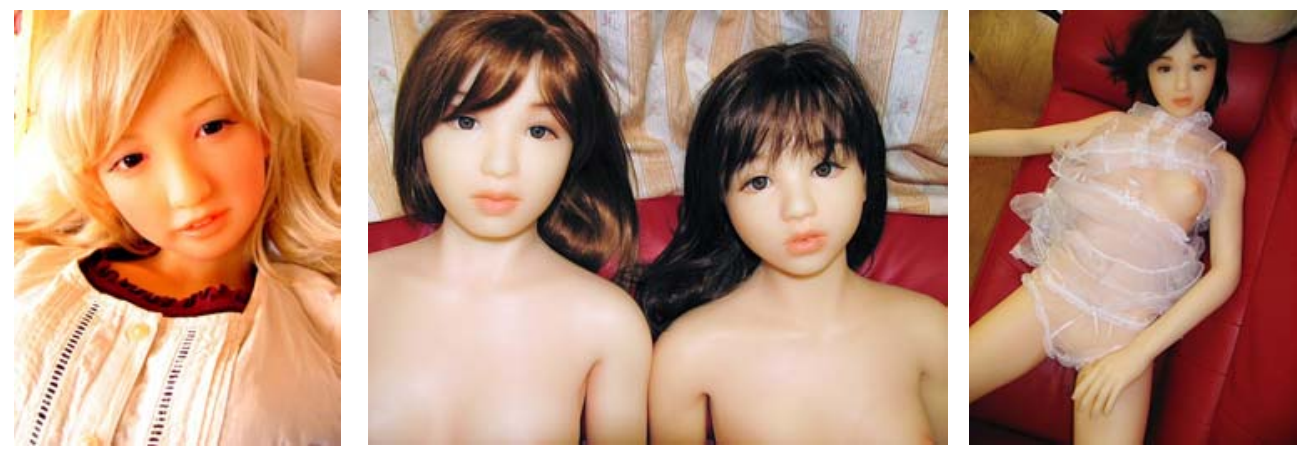

Fig. 33, fig. 34 y fig. 35. Diferentes rori-doll, modelo Candy Girl de la marca Orient Industry.
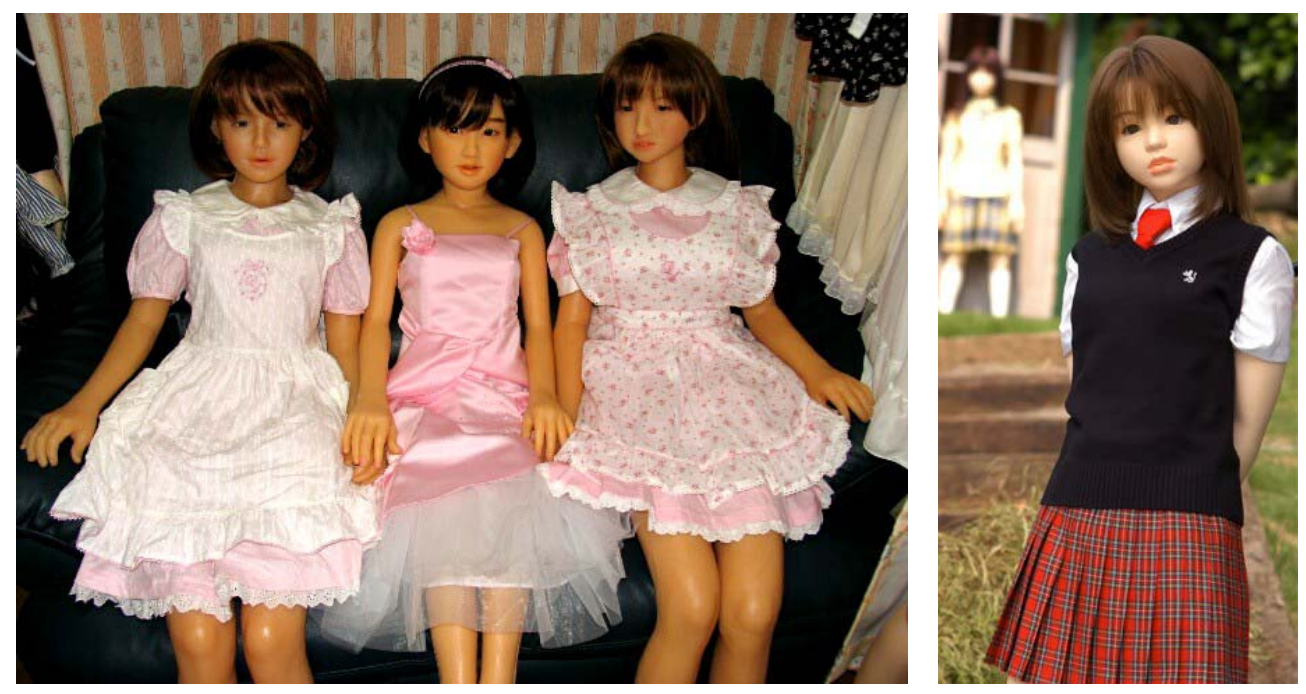

Fig. 36 y fig. 37. Diferentes rori-doll, modelo Candy Girl Petit Soft de la marca Orient Industry.

Entre las aficiones de algunos hombres japoneses, se halla también la de buscar la visión fugaz o fotografiar las braguitas de las adolescentes, acción que Ilaman panchira. La afición por el panchira y el burusera ha dado lugar a la variante namasera, que consiste en desprenderse de la braguita en el mismo momento en que las venden. Por razones legales, algunas de estas prácticas se han visto impedidas, dando lugar a otras formas como dejar que a sus clientes huelan sus braguitas llevándolas ellas todavía puestas. Este fetichismo por la ropa 
interior y en concreto por las braguitas, se manifiesta abiertamente en el manga o en el anime, incluso en aquéllos que no tiene contenido sexual, como los anime de Chicho Terremoto $^{46}$, el maestro Chen de Ranma 11/2, el Maestro Mutenroshi en Bola de Dragón o más recientemente Shinnosuke en Shin-chan.

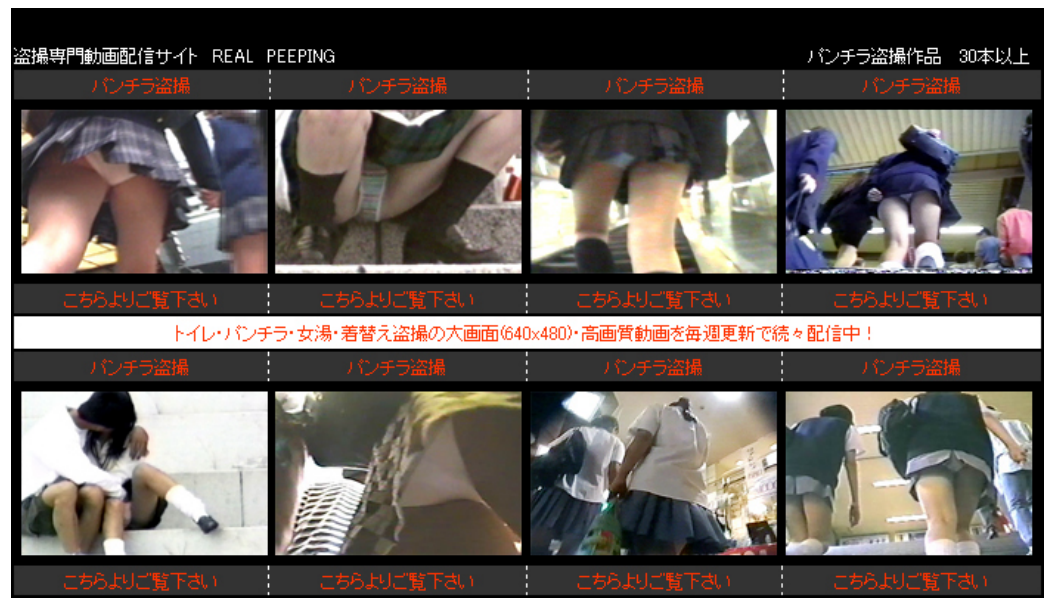

Fig. 38. Fotografías anónimas «robadas» de panchira difundidas en Internet.

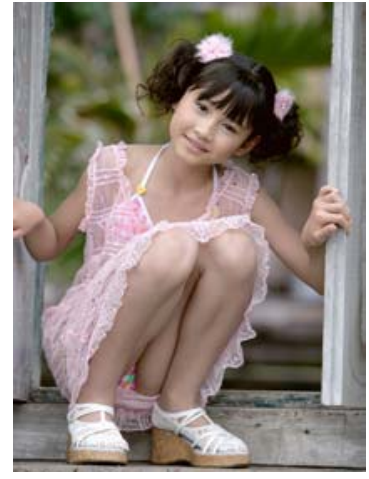

Fig. 39. Junior model posando panchira.

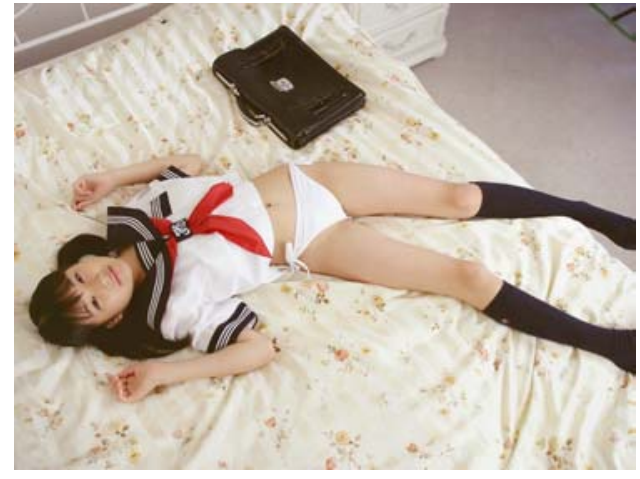

Fig. 40. Junior model posando panchira.

\footnotetext{
${ }^{46}$ Título original en japonés 'Dash! Kappei' (1981). Chicho es un muchachito de dieciséis años que en sus ratos libre juega al baloncesto encestando grandes canastas pero lo que más le gusta es levantar la falda a las chicas, sobretodo la de Rosita, y lograr ver sus braguitas blancas.
} 
Otra forma de obtener dinero rápido, productos de marca e incluso viajes por parte de algunas adolescentes japonesas es mediante las llamadas enjo kosai, que son citas pagadas por hombres -los sararimana las que las jóvenes acuden, y que consiguen con sus propios móviles,

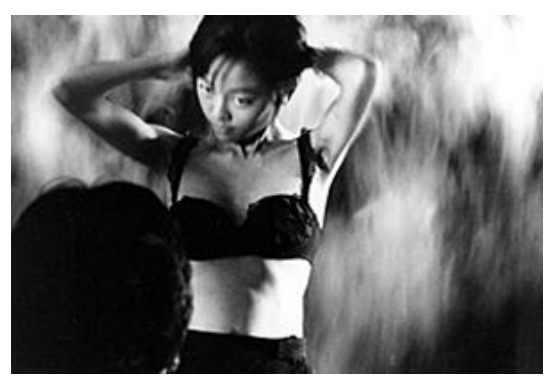

Fig. 41. Fotograma del documental Cotton Candy (Roshell Bissett, 1996). dejando pegatinas con sus números de teléfono en las cabinas telefónicas o a través de unos clubs telefónicos llamados terekura que les concierta las citas. Tales encuentros incluyen el pago de las consumiciones, regalos, etc, a cambio de compañía, aunque generalmente incluyen el servicio sexual ${ }^{47}$.

La prostitución adolescente en algunos países consumistas se ha elevado enormemente, siendo el máximo exponente Japón. Dentro de este fenómeno rorikon, se expande el universo de prostitución y pornografía de las Ilamadas camgirls -chicas de la cámara-, que son adolescentes japonesas -de entre 13 y 17 años- que vía Internet y mediante una webcam ${ }^{48}$, ofrecen a cambio de regalos comprados en tiendas virtuales, fotos íntimas y vídeos, aunque no necesariamente de desnudos. Éste fenómeno aunque mayoritariamente japonés también se está dando enormemente en otros países como Inglaterra. La siguiente fase es, que tales fotografías son incluso

\footnotetext{
47 Estas prácticas se dieron a conocer mundialmente tras el estreno del cortometraje Cotton Candy (Roshell Bissett, 1996) en la que se muestra la vida diaria de unas adolescentes colegialas que practican estas actividades.

${ }^{48}$ Una webcam se puede adquirir por unos $25 €$ y sólo se requiere una conexión a Internet y la privacidad de su dormitorio. Para estas jóvenes constituye un negocio «sencillo» con el que satisfacer sus ansias consumistas por objetos como móviles, ropa de marca y productos que estén a la «moda» o de lujo muy por encima de su nivel adquisitivo.
} 
distribuidas indiscriminadamente. Así, existen en Internet páginas especializadas en recopilar las fotografías de camgirls.

La permisividad social hacia este tipo de conductas adolescentes ligadas a la prostitución, se hace patente al comprobar con sorpresa cómo por ejemplo la leyes japonesas, no prohibieron explícitamente la pederastia hasta $1999^{49}$.

Por otro lado, la conducta mediatizada de las adolescentes ha dado lugar a tribus urbanas como las enjo kosai, que suelen vestirse con el sera fuku ${ }^{50}$ del mismo modo que algunas heroínas del manga como Sailor Moon ${ }^{51}$. Por su vestimenta, habitualmente se las relaciona con las kogals o kou-gyaru, una tribu urbana japonesa que comenzó a principios de la década de los noventa. Son chicas adolescentes de entre 16 y 22 años, estudiantes de secundaria, que visten de modo extravagante y que no necesariamente tienen relación con la prostitución como las enjo kosai -aunque algunas de ellas ciertamente lo sean- pero sí comparten actitudes, gustos y vestimenta con ellas. Las gal, como se les ha venido a llamar en los últimos años a las kogals, suelen vestir una mezcla ecléctica de la moda occidental o de instituto americano, el sera fuku, con los calcetines rusu-sokusu ${ }^{52}$, el pelo teñido de colores -chapatsu-, e incluso el bronceado de piel con rayos UVA, consiguiendo una estética de las playas de California en las gal llamadas ganguro. Sus nombres cambian dependiendo del tono de piel a gonguro o shirogyaru/ganjiro. Por otro lado se encuentran las aficionadas a la moda gothic Lolita o

49 WIJERS-HASEgAWA, Yumi. Japan coming up short on child rights [en línea]. Japan Times, Wednesday, March 31, 2004 [ref. de 17 de octubre de 2006]. Disponible en Web: http://www.japantimes.co.jp

${ }^{50}$ Uniforme escolar compuesto por faldita plisada y calcetines hasta la rodilla, tipo traje de marinerito que aparece en el anime.

${ }^{51}$ Manga Shojo, creado por Naoko Takeuchi en 1991 y del que se realizó en 1992 un anime.

${ }^{52}$ Calcetines caídos en los tobillos. 
goth Ioli, que visten con ropas de estilo victoriano, las kuro Lolita -que visten de negro-, las shiro Lolita -que visten de blanco-, sweet Lolita que visten en tonos pastel-, las classical Lolitas, las punk Lolita, etc, según sus formas de vestir, o los Cosplay que son jóvenes, tanto chicas como chicos que se disfrazan de sus personajes favoritos de manga y anime que se ha extendido entre los aficionados de todo el mundo.

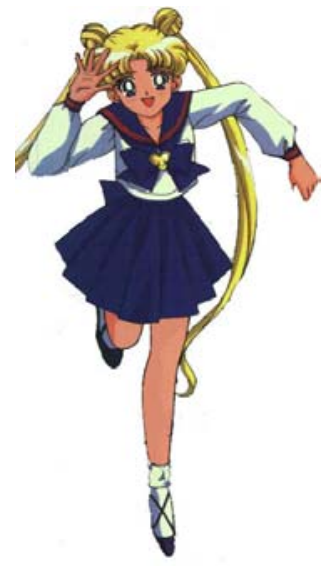

Fig. 42. Sailor Moon.

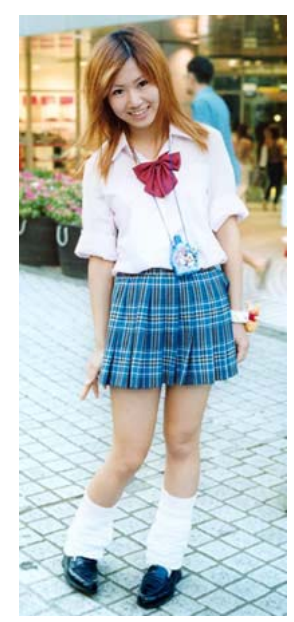

Fig. 43. Muchacha vistiendo sera fuku y rusu-sokusu.

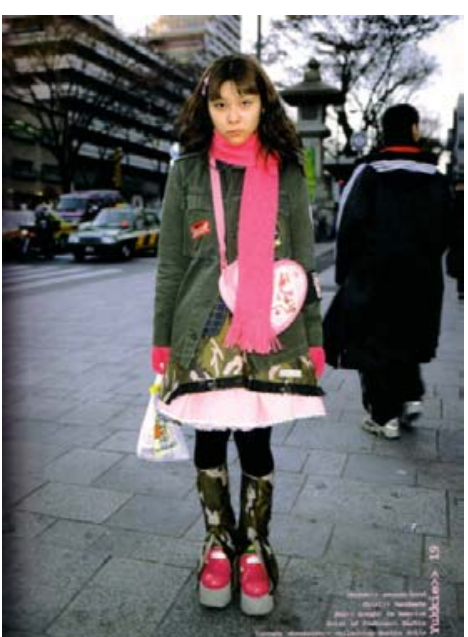

Fig. 45. Moda kogal. Fotografía por Shoichi Aochi.

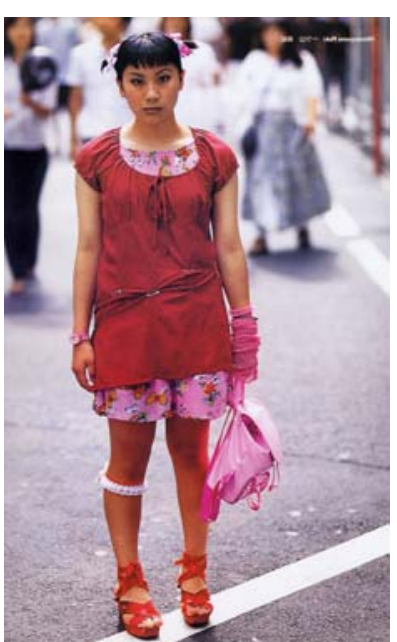

Fig. 46. Moda kogal. Fotografía por Shoichi Aochi.

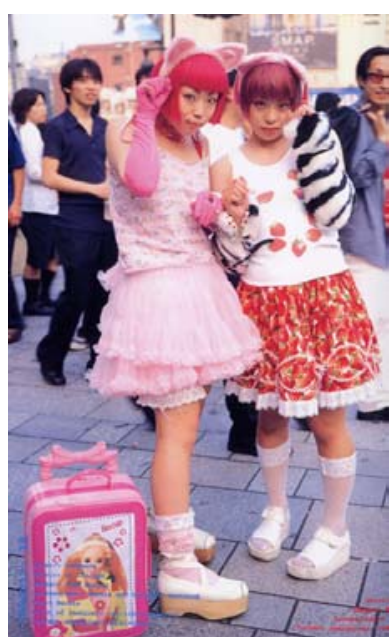

Fig. 47. Moda kogal. Fotografía por Shoichi Aochi. 


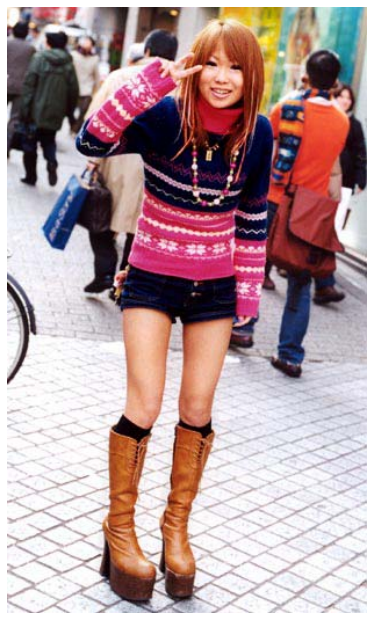

Fig. 48. Kogal gangiro.

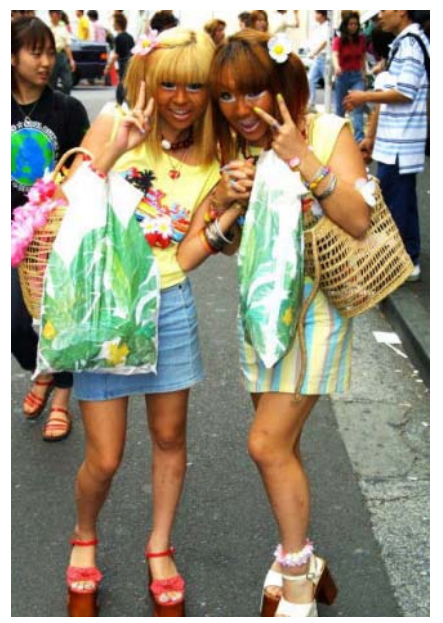

Fig. 49. Kogals ganguro.

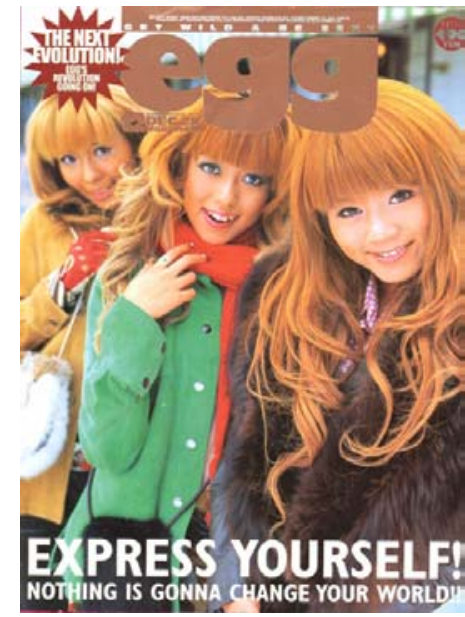

Fig. 50. Portada de la revista Egg Magazine.

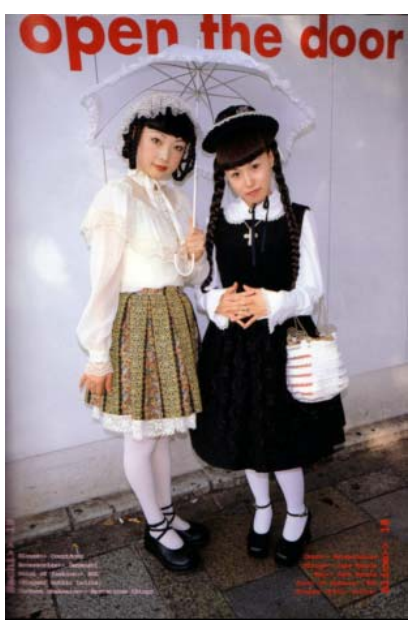

Fig. 51. Gothic Lolitas.

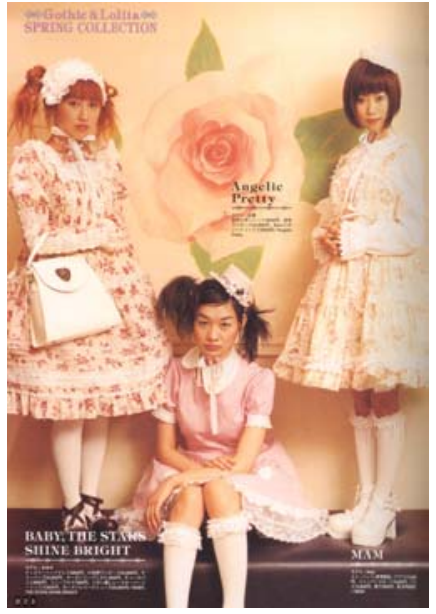

Fig. 52. Sweet Lolitas.

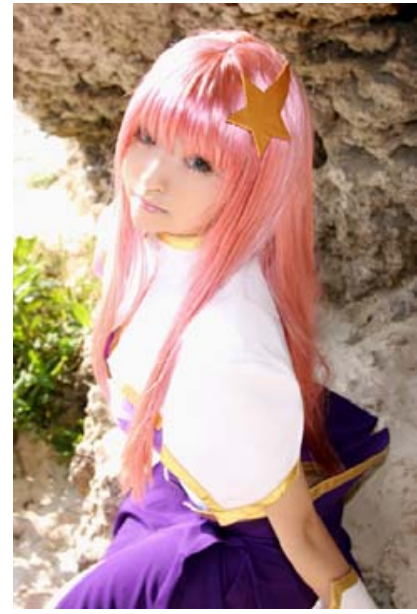

Fig. 53. Cosplay.

Todas estas diversas tendencias y modas pasajeras que caracterizan a la estética rorikon, forman parte del gran grupo al que llaman joshikosei ${ }^{53}$, en el que las jóvenes hallan una forma de vida contemporánea marcada por la resistencia a la disciplina y a la

\footnotetext{
${ }^{53}$ La traducción literal es colegiala.
} 
uniformidad escolar, por un consumismo feroz y la condición de rorikon en el que juega un papel primordial un complejo código de conducta sexual, en el que la diferencia entre sexualidad y pornografía es prácticamente inexistente. La sociedad japonesa ${ }^{54}$ no ha dado excesiva importancia a éstas formas de consumismo ligado a prostitución y moda adolescente. Son numerosos los sociólogos que hallan en los extremos contenidos eróticos y pedófilos de los manga y anime de la cultura otaku las causas en gran medida de la grave erotización de la infancia, sobre todo con la figura de la rorikon en la sociedad japonesa ${ }^{55}$. Sin embargo el fenómeno rorikon, ha descendido en los últimos años, en parte a las medidas legales que se han adoptado -con la prohibición del burusera por ejemplo- o a la presión capitalista y de los medios de masas que ejercen en una sociedad, la japonesa, tremendamente influenciable ante la novedad, tecnológica o sexual.

\footnotetext{
${ }^{54}$ Las religiones mayoritarias en Japón, la sintoísta y la budista, no se oponen a la práctica sexual libre lo que provoca una mayor permisividad sexual que en los países de mayoría religiosa musulmana, cristiana o judía.

${ }^{55}$ MCNICOL, Tony. Does comic relief hurt kids? [en línea]. Japan Times, Tuesday, April 27, 2004 [ref. de 17 de octubre de 2006]. Disponible en Web: http://www.japantimes.co.jp
} 

CONCLUSIONES.

La representación de la preadolescente ha evolucionado y cambiado de manera significativa, desde la identificación de los parámetros biológicos de la preadolescencia -como fase de desarrollo físico y mental del ser humano, comprendido entre la niñez y la adolescencia- y la concepción socio-cultural de finales del siglo XVIII hasta la actualidad. Por un lado la identificación del mismo, responde a la diferenciación biológica respecto al desarrollo mental, físico y psíquico de la persona y por tanto, a nivel legal, se establecen leyes que indiquen la «edad legal» y la regulación de los derechos, deberes y obligaciones del individuo preadolescente dentro de la sociedad. Sin embargo, la arbitrariedad para diferenciar la infancia de la edad adulta durante el siglo XIX, fue determinante en la construcción de la identidad de la preadolescencia femenina. Fue precisamente ésta indeterminación legal de la edad núbil durante éste periodo en Inglaterra, la raíz del problema de la diferencia entre madurez biológica y la social, manifestándose en una lamentable desprotección de la infancia y favoreciendo los matrimonios con menores y la prostitución infantil.

Asumiendo estos criterios, se encuentra la visión de la literatura y el arte que recogen la postura social y las condiciones de vida «reales» de la infancia dentro de la sociedad misma. Las «niñas» bajo la construcción histórica y social marcada por el pensamiento predominantemente masculino, han sido consideradas como objeto sexual prácticamente desde el principio, por su género femenino y precisamente por su sexo, inferior al hombre e incluso carente de derechos o voluntad a desarrollar como persona «todavía» no adulta. Sin embargo en éste sentido, el de inferioridad, se construyó una identidad de pureza e inocencia que marcaría la representación de la 
preadolescencia durante los últimos siglos. Al no ser «seres humanos completos» como el hombre -de género masculino-, ni plenamente desarrolladas como la mujer adulta, su naturaleza se hace diferente de la de los adultos y en parte misteriosa, ya que se le asocian características celestiales como la santidad, la pureza y la inocencia representaciones desarrolladas por la visión romántica de William Blake o Wordsworth, los artistas Prerrafaelistas- con las que descubrir y conocer la verdad, la belleza y lo divino, así como características malignas o demoníacas de índole mitológico o bíblico como en la representación de la preadolescente como Salomé o las sirenas. Ésta segunda visión concibe la sexualidad femenina, incluida y latente en las «no desarrolladas» niñas, que sin embargo y debido a esa sexualidad oculta, provoca un erotismo ligado a la perversidad, no siempre evidenciada en el desnudo o las poses provocativas, sino también en las expresiones y miradas perturbadoras que inducen a la duda sobre la naturaleza bondadosa o inocente de las niñas.

La sociedad occidental del siglo XIX, marcada por un profundo puritanismo y receptora de las contradicciones sociales generadas a partir de la lucha feminista, desarrollaría la perversidad femenina en sus formas artísticas sin dejar de lado la visión romántica y es en el choque de ambas concepciones que se crea uno de los iconos más fascinantes de los tipos humanos, la preadolescente.

A pesar de que a comienzos del siglo XX las leyes comenzaran a proteger a los menores y se concretaran biológicamente las edades que a éstos comprendían, en la sociedad occidental permanecería la heredada concepción victoriana de la imagen de la preadolescente ligada a una inocencia ambiguamente erótica. El icono de la preadolescente desarrollado por los pintores y los fotógrafos victorianos como Millais, Lewis Carroll o Julia Margaret Cameron, 
generó décadas más tarde multitud de representaciones condicionadas a las nuevas formas de los medios de masas como los iconos femeninos cinematográficos, desde la adulta aniñada en la actriz Mary Pickford a la niña erotizada en Shirley Temple, asimismo en los personajes marcados por la que sin duda dio nombre al icono de la preadolescente, Lolita de Vladimir Nabokov en la que se consolida la inocencia y la naturaleza demoníaca y perversa.

La Lolita como icono sería desarrollado por numerosos artistas del siglo XX como Balthus, buscando un tipo de ideal de pureza romántica y mística cristiana mediante un uso de la desnudez y del erotismo de las niñas que va más allá de lo anecdótico o lo provocativo; también los fotógrafos Sally Mann o Graham Ovenden, asociando la naturaleza primigenia infantil a la sensualidad evidente y provocadora de los metamórficos cuerpos durante la preadolescencia femenina, pero que en la fotografía de Sally Mann, como lo fuera en la de Julia Margaret Cameron, se integra una visión de la infancia y el erotismo desde el imaginario femenino y desde la maternidad.

El juego entre perversión e inocencia como recurso fácil en el tratamiento de la preadolescente en el cine, ha conducido a la iconografía de la Lolita a variar su patrón, que ni en edad, ni en físico, se corresponde con la que nos definió Nabokov. Pero la utilización del término Lolita de manera generalizada y estereotipada, ha degenerado progresivamente en un desgaste semántico del término dando lugar a iconos de la preadolescente basados únicamente en términos sexuales.

Éste desarrollo imparable de la figura de la preadolescente durante los siglos XIX, XX y principios del XXI, ha rozado, si no chocado inevitablemente, con las concepciones artísticas sobre la representación adulta del erotismo, identificándose el icono de la 
preadolescente con ésta sensualidad y midiéndose su imagen en términos de obscenidad y pornografía, proliferando además ésta visión a nivel mundial gracias a los medios de masas como Internet $y$ paralelamente con el desarrollo de la «persona» preadolescente, es decir, en la figura legal del «menor de edad».

Los cambios sociales respecto a la noción de infancia a finales del siglo $\mathrm{XX}$, bajo el dominio económico del sistema capitalista provocarán un profundo cambio en la imagen de la preadolescente -como reflejo recurrente de lo que ocurriera a finales del siglo XVIII y principios del XIX- dando lugar a fenómenos sociales y culturales como el «Complejo de Lolita».

Las más recientes representaciones de la preadolescente, sitúan a ésta figura infantil en un difícil plano clasificatorio. El icono se ha desvinculado de la sensibilidad artística y literaria, para ser concebido como un referente básicamente pornográfico, con jóvenes adolescentes o adultas de exuberantes pechos, pero también, vulnerable a las más aberrantes asociaciones como las que surgen del manga hentai japonés, la proliferación de la prostitución de lujo de adolescentes o el lucrativo mercado de la pornografía y la prostitución infantil.

Supone un reto predecir en qué sentido la representación del icono de la preadolescente se verá expresado o manifestado durante las próximas décadas. Como en la época victoriana, la concepción de la infancia sigue produciendo inquietud en la sociedad actual, que desea proteger a los menores, pero por otro lado, haya incertidumbre $y$ desasosiego ante el posible deseo que pueda despertar la imagen infantil. Sin duda, el choque antagónico entre inocencia y perversidad, supone la característica más atractiva del icono, no en vano ante los 
brutales resultados y consecuencias sociales de una imagen extremadamente obscena o pornográfica de la preadolescente, los mecanismos morales y legales de las sociedades a nivel global, tienden a censurar invariablemente y a tipificar como delito, las formas y representaciones de la imagen infantil, coartando las manifestaciones y expresiones artísticas que puedan mostrar una sexualidad infantil demasiado sugerente, equiparándolas con la imagen pornográfica. En numerosos casos la desproporcionada acción censora ha llegado a provocar el efecto contrario en la sociedad, es decir, ha incentivar la asociación directa entre sexualidad infantil y deseo pedófilo.

Nos encontramos pues, ante el vigente y polémico concepto ético y moral de la «libertad de expresión» pero también ante la necesidad de desarrollar una estética de las imágenes y la representación de la infancia, de lo que constituyen en sí mismas formas artísticas, obscenas o pornográficas, y de éste modo conciliar la siempre polémica visión y percepción artística de la realidad y del mundo de la imaginación con la visión socio-cultural y legal de las sociedades del mundo. 



\section{BIBLIOGRAFÍA.}

\section{Estudios y ensayos:}

AA.VV. El día del niño. La infancia como territorio para el miedo. Madrid: Valdremar, 2003.

AA.VV. Historia de la vida privada. De la Revolución francesa a la Primera Guerra Mundial. vol. IV. Barcelona: Círculo de Lectores, 1993.

AGUILERA, Emiliano. El desnudo en las artes. Madrid: Ediciones Giner, 1974.

ALISON, James; PROUT, Alan (eds.) Constructing and Reconstructing Childhood: Contemporary Issues in the Sociological Study of Childhood, Falmer Press, London, 1990.

AMSTRONG, Nancy. Deseo y ficción doméstica. Col. Feminismos. Madrid: Cátedra, 1991.

ANGER, Kenneth. Hollywood Babilonia. vols. I y II. Barcelona: Editorial TusQuets, 1985-1986.

ARISTOFF, n.s. Girl-love \& Girl-lust in $19^{\text {th }}$ Century England. New York: Passion Press, 1992.

AUERBACH, Nina. Romantic Imprisonment: Women and Other Glorified Outcast. New York: Columbia University Press, 1986.

-Woman and the Demon: The Life of a Victorian Myth. Harvard Cambridge: University Press, 1982.

BAKER, Kathleen. Play, Games and Sport: The Literary Works of Lewis Carroll. Ithaca \& London: Cornwell University Press, 1974.

BALTHUS; VIRCONDELET, Alain (ed.). Memorias. Barcelona: DeBolsillo, 2003.

BARTHES, Roland. La cámara lúcida. Notas sobre fotografía. Barcelona: Paidós Comunicación, 1999.

- Roland Barthes por Roland Barthes. Barcelona: Ediciones Piados Ibérica, 2004. 
BARTRAM, Michael. The Pre-Raphaelite Camera: Aspects of Victorian Photography. Boston: Little Brown, 1985.

BAUDRILLARD, Jean. De la seducción. Madrid: Cátedra, 2000.

BEAUVOIR, Simone De. Brigitte Bardot and The Lolita Syndrome. New York: Arno Press Cinema Program, 1972.

- El segundo sexo. vols. I y II. Col. Feminismos. Madrid: Ediciones Cátedra, 2000.

BEST, Marc. Those Endering Young Charms. Chil Performers of the Screen. London: A.S. Barnes and Co., 1971.

BeTTELHeIM, Bruno. Psicoanálisis de los cuentos de hadas. Biblioteca de bolsillo. Barcelona: Crítica, 2003.

- The Uses of Enchantment: The Meaning and Importance of Fairy Tales. New York: Vintage Books, 1975.

BLACK, Gregory D. Hollywood censurado. Cambridge-Madrid: Akal Cambridge, 1998.

BORNAY, Erika. La cabellera femenina. Un dialogo entre poesía y pintura. Ensayos Arte. Madrid: Cátedra, 1994.

- Las hijas de Lilith. Ensayos Arte. Madrid: Cátedra, 1998.

BOWRA, C.M. La imaginación romántica. Madrid: Taurus, 1972.

BRONFEN, Elisabeth. Over her Dead Body. Death, Feminity and the Aesthetic. Manchester. Manchester University Press, 1993.

BROWN, Penny. The Captured World: The Child and Childhood in Nineteenth Century Women's Writing in England. New York: St. Martin's Press, 1993.

BUNNELL, Peter C. A Photographic Vision: Pictorical Photography, 18991923. Salt Lake City: Peregrine Smith Inc., 1980.

CALVERT, Karin. Children in the House: The Material Culture of Early 366 
Childhood. Boston: Notheastern University Press, 1992.

DE LA CALLE, Román. Lineamientos de Estética. Valencia: Nau Llibres, 1985.

CARROLL, Lewis. El juego de la lógica y otros escritos. Madrid: Alianza, 1986.

CARROLL, Lewis; BRASSAÏ. Niñas, cartas y fotografías. Estudio preliminar de Brassaï. Pocas Palabras. Barcelona: Lumen, 1998.

CARROLL, Lewis; GREEN, Roger Lancelyn (ed.) The Diaries of Lewis Carroll. 2 vols. London: Cassell, 1953.

CARROLL, Lewis; GREEN, Roger Lancelyn (ed.); COHEN, Morton N. (ed.) The Letters of Lewis Carroll. Oxford: Oxford University Press, 1979.

COHEN, Morton N. Lewis Carroll. Barcelona: Anagrama, 1998.

- Lewis Carroll, Photographer of Children Four Nudes Studies. New York: Clarkson N. Potter Inc., 1979.

- Reflections in a Looking Glass. A Centennial Celebration of Lewis Carroll, Photographer. New York: Aperture, 1998.

COLINGWOOD, Stuart Dodgson. The Life and Letters of Lewis Carroll. C. L. Dodgson. London. T. Fisher. Unwin, 1898.

COVENEY, Peter. The Image of Childhood. The Individual and Society: a Study of the Theme in English Literature. London: Penguin Books, 1967.

CUNNINGHAM, Hugh. Children and Childhood in Western Society Since 1500. London: Longham Group Limited, 1995.

- Trabajo y explotación infantil: situación en la Inglaterra de los siglos XVII al XX. Colección Historia Social, 32. Madrid: Ministerio de Trabajo y Asuntos Sociales. 1994.

DAVENPORT, Guy. A Balthus Notebook. New York: The Ecco Press, 1989.

DE LAURENTIS, Teresa. Alicia ya no. Madrid: Cátedra, 1992. 
DIEGO OTERO, Estrella de. La Mujer y la pintura del XIX español: (cuatrocientas olvidadas y algunas más). Madrid: Cátedra, 1987.

- El andrógino sexuado. Eternos ideales, nuevas estrategias de género. Madrid: Visor, 1992.

DIJKISTRA, Bram. Ídolos de perversidad. Madrid: Debate, 1994.

DOYLE, Arthur Conan. El misterio de las hadas. El baquero. Barcelona: José J. de Olaneta, Editor, 2003.

DUNCAN, J. Matthews. Clinical Lectures on the Diseases of Women. London: J. And A. Churchill, 1889.

DYE, David. Child and Youth Actors. Filmographies of Their Entire Careers, 1914-1985. Jefferson (NorthCarolina) and London: Mc Farland \& Company. Inc. Publishers, 1988.

ETXEBARRÍA, Lucía; NUÑEZ PUENTE, Sonia. En brazos de la mujer fetiche. Col. Imago mundi. Barcelona: Ediciones Destino, 2002.

FIEDLER, L.A. Love and Death in American Novel. New York: Criterion Books, 1960.

FREEDMAN, Russell; HINE, Lewis (photographs). Kids at Work. Lewis Hine and The Crusade Against Child Labor. New York: Clarion Books, 1994.

FREIXAS, Ramón; BASSA, Joan. El sexo en el cine y el cine de sexo. Barcelona: Paidos, 2000.

FREUD, Sigmund. The Standard Edition of the Compleated Psychological Works. vol. 16. London: Hogarth Press, 1888.

- Obras completas (edición popular). Madrid: Editorial Biblioteca Nueva, 2006. FROUD, Brian; LEE, Alan; LACKIN, David (ed.). Hadas. Madrid: Modadori, 1983.

FURNISS, Harry. The confessions of a caricaturist. Toronto: W. Briggs, 1902. 
GAUNT, W. The Pre-Raphaelite Tragedy. Londres: Sphere Books, 1975. GERNSHEIM, Helmunt. Lewis Carroll, Victorian Photographer. Thames and Hudson, London: 1980.

- Lewis Carroll: Photographer. New York: Dover, 1969.

GIBSON, Ian. El vicio inglés. Madrid: Planeta, 1980.

GINSBERG \& RICHEY; HARRIS, Melissa (ed.) The Body in Question. New York: Aperture Foundation, 1990.

GOETHE; POTOCKI; HOFFMANN; POE; GAUTIER. El libro de los vampiros. Barcelona: Fontamara, 1982.

GOLDMAN, Paul. Victorian Illustration. Lund Humphries, Burlington, 2004.

GOLDSTIEN, G. M.; ZORNOW, E. The Screen Image of Youth. New Jersey: Scarecrow Press, 1980.

GORHAM, Deborah. The Victorian Girl and The femenine Ideal. Bloomington: Indiana University Press, 1982.

GRAVES, R. Los mitos griegos. 2 vols. Madrid: Alianza, 1988.

GREEN-LEWIS, Jennifer. Framing the Victorians. Photography and the Culture of Realism. Ithaca (N.Y): Cornell University, 1996.

GRIMAL, Pierre. Diccionario de mitología griega y romana. Barcelona: Paidos, 1981.

GUBERN, Román. La imagen pornográfica y otras perversiones ópticas. Barcelona: Anagrama, 2004.

HAMES, Peter. Dark Alchemy. The Films of Jan Švankmajer. Westport (C.T.): Praeger Publishers, 1995.

HARDING, Ellen. Re-framing the Pre-Raphaelites: Historical and Theoretical essays. Aldershot: Scolar Press, 1996. 
HARKER, Margaret H. Henry Peach Robinson, Master of Photography Art, 1830-1901. Oxford: Basil Blackwell, 1988.

HASKELL, Molly. From Reverence to Rape. The Treatment of Women in the Movies. New York: Penguin, 1974.

HeININGeR, M.L.S.; CALVERT, Karin. A Century of Childhood, 18201920. New York: Margaret Woodbury Strong Museum, 1984.

HESS, Thomas B.; NOCHLIN, Linda (eds.). Woman as Sex Object. Studies in Erotic Art. 1730-1970. New York: Newsweek Inc., 1973.

HIGONNET, Anne. Pictures of Innocence: The History and Crisis of Ideal Childhood. Interplay. London: Thames \& Huston, 1998.

HILTON, T. John Ruskin: The Early Years: New Haven: Yale University Press, 1985.

- John Ruskin: The Later Years. New Haven: Yale University Press, 2000. HOFTÄTTER, H. Historia de la pintura modernista europea. Barcelona: Blume, 1981.

HÖNNINGHAUSEN, Lothar. Präraphaeliten und Fin de Siècle. Symbolistische Tendenzen in der englischen Spätromantik. Munich: Wilhelm Fink, 1971.

HUDSON, Derek. Lewis Carroll: An Illustrated Biography. New York: Clarkson N. Potter, Inc., 1977.

IRIGARAY, Luce. Yo, tú, nosotras. Col. Feminismos. Madrid: Cátedra, 1992. JONES, Edgar Yoxall. Father of Art Photography: O. G. Rejlander, 18131875. New York: Greewich, 1973.

JULLIAN, Philippe. Dreamers Of Decadence: Symbolist Painters of the 1890s. New York: Praeger Pub., 1974.

KANT, Immanuel. Lo bello y lo sublime: ensayo de estética y moral. 
Alicante : Biblioteca Virtual Miguel de Cervantes, 2004

KAPPLER, C. Monstruos, demonios y maravillas. Madrid: Akal, 1986.

KAUFFMAN, Linda S. Malas y perversos. Fantasías en la cultura y el arte contemporáneos. Col. Frónesis. Madrid: Cátedra, 2000.

KINCAID, James R. Child Loving. The Erotic Child and Victorian Culture. New York: Routledge, 1992.

- Erotic Innocence: The Culture of Child Molesting. Durham and London: Duke University Press, 1998.

KRAFFTL-EBING. Psychopathia Sexualis. Brooklyn (N.Y.): Physicians and Surgeons Book Co., 1931.

LEACH, Karoline. In the Shadow of the Dreamchild. A New Understanding of Lewis Carroll. Chester Springs (P.A.): Dufour Editions, 1999.

LOVETT STOFFEL, Stephanie. Lewis Carroll in Wonderland. The Life and Times of Alice and Her Creator. Discoveries Series. New York: Abrams, 1997.

LUCIE-SMITH, Edward. Art in the Seventies. Oxford: Paidon Press Ltd., 1980.

- El arte simbolista. Barcelona: Ediciones Destino, 1991.

- La Sexualidad en el Arte Occidental. Barcelona: Ediciones Destino, 1992.

McGREGOR, Richard. Japan Swings: Politics, Culture and Sex in the New Japan. Sydney: Allen \& Unwin, 1996.

MANIERI ELIA, Mario. William Morris y la ideología de la arquitectura moderna. Barcelona: Gustavo Gili, 2001.

MARCUS, Steven. The Other Victorians. A Study of Sexuality and Pornography in Mid-Nineteenth-Century England. New York: Basic Books, 1964.

MARIN, Louise. Utopiques: Jeux d'espace. Paris: Les Éditions de Minuit, 1973. 
MARSH, Jan. The Pre-Raphaelites. Their Lives in Letters and Diaries. London: Collins \& Brown Limited, 1996.

MARSH, Jan; GERRISH NUMM, Pamela. Pre-Raphaelite Women Artist. New York: Thames and Huston, 1999.

MAVOR, Carol. Pleasures Taken. Performances of Sexuality and Loss in Victorian Photography. London: I.B. Tauris, 1996.

- The Girl's Own. A Social History of the Victorian Girl. University of Athens: Georgia Press, 1994.

MEINWALD, Dan. Memento Mori: Death in Ninetheenth-Century Photography. Riverside: University of California, 1990.

MELLOR, D. (ed.). Paradise Lost-The Neo-Romantic Imagination in Britain 1935-1955. London: Barbican, 1987.

MELTKEN, Günter. Los prerrafaelistas. El realismo ético y una torre de marfil en el siglo XIX. Barcelona: Blume, 1974.

MERRICK, Rev. G. P. Work Among the Fallen, as Seen in the Prison Cells. A paper read before the Ruri-Decanal Chapter of St. Margaret's and St. John's, Westminster, in the Jerusalem Chamber, on Thursday, July 17, 1890. London: Ward, Lock, 1890.

MONKHOUSE, Cosmo. British Contemporary Artist. London: Heinemann, 1899. MORENO, Montserrat. Cómo se enseña a ser niña. El sexismo en la escuela. Barcelona: Icaria Editorial, 1986.

MORRIS, Fraser. The Death of Narcissus. London: Secker and Warburg, 1976. NEAD, Lynda. El desnudo femenino. Arte Obscenidad y sexualidad. Metrópolis. Madrid: Editorial Tecnos, 1998.

- Myths of Sexuality Representations of Women in Victorian Britain. Oxford: Basil Blackwell, 1988.

NICKEL, Douglas R. Dreaming in Pictures: The Photography of Lewis 372 
Carroll. San Francisco: San Francisco Museum of Modern Art. Yale University Press, 2002.

NOCHLIN, Linda. Women, Art and Power, and Other Essays. ColoradoOxford (C.O.): Icon Editions, 1999.

NORTHROP MOOR, Jerrold; LAURIE, Lee; NAHUM, Peter. The Ruralists. A Celebration. Bodmin, Cornwall: Ruralist Fine Art Ltd., 2003.

OLDMAN, PAUL. Victorian Illustration. The Pre-Raphaelites, the Idyllic School and the High Victorians. London: New ed., 2004.

OVENDEN, Graham. A Victorian Album. Julia Margaret Cameron and Her Circle. London: Da Capo Press, 1975.

- Aspects of Lolita. London: Academy Editions, 1976.

- Marbel Mirrow. Cornwall: The Einna Press, 1984.

- Masters of Photography: Lewis Carroll. London: Macdonald, 1984.

- Nymphets \& Fairies. London: Academy Editions, 1976.

- Pre-Raphaelite Photography. London: Academy Editions, 1972.

- Recording Angels, Lewis Wickes Hine. Nottingham: University Press, 1993.

- Victorian Erotic Photography. London: Academy Editions, 1973.

OVENDEN, Graham; MELVILLE, Robert. Victorian Children. London: Academy Editions, 1972.

PAGLIA, Camille. Vamps \& Tramps: más allá del feminismo. Madrid: Valdemar, 2001.

PANOFSKY, Erwin y Dora. La caja de Pandora: Aspectos cambiantes de un símbolo mítico. Barcelona: Barral, 1975.

PARRIS, Leslie (ed.) Pre-Raphaelite Papers. The Tate Galley, London, 1984 PEARSALL, Ronald. The Worm in the Bud. The World of Victorian Sexuality. Penguin Books, London, 1983.

PEARSON, Michael. The Age of Concent: Victorian Prostitution and it's 
Enemies. New York: Randon House, 1962.

PEDRAZA, Pilar. Espectra. Descenso a las criptas de la literatura y el cine. Madrid: Valdemar, 2004.

- La Bella, enigma y pesadilla. Valencia: Almudín, 1983.

- Máquinas de amar: secretos del cuerpo artificial. Madrid: Valdemar, 1998.

PILKINGTON, Godfrey. Art and Design. London: The Academy Group Ltd., 1985. POE, Edgar Allan. Edgar Allan Poe: Essays and Reviews. Ed. G.R. Thompson. New York: The Library of America, 1984.

- Poesía Completa. Col. Ucieza. Barcelona: Ediciones 29, 2002.

POLLOCK, Griselda. Vision and Difference. Feminity, Feminism and the Histories of Art. London: Routledge, 1988.

PRAZ, Mario. PRAZ, Mario. La carne, la muerte y el diablo en la literatura romántica. Barcelona: El Acantilado, 1999.

PROPP, Vladimir. Las raíces históricas del cuento. Madrid: Editorial Fundamentos, 1987.

ROSE, Andrea. Pre-Raphelite Portraits. Oxford: The Oxford Illustrated Press, 1981.

ROSE, Jaqueline. The Case of Peter Pan. The Imposivility of Children's Fiction. Philadelphia: University of Pennsylvania Press, 1993.

RUSKIN, John. Sésamo y lirios. Ensayos Sociales. Buenos Aires: EspasaCalpe, 1950.

SCHARF, Aaron. Arte y fotografía. Madrid: Alianza Forma, 1994.

SELMA DE LA HOZ, J. V. Los Prerrafaelitas. Barcelona: Montesinos, 1991. SIGLER, Carolyn (ed.). Alternative Alices. Visions and Revisions of Lewis Carroll's Alices Books. An Anthology. Kentucky: The University Press of Kentucky, 1997. 
SANTIAGO, Pablo. Alicia en el lado oscuro. La pedofilia desde la antigua Grecia hasta la era Internet. Madrid: Imagine ediciones, 2004.

SINCLAIR, Marianne. Hollywood Lolitas. The Nymphette Syndrome in the Movies. London: Plexus, 1988.

SINYARD'S, Neil. Children in the Movies. New York: St. Martin's Press, 1992. SONTANG, Susan. Sobre la fotografía. Barcelona: Edhasa, 1996.

SPARKS, Patricia. La imaginación femenina. Madrid: Debate/Pluma, 1980. SPIELMANN, Marion H. Millais and His Works. London: Blackwood, 1898. STAFFORD, Ann. The Age of Consent. Hodder and Soughton, London, 1964. STALEY, Allen; NEWALL, Christopher. Prerrafaelistas. La visión de la naturaleza. Barcelona: Fundación La Caixa, 2004.

STEWARD, James Christen. The New Child: British Art and the Origin of Modern Childhood. 1730-1830. Washington: University of Washington, 1995.

THACKERAY, Hester F. Three Freshwater Friends: Tennyson. Watts and Mrs. Cameron. Newport: Hunnyhill Pubns, 1933.

TENNYSON, Alfred. In Memoriam, Maud and other poems. London: Everyman, 1996.

- La dama de Shalott; y otros poemas. Valencia: Editorial Pre-Textos, 2002.

- Poetical Works of Alfred Tennyson. London, Macmillan, 1911.

TOWNSEND, Chris. Vile Bodies. Photography and the Crisis of looking. Munich-NewYork: Prestel-Verlang, 1998.

TRIAS, Eugenio. Lo Bello y lo Siniestro. Barcelona: Ariel, 1992.

USHERWOOD, Nicholas. The Brotherhood of Ruralists. London: Lund Humphries, 1981.

VENTURA, Lourdes. La tiranía de la belleza. La mujeres ante los modelos 
estéticos. Barcelona: Plaza \& Janés, 2000.

VIRCONDELET, Alain. Les Chats de Balthus. Paris: Flammarion, 2000.

WALKOWITZ, Judit. Prostitution and Victorian Society, Women, Class and the State. Cambridge: Cambridge University Press, 1980.

- La ciudad de las pasiones terribles. Narraciones sobre el peligro sexual en el Londres Victoriano. Col. Feminismos. Madrid: Ediciones Cátedra, 1995.

"WALTER" (anón.). My Secret Life. Jesús Díez Editor, Barcelona, 1978 WEAVER, Mike. British Photography in the Nineteenth Century. The Fine Art Tradition. Cambridge: Cambridge University Press. 1989.

WEIERMAIR, Peter (ed.). Erotic Art. From the $17^{\text {th }}$ Century to the $20^{\text {th }}$ Century. Zurich/New York: Edition Stemmler, 1999.

WILSON, Edward. El castillo de Axel. Estudios sobre literatura imaginativa de 1870-1930. Barcelona: Destino, 1996.

WULLSCHLAGER, Jackie. Inventing Wonderland: The Lives and Fantasies of Lewis Carroll, Edward Leard, J.M. Barrie, Kenneth Grahame and A.A. Milne. London: Methurn, 1995.

ZEGHER,M. Catherine. Inside the Visible: An Elliptical Traverse of Twentieth Century Art in, of and from the Femenine. Cambridge: M.I.T. Press, 1995.

ZELIZER, Viviana A. Pricing the Priceless Child. The Changing Social Value of Children. Princeton (N.J.): Princeton University Press, 1994.

\section{Ficción, cuentos y poesía:}

AA.VV. Érase una Vez... Una colección de los Mejores Cuentos de Hadas. Montreal: Tormont Publications, 2004.

ANDERSEN, Hans Christian. Cuentos. Barcelona: Labor, 1974. 
BALZAC, Honoré de. Seraphita. Paris: L'Harmattan, 1995.

BAUDELAIRE, Charles. Las flores del mal. Madrid: Cátedra, 1997.

CARROLL, Lewis. Alicia en el País de las Maravillas. A través del espejo. Madrid: Editorial Cátedra, 2001.

- Aventuras Subterráneas de Alicia. Erase una vez... Biblioteca de cuentos maravillosos. Barcelona: José J. De Olañeta, Editor, 2000.

- El paraguas de la rectoría. Cajón de Sastre. (Ed., trad. y notas de Carlos Miguel Sánchez-Rodrigo), Barcelona: Parsifal Ediciones, 1998.

CARROLL, Lewis; GARDNER, Martín (ed.). Alicia anotada. Madrid: Akal Editor, 1984.

CARROLL, Lewis; SANTERBÁS, Santiago R. (ed. anotada). Silvia y Bruno. Madrid. Anaya, 1989.

DURAS, Marguerite. El amante. Barcelona: Tusquets, 2000.

- El amante de la China del Norte. Barcelona: Tusquets, 1998.

EUGENIDES, Jeffrey. Las vírgenes suicidas. Barcelona: Anagrama, 2001.

FRANK BAUM, L. El Mago de Oz. Edición Anotada. (Michael Patrick Hearn, intro. y notas; Martín Gardner, pref.; W. W. Denslow, ilust.), Barcelona: El Aleph Editores, 2002.

GAUTIER, Théophile. Mademoiselle de Maupin. Paris: Editions Gallimard, 2004. GRIMM, Hnos. Cuentos de los hermanos Grimm. Barcelona: Ediciones B, 2000. HOMERO. Odisea. Madrid: Ediciones Cátedra, 2005.

IBSEN, Henrik. Casa de muñecas. Madrid: Espasa-Calpe, 1980.

JAMES, Henry. Otra vuelta de tuerca. Madrid: Grupo Anaya, 1984.

LANG, Andrew (ed.). El libro azul de los cuentos de Hadas. 2 vol. Móstoles: Neo Person, 2000.

MANN, Thomas. Muerte en Venecia. Barcelona: Plaza y Janés Editores, 1999. 
MONTGOMERY, Lucy Maud. Ana la de Tejas Verdes. Barcelona: Emecé Editores, 1996.

- The Annotaded Anne of Green Gables. (Wendy E. Barry; Margaret Anne Doody; Mary E. Doody Jones, ed.). New YorK/Oxford: Oxford University Press, 1997.

NABOKOV, Vladimir. El hechicero. Barcelona: Anagrama, 1999.

- Lolita. Barcelona: Anagrama, 1995.

- The Annotated Lolita. New York: Mc Graw Hill, 1970.

OVIDIO NASÓN, Publio. Metamorfosis. V. Madrid: Ediciones Cátedra, 1995. ROSSETTI, Christina Georgina. El mercado de los duendes. Valencia: Pre-Textos, 2004.

SLAVITT, David R. Alicia a los ochenta. Barcelona: Laia, 1989.

WILDE, Oscar. Salomé. Barcelona: Lumen, 1979.

\section{Diccionarios y enciclopedias:}

BORGES, Jorge Luis. El libro de los seres imaginarios. Madrid: Alianza Editorial, 2003.

BRIGGS, C. An Encyclopaedia of Fairies: Hobgoblins, Brownies, Bogies and other Supernatural Creatures. New York: Pantheon Books, 1976.

PAGE, Michael; INGPEN, Robert. Enciclopedia de las cosas que nunca existieron. Criaturas, lugares y personas. Madrid: Anaya, 1990.

\section{Monografías:}

AA.VV. Balthus. New York: Metropolitan Museum of Art and Harry N. Abrams, 1984.

AA.VV. Cameron: The Work and the Career. New York: International 
Museum of Photography at George Eastman House, 1986.

AOKI, Shoichi. Fresh Fruit. Tokio: Phaidon Press, 2005.

BIGGS, Lewis. The Ruralist. Bristol: Arnolfini Review, 1981.

BALTHUS. Balthus, las tres hermanas. Milán: Landucci Editores, 2000.

GROPP, Rose Maria. Köning der Katzen-Fürst des Intimen Der Mater Balthus. Frankfurt: Frankfurter Algemeine Zeitung, 1966.

HAMILTON, David. The Age of Innocence. London: Aurum Press, 1995.

IONESCO, Irina; COLEMAN, A. D. Eva: Eloge de ma Fille. [s.I.]: Alice Press, 2004.

MANN, Sally. At Twelve. Portraits of Young Women by Sally Mann. New York: Aperture, 1988.

- Immediate Family. New York: Aperture, 1992.

NÉRET, Gilles. Balthus. Köln: Taschen, 2003.

OVENDEN, Graham. Aspects of Lolita. London: Academy Editions, 1976.

- Childhood Streets. New York: Ophelia Editions, 1998.

- Graham Ovenden. London; New York: Academy Editions/St. Martin's Press, 1987.

- States of Grace. Photographs, 1964-1989. New York: Ophelia Editions, 1992.

- The Ruralist. Graham Ovenden. London: Academy Editions, 1991.

STURGES, Jock. Jock Sturges. Zurich: Scalo Zurich-Berlin-New York, 1996.

- Radiant Identities. Photographs by Jock Sturges. New York: Aperture, 1994.

- The Last Day of Summer. Photographs by Jock Sturges. New York: Aperture, 1994.

WISSMAN, Fronia E. Bouguereau. San Francisco: Pomegranate Art Books, 1996. 


\section{Textos y artículos en catálogos, periódicos y revistas especializadas:}

AA.VV. C'est la vie. Sally Mann, Lucy Gunning, Joaquim Mogarra, Erwin Wurn, Joël Bartoloméo, Stefan Banz. Bruxelles, Salamanca y Québec: Ediciones Universidad de Salamanca and Centre d'Art ContemporainBruxelles, 1998.

AA.VV. Infancia robada. Testimonios de la explotación sexual infantil. Barcelona: Art Blume, 2001.

AA.VV. "Jodie Foster". Cinema Album no 59. [s.I]. Picture Book JAP, 1978.

AA.VV. "Minoría de edad". Luna Córnea, nº 9, 1996.

AA.VV. The Art-Journal, June $1^{\text {st }} 1863$ y June $1^{\text {st }} 1864$.

AA.VV. Winsconsin Studies in Contemporary Literature. vol. III, no 2, spring 1967.

AA.VV. (Rosa Olivares, Marta Gili, Celia Pardo, Martín Hentschel, Pascual Bruchel, José Luis Brea). "Un mundo adolescente/Teenager world", Tracey Moffat, Jouko Lethola, Céline Van Balen, Rineke Dijkstra, Fernando Moleres. Exit, imagen y cultura, no 4, 2001.

[Anón]. "'Bura-Sera' Vending Machines Stir Local Concerní". Mainichi Daily News. 12 de septiembre de 1993.

[Anón]. "Lewis Carroll Interrupts a Story". Children's Newspaper. 7 de febrero de 1931.

[Anón]. "Oxford in Seventies". Fortnightly Review, no 150, 1941.

[Anón]. "Shields' Mother Fights Photos of Nude Brooke". Los Angeles Times. 26 de septiembre de 1981.

ADAM, Paul. "Des Enfants". La Revue Blanche, no 9, 1895.

AMSTRONG, Nancy. "The Occidental Alice". Differences 2, nº 2, 1990, 
ARAZO, Guillermo. "Testigo de cargo. Lolita y la sexualidad". Cartelera Túria, junio, 1999.

ARMSTRONG, C. "Cupid's Pencil of Light: Julia Margaret Cameron and the Maternalization of Photography". October 76.

CARRILLO DE ALBORNOZ, Cristina. "Balthus un artista marginal y exquisito". Descubrir el ARTE. Año III, no 3, septiembre, 2001.

CARROLL. Lewis. "'Whoso Shall Offend One of These Little Ones?". St. James Gazette, 22 de julio de 1885.

COWARD, R. "A culture obsessed with abuse".The Observer. 6 de mayo, 1993, pág. 54.

DOWSON, Ernest. "The Cult of The Child". The Critic. $17^{\text {th }}$ august, 1889.

EDWARDS, S.H. "Pretty Babies - art, erotica, or kiddie porn?" Historial Photography, vol. 18, Spring 94. pág. 38-46.

EFE. "Nabokov, acusado de plagiar «Lolita» a un periodista alemán". $A B C, 19$ de marzo, 2004.

EUGENIDES, Jeffrey. "Sally Mann: Hayhook, 1989 - black and white photograph". Art Forum, decembre 1994.

GOLDSCHMIDT, A.M.E. "Alice in Wonderland Psycho-Analyzed". The New Oxford Outlook, vol. I, no 1, may, 1933.

GORHAM, Deborah. "The 'Maiden Tribute of Modern Babylon' ReExaminated: Child Prostitution and the Idea of Childhood in LateVictorian England". Victorian Studies 21, no 3, october, 1985.

HAYS, R.P. Daniel Lord; MARTIN QUIGLEY, S.J.; HAYS, Will H. "Versión textual del célebre código de censura Hays en Hollywood". Cinemateca. Montevideo-Uruguay: n. 19, marzo, 1979.

JONES, Sarah. Sarah Jones. Salamanca: Ediciones Universidad de 
Salamanca, 1999.

KINCAID, James R. "Alice's Invasion of Wonderland". PMLA 88, no 1 , january, 1973.

LEACH, Karoline. "On the Discovery of the 'cut pages' in diary document". Times Literary Supplement. May 3, 1996.

MACQUARRIAE, Brian. "No Clear Focus on Nude Photos". Boston Globe. $6^{\text {th }}$ january 1996.

MC MURDO, Wendy. Wendy McMurdo. Salamanca: Ediciones Universidad de Salamanca, 1998.

NEWTON, William. "Upon Photography in an Artistic View, and its relations to the Arts" en Journal of the Photographic Society, no 1. London: marzo, 1853.

PRIOLEAU, Elisabeth. "Humbert Humbert Through the Looking-Glass". Twentieth Century Literature 21, no 4, decembre, 1975.

QUIÑNONERO, Juan Pedro. "Las cartas de Balthus y su primera mujer escarban en el erotismo del pintor". ABC, septiembre, 2001.

ROBINSON, Henry Peach. "Heads I Have Taken Off". The Mirror. $17^{\text {th }}$ january, 1874.

RUEDA, Gerardo. "Balthus y las Lolitas". Arte y Parte, no. 1 febreromarzo, 1996.

SÁNCHEZ, Rosalía. "«Lolita» sedujo a Nabokov desde las páginas de «la Gioconda maldita», de Heinz von Lichberg". ABC, 20 de marzo, 2004.

SMITH, Joan. "Do We Want All Our Children to Be Little Lolitas?". The Independient on Sunday, London: March 26, 1998.

STEAD, William Thomas. "The Maiden Tribute of Modern Babylon". Palm Mall Gazette, july, 1885. 
The Art-Journal, June $1^{\text {st }} 1863,1864$.

TORNER, Gustavo. "Balthus y Lewis Carroll". Arte y Parte, no. 1 febreromarzo, 1996.

VALLS, Xavier. "Encuentro con Balthus". Arte y Parte, no. 1 febreromarzo, 1996.

VÁZQUEZ, Xesús. "La carne, la luz, el tiempo". Arte y Parte, no. 1 febrero-marzo, 1996.

WOOD, Bret. "Lolita Syndrome". Sight and Sound. June, 1994.

\section{Documentos electrónicos:}

AA.VV. XX Meeting a Reverse or Two [en línea]. Edward William Bok (1863-1930). The Americanization of Edward Bok, 1921. [ref. de 13 de septiembre de 2005]. Disponible en Web: http://www.bartleby.com/ $197 / 20 . h t m l$

AA.VV. The Cult of the Child. Images of Children in late $19^{\text {th }}$ Century Art [en línea]. [ref. de 3 de marzo de 2005]. Disponible en Web: http://www.artfund.org/main_site/artfundmags_archive.asp?id=551

Informe sobre la pornografía infantil en Internet [en línea]. ANESVAD [ref. de 31 de mayo de 2006]. Disponible en Web: http://www.anesvad.org/informe.pdf

BLACK, Louise. Page Two. [en línea]. Austin Chronicle [ref. de 3 de abril de 2002]. Disponible en Web: http://www.austinchronicle.com/issues/ vol18/issue07/cols.pagetwo.html

CALHOUN, Ada. The Man Who Loved Little Girls [en línea]. Austin Chronicle, 10-12-98. [ref. de 29 de marzo de 2002]. Disponible en Web: http://www.weeklywire.com/ww/10-12-98/austin_arts_feature1.html 
CREIGHTON, Susan J. Child Pornography: Images of the Abuse of Children. Information Briefings November 2003 [en línea]. NSPCC The Online Child Protection Resource. [ref. de 3 de diciembre de 2004]. Disponible en Web: http://www.nspcc.org.uk/inform

DRIBEN, Leila. Balthus el gran excéntrico [en línea]. Letras Libres, Mayo 2001. [ref. de 17 de octubre de 2006]. Disponible en Web: http://www.letraslibres.com/index.php?art $=6820$

ESTEBAN, Iñaki. La jovencita que sedujo a Nabokov [en línea]. La biblioteca de Mafaldas. [ref. del 26 de junio de 2006]. Disponible en Web: http://www.espacioblog.com/mafaldas/post/2006/03/24/la-jovencita-sedujonabokov

EUGENIDES, Jeffrey. Sally Mann: Hayhook, 1989 - black and white photograph [en línea]. [ref. del 17 de junio de 2006]. Disponible en Web: http://www.findarticles.com/p/articles/mi_m0268/is_n4_v33/ai_16547726 GUTEN COHEN, Keri. Photos Capture Childhood's Innocence. Sally Mann's Nude Portraits Reflect the Raw Honesty of Childhood [en línea]. Detroit Free Press [ref. del 7 de junio de 2000]. Disponible en Web: http://www.free.com

J. Sir A.; IANTHE. An Interview with artist and photographer Graham Ovenden. [en línea]. $11^{\text {th }}$ September 1999 [ref. del 14 de septiembre de 2000]. Disponible en Web: http://duende.f2s.com/ovenden/ovenden.html KINCAID, James R. 'Is this child pornography? [en línea]. Salon.com [ref. del 4 de octubre de 2006]. Disponible en Web: http://dir.salon.com/story/mwt/feature/2000/01/31/kincaid/index.html

LEACH, Karoline. The Ages of Charles Dodgson's Female Friends as Reflected in "The Letters of Lewis Carroll" [en línea]. Agora: An Online Graduate Journal, 2.2 (Spring 2003) [ref. del 16 de diciembre de 2004]. Disponible en Web: http://www.arts.ualberta.ca/agora 
LEBAILLY, Hugues. C. L. Dodgson and the Victorian Cult of the Child: A Reassenssment on the Hundredth Anniversay of 'Lewis Carroll's' Death [en línea].

- Charles Lutwidge Dodgson's Infatuation wih the Weaker and More Aesthetic Sex-Re-Examined [en línea].

- "Dreaming in Pictures" extractos de Douglas R Nickel. Dreaming in Pictures: The Photography of Lewis Carroll [en línea].

- Through a distorting looking-glass: Charles Lutwidge Dodgson's artistic interests as mirrored in his nieces edites version of his diaries. Looking for Lewis Carroll [en línea]. [ref. de 18 de febrero de 2006]. Disponible en Web: http://www.lookingforlewiscarrol.com

MCNICOL, Tony. Does comic relief hurt kids? [en línea]. Japan Times, Tuesday, April 27, 2004 [ref. de 17 de octubre de 2006]. Disponible en Web: http://www.japantimes.co.jp

RODRIGUEZ ALMODOVAR, A. Caperucita, el más enigmático de los cuentos [en línea]. [ref. de 24 de enero de 2005]. Disponible en Web: http://www.cuatrogatos.org/3caperucita.html

Sally Mann's Powerful Photographs Disturb Fascinate [en línea]. [ref. de 3 de abril de 2002]. Disponible en Web: http://www.mtholyoke/ edu/offices/com/csj/990402/sallymann.html

State Child Pornography Statutes [USA] [en línea]. [ref. de 28 de junio de 2006]. Disponible en Web: http://www.ndaaapri.org/pdf/statute_child_pornography_2004.pdf

STONEY, Elizabeth. Alice Does: The Erotic Child of Photography [en línea]. [ref. de 16 de noviembre de 2004]. Disponible en Web: http://www.ahcca.unimello.edu.aa/ screenscape/alice.htm 
SUAREZ, Beatriz. Nabokov podría haber plagiado «Lolita» a un periódico alemán [en línea]. La Razón digital. [ref. de 20 de marzo de 2004]. Disponible en Web: http://www.larazon.es/noticias/noti_cul03.htm '«Virtual Child» Pornograhy on the Internet: $A$ «Virtual Victim»? [en línea]. Duke Law and Tecnologhy Review [ref. de 14 de octubre de 2006]. Disponible en Web: http://www.law.duke.edu/journals/dltr/articles/2002dltr0019.html WIJERS-HASEGAWA, Yumi. Japan coming up short on child rights [en línea]. Japan Times, Wednesday, March 31, 2004 [ref. de 17 de octubre de 2006]. Disponible en Web: http://www.japantimes.co.jp

WOOD, Alexandra. Constructions of Childhood in Art and Media: Sexualized Innocence [en línea]. Agora: An Online Graduate Journal, 2.2 (Spring 2003). [ref. de 16 de diciembre de 2004]. Disponible en Web: http://www.arts.ualberta.ca/agora

YUSTI, Carlos. Balthus, pintor de lolitas a plena luz. Enfocarte.com. Arte y cultura en la red [en línea]. [ref. de 17 de julio de 2006]. Disponible en Web: http://www.enfocarte.com/1.9/articulo.html

\section{Trabajos de Investigación:}

SILVESTRE MARCO, María. La imagen de la preadolescente y su representación en el cine. El icono de Lolita. Dirigida por la Catedrática Dña. Pilar Roig Picazo. [Trabajo de Investigación tutelado]. Universidad Politécnica de Valencia, Facultad de Bellas Artes de San Carlos, Departamento de Conservación y Restauración de Bienes Culturales, 2003.

\section{Informes y legislación:}

Criminal Law Amendment Act. London: 1885. 
"Decisión relativa a la lucha contra la pornografía infantil en Internet". Consejo de la Unión Europea, 2000.

Hatfield House. MSS 3M/D XIII/101.

HAYS, R.P. Daniel Lord. Código de Producción. 1930.

"Informe sobre la pornografía infantil en Internet". ANESVAD, 2000.

"Report of the Royal Commission on the Administration and Operation of the Contagious Diseases Acts 1868-69". Parlamentary Papers, 29. London: C. 408, 1871.

State Child Pornography Statutes [USA] [en línea].

Thirthy-first Annual Report of the Rescue Society. London: 1883.

\section{Filmografía:}

Vladimir Nabokov-Apostrophes. Entrevista a Vladimir Nabokov. Programa Apostrophes presentado por Bernard Pivot [Vídeo]. Editagrama. Videoteca de la memoria literaria, Ediciones Trasbals Multimedia, mayo de 1975. 



\section{APÉNDICE:}

\section{Siglas y abreviaturas utilizadas.}

anón.: anónimo.

c.: circa (cerca, aproximadamente).

cap.: capítulo.

cf.: confer (compárese).

cit.: citado.

ej.: ejemplo.

fig.: figura, imagen.

ibíd.: ibídem (en el mismo lugar, misma obra y misma página).

íd.: ídem (el mismo, lo mismo).

n.: nota.

N.B.: Nota Bene (nótese bien, obsérvese).

N. del A.: nota del autor.

op. cit.: opus citatum, opere citato (en la obra ya citada).

pág., págs.: página, páginas.

s.: siglo.

s.a.: $\sin$ año.

s.d.: sine data (sin fecha de edición ni de impresión).

s.f.: $\sin$ fecha.

s.I.: $\sin$ lugar de edición.

trad.: traducción.

v.: véase.

vol., vols.: volumen, volúmenes.

2. Criterios para referenciar bibliografías, documentos electrónicos, documentos audiovisuales y filmografías.

Para la elaboración de las referencias bibliográficas se han seguido los criterios de la norma ISO 690-1987 y su equivalente UNE 50-104-94.

\subsection{Bibliografía. Normas:}

INTERNATIONAL STANDARIZATION ORGANIZATION. Documentation -Références bibliographiques-contenu, forme et structure. Norme international ISO 690:1987 (F). $2^{a}$ ed. Genève: ISO, 1987, pág. 11 . 
La imagen de la preadolescente y su representación en el arte.

INTERNATIONAL STANDARIZATION ORGANIZATION. Information -Références bibliographiques. Partie 2: Documents électroniques, documents ou parties de documents. Norme international ISO 690-2: 1997 (F). Genève: ISO, 1997, pág. 18.

AENOR: Documentación. Referencias bibliográficas. Contenido, formas y estructura. UNE 50104 94. Madrid: AENOR, 1994. 
ÍNDICE DE ILUSTRACIONES:

Pág.

20 1. Antecedentes literarios del icono de la preadolescente como fenómeno artístico.

23 Fig. 1. La dama de Shalott (1857), ilustración de Dante Gabriel Rossetti.

25 Fig. 2. La Dama de Shalott (c. 1888) por John William Waterhouse.

26 Fig. 3. Ofelia (1889) por John William Waterhouse.

29 Fig. 4. La Bella Durmiente (s.a) por William A. Breakspeare.

35 Fig. 5. Rapunzel (1882). Walter Crane para Household Stories from the Collection of the Brothers Grimm.

38 Fig. 6. Cenicienta (1899) por Valentine Cameron Prinsep.

41 Fig. 7. La juventud de la Virgen María (1848-9) por Dante Gabriel Rossetti.

41 Fig. 8. Santa Isabel de Hungría (1882) por Sándor Liezen-Mayer.

43 Fig. 9. Ecce Ancilla Domini (1850), Dante Gabriel Rossetti.

43 Fig. 10. Pájaro de Dios [Bird of God] (1861) por Joanna Boyce.

43 Fig. 11. Ángel (1887), Abbott Handerson Thayer.

43 Fig. 12. Lilith (1887) por John Collier.

48 Fig. 13. Lamia (1909) por John William Waterhouse.

48 Fig. 14. Sirena (1901) por John William Waterhouse.

49 Fig. 15. Un hada ofrece a Elsie un ramillete de jacintos silvestres (1917). Foto tomada por Frances.

49 Fig. 16. Frances y las hadas (1917). Fotografía tomada por Hélice.

49 Fig. 17. Ilustración del libro El Libro de Regalo de la Princesa María.
49 2. La sexualidad en el siglo XIX.

52 Fig. 1. Prostituta comprando el silencio a un policía (s. XIX), grabado anónimo.

53 Fig. 2. Wentworth Street. (s. XIX), grabado anónimo.

65 3. La Hermandad Prerrafaelista y el arte victoriano.

68 Fig. 1. En el Tepidarium (1881) por Sir Lawrence Alma-Tadema.

68 Fig. 2. Venus anudándose el cabello (1897) por John William Godward.

69 Fig. 3. Madre e hija (1865) por Frederick Leighton.

70 Fig. 4. La Virgen y Niño con Santa Ana (1510) por Leonardo Da Vinci.

70 Fig. 5. La lección de música (1877) por Frederick Leighton.

70 Fig. 6. Ecce Ancilla Domini (1850) por Dante Gabriel Rossetti.

71 Fig. 7. Beata Beatrix (1864-70) por Dante Gabriel Rossetti.

72 Fig. 8. Ofelia (1851-52) por Sir John Everett Millais.

72 Fig. 9. Ofelia (1853) por Arthur Hughes.

72 Fig. 10. Ofelia (XIX) por James Sant.

74 Fig. 11. La dama de Shalott (1850), dibujo de William Holmat Hunt.

74 Fig. 12. La dama de Shalott (1857), grabado de William Holmat Hunt.

74 Fig. 13. La dama de Shalott (1889) por William Holmat Hunt.

74 Fig. 14. La dama de Shalott (1853) dibujo de Elisabeth Siddall

75 Fig. 15. Estudio para La dama de Shalott (1894) por John William Waterhouse.

75 Fig. 16. La dama de Shalott (1894) por John William Waterhouse. 
76 Fig. 17. El anatomista (1869) por Gabriel Von Max.

76 Fig. 18. La muerte de Albine (1895) por John Collier.

77 Fig. 19. La hija del leñador (1860) por Arthur Hughes.

77 Fig. 20. Petirrojos en los tiempos modernos (c. 1860) por John Roddam Spencer Stanhope.

78 Fig. 21. Perdida en el bosque (1860) guache de Edmund George Warren.

79 Fig. 22. Descanso en la cosecha (1865) por Adolphe-William Bouguereau.

79 Fig. 23. Bohemia (1890) por AdolpheWilliam Bouguereau.

79 Fig. 24. El botijo roto (1891) por AdolpheWilliam Bouguereau.

80 Fig. 25. Joven Pastora (1885) por Adolphe-William Bouguereau.

80 Fig. 26. Meditación (1885) por AdolpheWilliam Bouguereau.

80 Fig. 27. Pastorcita (1891) por AdolpheWilliam Bouguereau.

81 Fig. 28. Hojas de otoño (1856) por Sir John Everet Millais.

81 Fig. 29. La muchacha ciega (1854-56) por Sir John Everett Millais.

82 Fig. 30. Cristo en la casa de sus padres (1849-5) por John Everett Millais.

83 Fig. 31. Mi primer sermón (1863) por John Everett Millais.

83 Fig. 32. Mi segundo sermón (1864) por John Everett Millais.

83 Fig. 33. Los ojos mas dulces que jamás haya visto (1881) por John Everett Millais.

84 Fig. 34. Madonna y niño (1907-98) por Marianne Stokes.

84 Fig. 35. Santa Isabel de Hungría hilando para los pobres (1895) por Marianne Stokes.

85 Fig. 36. La devoción de Santa Isabel de Hungría (1852) dibujo de Charles Allston Collins.
85 Fig. 37. Isabel (1889) por P. H. Calderon.

85 Fig. 38. Al acostarse (1862) por Arthur Hughes.

86 Fig. 39. La niña entronizada (c. 1894) por Thomas Cooper Gotch.

86 Fig. 40. Mi trono y mi cetro (1891) por Thomas Cooper Gotch.

87 Fig. 41. Aleluya (c. 1896) por Thomas Cooper Gotch.

87 Fig. 42. Una broma (s.a.) por Thomas Cooper Gotch.

87 Fig. 43. El desfile de niños (1895) por Thomas Cooper Gotch.

87 Fig. 44. La bandera (191?) por Thomas Cooper Gotch.

88 Fig. 45. La bañista (s.a) por Paul Emile Chabas.

88 Fig. 46. El bebé de Agua [The Water Baby] (1890) por John Collier.

88 Fig. 47. Niña en el baño (1886) por AdolpheWilliam Bouguereau.

88 Fig. 48. Salomé triunfante (1886) por Édouard Toudouze.

89 Fig. 49. Lady Godiva (1898) por John Collier.

89 Fig. 50. Autorretrato con la familia (c. 1903) de F. von Lembach.

91 Fig. 51. Ilustración de Jessie Wilcox Smith para Los bebés de agua [The Water Babies] (c. 1863) de Charles Kingsley.

92 Fig. 52. Bajo la ventana [Under the Window] (1878) por Kate Greenaway.

92 Fig. 53. Dejando el colegio [Leaving the School. St. Nicholas. Volume 6, No. 3 (Enero 1879) por Kate Greenaway.

85 Fig. 54. El jardín de caléndulas [Marigold Garden] (1885) por Kate Greenaway.

84 Fig. 55. El flautista de Hamelin [The Pied Piper of Hamelin] (1888) por Kate Greenaway.

94 Fig. 56. Cerezas maduras [Cherry Ripe] (1879) por John Everett Millais. 
94 Fig. 57. Las hijas del pintor atrapando una mariposa (1756) por Gainsborough.

94 Fig. 58. Little Miss Muffet (1886) por John Everett Millais.

94 Fig. 59. Bubble (1886) por John Everett Millais.

95 Fig. 60. Burbujas usado para Pear's Soap.

95 Fig. 61. Anuncios para Pear's Soap (c. 1914).

95 Fig. 62. La Bella Durmiente. Ilustraciones de Walter Crane para The Bluebeard Picture Book (1875).

96 Fig. 63 Blancanieves. Ilustraciones de Walter Crane para Household Stories from the Collection of the Brothers Grimm.

96 Fig. 64. Blancanieves. Ilustraciones de Walter Crane para Household Stories from the Collection of the Brothers Grimm.

97 Fig. 65. Blancanieves y los siete enanitos. Ilustración de Ada Dennis y E. Stuart Hardy para Grimm's Fairy Tales.

97 Fig. 66. Blancanieves. Ilustración de Arthur Rackham para The Fairy Tales of the Brothers Grimm.

98 Fig. 67. Caperucita (1867). Ilustración de Gustav Doré para Les Contes de Perrault.

98 Fig. 68. Caperucita (1865) por John Everet Millais.

98 Fig. 69. Caperucita roja (s.a.) por George Frederic Watts.

98 Fig. 70. Caperucita Roja. Ilustración de Walter Crane para Little Red Riding Hood (1875).

99 Fig. 71. Tarjetas de felicitación ilustradas por William S. Coleman.

99 Fig. 72. Tarjetas de felicitación ilustradas por William S. Coleman.

100 Fig. 73. Tarjetas de felicitación ilustradas por William S. Coleman.

100 Fig. 74. Tarjetas de felicitación ilustradas por William S. Coleman.

100 Fig. 75. El Arca de Noé. Grabado de Arthur Boyd Houghton para House Thoughts and Home Scenes (1865).
100 Fig. 76. El asiento del tren. Grabado de Arthur Boyd Houghton para House Thoughts and Home Scenes (1865).

102 Fig. 77. La habitación de las niñas (c. 1895), acuarela de Carl Larsson.

102 Fig. 78. Detalle. La habitación de las niñas (c. 1895), acuarela de Carl Larsson.

103 Fig. 79. Die Grenouillère (1892) ilustraciones de Choisy le Conin (Franz Von Bayros).

103 Fig. 80. Die Grenouillère (1892) ilustraciones de Choisy le Conin (Franz Von Bayros).

103 Fig. 81. Die Grenouillère (1892) ilustraciones de Choisy le Conin (Franz Von Bayros).

104 Fig. 82. Die Grenouillère (1892) ilustraciones de Choisy le Conin (Franz Von Bayros).

104 Fig. 83. Die Grenouillère (1892) ilustraciones de Choisy le Conin (Franz Von Bayros).

104 Fig. 84. Portada de la revista Town Talk, que ilustra la venta de una virgen y otras escenas, basadas en El tributo de las doncellas en la moderna Babilonia de The Palm Mall Gazette

107 4. Fotografía victoriana.

110 Fig. 1. Niña con espejo (1860) por Oscar G. Rejlander.

110 Fig. 2. Niña sosteniendo un jarroncito (1860) por Oscar G. Rejlander.

110 Fig. 3. Niña con la mirada perdida (1860) por Oscar G. Rejlander.

110 Fig. 4. Niña pensativa (1860) por Oscar G. Rejlander.

111 Fig. 5. Desnudo infantil (1902) por Alice Boughton.

111 Fig. 6. Estudio de desnudo infantil publicado por Schench de New York (1880).

111 Fig. 7. Sin título (finales del s. XIX), autor anónimo. 
111 Fig. 8. Joven del norte de África (principios s. XX), autor anónimo.

111 Fig. 9. Estudio infantil (1874) por Katie Morrison.

112 Fig. 10. Dormida (1855) por John Whistler.

112 Fig. 11. Serie de Caperucita roja (1858) por Henry Peach Robinson.

113 Fig. 12. La dama de Shalott (c. 1860) por Henry Peach Robinson.

113 Fig. 13. Dormidos (1858) por Henry Peach Robinson.

114 Fig. 14. Trayendo mayo al hogar (1862) por Henry Peach Robinson.

114 Fig. 15. Primavera (1856-9) por John Everett Millais.

115 Fig. 16. Interior de Tintern Abbey (1850) por Rober Fenton.

116 Fig. 17. Niña muerta (1865) por Southwares and Hawes.

118 Fig. 18. Niña con los dedos entrecruzados (1864) por Julia Margaret Cameron.

118 Fig. 19. Niña con la cabeza reclinada hacia el hombro (1864) por Julia Margaret Cameron.

118 Fig. 20. Daisy Bradley (1864) por Julia Margaret Cameron.

118 Fig. 21. Annie Philpott, mi primer éxito [My First Success] (1864) por Julia Margaret Cameron.

119 Fig. 22. El rey Lear repartiendo su reino entre sus tres hijas. ¿Que debe hacer Cordelia? Amar y estar en silencio. [King Lear allotting his Kingdom to his three daughters. 'What shall Cordelia do? Love and be silent] (1872) por Julia Margaret Cameron.

119 Fig. 23. Estudio de niña muerta (c. 1868) por Julia Margaret Cameron.

120 Fig. 24. Mi nieto Archie, hijo de Eugene, nacido en Barbados el 25 de mayo de 1853. Dos años $y$ tres meses (1865) por Julia Margaret Cameron.
120 Fig. 25. Mi nieto Archie, hijo de Eugene, nacido en Barbados el 25 de mayo de 1853. Dos años y tres meses (1865) por Julia Margaret Cameron.

120 Fig. 26. Hermanas del alma (1867) por Julia Margaret Cameron.

121 Fig. 27. La sombra de la Cruz (1865) por Julia Margaret Cameron.

121 Fig. 28. La sunamita y su hijo muerto (1865) por Julia Margaret Cameron.

122 Fig. 29. La Madonna Della Pace/ Perfecta en paz (1865) por Julia Margaret Cameron.

122 Fig. 30. La Madonna Esaltata/ Ferviente en el rezo (1865) por Julia Margaret Cameron.

123 Fig. 31. Querubín y Serafín (c. 1864-66) por Julia Margaret Cameron.

123 Fig. 32. Amor frívolo [Love in Idleness] (1866) por Julia Margaret Cameron.

123 Fig. 33. Cupido en pie (c. 1867) por Julia Margaret Cameron.

123 Fig. 34. Paul and Virginia (1864) por Julia Margaret Cameron.

124 Fig. 35. Hijo, ¿por qué has hecho esto? He aquí que tu padre $y$ yo te buscábamos angustiados ['Wist ye not that your father and I sought thee sorrowing?] (1865) por Julia Margaret Cameron.

124 Fig. 36. La belleza de la santidad [The Beauty of Holiness] (1866) por Julia Margaret Cameron.

124 Fig. 37. Sus desconsolados bebés/ iLa madre se movió! [The Bereaved Babes/The Mother Moved!] (1864) por Julia Margaret Cameron.

125 Fig. 38. Béatrice Cameron (1872) por Julia Margaret Cameron.

125 Fig. 39. Rosas rojas y blancas [Red and White Roses] (c. 1865) por Julia Margaret Cameron.

125 Fig. 40. El aniversario [The Anniversary] (1865) por Julia Margaret Cameron.

125 Fig. 41. Orante [Prayer] (c. 1866) por Julia Margaret. Cameron. 
126 Fig. 42. La reina Ginebre y la pequeña novicia (1874) por Julia Margaret Cameron.

126 Fig. 43. El susurro de la musa (1865) por Julia Margaret Cameron.

127 Fig. 44. Hágase tu voluntad [Thy will be Done] (1872) por Julia Margaret Cameron.

127 Fig. 45. Rachel Gurney. Espero [I Wait] (1872) por Julia Margaret Cameron.

127 Fig. 46. Cupido considerando [Cupid Considering] (1872) por Julia Margaret Cameron.

127 Fig. 47. Cupido descansando (1872) por Julia Margaret Cameron.

128 Fig. 48. Primavera [Spring] (1855) por Julia Margaret Cameron.

129 Fig. 49. Bondad [Goodness] (c. 1864) por Julia Margaret Cameron.

129 Fig. 50. Bendiciendo y bendecido [Blessing and Blessed] (1865)por Julia Margaret Cameron.

129 Fig. 51. Fe [Faith] (1864) por Julia Margaret Cameron.

129 Fig. 52. Amor (1864) por Julia Margaret Cameron.

129 Fig. 53. Mary Hillier, Elizabeth and Kate Kuhn. Sagrada Familia [Holy Family] (1864) por Julia Margaret Cameron.

129 Fig. 54. Mary Hillier, Elizabeth and Kate Kuhn. Sagrada Familia [Holy Family] (1864) por Julia Margaret Cameron.

130 Fig. 55. Florence Fisher. Estudio para San Juan Bautista (1872) por Julia Margaret Cameron.

122 Fig. 56. Florence Fisher (1872) por Julia Margaret Cameron.

130 Fig. 57. San Juan (s.a.) por John William Waterhouse.

130 Fig. 58. La rosaleda de muchachas [The Rosebud Garden of Girls] (1870) por Julia Margaret Cameron.
131 Fig. 59. La doble estrella (1862) por Julia Margaret Cameron.

132 Fig. 60. Hilandera en una factoría de algodón en Nueva Inglaterra. North Pownal, Vermont, Estados Unidos (1913) por Lewis Hine.

133 Fig. 61. Edith, cinco años de edad (c.1910) por Lewis Hine.

133 Fig. 62. Rosie, siete años de edad, una experimentada extractora de ostras. Bluffton, Carolina del Sur, Estado Unidos (1913) por Lewis Hine.

134 Fig. 63. Florence Holder (1876) por Dr. Barnardo.

134 Fig. 64. La noche en la calle del sinhogar [A night out homeless] (c. 1892-3) por Oscar G. Rejlander.

134 Fig. 65. Florence y Eliza Holder (1876) por Dr. Barnardo.

135 5. Lewis Carroll.

138 Fig. 1. No lloréis, damas (c. 1867) por Arthur Hughes.

138 Fig. 2. Las criadas del Faraón (1883) por John Collier.

135 Fig. 3. Dibujo y fotografía de Annie Gertrude Chataway (1876) por Lewis Carroll, a la que le dedicó La Caza del Snark.

136 Fig. 4. Phoebe Carlo interpretando a Alicia en la adaptación teatral de Henry Savile Clarke, estrenada la Navidad de 1886.

147 Fig. 5. Las 3 hermanas (1864) por William Blake Richmond.

153 Fig. 6. Fotografía oval que aparecía en el manuscrito de Aventuras Subterráneas de Alicia.

154 Fig. 7. Ilustraciones de Lewis Carroll para el manuscrito de Aventuras Subterráneas de Alicia.

154 Fig. 8. Ilustraciones de Lewis Carroll para el manuscrito de Aventuras Subterráneas de Alicia. 
154 Fig. 9. Ilustraciones de Lewis Carroll para el manuscrito de Aventuras Subterráneas de Alicia.

154 Fig. 10. Ilustraciones de Lewis Carroll para el manuscrito de Aventuras Subterráneas de Alicia.

155 Fig. 11. Ilustraciones de John Tenniel para Alicia en el País de las Maravillas.

155 Fig. 12. Ilustraciones de John Tenniel para Alicia en el País de las Maravillas.

155 Fig. 13. Ilustraciones de John Tenniel para Alicia en el País de las Maravillas.

155 Fig. 14. Ilustraciones de John Tenniel para Alicia en el País de las Maravillas.

156 Fig. 15. Ilustraciones de John Tenniel para Alicia en el País de las Maravillas.

156 Fig. 16. Ilustraciones de John Tenniel para Alicia en el País de las Maravillas.

157 Fig. 17. Ilustración de John Tenniel para $A$ través del espejo.

157 Fig. 18. Ilustración de John Tenniel para $A$ través del espejo.

158 Fig. 19. Ilustraciones de Arthur Rackman para Alicia en el País de las Maravillas.

158 Fig. 20. Ilustraciones de Arthur Rackman para Alicia en el País de las Maravillas.

158 Fig. 21. Ilustraciones de Arthur Rackman para Alicia en el País de las Maravillas.

160 Fig. 22. Ilustraciones de Harry Furnis para Silvia y Bruno.

160 Fig. 23. Ilustraciones de Harry Furnis para Silvia y Bruno.

160 Fig. 24. Ilustraciones de Harry Furnis para Silvia y Bruno.

161 Fig. 25. Ilustraciones de Gertrude Thomson para Tres atardeceres (1898).

161 Fig. 26. Ilustraciones de Gertrude Thomson para Tres atardeceres (1898).

164 Fig. 27. Arthur Hughes y su hija Agnes (12 de octubre de 1863).

165 Fig. 28. Reverendo R. Gandell and Florence (1862).
165 Fig. 29. Barker y su hija May (6 de junio, 1864).

165 Fig. 30. El novelista George MacDonald y su hija Lilia "Lily" en Kengsington (Octubre 14, 1863).

166 Fig. 31. Phoebe "Effie"Newall (1871).

167 Fig. 32. San Jorge y el Dragón (c. 1874).

169 Fig. 33. Gertrude Dykes (1862).

169 Fig. 34. Beatrice Hatch (24 de marzo, 1874).

169 Fig. 35. Florence Bickersteth (c. 1865-66).

169 Fig. 36. Beatrice Henley (1875).

170 Fig. 37. Alice Constance Westmacott (s.a).

170 Fig. 38. Effie Millais (1865).

173 Fig. 39. Retrato de Evelyn Hatch (c. 1878), coloreada.

174 Fig. 40. Beatrice Hatch (1873), coloreada por Anne Lydia Bond.

175 Fig. 41. Evelyn Hatch (c. 1879), coloreada.

176 Fig. 42. Annie y Frances Henderson con disfraces a lo Robinson Crusoe o como Náufragos (c. 1880), coloreada.

178 Fig. 43. Agnes Grace Weld como Caperucita roja (1859).

178 Fig. 44. Alice Donkin. La fuga (1862).

178 Fig. 45. Agnes Hughes (c. 1863).

178 Fig. 46. Agnes Hughes (c. 1863).

179 Fig. 47. Alexandra "Xie Kitchin" (1873).

179 Fig. 48. Irene MacDonald (1863).

180 Fig. 49. Irene McDonald. «No se alisa» (1863).

181 Fig. 50. Julia Arnold (s.a).

182 Fig. 51. Alexandra "Xie Kitchin" (c. 1874).

182 Fig. 52. Xie Kitchin disfrazada de chino (1873).

182 Fig. 53. Xie Kitchin disfrazada de chino (1873).

183 Fig. 54. Xie con parasol (1876).

183 Fig. 55. Xie vestida de Escandinava (1873).

183 Fig. 56. Xie como violinista (1876).

184 Fig. 57. Xie Kitchin. En vela (1874). 
184 Fig. 58. Xie Kitchin. Una noche de verano (1874).

184 Fig. 59. Xie Kitchin durmiendo (1873..

185 Fig. 60. Xie Kitchin como Penelope Boothby (1879).

185 Fig. 61. Xie Kitchin como Penelope Boothby (1879).

186 Fig. 62. Penelope Boothby (1788) por Joshua Reynolds.

186 Fig. 63. Penelope Boothby (1791), escultura funeraria por Thomas Banks.

188 Fig. 64. Alice Liddell como mendiga (c. 1858).

189 Fig. 65. Alice Liddell (1858).

190 Fig. 66. Alice Liddell (c. 1860).

191 Fig. 67. Fotografía de Alice que utilizaría para el manuscrito de Aventuras Subterráneas de Alicia (1864).

191 Fig. 68. Alice Liddell (s.a.).

191 Fig. 69. Las 3 hermanas Liddell en el jardín del Dean en Christ Church (1856).

192 Fig. 70. Las cerezas. Abre la boca y cierra los ojos (julio de 1860).

193 Fig. 71. Edith, Lorina y Alice Liddell (1859).

193 Fig. 72. Mary y Charlotte Webster y Margaret Gatey, Keswick (1857).

194 Fig. 73. Lorina y Alice Liddell disfrazadas de chinas (1860).

195 Fig. 74. Lorina Charlotte Liddell (1858-9).

195 Fig. 75. Edith Liddell (1858-59).

195 Fig. 76. Alice Liddell (1870).

197 6. «Las niñas del celuloide». La preadolescente en el cine a comienzos del siglo $X X$.

198 Fig. 1. Fotografía promocional de Olive Thomas.

200 Fig. 2. Fotografía promocional dedicada de Mary Miles Minter.

200 Fig. 3. Mary Miles Minter para la portada de la revista Motion Picture.

201 Fig. 4. Lilian Gish en Lirios rotos (1919).

201 Fig. 5. Lilian Gish en Lirios rotos (1919).
201 Fig. 6. Mary Pickford en Pobre niña rica (1917).

203 Fig. 7. Baby Mary Osborne en varios fotogramas de Little Mary Sunshine (1916).

203 Fig. 8. Baby Mary Osborne en varios fotogramas de Little Mary Sunshine (1916).

203 Fig. 9. Baby Mary Osborne en varios fotogramas de Little Mary Sunshine (1916).

204 Fig. 10. Virginia Lee Corbin en Aladino y la lámpara maravillosa (1917).

204 Fig. 11. Virginia Lee Corbin en Aladino y la lámpara maravillosa (1917).

204 Fig. 12. Virginia Lee Corbin en Aladino y la lámpara maravillosa (1917).

205 Fig. 13. Baby Peggy en El capitán alegría (1924).

205 Fig. 14. Baby Peggy en El capitán alegría (1924).

205 Fig. 15. Baby Peggy en El capitán alegría (1924).

207 Fig. 16. Shirley Temple en Kid 'in' Africa (1932).

207 Fig. 17. Shirley Temple en War Babies (1932).

207 Fig. 18. Shirley Temple en War Babies (1932).

207 Fig. 19. Shirley Temple en Baby Burlesks (1932).

207 Fig. 20. Shirley Temple en Baby Burlesks (1932).

207 Fig. 21. Shirley Temple en Baby Burlesks (1932).

209 Fig. 22. Shirley Temple y Cary Grant en El solterón y la menor (1947).

209 Fig. 23. Shirley Temple y Cary Grant en El solterón y la menor (1947).

209 Fig. 24. Shirley Temple y Cary Grant en El solterón y la menor (1947).

209 Fig. 25. Margaret O'Brian en Lost Angel (1943). 
209 Fig. 26. Margaret O'Brian en Bad Bascom (1946).

210 Fig. 27. Margaret O'Brian en Cita en St Louis (1944).

210 Fig. 28. Margaret O'Brian en Cita en St Louis (1944).

210 Fig. 29. Margaret O'Brian en Cita en St Louis (1944).

211 Fig. 30. Fotografía promocional de Baby Gum (1929).

211 Fig. 31. Judy Garland en El Mago de Oz (1934).

212 Fig. 32. Judy Garland junto a Mickey Rooney en Fuego de Juventud (1944).

212 Fig. 33. Judy Garland junto a Mickey Rooney en Fuego de Juventud (1944).

212 Fig. 34. Judy Garland junto a Mickey Rooney en Fuego de Juventud (1944).

213 Fig. 35. Fotografía promocional de Natalie Wood, a finales de la década de 1940.

213 Fig. 37. Natalie Wood en Milagro en la calle 34 (1947).

214 Fig. 38. Baby Sandy en Bachelor Daddy (1941).

215 Fig. 39. Fotografía publicitaria de Deanna Durbin en 1936.

215 Fig. 40. Fotografía publicitaria Gloria Jean, a finales de la década de 1940

209 7. Balthus.

219 Fig. 1. Muchacha con camisa blanca [Jeune Fille à la chemise blanche] (1955).

219 Fig. 2. Frédérique (1954).

219 Fig. 3. Busto de mujer joven (1960-70).

220 Fig. 4. Salón II [Le Salon II] (1942).

220 Fig. 5. Salón III [Le Salon III] (1943).

221 Fig. 6. La falda blanca [La jupe blanche] (1937).

221 Fig. 7. La muchacha [Jeune fille lisant] (1957).

221 Fig. 8. Katia leyendo, [Lecture de Katia ] (1968-70), dibujo preparatorio.

221 Fig. 9. Muchacha adormecida [Jeune fille endormie], (1994).
222 Fig. 10. Katia con los brazos cruzados [Katia aux bras croisés] (c. 1970).

222 Fig. 11. Muchacha con sobrero [Fille avec un béret] (1963).

222 Fig. 12. Muchacha con los brazos cruzados [Jeune fille aux bras croisés] (1955).

223 Fig. 13. El pintor y su modelo [Le Peintre et son Modèle] (1980-81).

224 Fig. 14. Tres hermanas [Les Trois Sœurs] (1955).

224 Fig. 15. Tres hermanas [Les Trois Sœurs] (1964).

224 Fig. 16. Tres hermanas [Les Trois Sœurs] (1964).

225 Fig. 17. Los peces rojos [Les Poissons Rouges] (1948).

226 Fig. 18. Gato en el espejo [Le Chat au miroir I] (1977-1980).

226 Fig. 19. Gato en el espejo II[Le Chat au miroir II] (1986-1980).

226 Fig. 20. Gato en el espejo III [Le Chat au miroir III] (1989-1994).

227 Fig. 21. La lección de música (1877) por Frederick Leighton.

227 Fig. 22. Desnudo con guitarra [Nu à la guitare] (1983-86).

227 Fig. 23. Desnudo con mandolina (1873) por Georges Callot.

227 Fig. 24. Muchacha con mandolina [Jeune fille à la mandoline] (2000-2001).

229 Fig. 25. Pietà de Villeneuve-les-Avignons (c. 1470) por Enguerrand Quarton.

229 Fig. 26. Estudio para La lección de guitarra (1934).

229 Fig. 27. La lección de guitarra [La Leçon de guitare] (1934).

230 Fig. 28. Desnudo frente a la chimenea [Nu devant la cheminée] (1955).

231 Fig. 29. La habitación [La chambre] (1947-48).

231 Fig. 30. Amanecer [Le Lever] (1975-78). 
231 Fig. 31. Desnudo con foulard [Nu au foulard] (1981-1982).

231 Fig. 32. Desnudo de perfil [Nu de profil] (1973-1977)

232 Fig. 33. Joven ante el espejo [Fille devant le miroir ] (1948).

232 Fig. 34. Georgette aseandose [La toilette de Georgette] (1948-49).

232 Fig. 35. La víctima [La victime] (19391946).

233 Fig. 36. Desnudo reclinado [Un couché] (1945).

233 Fig. 37. Amanecer [Le Lever] (1955).

234 Fig. 39. Los días felices [Les Beaux Jours] (1944).

235 Fig. 40. Retrato de Evelyn Hatch (c. 1878), fotografía de Lewis Carroll.

235 Fig. 42. Thérèse (1938).

235 Fig. 43. Niña con gato [Jeune fille au chat] (1937).

235 Fig. 44. Thérèse soñando [Thérèse sommeil] (1938).

236 Fig. 45. La habitación turca [La chambre turque] (1963-66)

236 Fig. 46. Desnudo adormecido [Nu assoupi] (1980).

237 Fig. 47. La calle [La Chambre] (1933).

238 Fig. 48. La habitación [La Chambre] (1952-54)

239 Fig. 49. Para las calendas griegas [La Seimaine des quatre jeudis] (1949).

239 Fig. 50. Thérèse sobre un banco [Therese sur une banquette] (1939).

240 Fig. 51. La toilette de Cathy (1933).

241 Fig. 52. Jinete montando un caballo blanco [Ecuyère montant au cheval] (1941, modificado en 1946).

242 Fig. 53. La falena [La phaléne] (1959).

261 9. El icono de Lolita. La preadolescente en el cine.

265 Fig. 1. Blancanieves y los 7 enanitos (Snow White and the Seven Dwarfs; Walt Disney, 1937).
265 Fig. 2. Wendy en Peter Pan (Clyde Geromini; Wilfred Jackson; Hamilton Luske, 1954).

265 Fig. 3. Campanilla en Peter Pan (Clyde Geromini; Wilfred Jackson; Hamilton Luske, 1954).

266 Fig. 4. Hayley Mills y Maurice Chevalier en Los hijos del Capitán Grant (1962).

266 Fig. 5. Hayley Mills en Tú a Boston y yo a California (1963).

266 Fig. 5. Hayley Mills en Tú a Boston y yo a California (1963).

267 Fig. 6. Carroll Baker en Baby Doll (1956).

267 Fig. 7. Carroll Baker y Eli Wallach en Baby Doll (1956).

268 Fig. 8. Sue Lyon en Lolita (1962).

268 Fig. 9. Sue Lyon en Lolita (1962).

269 Fig. 10. Créditos iniciales de Lolita (1962).

269 Fig. 11. Sue Lyon y James Mason en Lolita (1962).

269 Fig. 12. Sue Lyon y James Mason en Lolita (1962).

271 Fig. 13. Olivia Hussey en Escándalo en Villa Fiorita (1965).

271 Fig. 14. Olivia Hussey en Escándalo en Villa Fiorita (1965).

271 Fig. 15. Olivia Hussey en Escándalo en Villa Fiorita (1965).

272 Fig. 16. Tatum O'Neal en Luna de Papel (1973).

272 Fig. 17. Tatum O'Neal en Luna de Papel (1973).

272 Fig. 18. Tatum O'Neal en Luna de Papel (1973).

273 Fig. 19. Jodie Foster en Bugsy Malone, nieto de Al Capone (1976).

274 Fig. 20. Brooke Shields en Pretty Baby (1978).

274 Fig. 21. Brooke Shields en Pretty Baby (1978).

274 Fig. 22. Brooke Shields en Pretty Baby (1978). 
274 Fig. 23. Brooke Shields en Pretty Baby (1978).

275 Fig. 24. Brooke Shields en Pretty Baby (1978).

275 Fig. 25. Brooke Shields en Pretty Baby (1978).

275 Fig. 26. Brooke Shields en Pretty Baby (1978).

275 Fig. 27. Brooke Shields en Pretty Baby (1978).

275 Fig. 28. Brooke Shields en Pretty Baby (1978).

276 Fig. 29. Jodie Foster en Taxi Driver (1976).

276 Fig. 30. Fotograma de Taxi Driver (1976).

277 Fig. 31. Fotograma de La rodilla de Clara (1970).

277 Fig. 32. Cartel de Tender Cousins (1980).

277 Fig. 33. Cartel de Tú me hicistes mujer (1981).

278 Fig. 34. Fotogramas de El amante (1992).

278 Fig. 35. Fotogramas de El amante (1992).

278 Fig. 36. Fotogramas de Lolita (1996).

278 Fig. 37. Fotogramas de Lolita (1996).

278 Fig. 38. Fotogramas de Lolita (1996).

279 Fig. 39. Dominique Swain en Lolita (1996).

279 Fig. 40. Dominique Swain en Lolita (1996).

279 Fig. 41. Dominique Swain en Lolita (1996).

280 Fig. 42. Mena Suvari en American Beauty (1999).

280 Fig. 43. Mena Suvari y Thora Birch en American Beauty (1999).

280 Fig. 44. Thora Birch en American Beauty (1999).

281 Fig. 45. Thora Birch en El retorno de las Brujas (1993).

281 Fig. 46. Thora Birch en Un ladrón de cuatro manos (1994).

281 Fig. 47. Thora Birch en Amigas para siempre (1995).
275 Fig. 48. Alicia Silverstone en Clueless. Fuera de onda (1995).

282 Fig. 49. Drew Barrymore en Scream (1996).

282 Fig. 50. Neve Campbell y Rose McGowan en Scream (1996).

282 Fig. 51. Jennifer Love Hewitt en primer término. Cartel en castellano de Se lo que hicisteis el último verano (1997).

282 Fig. 52. Sarah Michelle Gellar en Se lo que hicisteis el último verano (1997).

282 Fig. 53. Sarah Michelle Gellar en Se lo que hicisteis el último verano (1997).

282 Fig. 54. Neve Campbell Denise Richards en Juegos Salvajes (Wild Things; John McNaughton, 1997).

283 Fig. 55. Vahina Giocante en varias escenas de Marie Baie des Anges (1997).

283 Fig. 56. Vahina Giocante en varias escenas de Marie Baie des Anges (1997).

283 Fig. 57. Vahina Giocante en varias escenas de Marie Baie des Anges (1997).

283 Fig. 58. Vahina Giocante en Lila dice (2004).

283 Fig. 59. Vahina Giocante en Lila dice (2004).

283 Fig. 60. Vahina Giocante en Lila dice (2004).

285 Fig. 61. Brigitte Fossey en Juegos prohibidos (1952).

285 Fig. 62. Fotograma de Juegos prohibidos (1952).

285 Fig. 63. Brigitte Fossey en Juegos prohibidos (1952).

285 Fig. 64. Picnic en Hanging Rock (1975).

285 Fig. 65. Picnic en Hanging Rock (1975).

285 Fig. 66. Picnic en Hanging Rock (1975).

286 Fig. 67. Fotograma de Las vírgenes suicidas (1999).

286 Fig. 68. Fotograma de Las vírgenes suicidas (1999).

286 Fig. 69. Kristen Dunst en Las vírgenes suicidas (1999). 
287 Fig. 70. Fotogramas de Alicia en el País de las Maravillas (1903).

287 Fig. 71. Fotograma de Alicia en el País de las Maravillas (Norman Z. McLeod, 1933).

287 Fig. 70. Fotogramas de Alicia en el País de las Maravillas (1903)

289 Fig. 73. Fotogramas Dreamchild (1985).

289 Fig. 74. Fotogramas Dreamchild (1985).

289 Fig. 75. Fotogramas Dreamchild (1985).

290 Fig. 76. Fotogramas de Alice (1988).

290 Fig. 77. Fotogramas de Alice (1988).

290 Fig. 78. Fotogramas de Alice (1988).

292 Fig. 82. Patty McCormack en La mala semilla (1956).

292 Fig. 83. Fotograma de La mala semilla (1956).

292 Fig. 84. Fotograma de El pueblo de los malditos (1960).

293 Fig. 85. Fotogramas de El exorcista (1973).

293 Fig. 86. Fotogramas de El exorcista (1973)

293 Fig. 87. Linda Blair en El exorcista (1973).

294 Fig. 88. Fotogramas de iSuspense! (1961)

294 Fig. 89. Fotogramas de iSuspense! (1961)

294 Fig. 90. Fotogramas de iSuspense! (1961).

294 Fig. 91. Ana Torrent en El espíritu de la colmena (1973).

294 Fig. 92. Ana Torrent en El espíritu de la colmena (1973).

294 Fig. 93. Heather O'Rourke en Poltergeist (1982).

295 Fig. 94. Fotograma de Las dos vidas de Audrey Rose (1977).

295 Fig. 95. Fotograma de ¿Quién mató a Tía Roo? (1971)

297 Fig. 96. Kristen Dunst en Entrevista con el vampiro (1994).

297 Fig. 97. Kristen Dunst en Entrevista con el vampiro (1994)
297 Fig. 98. Fotograma de Entrevista con el vampiro (1994).

298 Fig. 99. Fotograma de El exorcismo de Emily Rose (2005).

298 Fig. 100. Fotograma de Maleficio (2006).

298 Fig. 101. Fotograma de The Hole (2001).

298 Fig. 102. Cartel de Hard Candy (2005).

299 Fig. 103. Fotogramas de Hard Candy (2005).

299 Fig. 104. Fotogramas de Hard Candy (2005).

299 Fig. 105. Fotogramas de Hard Candy (2005).

301 10. La preadolescente fotografiada.

301 Fig. 1. Sin título (s.a.) por Betsy Cameron.

301 Fig. 2. Bebé de rosas (s.a) por Anne Geddes.

301 Fig. 3. Sin título (s.a.) del álbum Eva: Eloge de ma Fille de Irina Ionesco.

303 Fig. 4. Sin título (s.a.) del álbum Eva: Eloge de ma Fille de Irina Ionesco.

304 Fig. 5. Sin título (s.a.) del álbum The Age of Innocence por David Hamilton.

304 Fig. 6. Sin título (s.a.) del álbum The Age of Innocence por David Hamilton.

305 Fig. 7. Sin título (1995-1996) por Bill Henson.

305 Fig. 8. Sin título (1995-1996) por Bill Henson.

305 Fig. 9. Sin título (1995-1996) por Bill Henson.

306 Fig. 10. Minna, norte de California (1978) por Jock Sturges.

306 Fig. 11. Fanny, Montalivet, Francia (1995) por Jock Sturges.

306 Fig. 12. Lisa C., norte de California (1981) por Jock Sturges.

306 Fig. 13. Lotte, Montalivet, Francia (1995) por Jock Sturges.

306 Fig. 14. Nikki, Montalivet, Francia (1997) por Jock Sturges. 
308 Fig. 15. Brooke Shields (1975) por Gary Gross.

308 Fig. 16. Brooke Shields (1975) por Gary Gross.

309 Fig. 17. Emmett, Jessie y Virginia (1989).

310 Fig. 18. Sunday Funnies (1991).

310 Fig. 19. Sorry! [Sorry Game] (1989).

310 Fig. 20. Hermanas en guerra [Sisters at War] (1991).

310 Fig. 21. Almuerzo sobre la hierba [Luncheon on the Grasses] (1991).

311 Fig. 22. Jessie a los cinco (1987).

312 Fig. 23. Cigarrillo de caramelo [Candy Cigarette ] (1989).

313 Fig. 24. Las nuevas madres [The New Mothers] (1989).

313 Fig. 25. Guapísima ["Gorjus"] (1989).

314 Fig. 26. La imagen terrible [The Terrible Picture] (1989).

314 Fig. 27. Seven Years old Rosie, an experienced oyster shucker, Bluffton, South Carolina (1913) por Lewis Hine.

314 Fig. 28. Mordedura de Jessie [Jessie Bites] (1985).

314 Fig. 29. Niña caída [Fallen Child] (1989).

314 Fig. 30. Siesta [Naptime] (1989).

314 Fig. 31. La niña pudorosa [The Modest Child] (1988).

315 Fig. 32. La cama mojada [The Wet Bed] (1987).

315 Fig. 33. La sunamita y su hijo muerto [The Sunamite Woman and Her Dead Son] (1865) por Julia Margaret Cameron.

316 Fig. 34. La última luz [Last Light] (1990).

317 Fig. 35. Gancho de Heno [Hayhook] (1989).

317 Fig. 36. Jessie y el ciervo [Jessie and the Deer] (1985).

318 Fig. 37. Las dos Virginias [The Two Virginias] (1988).

318 Fig. 38. El corte de Jessie [Jessie's Cut] (1985).
318 Fig. 39. Niña dañada [Damaged Child] (1984)

318 Fig. 40. Imagen divertida [Fun Picture] (1992).

319 Fig. 41. Jessie sucia [Dirty Jessie] (1985).

320 Fig. 42. Sin título (s.a), At Twelve.

320 Fig. 43. Sin título (s.a), At Twelve.

320 Fig. 44. Sin título (s.a), At Twelve.

320 Fig. 45. Sin título (s.a), At Twelve.

322 Fig. 46. April como Ofelia (1969).

322 Fig. 47. Ofelia (1980-81). Óleo sobre lienzo.

323 Fig. 48. Anouchka (2001).

323 Fig. 49. Anouchka (2004). Óleo sobre lienzo.

324 Fig. 50. Anouchka (2001).

324 Fig. 51. Rebecca (1976).

324 Fig. 52. Beata Beatrix (1864-1870) por Dante Gabriel Rossetti.

324 Fig. 53. La novia (1851) por Sir John Everett Millais.

324 Fig. 54. Initial Rites (1974-5). Ilustración de Graham Ovenden para Aspects of Lolita.

325 Fig. 55. Alice (1985).

325 Fig. 56. Alice (1985).

326 Fig. 57. Paddling, Regent Canal (1957).

326 Fig. 58. Stepney (1957).

326 Fig. 59. Bloque de apartamentos, Shoreditch (1960).

326 Fig. 60. Victoria Park (1961).

326 Fig. 61. Mile End (1961).

327 Fig. 62. Lorraine (1964). Serie States of Grace.

327 Fig. 63. Lorraine (1964). Serie States of Grace.

328 Fig. 64. Sam (1972).

328 Fig. 65. Elinore (1981).

328 Fig. 66. Ashley (1970). Serie Five Girls.

328 Fig. 67. Lorraine (1970). Serie Five Girls.

329 11. Alcance del icono de Lolita.

333 Fig. 1. Fotografías de Oliviero Toscani para Benetton.

333 Fig. 2. Fotografías de Oliviero Toscani para Benetton. 
333 Fig. 3. Envase de Ivory Soap.

334 Fig. 4. Brooke Shields para GOLD FORMULA BRECK de Ivory Soap (1974).

334 Fig. 5. Brooke Shields para la campaña de jeans Calvin Klein (1980).

334 Fig. 6. Kate Moss para Calvin Klein (1995).

336 Fig. 7. Gemma Ward.

336 Fig. 8. Gemma Ward.

336 Fig. 9. Sacha Pivovarova.

336 Fig. 10. Natalia Vodianova.

336 Fig. 11. Heather Marks.

337 Fig. 12. Britney Spears en el video clip Baby One More Time (1998).

337 Fig. 13. Britney Spears para la portada de la revista Rolling Stone.

338 Fig. 14. Fotografía promocional de Alizée.

338 Fig. 15. Fotogramas del vídeo clip Moi... Lolita (2000) de Alizée.

338 Fig. 16. Fotogramas del vídeo clip Moi.. Lolita (2000) de Alizée.

338 Fig. 17. Fotogramas del vídeo clip All The Things You Said (2002) de TATU.

338 Fig. 18. Fotogramas del vídeo clip All The Things You Said (2002) de TATU.

338 Fig. 19. Fotogramas del vídeo clip All The Things You Said (2002) de TATU.

347 Fig. 20. La junior model Saaya Irie.

347 Fig. 21. Portada del Loli photobook de Ryo Shihono.

341 Fig. 22. Portada de un manga shojo.

349 Fig. 23. Manga Iolikon.

349 Fig. 24. Manga Iolikon.

349 Fig. 25. Manga hentai.

349 Fig. 27. Manga hentai.

349 Fig. 28. Manga ero-guro.

349 Fig. 29. Manga toddlerkon.

350 Fig. 30. Figura del anime Fate/Hollow Ataraxia.

350 Fig. 31. Escultura del artista Takash Murakami.

350 Fig. 32. Escultura del artista Takashi Murakami.
351 Fig. 33. Diferentes rori-doll, modelo Candy Girl de la marca Orient Industry.

351 Fig. 34. Diferentes rori-doll, modelo Candy Girl de la marca Orient Industry.

351 Fig. 35. Diferentes rori-doll, modelo Candy Girl de la marca Orient Industry.

351 Fig. 36. Diferentes rori-doll, modelo Candy Girl Petit Soft de la marca Orient Industry.

351 Fig. 37. Diferentes rori-doll, modelo Candy Girl Petit Soft de la marca Orient Industry.

352 Fig. 38. Fotografías anónimas «robadas» de panchira difundidas en Internet.

352 Fig. 39. Junior model posando panchira.

352 Fig. 40. Junior model posando panchira.

353 Fig. 41. Fotograma del documental Cotton Candy (Roshell Bissett, 1996).

355 Fig. 42. Sailor Moon.

355 Fig. 43. Muchacha vistiendo sera fuku y rusu-sokusu.

355 Fig. 44. Niñas kogals.

355 Fig. 45. Moda kogal. Fotografía por Shoichi Aochi.

355 Fig. 46. Moda kogal. Fotografía por Shoichi Aochi.

355 Fig. 47. Moda kogal. Fotografía por Shoichi Aochi.

356 Fig. 48. Kogal gangiro.

356 Fig. 50. Portada de la revista Egg Magazine.

356 Fig. 51. Gothic Lolitas.

356 Fig. 52. Sweet Lolitas.

356 Fig. 53. Cosplay. 



\section{RESUMEN.}

\section{Resumen. Versión en castellano.}

La preadolescente no tuvo una iconografía propia en el arte hasta mediados del siglo XVIII, cuando se originó un concepto de infancia como estado biológico humano diferente al adulto. Durante el siglo XIX en Inglaterra, la imagen infantil y en concreto la de «las niñas», se desarrolló notablemente a través de la literatura, la pintura, la ilustración y la naciente fotografía. El fenómeno cultural, casi obsesivo de la imagen infantil por parte de numerosos intelectuales y artistas victorianos como John Everett Millais o Lewis Carroll, se vino a llamar «Culto por las niñas», que las dotaba de una naturaleza inocente, pura e idealizada, pero por otro lado, les otorgaba misterio y perversidad. A partir del siglo XX hasta la actualidad, las artes y los medios de masas tomarían la imagen preadolescente generada durante la etapa victoriana como base para la construcción de diversos iconos y estereotipos de la feminidad infantil, como la inocente ambigua Shirley Temple en el cine de la década de 1930, las provocadoras escenas con niñas desnudas del pintor Balthus, la concreción de un icono femenino de naturaleza sensual y nínfica con nombre propio a través de la novela Lolita de Vladimir Nabokov, y la repercusión de éste, sobre todo en la última década en manifestaciones artísticas y visuales como el manga japonés o la pornografía infantil en Internet.

\section{Palabras clave:}

Preadolescente, niñas, infancia, inocencia, pureza, erotismo, sexo, sexualidad, sensualidad, perversidad, nínfula, arte, pintura, cine, ilustración, fotografía, literatura, prerrafaelismo, Inglaterra victoriana, pornografía, obscenidad, manga, rorikon, pederastia, pedofilia, representación, imagen, icono, Alicia, Lolita, Lewis Carroll, Julia Margaret Cameron, Balthus, Vladimir Nabokov, Sally Mann, Graham Ovenden. 


\section{Resum. Versió en valencià.}

La preadolescent no va tindre una iconografia pròpia en l'art fins mitjans del segle XVIII, quan es va originar un concepte d'infància com a estat biològic humà diferent de l'adult. Durant el segle XIX a Anglaterra, la imatge infantil i en concret la de «les xiquetes», es va desenvolupar notablement a través de la literatura, la pintura, la il.lustració i la naixent fotografia. El fenomen cultural, quasi obsessiu de la imatge infantil per part de nombrosos intel-lectuals i artistes victorians com John Everett Millais o Lewis Carroll, es va vindre a nomenar «Culte per les xiquetes», que les dotava d'una naturalesa innocent, pura i idealitzada, però d'altra banda, els atorgava misteri i perversitat. A partir del segle XX fins a l'actualitat, les arts i els mitjans de masses prendrien la imatge preadolescent generada durant l'etapa victoriana com a base per a la construcció de diverses icones i estereotips de la feminitat infantil, com la innocent però ambigua Shirley Temple en el cine de la dècada de 1930, les provocadores escenes amb xiquetes nues del pintor Balthus, la concreció d'un icona femenina de naturalesa sensual i nimfica amb nom propi a través de la novel-la Lolita de Vladimir Nabokov, i la repercussió d'este, sobretot en l'última dècada en manifestacions artístiques i visuals com el manga japonés o la pornografia infantil en Internet.

\section{Paraules clau:}

Preadolescent, xiquetes, infància, innocència, puresa, erotisme, sexe, sexualitat, sensualitat, perversitat, nimfula, art, pintura, cine, il-lustració, fotografia, literatura, prerrafaelisme, I'Anglaterra victoriana, pornografia, obscenitat, manga, rorikon, pederàstia, pedofília, representació, imatge, icona, Alicia, Lolita, Lewis Carroll, Julia Margaret Cameron, Balthus, Vladimir Nabokov, Sally Mann, Graham Ovenden. 


\section{Summary. English version.}

The preadolescent did not have an own iconography in the art about the middle of $18^{\text {th }}$ century, when a concept of childhood like a human biological state was originated different from the adult. During the $19^{\text {th }}$ century in England, the childhood image and in particular, the one of «little girls», was developed remarkably through literature, the painting, the illustration and the rising photography. The cultural, almost obsessive phenomenon about the childhood image on the part of numerous intellectuals and Victorian artists like John Everett Millais or Lewis Carroll, came to be named «Cult of the little girls», which conceded them an innocent, pure and idealized nature, but on the other hand, it granted mystery and perversity to them. From the $20^{\text {th }}$ century until the present time, the arts and the mass media would take the preadolescent image generated during the Victorian time as bases for the construction of diverse icons and stereotypes of the childhood femininity, like the innocent but ambiguous Shirley Temple in the cinema of the decade of 1930, the provoking scenes with naked little girls of the painter Balthus, the concretion of a feminine icon of sensual and nymphic nature with own name through the Vladimir Nabokov's novel Lolita, and the repercussion of this one, above all in the last decade in artistic and visual manifestations like the Japanese manga or the child pornography in Internet.

\section{Key Words:}

Preadolescent, little girls, childhood, innocence, purity, eroticism, sex, sexuality, sensuality, perversity, nymphet, art, painting, cinema, illustration, photography, literature, pre-raphaelite, Victorian England, pornography, obscenity, manga, rorikon, pederasty, paedophilia, representation, image, icon, Alicia, Lolita, Lewis Carroll, Julia Margaret Cameron, Balthus, Vladimir Nabokov, Sally Mann, Graham Ovenden. 
